\section{Pacific Northwest}

National Laboratory

Operated by Battelle for the

U.S. Department of Energy

\title{
Gas Generation from K East Basin Sludges and Irradiated Metallic Uranium Fuel Particles - Series III Testing
}
A. J. Schmidt
R. L. Sell
C. H. Delegard
K. L. Silvers
S. A. Bryan
S. R. Gano
M. R. Elmore
B. M. Thornton

August 2003

Prepared for the U.S. Department of Energy under Contract DE-AC06-76RL01830 


\title{
DISCLAIMER
}

This report was prepared as an account of work sponsored by an agency of the United States Government. Neither the United States Government nor any agency thereof, nor Battelle Memorial Institute, nor any of their employees, makes any warranty, express or implied, or assumes any legal liability or responsibility for the accuracy, completeness, or usefulness of any information, apparatus, product, or process disclosed, or represents that its use would not infringe privately owned rights. Reference herein to any specific commercial product, process, or service by trade name, trademark, manufacturer, or otherwise does not necessarily constitute or imply its endorsement, recommendation, or favoring by the United States Government or any agency thereof, or Battelle Memorial Institute. The views and opinions of authors expressed herein do not necessarily state or reflect those of the United States Government or any agency thereof.

\author{
PACIFIC NORTHWEST NATIONAL LABORATORY \\ operated by \\ BATTELLE \\ for the \\ UNITED STATES DEPARTMENT OF ENERGY \\ under Contract DE-AC06-76RL01830
}

This document was printed on recycled paper. 
PNNL-14346

\title{
Gas Generation from K East Basin Sludges and Irradiated Metallic Uranium Fuel Particles - Series III Testing
}

\author{
A. J. Schmidt \\ C. H. Delegard \\ S. A. Bryan \\ M. R. Elmore \\ R. L. Sell \\ K. L. Silvers \\ S. R. Gano \\ B. M. Thornton
}

August 2003

Prepared for Fluor Hanford

Work Supported by

the U.S. Department of Energy

under Contract DE-AC06-76RL01830

Pacific Northwest National Laboratory

Richland, Washington 99352 


\section{Summary}

The path forward for managing Hanford K Basin sludge calls for it to be packaged, shipped, and stored at T Plant until final processing at a future date. An important consideration for the design and cost of retrieval, transportation, and storage systems is the potential for heat and gas generation through oxidation reactions between uranium metal and water. This report, the third in a series (Series III), describes work performed at the Pacific Northwest National Laboratory (PNNL) to assess corrosion and gas generation from irradiated metallic uranium particles (fuel particles) with and without sludge addition. The first test series (Series I; Delegard et al. 2000) focused on gas generation from K East (KE) Basin floor and canister sludge (size-fractionated and unfractionated samples collected using a consolidated sampling technique (Baker et al. 2000). The second series (Series II; Bryan et al. 2001) examined the gas generation behavior of KE Basin floor, pit, and canister sludge. Mixed and unmixed and fractionated $\mathrm{KE}$ canister sludge materials were tested, along with floor and pit sludge from areas in the KE Basin not previously sampled. The sludge material used in all three test series was saturated with water, consistent with sludge management plans. The work for all three test series was conducted under the direction of the Spent Nuclear Fuel (SNF) Sludge Handling Project managed by Fluor Hanford, and in accordance with the corresponding data quality objectives (Makenas 2000) and the sampling and analysis plan (Baker et al. 2000).

The overall goal for the Series III testing was to evaluate the behavior and reactivity of the fuel particles, with and without $\mathrm{K}$ Basin sludge, under known conditions, through the evaluation of gas generation rate and composition data. Specific objectives for Series III included:

1. Provide data on irradiated uranium metal fuel corrosion rates that can be compared with published studies on metallic uranium corrosion kinetics and thus be used to more accurately assign appropriate reaction rate safety factors.

2. Obtain reaction rate data as a function of temperature and fuel fragment particle size to calibrate and validate thermal stability and gas generation models that are being used to provide nominal and safety-basis input for the design of sludge storage and shipping systems.

3. Determine how larger fuel fragments (500 to $6350 \mu \mathrm{m}$ in diameter) corrode. In particular, determine whether the fuel fragments corrode isotropically in accordance with a "shrinking core" model or undergo significant fragmentation in the course of corrosion.

4. Evaluate the effects of an intimate overlying sludge layer ("blanket") on the uranium metal corrosion rate. Determine whether the source of the overlying sludge layer (e.g., floor vs. canister sludge) affects the uranium metal reaction rate. Also determine if the overlying sludge layer affects the corrosion rate differently for various sizes of fuel particles.

5. Continue the test with $\mathrm{KC}-2 / 3 \mathrm{P} 250 \mathrm{~L}$ ( $>250-\mu \mathrm{m}$ particle size canister sludge known to contain $\sim 7.4 \mathrm{wt} \%$ uranium metal) at ambient hot cell temperature to further evaluate the behavior of sludge with a high uranium metal content under conditions similar to those expected at $\mathrm{T}$ Plant.

Most of the tests to meet these objectives were conducted from September 2000 through January 2001; one test (with a single, $\sim 7150-\mu \mathrm{m}$ fuel fragment) ran from July 2000 through January 2001 (Series II 
testing). The KC-2/3 P250L test ran from October 1999 (Series I testing) through January 2001. The major conclusions from the Series III testing are given below:

- Reaction rate data, obtained as a function of temperature and fuel fragment particle size, may be used to calibrate and validate the thermal stability and gas generation models. The data show that fuel particle corrosion in water occurred at rates that are about one-third to one-half of those predicted in the technical literature. The differences may be attributed to the fact that most prior studies were conducted over short experimental times with massive uranium pieces and, therefore, had little overlying corrosion product to inhibit reaction. The reaction rate activation energies were near those obtained by the Hilton (2000) Arrhenius model and prior (Series I) studies and were consistent, but slightly higher, than those obtained by the SNF Databook, Vol. 1 (Reilly 1998) fit of published uranium corrosion rate data.

- Corrosion of various populations of 0 - to $6350-\mu \mathrm{m}$ fuel particles follows kinetics consistent with an isotropic "shrinking core" model. A test with the single, 3.72-g, fuel fragment ( $\sim 7150 \mu \mathrm{m})$ had a sigmoidal gas generation plot shape, with the rate increasing with time up to $\sim 1800 \mathrm{hr}$ ( 75 days). After $1800 \mathrm{hr}$, the reaction rate began to decrease as reactant (uranium metal) was consumed. A cladding shard and a single, intact fuel fragment with sharp faces were found during post-test examination. Evidently, the attached piece of cladding was slowly sloughed, progressively exposing fresh surface to corrosion to accelerate the observed gas generation rate, but no crumbling occurred over the course of testing. The remaining large fuel piece at the end of the test maintained its sharpedged appearance, as did smaller residual fuel particles observed in other experiments. No fragmentation was observed in this or other testing.

- Sludge layers intentionally added to cover (or blanket) the underlying fuel particles were observed to decrease the uranium metal corrosion rate. Lower observed rates also seemed to occur with selfblanketing by fuel metal corrosion products. The decrease in rate became more pronounced as the blanketing depth increased. In some cases, the overlying sludge layer source (e.g., floor versus canister sludge) had little effect on the uranium metal reaction rate. However, hydrogen consumption seemed to occur for some sludge, inhibiting the reaction rates as observed by $\mathrm{H}_{2}$ gas generation and fission product gas release. The effect of blanketing diminished as temperature increased (i.e., blanketed and unblanketed fuel particles reacted at similar rates as temperature was increased to $\left.95^{\circ} \mathrm{C}\right)$.

- Apparently because of blanketing, the observed uranium metal fuel corrosion rates were lower than those reported in the technical literature by a factor of 2 to 3 . The reaction rate safety factor for fuel (Reilly 1998) is more conservative than necessary for sludge, based on the present testing.

- After the Series III testing, the sample material was recovered and analyzed. Results for the tests (with fuel particles only) run to completion (i.e., all uranium metal corroded) show that the volume of the resulting corrosion products (uranium oxides) was 4.3 to 5.4 times greater than the settled volume of the initial fuel particles.

- Only about $1.5 \%$ of the uranium metal in the KC-2/3 P250L sludge test corroded in an 800-ml vessel at ambient hot cell temperature $\left(\sim 33^{\circ} \mathrm{C}\right.$ average; ranging from $30^{\circ} \mathrm{C}$ to $\left.37^{\circ} \mathrm{C}\right)$ during the $10,140 \mathrm{hr}$ of testing, and, of this, only $7 \%$ was by reaction with water to produce hydrogen. This behavior contrasts sharply with that of a Series I test conducted in a $\sim 30-\mathrm{ml}$ vessel at $40^{\circ} \mathrm{C}$ with a subsample of the same sludge material. At $40^{\circ} \mathrm{C}$, after an initial $\sim 335-\mathrm{hr}$ induction time (before onset of fission 
gas release), $\sim 50 \%$ of the uranium metal in the KC-2/3 P250 material reacted with water in $3220 \mathrm{hr}$ ( $\sim 134$ days). The $\mathrm{KC}-2 / 3 \mathrm{P} 250 \mathrm{~L}$ test and the $40^{\circ} \mathrm{C}$ test in Series I were started at the same time.

- The behavior of the KC-2/3 P250L sludge (during the first $6000 \mathrm{hr}$ of the test) was compared to short-term gas generation observations made in 1996 of similar $\mathrm{KE}$ canister sludge samples at $32^{\circ} \mathrm{C}$ (Delegard et al. 2000). In some cases, the $1996 \mathrm{KE}$ canister sludge samples exhibited a minimal induction period followed by a gas generation rate many times greater than that exhibited by the KC-2/3 P250L test. Several contributing factors for the differences in the observed offgas generation behavior of KC-2/3 P250L can be postulated. The $1996 \mathrm{KE}$ canister sludge samples may have contained a finer distribution of uranium metal than KC-2/3 P250L (which only contained particles larger than $250 \mu \mathrm{m}$ ). Another factor may have been the bed depth (about $1 \mathrm{~cm}$ in the KC-2/3 P250L test compared with 5 to $7 \mathrm{~cm}$ in the $1996 \mathrm{KE}$ canister sludge tests and the Series I tests with the same material) and its effect on limiting hydrogen diffusion outward and oxygen diffusion inward. For $\mathrm{KC}-2 / 3 \mathrm{P} 250 \mathrm{~L}$, bulk water circulation may have occurred within the 1-cm layer of sludge that contained only particles between 250 and $6350 \mu \mathrm{m}$ (i.e., no fine particulate). The sludge layer was likely too permeable to promote a buildup of sufficient hydrogen partial pressure and provided little resistance to oxygen convection and diffusion, preventing the uranium metal from undergoing $\mathrm{UH}_{3}$-mediated corrosion.

- During containerization and storage of KE Basin sludge, it is expected that most of the uranium metal particles will be blanketed by more than $5 \mathrm{~cm}$ of sludge and a significant fraction of the sludge will be made up of particles less than $250 \mu \mathrm{m}$. Consequently, the gas generation behavior of KC-2/3 P250L should not be assumed to be representative of the behavior of the sludge during retrieval, containerization, or storage.

The tests and further interpretation of the results are summarized below.

\section{Test Materials and Description}

The Series III testing described in this report consisted of 12 tests. In 10 of the tests, 4.3 to $26.4 \mathrm{~g}$ of fuel particles of selected size distribution were placed into 60 - or $800-\mathrm{ml}$ reaction vessels; in four of those tests, 19.1 to $98.9 \mathrm{~g}$ of settled sludge were added. In another test, a single, 3.72-g, fuel fragment (i.e., $7150-\mu \mathrm{m}$ particle) was placed in a $60-\mathrm{ml}$ reaction vessel with no added sludge. The twelfth test contained only sludge. The fuel particles were prepared by crushing archived coupons (samples) of irradiated metallic uranium fuel element SFEC04, 2540E (N Reactor fuel), a highly damaged element exhibiting a significant number of fractures and breaks. Only coupons with at least one broken face were selected for crushing. Some of these samples included cladded faces. The coupons used were taken to be representative of fuel particles broken off during handling operations, since the uranium near a fractured or damaged fuel element surface tends to be more brittle and friable. The coupons were crushed in the laboratory hot cell and were size-classified by sieving. Although visibly degraded, the coupons maintained considerable integrity, and substantial physical effort was required to crush them. Weighed portions of various size fractions were used in testing to determine the effects of particle size on reaction rates. The single fuel fragment used in one test was taken from the same fuel element as was used to prepare the various-sized fuel particles. The sludge used in the tests included both uranium-rich (62 to $68 \mathrm{wt} \%$ total uranium, dry basis) canister sludge and uranium-poor (11 wt $\%$ total uranium, dry basis) floor sludge.

The test matrix shown below displays the mass and size distribution of the fuel particles (and any associated cladding), the type and quantity of the added K Basin sludge, the test vessel size, test temperatures, and total test duration. The last column lists the fraction of the sample that was corroded at 


\section{Gas Generation Series III Test Matrix}

\begin{tabular}{|c|c|c|c|c|c|c|c|c|c|}
\hline \multirow{2}{*}{$\begin{array}{l}\text { Test } \\
\text { No. }\end{array}$} & \multirow[b]{2}{*}{ Test ID } & \multicolumn{2}{|c|}{ Fuel Particles } & \multicolumn{2}{|c|}{ Added Sludge } & \multirow{2}{*}{$\begin{array}{c}\text { Approx. } \\
\text { Reaction } \\
\text { Vessel } \\
\text { Vol., ml }\end{array}$} & \multirow{2}{*}{$\begin{array}{c}\text { Approx. } \\
\text { Temperature, } \\
{ }^{\circ} \mathbf{C}^{(\mathbf{a})}\end{array}$} & \multirow{2}{*}{$\begin{array}{c}\text { Test } \\
\text { Duration, } \\
\text { hr }\end{array}$} & \multirow{2}{*}{$\begin{array}{c}\text { Fraction of } \\
\text { Fuel } \\
\text { Sample } \\
\text { Reacted, } \\
\text { wt } \%^{(b)}\end{array}$} \\
\hline & & $\begin{array}{c}\text { Particle Size, } \\
\mu \mathrm{m}\end{array}$ & $\begin{array}{l}\text { Mass, } \\
\text { g }\end{array}$ & $\begin{array}{c}\text { Sample } \\
\text { ID }\end{array}$ & Mass, $\mathbf{g}$ & & & & \\
\hline 1 & $\begin{array}{l}\text { SNF + Can } \\
\text { Fines 60S }\end{array}$ & $0-500$ & 4.27 & $\begin{array}{l}\mathrm{KC}-2 / 3 \\
\mathrm{M} 250\end{array}$ & 26.43 & 60 & $38 / 60 / 80 / 95$ & 2965 & 37 \\
\hline 2 & $\begin{array}{l}\text { SNF + Can } \\
60 S\end{array}$ & $500-2000$ & 8.39 & $\begin{array}{l}\text { KC Can } \\
\text { Comp }\end{array}$ & 19.10 & 60 & $33 / 60 / 80 / 95$ & 2999 & 18 \\
\hline 3 & SNF Mid 60S & $500-2000$ & 8.24 & None & 0 & 60 & $33 / 60 / 80 / 95$ & 2981 & 26 \\
\hline 4 & SNF Mid 40S & $500-2000$ & 8.61 & None & 0 & 60 & $33 / 40 / 60 / 80$ & 3133 & 12 \\
\hline 5 & $\begin{array}{l}\text { SNF P2000 } \\
80 \mathrm{~S}\end{array}$ & $2000-6350$ & 9.95 & None & 0 & 60 & $33 / 80$ & 2908 & 47 \\
\hline 6 & $\begin{array}{l}\text { SNF M500 } \\
80 \mathrm{~L}\end{array}$ & $0-500$ & 7.95 & None & 0 & 800 & $\begin{array}{l}33 / 80 / 95 \text { to } \\
\text { completion }\end{array}$ & 3124 & 74 \\
\hline 7 & SNF Mid 80L & $500-2000$ & 8.87 & None & 0 & 800 & $\begin{array}{l}33 / 80 / 95 \text { to } \\
\text { completion }\end{array}$ & 2988 & 91 \\
\hline 8 & $\begin{array}{l}\text { SNF Mid 80L } \\
\text { Dup }\end{array}$ & $500-2000$ & 8.15 & None & 0 & 800 & $\begin{array}{l}33 / 80 / 95 \text { to } \\
\text { completion }\end{array}$ & 2988 & 95 \\
\hline 9 & $\begin{array}{l}\text { Fuel } \\
\text { Fragment }^{(c)}\end{array}$ & $\sim 7150$ & 3.72 & None & 0 & 60 & 80 & 4250 & 33 \\
\hline 10 & $\begin{array}{l}\text { SNF + Can } \\
60 \mathrm{~L}\end{array}$ & $0-6350$ & 26.36 & $\begin{array}{l}\text { KC Can } \\
\text { Comp }\end{array}$ & 68.14 & 800 & $33 / 60 / 80 / 95$ & 3011 & 32 \\
\hline 11 & $\begin{array}{l}\text { SNF Floor } \\
60 \mathrm{~L}\end{array}$ & $0-6350$ & 25.52 & KC Floor & 98.87 & 800 & $33 / 60 / 80 / 95$ & 3011 & 25 \\
\hline 12 & $\begin{array}{l}\text { KC-2/3 } \\
\mathrm{P}^{2} 50 \mathrm{~L}^{(\mathrm{d})}\end{array}$ & None & 0 & $\begin{array}{l}\mathrm{KC}-2 / 3 \\
\mathrm{P} 250\end{array}$ & 65.98 & 800 & 33 & 10,143 & 1.5 \\
\hline \multicolumn{10}{|c|}{$\begin{array}{l}\text { (a) Tests 1-8, 10, and } 11 \text { began with } \sim 138 \mathrm{hr} \text { at am } \\
\text { tests ended at ambient hot cell temperature. } \\
\text { (b) Percent of the original sample mass, as uraniun } \\
\text { gas analyses, the } \mathrm{H}_{2} \text { fraction in the analyzed ga } \\
\text { (except Test } 12 \text {, which was based on } \sim 7.4 \mathrm{wt} \% \\
2 \mathrm{H}_{2} \mathrm{O} \text {. As seen for Tests } 6 \text { through } 8 \text {, which } \\
\text { metal, but evidently contained some cladding a } \\
\text { (c) Started during Series II testing (July 2000). } \\
\text { (d) Started during Series I testing (October 1999). }\end{array}$} \\
\hline
\end{tabular}

the completion of Series III testing, as determined by hydrogen gas evolution (gas analyses) and assuming the fuel particles were pure uranium metal. Tests 6 through 8 were reacted to completion of the gasgenerating reactions. None of the other tests were reacted to completion.

As in the Series I and II testing, the sludge materials (whether fuel particles, mixtures of fuel particles and sludge, or sludge-only) were loaded into $60-$ or $800-\mathrm{ml}$ vessels. The solids were covered with an excess of $\mathrm{K}$ Basin water, the vessels closed and connected to a gas measurement manifold, and the vessels backflushed with inert neon cover gas. The vessels were then heated to constant temperature. The gas pressures and temperatures were monitored continuously from the time the vessels were purged. Gas samples were collected at various times during the tests, and the samples analyzed by mass spectrometry. For some of the tests, product gases occasionally were vented without analysis to avoid exceeding the 
pressure rating of the transducers. The test vessel temperatures were lowered to that of the hot cell prior to gas sampling and venting, and the vessels were purged with neon after sampling or venting. In general, testing at the initial temperature continued for a prolonged period and was followed by shorter periods at higher temperatures.

\section{Gas Generation Testing}

After loading, the reaction vessels were connected to the gas measurement manifold for about $138 \mathrm{hr}$ at ambient hot cell temperature $\left(\sim 33^{\circ} \mathrm{C}\right)$ before being heated to the target test temperatures. While at the ambient hot cell temperature, the 60 -ml vessel containing 0 to $500-\mu \mathrm{m}$ fuel particles and $<250$ - $\mu \mathrm{m}$-particle-size canister sludge (Test 1 ) self-heated by reaction to $\sim 38^{\circ} \mathrm{C}$. Self-heating was not observed in any other vessels during the initial $138 \mathrm{hr}$. Because of the temperature difference between the ambient hot cells $\left(\sim 33^{\circ} \mathrm{C}\right)$ and the $\mathrm{K}$ Basin pools $\left(10^{\circ} \mathrm{C}\right.$ to $\left.25^{\circ} \mathrm{C}\right)$, the behavior of fuel particles in the pools is expected to be different (i.e., may not undergo significant self heating).

The tests with added crushed fuel particles (Tests 1-8, 10, and 11) showed nearly linear gas generation rates when held at constant temperature, decreasing slightly with time (and reactant consumption) at a given temperature. The rates increased distinctly with increasing reaction temperature.

As expected, the specific (mass-based) reaction rates increased with decreasing particle size. For example, at $80^{\circ} \mathrm{C}$, maximum gas generation rates (at standard temperature and pressure) were 19.0 liters $/ \mathrm{kg}$ fuel particles-day for the $<500-\mu \mathrm{m}$ particles (Test 6 ), 8.2 and 10.6 liters $/ \mathrm{kg}$ fuel particles-day for the $500-2000-\mu \mathrm{m}$ particles (Tests 7 and 8), 2.5 liters/kg fuel particles-day for the $2000-6350-\mu \mathrm{m}$ particles (Test 5), and 0.59 liters $/ \mathrm{kg}$ fuel particles-day for the $\sim 7150-\mu \mathrm{m}$ fuel fragment (Test 9).

Tests 6 through 8 were run to completion of the gas-generating reactions. All of the evolved gases were sampled and analyzed to determine the amounts of uranium metal present in the starting fuel particles according to the reaction $\mathrm{U}+2 \mathrm{H}_{2} \mathrm{O} \rightarrow \mathrm{UO}_{2}+2 \mathrm{H}_{2}$. The $<500-\mu \mathrm{m}$ particles (Test 6) were found to be $74.2 \mathrm{wt} \%$ uranium metal and the $500-2000-\mu \mathrm{m}$ particles (the duplicate Tests 7 and 8 ) were $90.8 \mathrm{wt} \%$ and $95.2 \mathrm{wt} \%$, respectively, or $93.0 \mathrm{wt} \%$ (average) uranium metal. The lower uranium metal concentrations in the smaller particles likely occurred because the smaller particles had higher specific surface area (that is, were subject to more surface corrosion before initiation of the testing) and because heating associated with the more mechanically aggressive crushing, necessary to produce the smaller particles, accelerated corrosion by atmospheric oxygen. [Note: in actual K Basin sludge and fuel handling operations, the sludge will not be subjected to this type of aggressive crushing or to atmospheric oxygen.]

Sludge overburden (blanketing) in Test 2 apparently decreased the reaction rate at $60^{\circ} \mathrm{C}$, as compared with the corresponding Test 3 having the same distribution of fuel particle sizes but no sludge overburden. However, the inhibition of the corrosion reaction by blanketing decreased with increasing temperature and, ultimately, was insignificant at $95^{\circ} \mathrm{C}$. Comparing Tests 2 and 3, the reaction rate with blanketing is about $68 \%$ of the rate without blanketing at $60^{\circ} \mathrm{C} ; 87 \%$ of that found without blanketing at $80^{\circ} \mathrm{C}$; and $97 \%$ of the rate without blanketing at $95^{\circ} \mathrm{C}$. The effects of blanketing depth on corrosion rates were also analyzed by plotting the observed versus expected (literature-derived) corrosion rates for tests performed at $80^{\circ} \mathrm{C}$, the temperature for which the most extensive comparative values were available. Literature correlations were made based on the SNF Databook, Vol. 1 (Reilly 1998) and a more recent compilation (Hilton 2000). Based on the analysis, it was found that the corrosion rate decreases 
significantly as the blanketing depth increases, but approaches that predicted based on the technical literature data as the solids depth approaches zero.

Hydrogen dominated the measured generated gases for the tests with added fuel particles, constituting $99.6 \%$ or more of the gas for those experiments with fuel particles only and at least $94.5 \%$ of the generated gas for those experiments with both fuel particles and sludge. The lower hydrogen concentrations in the tests with sludge were due to higher $\mathrm{CO}_{2}$ concentrations. For these tests, the rate of total gas generation, monitored by system pressure, temperature, and volume, largely reflected the rate of hydrogen generation. The gas product from the long-running experiment (Test 12), containing only canister sludge and no added fuel particles, was $96.9 \%$ carbon dioxide and $3.06 \%$ hydrogen.

Hydrocarbons (primarily methane) and isotopes of krypton and xenon fission product gas comprised the balance of the gas products in the tests. Trace amounts of oxygen were consumed, and trace amounts of nitrogen evolved in most tests.

The tests with fuel and sludge generally ended at lower $\mathrm{pH}$ (4.9 to 8.6) than tests with only fuel and no added sludge ( $\mathrm{pH} 7.9$ to 10.9). The lower $\mathrm{pH}$ in tests with sludge, and the additional $\mathrm{CO}_{2}$ released in those tests, provides evidence for the reaction of schoepite and calcite to form becquerelite as posited in the Series I and II reports. The higher $\mathrm{pH}$ observed in the fuel particles-only tests may indicate the formation and subsequent decomposition of uranium nitride to release ammonia.

Analysis of the 10.76-year half-life ${ }^{85} \mathrm{Kr}$ isotopic fraction in the product gases for Tests 1-11 allowed estimation of the time since irradiation for the source fuel element from which the particles and single fuel fragment were derived. The average time estimated from the 11 tests is $23.0 \pm 1.7$ years, essentially in agreement with the fuel element's discharge in November 1975, 25 years before gas generation testing.

Activation energies were calculated for the tests conducted at multiple reaction temperatures (Tests 1-4, $6-8,10,11)$. The activation energies were calculated based on both total gas ( $>94 \%$ hydrogen) and fission product gas release rates. The activation energies are consistently higher for the $\mathrm{H}_{2}$-based data than for the krypton or xenon-based data. The divergence between the $\mathrm{H}_{2}$ and fission product gas data is greater for the fuel particles-plus-sludge tests than for the fuel particles-only tests. The higher activation energy for $\mathrm{H}_{2}$ measurements may reflect the effect of higher temperature in driving $\mathrm{H}_{2}$ from the fuel particles to diminish the fraction remaining as the metal hydride intermediate.

The activation energies for Tests 3 and 4 conducted at multiple temperatures (fuel particles only), based on fission product gases are closely grouped, lying between 16.4 and $17.1 \mathrm{kcal} / \mathrm{mole}$. This range of activation energies is closer to the Hilton (2000) activation energy ( $15.9 \mathrm{kcal} / \mathrm{mole})$ than to the Reilly (1998) value $(13.8 \mathrm{kcal} / \mathrm{mole})$ and near the KC-2/3 P250 Series I test value of $15.8 \mathrm{kcal} / \mathrm{mole}$ as found based on xenon release rate data in the Series II report (Bryan et al. 2001). The range of activation energies (15.5 to $17.1 \mathrm{kcal} / \mathrm{mole}$ ) observed from fission product gas data in the fuel particles-plus-sludge tests (Tests 2 and 10) is in better agreement with the Hilton (2000) activation energy and Series I results than with the Reilly (1998) value.

Consistent with the data quality objectives (Makenas 2000) and the sampling and analysis plan (Baker et al. 2000), this series of tests provides base supporting information and data for the design and evaluation of the systems being developed to transport and store the K Basin sludge at T Plant. 


\section{References}

Baker, R. B., T. L. Welsh, and B. J. Makenas. 2000. Sampling and Analysis Plan for Sludge from the 105-K Basins to Support Transport to and Storage in T Plant. HNF-6479, Rev. 0, Fluor Hanford, Richland, WA.

Bryan, S. A., C. H. Delegard, A. J. Schmidt, R. L. Sell, K. L. Silvers, S. R. Gano, and B. M. Thornton. 2001. Gas Generation from K East Basin Sludges - Series II Testing. PNNL-13446, Pacific Northwest National Laboratory, Richland, WA.

Delegard, C. H., S. A. Bryan, A. J. Schmidt, P. R. Bredt, C. M. King, R. L. Sell, L. L. Burger, and K. L. Silvers. 2000. Gas Generation from K East Basin Sludges - Series I Testing. PNNL-13320, Pacific Northwest National Laboratory, Richland, WA.

Duncan, D. R. 2001. Spent Nuclear Fuel Project Technical Datebook, Vol. 1. HNF-SD-SNF-TI-015, Rev. 7, Fluor Hanford, Richland, WA.

Hilton, B. A. 2000. Review of Oxidation Rates of DOE Spent Nuclear Fuel Part 1: Metallic Fuel. ANL-00/24, Argonne National Laboratory, Idaho Falls, ID.

Makenas, B. J. 2000. Data Quality Objectives for Analysis of Hanford K Basin Sludge to Support Transport to and Storage in T Plant. HNF-5345, Rev. 0, Fluor Hanford, Richland, WA.

Reilly, M. A. 1998. Spent Nuclear Fuel Project Technical Databook, Vol. 1. HNF-SD-SNF-TI-015, Rev. 6, DE\&S Hanford, Inc., Richland, WA. [While the SNF Project has revised this document (Duncan 2001), no revisions were made to the values/equations of interest (Table 4-4)]. 


\section{Nomenclature}

The nomenclature used throughout this report, conveys a significant amount of information:

\begin{tabular}{|c|l||}
\hline Nomenclature & \multicolumn{1}{|c|}{ Definition } \\
\hline SNF & $\begin{array}{l}\text { Test includes crushed irradiated metallic uranium fuel } \\
\text { particles, with particles in the size range of "sludge" } \\
(<6350 \mu \mathrm{m}) .\end{array}$ \\
\hline Fuel Fragment & Single $\sim 7150-\mu \mathrm{m}$ fuel fragment $(3.72 \mathrm{~g})$ \\
\hline Can & Test includes KE canister sludge \\
\hline Floor & Test includes KE floor sludge \\
\hline Fines or M500 & Fuel particles less than $500 \mu \mathrm{m}$ \\
\hline Mid & Fuel particles between 500 and $2000 \mu \mathrm{m}$ \\
\hline P2000 & Fuel particles between 2000 and $6350 \mu \mathrm{m}$ \\
\hline 2-digit number & Initial test temperature, ${ }^{\circ} \mathrm{C}$ \\
\hline $\mathrm{S}$ & $\mathrm{S}=$ small; test conducted in 60 -ml reaction vessel \\
\hline $\mathrm{L}$ & $\mathrm{L}=$ large; test conducted in 800 -ml reaction vessel \\
\hline
\end{tabular}




\section{Contents}

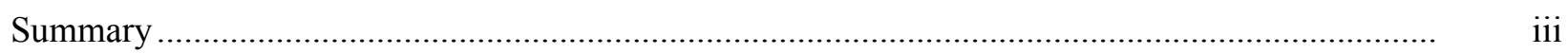

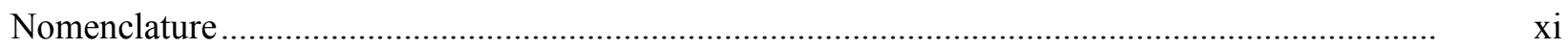

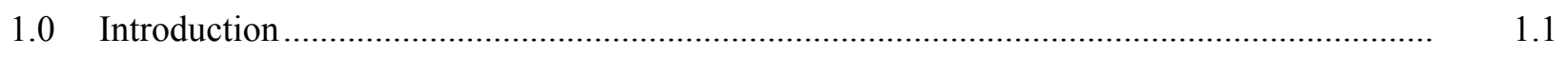

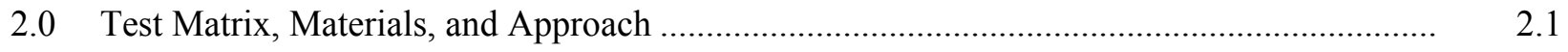

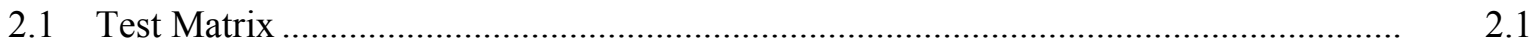

2.2 Test Materials .................................................................................................. 2.4

2.2.1 Fuel Particles ......................................................................................

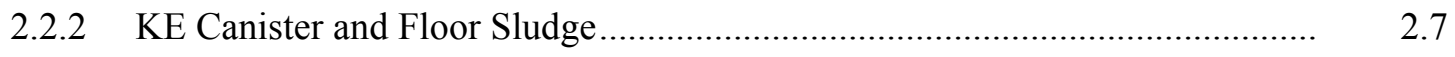

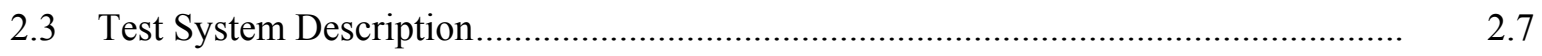

3.0 Gas Generation from Crushed Fuel and K Basin Sludge Samples ......................................... 3.1

3.1 Gas Generation from $60-\mathrm{ml}$ Reaction Vessel Tests at Ambient, $40^{\circ} \mathrm{C}, 60^{\circ} \mathrm{C}, 80^{\circ} \mathrm{C}$,

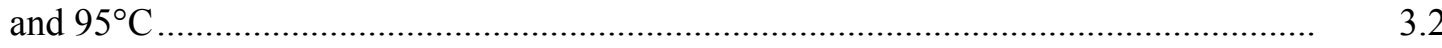

3.2 Gas Generation from Tests of Various-Sized Fuel Particles and a Single Fuel

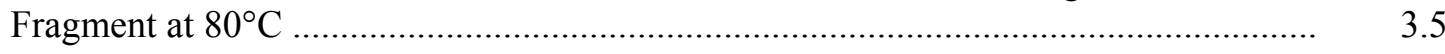

3.3 Gas Generation from Tests Run to Completion …………………………………….... 3.7

3.4 Gas Generation from 800-ml Reaction Vessel Tests with Sludge Blanketing............... 3.8

3.5 Gas Generation from Long-Term Test with Canister Sludge........................................ 3.9

4.0 Gas Generation Chemistry …………………………………………………………...

4.1 Uranium Corrosion and the Roles of Hydrogen, Oxygen, and Nitrogen ....................... 4.1

4.2 Nitrogen and the Possible Formation of Ammonia ......................................................... 4.3

4.3 Release of Fission Product Gases.........................................................................

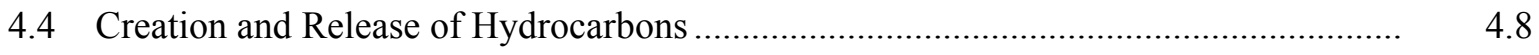

$4.5 \quad$ Carbon Dioxide Generation................................................................................... 4.9 
5.0 Analysis and Discussion of Gas Generation Results................................................

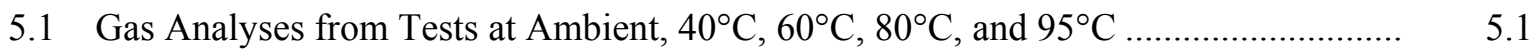

5.2 Gas Analyses from Tests with Various-Sized Fuel Particles and a

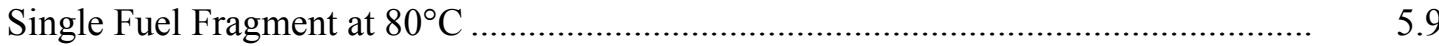

5.3 Gas Analyses from Tests Run to Completion …...................................................... 5.17

5.4 Gas Analyses from Tests with Sludge Blanketing …............................................... 5.20

5.5 Gas Analyses from Long-Term Test with Canister Sludge ........................................

5.6 Assessment of Uranium Metal Reacted During Testing ...........................................

6.0 Reaction Rate Data Analysis and Comparisons to Related Spent Nuclear Fuel and Literature Equation Rates.

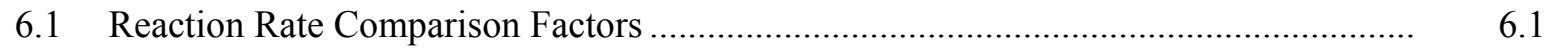

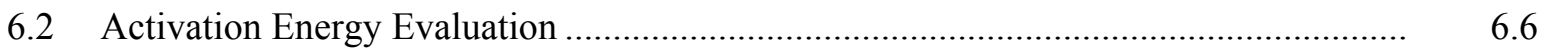

6.3 Conclusions from Reaction Rate Analysis ..............................................................

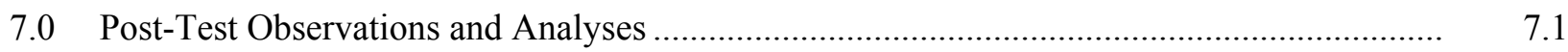

7.1 Recovery of Sludge/Fuel Particles from Reaction Vessels .......................................

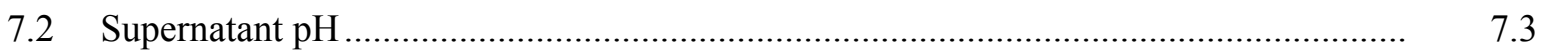

7.3 Settled Sludge Density Measurements and Void Fraction Estimates............................ 7.4

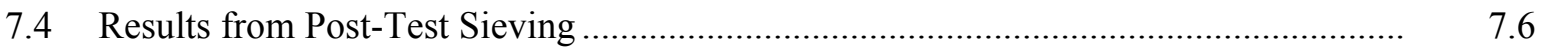

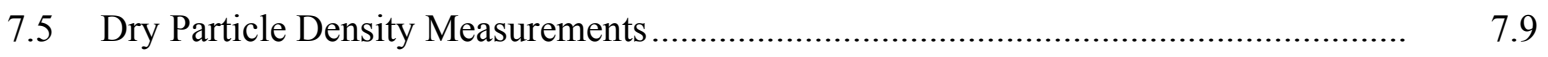

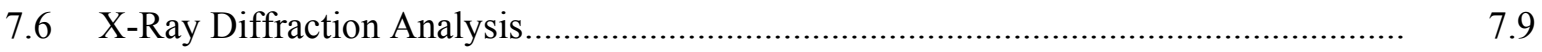

7.7 Volume Expansion Due to Corrosion................................................................

7.7.1 Initial Void Fraction, Settled Densities, and Uranium Content of Fuel Particles............................................................................................ $\quad 7.10$

7.7.2 Volumetric Expansion Based on Observations/Measurements .......................... $\quad 7.11$ 
7.7.3 Volumetric Expansion Based on Measured Properties

7.7.4 Comparison of Expansion Factor Results

8.0 References

8.1

Appendix A - Preparation of Fuel Particles for Series III

A. 1

Appendix B - Gas Analysis and Gas Generation Rate Data .....

B. 1

Appendix C - Analysis of Reaction Rate Data from Series III and Comparison to Related Spent Nuclear Fuel and Literature Equation Rates....

C. 1

Appendix D - Impacts of Radiolysis on Assumption of Oxygen-Free Reaction Environment.........

D. 1

Appendix E - Post-Test Sample Flowcharts and Photographs

E.1 


\section{Figures}

2.1 Photos of N Reactor Fuel Element 2540E (Used for Source of Fuel Particles) While Being Removed from Storage Canister in KE Basin

2.2 Layout of Gas Pressure Measurement and Gas Sampling Manifold

2.3 Schematic of a 60-ml Reaction Vessel

2.4 Schematic of an 800-ml Reaction Vessel.

3.1 Total Gas Generation of SNF + Can Fines 60S, SNF Mid 60S, SNF Mid 40S, and $\mathrm{SNF}+\mathrm{Can} 60 \mathrm{~S}$ at Ambient Hot Cell Temperature $\left(\sim 33^{\circ} \mathrm{C}\right)$

3.2 Total Gas Generation of SNF + Can Fines 60S, SNF Mid 60S, SNF Mid 40S, and $\mathrm{SNF}+\mathrm{Can} 60 \mathrm{~S}$ at Ambient Hot Cell Temperature (at Beginning and End of Run) to $95^{\circ} \mathrm{C}$..

3.3 Expanded Comparison of Total Gas Generation at $60^{\circ} \mathrm{C}, 80^{\circ} \mathrm{C}$, and $95^{\circ} \mathrm{C}$ from $500-2000-\mu \mathrm{m}$ Fuel Particles With and Without Blanketing by KC Can Comp Sludge

3.4 Total Gas Generation from Various-Sized Fuel Particles Reacted at $80^{\circ} \mathrm{C}$

3.5 Total Gas Generation for Fuel Particle Tests Run to Completion in 800-ml Reaction Vessels

3.6 Total Gas Generation for 800-ml Reaction Vessel Tests with Sludge Blanketing

3.7 Total Gas Generation for the KC-2/3 P250L Test in 800-ml Reaction Vessel

4.1 Comparison of Linear Penetration Uranium Corrosion Rates in Oxygen-Free Water.

4.2 Metallographic Image of Irradiated N Reactor Fuel Showing Uranium Carbide Inclusions...

6.1 Ratio of Actual to Theoretical Fuel Particle Diameters (Enhancement Factor) as a Function of Solids Depth (Sludge Blanket) in the Gas Generation Reaction Vessels (Reilly Fit)..........

6.2 Ratio of Actual to Theoretical Fuel Particle Diameters (Enhancement Factor) as a Function of Solids Depth (Sludge Blanket) in the Gas Generation Reaction Vessels (Hilton Fit) .........

6.3 Comparison of Total Gas Generation at $80^{\circ} \mathrm{C}$ from SNF M500 80L $(<500 \mu \mathrm{m})$ Test 6 with Gas Generation Profiles Predicted by the SNF Databook Equation and Hilton Equation for Monodisperse 290- $\mu \mathrm{m}$ Fuel Particles Containing 74.2 wt\% Uranium Metal

6.4 Comparison of Total Gas Generation at $80^{\circ} \mathrm{C}$ from SNF Mid 80L and SNF Mid 80L Dup (500 - 2000- $\mu \mathrm{m})$ (Tests 7 and 8) with Gas Generation Profiles Predicted by the SNF Databook Equation and Hilton Equation for Monodisperse 1250- $\mu \mathrm{m}$ Fuel Particles Containing 93 wt\% Uranium Metal 
6.5 Arrhenius Plot (Kr, Xe, and $\mathrm{H}_{2}$ Determined Inverse Cubic Rates) for SNF + Can Fines,

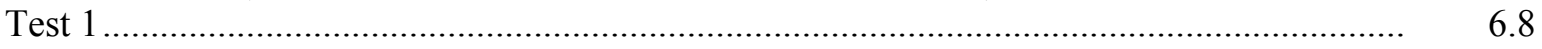

6.6 Arrhenius Plot (Kr, Xe, and $\mathrm{H}_{2}$ Determined Inverse Cubic Rates) for SNF + Can 60S, Test 2

6.7 Arrhenius Plot (Kr, $\mathrm{Xe}$, and $\mathrm{H}_{2}$ Determined Inverse Cubic Rates) for SNF Mid 60S, Test 3

6.8 Arrhenius Plot (Kr, Xe, and $\mathrm{H}_{2}$ Determined Inverse Cubic Rates) for SNF Mid 60S, SNF Mid 40S, SNF Mid 80L, and SNF Mid 80L Dup, Tests 3, 4, 7 and 8

6.9 Arrhenius Plot (Kr, Xe, and $\mathrm{H}_{2}$ Determined Inverse Cubic Rates) for SNF + Can 60L, Test 10

6.10 Arrhenius Plot (Kr, Xe, and $\mathrm{H}_{2}$ Determined Inverse Cubic Rates) for SNF + Floor 60L, Test 11

7.1 Density of Post-Test Sludge as a Function of Percent Fuel Particles (Uranium Metal) Reacted

7.2 Calculated Volume Percent Water in Post-Test Sludge as a Function of Percent Fuel Particles (Uranium Metal) Reacted.... 


\section{Tables}

2.1 Test Matrix for Series III Gas Generation Testing ......................................................... 2.2

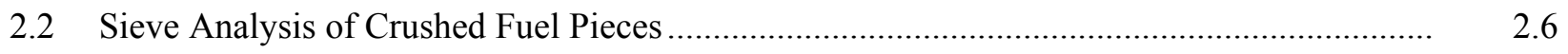

2.3 Chemical Compositions of Sludge Materials ................................................................ 2.8

$2.4 \quad$ Test Material Masses and Gas Sampling Events........................................................... 2.10

4.1 Nitrogen Consumed and Ratios of $\mathrm{m} / \mathrm{e}(17)$ to $\mathrm{m} / \mathrm{e}(18)$ Intensities .........................................

4.2 Fission Product Gas and Burnup Calculations for Tests Run to Completion ........................

4.3 Fission Product Gas Isotope Data for SNF M500 80L, SNF Mid 80L, and SNF Mid 80L Dup

5.1 Net and Cumulative Quantities of Gas Evolved for SNF + Can Fines 60S (Test 1) ............. 5.2

5.2 Net and Cumulative Quantities of Gas Evolved for SNF + Can 60S (Test 2) .....................

5.3 Net and Cumulative Quantities of Gas Evolved for SNF Mid 60S (Test 3) ........................ 5.4

5.4 Net and Cumulative Quantities of Gas Evolved for SNF Mid 40S (Test 4) ........................

5.5 Reacted Metallic Uranium Calculated from Gas Generation and Consumption

Reactions in Tests 1 Through 4 During Intervals for Which Gas Samples Were Analyzed.... $\quad 5.6$

5.6 Fission Product Gas Isotope Data for Tests 1 Through 4 Compared with ORIGEN Predictions.

5.7 Carbon Concentration Based on Hydrocarbon, $\mathrm{Kr}$, and Xe Gas Release for

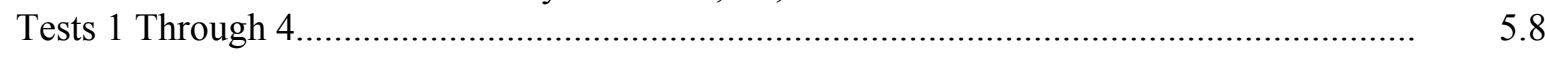

5.8 Carbon Dioxide Produced in Tests 1 Through 4 .......................................................... 5.8

5.9 Net and Cumulative Quantities of Gas Evolved for SNF P2000 80S (Test 5)..................... 5.10

5.10 Net and Cumulative Quantities of Gas Evolved for SNF M500 80L (Test 6) ...................... 5.11

5.11 Net and Cumulative Quantities of Gas Evolved for SNF Mid 80L (Test 7) ......................... 5.12

5.12 Net and Cumulative Quantities of Gas Evolved for SNF Mid 80L Dup (Test 8) .................. 5.13

5.13 Net and Cumulative Quantities of Gas Evolved for Fuel Fragment (Test 9) ........................ 5.14

5.14 Reacted Metallic Uranium Calculated from Gas Generation and Consumption Reactions in Tests 5 Through 9 
5.15 Fission Product Gas Isotope Data for Tests 5 Through 9 Compared with ORIGEN

Predictions

5.16 Carbon Concentration Based on Hydrocarbon, Kr, and Xe Gas Release

for Tests 5 Through 9

5.17 Carbon Dioxide Produced in Tests 5 Through 9.

5.18 Reacted Metallic Uranium Calculated from Gas Generation and Consumption

Reactions in Tests 6 Through 8

5.19 Carbon Concentration Based on Hydrocarbon, $\mathrm{Kr}$, and $\mathrm{Xe}$ Gas Release for

Tests 6 Through 8 .

5.20 Carbon Dioxide Produced in Tests 6 Through 8.

5.21 Net and Cumulative Quantities of Gas Evolved for SNF + Can 60L (Test 10) ..................... 5.21

5.22 Net and Cumulative Quantities of Gas Evolved for SNF + Floor 60L (Test 11) ................... 5.22

5.23 Reacted Metallic Uranium Calculated from Gas Generation and Consumption

Reactions in Tests 10 and 11.

5.24 Fission Product Gas Isotope Data for Tests 10 and 11.

5.25 Carbon Concentration Based on Hydrocarbon, Kr, and Xe Gas Release for

Tests 10 and 11.

5.26 Carbon Dioxide Produced in Tests 10 and 11

5.27 Net and Cumulative Quantities of Gas Evolved for KC-2/3 P250L (Test 12)

5.28 Reacted Metallic Uranium Calculated from Gas Generation and Consumption

5.29 Fission Product Gas Isotope Data for Tests with KC-2/3 P250

5.30 Uranium Metal Reacted During Series III Testing

6.1 Rate Comparison/Enhancement Factors

6.2 Inverse Cubic Rates and Fractional Rates for Series III Tests

6.3 Arrhenius Parameters and Activation Energies from Inverse Cubic Rates..

7.1 Matrix of Post-Testing Analyses.

7.2 $\mathrm{pH}$ of Supernatant Before and After Series III Tests 
7.3 Post-Test Settled Density Measurements.

7.4 Void Fraction Estimates Based on Measured Settled Densities and Assumed Post-Test

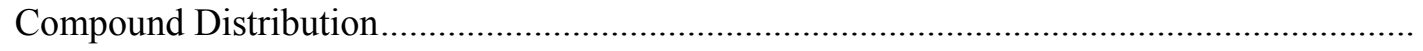

7.5 Sieving Results from Tests with Partially Reacted Fuel Particles ...................................

7.6 Sieving Results from Tests with Completely Reacted Fuel Particles ................................. 7.8

7.7 Percent Solids Results, SNF M500 80L and SNF Mid 80L Comp ....................................

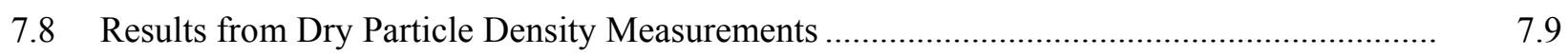

7.9 Crystalline Phases Identified by X-Ray Diffraction in Recovered Post-Test Material............ $\quad 7.10$

7.10 Volumetric Expansion Based on Direct Observation/Measurements ............................... 7.12 


\subsection{Introduction}

During the time that N Reactor fuel elements were stored at the Hanford K East (KE) and K West (KW) Basins, approximately $52 \mathrm{~m}^{3}$ of heterogeneous solid material (sludge) accumulated in the canisters, as well as on the floor and in the associated pits. In the Spent Nuclear Fuel (SNF) Project, sludge is defined as any material in the $\mathrm{K}$ Basins, including fuel fragments, that is less than or equal to $6350 \mu \mathrm{m}(0.25 \mathrm{in}$.) in diameter. This sludge consists of various proportions of fuel, structural corrosion products, windblown material, and miscellaneous constituents such as ion exchange material (both organic and inorganic) and paint chips (Makenas et al. 1996-99). Pearce (2001) describes the inventory and compositions of all $\mathrm{K}$ Basin sludge materials in detail. The path forward for managing the $\mathrm{K}$ Basin sludge calls for it to be packaged, shipped, and stored at T Plant until final processing at a future date.

The presence of uranium metal fuel particles in the K Basin sludge creates the primary technical challenge to the design of the storage systems to hold sludge removed from the K Basins. The metallic uranium within the sludge will corrode, hydrate, and, consequently, generate heat and hydrogen gas during storage. The product uranium oxides undergo further reactions to form more voluminous oxides. The results provided in this report are derived from the third series (Series III) of gas generation tests on K Basin sludge materials conducted for the SNF Sludge Handling Project by Pacific Northwest National Laboratory (PNNL) to support design and safety analyses.

The Series I testing (Delegard et al. 2000) focused on gas generation from KE Basin floor and canister sludge collected using a consolidated sampling technique (Baker et al. 2000). The Series II testing (Bryan et al. 2001) examined gas generation from mixed and unmixed and fractionated KE canister sludge, along with floor and pit sludge (Weasel Pit, North Loadout Pit, Dummy Elevator Pit, and Tech View Pit) from the KE Basin. A key objective for the Series I and II tests was to estimate the uranium metal content in the various sludge types from the gas generation/composition data.

The purpose of the Series III testing was to examine the gas generation behavior of irradiated uranium metal fuel particles typical of those expected from fuel elements stored at the K Basins. For these tests, coupons cut from a fuel element were crushed and fractionated by particle size using wire mesh sieves. The fractionated and unfractionated fuel particles were tested with and without KE Basin sludge addition. This testing was funded and conducted under the direction of the SNF Sludge Handling Project managed by Fluor Hanford, and in accordance with the Sampling and Analysis Plan for Sludge from the 105-K Basins to Support Transport to and Storage in T Plant (Baker et al. 2000). Fluor Hanford Technology Management provided co-funding for many of the data analyses conducted in this report.

The overall goal for this testing was to collect gas generation rate and composition data under known conditions to evaluate the reactivity of uranium metal fuel particles that will likely be present in several types of K Basin sludge. Further explanation on the rationale for this work is provided in the Data Quality Objectives for Analysis of Hanford K Basin Sludge to Support Transport to and Storage in T Plant (Makenas 2000). Specific objectives for Series III testing included:

1. Provide data on irradiated uranium metal fuel corrosion rates that can be compared with published studies on metallic uranium corrosion kinetics and thus be used to more accurately assign appropriate reaction rate safety factors. 
2. Obtain reaction rate data as a function of temperature and fuel particle size to calibrate and validate thermal stability and gas generation models that are being used to provide nominal and safety-basis input for the design of sludge storage and shipping systems.

3. Determine how larger fuel fragments $(500$ to $6350 \mu \mathrm{m})$ corrode. In particular, determine whether the fuel fragments corrode isotropically in accordance with a "shrinking core" model or undergo significant fragmentation in the course of corrosion.

4. Evaluate the effects of an intimate overlying sludge layer ("blanket") on the uranium metal corrosion rate. Determine whether the source of the overlying sludge layer (e.g., floor vs. canister sludge) affects the uranium metal reaction rate. Also determine if the overlying sludge layer affects the corrosion rate differently for various sizes of fuel particles.

5. Continue the test with $\mathrm{KC}-2 / 3 \mathrm{P} 250 \mathrm{~L}(>250-\mu \mathrm{m}$ particle size canister sludge known to contain $\sim 7.4 \mathrm{wt} \%$ uranium metal) at ambient hot cell temperature to further evaluate the behavior of sludge with a high uranium content under conditions similar to those expected at $\mathrm{T}$ Plant.

In this report, Section 2.0 describes the Series III test matrix, test materials (sludge and fuel particles), equipment, and experimental methods. Section 3.0 presents the overall gas generation data derived from the testing. During the tests, hydrogen; fission gas products, krypton and xenon; methane and higher hydrocarbons; and carbon dioxide were generated or released. At the same time, oxygen and nitrogen in the test vessels were consumed (depleted), with nitrogen occasionally evolved. Section 4.0 details the chemistry of the gas-generating (and consuming) reactions. Section 5.0 interprets and discusses the test results, and Section 6.0 compares the observed gas generation rates to the rates predicted by the literature. Observations and results from post-test analyses are reported in Section 7.0. The appendices contain a detailed description of the fuel particle generation (Appendix A), gas composition and rate data (Appendix B), uranium corrosion rate comparisons (Appendix C), impacts of radiolysis on corrosion chemistry assumptions (Appendix D), and flowcharts and photographs from post-test analyses (Appendix E).

Most of the tests to meet the specific objectives for Series III were conducted from September 2000 through January 2001. One test began in October 1999 and another in July 2000. A technical data package containing the laboratory bench sheets and raw data (i.e., test instructions, laboratory record book pages, calibrations, temperature and pressure data, gas analysis data, etc.) is available from Fluor Hanford (R. B. Baker). 


\subsection{Test Matrix, Materials, and Approach}

This section describes the overall test approach and methods used for the Series III tests. A general description of the testing and the test matrix is provided in Section 2.1, which also gives the rationale for each test. Section 2.2 describes the fuel particles and the sludge sample collection and handling, along with the chemical and radiochemical composition of the samples and KE Basin sludge samples used in the testing (a detailed description of the fuel particle preparation from fuel coupons is given in Appendix A). The equipment and measurement techniques used for the testing are described in Section 2.3. The same test equipment and system (with some upgrades) used in Series I and II are used here; see Appendix A of the Series I report (Delegard et al. 2000) for information on system verification, reliability, and performance.

\subsection{Test Matrix}

For the gas generation testing, 0 to $26.4 \mathrm{~g}$ of fuel particles, with 19.1 to $98.9 \mathrm{~g}$ of settled sludge samples, were placed into 60 - or $800-\mathrm{ml}$ (nominal volumes) reaction vessels. The use of a $60-$ or $800-\mathrm{ml}$ reaction vessel for a particular test was based on the anticipated rate of gas production as estimated from the mass and particle size distribution of the fuel particles and the test temperature(s). The objective in the vessel selection was to avoid the need for frequent gas sampling or venting (i.e., equipment has pressure limits).

The reaction vessels were sealed, connected to the manifold system, and purged (multiple purges) with neon gas to remove air, then heated to the target conditions. Temperatures and gas pressures were monitored continuously. Gas samples were collected periodically from each vessel during the testing period and analyzed via mass spectrometry. The gas generated during some test intervals was vented without sampling. The decisions to sample or vent were based on consistency of results from previous analyses and the costs of the analyses. The tests were conducted at a series of temperatures, ranging from ambient $\left(\sim 33^{\circ} \mathrm{C}\right)$ to $95^{\circ} \mathrm{C}$. The use of a series of elevated temperatures provided data to evaluate the reaction kinetics and accelerated the reactions to provide conclusive gas generation data within a reasonable testing period. After the testing at elevated temperatures was completed, the test vessels were monitored for 330 to $1660 \mathrm{hr}$ at ambient hot cell temperature.

The Series III testing consisted of 12 tests. Table 2.1 shows the general matrix, including the mass of fuel particles (and any associated cladding) used in each test, along with the size range of the particles. The type and quantity of the added $\mathrm{K}$ Basin sludge are also listed, as well as the reaction vessel size, test temperatures, and total duration of the tests. The last column in Table 2.1 shows, based on hydrogen gas evolution, the fraction of uranium metal in the sample that was corroded at the completion of the test series. Tests 1 through 8 and 10 and 11 were initiated on September 25, 2000, and continued approximately $3000 \mathrm{hr}$ through January 2001. Test 9 was initiated during the start of the Series II tests (July 24, 2000) and continued through the Series III testing. Test 12 was started during the Series I testing (October 1999) and continued through Series II and III to provide a long-term test at conditions similar to those expected during T Plant storage. All tests were conducted at the High-Level Radiochemistry Facility (325A HLRF) in the Radiochemical Processing Laboratory (RPL), Hanford 300 Area. 
Table 2.1. Test Matrix for Series III Gas Generation Testing

\begin{tabular}{|c|c|c|c|c|c|c|c|c|c|c|}
\hline \multirow[b]{2}{*}{$\begin{array}{l}\text { Test } \\
\text { No. }\end{array}$} & \multirow[b]{2}{*}{ Test ID } & \multicolumn{2}{|c|}{ Fuel Particles } & \multicolumn{2}{|c|}{$\begin{array}{l}\text { KE Basin Sludge } \\
\text { Sample Fraction }\end{array}$} & \multirow{2}{*}{$\begin{array}{c}\text { Approx. } \\
\text { Reaction } \\
\text { Vessel } \\
\text { Volume, } \\
\text { ml }\end{array}$} & \multicolumn{2}{|c|}{ Test Temperature, ${ }^{\circ} \mathrm{C}$} & \multirow[b]{2}{*}{$\begin{array}{c}\text { Total Test } \\
\text { Duration, hr }\end{array}$} & \multirow{2}{*}{$\begin{array}{c}\text { Fraction of } \\
\text { Fuel Sample } \\
\text { Reacted, } \\
\text { wt\% }^{(\mathbf{b})}\end{array}$} \\
\hline & & $\begin{array}{l}\text { Particle Size } \\
\text { Fraction, } \mu \mathbf{m}\end{array}$ & Mass, $\mathrm{g}$ & Sample ID & Mass, $\mathbf{g}$ & & \begin{tabular}{|} 
Sept. 25, \\
2000
\end{tabular} & $\begin{array}{l}\text { Additional Temps. } \\
\text { After Nov. 6, 2000 }\end{array}$ & & \\
\hline 1 & $\begin{array}{l}\text { SNF + Can Fines } \\
60 \mathrm{~S}\end{array}$ & $0-500$ & 4.27 & $\begin{array}{l}\mathrm{KC}-2 / 3 \\
\mathrm{M} 250\end{array}$ & 26.43 & 60 & 60 & $\begin{array}{l}80-1 \text { week } \\
95-1 \text { week }\end{array}$ & 2965 & 37 \\
\hline 2 & SNF + Can 60S & $500-2000$ & 8.39 & $\begin{array}{l}\text { KC Can } \\
\text { Comp }\end{array}$ & 19.10 & 60 & 60 & $\begin{array}{l}80-1 \text { week } \\
95-1 \text { week }\end{array}$ & 2999 & 18 \\
\hline 3 & SNF Mid 60S & $500-2000$ & 8.24 & None & 0 & 60 & 60 & $\begin{array}{l}80-1 \text { week } \\
95-1 \text { week }\end{array}$ & 2981 & 26 \\
\hline 4 & SNF Mid 40S & $500-2000$ & 8.61 & None & 0 & 60 & 40 & $\begin{array}{c}60 \text { - } 2 \text { weeks } \\
80 \text { - } 2 \text { days }\end{array}$ & 3133 & 12 \\
\hline 5 & SNF P2000 80S & $2000-6350$ & 9.95 & None & 0 & 60 & 80 & 80 & 2908 & 47 \\
\hline 6 & SNF M500 80L & $0-500$ & 7.95 & None & 0 & 800 & 80 & 95 - to completion ${ }^{(b)}$ & 3124 & 74 \\
\hline 7 & SNF Mid 80L & $500-2000$ & 8.87 & None & 0 & 800 & 80 & 95 - to completion ${ }^{(b)}$ & 2988 & 91 \\
\hline 8 & $\begin{array}{l}\text { SNF Mid 80L } \\
\text { Dup }\end{array}$ & $500-2000$ & 8.15 & None & 0 & 800 & 80 & 95 - to completion ${ }^{(b)}$ & 2988 & 95 \\
\hline 9 & Fuel Fragment ${ }^{(\mathrm{c})}$ & $\sim 7150$ & 3.72 & None & 0 & 60 & 80 & 80 & 4250 & 33 \\
\hline 10 & SNF + Can 60L & $0-6350$ & 26.36 & $\begin{array}{l}\text { KC Can } \\
\text { Comp }\end{array}$ & 68.14 & 800 & 60 & $\begin{array}{l}80-1 \text { week } \\
95-1 \text { week }\end{array}$ & 3011 & 32 \\
\hline 11 & SNF + Floor $60 \mathrm{~L}$ & $0-6350$ & 25.52 & KC Floor & 98.87 & 800 & 60 & $\begin{array}{l}80-1 \text { week } \\
95-1 \text { week }\end{array}$ & 3011 & 25 \\
\hline 12 & KC-2/3 P250L ${ }^{(d)}$ & None & 0 & KC-2/3 P250 & 65.98 & 800 & $\sim 33$ & 33 & 10,143 & 1.5 \\
\hline \multicolumn{11}{|c|}{$\begin{array}{l}\text { (a) Tests } 1-8,10 \text {, and } 11 \text { began with } \sim 138 \mathrm{hr} \text { at ambient hot cell temperature }\left(\sim 33^{\circ} \mathrm{C}\right) \text {, but Test } 1 \text { self-heated to } \sim 38^{\circ} \mathrm{C} \text {. All tests ended at ambient hot cell temperature. } \\
\text { (b) Percent of the original sample mass, as uranium, corroded. Percent of sample reacted is based on the total gas generated, gas analyses, the } \mathrm{H}_{2} \text { fraction in the } \\
\text { analyzed gases, the assumption that the added fuel particles were pure uranium metal (except Test } 12 \text {, which was based on } \sim 7.4 \text { wt } \% \text { metal in the starting sludge) } \\
\text { and the reaction } \mathrm{U}+2 \mathrm{H}_{2} \mathrm{O} \rightarrow \mathrm{UO}_{2}+2 \mathrm{H}_{2} \mathrm{O} \text {. As seen for Tests } 6 \text { through } 8 \text {, which were reacted to completion, the initial crushed fuel was not } 100 \% \text { uranium } \\
\text { metal, but evidently contained some cladding and uranium oxide. } \\
\text { (c) Started during Series II testing (July 2000). } \\
\text { (d) Started during Series I testing (October 1999). }\end{array}$} \\
\hline
\end{tabular}


The specific objectives of the tests are briefly described below. Some of the tests were designed to satisfy several objectives.

Test 1. Fuel particles with M250 canister composite sludge. This test was conducted to provide information on how a blanket of fine sludge particles $(<250 \mu \mathrm{m})$ affects the corrosion rate of fine fuel particles $(<500 \mu \mathrm{m})$. The material tested is expected to be similar to the sludge that will be collected in the KW Basin integrated water system settler tanks.

Tests 2 and 3. Fuel particles with and without whole canister sludge composite. Test 2 was conducted with $500-2000-\mu \mathrm{m}$ fuel particles and a whole (i.e., entire sludge particle size distribution: 0 to $6350 \mu \mathrm{m})$ canister sludge composite. Results from this test can be compared directly with those of Test 3 $(500-2000-\mu \mathrm{m}$ fuel particles with no sludge) to provide information on how a canister sludge blanket (whole distribution or typical particle size range) affects the corrosion rate of $500-2000-\mu \mathrm{m}$ fuel particles.

Tests 3 through 8. Gas generation from fuel particles only (no sludge) as a function of temperature. These tests provide data to derive the activation energy for comparison with the reaction rate expression derived from testing with KC-2/3 P250 (Series I) and the baseline SNF Databook, Vol. 1 rate (Reilly 1998). Because the geometries and compositions of the fuel particles were roughly known by sieving, more accurate rate analyses could be conducted than in the Series I and II testing. Also, the results from these tests are partially applicable to the KW knockout pot sludge.

Test 5. Larger fuel particles $(2000-6350 \mu \mathrm{m})$ without sludge. This test was conducted to determine the fate of $2000-6350-\mu \mathrm{m}$ particles as a function of reaction time. Specifically, do the large pieces corrode isotropically or fracture into smaller pieces to give higher surface areas and increased reaction rates?

Tests 5 through 9. Fuel particles only (no sludge) as a function of particle size at $80^{\circ} \mathrm{C}$. These tests were performed to verify that fuel particles of various sizes corrode in a similar manner (i.e., show that particles or larger fragments do not undergo significant crumbling while corroding) and to allow comparison of reaction rates as a function of particle size at $80^{\circ} \mathrm{C}$. Additionally, these tests provided baseline data to interpret the results from Tests 3 and 4.

Tests 6 through 8. Gas generation from fuel particles reacted to completion (no sludge). These tests were reacted to completion to determine the uranium metal concentrations in the $<500-\mu \mathrm{m}$ and $500-$ $2000-\mu \mathrm{m}$ fuel particles and to determine the fission product gas (xenon and krypton) concentrations in the fuel so that percent uranium metal reacted to in other tests, derived from the same fuel particles, could be estimated by measurements of fission product gas release. This information provides insight into the metal concentration of the sludge generated from the fuel element washing system. Analysis of the reacted material also provides data for estimating volumetric sludge expansion from corrosion.

Test 9. Unmodified single fragment from fuel element break. This test, which was started in Series II and continued for $\sim 3900 \mathrm{hr}$ at $80^{\circ} \mathrm{C}$, was conducted to provide gas generation information on an unmodified fuel fragment (i.e., fragment was not generated from crushing a larger piece) and to give an indication whether large pieces of fuel will crumble into smaller fragments during storage at $\mathrm{T}$ Plant. It served to provide early information on how uranium metal behaves in the gas generation test system before the start of Series III testing. 
Tests 10 and 11. Full spectrum fuel particles and sludge. These tests were conducted to provide baseline data using the full spectrum of fuel particle sizes and associated sludge. These tests were also conducted to examine the effect of the sludge type (i.e., canister versus floor) on the gas generation rate.

Test 12. Continuation of ambient temperature test (sludge only) with KC-2/3 P250 in an 800-ml vessel. This test, which continued for more than $10,140 \mathrm{hr}$ ( $\sim 14$ months) at ambient hot cell temperature, was performed to provide insight into how canister sludge in T Plant may behave during prolonged storage. Tests with the same material at elevated temperatures (Series I) showed that the material contains $\sim 7.4 \mathrm{wt} \%$ uranium metal on a settled sludge basis. This test also provided data for comparison to short-term observations of gas generation in KE canister sludge samples collected in 1996 (see Delegard et al. 2000).

\subsection{Test Materials}

The materials used in the Series III gas generation tests consisted of 1) fuel particles that were generated from crushing spent fuel coupons and 2) sludge that was collected from the KE Basin floor and fuel storage canisters during the consolidated sludge sampling campaign in 1999. In addition, one test system contained an intact, single piece from a fuel element.

\subsubsection{Fuel Particles}

Details on the preparation of the fuel particles, including photos of the crushed particles, are provided in Appendix A. Archived coupons of an irradiated metallic uranium fuel element from KE Basin were crushed in the laboratory hot cell to resemble the crumbled fuel pieces expected in the retrieved K Basin sludge (Pearce 2001). The spent fuel starting materials were selected from archived characterization samples of KE Basin SNF element SFEC04, 2540E that were stored in a closed storage can under inert argon gas in the RPL. The outer fuel element had originally been taken by the SNF Project from a canister in cubicle 2540 in the KE Basin to obtain fuel coupons for drying studies. This element was highly damaged, exhibiting a significant number of fractures and breaks (Figure 2.1). A large number of coupons were cut from this element (under an inert atmosphere) for fuel characterization studies. Only coupons with at least one broken face were selected for crushing, since the uranium near a fractured or damaged fuel element surface tends to be more brittle and friable than uranium even a short distance from the fracture. The intact fuel fragment used in the Fuel Fragment test (see Table 2.1, Test 9) was also obtained from Element 2540E.

A Plattner's mortar and pestle, made from hardened alloy tool steel, and a manipulator-held hammer were used for crushing the fuel. The crushed fuel was screened frequently to monitor the size reduction progress, and oversized pieces were re-crushed as necessary. As a result of the frequent screening, the quantity of fines generated was minimized. Crushing and screening was continued until the appropriate quantities of the various size fractions of fuel particles were generated. The crushed particles were re-combined and sieved through a series of US Standard Testing Sieves to characterize the size distribution and to produce the specified particle size fractions for the gas generation tests. Subsampling of the fractions involved coning and quartering. Table 2.2 provides particle size distribution information and estimates of the average particle diameter size (mass basis) of each fraction used for the testing. The average particle diameter values are used in the analyses to evaluate and interpret the uranium corrosion rates determined from the gas generation data. 


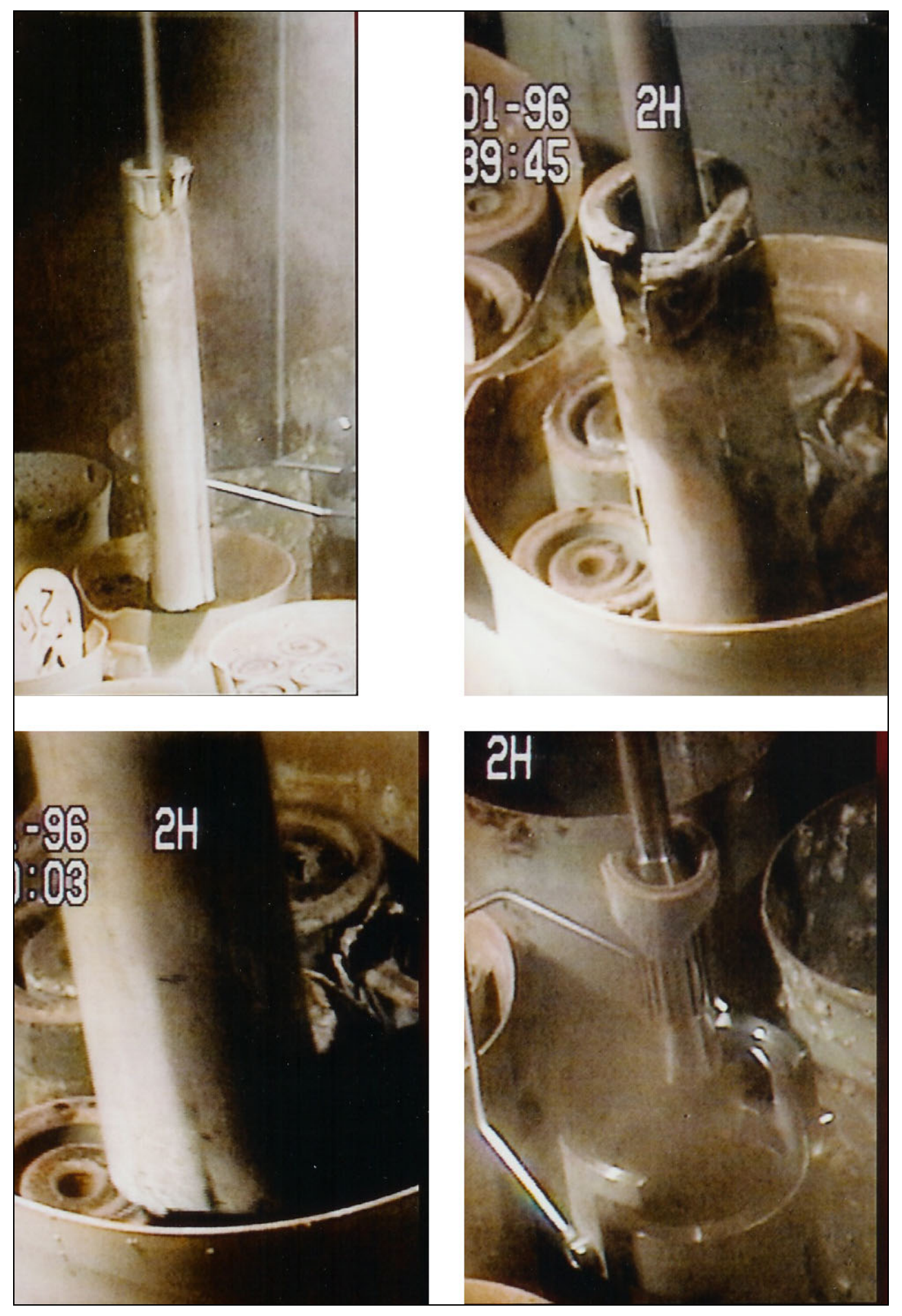

Figure 2.1. Photos of N Reactor Fuel Element 2540E (Used for Source of Fuel Particles) While Being Removed from Storage Canister in KE Basin 
Table 2.2. Sieve Analysis of Crushed Fuel Pieces

\begin{tabular}{|c|c|c|c|c|c|}
\hline Screen Size, $\mu \mathbf{m}$ & $\begin{array}{l}\text { Mass on } \\
\text { Screen, } g\end{array}$ & $\begin{array}{c}\text { Cumulative \% } \\
\text { Fines }\end{array}$ & $\begin{array}{c}\text { Composited Size } \\
\text { Fraction for Gas } \\
\text { Generation Tests, } \mu \mathrm{m}\end{array}$ & Mass, $\mathbf{g}$ & 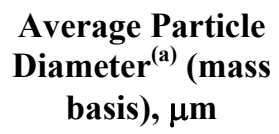 \\
\hline 6350 (1/4-in.) & 0.00 & 100.0 & \multirow{3}{*}{$-6350+2000$} & \multirow{3}{*}{20.70} & \multirow{3}{*}{3310} \\
\hline 3350 & 5.93 & 93.7 & & & \\
\hline 2000 & 14.86 & 77.8 & & & \\
\hline 1000 & 37.94 & 37.4 & \multirow{2}{*}{$-2000+500$} & \multirow{2}{*}{57.58} & \multirow{2}{*}{1250} \\
\hline 500 & 19.79 & 16.3 & & & \\
\hline 300 & 7.97 & 7.8 & \multirow{3}{*}{-500} & \multirow{3}{*}{15.23} & \multirow{3}{*}{290} \\
\hline 180 & 3.51 & 4.1 & & & \\
\hline $\begin{array}{l}-180 \text { (bottom } \\
\text { pan) }\end{array}$ & 3.85 & N/A & & & \\
\hline \multicolumn{3}{|c|}{ Separated prior to screening $\rightarrow$} & $\begin{array}{l}-6350 \text { (full } \\
\text { distribution) }\end{array}$ & 51.92 & 1550 \\
\hline \multicolumn{6}{|c|}{$\begin{array}{l}\text { (a) For the material retained on each sieve, the effective diameter was assumed to be the average of the } \\
\text { retaining sieve and the sieve just above it. For a given fraction (e.g., }-2000+500) \text {, the effective } \\
\text { diameters were multiplied by the mass of fragments retained and summed for each sieve in the fraction. } \\
\text { The value was divided by the total mass of fragments in the fraction to yield the Average Particle } \\
\text { Diameter. }\end{array}$} \\
\hline
\end{tabular}

The effective particle diameter $(\sim 7150 \mu \mathrm{m})$ for the intact Fuel Fragment used in Test 9 was calculated by assuming that the $3.59 \mathrm{~g}$ initial uranium metal mass $\left(3.72 \mathrm{~g}\right.$ initial mass minus $0.13 \mathrm{~g}$ cladding; $19.0 \mathrm{~g} / \mathrm{cm}^{3}$ $\mathrm{U}$ metal density) existed as a smooth sphere. A sphere of this diameter has a $161-\mathrm{mm}^{2}$ surface area. In comparison, the measured surface area (not including clad surfaces) based on dimensions taken in the hot cell with calipers was $\sim 225 \mathrm{~mm}^{2}$ (see Appendix C, footnote b). The surface associated with the two clad faces would give an additional $50 \mathrm{~mm}^{2}$ of uranium surface area once the cladding was removed. An element of conservatism is added, therefore, when comparing the observed gas generation rates with those predicted for spherical particles corroding at published rates. This is because the corrosion rates are directly proportional to the metal surface area, and the spherical geometry has the lowest weight-specific surface area of any geometric solid.

Even though the metal fuel coupons subjected to crushing came from a highly damaged fuel element, and were fairly brittle (did not behave as a malleable metal), the crushing required very significant physical effort. Attempts were made to crush fuel from a broken, highly fractured, end piece of the element that weighed about $440 \mathrm{~g}$. The cladding was pealed from this end piece, and the exposed fuel was aggressively attacked using a pick and a hammer. However, after considerable effort, only about $20 \mathrm{~g}$ of fuel pieces were recovered for further crushing, and the end piece (now in three separate pieces) was returned to storage. These observations are consistent with those of Pitner (1997), who removed cladding around breached and cracked areas on three fuel elements. Pitner (1997) concluded: "Despite the fragile physical appearance of some of the elements examined, they actually proved to retain substantial structural integrity. Considerable effort was required to physically break the elements or break fuel pieces free from the elements." 


\subsubsection{KE Canister and Floor Sludge}

The sludge used in Series III tests was collected by the Hanford SNF Project from the KE Basin floor and fuel canisters in March and April 1999 (Baker et al. 2000). A consolidated sampling technique was employed for collecting this material (i.e., sludge from several locations was combined during sampling to form "consolidated samples," Pitner 1999). Several combined or composited samples were used in the tests and were designated: KC-2/3 M250 and P250 (canister sludge), KC Can Comp, and KC Floor Comp. The KC-2/3 canister sludge composite was prepared by combining two consolidated sludge samples (i.e., KC-2, collected from canisters containing highly damaged fuel, and $\mathrm{KC}-3$, collected from canisters containing moderately damaged fuel). Portions of these samples were sieved to separate particles greater than or "plus" $250 \mu \mathrm{m}$ (designated as P250) from particles less than or "minus" $250 \mu \mathrm{m}$ (designated as M250). On a mass basis, approximately $75 \%$ of $\mathrm{KC}-2 / 3$ was composed of particles that passed through a $250-\mu \mathrm{m}$ sieve. Details on the preparation and composition of the KC-2/3 canister composite are provided in Bredt et al. (1999).

The KC Can Comp was a combination of settled sludge samples KC-2/3 [85 vol\% (or 89.4 mass\%)] and KC-1 [15 vol\% (10.6 mass\%)]. Sample KC-1 was a single pull sample collected from a single fuel storage canister barrel containing highly damaged fuel elements. The KC Can Comp was a volumeweighted composite, based on the number of sampling locations, that represented the whole sludge particle size distribution. Similarly, the KC Floor Comp represented the whole sludge particle size distribution of floor sludge. The KC Floor Comp was a combination of settled sludge collected from the $\mathrm{KE} \mathrm{Basin} \mathrm{floor} \mathrm{between} \mathrm{slotted} \mathrm{fuel} \mathrm{canister} \mathrm{barrels} \mathrm{containing} \mathrm{highly} \mathrm{damaged} \mathrm{fuel} \mathrm{(i.e.,} \mathrm{sample} \mathrm{KC-4),}$ $40 \mathrm{vol} \%$ (41 mass \%), and floor sludge collected away from fuel canisters and away from areas known to contain high concentrations of organic ion exchange resin (i.e., sample KC-5), $60 \mathrm{vol} \%$ (59 mass\%). Details on the preparation and compositions of the composites are provided in Silvers et al. (2000).

Table 2.3 summarizes key characterization data from the consolidated sludge samples used in the gas generation testing. The values given for percent solids and density for sludge material are those measured at the time the samples were characterized. Very limited characterization was performed on the KC Can Comp and the KC Floor Comp; therefore, the values for these materials were calculated using the weighted average values of the sludge materials that were used to prepare the composites. As expected, the canister sludge material (KC-1, KC-2/3, and $\mathrm{KC}$ Can Comp) contains a significantly higher concentration of uranium than the floor sludge material (KC-4, KC-5, and $\mathrm{KC}$ Floor Comp). Also, Table 2.3 shows that the $\mathrm{M} 250$ fraction of $\mathrm{KC}-2 / 3$ has about twice the uranium concentration as the P250 fraction. The floor sludges contain a higher concentration of aluminum, iron, and silicon.

\subsection{Test System Description}

For Tests 1 through 11, 3.7 to $26.4 \mathrm{~g}$ of fuel particles, or a single fuel fragment in Test 9 (continued from Series II testing), were placed into $60-\mathrm{ml}$ or $800-\mathrm{ml}$ reaction vessels. For the tests in which sludge was used, 19.1 to $98.9 \mathrm{~g}$ of settled KE Basin sludge were added into the reaction vessels on top of the fuel particles. Test $12, \mathrm{KC}-2 / 3 \mathrm{P} 250 \mathrm{~L}$, continued from Series I testing, included only sludge. K Basin decant water was added to provide abundant excess water for the uranium metal corrosion reactions and to prevent sludge dry-out. The reaction vessels then were closed, and the vapor space purged and evacuated multiple times with $99.999 \%$ neon gas. The approved procedures and data from loading the reaction 
Table 2.3. Chemical Compositions of Sludge Materials

\begin{tabular}{|c|c|c|c|c|c|c|c|}
\hline \multicolumn{8}{|c|}{ Concentration, Dry Basis, wt $\%$} \\
\hline Analyte & KC-1 & $\begin{array}{c}\mathrm{KC}-2 / 3 \\
\mathrm{M} 250\end{array}$ & $\begin{array}{c}\mathrm{KC}-2 / 3 \\
\mathrm{P250}\end{array}$ & KC Can Comp ${ }^{(a)}$ & KC-4 & KC-5 & $\begin{array}{c}\text { KC Floor } \\
\text { Comp }^{(\mathbf{b})}\end{array}$ \\
\hline $\mathrm{Al}$ & 2.04 & 1.92 & 13.5 & 4.2 & 6.82 & 15.3 & 11.8 \\
\hline $\mathrm{Ca}$ & 0.12 & 0.096 & 0.23 & 0.125 & 1.04 & 0.481 & 0.711 \\
\hline $\mathrm{Fe}$ & 0.339 & 1.43 & 2.91 & 1.60 & 24.3 & 16.1 & 19.5 \\
\hline $\mathrm{Mg}$ & 0.020 & 0.030 & 0.088 & 0.40 & 0.330 & 0.177 & 0.240 \\
\hline $\mathrm{Na}$ & 0.237 & 0.216 & 0.301 & 0.235 & 0.360 & 0.374 & 0.368 \\
\hline $\mathrm{Si}$ & 0.160 & 0.29 & 1.94 & 0.60 & 4.91 & 5.46 & 5.23 \\
\hline $\mathrm{U}^{(\mathrm{c})}$ & 68.6 & 68.3 & 35.2 & 61.8 & 16.6 & 6.36 & 10.6 \\
\hline Analyte & \multicolumn{7}{|c|}{ Concentration, Dry Basis, $\mu \mathrm{Ci} / \mathrm{g}$} \\
\hline${ }^{60} \mathrm{Co}$ & 0.209 & 0.438 & 0.451 & 0.416 & 1.09 & 1.10 & 1.10 \\
\hline${ }^{137} \mathrm{Cs}$ & 392 & 401 & 2040 & 721 & 1680 & 1320 & 1468 \\
\hline${ }^{154} \mathrm{Eu}$ & 8.62 & 8.84 & 6.32 & 8.32 & 2.60 & 1.11 & 1.72 \\
\hline${ }^{241} \mathrm{Am}$ & 122 & 96.3 & 75.5 & 94.9 & 29.3 & 13.1 & 19.8 \\
\hline${ }^{238} \mathrm{Pu}$ & 21.5 & 17.4 & 13.0 & 17.0 & 4.91 & 1.99 & 3.19 \\
\hline${ }^{239,240} \mathrm{Pu}$ & 142 & 123 & 90.3 & 119 & 39.2 & 13.1 & 23.8 \\
\hline \multicolumn{8}{|c|}{ Concentration, Settled Sludge Basis, wt\% } \\
\hline Analyte & KC-1 & $\begin{array}{c}\mathrm{KC}-2 / 3 \\
\mathrm{M} 250\end{array}$ & $\begin{array}{c}\mathrm{KC}-2 / 3 \\
\mathrm{P250}\end{array}$ & KC Can Comp & KC-4 & KC-5 & $\begin{array}{c}\text { KC Floor } \\
\text { Comp } \\
\end{array}$ \\
\hline $\mathrm{Al}$ & 1.11 & 1.13 & 6.90 & 2.95 & 2.20 & 5.36 & 4.30 \\
\hline $\mathrm{Ca}$ & 0.065 & 0.057 & 0.118 & 0.087 & 0.335 & 0.168 & 0.26 \\
\hline $\mathrm{Fe}$ & 0.184 & 0.842 & 1.49 & 1.13 & 7.82 & 5.64 & 7.09 \\
\hline $\mathrm{Mg}$ & 0.011 & 0.018 & 0.045 & 0.028 & 0.106 & 0.062 & 0.09 \\
\hline $\mathrm{Na}$ & 0.129 & 0.127 & 0.154 & 0.165 & 0.116 & 0.131 & 0.13 \\
\hline $\mathrm{Si}$ & 0.087 & 0.171 & 0.991 & 0.420 & 1.58 & 1.91 & 1.91 \\
\hline $\mathrm{U}^{(\mathrm{c})}$ & 37.2 & 41.2 & 18.0 & 43.4 & 5.35 & 2.23 & 3.85 \\
\hline Solids & 54.3 & 58.9 & 51.1 & 70.1 & 32.2 & 35.0 & 36.4 \\
\hline $\begin{array}{l}\text { Density, } \\
\mathrm{g}^{(\mathrm{d})} \mathrm{cm}^{3}\end{array}$ & 1.49 & $2.13(2.4)$ & 2.11 & $2.19(2.4)$ & 1.24 & 1.19 & $1.24(1.4)$ \\
\hline Analyte & \multicolumn{7}{|c|}{ Concentration, Settled Sludge Basis, $\mu \mathrm{Ci} / \mathrm{g}$} \\
\hline${ }^{60} \mathrm{Co}$ & 0.113 & 0.258 & 0.230 & 0.292 & 0.351 & 0.385 & 0.40 \\
\hline${ }^{137} \mathrm{Cs}$ & 213 & 236 & 1042 & 506 & 541 & 462 & 534 \\
\hline${ }^{154} \mathrm{Eu}$ & 4.68 & 5.21 & 3.23 & 5.83 & 0.837 & 0.389 & 0.63 \\
\hline${ }^{241} \mathrm{Am}$ & 66.2 & 56.7 & 38.6 & 66.6 & 9.43 & 4.69 & 7.19 \\
\hline${ }^{238} \mathrm{Pu}$ & 11.7 & 10.2 & 6.64 & 11.9 & 1.58 & 0.697 & 1.16 \\
\hline${ }^{239,240} \mathrm{Pu}$ & 77.1 & 72.4 & 46.1 & 83.1 & 12.6 & 4.59 & 8.67 \\
\hline $\begin{array}{l}\text { (a) KC Can } \\
19.6 \mathrm{wt}^{0} \\
\text { (b) KC Floo } \\
\text { (c) U measu } \\
\text { (d) Value sh } \\
\text { Sludge c }\end{array}$ & $\begin{array}{l}\text { p was pre } \\
\text {-2/3 P250 } \\
\text { mp was p1 } \\
\text { oy kinetic } \\
\text { is density } \\
\text { ty values }\end{array}$ & $\begin{array}{l}\text { ared by con } \\
\text { pared by co } \\
\text { hosphoresce } \\
\text { measured at } \\
\text { parenthese }\end{array}$ & $\begin{array}{l}\text { nbining settl } \\
\text { mbining set } \\
\text { ence. } \\
\text { time of che } \\
\text { s are those } n\end{array}$ & $\begin{array}{l}\text { sludge material: } 10 \text {. } \\
\text { d sludge material: } 4 \\
\text { cal analysis and use } \\
\text { asured just before st }\end{array}$ & $\begin{array}{l}\text { wt } \% \mathrm{KC}-1, \mathrm{t} \\
\mathrm{wt} \% \mathrm{KC}-4 \\
\text { determine } \\
\text { ing the Serie }\end{array}$ & $\begin{array}{l}\text { vt } \% \mathrm{KC}-2 / 3 \\
58.9 \mathrm{wt} \% \mathrm{~K} \\
\text { d sludge cor } \\
\text { testing. }\end{array}$ & 50, and \\
\hline
\end{tabular}


vessels are documented in PNNL Test Instruction, 40143-T11 ["K Basin Fuel Fragment (minus 1/4 in.) Gas Generation Tests - Series III"]. The reaction vessels were heated to maintain selected temperatures; the gas pressure was monitored continuously; and gas samples were collected periodically and analyzed via mass spectrometry. In some instances, the generated gas was vented from the reaction vessels with no offgas sample collected. The decisions to sample or vent the offgas were based on the consistency and predictability of offgas analyses and the costs of the analyses. Table 2.4 presents details on the gas sampling/gas venting events throughout the course of the testing.

The reaction vessels and the gas manifold system (Figure 2.2) used for the gas generation tests are similar to those described in the previous gas generation testing with K Basin sludge: Delegard et al. (2000), Series I, and Bryan et al. (2001), Series II. Each vessel has a separate pressure transducer on the gas manifold line. The entire surface of the reaction system exposed to the sludge sample is stainless steel, except for a gold-plated copper gasket seal between the flange and the top of the reaction vessel.

Temperatures and pressures were recorded every $10 \mathrm{~s}$ on a Campbell Scientific CR10 data logger; the data were averaged every $20 \mathrm{~min}$ and saved in a computer file. Temperature and pressure data were also manually logged once each working day. Copies of the temperature and pressure data collected by the data logger (and the respective gas generation calculations) are included in the data package, which is available from Fluor Hanford (R. B. Baker).

Figure 2.3 illustrates a $60-\mathrm{ml}$ reaction vessel and shows where the thermocouples are placed inside and outside the vessel. These reaction vessels are 304 stainless steel cylinders, each internally $\sim 1.75 \mathrm{~cm}$ diameter and $27 \mathrm{~cm}$ high (internal volume $\sim 60 \mathrm{~cm}^{3}$ ). [Note: the internal volume of each reaction vessel was accurately measured.] For the gas generation testing, each reaction vessel was wrapped in heating tape and insulated. Two thermocouples were attached to the external body, one for temperature control and one for over-temperature protection. Two thermocouples were inserted through the flange. The thermocouple centered in the lower half of the reaction vessel monitored the temperature of the liquid phase; the one centered in the upper half monitored the gas phase temperature within the vessel. The reaction vessels were placed in a hot cell and connected by a thin $(0.0058-\mathrm{cm}$ inside diameter) stainless steel tube to the gas manifold outside the hot cell. A stainless steel filter (2- $\mu \mathrm{m}$ pore size, Nupro) protected the tubing and manifold from contamination. A thermocouple was attached to this filter as well.

Figure 2.4 illustrates an $800-\mathrm{ml}$ reaction vessel and the thermocouple locations. These reaction vessels are 304 stainless steel cylinders, each internally $6.35 \mathrm{~cm}$ diameter and $\sim 25$ to $27 \mathrm{~cm}$ high (internal volume $\sim 800$ to $850 \mathrm{~cm}^{3}$ ). [Note: the internal volume of each reaction vessel was accurately measured.] For the tests, these vessels were configured similar to the $60-\mathrm{ml}$ reaction vessels. Two thermocouples were inserted through the lid. The thermocouple centered in the lower half of the reaction vessel monitored the temperature of the sample; the one centered in the upper half monitored the gas phase temperature within the vessel. The reaction vessels were placed in a hot cell and connected by a thin tube $(0.0058-\mathrm{cm}$ inside diameter) to the gas manifold outside the hot cell. Again, a stainless steel filter (2- $\mu$ m pore size, Nupro) was added to protect the tubing and manifold from contamination, and a thermocouple was attached to the filter. Like the $60-\mathrm{ml}$ vessels, the $800-\mathrm{ml}$ vessels were equipped with heating tape and two external thermocouples (not shown in Figure 2.4), one for control and one for over-temperature protection. 
Table 2.4. Test Material Masses and Gas Sampling Events

\begin{tabular}{|c|c|c|c|c|c|c|}
\hline \multirow{2}{*}{\begin{tabular}{|c|} 
Test Number, \\
Identification, and \\
Reaction Vessel Size
\end{tabular}} & \multirow[b]{2}{*}{ Mass, $g$} & \multirow{2}{*}{$\begin{array}{c}\text { Approx. } \\
\text { Temp., }{ }^{\circ} \mathbf{C}^{(a)}\end{array}$} & \multirow{2}{*}{$\begin{array}{l}\text { Start } \\
\text { Date }\end{array}$} & \multirow{2}{*}{$\begin{array}{l}\text { Sample } \\
\text { Date }\end{array}$} & \multicolumn{2}{|c|}{ Time (hr) at Temperature } \\
\hline & & & & & Run Interval $^{(\mathbf{b})}$ & Total \\
\hline $\begin{array}{l}1 \\
\text { SNF }+ \text { Can Fines } 60 \mathrm{~S} \\
60 \mathrm{ml}\end{array}$ & $\begin{array}{l}\text { 4.27, particles } \\
26.43 \text {, sludge }\end{array}$ & $\begin{array}{c}\text { Hot Cell } \\
60 \\
60 \\
60 \\
60 \\
80 \\
95 \\
\text { Hot Cell }\end{array}$ & $\begin{array}{c}9 / 14 / 00 \\
9 / 20 / 00 \\
9 / 25 / 00 \\
10 / 12 / 00 \\
10 / 26 / 00 \\
11 / 7 / 00 \\
11 / 14 / 00 \\
11 / 16 / 00\end{array}$ & $\begin{array}{c}9 / 20 / 00^{(\mathrm{c})} \\
9 / 25 / 00 \\
10 / 12 / 00 \\
10 / 26 / 00 \\
11 / 6 / 00^{(\mathrm{d})} \\
11 / 13 / 00 \\
11 / 16 / 00 \\
1 / 24 / 01^{\text {(e) }}\end{array}$ & 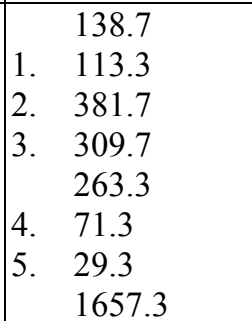 & $\begin{array}{ll} & 138.7 \\
1 . & 252.0 \\
\text { 2. } & 633.7 \\
3 . & 943.3 \\
& 1206.7 \\
4 . & 1278.0 \\
5 . & 1307.3 \\
& 2964.7\end{array}$ \\
\hline $\begin{array}{l}2 \\
\text { SNF }+ \text { Can } 60 \mathrm{~S} \\
60 \mathrm{ml}\end{array}$ & \begin{tabular}{|l} 
8.39, particles \\
19.10 , sludge
\end{tabular} & $\begin{array}{c}\text { Hot Cell } \\
60 \\
60 \\
80 \\
95 \\
\text { Hot Cell } \\
\end{array}$ & $\begin{array}{c}9 / 14 / 00 \\
9 / 20 / 00 \\
10 / 12 / 00 \\
11 / 7 / 00 \\
11 / 14 / 00 \\
11 / 16 / 00 \\
\end{array}$ & $\begin{array}{c}9 / 20 / 00^{(\mathrm{c})} \\
10 / 12 / 00 \\
11 / 6 / 00^{(\mathrm{d})} \\
11 / 13 / 00 \\
11 / 16 / 00 \\
1 / 24 / 01^{(\mathrm{e})}\end{array}$ & \begin{tabular}{|ll} 
& 138.3 \\
1. & 507.3 \\
& 594.0 \\
2. & 72.7 \\
3. & 29.3 \\
& 1657.3
\end{tabular} & $\begin{array}{ll} & 138.3 \\
1 . & 645.7 \\
& 1239.7 \\
2 . & 1312.3 \\
3 . & 1341.7 \\
& 2999.0\end{array}$ \\
\hline \begin{tabular}{|l}
3 \\
SNF Mid $60 \mathrm{~S}$ \\
$60 \mathrm{ml}$
\end{tabular} & 8.24, particles & $\begin{array}{c}\text { Hot Cell } \\
60 \\
60 \\
60 \\
80 \\
95 \\
\text { Hot Cell } \\
\end{array}$ & $\begin{array}{c}9 / 14 / 00 \\
9 / 20 / 00 \\
10 / 6 / 00 \\
10 / 26 / 00 \\
11 / 7 / 00 \\
11 / 14 / 00 \\
11 / 16 / 00 \\
\end{array}$ & $\begin{array}{c}9 / 20 / 00^{(\mathrm{c})} \\
10 / 6 / 00 \\
10 / 26 / 00 \\
11 / 6 / 00^{(\mathrm{d})} \\
11 / 13 / 00 \\
11 / 16 / 00 \\
1 / 24 / 01^{(\mathrm{e})} \\
\end{array}$ & \begin{tabular}{|ll} 
& 138.3 \\
1. & 362.7 \\
2. & 458.7 \\
& 263.3 \\
3. & 71.0 \\
4. & 29.3 \\
& 1657.3 \\
\end{tabular} & $\begin{array}{ll} & 138.3 \\
1 . & 501.0 \\
2 . & 959.7 \\
& 1223.0 \\
3 . & 1294.0 \\
4 . & 1323.3 \\
& 2980.7 \\
\end{array}$ \\
\hline \begin{tabular}{|l}
4 \\
SNF Mid 40S \\
$60 \mathrm{ml}$
\end{tabular} & 8.61, particles & $\begin{array}{c}\text { Hot Cell } \\
40 \\
60 \\
80 \\
\text { Hot Cell } \\
\end{array}$ & $\begin{array}{c}9 / 14 / 00 \\
9 / 20 / 00 \\
11 / 7 / 00 \\
11 / 20 / 00 \\
11 / 22 / 00 \\
\end{array}$ & $\begin{array}{c}9 / 20 / 00^{(\mathrm{c})} \\
11 / 6 / 00 \\
11 / 20 / 00^{(\mathrm{d})} \\
11 / 22 / 00^{(\mathrm{c})} \\
1 / 24 / 01^{(\mathrm{e})}\end{array}$ & \begin{tabular}{|ll}
1. & 138.3 \\
1. & 1127.7 \\
& 311.0 \\
& 47.3 \\
& 1508.3 \\
\end{tabular} & \begin{tabular}{|ll} 
& 138.3 \\
1. & 1266.0 \\
& 1577.0 \\
& 1624.3 \\
& 3132.7 \\
\end{tabular} \\
\hline \begin{tabular}{|l}
5 \\
SNF P2000 80S \\
$60 \mathrm{ml}$
\end{tabular} & 9.95, particles & $\begin{array}{c}\text { Hot Cell } \\
80 \\
80 \\
80 \\
80 \\
80 \\
80 \\
80 \\
80 \\
80 \\
80 \\
\text { Hot Cell } \\
\end{array}$ & $\begin{array}{c}9 / 14 / 00 \\
9 / 20 / 00 \\
9 / 25 / 00 \\
10 / 2 / 00 \\
10 / 6 / 00 \\
10 / 12 / 00 \\
10 / 20 / 00 \\
10 / 26 / 00 \\
11 / 6 / 00 \\
11 / 20 / 00 \\
12 / 15 / 00 \\
1 / 10 / 01 \\
\end{array}$ & $\begin{array}{c}9 / 20 / 00^{(\mathrm{c})} \\
9 / 25 / 00 \\
10 / 2 / 00 \\
10 / 6 / 00 \\
10 / 12 / 00 \\
10 / 20 / 00 \\
10 / 26 / 00 \\
11 / 6 / 00^{(\mathrm{d})} \\
11 / 20 / 00^{(\mathrm{d})} \\
12 / 15 / 00^{(\mathrm{d})} \\
1 / 10 / 01 \\
1 / 24 / 01^{(\mathrm{e})} \\
\end{array}$ & \begin{tabular}{|ll} 
& 138.3 \\
1. & 114.7 \\
2. & 92.7 \\
3. & 73.7 \\
4. & 123.0 \\
5. & 165.7 \\
6. & 124.0 \\
& 263.3 \\
& 329.3 \\
& 593.3 \\
7. & 552.3 \\
& 337.3 \\
\end{tabular} & $\begin{array}{ll} & 138.3 \\
1 . & 253.0 \\
2 . & 345.7 \\
3 . & 419.3 \\
4 . & 542.3 \\
5 . & 708.0 \\
6 . & 832.0 \\
& 1095.3 \\
& 1424.7 \\
& 2018.0 \\
7 . & 2570.3 \\
& 2907.7 \\
\end{array}$ \\
\hline \begin{tabular}{|l}
6 \\
SNF M500 80L \\
$800 \mathrm{ml}$
\end{tabular} & 7.95, particles & $\begin{array}{c}\text { Hot Cell } \\
80 \\
80 \\
95 \\
\text { Hot Cell }\end{array}$ & $\begin{array}{c}9 / 14 / 00 \\
9 / 20 / 00 \\
9 / 25 / 00 \\
11 / 6 / 00 \\
11 / 28 / 00\end{array}$ & $\begin{array}{c}9 / 20 / 00^{(\mathrm{c})} \\
9 / 25 / 00 \\
11 / 6 / 00 \\
11 / 28 / 00 \\
1 / 24 / 01^{(\mathrm{e})}\end{array}$ & \begin{tabular}{|ll} 
& 136.3 \\
1. & 115.3 \\
2. & 1001.7 \\
3. & 501.0 \\
& 1369.7 \\
\end{tabular} & \begin{tabular}{|ll} 
& 136.3 \\
1. & 251.7 \\
2. & 1253.3 \\
3. & 1754.3 \\
& 3124.0 \\
\end{tabular} \\
\hline
\end{tabular}


Table 2.4. (contd)

\begin{tabular}{|c|c|c|c|c|c|c|}
\hline \multirow{2}{*}{\begin{tabular}{|c|} 
Test Number, \\
Identification, and \\
Reaction Vessel Size \\
\end{tabular}} & \multirow[b]{2}{*}{ Mass, $\mathrm{g}$} & \multirow[b]{2}{*}{$\begin{array}{l}\text { Approx. } \\
\text { Temp., }^{\circ}{ }^{(a)}\end{array}$} & \multirow[b]{2}{*}{$\begin{array}{l}\text { Start } \\
\text { Date }\end{array}$} & \multirow[b]{2}{*}{$\begin{array}{l}\text { Sample } \\
\text { Date }\end{array}$} & \multicolumn{2}{|c|}{ Time (hr) at Temperature } \\
\hline & & & & & Run Interval $^{(\mathbf{b})}$ & Total \\
\hline $\begin{array}{l}7 \\
\text { SNF Mid 80L } \\
800 \mathrm{ml}\end{array}$ & 8.87 , particles & $\begin{array}{c}\text { Hot Cell } \\
80 \\
80 \\
95 \\
95 \\
\text { Hot Cell } \\
\end{array}$ & $\begin{array}{c}9 / 14 / 00 \\
9 / 20 / 00 \\
10 / 12 / 00 \\
11 / 6 / 00 \\
11 / 28 / 00 \\
1 / 10 / 01 \\
\end{array}$ & $\begin{array}{c}9 / 20 / 00^{(\mathrm{c})} \\
10 / 12 / 00 \\
11 / 6 / 00 \\
11 / 28 / 00 \\
1 / 10 / 01 \\
1 / 24 / 01^{(\mathrm{e})} \\
\end{array}$ & \begin{tabular}{|ll} 
& 136.3 \\
1. & 505.0 \\
2. & 594.0 \\
3. & 501.0 \\
4. & 917.3 \\
& 334.0 \\
\end{tabular} & \begin{tabular}{|ll} 
& 136.3 \\
1. & 641.3 \\
2. & 1235.3 \\
3. & 1736.3 \\
4. & 2653.7 \\
& 2987.7 \\
\end{tabular} \\
\hline $\begin{array}{l}8 \\
\text { SNF Mid 80L Dup } \\
800 \mathrm{ml}\end{array}$ & 8.15, particles & $\begin{array}{c}\text { Hot Cell } \\
80 \\
80 \\
95 \\
95 \\
\text { Hot Cell } \\
\end{array}$ & $\begin{array}{c}9 / 14 / 00 \\
9 / 20 / 00 \\
10 / 12 / 00 \\
11 / 6 / 00 \\
11 / 28 / 00 \\
1 / 10 / 01 \\
\end{array}$ & $\begin{array}{c}9 / 20 / 00^{(\mathrm{c})} \\
10 / 12 / 00 \\
11 / 6 / 00 \\
11 / 28 / 00 \\
1 / 10 / 01 \\
1 / 24 / 01^{(\mathrm{e})} \\
\end{array}$ & \begin{tabular}{|ll} 
& 136.3 \\
1. & 505.0 \\
2. & 594.3 \\
3. & 501.0 \\
4. & 917.3 \\
& 334.0 \\
\end{tabular} & $\begin{array}{ll} & 136.3 \\
1 . & 641.3 \\
2 . & 1235.7 \\
3 . & 1736.7 \\
4 . & 2654.0 \\
& 2988.0\end{array}$ \\
\hline $\begin{array}{l}9 \\
\text { Fuel Fragment } \\
60 \mathrm{ml}\end{array}$ & 3.72 , fragment & $\begin{array}{c}80 \\
80 \\
80 \\
80 \\
80 \\
\text { Hot Cell }\end{array}$ & $\begin{array}{c}7 / 24 / 00 \\
8 / 7 / 00 \\
9 / 5 / 00 \\
10 / 12 / 00 \\
12 / 15 / 00 \\
1 / 10 / 01\end{array}$ & $\begin{array}{c}8 / 7 / 00 \\
9 / 5 / 00 \\
10 / 12 / 00 \\
12 / 15 / 00^{(\mathrm{d})} \\
1 / 10 / 01 \\
1 / 24 / 01^{(\mathrm{e})}\end{array}$ & $\begin{array}{ll}1 . & 307.3 \\
2 . & 663.3 \\
3 . & 884.0 \\
4 . & 1505.0 \\
5 . & 553.0 \\
& 337.3\end{array}$ & $\begin{array}{ll}1 . & 307.3 \\
2 . & 970.7 \\
3 . & 1854.7 \\
4 . & 3359.7 \\
5 . & 3912.7 \\
& 4250.0\end{array}$ \\
\hline $\begin{array}{l}10 \\
\text { SNF + Can 60L } \\
800 \mathrm{ml}\end{array}$ & $\begin{array}{c}\text { 26.36, particles } \\
66.98, \text { sludge }\end{array}$ & $\begin{array}{c}\text { Hot Cell } \\
60 \\
60 \\
80 \\
95 \\
\text { Hot Cell } \\
\end{array}$ & $\begin{array}{c}9 / 14 / 00 \\
9 / 20 / 00 \\
10 / 12 / 00 \\
11 / 6 / 00 \\
11 / 13 / 00 \\
11 / 16 / 00 \\
\end{array}$ & $\begin{array}{c}9 / 20 / 00^{(\mathrm{c})} \\
10 / 12 / 00 \\
11 / 6 / 00^{(\mathrm{d})} \\
11 / 13 / 00 \\
11 / 16 / 00 \\
1 / 24 / 01^{(\mathrm{e})} \\
\end{array}$ & \begin{tabular}{|ll} 
& 136.3 \\
1. & 503.0 \\
2. & 594.7 \\
3. & 71.0 \\
4. & 47.7 \\
& 1658.3 \\
\end{tabular} & $\begin{array}{ll} & 136.3 \\
1 . & 639.3 \\
2 . & 1234.0 \\
3 . & 1305.0 \\
4 . & 1352.7 \\
& 3011.0 \\
\end{array}$ \\
\hline $\begin{array}{l}11 \\
\text { SNF + Floor 60L } \\
800 \mathrm{ml}\end{array}$ & $\begin{array}{c}\text { 25.52, particles } \\
98.87 \text {, sludge }\end{array}$ & $\begin{array}{c}\text { Hot Cell } \\
60 \\
80 \\
95 \\
\text { Hot Cell } \\
\end{array}$ & $\begin{array}{c}9 / 14 / 00 \\
9 / 20 / 00 \\
11 / 6 / 00 \\
11 / 13 / 00 \\
11 / 16 / 00 \\
\end{array}$ & $\begin{array}{c}9 / 20 / 00^{(\mathrm{c})} \\
11 / 6 / 00 \\
11 / 13 / 00 \\
11 / 16 / 00 \\
1 / 24 / 01^{(\mathrm{e})} \\
\end{array}$ & \begin{tabular}{|ll} 
& 136.3 \\
1. & 1104.7 \\
2. & 71.0 \\
3. & 47.7 \\
& 1658.3 \\
\end{tabular} & \begin{tabular}{|ll} 
& 136.3 \\
1. & 1241.0 \\
2. & 1312.0 \\
3. & 1359.7 \\
& 3011.0 \\
\end{tabular} \\
\hline $\begin{array}{l}12 \\
\text { KC-2/3 P250L } \\
800 \mathrm{ml}\end{array}$ & 65.98, sludge & Hot Cell & $\begin{array}{c}10 / 7 / 99 \\
10 / 26 / 99 \\
3 / 13 / 00 \\
4 / 19 / 00 \\
6 / 20 / 00 \\
7 / 27 / 00 \\
8 / 15 / 00 \\
11 / 6 / 00 \\
\end{array}$ & $\begin{array}{c}10 / 25 / 99 \\
3 / 13 / 00 \\
4 / 19 / 00 \\
6 / 20 / 00 \\
7 / 27 / 00^{(f)} \\
8 / 15 / 00 \\
11 / 6 / 00 \\
1 / 10 / 01 \\
\end{array}$ & $\begin{array}{ll}\text { 1. } & 453.7 \\
\text { 2. } & 3332.3 \\
\text { 3. } & 880.0 \\
\text { 4. } & 1479.7 \\
& 888.0 \\
\text { 5. } & 455.0 \\
\text { 6. } & 1990.3 \\
7 . & 1552.0\end{array}$ & $\begin{array}{ll}1 . & 453.7 \\
\text { 2. } & 3786.0 \\
\text { 3. } & 4666.0 \\
\text { 4. } & 6145.7 \\
& -- \\
\text { 5. } & 6600.7 \\
6 . & 8591.0 \\
\text { 7. } & 10143.0 \\
\end{array}$ \\
\hline $\begin{array}{l}\text { (a) Target test temper } \\
\text { deviate from the t } \\
\text { (b) Numbers }(1-7) \text { in } \\
\text { (c) Dates of temperatu } \\
\text { (d) Dates of gas venti } \\
\text { (e) End date (January } \\
\text { date for all tests e } \\
\text { (f) Disconnected from }\end{array}$ & $\begin{array}{l}\text { dicate when ga } \\
\text { re transitions } \\
\text { g. } \\
24,2001) \text { with } \\
\text { cept KC-2/3 P } \\
\text { gas collection }\end{array}$ & $\begin{array}{l}\text { amples were } \\
\text { nout sampling } \\
\text { sampling. } \mathrm{Pr} \\
\text { 0L, which wa } \\
\text { paratus in this }\end{array}$ & $\begin{array}{l}\text { Ire } \sim 33^{\circ} \mathrm{C} \text {. } \\
\text { kinetics ana } \\
\text { llected. } \\
\mathrm{r} \text { venting. } \\
\text { ssure and te } \\
\text { monitored } \mathrm{x} \\
\text { nterval. }\end{array}$ & $\begin{array}{l}\text { erature } \\
\text { il Januar }\end{array}$ & $\begin{array}{l}\text { urements we } \\
2001 .\end{array}$ & en to this \\
\hline
\end{tabular}




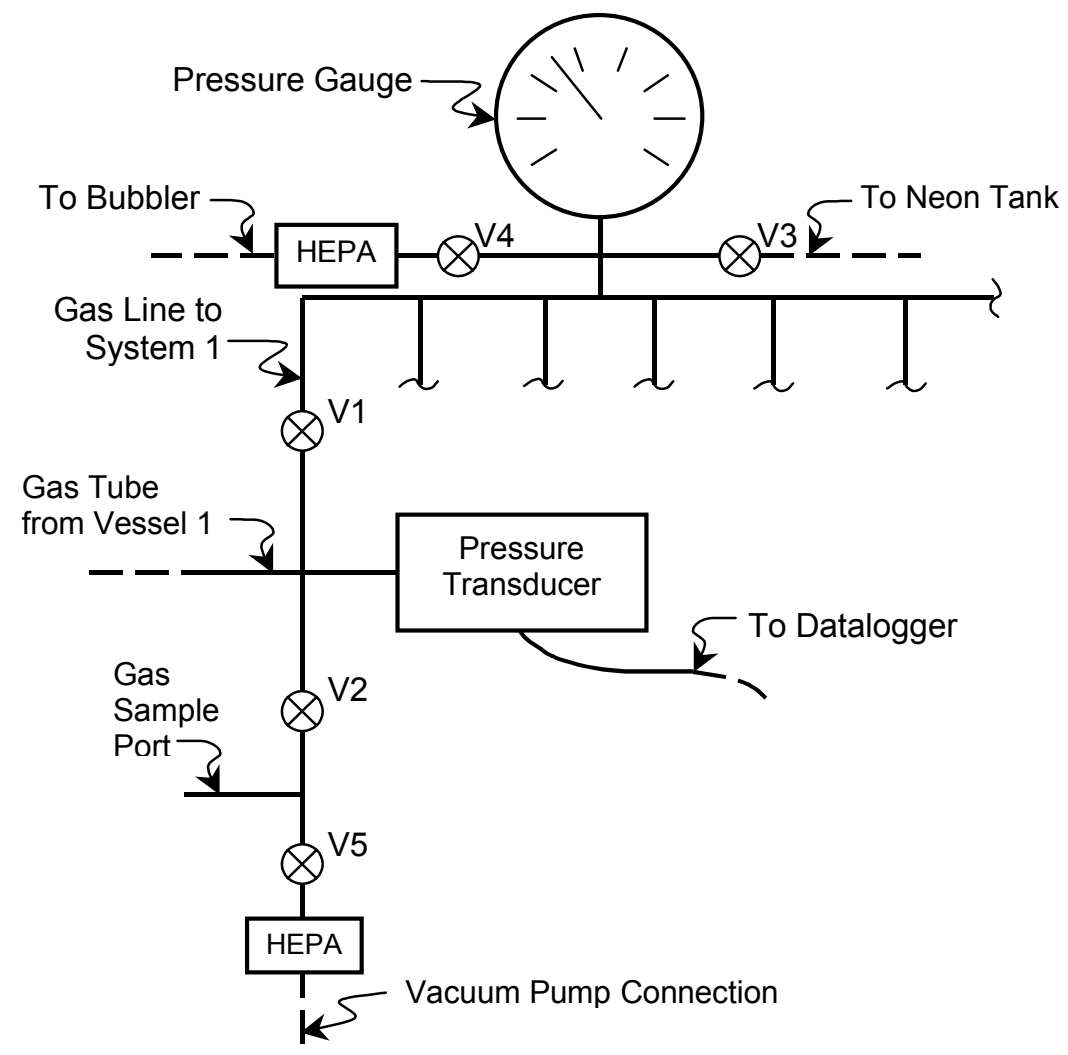

Figure 2.2. Layout of Gas Pressure Measurement and Gas Sampling Manifold. Includes Details for One of 12 Systems.

An atmospheric pressure gauge was attached to the data logger. The pressure in each system was the sum of atmospheric pressure and the differential pressure between the system internal and external (atmospheric) pressures. An inert cover gas (neon) was required to identify product gases and isolate the chemical reactions occurring in the settled sludge. Argon was not used because it served as an indicator of atmospheric contamination. The neon gas used was analyzed independently by mass spectrometry and determined to contain no impurities in concentrations significant enough to warrant correction.

At the start of each run, each system was purged by at least eight cycles of pressurizing with $99.999 \%$ neon at $45 \mathrm{psi}(310 \mathrm{kPa})$ and venting to the atmosphere. The systems were at atmospheric pressure, about $745 \mathrm{~mm} \mathrm{Hg}(99.3 \mathrm{kPa})$, when sealed. The vessels were then heated, and the temperature set points were adjusted to keep the material within $1^{\circ} \mathrm{C}$ of the desired liquid phase temperatures.

As necessary during the testing (i.e., to avoid exceeding the pressure rating of the pressure transducers) and at the end of each reaction sequence, the reaction vessels were allowed to cool to ambient temperature and then, as noted earlier, either a sample of the gas was taken from the headspace for mass spectrometry analysis or the gas was vented. Gases in the reaction system were assumed to be well mixed. The metal bottles used for gas collection were equipped with a valve and had a volume of approximately $75 \mathrm{ml}$. 


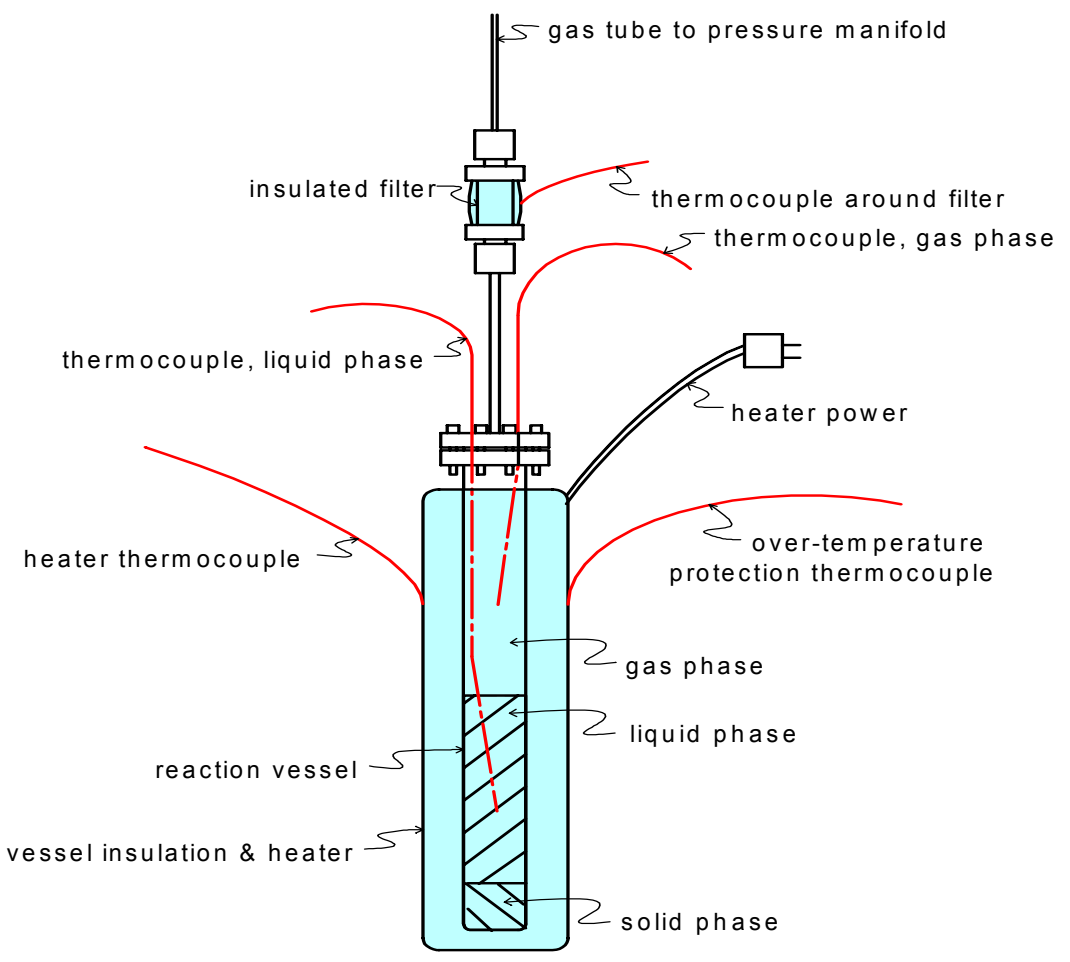

Figure 2.3. Schematic of a 60-ml Reaction Vessel

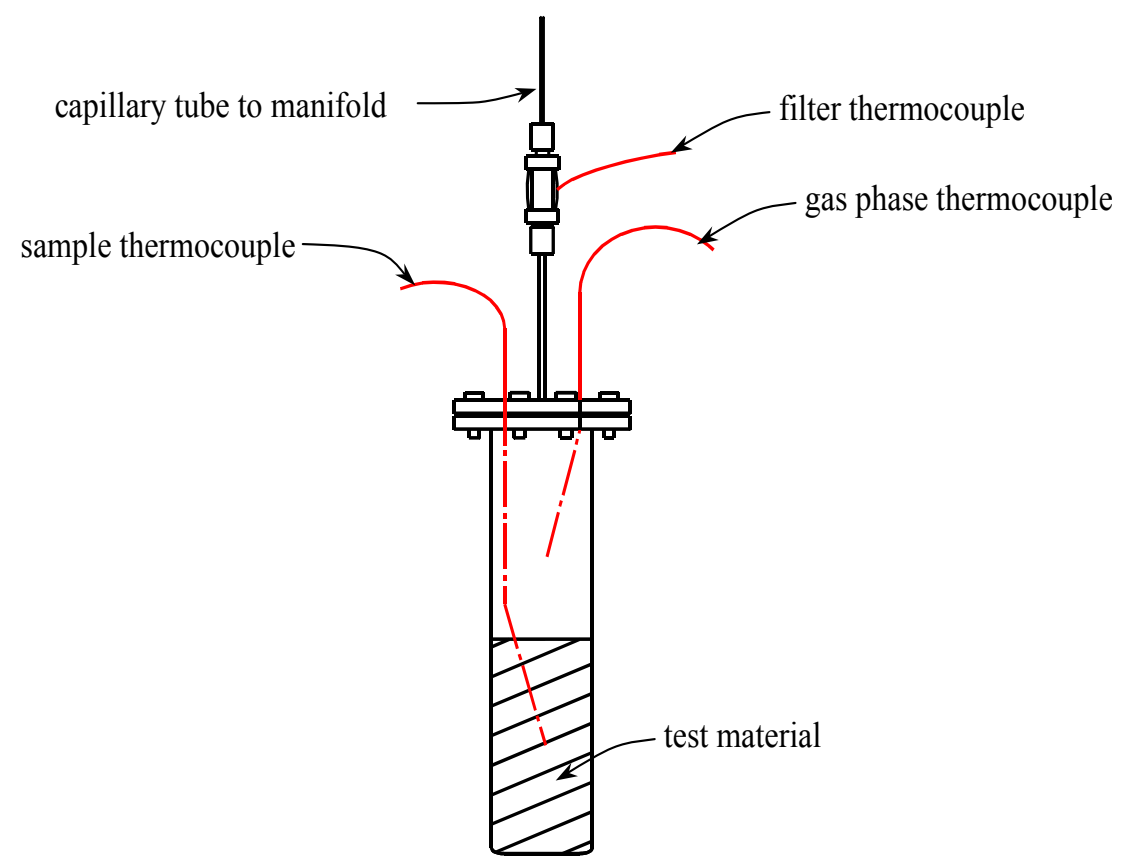

Figure 2.4. Schematic of an 800-ml Reaction Vessel 
After each bottle was evacuated overnight at high vacuum, it was attached to the gas sample port. The reaction vessel was purged again with neon after each sampling or venting event and before the next reaction sequence. The compositions of the gas phase of each reaction vessel during selected gas samplings were analyzed by PNNL using the mass spectrometric analytical procedure PNNL-98523-284 Rev. 0. The gas analysis data are included in the data package, which is available from Fluor Hanford (R. B. Baker). 


\subsection{Gas Generation from Crushed Fuel and K Basin Sludge Samples}

During Series III testing, the pressure in each reaction vessel was monitored continuously to track total gas generation, and gas samples were taken from the vessels periodically, in accordance with the test plan. After each gas sample was taken, the reaction vessel was purged with neon to remove the previously generated gases before testing resumed. Gas generation rates were determined for each gas sample based on the heating time, the gas composition, and the total gas quantity in the system from which the sample was taken. Reaction rates were calculated based on the mass of crushed fuel added to each reaction vessel (or on the sludge mass for the sludge-only test).

In eight of the Series III tests, gas generated was vented periodically (to avoid exceeding equipment pressure ratings) without sampling for analysis. For those test periods, quantitative measurements of the generation rates for individual gas species were not possible. However, hydrogen dominated the measured generated gases, constituting $99.6 \%$ or more of the gas for the tests with fuel particles only and at least $94.5 \%$ of the generated gas for the tests with both fuel particles and sludge. Thus, for the first 11 tests, the rate of total gas generation, monitored by system pressure, volume, and temperature, largely reflected the rate of hydrogen generation. The twelfth test, the long-running test, containing only canister sludge and no added fuel particles, generated primarily $\mathrm{CO}_{2}$. In this test, all of the generated gas was sampled for analysis.

The results of the gas generation measurements from the 12 tests are presented here. Section 3.1 provides the general gas generation measurements from studies of mid-range fuels $(500-2000 \mu \mathrm{m})$ with and without canister sludge (KC Can Comp) and of fine fuel particles $(<500 \mu \mathrm{m})$ with fine canister sludge (KC-2/3 M250). These studies were conducted at ambient hot cell temperature $\left(\sim 33^{\circ} \mathrm{C}\right)$ to $95^{\circ} \mathrm{C}$. Section 3.2 presents gas generation measurements at $80^{\circ} \mathrm{C}$ for tests with various fuel particle size fractions. Section 3.3 shows gas generation measurements for tests of mid-range $(500-2000 \mu \mathrm{m})$ and fine $(<500 \mu \mathrm{m})$ fuel particles reacted to completion (mostly at $80^{\circ} \mathrm{C}$ but completed at $95^{\circ} \mathrm{C}$ ). The effects of sludge blanket composition or source (i.e., floor sludge and fuel canister sludge) on gas generation from the entire distribution of fuel particle sizes $(0-6350 \mu \mathrm{m})$ reacted at ambient, $60^{\circ} \mathrm{C}, 80^{\circ} \mathrm{C}$, and $95^{\circ} \mathrm{C}$ are discussed in Section 3.4. Section 3.5 describes the gas generation observed over 10,140 hr ( $\sim 14$ months) for larger particle-sized canister sludge, without any added crushed fuel particles, at ambient hot cell temperature.

The gas generation plots for Tests 1 through 11 in Sections 3.1 through 3.5 display the total gas generated (based on reaction vessel pressure measurements) - corrected to deduct the contribution of water vaporin gram moles ${ }^{(\mathrm{a})}$ of gas generated per $\mathrm{kg}$ fuel particles (per $\mathrm{kg}$ of sludge for Test 12). (Note: at standard temperature and pressure, 1 gram mole of gas is equal to 22.4 liters). If the starting fuel particles were $100 \%$ uranium metal, and $100 \%$ of the uranium metal reacted to produce hydrogen gas and $\mathrm{UO}_{2}$, then $8.402 \mathrm{~g}$ moles of hydrogen gas $/ \mathrm{kg}$ fuel particles would be generated. Because of minor temperature gradients across each test system, and some intermittent offgas line blockage (due to water condensation) with the $800-\mathrm{ml}$ reaction vessels, the gas generation plots are not strictly accurate (i.e., some are off by several percent).

(a) Unless stated otherwise, "moles" refers to "gram moles" throughout this document. 


\subsection{Gas Generation from $60-\mathrm{ml}$ Reaction Vessel Tests at Ambient, $40^{\circ} \mathrm{C}$, $60^{\circ} \mathrm{C}, 80^{\circ} \mathrm{C}$, and $95^{\circ} \mathrm{C}$}

Gas generation results are given here for the tests conducted in $60-\mathrm{ml}$ reaction vessels at ambient, $40^{\circ} \mathrm{C}$, $60^{\circ} \mathrm{C}, 80^{\circ} \mathrm{C}$, and $95^{\circ} \mathrm{C}$ :

- Test 1, SNF + Can Fines 60S (<500- $\mu$ m particles with KC-2/3 M250 canister sludge)

- Test 2, SNF + Can 60S (500-2000- $\mu$ m particles with KC Can Comp)

- Test 3, SNF Mid 60S (500 - 2000- $\mu$ m particles)

- Test 4, SNF Mid 40S (500 - 2000- $\mu$ m particles).

In each of these tests, the initial $\sim 138 \mathrm{hr}$ and final $\sim 1600 \mathrm{hr}$ occurred at uncontrolled, but monitored, ambient hot cell temperature. Reaction temperatures during the initial 138-hr period for three of the systems were $\sim 33^{\circ} \mathrm{C}$, but the test with fine fuel particles (SNF + Can Fines 60S) self-heated by its own reaction energy to attain $\sim 38^{\circ} \mathrm{C}$ during the same period. As shown in Figure 3.1, gas generation reactions were underway to varying degrees even during this initial low-temperature period. After the initial $138 \mathrm{hr}$, controlled heating was used to increase the test vessel temperatures in a stepwise manner to $60^{\circ} \mathrm{C}$, $80^{\circ} \mathrm{C}$, and finally to $95^{\circ} \mathrm{C}$ for three of the tests before heating was stopped. In the fourth test (SNF Mid 40S), the heating steps were at $40^{\circ} \mathrm{C}, 60^{\circ} \mathrm{C}$, and $80^{\circ} \mathrm{C}$ before heating was stopped. The reactant material (primarily uranium metal) was not completely consumed in any of these tests, as shown by the continuing gas evolution. Therefore, it was not possible to independently confirm the quantity of uranium metal present in the initial test materials by measuring the total gas produced and consumed.

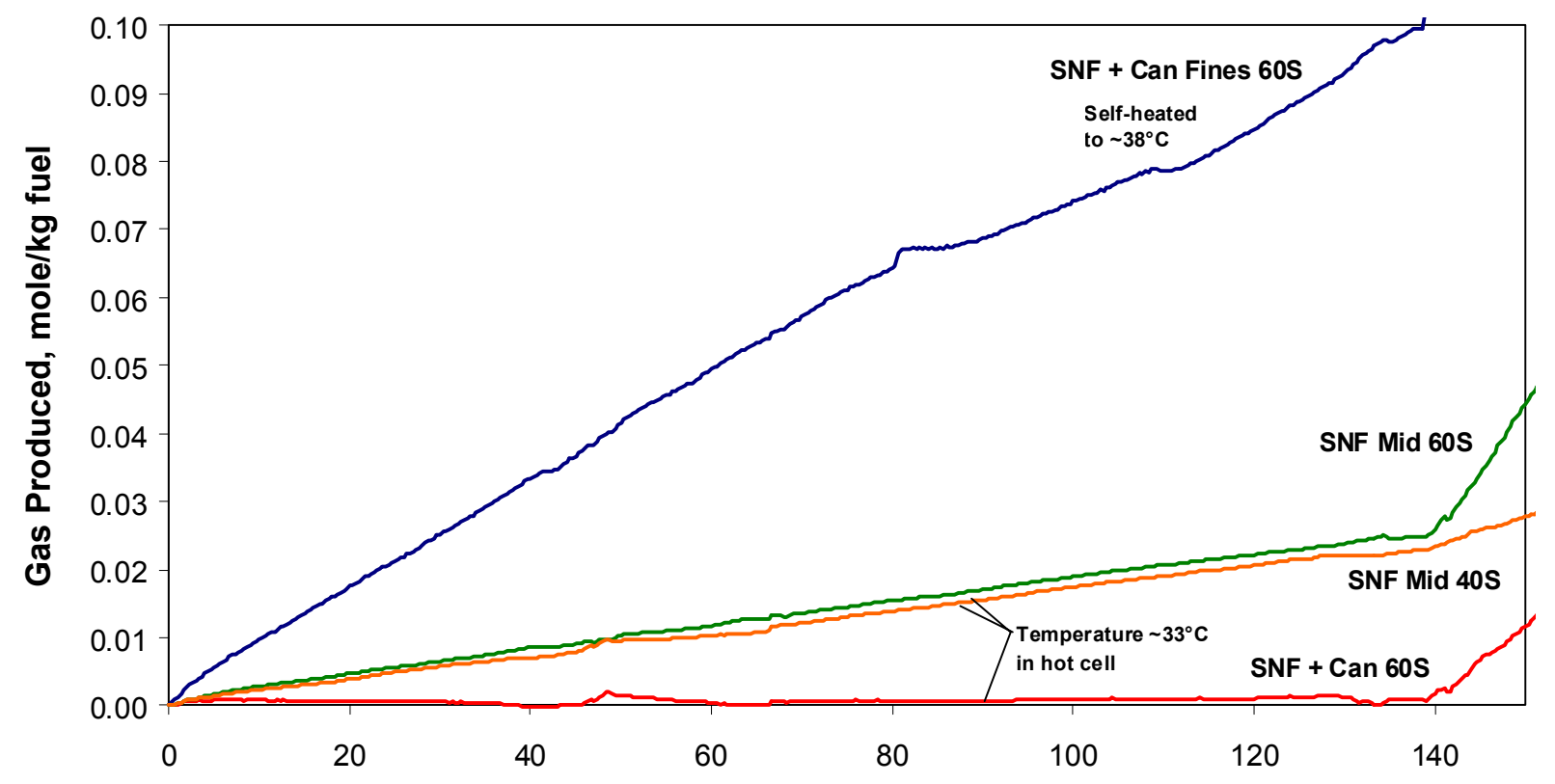

Time, hours

Figure 3.1. Total Gas Generation of SNF + Can Fines 60S, SNF Mid 60S, SNF Mid 40S, and SNF + Can $60 \mathrm{~S}$ at Ambient Hot Cell Temperature $\left(\sim 33^{\circ} \mathrm{C}\right)$. Controlled heating started at $\sim 138 \mathrm{hr}$. 
The total amounts of gas produced (i.e., $\mathrm{H}_{2}, \mathrm{CO}_{2}, \mathrm{CH}_{4}$, etc.), in gram moles per $\mathrm{kg}$ fuel particles versus reaction time, are plotted in Figure 3.2 for the four tests. In all cases, the gas generation rates clearly increase with increasing temperature (though temperature control was erratic for SNF + Can Fines 60S from about 250 to $600 \mathrm{hr}$ ). The time to the onset of gas generation (the reaction induction time) at ambient hot cell temperature (Figure 3.1) essentially was zero for all but SNF + Can 60S. On close inspection, the SNF Mid 40S test appeared to begin generating gas about 40 min after the vessel was closed and data collection began, while the equivalent SNF Mid 60S test began gas generation after 20 min. The induction time observed before onset of gas generation in SNF + Can 60S was about $70 \mathrm{hr}$ after vessel closing at ambient hot cell temperature. Note, however, that these reported induction times ignore the likely onset of reaction at hot cell temperature even before the contents of the vessels were sealed.

In Figure 3.2, nearly linear gas generation rates are observed at the various temperature steps. The rates decrease slightly with time (and reactant consumption) at a given temperature. Other observations can be made by comparing the Figure 3.2 test results. For example, the plot shows that fine fuel particles $(<500 \mu \mathrm{m})$, even with a sludge blanket (SNF + Can Fines $60 \mathrm{~S})$, react faster than mid-range particles $(500-2000 \mu \mathrm{m})$ with no sludge blanket (SNF Mid 60S). The plot also shows the important finding that the over-burden of sludge in SNF + Can $60 \mathrm{~S}$ apparently decreased the reaction rate at $60^{\circ} \mathrm{C}$, whereas the corresponding test, SNF Mid 60S, had the same distribution of fuel particle sizes but no sludge overburden.

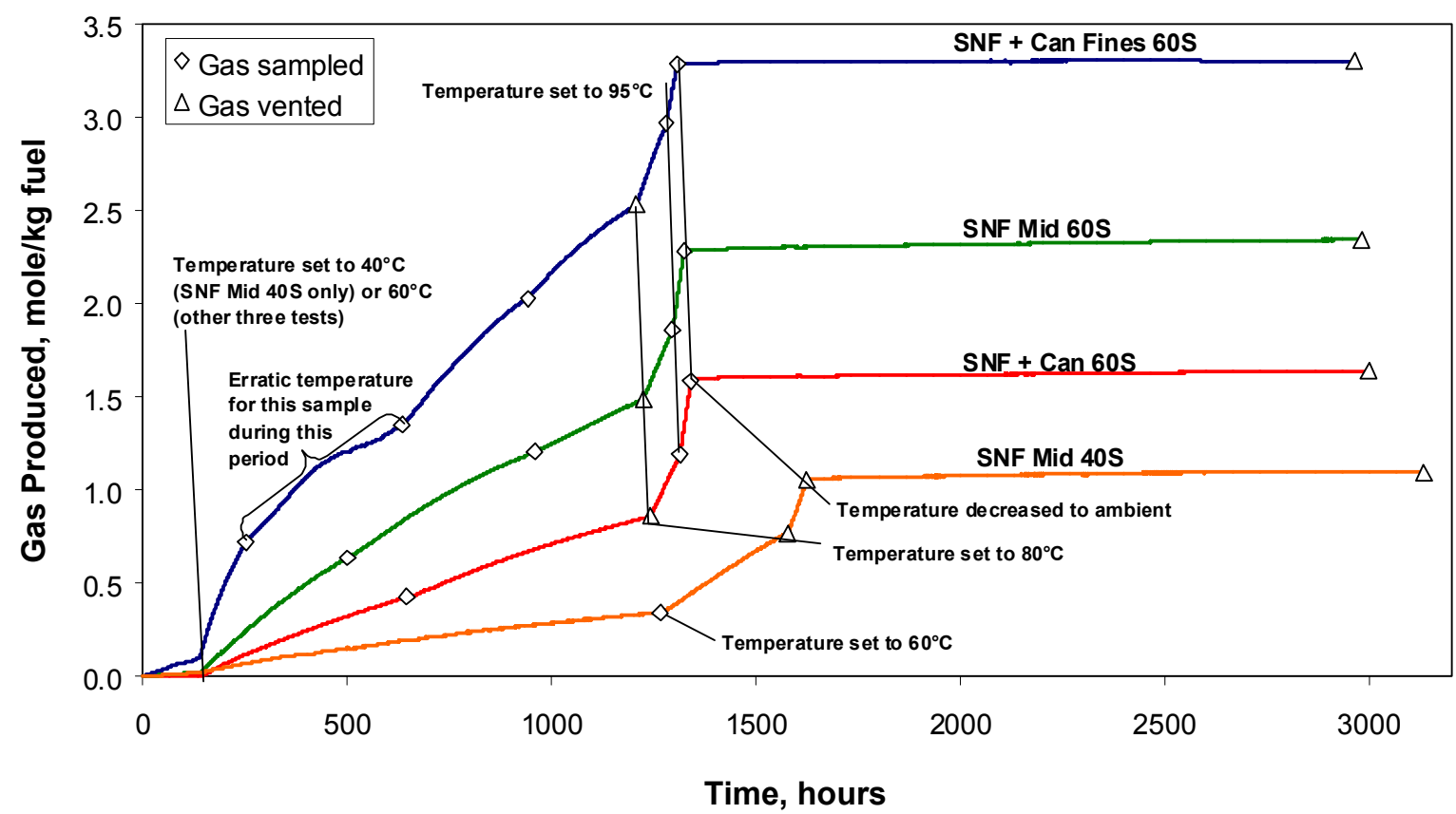

Figure 3.2. Total Gas Generation of SNF + Can Fines 60S, SNF Mid 60S, SNF Mid 40S, and SNF + Can 60S at Ambient Hot Cell Temperature (at Beginning and End of Run) to $95^{\circ} \mathrm{C}$ 
Figure 3.3 shows the influence of temperature on sludge blanketing by comparing the $\mathrm{SNF}+\mathrm{Can} 60 \mathrm{~S}$ and SNF Mid $60 \mathrm{~S}$ test results at $60^{\circ} \mathrm{C}, 80^{\circ} \mathrm{C}$, and $95^{\circ} \mathrm{C}$ in expanded scaling that is re-indexed to begin at the origin for each temperature. The effect of blanketing on inhibiting the corrosion reaction decreases with increasing temperature and, ultimately, is insignificant at $95^{\circ} \mathrm{C}$. As shown in Figure 3.3, the reaction rate with blanketing is about $68 \%$ of the rate without blanketing at $60^{\circ} \mathrm{C}, 87 \%$ of that found without blanketing at $80^{\circ} \mathrm{C}$, and $97 \%$ of the rate without blanketing at $95^{\circ} \mathrm{C}$. The effects of blanketing on corrosion rates are described further in Section 6.0.

The gas sample compositions from the four tests, as determined by mass spectrometry, are given in Tables B.1 through B.4 (Appendix B). Note, again, that gas occasionally was vented and not sampled for analysis. Gas sample collection and gas venting times are indicated in Figure 3.2, Table 2.4, and Tables B.1 through B.4. The compositions of the generated gases, derived from the compositions of sampled gas by excluding the neon cover gas and trace argon, nitrogen, and oxygen from atmospheric contamination, are also presented in Tables B.1 through B.4. For example, if analysis found $80 \%$ neon, $5 \% \mathrm{CO}_{2}$, and $15 \% \mathrm{H}_{2}$, the composition of gas formed by excluding neon would be $25 \% \mathrm{CO}_{2}$ and $75 \% \mathrm{H}_{2}$. The uncertainties in all the entries in these tables are approximately plus or minus 1 in the last digit.

The presence of argon in the gas samples indicates atmospheric contamination because argon, though present in the natural atmosphere, is not present in the cover gas and is not produced by the sludge. Nitrogen could have been generated or consumed by the sludge or could have come from atmospheric contamination. The amount of nitrogen actually generated or consumed is calculated to be the percent nitrogen found in a particular gas sample minus 83.6 times the percent argon in the sample (the ratio of nitrogen to argon in dry air is 83.6). The percent oxygen actually generated or consumed in the samples may be calculated by a similar method. The sum of all percents for a run in Tables B.1 through B.4 may not be exactly $100 \%$, because the values were rounded.

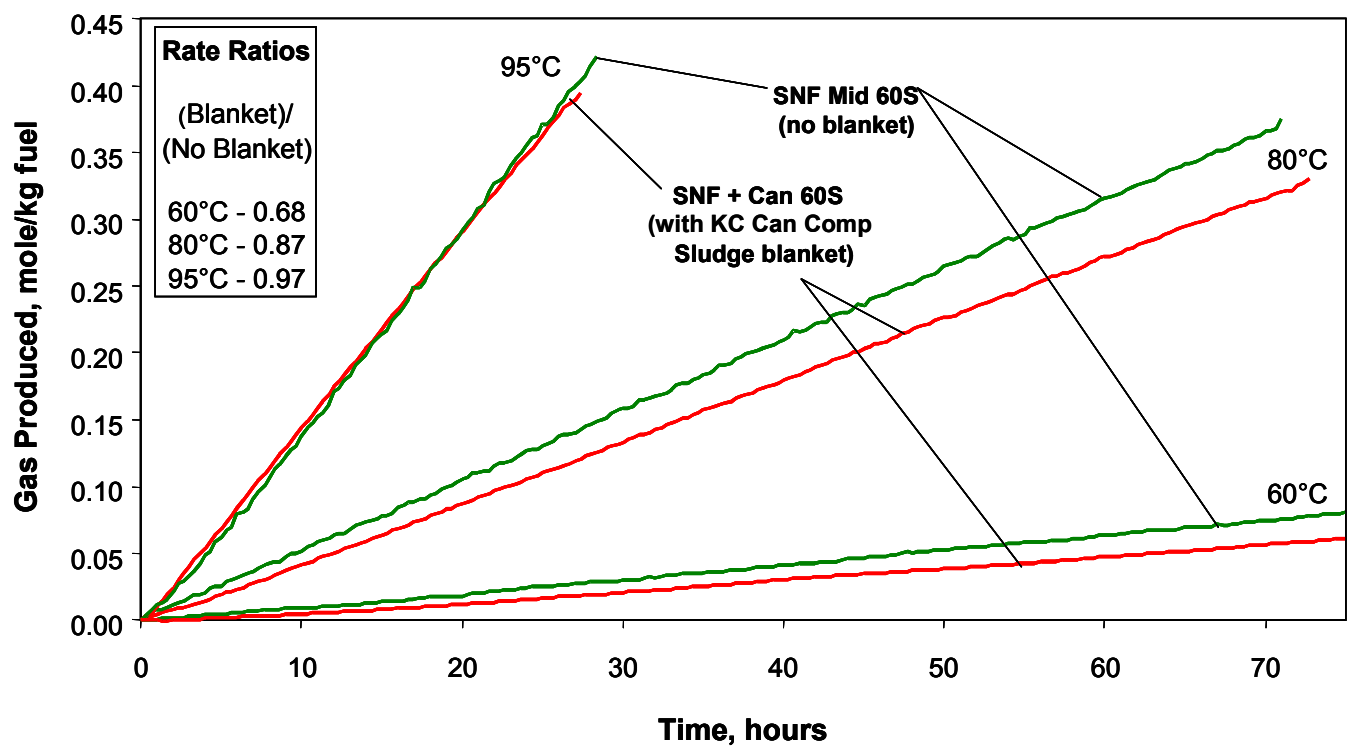

Figure 3.3. Expanded Comparison of Total Gas Generation at $60^{\circ} \mathrm{C}, 80^{\circ} \mathrm{C}$, and $95^{\circ} \mathrm{C}$ from $500-2000-\mu \mathrm{m}$ Fuel Particles With and Without Blanketing by KC Can Comp Sludge 
Individual gas generation rates were calculated based on the total moles of gas produced (Figure 3.2) and the generated gas compositions (Tables B.1 through B.4). Tables B.5 through B.8 show the gas generation rates derived in this manner.

\subsection{Gas Generation from Tests of Various-Sized Fuel Particles and a Single Fuel Fragment at $80^{\circ} \mathrm{C}$}

In this section, gas generation results are presented for five tests having different size populations of crushed fuel particles but no added sludge:

- Test 5, SNF P2000 80S (>2000- $\mu \mathrm{m}$ particles; 60-ml vessel)

- Test 6, SNF M500 80L ( $<500-\mu \mathrm{m}$ particles; 800-ml vessel)

- Test 7, SNF Mid 80L (500 - 2000- $\mu$ m particles; 800-ml vessel)

- Test 8, SNF Mid 80L Dup (500 - 2000- $\mu$ m particles; 800-ml vessel)

- Test 9, Fuel Fragment (single 3.72-g, $7150-\mu \mathrm{m}$, fuel fragment; 60-ml vessel).

Four of the five tests were run at $80^{\circ} \mathrm{C}$, but were begun (i.e., during the initial $\sim 138 \mathrm{hr}$ ) and ended at ambient hot cell temperature. The fifth test (Fuel Fragment, Test 9) began immediately at $80^{\circ} \mathrm{C}$ and ended at ambient hot cell temperature. In three tests, SNF M500 80L (Test 6) and SNF Mid 80L (Test 7) and its duplicate (Test 8), the temperature was raised to $95^{\circ} \mathrm{C}$ for 21 and 59 days, respectively, to force the reactions to completion.

Data on the total amounts of gas produced versus time for these five tests are shown in Figure 3.4.

Ragged step-wise increases in evolved gas are noted in the gas generation plots for the tests conducted in $800-\mathrm{ml}$ reaction vessels, particularly at extended times when gas generation rates are lower. It is surmised that this behavior was caused by water condensing in the cooler tubing or gas filters leading from the vessel. In this way, the condensate sporadically interrupted the gas flow. Similar behavior was not seen for the 60-ml reaction vessels having less surface area (and thus lower flux) of water to evaporate.

As seen in Figure 3.4, the specific gas generation rates clearly increase with decreasing fuel particle size and correspondingly larger specific metal surface area. In addition, and as noted previously for Tests 1 through 4 , the rates also decrease with time. This gives qualitative evidence that the fuel particles did not fracture (and thus present more uranium metal surface area for reaction) during the gas generation testing. However, the Fuel Fragment (Test 9) plot shape is sigmoidal, showing an accelerating rate with time up to $\sim 1800 \mathrm{hr}$ ( 75 days) followed by a decreasing rate (1800 to $3900 \mathrm{hr}$ ). A cladding shard and one intact large fuel particle with sharp faces were found during post-test examination. Evidently, the attached piece of cladding was slowly sloughed, exposing increasing fresh surface to corrosion to accelerate the observed gas generation rate. However, no crumbling occurred over the course of the Fuel Fragment testing.

In the maximum rate regions of the five $80^{\circ} \mathrm{C}$ tests, gas generation rates (at standard temperature and pressure) were about 19.0 liters $/ \mathrm{kg}$ fuel particles-day for the $<500-\mu \mathrm{m}$ particles, 8.2 and 9.9 liters $/ \mathrm{kg}$ fuel particles-day for the two tests with $500-2000-\mu \mathrm{m}$ particles, 2.5 liters $/ \mathrm{kg}$ fuel particles-day for the $>2000-\mu \mathrm{m}$ particles, and 0.59 liters/kg fuel particles-day for the Fuel Fragment (likely after cladding loss had occurred). 


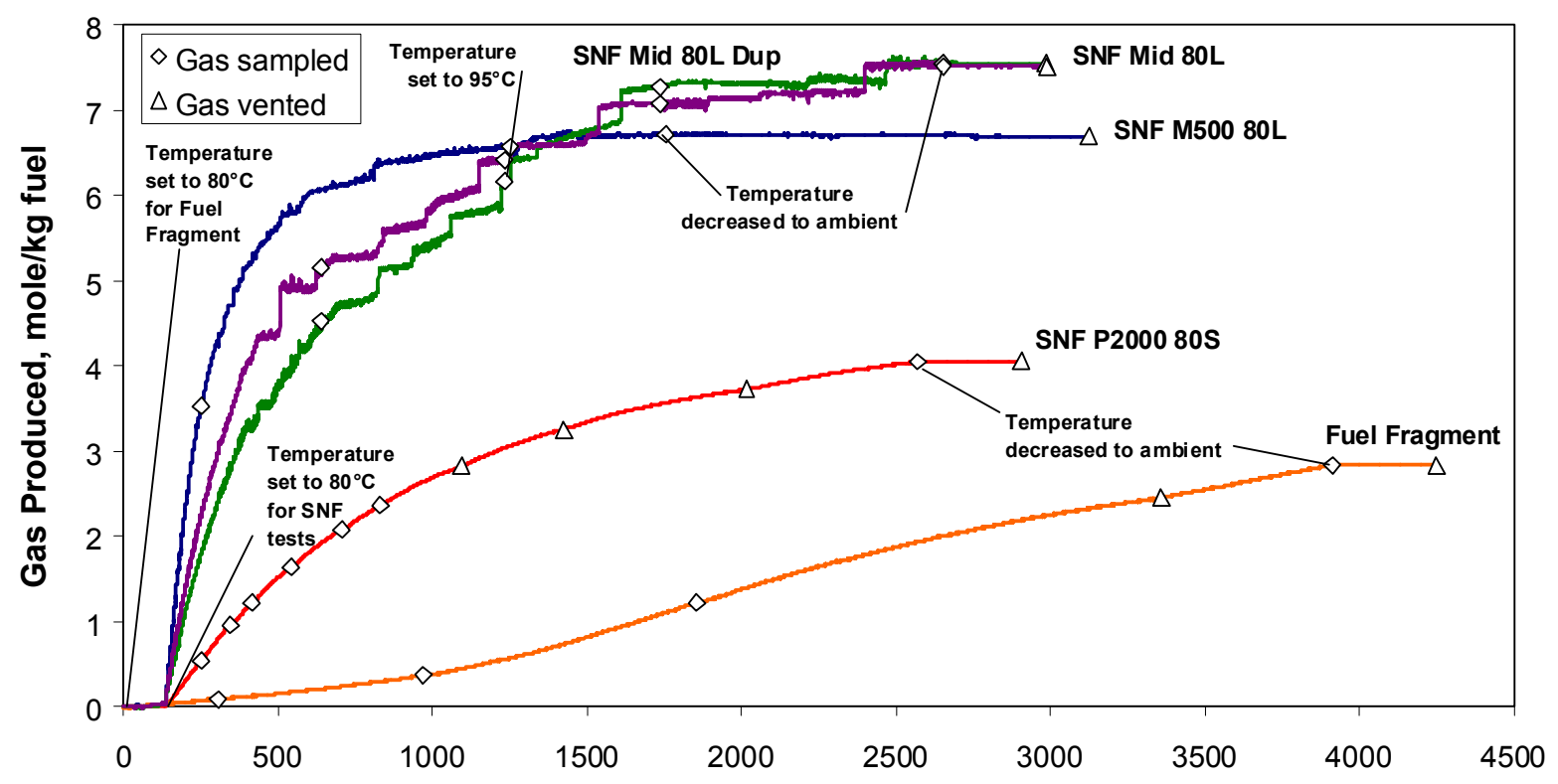

Time, hours

Figure 3.4. Total Gas Generation from Various-Sized Fuel Particles Reacted at $80^{\circ} \mathrm{C}$

The induction times (times elapsed before onset of gas generation) also were examined for these tests. For the three tests conducted in the 800-ml vessels with the finest and next finest fuel particle sizes (SNF M500 80L, SNF Mid 80L, and SNF Mid 80L Dup, respectively), induction times were about $70 \mathrm{hr}$ at ambient hot cell temperature. The induction time was about 40 min for SNF P2000 80S (Test 5) the next largest size particles in this series (at ambient hot cell temperature). Note, however, that this test was conducted in a $60-\mathrm{ml}$ vessel and thus could build hydrogen concentrations more rapidly as a result of the smaller gas volume. The induction time to gas generation for the Fuel Fragment test was zero, but this test began with immediate heating to $80^{\circ} \mathrm{C}$. Again, the noted induction times do not account for the time intervals before the individual vessels were sealed and during which some initial reaction likely was underway.

As noted in the Series I testing, induction periods prior to more rapid gas generation are observed in the corrosion of uranium in aerated waters (Montenyohl 1960). The induction time encompasses the period in which the protective $\mathrm{UO}_{2}$ layer is lost and an initial uranium hydride layer (required for evolution of hydrogen gas by the reaction of uranium with water in anoxic media) is created. The relatively lengthy induction times found for the 800 -ml vessel tests also suggest that, besides the hydrogen consumed (gettered) to form uranium hydride solid, reactions to consume the trace residual oxygen first had to be satisfied. While the quantities of fuel particles in Tests 6 through 8 were approximately equal (i.e., 8 to $10 \mathrm{~g}$ ), the water and free gas volumes associated with the $800-\mathrm{ml}$ vessels were about 7 and 12 times, respectively, more than those of the $60-\mathrm{ml}$ vessel (Test 5). Once the residual oxygen was consumed and the uranium hydride layer established, free hydrogen became available to the gas phase, and significant gas generation was observed.

Selected gas samples from the 60-ml vessel tests (SNF P2000 80S and Fuel Fragment) and all of the gas samples from the 800-ml vessel tests (SNF M500 80L, SNF Mid 80L, and SNF Mid 80L Dup) were analyzed by mass spectrometry. The respective gas compositions are given in Tables B.9 through B.13. 
The generated gas compositions, determined by deducting the neon cover gas and correcting for atmospheric contamination (using argon concentrations), are also presented. On this basis, the amounts of nitrogen and oxygen consumed or generated by the sludge reactions could be determined. The sum of all percents in Tables B.9 through B.13 for a gas sample may not be exactly $100 \%$, again because the values were rounded.

Individual gas generation rates are calculated based on the total moles of gas produced (Figure 3.4) and the gas compositions (Tables B.9 through B.13). Tables B.14 through B.18 display the gas generation rates for the tests.

\subsection{Gas Generation from Tests Run to Completion}

In this section, gas generation data are presented for tests with mid-range $(500-2000-\mu \mathrm{m})$ and fine $(<500-\mu \mathrm{m})$ fuel particles reacted to completion in $800-\mathrm{ml}$ reaction vessels (these tests were described in Section 3.2, but are further examined here because the fuel particles were completely reacted):

- Test 6, SNF M500 80L ( $<500-\mu \mathrm{m}$ particles)

- Test 7, SNF Mid 80L (500 - 2000- $\mu$ m particles)

- Test 8, SNF Mid 80L Dup (500 - 2000- $\mu$ m particles).

The tests were begun with about $138 \mathrm{hr}$ at ambient hot cell temperature. The temperature was raised to $80^{\circ} \mathrm{C}$ for about $1100 \mathrm{hr}$ (46 days), and then to $95^{\circ} \mathrm{C}$ for an additional 500 and $1420 \mathrm{hr}$ (for SNF M500 80L and the two SNF Mid 80L tests, respectively) to force the reactions to completion.

The total amounts of gas produced (in gram moles) versus reaction time were measured for each test. These results are shown in Figure 3.5. Step-wise increases in evolved gas again are noted in these tests in the $800-\mathrm{ml}$ vessels, particularly at extended times, and likely were caused by water condensing in the exit tubing and the gas filter, erratically interrupting the gas flow. It is seen that, at completion, the SNF M500 80L test produced 6.69 moles of gas per $\mathrm{kg}$ of initial fuel particles. Hydrogen was $99.79 \%$ of the total gas, according to mass spectrometric analysis. The SNF Mid 80L test and its duplicate produced, respectively, 7.55 and 7.51 moles of gas per $\mathrm{kg}$ of initial uranium metal particles. Of this, $99.87 \%$ and $99.62 \%$, respectively, was hydrogen. If the initial starting material were $100 \%$ uranium metal, the total hydrogen gas produced from these tests (assuming a stoichiometric $\mathrm{UO}_{2}$ product and ignoring corrosion by trace atmospheric $\mathrm{O}_{2}$ and $\mathrm{N}_{2}$ ) would have been $8.402 \mathrm{moles} / \mathrm{kg}$. The results thus indicate that neither the $<500-\mu \mathrm{m}$ particles (SNF M500 80L test) nor the 500 - 2000- $\mu \mathrm{m}$ particles (SNF Mid 80L and Dup) were $100 \%$ uranium metal. Post-test examination of the three experiments showed shards of Zircaloy cladding. [Note: Zircaloy cladding is approximately $6.9 \mathrm{wt} \%$ of normal $\mathrm{N}$ Reactor outer fuel elements.] The additional crushing necessary to create the M500 $(<500-\mu \mathrm{m})$ material compared to the Mid (500 $2000-\mu \mathrm{m})$ particles also may have oxidized more of the original uranium metal and caused the relatively lower specific quantity of product gas. Reaction stoichiometry is examined in more detail in Sections 4.0 and 5.0.

Induction times to onset of reaction at the ambient hot cell temperature were difficult to determine because of fluctuations in gas quantities in these three tests. The fluctuations likely can be attributed to the large volume of headspace gas (subject to variabilities in temperature and pressure measurement) in comparison with the relatively smaller volume of generated gas. However, in all three cases, clear onset of steady gas generation occurred after about $70 \mathrm{hr}$. 


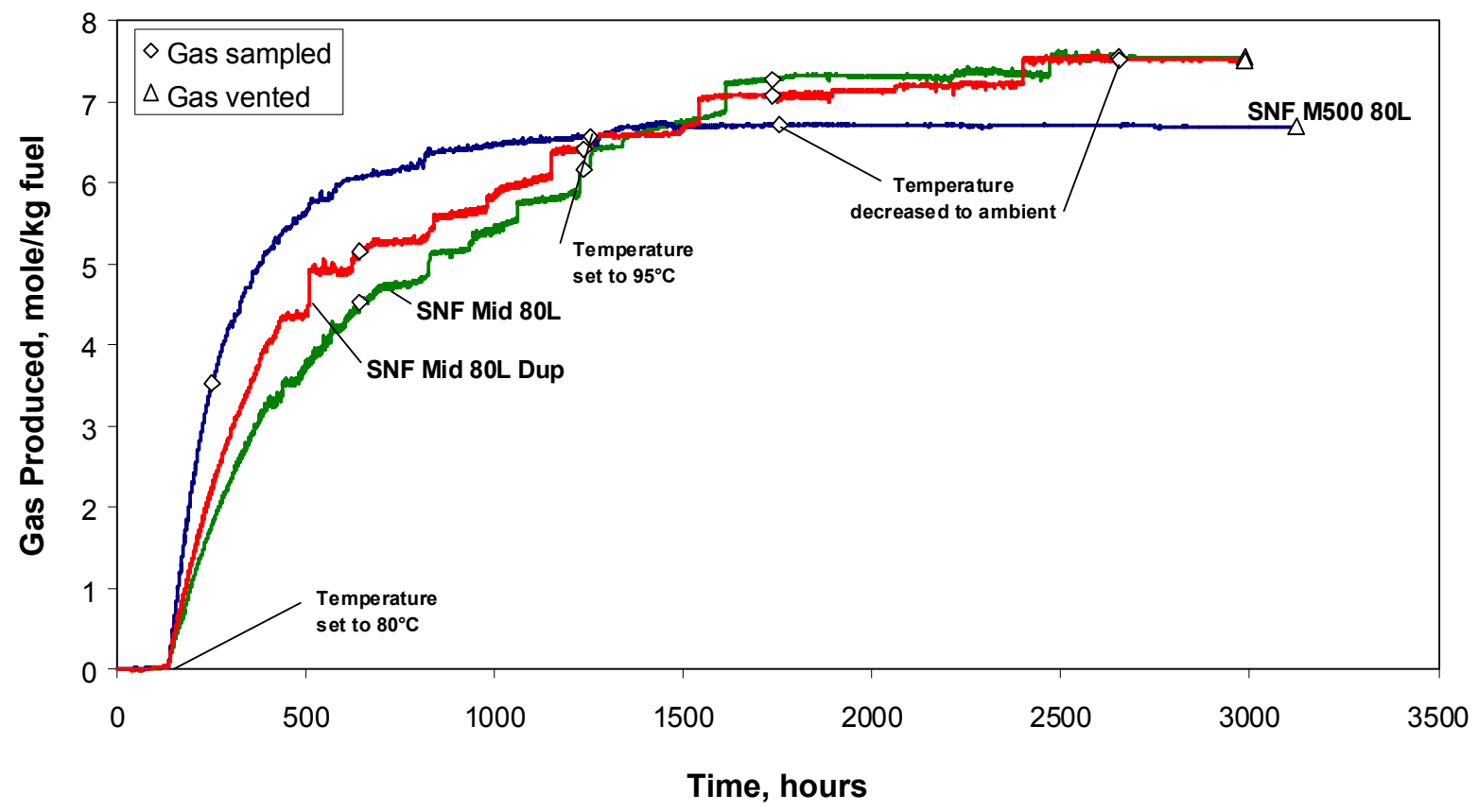

Figure 3.5. Total Gas Generation for Fuel Particle Tests Run to Completion in 800-ml Reaction Vessels

Gas samples were analyzed by mass spectrometry to obtain generation rates for each gas species present. The gas compositions found in the SNF M500 80L, SNF Mid 80L, and SNF Mid 80L Dup tests are given in Tables B.10 through B.12. The generated gas compositions again are included for each run. The generation rates of individual gases were then calculated based on the total moles of gas produced (Figure 3.5) and the compositions of the generated gas (Tables B.10 through B.12). Tables B.15 through B.17 present the gas generation rates for SNF M500 80L, SNF Mid 80L, and SNF Mid 80L Dup, respectively.

\subsection{Gas Generation from 800-ml Reaction Vessel Tests with Sludge Blanketing}

Gas generation data were measured for the full spectrum of crushed fuel particle sizes $(0-6350 \mu \mathrm{m})$ in two tests in $800-\mathrm{ml}$ reaction vessels with a blanket of sludge covering the fuel particles:

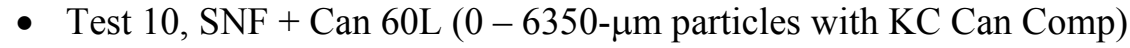

- Test 11, SNF + Floor 60L (0 - 6350- $\mu$ m particles with KC Floor Comp).

The tests were begun with about $138 \mathrm{hr}$ at ambient hot cell temperature. The test temperature was then adjusted to $60^{\circ} \mathrm{C}$ for $\sim 1100 \mathrm{hr}$ (46 days), to $80^{\circ} \mathrm{C}$ for $71 \mathrm{hr}\left(\sim 3\right.$ days), and to $95^{\circ} \mathrm{C}$ for $48 \mathrm{hr}$ ( 2 days) when external heating was stopped.

Figure 3.6 presents data for the total gas produced versus reaction time for the two tests. Erratic step-wise increases in evolved gas, again observed for the tests conducted in $800-\mathrm{ml}$ vessels, probably were brought about by sporadic interruption in gas flow caused by water condensation in the exit tubing and gas filter. The gas evolution rates were nearly identical for the two tests (i.e., canister sludge or floor sludge), although, on closer inspection, the rates were slightly higher at each temperature for the test with the floor 
sludge blanket. At standard temperature and pressure, gas generation rates were about $0.76,2.8$, and 7.7 liters $/ \mathrm{kg}$ fuel particles-day at $60^{\circ} \mathrm{C}, 80^{\circ} \mathrm{C}$, and $95^{\circ} \mathrm{C}$, respectively.

The induction times to onset of gas generation at ambient hot cell temperature were about $64 \mathrm{hr}$ for the test with the canister sludge blanket and about $56 \mathrm{hr}$ for the floor sludge blanket test. As in the other tests conducted in 800-ml vessels, the gas generation versus time plots were noisy in this region of low rates. Again, the significance of these induction times is diminished by fact that the extent of reactions of the fuel/sludge mixtures before the vessels were sealed is not known.

The compositions of gas samples taken from the tests are presented in Tables B.19 and B.20. Gas was vented and not sampled for analysis after the second $60^{\circ} \mathrm{C}$ period for the test with the canister sludge blanket and at the end of the final period at ambient hot cell temperature for both tests. Gas sample collection and gas venting times are indicated in Figure 3.6. Gas generation rate data are given in Tables B.21 and B.22.

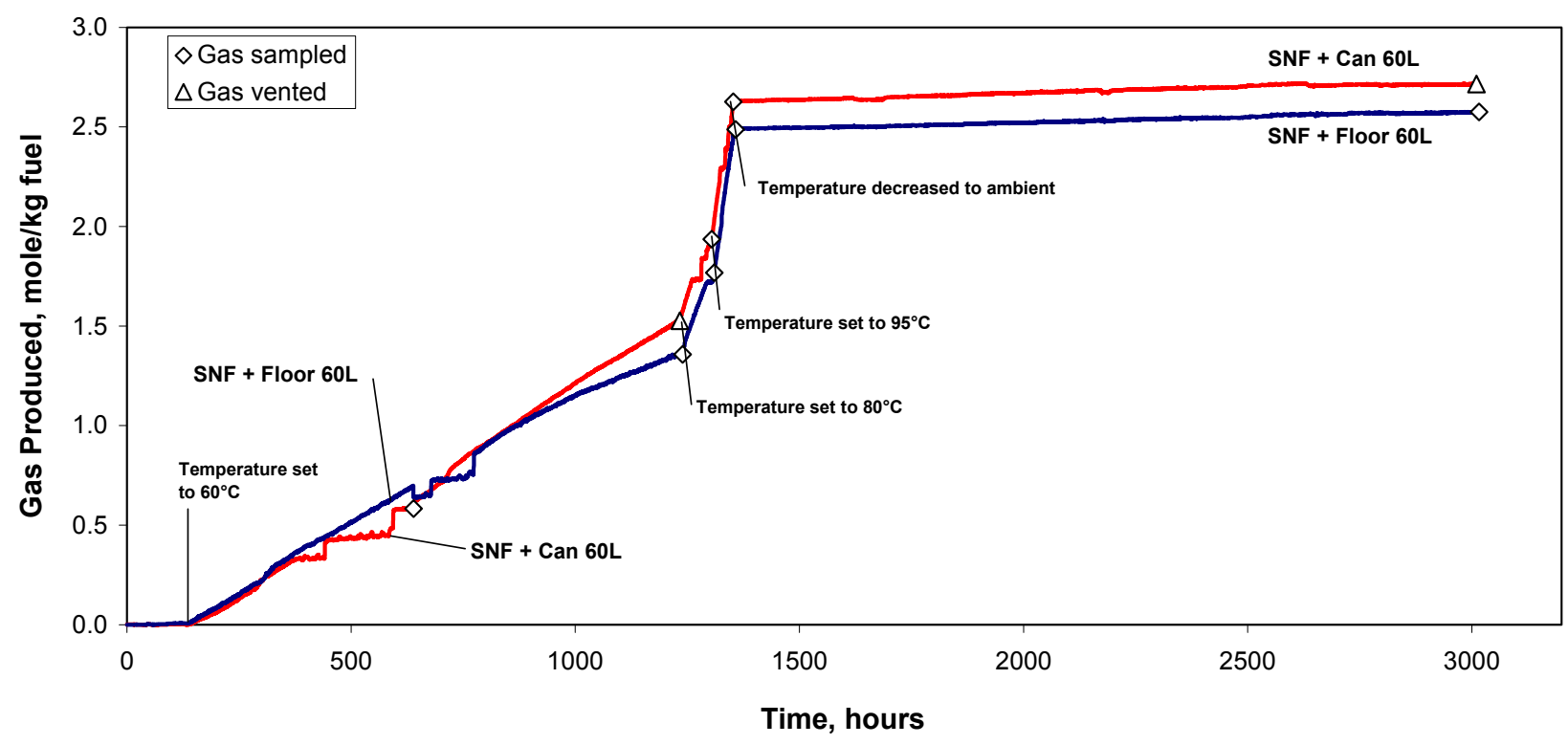

Figure 3.6. Total Gas Generation for $800-\mathrm{ml}$ Reaction Vessel Tests with Sludge Blanketing

\subsection{Gas Generation from Long-Term Test with Canister Sludge}

Gas generation testing was conducted at ambient hot cell temperature for 10,140 hr ( 14 months) on KC-2/3 P250 sludge in an 800-ml reaction vessel (Test 12). Early results from this test, gathered after $6120 \mathrm{hr}$ ( $\sim 81 / 2$ months) of testing, were presented in the Series I report (Delegard et al. 2000). Aside from an 888-hr (37-day) interval when the apparatus was disconnected from the gas measurement system, the evolution of gas versus reaction time was measured over the entire 10,140-hr test interval. As shown in Figure 3.7, gas production was minor and erratic over the entire test period. Over the extended period of this test, the KC-2/3 P250 sludge seemingly never achieved the more rapid hydride-mediated uranium corrosion observed for the same sludge in other Series I tests, i.e., KE canister sludge containing $\sim 7.4 \mathrm{wt} \%$ uranium metal (Delegard et al. 2000). 


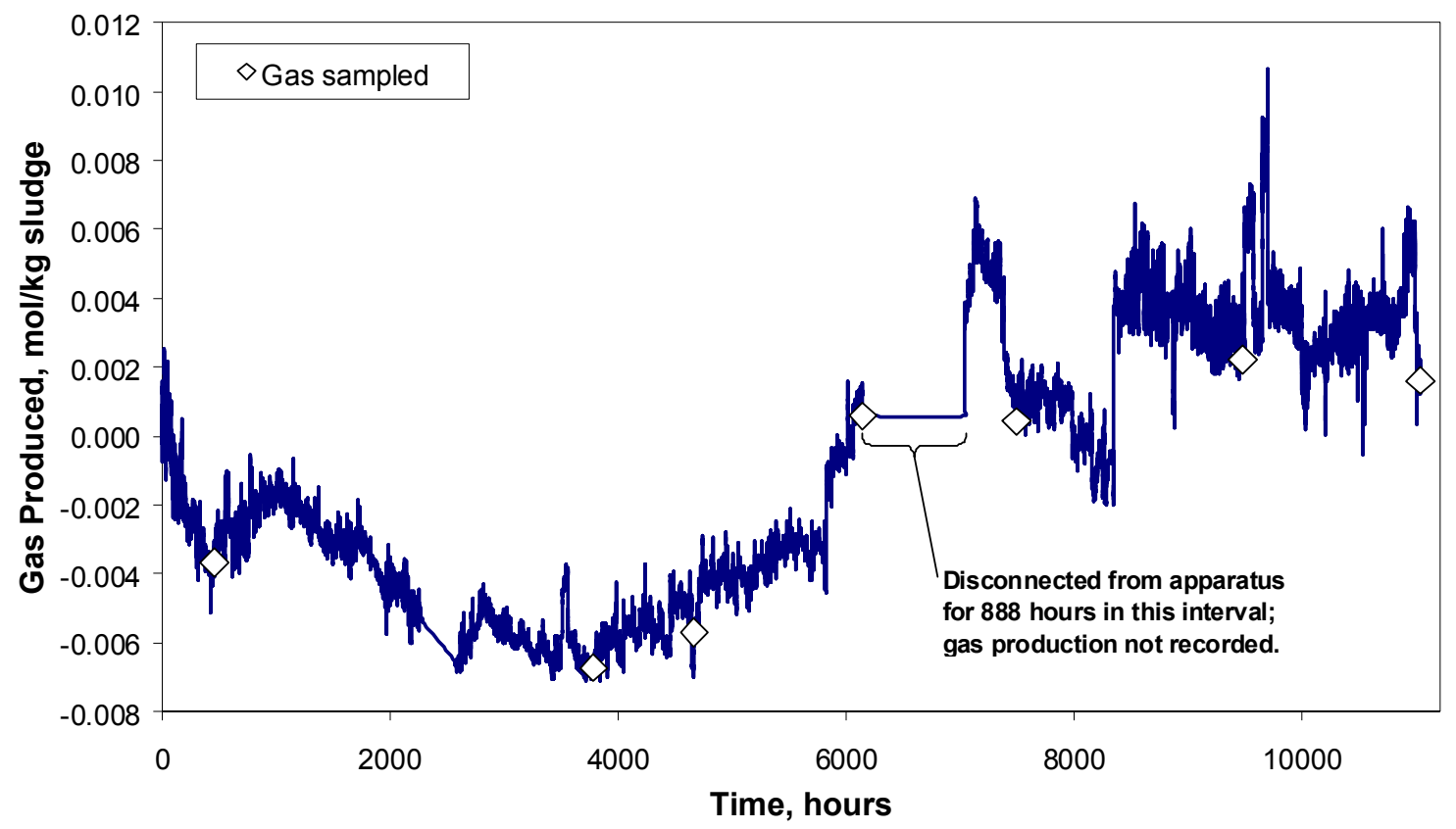

Figure 3.7. Total Gas Generation for the KC-2/3 P250L Test in 800-ml Reaction Vessel

In Section 5.5, the gas generation behavior of $\mathrm{KC}-2 / 3 \mathrm{P} 250$ is further discussed and compared to observations made in 1996 on other KE canister sludge samples at ambient hot cell temperature. The uranium metal particles in some of the $1996 \mathrm{KE}$ canister sludge samples oxidized in accordance with the hydride-mediated corrosion reaction.

The fluctuations in gas quantities observed in the present test were caused by the very low gas generation rates, compared with the total contained vessel gas volume and temperature variations over the test period. The product gases were sampled and analyzed by mass spectrometry to obtain generation rates for each gas. The mole percent gas compositions calculated in this system are given in Table B.23, along with the composition of generated gas. Gas generation rate data are given in Table B.24. 


\subsection{Gas Generation Chemistry}

The chemistry related to gas production during testing is discussed here to provide a basis for interpreting the results from the Series III experiments (Sections 5.0 through 7.0). The absolute and relative rates and amounts of the appearance and disappearance of the gases testify to (and allow quantitative interpretation of) the underlying chemical reactions occurring in the irradiated uranium and the sludge. Such reactions affect both the short-term and the long-term behavior of the K Basin sludge and the irradiated fuel particles less than $1 / 4-$ in. $(6350 \mu \mathrm{m})$ consigned to the sludge fraction. Thus, consideration of the observed reactions is important in the engineering, design, and safety for sludge retrieval, transport, and storage. The postulated chemical reactions are discussed in this section and have also been described with varying emphasis in the Series I and II reports.

Hydrogen $\left(\mathrm{H}_{2}\right)$ is the predominant gas evolved in the Series III tests with added fuel particles (Tests 1 through 11). Carbon dioxide $\left(\mathrm{CO}_{2}\right)$ is the primary gas observed in the long-term test containing only $\mathrm{KC}-2 / 3 \mathrm{P} 250$ canister sludge (Test 12). In addition, krypton ( $\mathrm{Kr}$ ) and xenon (Xe) fission product gas isotopes, and methane $\left(\mathrm{CH}_{4}\right)$, ethane $\left(\mathrm{C}_{2} \mathrm{H}_{6}\right)$, and lesser amounts of higher hydrocarbons were observed in the current tests. The same gases were observed in the 1996 gas collection tests associated with KE canister sludge (Makenas et al. 1997); in 1997 gas collection tests (conducted by PNNL) associated with KW canister sludge samples ${ }^{(a)}$ and in the Series I and II tests using KE Basin floor and canister sludge samples (Delegard et al. 2000; Bryan et al. 2001, respectively). Additionally, the consumption of oxygen $\left(\mathrm{O}_{2}\right)$ and the consumption and evolution of nitrogen $\left(\mathrm{N}_{2}\right)$ gases originally present from trace atmosphere intrusion were observed in many of the Series III tests.

\subsection{Uranium Corrosion and the Roles of Hydrogen, Oxygen, and Nitrogen}

The oxidation of metallic uranium under water-immersed conditions relevant to K Basin sludge occurs by several reactions that involve the chemical production and consumption of gases:

$$
\begin{aligned}
& \mathrm{U}+2 \mathrm{H}_{2} \mathrm{O} \rightarrow \mathrm{UO}_{2}+2 \mathrm{H}_{2(\mathrm{~g})} \\
& \mathrm{U}+\mathrm{O}_{2(\mathrm{aq})} \rightarrow \mathrm{UO}_{2} \\
& \mathrm{U}+0.875 \mathrm{~N}_{2(\mathrm{aq})} \rightarrow \mathrm{UN}_{1.75} \\
& \mathrm{U}+1.5 \mathrm{H}_{2(\mathrm{~g})} \rightarrow \mathrm{UH}_{3} \\
& \mathrm{UH}_{3}+2 \mathrm{H}_{2} \mathrm{O} \rightarrow \mathrm{UO}_{2}+7 \mathrm{H} \cdot\left(\text { or } 3.5 \mathrm{H}_{2(\mathrm{~g})}\right)
\end{aligned}
$$

In aerated waters, uranium metal corrosion occurs largely by reactions with dissolved oxygen (Reaction 2; Montenyohl 1960), and nitrogen (Reaction 3; discussed in Section 4.2). However, if the system becomes isolated from the atmosphere (as would occur for sealed vessels, under occluding corrosion products, and in confined layers of a settled sludge blanket in containers for sludge transport and storage), and the dissolved oxygen becomes depleted by Reaction 2, the direct reaction of uranium with water becomes dominant and Reaction 1 occurs to produce hydrogen gas. While both Reactions 1

(a) "K West Basin Canister Sludge Sample Analysis," Rev. 1. Pacific Northwest National Laboratory, Richland, WA. Letter report to R. B. Baker, Fluor Hanford, from K. L. Silvers, PNNL, September 16, 1997. 
and 2 occur in water to produce $\mathrm{UO}_{2}$, the rate of Reaction 2 (that is, uranium metal immersed in water reacting with dissolved oxygen) is 30 to 40 times slower than that of the anoxic Reaction 1 (the direct reaction of uranium with water itself; Johnson et al. 1994; Montenyohl 1960). Furthermore, the reaction with water (Reaction 1) seemingly does not occur to a great extent until the oxygen content is depleted (i.e., anoxic conditions are achieved). The transition from Reaction 2 to Reaction 1 is postulated to occur below $\sim 5 \mathrm{ppm} \mathrm{O}_{2}$ in water (weight basis) based on the transition occurring at $70^{\circ} \mathrm{C}$ in air-saturated water at the $5 \mathrm{ppm} \mathrm{O}_{2}$ concentration at that temperature (Hilton 2000). Thus, it is observed that the presence of dissolved oxygen inhibits uranium metal corrosion in water.

Hydrogen accelerates the corrosion of uranium metal in water through the formation, by Reaction 4, of the poorly adherent uranium hydride $\left(\mathrm{UH}_{3}\right)$ corrosion product (Montenyohl 1960). The hydride is inferred by the lag in $\mathrm{H}_{2}$ evolution by Reactions 1 and 2 and is directly observed at the metal surface and within cavities and around inclusions in the metal surface (Tyfield 1988). Uranium hydride also has been observed by X-ray diffraction (XRD) in carefully prepared KW Basin canister sludge samples (Makenas et al. 1998). However, the $\mathrm{UH}_{3}$ intermediate is unstable in water and reacts to form $\mathrm{UO}_{2}$ and hydrogen atom radicals (Reaction 5). The released hydrogen atoms may combine to form $\mathrm{H}_{2}$ gas or, especially if occluded, interact with the underlying bulk uranium metal to form more $\mathrm{UH}_{3}$ by Reaction 4 to continue the corrosion cycle through Reaction 5. Note that the sum of Reactions 4 and 5 is Reaction 1.

The transition in closed experimental vessels to rapid anoxic corrosion dominated by Reactions 4 and 5 usually is preceded by an induction time. The induction times vary unpredictably, even at experimentally identical conditions (Tyfield 1988; Wilkinson 1962). While rapid corrosion via Reactions 4 and 5 (i.e., the hydride intermediate) is observed in anoxic conditions, the stoichiometrically equivalent Reaction 1 , or possibly the combined Reactions 4 and 5 in an isolated anoxic cell, evidently also occurs during the induction time, though at a much lower rate than observed after the induction time, to provide the hydrogen necessary to initiate the more rapid anoxic corrosion by Reaction 4 . Therefore, uranium reaction with water can occur under two regimes. The first is during an initial period of low reaction rate (in the presence of oxygen and absence of significant free hydrogen and hydride hydrogen concentrations) by Reaction 1 or, alternatively, by Reactions 4 and 5 in small anoxic regions. With sufficient hydrogen, the second regime is entered in which uranium corrosion by water occurs universally at the much higher rate afforded by $\mathrm{UH}_{3}$ mediation (the combined Reactions 4 and 5).

Uranium corrosion by Reactions 4 and 5 follows kinetics that are first order in the uranium metal surface area. Data from the technical literature have been evaluated (SNF Databook, Vol. 1, Reilly 1998) ${ }^{(\mathrm{a})}$ to derive the following rate equation (for temperatures less than $100^{\circ} \mathrm{C}$ ) used as a basis for $\mathrm{K}$ Basin engineering decisions:

$$
\log \text { rate }\left(\mathrm{U} \text { weight loss, } \mathrm{mg} / \mathrm{cm}^{2} \cdot \mathrm{hr}\right)=8.505-\frac{3016}{\mathrm{~T}}
$$

The absolute temperature, $\mathrm{T}$, in Equation $\mathrm{A}$ is in $\mathrm{K}$. The temperature dependence of this rate equation corresponds to an activation energy of $13.8 \mathrm{kcal} / \mathrm{mole}$. A later review of reported uranium corrosion studies in anoxic water (Hilton 2000) fit the combined rate data at $20-300^{\circ} \mathrm{C}$ to the equation:

(a) While the SNF Project has revised this document (Duncan 2001), no revisions were made to the values/equations of interest (Table 4-4). 


$$
\log \text { rate }\left(\mathrm{U} \text { weight loss, } \mathrm{mg} / \mathrm{cm}^{2} \cdot \mathrm{hr}\right)=9.701-\frac{3470}{\mathrm{~T}}
$$

The slope of Equation B indicates an activation energy of $15.8 \mathrm{kcal} / \mathrm{mole}$. The linear penetration corrosion rates, derived from Equations $\mathrm{A}$ and $\mathrm{B}$ by multiplying the areal mass loss rates by the density of uranium metal $\left(19.05 \mathrm{~g} / \mathrm{cm}^{3}\right)$, are compared in Figure 4.1 . It is seen that at $30^{\circ} \mathrm{C}$, the rate predicted by the SNF Databook ( $\sim 0.02 \mu \mathrm{m} / \mathrm{hr}$ ) (Reilly 1998) is about two times that predicted by the review of Hilton (2000). However, the rates converge with increasing temperature, becoming equal $(\sim 2 \mu \mathrm{m} / \mathrm{hr})$ at about $106^{\circ} \mathrm{C}$. Above that temperature, the rates predicted by the Hilton (2000) fit are higher than the SNF Databook fit.

No corrosion rate data to describe the initial slow reaction of uranium metal with water to form $\mathrm{H}_{2}$ have been found in the review of the technical literature.

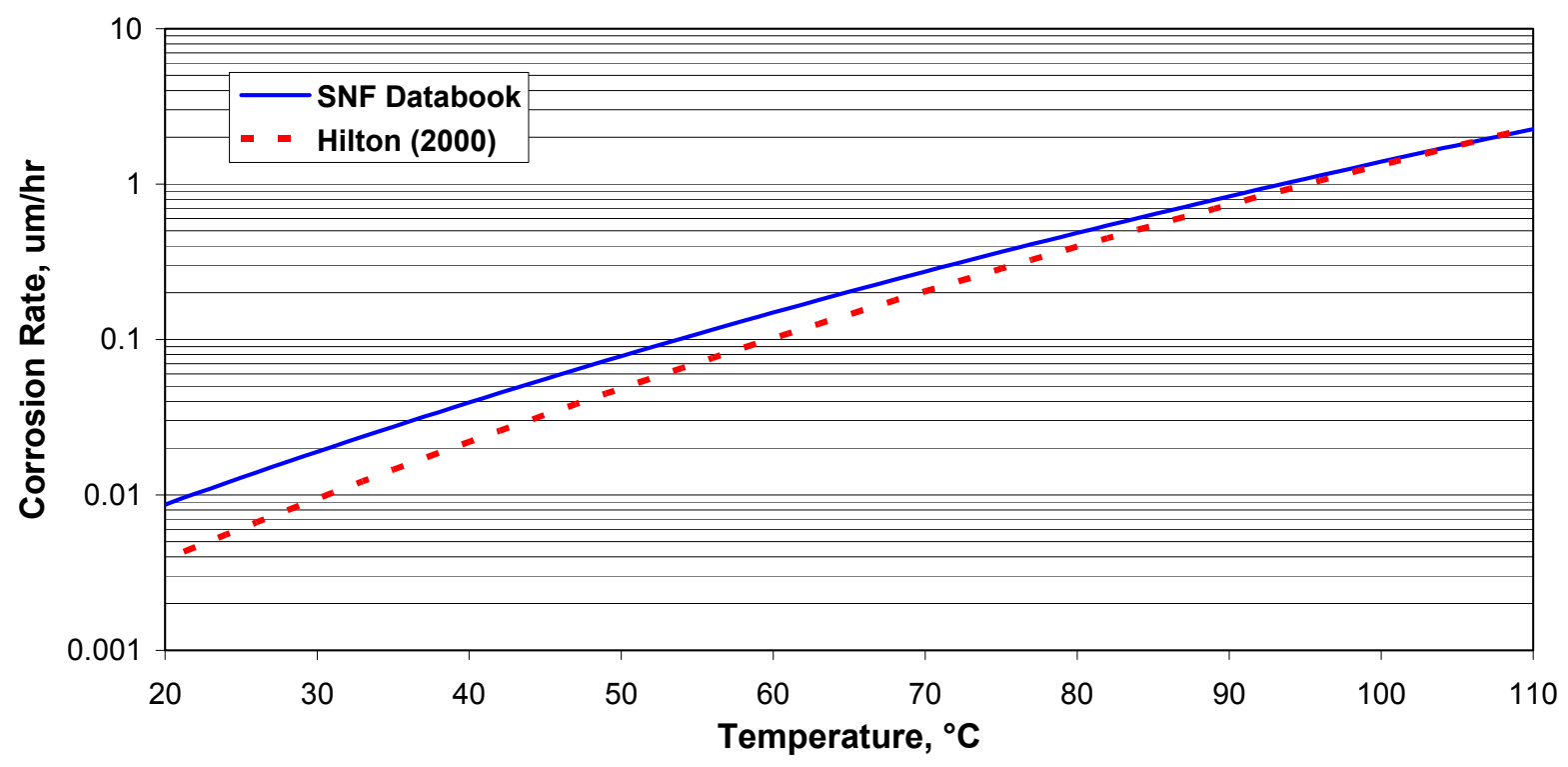

Figure 4.1. Comparison of Linear Penetration Uranium Corrosion Rates in Oxygen-Free Water. The rates were derived from SNF Databook equation and Hilton equation.

\subsection{Nitrogen and the Possible Formation of Ammonia}

No explicit reference was found in the technical literature for Reaction 3, the proposed reaction of uranium metal with $\mathrm{N}_{2}$ occurring in aqueous systems. The postulated Reaction 3 is based on the observed depletion of $\mathrm{N}_{2}$ from the gas phase in the present and prior (Series I and II) tests, $\mathrm{pH}$ measurements of the test materials before and after reaction, and on a variety of published findings regarding reactions of gasphase $\mathrm{N}_{2}$ (and other gases) with uranium metal. For example, it is reported that $\mathrm{UN}_{1.75}$ can be prepared by direct reaction of uranium metal with $\mathrm{N}_{2}$ at $200^{\circ} \mathrm{C}$ to $300^{\circ} \mathrm{C}$ (Cordfunke 1969). Like the case for the combined Reactions 4 and 5, in which $\mathrm{H}_{2}$ can accelerate the reaction of uranium with water, it has been found that $\mathrm{H}_{2}$ also can mediate the reaction of uranium with $\mathrm{N}_{2}$ and accelerate Reaction 3. Thus, $\mathrm{H}_{2}$ is observed to lower the temperature required to form $\alpha-\mathrm{U}_{2} \mathrm{~N}_{3+\mathrm{x}}$ from the reaction of uranium metal with $\mathrm{N}_{2}$ (Katsura et al. 1998). Ammonia $\left(\mathrm{NH}_{3}\right)$ is observed to be an eventual product of this reaction. 
Related thermogravimetric experiments showed that uranium metal with mixed $\mathrm{N}_{2}$ and $\mathrm{H}_{2}$ gas begins to form uranium nitride at about $250^{\circ} \mathrm{C}$, whereas uranium hydride with $\mathrm{N}_{2}$ begins to form uranium nitride at $160^{\circ} \mathrm{C}$. Together, these observations indicate that $\mathrm{UH}_{3}$ can act as an intermediate to accelerate the formation of uranium nitride (Tagawa 1973). In both cases, $\mathrm{NH}_{3}$ also is formed. It is significant to note that early pioneering work by Haber and le Rossignol (1913) found uranium (and osmium) to be effective catalysts to prepare $\mathrm{NH}_{3}$ from heated and pressurized $\mathrm{N}_{2}$ and $\mathrm{H}_{2}$ gases. ${ }^{\text {(a) }}$ Other work shows that the reaction of the uranium nitride compound $\mathrm{UN}$ with water at $23^{\circ} \mathrm{C}$ to $92^{\circ} \mathrm{C}$ forms $\mathrm{UO}_{2}, \mathrm{U}_{3} \mathrm{O}_{7}, \mathrm{U}_{2} \mathrm{~N}_{3}$, and evolves some $\mathrm{NH}_{3}$ (Sunder and Miller 1998).

Nitrogen also is known to be a minor constituent of $\mathrm{N}$ Reactor fuel, comprising 75 parts per million part (ppmp) uranium on a weight basis (Weakley 1979). The disposition of nitrogen (e.g., as uranium nitride inclusions) in the fuel is not known.

Increases in solution $\mathrm{pH}$ and depletion of atmospheric $\mathrm{N}_{2}$ (and $\left.\mathrm{O}_{2}\right)$ relative to atmospheric argon were observed in aqueous corrosion testing of uranium metal in $90^{\circ} \mathrm{C}$ simulated well water containing $\sim 0.002 \mathrm{M}$ bicarbonate (Fonnesbeck 2000). Unintentional atmospheric contamination occurred in the tests, introducing $\mathrm{O}_{2}$ and $\mathrm{N}_{2}$. In addition to the depletion of the $\mathrm{O}_{2}$ and $\mathrm{N}_{2}$ atmospheric contaminant gases, the initial solution $\mathrm{pH}$ was found to increase from 8.65 to values ranging from 9.79 to 10.38 after 9 to 21 days of reaction, partially overcoming the buffering provided by the dissolved bicarbonate present in the simulated well water.

The possible formation of $\mathrm{NH}_{3}$ in the aqueous reaction of uranium with atmospheric $\mathrm{N}_{2}$ and $\mathrm{H}_{2}$ generated by uranium metal corrosion or reaction of trace nitrogen from the fuel may explain the $\mathrm{pH}$ increases observed in a number of the Series I, II, and III tests and in the tests of Fonnesbeck (2000). The product $\mathrm{NH}_{3}$, dissolved in water, produces a mildly alkaline solution (for example, the $\mathrm{pH}$ of a $0.01 \mathrm{M} \mathrm{NH}_{3}$ solution is 10.6):

$$
\mathrm{NH}_{3(\mathrm{~g})}+\mathrm{H}_{2} \mathrm{O}_{(\mathrm{l})} \rightarrow \mathrm{NH}_{4} \mathrm{OH}_{(\mathrm{aq})} \leftrightarrow \mathrm{NH}_{4}^{+}+\mathrm{OH}^{-}
$$

To ascertain if $\mathrm{NH}_{3}$ might have formed in the current test series, mass spectrometric analyses of gas products from selected tests (the first samples taken from the tests SNF P2000 80S, SNF M500 80L, SNF Mid 80L, and SNF Mid 80L Dup) were carefully examined to determine the signal intensities for mass/charge $\left(\mathrm{m} / \mathrm{e}\right.$ ) values of 17 (corresponding to $\mathrm{NH}_{3}$ but also $\mathrm{OH}$ ) and 18 (corresponding to $\mathrm{H}_{2} \mathrm{O}$ ). Gas products from these four test intervals represented the samplings having the highest observed $\mathrm{N}_{2}$ gas consumption in Series III. The ratios of the $\mathrm{m} / \mathrm{e}(17)$ to $\mathrm{m} / \mathrm{e}(18)$ intensities were calculated and compared with the ratio found in a test for water vapor alone injected into the mass spectrometer. If significant amounts of $\mathrm{NH}_{3}$ were present in the gas phase, the $\mathrm{m} / \mathrm{e}(17): \mathrm{m} / \mathrm{e}(18)$ ratio should be elevated compared to that for water alone. However, the results (Table 4.1) find no marked increase in the $\mathrm{m} / \mathrm{e}(17)$ to $\mathrm{m} / \mathrm{e}(18)$ ratio for any of the samples above that of water alone and thus provide no evidence for $\mathrm{NH}_{3}$ formation.

According to Henry's Law, the vapor pressure of a gas above its dilute aqueous solution is proportional to the mole fraction of that gas in solution. For $\mathrm{NH}_{3}$, Henry's Law is expressed by $\mathrm{P}_{\mathrm{NH} 3}=\mathrm{k}_{\mathrm{H}} \mathrm{X}_{\mathrm{NH} 3}$ where $\mathrm{P}_{\mathrm{NH} 3}$ is the vapor pressure of $\mathrm{NH}_{3}, \mathrm{k}_{\mathrm{H}}$ is the Henry's Law constant, and $\mathrm{X}_{\mathrm{NH} 3}$ is the mole fraction of $\mathrm{NH}_{3}$ in solution. Therefore, the maximum $\mathrm{NH}_{3}$ vapor pressure expected if all lost atmospheric $\mathrm{N}_{2}$ were

(a) This work, cited in the presentation speech for Fritz Haber's 1918 Nobel Prize in chemistry, is the laboratory basis for the industrial production of ammonia. Current ammonia production plants generally use "promoted iron" catalysts and do not use uranium. 
Table 4.1. Nitrogen Consumed and Ratios of $\mathrm{m} / \mathrm{e}(17)$ to $\mathrm{m} / \mathrm{e}(18)$ Intensities

\begin{tabular}{|c|c|c|c|c|}
\hline \multirow[b]{2}{*}{ Sample } & \multirow{2}{*}{$\begin{array}{l}\text { N Lost, } \\
\mathrm{X}_{\mathrm{NH} 3}{ }^{(a)}\end{array}$} & \multicolumn{2}{|c|}{ Signal, volts } & \multirow{2}{*}{$\begin{array}{c}\text { Ratio } \\
\mathrm{m} / \mathrm{e}(17): \mathrm{m} / \mathrm{e}(18)\end{array}$} \\
\hline & & $\mathbf{m} / \mathbf{e}(17)$ & $\mathrm{m} / \mathrm{e}(18)$ & \\
\hline $\mathrm{H}_{2} \mathrm{O}$ standard & -- & 1.2689 & 4.9678 & 0.25542 \\
\hline SNF P2000 80S (Test 5) & $8.2 \mathrm{E}-6$ & $7.04 \mathrm{E}-4$ & $2.75 \mathrm{E}-3$ & 0.25569 \\
\hline SNF M500 80L (Test 6) & $3.7 \mathrm{E}-6$ & $5.22 \mathrm{E}-3$ & $2.06 \mathrm{E}-2$ & 0.25373 \\
\hline SNF Mid 80L (Test 7) & $8.6 \mathrm{E}-7$ & $2.36 \mathrm{E}-3$ & $9.20 \mathrm{E}-3$ & 0.25658 \\
\hline SNF Mid 80L Dup (Test 8) & $1.1 \mathrm{E}-5$ & $1.88 \mathrm{E}-3$ & $7.54 \mathrm{E}-3$ & 0.24909 \\
\hline
\end{tabular}

(a) $\mathrm{X}_{\mathrm{NH} 3}$ is mole fraction concentration of $\mathrm{NH}_{3}$ assuming all lost $\mathrm{N}$ is present as dissolved $\mathrm{NH}_{3}$; $10^{-5}$ mole fraction $\mathrm{NH}_{3}$ corresponds to $5.6 \times 10^{-4} \mathrm{M} \mathrm{NH}_{3}$.

converted to $\mathrm{NH}_{3}$ would be found for the solution having the highest potential mole fraction $\mathrm{NH}_{3}$ in solution. This occurs for SNF Mid 80L Dup (Table 4.1) with a mole fraction, $\mathrm{X}_{\mathrm{NH} 3}$, of $1.1 \times 10^{-5}$ or about $6.1 \times 10^{-4} \mathrm{M} \mathrm{NH}_{3}$. The Henry's Law constant, $\mathrm{k}_{\mathrm{H}}$, for $\mathrm{NH}_{3}$ in $30^{\circ} \mathrm{C}$ water is 856 torr (calculated based on Weber 1999). Therefore, the maximum potential $\mathrm{NH}_{3}$ vapor pressure would be 856 torr $\times\left(1.1 \times 10^{-5}\right)=$ 0.0096 torr. The vapor pressure of water at $30^{\circ} \mathrm{C}$ is $\sim 32$ torr or about 3300 times that of $\mathrm{NH}_{3}$. To a first approximation, the increment that $\mathrm{NH}_{3}$ could contribute to the $\mathrm{m} / \mathrm{e}(17)$ signal would increase the $\mathrm{m} / \mathrm{e}(17): \mathrm{m} / \mathrm{e}(18)$ ratio by $\sim 0.0001$ and would not be perceptible by mass spectrometry. Thus, detection of any potential $\mathrm{NH}_{3}$ product by mass spectrometry would be difficult, owing to the high solubility of $\mathrm{NH}_{3}$ in water.

Nitrogen gas is evolved in certain of the latter gas samples taken in the Series III testing as well as the Series I and II testing. However, the possibility that $\mathrm{N}_{2}$ may be released by corrosion of the purported uranium nitride phase in water was not found in any published literature. For example, studies of $\mathrm{UN}$ decomposition in water considered only $\mathrm{NH}_{3}$ product and not $\mathrm{N}_{2}$ (Sunder and Miller 1998).

At $\mathrm{T}$ Plant, the KE Basin sludge will be stored in vented containers (i.e., aerobic conditions). The Series III tests, and Series I and II tests, were performed in neon-purged systems with only trace atmospheric contamination. Before the possibility of $\mathrm{NH}_{3}$ formation is dismissed, further tests of uranium corrosion in aerated water should be performed and the water itself analyzed to determine if $\mathrm{NH}_{3}$ is present in the product solution.

\subsection{Release of Fission Product Gases}

The existence of the $\mathrm{Kr}$ and $\mathrm{Xe}$ fission products in the generated gases gives qualitative evidence for the corrosion of irradiated uranium metal. This is based on the suppositions that, until corrosion occurs, the fission gases remain trapped within the solid uranium metal fuel matrix and the metal corrosion products (e.g., $\mathrm{UO}_{2}, \mathrm{UH}_{3}$ ), and other sludge components cannot react with, and thus retain (except through physical entrapment and dissolution in water), the inert $\mathrm{Kr}$ and $\mathrm{Xe}$ gases. Once corrosion occurs, the fission gases are assumed to be released through grain formation and oxidation of the matrix.

According to burnup calculations by the ORIGEN code (see Delegard et al. 2000), the isotopic ratios and the total $\mathrm{Kr}$ /total Xe mole ratios remain relatively unaffected by irradiation exposure. The ORIGEN calculations show that the $\mathrm{Kr} / \mathrm{Xe}$ mole ratio increases from $\sim 11.6$ to 13.1 ( 7.4 to 8.3 mole ratio) as burnup increases from $\sim 1000$ to $3600 \mathrm{MWD} / \mathrm{TeU}$ (megawatt-days per metric tonne of uranium). On the other 
hand, $\mathrm{Kr}$ and $\mathrm{Xe}$ production increases almost linearly with increasing irradiation levels (i.e., exposure or burnup). Thus, if burnup is known, the quantity of $\mathrm{Kr}$ or Xe released by corrosion of uranium metal can be used to determine the quantity of uranium metal consumed by corrosion. Conversely, if the concentrations of $\mathrm{Kr}$ and $\mathrm{Xe}$ in the uranium metal (determined by analyzing the gas generated from metal corrosion) are known, burnup may be calculated. Output data from the ORIGEN code may be fit to correlate burnup to the total mass concentrations of $\mathrm{Xe}$ or $\mathrm{Kr}$ gas in the uranium metal fuel:

$$
\begin{gathered}
\text { Burnup }(\mathrm{MWD} / \mathrm{TeU})=-9.94 \times 10^{-5}(\mathrm{Xe}, \mathrm{ppmp} \mathrm{U})^{2}+4.87(\mathrm{Xe}, \mathrm{ppmp} \mathrm{U}) \\
\text { Burnup }(\mathrm{MWD} / \mathrm{TeU})=0.154(\mathrm{Kr}, \mathrm{ppmp} \mathrm{U})^{2}+54.1(\mathrm{Kr}, \mathrm{ppmp} \mathrm{U})
\end{gathered}
$$

The concentration of uranium metal in a sludge or batch of crushed fuel particles can only be determined for those tests run to complete reaction of the uranium metal. In Series III, the uranium metal was completely reacted in the SNF M500 80L test (for the $<500-\mu \mathrm{m}$ particles) and in the SNF Mid $80 \mathrm{~L}$ and SNF Mid 80L Dup tests (for the 500-2000- $\mu \mathrm{m}$ particles). Analyses of the gas production/consumption data (explained in detail in Section 5.2) show that the $<500-\mu \mathrm{m}$ particles were $74.2 \mathrm{wt} \%$ uranium metal, with the balance being Zircaloy cladding shards observed in post-test examination and likely some preexisting uranium metal fuel reaction products (e.g., $\mathrm{UO}_{2}$ ). Similarly, the $500-2000-\mu \mathrm{m}$ particles were $90.8 \mathrm{wt} \%$ and $95.2 \mathrm{wt} \%$ uranium metal (93.0 wt\% average) in the respective SNF Mid 80L and SNF Mid 80L Dup tests, according to the gas analysis data. The burnup then can be calculated using Equations $\mathrm{C}$ and $\mathrm{D}$, based on the associated fission product gas concentrations released in these tests. The fission product gas concentrations and burnup values are summarized in Table 4.2.

Averaged values for the fission product gas concentrations and burnup were calculated based on Tests 6 through 8. Averaging these values is meaningful, because the reacting metals were derived from the same population of original irradiated uranium fuel particles. As discussed, the Series III tests were conducted with irradiated fuel particles taken from the same fuel coupons and therefore assumed to contain approximately the same $\mathrm{Kr}$ and $\mathrm{Xe}$ concentrations with respect to uranium metal and burnup as found in Table 4.2. Note, however, that the burnups calculated based on $\operatorname{Kr}(\sim 2560 \mathrm{MWD} / \mathrm{TeU})$ and $\mathrm{Xe}$ $(\sim 3120 \mathrm{MWD} / \mathrm{TeU})$ differ by about $20 \%$. The disparity arises because Equations $\mathrm{C}$ and $\mathrm{D}$ are based on

Table 4.2. Fission Product (FP) Gas and Burnup Calculations for Tests Run to Completion

\begin{tabular}{|l|l|c|c|}
\hline \multicolumn{1}{|c|}{ Test } & $\begin{array}{c}\text { FP } \\
\text { Gas }\end{array}$ & $\begin{array}{c}\text { [FP Gas], } \\
\boldsymbol{\mu g} \text { gas/g U }\end{array}$ & $\begin{array}{c}\text { Burnup, } \\
\text { MWD/TeU }\end{array}$ \\
\hline \multirow{2}{*}{ SNF M500 80L (Test 6) } & $\mathrm{Kr}$ & 42.8 & 2600 \\
\cline { 2 - 4 } & $\mathrm{Xe}$ & 679 & 3260 \\
\hline \multirow{2}{*}{ SNF Mid 80L (Test 7) } & $\mathrm{Kr}$ & 43.7 & 2660 \\
\cline { 2 - 4 } & $\mathrm{Xe}$ & 629 & 3020 \\
\hline \multirow{2}{*}{ SNF Mid 80L Dup (Test 8) } & $\mathrm{Kr}$ & 40.1 & 2420 \\
\cline { 2 - 4 } & $\mathrm{Xe}$ & 644 & 3090 \\
\hline \multirow{2}{*}{ Average } & $\mathrm{Kr}$ & $42.2 \pm 1.9$ & $2560 \pm 120$ \\
\cline { 2 - 4 } & $\mathrm{Xe}$ & $651 \pm 26$ & $3120 \pm 120$ \\
\hline \hline
\end{tabular}


ORIGEN, a code to predict averaged burnups for complete fuel elements over the entire N Reactor. This prediction is inevitably imprecise for a particular collection of fuel particles, with each particle likely having a different exposure level according to its original location within the fuel element and in the reactor. The observed $\mathrm{Kr}$ concentration in the fuel particles, $42.2 \pm 1.9 \mu \mathrm{g} \mathrm{Kr} / \mathrm{g} \mathrm{U}$, may be compared with $46.4 \mu \mathrm{g} \mathrm{Kr} / \mathrm{g} \mathrm{U}$, based on an average $2840 \mathrm{MWD} / \mathrm{TeU}$ burnup and ORIGEN calculations, and $651 \pm$ $26 \mu \mathrm{g} \mathrm{Xe} / \mathrm{g} \mathrm{U}$ (instead of $590 \mu \mathrm{g} \mathrm{Xe/g} \mathrm{U}$ based on ORIGEN and $2840 \mathrm{MWD} / \mathrm{TeU}$ burnup). The $2840 \mathrm{MWD} / \mathrm{TeU}$ value is the average of the burnups observed by $\mathrm{Kr}$ and Xe evolution.

The fission product gas isotopic concentrations for the tests presented in Table 4.3 are similar to those predicted based on ORIGEN calculations. The average fuel cooling time, $23.0 \pm 2.6$ years based on ${ }^{85} \mathrm{Kr}$ decay, is consistent with the discharge date for the source element (November 1975). The gas generation testing and mass spectrometric analyses of the product gas (Table 2.4) largely occurred in September through November 2000, 25 years after the discharge date for the source element.

The Fuel Fragment test (Test 9 using the single fuel piece), though from the same element, would not necessarily show the same $\mathrm{Kr}$ and $\mathrm{Xe}$ isotopic signature as that shown by the 10 tests derived from a separate collection of crushed fuel. The KC-2/3 P250L, sludge-only, test (Test 12) had much lower uranium metal concentrations, and correspondingly lower quantities of $\mathrm{Kr}$ and Xe would be released. In this situation, the quantities of $\mathrm{Kr}$ and Xe dissolved in solution or present interstitially in the sludge solids may become significant. In general, for sludges containing miniscule particles of residual

Table 4.3. Fission Product Gas Isotope Data for SNF M500 80L, SNF Mid 80L, and SNF Mid 80L Dup

\begin{tabular}{|c|c|c|c|c|}
\hline \multirow[b]{2}{*}{ Gas } & \multicolumn{3}{|c|}{ Isotopic Composition, atom\% $^{(\mathbf{a})}$} & \multirow[b]{2}{*}{ ORIGEN $^{(\mathbf{b})}$} \\
\hline & $\begin{array}{l}\text { SNF M500 80L } \\
\text { (Test 6) }\end{array}$ & SNF Mid 80L (Test 7) & $\begin{array}{l}\text { SNF Mid 80L Dup } \\
\text { (Test 8) }\end{array}$ & \\
\hline${ }^{83} \mathrm{Kr}$ & 13.0 & 14.7 & 14.3 & 13.3 \\
\hline${ }^{84} \mathrm{Kr}$ & 27.8 & 29.6 & 30.7 & 28.3 \\
\hline${ }^{85} \mathrm{Kr}$ & 2.0 & 1.4 & 1.4 & 6.8 \\
\hline${ }^{86} \mathrm{Kr}$ & 57.2 & 54.3 & 53.6 & 51.5 \\
\hline${ }^{130} \mathrm{Xe}$ & 0.036 & 0.029 & 0.028 & 0.05 \\
\hline${ }^{131} \mathrm{Xe}$ & 10.4 & 10.5 & 10.4 & 10.7 \\
\hline${ }^{132} \mathrm{Xe}$ & 18.0 & 18.4 & 18.2 & 18.0 \\
\hline${ }^{134} \mathrm{Xe}$ & 28.9 & 28.7 & 28.6 & 28.0 \\
\hline${ }^{136} \mathrm{Xe}$ & 42.6 & 42.4 & 42.8 & 43.2 \\
\hline $\begin{array}{c}\mathrm{Xe}: \mathrm{Kr} \\
\text { mole ratio }\end{array}$ & 10.0 & 9.1 & 10.1 & 8.2 \\
\hline \multirow{2}{*}{$\begin{array}{l}\text { Based on } \\
{ }^{85} \text { Kr decay }\end{array}$} & \multicolumn{4}{|c|}{ Calculated Cooling Time, years $^{(\mathrm{c})}$} \\
\hline & 20.0 & 24.5 & 24.5 & -- \\
\hline \multicolumn{5}{|c|}{$\begin{array}{l}\text { (a) Correcting the } \mathrm{Kr} \text { isotopic compositions for }{ }^{85} \mathrm{Kr} \text { decay would decrease the stated }{ }^{83} \mathrm{Kr} \text { values by } \sim 0.75 \% \text {, } \\
\text { decrease }{ }^{84} \mathrm{Kr} \text { values by } \sim 1.6 \% \text {, increase the }{ }^{85} \mathrm{Kr} \text { values by } \sim 5.25 \% \text {, and decrease the }{ }^{86} \mathrm{Kr} \text { values by } \sim 2.9 \% \text {. } \\
\text { (b) ORIGEN } 2 \text { calculation for N Reactor MkIV fuel at } 2921 \mathrm{MWD} / \mathrm{TeU} \text {; ratios change }<3 \% \text { relative at lower } \\
\text { burnups; }{ }^{85} \mathrm{Kr} \text { has a } 10.76 \text {-year half-life. } \\
\text { (c) Actual cooling years, based on discharge date of November } 1975 \text {, is } 25 \text { years. }\end{array}$} \\
\hline
\end{tabular}


uranium metal, a slightly larger fraction of fission product $\mathrm{Kr}$ or Xe can diffuse out of the metal matrix (due to a higher concentration of grain boundaries per unit mass) than would be expected from corrosion alone. These effects, which act in opposite directions, decrease the reliability of obtaining quantitative uranium metal concentration and estimates of burnup based on $\mathrm{Kr}$ and $\mathrm{Xe}$ gas analyses for samples having low metal concentrations.

\subsection{Creation and Release of Hydrocarbons}

Methane $\left(\mathrm{CH}_{4}\right)$, ethane $\left(\mathrm{C}_{2} \mathrm{H}_{6}\right)$, higher hydrocarbons, and small quantities of $\mathrm{H}_{2}$ arise from the reaction of water with the carbide carbon present in the uranium metal fuel. Hydrogen, methane, ethane, propane $\left(\mathrm{C}_{3} \mathrm{H}_{8}\right)$, butane $\left(\mathrm{C}_{4} \mathrm{H}_{10}\right)$, pentane $\left(\mathrm{C}_{5} \mathrm{H}_{12}\right)$, and hexane $\left(\mathrm{C}_{6} \mathrm{H}_{14}\right)$ have been observed in the reaction of mixtures of uranium metal and uranium monocarbide (UC) with water at $80^{\circ} \mathrm{C}$ (Bradley and Ferris 1962 , 1964). Methane also was observed in corrosion tests of uranium metal with water at $50^{\circ} \mathrm{C}$ (Waber 1956). The carbon content in the metallic uranium fuels stored in the $\mathrm{K}$ Basins nominally ranges from 365 to 735 ppmp uranium (average 550 ppmp U; Weakley 1979). At these low carbon concentrations in the uranium-carbon system, the carbon is present as UC dispersed within metallic uranium (Wilkinson 1962). Uranium carbide inclusions appear in photomicrographs of irradiated N Reactor fuel (Figure 4.2) and unirradiated test fuel (Troutner 1960) as rectangles or parallelograms, $\sim 4 \mu \mathrm{m}$ to $\sim 20 \mu \mathrm{m}$ on a side.

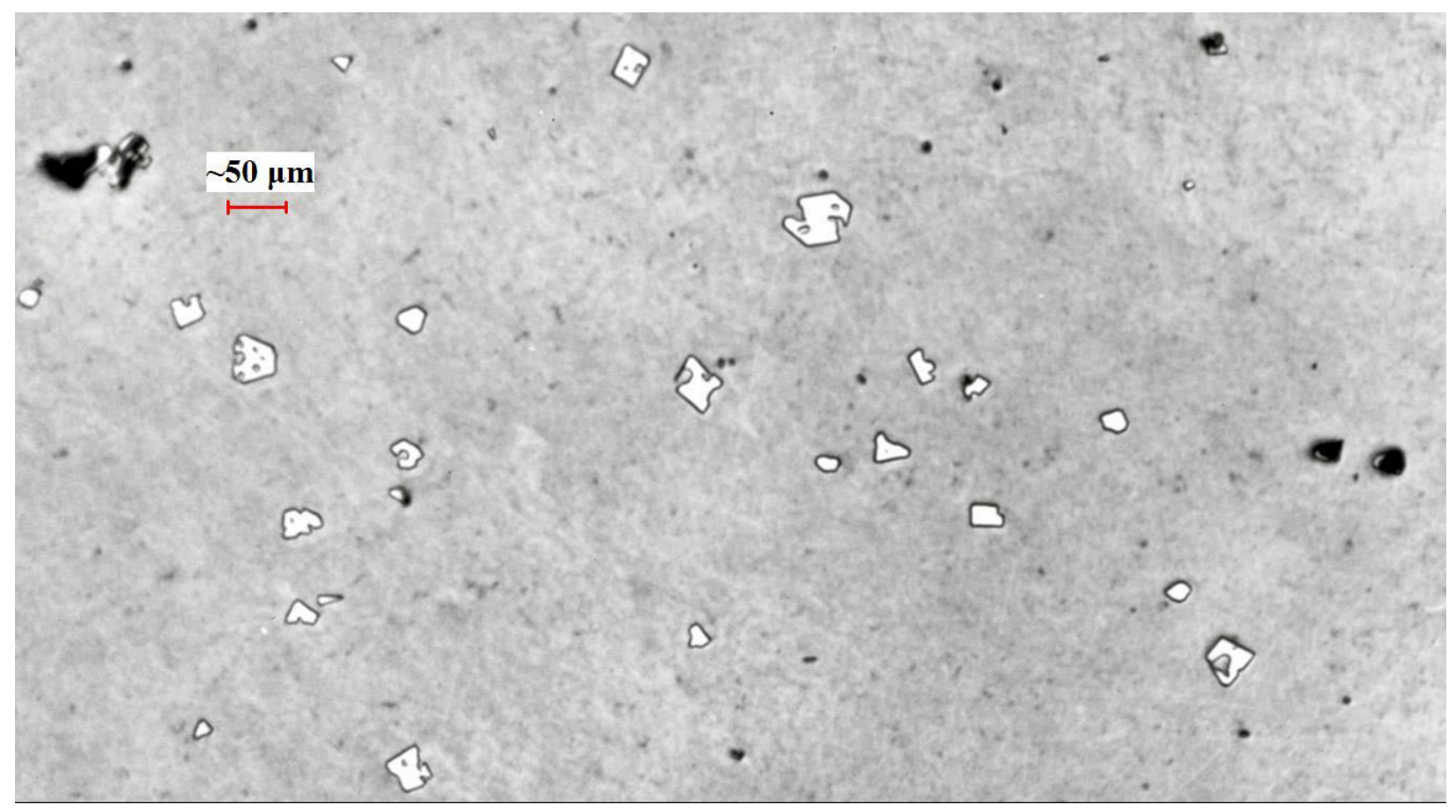

Figure 4.2. Metallographic Image of Irradiated N Reactor Fuel Showing Uranium Carbide (UC) Inclusions (Marschman et al. 1997) 
Hydrocarbon gas products were quantified in the Series I and II testing, and the resulting data were used to confirm the quantity of uranium metal originally present in the sludge samples. Reaction 7 rationalizes the hydrocarbon product distribution, observed in Series I testing, that arises when the UC contained in the fuel reacts with water:

$$
\mathrm{UC}+2 \mathrm{H}_{2} \mathrm{O} \rightarrow \mathrm{UO}_{2}+0.591 \mathrm{CH}_{4}+0.085 \mathrm{C}_{2} \mathrm{H}_{6}+0.060 \mathrm{C}_{3} \mathrm{H}_{8}+0.015 \mathrm{C}_{4} \mathrm{H}_{10}+0.248 \mathrm{H}_{2}
$$

Because the $\mathrm{C}_{3}$ and higher hydrocarbons are not discriminated by mass spectrometry in the present tests, the $\mathrm{C}_{23}$ hydrocarbons were projected to be $\mathrm{C}_{3.2} \mathrm{H}_{8.4}$, on average, based on the observations of Bradley and Ferris $(1962,1964)$, and are represented in Reaction 7 by propane and butane in that proportion. The projected 0.248 moles of hydrogen arising per mole of UC is a significant contributor to the total gas generated from $\mathrm{UC}$ reaction with $\mathrm{H}_{2} \mathrm{O}$ (Reaction 7$)$. However, it is a negligible $(\sim 0.14 \%)$ addition to the $\mathrm{H}_{2}$ generated by reaction of uranium metal with water in nominal 550-ppm carbon fuel.

As is the case of fission product $\mathrm{Kr}$ and $\mathrm{Xe}$, tests having relatively low uranium metal concentrations produce correspondingly low quantities of hydrocarbon from fuel corrosion. In Series III, however, 11 of the 12 tests contained added irradiated uranium metal fuel such that hydrocarbon gas products were readily found in the samples analyzed by mass spectrometry. Only the KC-2/3 P250L test had negligible hydrocarbon gas product. In such instances of little uranium metal corrosion, the fraction of the hydrocarbon arising from degradation of other reduced (non-carbonate) carbon sources in the sludge may become a significant fraction of the total hydrocarbon. Reduced carbon sources in sludge might include organic ion exchange resin, plant and animal debris (e.g., twigs, insects), paper and other cellulose, plastic, and rubber used in K Basin operations.

\subsection{Carbon Dioxide Generation}

Significant quantities of $\mathrm{CO}_{2}$ were found in gases generated from sludge-bearing tests, whereas fuel-only tests contained much lower fractions and absolute quantities of $\mathrm{CO}_{2}$. One explanation for the evolution of $\mathrm{CO}_{2}$ in tests with sludge is the reaction in water of schoepite, $\left(\mathrm{UO}_{2}\right)_{8} \mathrm{O}_{2}(\mathrm{OH})_{12}\left(\mathrm{H}_{2} \mathrm{O}\right)_{12}\left(\right.$ or $\left.4 \mathrm{UO}_{3} \cdot 9 \mathrm{H}_{2} \mathrm{O}\right)$, with calcite, $\mathrm{CaCO}_{3}$, to form the more stable uranium phase, becquerelite, $\mathrm{Ca}\left(\mathrm{UO}_{2}\right)_{6} \mathrm{O}_{4}(\mathrm{OH})_{6}\left(\mathrm{H}_{2} \mathrm{O}\right)_{8}$ (or $\left.\mathrm{CaU}_{6} \mathrm{O}_{19} \cdot 11 \mathrm{H}_{2} \mathrm{O}\right)$, and carbonic acid $\left(\mathrm{H}_{2} \mathrm{CO}_{3}\right)$ :

$$
\begin{gathered}
3\left(\mathrm{UO}_{2}\right)_{8} \mathrm{O}_{2}(\mathrm{OH})_{12}\left(\mathrm{H}_{2} \mathrm{O}\right)_{12}+4 \mathrm{CaCO}_{3} \rightarrow 4 \mathrm{Ca}\left(\mathrm{UO}_{2}\right)_{6} \mathrm{O}_{4}(\mathrm{OH})_{6}\left(\mathrm{H}_{2} \mathrm{O}\right)_{8}+4 \mathrm{H}_{2} \mathrm{CO}_{3}+6 \mathrm{H}_{2} \mathrm{O} \\
\rightarrow 4 \mathrm{Ca}\left(\mathrm{UO}_{2}\right)_{6} \mathrm{O}_{4}(\mathrm{OH})_{6}\left(\mathrm{H}_{2} \mathrm{O}\right)_{8}+10 \mathrm{H}_{2} \mathrm{O}+4 \mathrm{CO}_{2}(\mathrm{~g})
\end{gathered}
$$

Calcite and a calcium uranium oxide hydrate, $\mathrm{CaU}_{6} \mathrm{O}_{19} \cdot 12 \mathrm{H}_{2} \mathrm{O}$, have been observed by XRD in KE Basin floor sludge (Makenas et al. 1996), and schoepite and metaschoepite $\left[\left(\mathrm{UO}_{2}\right)_{8} \mathrm{O}_{2}(\mathrm{OH})_{12}\left(\mathrm{H}_{2} \mathrm{O}\right)_{10}\right]$ have been found in KE Basin canister sludge (Makenas et al. 1997). Several research groups have studied

Reaction 8 and published their findings (Vochten and Van Haverbeke 1990; Sandino et al. 1994; Sowder et al. 1996, 1999; Wronkiewicz et al. 1996). The salient features of these reported studies are described and compared in the Series I report (Delegard et al. 2000).

Reaction 8 indicates that $\mathrm{Ca}^{2+}$ substitutes for $2 \mathrm{H}^{+}$to form, in this case, $\mathrm{H}_{2} \mathrm{CO}_{3}$. Therefore, if Reaction 8 occurs, the solution $\mathrm{pH}$ should decrease. In Series III, tests with added sludge generally had lower $\mathrm{pH}$ (range 4.9 to 8.6 ) than tests without sludge ( $\mathrm{pH} 7.9$ to 10.9). 


\subsection{Analysis and Discussion of Gas Generation Results}

The results present in Section 3.0 are further discussed and evaluated here. As in Series I and II, the evaluation addresses gas generation reactions and rates, gas ratios, and fuel burnup. The evaluations in Section 5.1 through 5.5 address only the test intervals for which gas samples were collected and analyzed. In turn, these analyses are used for the reaction kinetics evaluation presented in Section 6.0. Section 5.5, an evaluation of long-term gas generation from KC-2/3 P250L at ambient hot cell temperature, includes a comparison of previous offgas generation tests also conducted at ambient hot cell temperature. Section 5.6 provides an assessment of the amount of sample/fuel fragments reacted as uranium metal during the course of the testing, based on pressure and temperature measurements and gas analyses.

\subsection{Gas Analyses from Tests at Ambient, $40^{\circ} \mathrm{C}, 60^{\circ} \mathrm{C}, 80^{\circ} \mathrm{C}$, and $95^{\circ} \mathrm{C}$}

Four tests were conducted in $60-\mathrm{ml}$ reaction vessels at ambient hot cell temperature to $95^{\circ} \mathrm{C}$, using fine fuel particles $(<500 \mu \mathrm{m})$ with fine canister sludge (Test 1) and mid-range fuel particles $(500-2000 \mu \mathrm{m})$ with and without composite canister sludge (Tests 2 through 4 ). None of these tests were run to completion. The total $\mathrm{H}_{2}$ that might have formed by reaction of uranium metal with water would be 8.4 moles (in gram moles) per $\mathrm{kg}$ fuel, based on $\mathrm{UO}_{2}$ product and assuming the fuel particles were $100 \%$ uranium metal with no initial uranium oxide or cladding. As shown in Figure 3.2, by the end of the gas generation testing, about 1.1 to 3.3 moles of gas were produced per $\mathrm{kg}$ of fuel particles.

At $60^{\circ} \mathrm{C}$, gas generation rates for the four tests ranged from 0.39 to 0.99 liters $/ \mathrm{kg}$ fuel particles-day (at standard temperature and pressure). At $80^{\circ} \mathrm{C}$, gas generation rates ranged from 2.4 to 3.3 liters $/ \mathrm{kg}$ fuel particles-day. Rates were higher for the smaller-sized fuel particles (SNF + Can Fines 60S test) and were higher without sludge blanketing.

The quantities of gas produced and consumed in Tests 1 through 4 are presented, respectively, in Tables 5.1 through 5.4. The gas product quantities are based on total gas pressure, volume, and temperature measurements, and analyses for particular gases by mass spectrometry (discussed in Section 2.3). As shown in Tables 5.1 through 5.4, gas products from certain intervals were vented without analysis. In such cases, the gas analysis data spaces are blank and no contributions to the respective cumulative gas products are included. The "Total Gas" values given in the last rows of each table, calculated based on reaction vessel pressure measurements and the ideal gas law (PVT, or pressure, volume, temperature) summed over all test intervals, provide estimates of the total net gas evolved during each test (including the intervals where gas was vented without analysis). These values are not strictly accurate, however, because of minor temperature gradients across each test system (i.e., total gas evolution may be off by several percent).

Overall, the sampled and analyzed gas products were $98.9 \%$ and $98.2 \% \mathrm{H}_{2}$ for the tests with sludge added (SNF + Can Fines 60S and SNF + Can 60S, respectively) and $99.88 \%$ and $99.86 \% \mathrm{H}_{2}$ for the tests with fuel particles only (SNF Mid 60S and SNF Mid 40S, respectively). Based on the high proportion of $\mathrm{H}_{2}$ in all of the analyzed samples, the vented gases also are expected to be $\mathrm{H}_{2}$ at roughly these concentrations. Carbon dioxide comprised $0.50 \%$ and $1.03 \%$ of the analyzed product gas in SNF + Can Fines $60 \mathrm{~S}$ and SNF + Can $60 \mathrm{~S}$, respectively, but only $0.004 \%$ and $0.015 \%$ of the product in the fuel-only SNF Mid $60 \mathrm{~S}$ and SNF Mid 40S tests, respectively. Hydrocarbon and fission product gases constituted the balance of the gas production; $\mathrm{O}_{2}$ was consumed in all cases, and net $\mathrm{N}_{2}$ consumption was observed in the initial samples for the SNF + Can Fines 60S and SNF Mid 40S tests. 
Table 5.1. Net and Cumulative Quantities of Gas Evolved for SNF + Can Fines 60S (Test 1)

\begin{tabular}{|c|c|c|c|c|c|c|c|}
\hline \multirow[b]{2}{*}{ Gas } & \multicolumn{7}{|c|}{ Gas Quantities, Moles, at Sampling Times, hr } \\
\hline & $\begin{array}{c}138.7 \text { at } \\
\text { Ambient; } \\
252.0 \text { at } 60^{\circ} \mathrm{C}\end{array}$ & $\begin{array}{c}633.7 \text { at } \\
60^{\circ} \mathrm{C}\end{array}$ & $\begin{array}{c}943.3 \text { at } \\
60^{\circ} \mathrm{C}\end{array}$ & $\mid \begin{array}{c}1206.7 \text { at } \\
60^{\circ} \mathrm{C} \\
\text { (vent) }\end{array}$ & $\begin{array}{c}1278.0 \text { at } \\
80^{\circ} \mathrm{C}\end{array}$ & $\begin{array}{c}1307.3 \text { at } \\
95^{\circ} \mathrm{C}\end{array}$ & $\begin{array}{c}2964.7 \text { at } \\
\text { Ambient } \\
\text { (vent) }\end{array}$ \\
\hline \multirow{2}{*}{$\begin{array}{l}\mathrm{CO}_{2} \\
\text { Cumulative }\end{array}$} & $2.79 \mathrm{E}-05$ & $7.00 \mathrm{E}-06$ & $5.13 \mathrm{E}-06$ & & $5.37 \mathrm{E}-06$ & $1.08 \mathrm{E}-05$ & \\
\hline & 2.79E-05 & $3.49 \mathrm{E}-05$ & $4.01 \mathrm{E}-05$ & & $4.54 \mathrm{E}-05$ & $5.63 \mathrm{E}-05$ & \\
\hline \multirow{2}{*}{$\begin{array}{l}\mathrm{H}_{2} \\
\text { Cumulative }\end{array}$} & $2.71 \mathrm{E}-03$ & $2.60 \mathrm{E}-03$ & $2.70 \mathrm{E}-03$ & & $1.82 \mathrm{E}-03$ & $1.37 \mathrm{E}-03$ & \\
\hline & $2.71 \mathrm{E}-03$ & $5.31 \mathrm{E}-03$ & $8.01 \mathrm{E}-03$ & & $9.83 \mathrm{E}-03$ & $1.12 \mathrm{E}-02$ & \\
\hline \multirow{2}{*}{$\begin{array}{l}\mathrm{N}_{2} \\
\text { Cumulative }\end{array}$} & $-1.57 \mathrm{E}-06$ & $3.77 \mathrm{E}-06$ & $4.77 \mathrm{E}-06$ & & $1.93 \mathrm{E}-06$ & $1.27 \mathrm{E}-06$ & \\
\hline & $-1.57 \mathrm{E}-06$ & $2.20 \mathrm{E}-06$ & $6.98 \mathrm{E}-06$ & & $8.91 \mathrm{E}-06$ & $1.02 \mathrm{E}-05$ & \\
\hline \multirow{2}{*}{$\begin{array}{l}\mathrm{O}_{2} \\
\text { Cumulative }\end{array}$} & $-7.52 \mathrm{E}-06$ & $-7.07 \mathrm{E}-07$ & $-8.30 \mathrm{E}-07$ & & $-7.62 \mathrm{E}-07$ & $-4.39 \mathrm{E}-06$ & \\
\hline & $-7.52 \mathrm{E}-06$ & $-8.22 \mathrm{E}-06$ & $-9.05 \mathrm{E}-06$ & & $-9.81 \mathrm{E}-06$ & $-1.42 \mathrm{E}-05$ & \\
\hline \multirow{2}{*}{$\begin{array}{l}\mathrm{CH}_{4} \\
\text { Cumulative }\end{array}$} & $7.82 \mathrm{E}-06$ & 4.99E-06 & $1.05 \mathrm{E}-05$ & & $1.39 \mathrm{E}-05$ & $1.29 \mathrm{E}-05$ & \\
\hline & 7.82E-06 & $1.28 \mathrm{E}-05$ & 2.33E-05 & & $3.73 \mathrm{E}-05$ & $5.02 \mathrm{E}-05$ & \\
\hline \multirow{2}{*}{$\begin{array}{l}\mathrm{C}_{2} \mathrm{H}_{\mathrm{x}} \\
\text { Cumulative }\end{array}$} & $9.65 \mathrm{E}-07$ & 9.39E-07 & $1.49 \mathrm{E}-06$ & & \begin{tabular}{|c|}
$1.65 \mathrm{E}-06$ \\
\end{tabular} & $1.45 \mathrm{E}-06$ & \\
\hline & $9.65 \mathrm{E}-07$ & $1.90 \mathrm{E}-06$ & 3.39E-06 & & \begin{tabular}{|l|}
$5.04 \mathrm{E}-06$ \\
\end{tabular} & $6.48 \mathrm{E}-06$ & \\
\hline \multirow{2}{*}{$\begin{array}{l}\geq \mathrm{C}_{3} \mathrm{H}_{\mathrm{x}} \\
\text { Cumulative }\end{array}$} & $3.55 \mathrm{E}-07$ & $3.84 \mathrm{E}-07$ & $5.40 \mathrm{E}-07$ & & 5.01E-07 & $4.40 \mathrm{E}-07$ & \\
\hline & $3.55 \mathrm{E}-07$ & 7.39E-07 & $1.28 \mathrm{E}-06$ & & \begin{tabular}{|c|}
$1.78 \mathrm{E}-06$ \\
\end{tabular} & $2.22 \mathrm{E}-06$ & \\
\hline \multirow{2}{*}{$\begin{array}{l}\sum \mathrm{C}_{\mathrm{y}} \mathrm{H}_{\mathrm{x}} \mathrm{C} \\
\text { Cumulative }\end{array}$} & $1.09 \mathrm{E}-05$ & 8.09E-06 & $1.52 \mathrm{E}-05$ & & \begin{tabular}{|l|}
$1.88 \mathrm{E}-05$ \\
\end{tabular} & $1.72 \mathrm{E}-05$ & \\
\hline & $1.09 \mathrm{E}-05$ & $1.90 \mathrm{E}-05$ & $3.42 \mathrm{E}-05$ & & $5.30 \mathrm{E}-05$ & $7.02 \mathrm{E}-05$ & \\
\hline \multirow{2}{*}{$\begin{array}{l}83 \mathrm{Kr} \\
\text { Cumulative }\end{array}$} & $3.55 \mathrm{E}-08$ & $5.12 \mathrm{E}-08$ & $4.05 \mathrm{E}-08$ & & $1.79 \mathrm{E}-08$ & $1.26 \mathrm{E}-08$ & \\
\hline & $3.55 \mathrm{E}-08$ & 8.67E-08 & $1.27 \mathrm{E}-07$ & & $1.45 \mathrm{E}-07$ & $1.58 \mathrm{E}-07$ & \\
\hline \multirow{2}{*}{$\begin{array}{l}{ }^{84} \mathrm{Kr} \\
\text { Cumulative }\end{array}$} & $7.11 \mathrm{E}-08$ & $1.15 \mathrm{E}-07$ & 7.20E-08 & & $3.58 \mathrm{E}-08$ & $2.83 \mathrm{E}-08$ & \\
\hline & $7.11 \mathrm{E}-08$ & $1.86 \mathrm{E}-07$ & $2.58 \mathrm{E}-07$ & & \begin{tabular}{|l|}
$2.94 \mathrm{E}-07$ \\
\end{tabular} & $3.22 \mathrm{E}-07$ & \\
\hline \multirow{2}{*}{$\begin{array}{l}{ }^{85} \mathrm{Kr} \\
\text { Cumulative }\end{array}$} & $5.08 \mathrm{E}-09$ & 4.27E-09 & 3.15E-09 & & $1.79 \mathrm{E}-09$ & $1.26 \mathrm{E}-09$ & \\
\hline & 5.08E-09 & 9.34E-09 & $1.25 \mathrm{E}-08$ & & \begin{tabular}{|c|}
$1.43 \mathrm{E}-08$ \\
\end{tabular} & $1.55 \mathrm{E}-08$ & \\
\hline \multirow{2}{*}{$\begin{array}{l}{ }^{86} \mathrm{Kr} \\
\text { Cumulative }\end{array}$} & $1.47 \mathrm{E}-07$ & $1.75 \mathrm{E}-07$ & $1.31 \mathrm{E}-07$ & & $6.80 \mathrm{E}-08$ & 4.72E-08 & \\
\hline & $1.47 \mathrm{E}-07$ & $3.22 \mathrm{E}-07$ & $4.53 \mathrm{E}-07$ & & $5.21 \mathrm{E}-07$ & $5.68 \mathrm{E}-07$ & \\
\hline \multirow{2}{*}{\begin{tabular}{|l}
$\Sigma \mathrm{Kr}$ \\
Cumulative
\end{tabular}} & $2.59 \mathrm{E}-07$ & $3.46 \mathrm{E}-07$ & $2.46 \mathrm{E}-07$ & & $1.24 \mathrm{E}-07$ & $8.93 \mathrm{E}-08$ & \\
\hline & $2.59 \mathrm{E}-07$ & $6.05 \mathrm{E}-07$ & $8.51 \mathrm{E}-07$ & & \begin{tabular}{|c|}
$9.74 \mathrm{E}-07$ \\
\end{tabular} & $1.06 \mathrm{E}-06$ & \\
\hline \multirow{2}{*}{$\begin{array}{l}{ }^{130} \mathrm{Xe} \\
\text { Cumulative }\end{array}$} & $1.02 \mathrm{E}-09$ & $1.28 \mathrm{E}-09$ & $9.01 \mathrm{E}-10$ & & \begin{tabular}{|l}
$3.58 \mathrm{E}-10$ \\
\end{tabular} & $3.14 \mathrm{E}-10$ & \\
\hline & $1.02 \mathrm{E}-09$ & $2.30 \mathrm{E}-09$ & $3.20 \mathrm{E}-09$ & & \begin{tabular}{|c|}
$3.55 \mathrm{E}-09$ \\
\end{tabular} & $3.87 \mathrm{E}-09$ & \\
\hline \multirow{2}{*}{$\begin{array}{l}{ }^{131} \mathrm{Xe} \\
\text { Cumulative }\end{array}$} & 2.79E-07 & $3.37 \mathrm{E}-07$ & 2.39E-07 & & $1.32 \mathrm{E}-07$ & $9.43 \mathrm{E}-08$ & \\
\hline & $2.79 \mathrm{E}-07$ & $6.16 \mathrm{E}-07$ & $8.55 \mathrm{E}-07$ & & \begin{tabular}{|c|}
$9.87 \mathrm{E}-07$ \\
\end{tabular} & $1.08 \mathrm{E}-06$ & \\
\hline \multirow{2}{*}{$\begin{array}{l}{ }^{132} \mathrm{Xe} \\
\text { Cumulative }\end{array}$} & 4.77E-07 & $5.55 \mathrm{E}-07$ & 4.19E-07 & & \begin{tabular}{|l|}
$2.22 \mathrm{E}-07$ \\
\end{tabular} & $1.57 \mathrm{E}-07$ & \\
\hline & 4.77E-07 & $1.03 \mathrm{E}-06$ & $1.45 \mathrm{E}-06$ & & \begin{tabular}{|c|}
$1.67 \mathrm{E}-06$ \\
\end{tabular} & $1.83 \mathrm{E}-06$ & \\
\hline \multirow{2}{*}{$\begin{array}{l}{ }^{134} \mathrm{Xe} \\
\text { Cumulative }\end{array}$} & $7.62 \mathrm{E}-07$ & $8.96 \mathrm{E}-07$ & $6.75 \mathrm{E}-07$ & & \begin{tabular}{|l}
$3.54 \mathrm{E}-07$ \\
\end{tabular} & $2.48 \mathrm{E}-07$ & \\
\hline & 7.62E-07 & $1.66 \mathrm{E}-06$ & 2.33E-06 & & \begin{tabular}{|l}
$2.69 \mathrm{E}-06$ \\
\end{tabular} & 2.94E-06 & \\
\hline \multirow{2}{*}{$\begin{array}{l}{ }^{136} \mathrm{Xe} \\
\text { Cumulative }\end{array}$} & $1.12 \mathrm{E}-06$ & $1.32 \mathrm{E}-06$ & $9.91 \mathrm{E}-07$ & & \begin{tabular}{|l|}
$5.37 \mathrm{E}-07$ \\
\end{tabular} & $3.77 \mathrm{E}-07$ & \\
\hline & $1.12 \mathrm{E}-06$ & $2.44 \mathrm{E}-06$ & $3.43 \mathrm{E}-06$ & & \begin{tabular}{|l|}
$3.97 \mathrm{E}-06$ \\
\end{tabular} & 4.34E-06 & \\
\hline \multirow{2}{*}{$\begin{array}{l}\sum \mathrm{Xe} \\
\text { Cumulative }\end{array}$} & 2.64E-06 & $3.11 \mathrm{E}-06$ & 2.32E-06 & & $1.25 \mathrm{E}-06$ & $8.78 \mathrm{E}-07$ & \\
\hline & $2.64 \mathrm{E}-06$ & $5.75 \mathrm{E}-06$ & $8.07 \mathrm{E}-06$ & & $9.32 \mathrm{E}-06$ & $1.02 \mathrm{E}-05$ & \\
\hline \multirow{2}{*}{$\begin{array}{l}\text { Total Gas } \\
\text { Cumulative }\end{array}$} & 3.09E-03 & 2.69E-03 & $2.90 \mathrm{E}-03$ & $2.16 \mathrm{E}-03$ & $1.85 \mathrm{E}-03$ & $1.36 \mathrm{E}-03$ & $6.91 \mathrm{E}-05$ \\
\hline & $3.09 \mathrm{E}-03$ & $5.78 \mathrm{E}-03$ & $8.67 \mathrm{E}-03$ & $1.08 \mathrm{E}-02$ & $1.27 \mathrm{E}-02$ & $1.40 \mathrm{E}-02$ & $1.41 \mathrm{E}-02$ \\
\hline
\end{tabular}


Table 5.2. Net and Cumulative Quantities of Gas Evolved for SNF + Can 60S (Test 2)

\begin{tabular}{|c|c|c|c|c|c|}
\hline \multirow[b]{2}{*}{ Gas } & \multicolumn{5}{|c|}{ "Gas Quantities, Moles, at Sampling Times, hr } \\
\hline & $\begin{array}{c}138.3 \text { at } \\
\text { Ambient; } \\
645.7 \text { at } 60^{\circ} \mathrm{C}\end{array}$ & $\begin{array}{c}1239.7 \text { at } \\
60^{\circ} \mathrm{C} \\
\text { (vent) }\end{array}$ & $\begin{array}{c}1312.3 \text { at } \\
80^{\circ} \mathrm{C}\end{array}$ & $\begin{array}{c}1341.7 \text { at } \\
95^{\circ} \mathrm{C}\end{array}$ & $\begin{array}{c}2999.0 \text { at } \\
\text { Ambient } \\
\text { (vent) }\end{array}$ \\
\hline \multirow{2}{*}{$\begin{array}{l}\mathrm{CO}_{2} \\
\text { Cumulative }\end{array}$} & $2.88 \mathrm{E}-05$ & & $1.72 \mathrm{E}-05$ & $4.70 \mathrm{E}-05$ & \\
\hline & $2.88 \mathrm{E}-05$ & & $4.60 \mathrm{E}-05$ & 9.30E-05 & \\
\hline \multirow{2}{*}{$\begin{array}{l}\mathrm{H}_{2} \\
\text { Cumulative }\end{array}$} & $3.16 \mathrm{E}-03$ & & $2.53 \mathrm{E}-03$ & $3.15 \mathrm{E}-03$ & \\
\hline & $3.16 \mathrm{E}-03$ & & $5.69 \mathrm{E}-03$ & $8.85 \mathrm{E}-03$ & \\
\hline \multirow{2}{*}{$\begin{array}{l}\mathrm{N}_{2} \\
\text { Cumulative }\end{array}$} & $3.06 \mathrm{E}-06$ & & $5.40 \mathrm{E}-06$ & 2.89E-06 & \\
\hline & $3.06 \mathrm{E}-06$ & & $8.46 \mathrm{E}-06$ & $1.14 \mathrm{E}-05$ & \\
\hline \multirow{2}{*}{$\begin{array}{l}\mathrm{O}_{2} \\
\text { Cumulative }\end{array}$} & $-9.74 \mathrm{E}-07$ & & $1.59 \mathrm{E}-07$ & $-1.27 \mathrm{E}-06$ & \\
\hline & $-9.74 \mathrm{E}-07$ & & $-8.15 \mathrm{E}-07$ & $-2.08 \mathrm{E}-06$ & \\
\hline \multirow{2}{*}{$\begin{array}{l}\mathrm{CH}_{4} \\
\text { Cumulative }\end{array}$} & $1.01 \mathrm{E}-05$ & & $1.70 \mathrm{E}-05$ & $2.53 \mathrm{E}-05$ & \\
\hline & $1.01 \mathrm{E}-05$ & & $2.71 \mathrm{E}-05$ & $5.24 \mathrm{E}-05$ & \\
\hline \multirow{2}{*}{$\begin{array}{l}\mathrm{C}_{2} \mathrm{H}_{\mathrm{x}} \\
\text { Cumulative }\end{array}$} & $1.15 \mathrm{E}-06$ & & $1.96 \mathrm{E}-06$ & $3.01 \mathrm{E}-06$ & \\
\hline & $1.15 \mathrm{E}-06$ & & $3.12 \mathrm{E}-06$ & $6.12 \mathrm{E}-06$ & \\
\hline \multirow{2}{*}{$\begin{array}{l}\geq \mathrm{C}_{3} \mathrm{H}_{\mathrm{x}} \\
\text { Cumulative }\end{array}$} & 4.20E-07 & & 5.79E-07 & 8.98E-07 & \\
\hline & $4.20 \mathrm{E}-07$ & & $9.99 \mathrm{E}-07$ & $1.90 \mathrm{E}-06$ & \\
\hline \multirow{2}{*}{\begin{tabular}{|l}
$\sum \mathrm{C}_{\mathrm{y}} \mathrm{H}_{\mathrm{x}} \mathrm{C}$ \\
Cumulative
\end{tabular}} & $1.37 \mathrm{E}-05$ & & $2.27 \mathrm{E}-05$ & $3.42 \mathrm{E}-05$ & \\
\hline & $1.37 \mathrm{E}-05$ & & $3.64 \mathrm{E}-05$ & $7.07 \mathrm{E}-05$ & \\
\hline \multirow{2}{*}{$\begin{array}{l}{ }^{83} \mathrm{Kr} \\
\text { Cumulative }\end{array}$} & $4.20 \mathrm{E}-08$ & & $3.12 \mathrm{E}-08$ & $2.64 \mathrm{E}-08$ & \\
\hline & 4.20E-08 & & 7.32E-08 & 9.96E-08 & \\
\hline \multirow{2}{*}{$\begin{array}{l}{ }^{84} \mathrm{Kr} \\
\text { Cumulative }\end{array}$} & $9.44 \mathrm{E}-08$ & & 5.79E-08 & $6.34 \mathrm{E}-08$ & \\
\hline & $9.44 \mathrm{E}-08$ & & $1.52 \mathrm{E}-07$ & $2.16 \mathrm{E}-07$ & \\
\hline \multirow{2}{*}{ 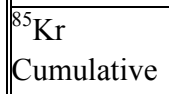 } & $4.72 \mathrm{E}-09$ & & 3.12E-09 & $3.17 \mathrm{E}-09$ & \\
\hline & 4.72E-09 & & 7.84E-09 & $1.10 \mathrm{E}-08$ & \\
\hline \multirow{2}{*}{ 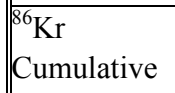 } & $1.63 \mathrm{E}-07$ & & $9.81 \mathrm{E}-08$ & $1.06 \mathrm{E}-07$ & \\
\hline & $1.63 \mathrm{E}-07$ & & $2.61 \mathrm{E}-07$ & $3.66 \mathrm{E}-07$ & \\
\hline \multirow{2}{*}{\begin{tabular}{|l}
$\Sigma \mathrm{Kr}$ \\
Cumulative
\end{tabular}} & $3.04 \mathrm{E}-07$ & & $1.90 \mathrm{E}-07$ & $1.99 \mathrm{E}-07$ & \\
\hline & $3.04 \mathrm{E}-07$ & & 4.94E-07 & $6.93 \mathrm{E}-07$ & \\
\hline \multirow{2}{*}{$\mid \begin{array}{l}{ }^{130} \mathrm{Xe} \\
\text { Cumulative }\end{array}$} & $1.05 \mathrm{E}-09$ & & $4.46 \mathrm{E}-10$ & $5.28 \mathrm{E}-10$ & \\
\hline & $1.05 \mathrm{E}-09$ & & 1.49E-09 & $2.02 \mathrm{E}-09$ & \\
\hline \multirow{2}{*}{$\begin{array}{l}{ }^{131} \mathrm{Xe} \\
\text { Cumulative }\end{array}$} & $3.20 \mathrm{E}-07$ & & $1.83 \mathrm{E}-07$ & $2.11 \mathrm{E}-07$ & \\
\hline & $3.20 \mathrm{E}-07$ & & $5.03 \mathrm{E}-07$ & 7.14E-07 & \\
\hline \multirow{2}{*}{$\begin{array}{l}{ }^{132} \mathrm{Xe} \\
\text { Cumulative }\end{array}$} & $5.25 \mathrm{E}-07$ & & $3.08 \mathrm{E}-07$ & $3.48 \mathrm{E}-07$ & \\
\hline & $5.25 \mathrm{E}-07$ & & $8.32 \mathrm{E}-07$ & $1.18 \mathrm{E}-06$ & \\
\hline \multirow{2}{*}{$\begin{array}{l}{ }^{134} \mathrm{Xe} \\
\text { Cumulative }\end{array}$} & $8.39 \mathrm{E}-07$ & & 4.90E-07 & $5.81 \mathrm{E}-07$ & \\
\hline & 8.39E-07 & & $1.33 \mathrm{E}-06$ & $1.91 \mathrm{E}-06$ & \\
\hline \multirow{2}{*}{$\begin{array}{l}{ }^{136} \mathrm{Xe} \\
\text { Cumulative }\end{array}$} & $1.26 \mathrm{E}-06$ & & $7.13 \mathrm{E}-07$ & $7.92 \mathrm{E}-07$ & \\
\hline & $1.26 \mathrm{E}-06$ & & $1.97 \mathrm{E}-06$ & $2.76 \mathrm{E}-06$ & \\
\hline \multirow{2}{*}{\begin{tabular}{|l}
$\sum \mathrm{Xe}$ \\
Cumulative
\end{tabular}} & 2.94E-06 & & $1.69 \mathrm{E}-06$ & $1.93 \mathrm{E}-06$ & \\
\hline & $2.94 \mathrm{E}-06$ & & $4.64 \mathrm{E}-06$ & $6.57 \mathrm{E}-06$ & \\
\hline \multirow{2}{*}{$\begin{array}{l}\text { Total Gas } \\
\text { Cumulative }\end{array}$} & $3.58 \mathrm{E}-03$ & $3.67 \mathrm{E}-03$ & $2.78 \mathrm{E}-03$ & $3.31 \mathrm{E}-03$ & $4.37 \mathrm{E}-04$ \\
\hline & $3.58 \mathrm{E}-03$ & $7.25 \mathrm{E}-03$ & $1.00 \mathrm{E}-02$ & $1.33 \mathrm{E}-02$ & $1.38 \mathrm{E}-02$ \\
\hline
\end{tabular}


Table 5.3. Net and Cumulative Quantities of Gas Evolved for SNF Mid 60S (Test 3)

\begin{tabular}{|c|c|c|c|c|c|c|}
\hline \multirow[b]{2}{*}{ Gas } & \multicolumn{6}{|c|}{ "Gas Quantities, Moles, at Sampling Times, hr } \\
\hline & $\begin{array}{c}138.3 \text { at } \\
\text { Ambient; } \\
501.0 \text { at } 60^{\circ} \mathrm{C}\end{array}$ & $\begin{array}{c}959.7 \text { at } \\
60^{\circ} \mathrm{C}\end{array}$ & $\begin{array}{c}1223.0 \text { at } \\
60^{\circ} \mathrm{C} \\
\text { (vent) }\end{array}$ & $\begin{array}{c}1294.0 \text { at } \\
80^{\circ} \mathrm{C}\end{array}$ & $\begin{array}{c}1323.3 \text { at } \\
95^{\circ} \mathrm{C}\end{array}$ & $\begin{array}{c}2980.7 \text { at } \\
\text { Ambient } \\
\text { (vent) }\end{array}$ \\
\hline \multirow{2}{*}{$\begin{array}{l}\mathrm{CO}_{2} \\
\text { Cumulative }\end{array}$} & $2.85 \mathrm{E}-07$ & $1.30 \mathrm{E}-07$ & & $1.01 \mathrm{E}-07$ & $1.09 \mathrm{E}-07$ & \\
\hline & $2.85 \mathrm{E}-07$ & $4.16 \mathrm{E}-07$ & & $5.17 \mathrm{E}-07$ & $6.26 \mathrm{E}-07$ & \\
\hline \multirow{2}{*}{$\mid \begin{array}{l}\mathrm{H}_{2} \\
\text { Cumulative }\end{array}$} & $5.10 \mathrm{E}-03$ & 4.49E-03 & & $3.00 \mathrm{E}-03$ & $3.34 \mathrm{E}-03$ & \\
\hline & $5.10 \mathrm{E}-03$ & $9.59 \mathrm{E}-03$ & & $1.26 \mathrm{E}-02$ & $1.59 \mathrm{E}-02$ & \\
\hline \multirow{2}{*}{$\mid \begin{array}{l}\mathrm{N}_{2} \\
\text { Cumulative }\end{array}$} & $2.02 \mathrm{E}-06$ & 5.99E-06 & & $5.29 \mathrm{E}-06$ & $6.12 \mathrm{E}-06$ & \\
\hline & $2.02 \mathrm{E}-06$ & $8.02 \mathrm{E}-06$ & & $1.33 \mathrm{E}-05$ & $1.94 \mathrm{E}-05$ & \\
\hline \multirow{2}{*}{$\begin{array}{l}\mathrm{O}_{2} \\
\text { Cumulative }\end{array}$} & $-5.32 \mathrm{E}-06$ & $7.73 \mathrm{E}-07$ & & 4.04E-07 & $5.93 \mathrm{E}-07$ & \\
\hline & $-5.32 \mathrm{E}-06$ & $-4.54 \mathrm{E}-06$ & & $-4.14 \mathrm{E}-06$ & $-3.55 \mathrm{E}-06$ & \\
\hline \multirow{2}{*}{$\begin{array}{l}\mathrm{CH}_{4} \\
\text { Cumulative }\end{array}$} & $2.78 \mathrm{E}-06$ & $8.47 \mathrm{E}-07$ & & $7.57 \mathrm{E}-07$ & $1.15 \mathrm{E}-06$ & \\
\hline & $2.78 \mathrm{E}-06$ & $3.63 \mathrm{E}-06$ & & 4.39E-06 & $5.53 \mathrm{E}-06$ & \\
\hline \multirow{2}{*}{$\begin{array}{l}\mathrm{C}_{2} \mathrm{H}_{\mathrm{x}} \\
\text { Cumulative }\end{array}$} & $4.28 \mathrm{E}-07$ & $3.26 \mathrm{E}-07$ & & $1.51 \mathrm{E}-07$ & $2.18 \mathrm{E}-07$ & \\
\hline & $4.28 \mathrm{E}-07$ & $7.54 \mathrm{E}-07$ & & $9.05 \mathrm{E}-07$ & $1.12 \mathrm{E}-06$ & \\
\hline \multirow{2}{*}{$\begin{array}{l}\geq \mathrm{C}_{3} \mathrm{H}_{\mathrm{x}} \\
\text { Cumulative }\end{array}$} & $2.14 \mathrm{E}-07$ & $1.96 \mathrm{E}-07$ & & $1.01 \mathrm{E}-07$ & $1.09 \mathrm{E}-07$ & \\
\hline & $2.14 \mathrm{E}-07$ & $4.09 \mathrm{E}-07$ & & $5.10 \mathrm{E}-07$ & $6.20 \mathrm{E}-07$ & \\
\hline \multirow{2}{*}{\begin{tabular}{|l}
$\sum \mathrm{C}_{\mathrm{y}} \mathrm{H}_{\mathrm{x}} \mathrm{C}$ \\
Cumulative
\end{tabular}} & $4.31 \mathrm{E}-06$ & $2.12 \mathrm{E}-06$ & & $1.38 \mathrm{E}-06$ & $1.93 \mathrm{E}-06$ & \\
\hline & $4.31 \mathrm{E}-06$ & $6.43 \mathrm{E}-06$ & & $7.81 \mathrm{E}-06$ & $9.74 \mathrm{E}-06$ & \\
\hline \multirow{2}{*}{$\begin{array}{l}{ }^{83} \mathrm{Kr} \\
\text { Cumulative }\end{array}$} & $4.28 \mathrm{E}-08$ & $5.21 \mathrm{E}-08$ & & $2.02 \mathrm{E}-08$ & $3.28 \mathrm{E}-08$ & \\
\hline & $4.28 \mathrm{E}-08$ & $9.49 \mathrm{E}-08$ & & $1.15 \mathrm{E}-07$ & $1.48 \mathrm{E}-07$ & \\
\hline \multirow{2}{*}{$\begin{array}{l}{ }^{84} \mathrm{Kr} \\
\text { Cumulative }\end{array}$} & $7.84 \mathrm{E}-08$ & $9.78 \mathrm{E}-08$ & & $5.05 \mathrm{E}-08$ & $6.55 \mathrm{E}-08$ & \\
\hline & $7.84 \mathrm{E}-08$ & $1.76 \mathrm{E}-07$ & & $2.27 \mathrm{E}-07$ & $2.92 \mathrm{E}-07$ & \\
\hline \multirow{2}{*}{ 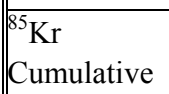 } & $6.42 \mathrm{E}-09$ & $4.56 \mathrm{E}-09$ & & $2.52 \mathrm{E}-09$ & $3.28 \mathrm{E}-09$ & \\
\hline & $6.42 \mathrm{E}-09$ & $1.10 \mathrm{E}-08$ & & $1.35 \mathrm{E}-08$ & $1.68 \mathrm{E}-08$ & \\
\hline \multirow{2}{*}{$\begin{array}{l}{ }^{86} \mathrm{Kr} \\
\text { Cumulative }\end{array}$} & $1.71 \mathrm{E}-07$ & $1.63 \mathrm{E}-07$ & & $1.01 \mathrm{E}-07$ & $1.09 \mathrm{E}-07$ & \\
\hline & $1.71 \mathrm{E}-07$ & $3.34 \mathrm{E}-07$ & & $4.35 \mathrm{E}-07$ & 5.44E-07 & \\
\hline \multirow{2}{*}{\begin{tabular}{|l}
$\sum \mathrm{Kr}$ \\
Cumulative
\end{tabular}} & 2.99E-07 & $3.17 \mathrm{E}-07$ & & $1.74 \mathrm{E}-07$ & $2.11 \mathrm{E}-07$ & \\
\hline & 2.99E-07 & $6.16 \mathrm{E}-07$ & & $7.90 \mathrm{E}-07$ & $1.00 \mathrm{E}-06$ & \\
\hline \multirow{2}{*}{$\begin{array}{l}{ }^{130} \mathrm{Xe} \\
\text { Cumulative }\end{array}$} & $1.43 \mathrm{E}-09$ & $1.30 \mathrm{E}-09$ & & $5.05 \mathrm{E}-10$ & $1.09 \mathrm{E}-09$ & \\
\hline & $1.43 \mathrm{E}-09$ & $2.73 \mathrm{E}-09$ & & $3.23 \mathrm{E}-09$ & 4.33E-09 & \\
\hline \multirow{2}{*}{$\begin{array}{l}{ }^{131} \mathrm{Xe} \\
\text { Cumulative }\end{array}$} & $3.07 \mathrm{E}-07$ & $3.13 \mathrm{E}-07$ & & $1.82 \mathrm{E}-07$ & $2.02 \mathrm{E}-07$ & \\
\hline & $3.07 \mathrm{E}-07$ & $6.19 \mathrm{E}-07$ & & $8.01 \mathrm{E}-07$ & $1.00 \mathrm{E}-06$ & \\
\hline \multirow{2}{*}{$\begin{array}{l}{ }^{132} \mathrm{Xe} \\
\text { Cumulative }\end{array}$} & $5.42 \mathrm{E}-07$ & $5.15 \mathrm{E}-07$ & & $3.13 \mathrm{E}-07$ & $3.50 \mathrm{E}-07$ & \\
\hline & $5.42 \mathrm{E}-07$ & $1.06 \mathrm{E}-06$ & & $1.37 \mathrm{E}-06$ & $1.72 \mathrm{E}-06$ & \\
\hline \multirow{2}{*}{$\begin{array}{l}{ }^{134} \mathrm{Xe} \\
\text { Cumulative }\end{array}$} & $8.56 \mathrm{E}-07$ & $8.47 \mathrm{E}-07$ & & $5.00 \mathrm{E}-07$ & $5.46 \mathrm{E}-07$ & \\
\hline & $8.56 \mathrm{E}-07$ & $1.70 \mathrm{E}-06$ & & $2.20 \mathrm{E}-06$ & $2.75 \mathrm{E}-06$ & \\
\hline \multirow{2}{*}{$\begin{array}{l}{ }^{136} \mathrm{Xe} \\
\text { Cumulative }\end{array}$} & $1.28 \mathrm{E}-06$ & $1.24 \mathrm{E}-06$ & & $7.57 \mathrm{E}-07$ & $8.19 \mathrm{E}-07$ & \\
\hline & $1.28 \mathrm{E}-06$ & $2.52 \mathrm{E}-06$ & & $3.28 \mathrm{E}-06$ & $4.10 \mathrm{E}-06$ & \\
\hline \multirow{2}{*}{$\mid \begin{array}{l}\sum \mathrm{Xe} \\
\text { Cumulative }\end{array}$} & $2.99 \mathrm{E}-06$ & $2.91 \mathrm{E}-06$ & & $1.75 \mathrm{E}-06$ & $1.92 \mathrm{E}-06$ & \\
\hline & $2.99 \mathrm{E}-06$ & $5.90 \mathrm{E}-06$ & & $7.66 \mathrm{E}-06$ & 9.57E-06 & \\
\hline \multirow{2}{*}{\begin{tabular}{||l} 
Total Gas \\
Cumulative
\end{tabular}} & $5.26 \mathrm{E}-03$ & $4.69 \mathrm{E}-03$ & $2.31 \mathrm{E}-03$ & $3.08 \mathrm{E}-03$ & $3.47 \mathrm{E}-03$ & $5.13 \mathrm{E}-04$ \\
\hline & $5.26 \mathrm{E}-03$ & $9.95 \mathrm{E}-03$ & $1.23 \mathrm{E}-02$ & $1.53 \mathrm{E}-02$ & $1.88 \mathrm{E}-02$ & $1.93 \mathrm{E}-02$ \\
\hline
\end{tabular}


Table 5.4. Net and Cumulative Quantities of Gas Evolved for SNF Mid 40S (Test 4)

\begin{tabular}{|c|c|c|c|c|}
\hline \multirow[b]{2}{*}{ Gas } & \multicolumn{4}{|c|}{ Gas Quantities, Moles, at Sampling Times, hr } \\
\hline & \begin{tabular}{|c|}
138.3 at \\
Ambient; \\
1266.0 at $40^{\circ} \mathrm{C}$
\end{tabular} & $\begin{array}{c}1577.0 \text { at } \\
60^{\circ} \mathrm{C} \\
\text { (vent) }\end{array}$ & $\begin{array}{c}1624.3 \text { at } \\
80^{\circ} \mathrm{C} \\
\text { (vent) }\end{array}$ & $\begin{array}{c}3132.7 \text { at } \\
\text { Ambient } \\
\text { (vent) }\end{array}$ \\
\hline \multirow{2}{*}{$\begin{array}{l}\mathrm{CO}_{2} \\
\text { Cumulative }\end{array}$} & $4.33 \mathrm{E}-07$ & & & \\
\hline & 4.33E-07 & & & \\
\hline \multirow{2}{*}{$\begin{array}{l}\mathrm{H}_{2} \\
\text { Cumulative }\end{array}$} & $2.81 \mathrm{E}-03$ & & & \\
\hline & $2.81 \mathrm{E}-03$ & & & \\
\hline \multirow{2}{*}{$\begin{array}{l}\mathrm{N}_{2} \\
\text { Cumulative }\end{array}$} & $-3.83 \mathrm{E}-06$ & & & \\
\hline & $-3.83 \mathrm{E}-06$ & & & \\
\hline \multirow{2}{*}{$\begin{array}{l}\mathrm{O}_{2} \\
\text { Cumulative }\end{array}$} & $-4.31 \mathrm{E}-06$ & & & \\
\hline & $-4.31 \mathrm{E}-06$ & & & \\
\hline \multirow{2}{*}{\begin{tabular}{|l}
$\mathrm{CH}_{4}$ \\
Cumulative
\end{tabular}} & $1.20 \mathrm{E}-06$ & & & \\
\hline & $1.20 \mathrm{E}-06$ & & & \\
\hline \multirow{2}{*}{\begin{tabular}{|l}
$\mathrm{C}_{2} \mathrm{H}_{\mathrm{x}}$ \\
Cumulative
\end{tabular}} & $2.40 \mathrm{E}-07$ & & & \\
\hline & $2.40 \mathrm{E}-07$ & & & \\
\hline \multirow{2}{*}{\begin{tabular}{|l}
$\geq \mathrm{C}_{3} \mathrm{H}_{\mathrm{x}}$ \\
Cumulative
\end{tabular}} & $1.44 \mathrm{E}-07$ & & & \\
\hline & $1.44 \mathrm{E}-07$ & & & \\
\hline \multirow{2}{*}{\begin{tabular}{|l}
$\sum \mathrm{C}_{\mathrm{y}} \mathrm{H}_{\mathrm{x}} \mathrm{C}$ \\
Cumulative
\end{tabular}} & $2.14 \mathrm{E}-06$ & & & \\
\hline & 2.14E-06 & & & \\
\hline \multirow{2}{*}{$\begin{array}{l}{ }^{83} \mathrm{Kr} \\
\text { Cumulative }\end{array}$} & $2.40 \mathrm{E}-08$ & & & \\
\hline & $2.40 \mathrm{E}-08$ & & & \\
\hline \multirow{2}{*}{$\begin{array}{l}{ }^{84} \mathrm{Kr} \\
\text { Cumulative }\end{array}$} & $4.81 \mathrm{E}-08$ & & & \\
\hline & $4.81 \mathrm{E}-08$ & & & \\
\hline \multirow{2}{*}{$\begin{array}{l}{ }^{85} \mathrm{Kr} \\
\text { Cumulative }\end{array}$} & $2.40 \mathrm{E}-09$ & & & \\
\hline & $2.40 \mathrm{E}-09$ & & & \\
\hline \multirow{2}{*}{$\begin{array}{l}{ }^{86} \mathrm{Kr} \\
\text { Cumulative }\end{array}$} & $1.01 \mathrm{E}-07$ & & & \\
\hline & $1.01 \mathrm{E}-07$ & & & \\
\hline \multirow{2}{*}{$\begin{array}{l}\Sigma \mathrm{Kr} \\
\text { Cumulative }\end{array}$} & $1.75 \mathrm{E}-07$ & & & \\
\hline & $1.75 \mathrm{E}-07$ & & & \\
\hline \multirow{2}{*}{$\begin{array}{l}{ }^{130} \mathrm{Xe} \\
\text { Cumulative }\end{array}$} & $4.81 \mathrm{E}-10$ & & & \\
\hline & $4.81 \mathrm{E}-10$ & & & \\
\hline \multirow{2}{*}{$\begin{array}{l}{ }^{131} \mathrm{Xe} \\
\text { Cumulative }\end{array}$} & $1.83 \mathrm{E}-07$ & & & \\
\hline & $1.83 \mathrm{E}-07$ & & & \\
\hline \multirow{2}{*}{$\begin{array}{l}{ }^{132} \mathrm{Xe} \\
\text { Cumulative }\end{array}$} & $3.22 \mathrm{E}-07$ & & & \\
\hline & $3.22 \mathrm{E}-07$ & & & \\
\hline \multirow{2}{*}{$\begin{array}{l}{ }^{134} \mathrm{Xe} \\
\text { Cumulative }\end{array}$} & 5.29E-07 & & & \\
\hline & $5.29 \mathrm{E}-07$ & & & \\
\hline \multirow{2}{*}{$\begin{array}{l}{ }^{136} \mathrm{Xe} \\
\text { Cumulative }\end{array}$} & 7.69E-07 & & & \\
\hline & 7.69E-07 & & & \\
\hline \multirow{2}{*}{\begin{tabular}{|l|}
$\mathrm{Xe}$ \\
Cumulative
\end{tabular}} & $1.80 \mathrm{E}-06$ & & & \\
\hline & $1.80 \mathrm{E}-06$ & & & \\
\hline \multirow{2}{*}{$\begin{array}{l}\text { Total Gas } \\
\text { Cumulative }\end{array}$} & $2.96 \mathrm{E}-03$ & $3.66 \mathrm{E}-03$ & $2.46 \mathrm{E}-03$ & $3.66 \mathrm{E}-04$ \\
\hline & $2.96 \mathrm{E}-03$ & $6.62 \mathrm{E}-03$ & $9.08 \mathrm{E}-03$ & $9.45 \mathrm{E}-03$ \\
\hline
\end{tabular}


Note that the quantities of uranium metal corroded in each test are evaluated here for only those intervals for which gas samples were analyzed. As shown below, the amounts of uranium reacted during the intervals with gas sampling were estimated based on the quantities of $\mathrm{H}_{2}$ formed and $\mathrm{O}_{2}$ and $\mathrm{N}_{2}$ consumed by net Reactions 1, 2, and 3, respectively. For three of the tests, the net amount of uranium reacting with $\mathrm{N}_{2}$ was negative, indicating that nitrogen captured during the initial sampling interval, and possibly also present on the initial uranium metal particles, subsequently was released. Amounts of uranium metal reacted are estimated more accurately from fission product gas $(\mathrm{Kr}$ and $\mathrm{Xe})$ release. Table 5.5 presents the estimated moles of uranium metal reacted during the intervals that gas samples were taken and analyzed. The total amounts of uranium metal initially present in each test are also shown in Table 5.5, based on the weights of fuel particles added and the uranium concentrations available in those particle populations (as determined in Section 4.2). The total quantity of uranium metal reacted during all test intervals based on total gas generated is discussed in Section 5.6.

Table 5.5. Reacted Metallic Uranium Calculated from Gas Generation and Consumption Reactions in Tests 1 Through 4 During Intervals for Which Gas Samples Were Analyzed

\begin{tabular}{|c|c|c|c|c||}
\hline & \multicolumn{3}{|c|}{ Moles U Reacted Based on Various Reactions } \\
\cline { 2 - 5 } Reaction & $\begin{array}{c}\text { SNF + Can Fines 60S SNF + Can 60S } \\
\text { (Test 1) }\end{array}$ & $\begin{array}{c}\text { SNF Mid 60S } \\
\text { (Test 3) }\end{array}$ & $\begin{array}{c}\text { SNF Mid 40S } \\
\text { (Test 4) }\end{array}$ \\
\hline $\begin{array}{c}\text { Reaction 1 } \\
\mathrm{U}+2 \mathrm{H}_{2} \mathrm{O} \rightarrow \mathrm{UO}_{2}+2 \mathrm{H}_{2}\end{array}$ & $5.60 \mathrm{E}-3$ & $4.42 \mathrm{E}-3$ & $7.96 \mathrm{E}-3$ & $1.40 \mathrm{E}-3$ \\
\hline $\begin{array}{c}\text { Reaction 2 } \\
\mathrm{U}+\mathrm{O}_{2} \rightarrow \mathrm{UO}_{2}\end{array}$ & $1.42 \mathrm{E}-5$ & $2.08 \mathrm{E}-6$ & $3.55 \mathrm{E}-6$ & $4.31 \mathrm{E}-6$ \\
\hline $\begin{array}{c}\text { Reaction 3 } \\
\mathrm{U}+0.875 \mathrm{~N}_{2} \rightarrow \mathrm{UN}_{1.75}\end{array}$ & $-1.16 \mathrm{E}-5$ & $-1.30 \mathrm{E}-5$ & $-2.22 \mathrm{E}-5$ & $4.37 \mathrm{E}-6$ \\
\hline $\begin{array}{c}\text { Total Moles U } \\
(\text { Sum of Reactions 1-3) }\end{array}$ & $5.61 \mathrm{E}-3$ & $4.41 \mathrm{E}-3$ & $7.94 \mathrm{E}-3$ & $1.41 \mathrm{E}-3$ \\
\hline Total Moles U by Kr Release & $8.96 \mathrm{E}-3$ & $5.83 \mathrm{E}-3$ & $8.43 \mathrm{E}-3$ & $1.48 \mathrm{E}-3$ \\
\hline Total Moles U by Xe Release & $8.51 \mathrm{E}-3$ & $5.49 \mathrm{E}-3$ & $7.99 \mathrm{E}-3$ & $1.51 \mathrm{E}-3$ \\
\hline Initial Moles U Metal Present & $13.31 \mathrm{E}-3$ & $32.78 \mathrm{E}-3$ & $32.19 \mathrm{E}-3$ & $33.64 \mathrm{E}-3$ \\
\hline
\end{tabular}

The chemical reaction gas $\left(\mathrm{H}_{2}, \mathrm{O}_{2}\right.$, and $\left.\mathrm{N}_{2}\right)$ data show that Reaction 1 dominates the corrosion of uranium metal. Although the number of moles of uranium reacted as determined by $\mathrm{Kr}$ and $\mathrm{Xe}$ fission gas release agree within about 5\% for each test, the total moles of uranium reacted as determined by Reactions 1, 2, and 3 clearly lag those determined by $\mathrm{Kr}$ and $\mathrm{Xe}$ gas release. The lag widens as the amount of reaction spent at the lower test temperatures increases (see Figure 3.2). The lag in $\mathrm{H}_{2}$ gas release behind that of the fission product gases was noted in the Series I and II test reports, and is attributed to the incorporation of hydrogen as a uranium hydride reaction intermediate by Reaction 4, the first step in the reaction of uranium with water. The decrease in the lag in $\mathrm{H}_{2}$ evolution as temperature increases was noted in the Series II report (see Figure 4.1 in Bryan et al. 2001).

In Table 5.6, the $\mathrm{Kr}$ and $\mathrm{Xe}$ isotope ratios observed in the product gases for the four $60-\mathrm{ml}$ vessel tests are compared with those expected based on burnup calculations using the ORIGEN code. The Xe isotope mass distributions (except that of the scarce ${ }^{130} \mathrm{Xe}$ ) are similar among the four tests and near those predicted by the ORIGEN code. The Kr mass distributions are more variable but, if adjusted for ${ }^{85} \mathrm{Kr}$ decay, likewise are consistent with the values predicted by ORIGEN. The regularity of values among the four tests can be attributed to the accuracy and sensitivity of the mass spectrometric measurements, the relatively large amount of irradiated uranium corroded (and thus fission product gas released), and the fact that the uranium metal particles in all of these tests were taken from the same population of fuel 
hydrocarbon released in all fuel-only tests were lower than would be expected based on nominal carbon contents in N Reactor fuel. This finding suggests that the fuel particles used in the present tests were anomalously low in carbon impurity or that the hydrocarbons somehow were retained in the corrosion products, although the latter explanation seems improbable.

The methane fraction of the total hydrocarbon carbon is about 71 and 74 atom $\%$ for the tests with sludge and about 56 atom $\%$ for the two tests without added sludge. This compares with about 92 atom $\%$ at $\sim 40,000$ to $50,000 \mathrm{ppmp}$ (up to pure UC) to about 71 atom $\%$ at $20,000 \mathrm{ppmp}$ carbon in U/UC mixtures observed in reactions in $80^{\circ} \mathrm{C}$ water (Bradley and Ferris 1962,1964$)$.

Carbon dioxide production is relatively low in these four tests conducted with relatively large amounts of uranium metal. Table 5.8 shows the $\mathrm{CO}_{2}$ comprises a greater fraction of the total evolved gas for the tests containing sludge than for those without sludge. The $\mathrm{CO}_{2}$ from the tests with sludge likely arises from the reaction of solid phase calcite and schoepite (Reaction 8). In Series I testing, the KC-2/3 M250 sludge (the same sludge as used in the SNF + Can Fines 60S test) was taken to extinction in gas generation reactions to show an amount of $\mathrm{CO}_{2}$ equivalent to a purported 500-ppm total inorganic carbon (TIC) in the settled sludge (see Table 4.19 in Delegard et al. 2000). In the present testing, the amount of $\mathrm{CO}_{2}$ collected in the SNF + Can Fines $60 \mathrm{~S}$ test is equivalent to only about $25 \mathrm{ppm}$ TIC. The present testing did not collect and analyze all the product gas, but this factor alone could not account for all of the difference. Some of the shortfall in $\mathrm{CO}_{2}$ may be attributed to the higher $\mathrm{pH}$ found in the present test with fuel particles ( $\mathrm{pH}$ 8.6) than in the Series I test without fuel particles ( $\mathrm{pH}$ 6.7). The higher $\mathrm{pH}$ would keep $\mathrm{CO}_{2}$ dissolved in solution as bicarbonate $\left(\mathrm{HCO}_{3}{ }^{-}\right)$and prevent its release to the gas phase. Some of the shortfall in the amount of $\mathrm{CO}_{2}$ evolved may have occurred because Reaction 8 continued during the $\sim 1$-year period that the KC-2/3 M250 sludge resided in the hot cell (time interval between the Series I and Series III tests) to deplete some of the initial carbonate mineral reactant. The amount of $\mathrm{CO}_{2}$ produced in the SNF + Can 60S test (with KC Can Comp sludge) would indicate a minimum TIC concentration of about $58 \mathrm{ppm}$ (wet sludge basis). Again, this value is much lower than anticipated. The TIC concentration estimated for the KC Can Comp is $\sim 2400$ ppm, as estimated based on analyses of the constituent samples used in creating a similar KE canister sludge composite (p. 5.7 of Schmidt et al. 1999). The $\mathrm{CO}_{2}$ arising from the two fuel particles-only tests likely is due to displacement of dissolved $\mathrm{CO}_{2}$ from the overlying $\mathrm{K}$ Basin supernatant water.

Table 5.7. Carbon Concentration Based on Hydrocarbon, Kr, and Xe Gas Release for Tests 1 Through 4

\begin{tabular}{||c|c|c|c|c||}
\hline \multirow{3}{*}{ Based on } & \multicolumn{4}{|c|}{ Carbon Concentration, ppmp U } \\
\cline { 2 - 5 } & $\begin{array}{c}\text { SNF + Can Fines 60S } \\
\text { (Test 1) }\end{array}$ & $\begin{array}{c}\text { SNF + Can 60S } \\
\text { (Test 2) }\end{array}$ & $\begin{array}{c}\text { SNF Mid 60S } \\
\text { (Test 3) }\end{array}$ & $\begin{array}{c}\text { SNF Mid 40S } \\
\text { (Test 4) }\end{array}$ \\
\hline Kr Release & 394 & 610 & 58 & 73 \\
\hline Xe Release & 401 & 627 & 59 & 69 \\
\hline
\end{tabular}

Table 5.8. Carbon Dioxide Produced in Tests 1 Through 4

\begin{tabular}{|c|c|c|c||}
\hline \multicolumn{4}{|c|}{ Carbon Dioxide Concentration, \% of Total Gas } \\
\hline $\begin{array}{c}\text { SNF + Can Fines 60S } \\
\text { (Test 1) }\end{array}$ & $\begin{array}{c}\text { SNF + Can 60S } \\
\text { (Test 2) }\end{array}$ & $\begin{array}{c}\text { SNF Mid 60S } \\
\text { (Test 3) }\end{array}$ & $\begin{array}{c}\text { SNF Mid 40S } \\
\text { (Test 4) }\end{array}$ \\
\hline 0.50 & 1.03 & 0.0039 & 0.015 \\
\hline
\end{tabular}




\subsection{Gas Analyses from Tests with Various-Sized Fuel Particles and a Single Fuel Fragment at $80^{\circ} \mathrm{C}$}

Five tests were conducted at $80^{\circ} \mathrm{C}$ with different size populations of crushed fuel particles but no added sludge (Tests 5 through 9). As was shown in Figure 3.4, three tests, SNF M500 80L, SNF Mid 80L, and SNF Mid 80L Dup, were run to complete reaction of the uranium metal. Two tests (SNF P2000 80S and Fuel Fragment) were run to about $40 \%$ to $50 \%$ completion, as shown in Figure 3.4 and by the fact that about 8.4 moles of $\mathrm{H}_{2}$ gas per kg uranium would have formed in the complete reaction of $100 \%$ uranium metal with water. Maximum gas generation rates at $\sim 80^{\circ} \mathrm{C}$ for the five tests were, respectively, $0.59,2.5$, $8.2,10.6$, and 19 liters $/ \mathrm{kg}$ fuel particles-day (at standard temperature and pressure), with rates increasing with decreasing metal particle size.

The quantities of gas produced and consumed in the five tests are presented in Tables 5.9 through 5.13 based on total gas pressure, volume, and temperature measurements, and analyses for particular gases by mass spectrometry. Gas products from certain intervals in the SNF P2000 80 S and Fuel Fragment tests were vented without analysis. At those intervals, the corresponding gas analysis data spaces are blank with no contributions to the respective cumulative gas products included. The "Total Gas" values given in the last rows of each table estimate the total net gas evolved during each test, based on the reaction vessel pressure measurements and the ideal gas law. Again, these values are not strictly accurate because of minor temperature gradients across each test system and some intermittent offgas line blockage (due to condensation of water vapor) with the $800-\mathrm{ml}$ reaction vessels.

The combined sampled and analyzed gas products were $99.62 \%$ to $99.87 \% \mathrm{H}_{2}$ for all five tests. The vented gases also were presumed to be $\mathrm{H}_{2}$ at these high concentrations. Carbon dioxide was the next most prevalent gas, but $<0.1 \%$ for all tests. Hydrocarbon and fission product gases constituted the balance of the gas production; $\mathrm{O}_{2}$ was consumed in all samples, and $\mathrm{N}_{2}$ consumption observed in the initial samples for all tests. The $\mathrm{O}_{2}$ and $\mathrm{N}_{2}$ were present as trace atmospheric contamination.

As noted, the SNF M500 80L, SNF Mid 80L, and SNF Mid 80L Dup tests were taken to complete uranium reaction. Because the uranium particles for the SNF P2000 80S test arose from the same population of fuel particles as used in the tests taken to completion, uranium metal corrosion may be estimated accurately based on $\mathrm{Xe}$ and $\mathrm{Kr}$ fission gas released. Since the Fuel Fragment test used uranium metal from a different portion of the element than used for the other tests with added fuel particles, it might show a somewhat different relative amount of $\mathrm{Kr}$ and $\mathrm{Xe}$ released in proportion to uranium corroded.

The quantities of uranium metal corroded in each test were evaluated for those intervals for which gas samples were analyzed. All gas was sampled for the SNF Mid 500L and SNF Mid 80L tests, but some samples were vented without analysis in the SNF P2000 80S and Fuel Fragment tests. The amounts of uranium reacted during the intervals with gas sampling were estimated from the quantities of $\mathrm{H}_{2}$ produced and $\mathrm{O}_{2}$ and $\mathrm{N}_{2}$ consumed by net Reactions 1, 2, and 3, respectively. For all five tests, the net amount of uranium reacting with $\mathrm{N}_{2}$ was negative, indicating that nitrogen captured during the initial sampling interval, and possibly also present on the initial uranium metal particles, subsequently was released. More accurate estimates of reacted uranium metal are based on $\mathrm{Kr}$ and $\mathrm{Xe}$ release. 
Table 5.9. Net and Cumulative Quantities of Gas Evolved for SNF P2000 80S (Test 5)

\begin{tabular}{|c|c|c|c|c|c|c|c|c|c|}
\hline \multirow[b]{2}{*}{ Gas } & \multicolumn{9}{|c|}{ Gas Quantities, Moles, at Sampling Times, hr } \\
\hline & $\begin{array}{c}138.3 \text { at } \\
\text { Ambient; } \\
253.0 \text { at } 80^{\circ} \mathrm{C}\end{array}$ & $\begin{array}{c}345.7 \text { at } \\
80^{\circ} \mathrm{C}\end{array}$ & $\begin{array}{c}419.3 \text { at } \\
80^{\circ} \mathrm{C}\end{array}$ & $\begin{array}{c}542.3 \text { at } \\
80^{\circ} \mathrm{C}\end{array}$ & $\begin{array}{c}708.0 \text { at } \\
80^{\circ} \mathrm{C}\end{array}$ & $\begin{array}{l}832.0 \text { at } \\
80^{\circ} \mathrm{C}\end{array}$ & $\begin{array}{c}2018.0 \text { at } \\
80^{\circ} \mathrm{C} \\
\text { (3 vents) }\end{array}$ & $\begin{array}{c}2570.3 \text { at } \\
80^{\circ} \mathrm{C}\end{array}$ & $\begin{array}{c}2907.7 \text { at } \\
\text { Ambient } \\
\text { (vent) }\end{array}$ \\
\hline \multirow{2}{*}{$\begin{array}{l}\mathrm{CO}_{2} \\
\text { Cumulative }\end{array}$} & $1.25 \mathrm{E}-07$ & $5.43 \mathrm{E}-07$ & 5.01E-07 & $2.39 \mathrm{E}-07$ & $2.49 \mathrm{E}-07$ & $2.32 \mathrm{E}-07$ & & $2.06 \mathrm{E}-07$ & \\
\hline & $1.25 \mathrm{E}-07$ & $6.68 \mathrm{E}-07$ & $1.17 \mathrm{E}-06$ & $1.41 \mathrm{E}-06$ & $1.66 \mathrm{E}-06$ & $1.89 \mathrm{E}-06$ & & $2.09 \mathrm{E}-06$ & \\
\hline \multirow{2}{*}{$\begin{array}{l}\mathrm{H}_{2} \\
\text { Cumulative }\end{array}$} & $5.14 \mathrm{E}-03$ & $3.94 \mathrm{E}-03$ & $2.54 \mathrm{E}-03$ & $3.84 \mathrm{E}-03$ & $4.16 \mathrm{E}-03$ & $2.65 \mathrm{E}-03$ & & $3.16 \mathrm{E}-03$ & \\
\hline & $5.14 \mathrm{E}-03$ & $9.08 \mathrm{E}-03$ & $1.16 \mathrm{E}-02$ & $1.55 \mathrm{E}-02$ & $1.96 \mathrm{E}-02$ & $2.23 \mathrm{E}-02$ & & $2.54 \mathrm{E}-02$ & \\
\hline \multirow{2}{*}{$\begin{array}{l}\mathrm{N}_{2} \\
\text { Cumulative }\end{array}$} & $-4.33 \mathrm{E}-06$ & $3.74 \mathrm{E}-06$ & $6.76 \mathrm{E}-06$ & 4.89E-06 & $6.98 \mathrm{E}-06$ & 4.23E-06 & & $2.63 \mathrm{E}-06$ & \\
\hline & $-4.33 \mathrm{E}-06$ & $-5.90 \mathrm{E}-07$ & $6.17 \mathrm{E}-06$ & $1.11 \mathrm{E}-05$ & $1.80 \mathrm{E}-05$ & $2.23 \mathrm{E}-05$ & & $2.49 \mathrm{E}-05$ & \\
\hline \multirow{2}{*}{\begin{tabular}{|l}
$\mathrm{O}_{2}$ \\
Cumulative
\end{tabular}} & $-6.21 \mathrm{E}-06$ & $5.18 \mathrm{E}-08$ & $3.84 \mathrm{E}-07$ & 4.09E-07 & $7.39 \mathrm{E}-07$ & $3.05 \mathrm{E}-07$ & & $-1.31 \mathrm{E}-06$ & \\
\hline & $-6.21 \mathrm{E}-06$ & $-6.16 \mathrm{E}-06$ & $-5.78 \mathrm{E}-06$ & $-5.37 \mathrm{E}-06$ & $-4.63 \mathrm{E}-06$ & $-4.32 \mathrm{E}-06$ & & $-5.63 \mathrm{E}-06$ & \\
\hline \multirow{2}{*}{$\begin{array}{l}\mathrm{CH}_{4} \\
\text { Cumulative }\end{array}$} & 4.93E-06 & $1.33 \mathrm{E}-06$ & 7.29E-07 & $1.07 \mathrm{E}-06$ & $1.25 \mathrm{E}-06$ & $7.89 \mathrm{E}-07$ & & $1.08 \mathrm{E}-06$ & \\
\hline & 4.93E-06 & $6.26 \mathrm{E}-06$ & $6.99 \mathrm{E}-06$ & 8.06E-06 & $9.31 \mathrm{E}-06$ & $1.01 \mathrm{E}-05$ & & $1.12 \mathrm{E}-05$ & \\
\hline \multirow{2}{*}{$\begin{array}{l}\mathrm{C}_{2} \mathrm{H}_{\mathrm{x}} \\
\text { Cumulative }\end{array}$} & $7.36 \mathrm{E}-07$ & $3.01 \mathrm{E}-07$ & & $2.39 \mathrm{E}-07$ & $3.12 \mathrm{E}-07$ & 2.32E-07 & & $3.09 \mathrm{E}-07$ & \\
\hline & $7.36 \mathrm{E}-07$ & $1.04 \mathrm{E}-06$ & $1.04 \mathrm{E}-06$ & $1.28 \mathrm{E}-06$ & $1.59 \mathrm{E}-06$ & $1.82 \mathrm{E}-06$ & & $2.13 \mathrm{E}-06$ & \\
\hline \multirow{2}{*}{$\begin{array}{l}\geq \mathrm{C}_{3} \mathrm{H}_{\mathrm{x}} \\
\text { Cumulative }\end{array}$} & $3.68 \mathrm{E}-07$ & $1.81 \mathrm{E}-07$ & $9.11 \mathrm{E}-08$ & $1.19 \mathrm{E}-07$ & $1.87 \mathrm{E}-07$ & $9.28 \mathrm{E}-08$ & & $1.54 \mathrm{E}-07$ & \\
\hline & $3.68 \mathrm{E}-07$ & $5.49 \mathrm{E}-07$ & $6.40 \mathrm{E}-07$ & $7.59 \mathrm{E}-07$ & $9.46 \mathrm{E}-07$ & $1.04 \mathrm{E}-06$ & & $1.19 \mathrm{E}-06$ & \\
\hline \multirow{2}{*}{\begin{tabular}{|l}
$\sum \mathrm{C}_{\mathrm{y}} \mathrm{H}_{\mathrm{x}} \mathrm{C}$ \\
Cumulative
\end{tabular}} & $7.57 \mathrm{E}-06$ & $2.50 \mathrm{E}-06$ & $1.02 \mathrm{E}-06$ & $1.93 \mathrm{E}-06$ & $2.46 \mathrm{E}-06$ & $1.55 \mathrm{E}-06$ & & $2.19 \mathrm{E}-06$ & \\
\hline & $7.57 \mathrm{E}-06$ & $1.01 \mathrm{E}-05$ & $1.11 \mathrm{E}-05$ & $1.30 \mathrm{E}-05$ & $1.55 \mathrm{E}-05$ & $1.70 \mathrm{E}-05$ & & $1.92 \mathrm{E}-05$ & \\
\hline \multirow{2}{*}{$\begin{array}{l}{ }^{83} \mathrm{Kr} \\
\text { Cumulative }\end{array}$} & $4.42 \mathrm{E}-08$ & 4.82E-08 & $1.82 \mathrm{E}-08$ & $3.58 \mathrm{E}-08$ & $3.74 \mathrm{E}-08$ & 2.32E-08 & & 3.09E-08 & \\
\hline & 4.42E-08 & $9.24 \mathrm{E}-08$ & $1.11 \mathrm{E}-07$ & $1.46 \mathrm{E}-07$ & $1.84 \mathrm{E}-07$ & 2.07E-07 & & $2.38 \mathrm{E}-07$ & \\
\hline \multirow{2}{*}{$\begin{array}{l}{ }^{84} \mathrm{Kr} \\
\text { Cumulative }\end{array}$} & $1.03 \mathrm{E}-07$ & $7.84 \mathrm{E}-08$ & $4.10 \mathrm{E}-08$ & $7.16 \mathrm{E}-08$ & $7.48 \mathrm{E}-08$ & $4.64 \mathrm{E}-08$ & & $6.69 \mathrm{E}-08$ & \\
\hline & $1.03 \mathrm{E}-07$ & $1.81 \mathrm{E}-07$ & $2.22 \mathrm{E}-07$ & $2.94 \mathrm{E}-07$ & $3.69 \mathrm{E}-07$ & $4.15 \mathrm{E}-07$ & & $4.82 \mathrm{E}-07$ & \\
\hline \multirow{2}{*}{$\begin{array}{l}85 \mathrm{Kr} \\
\text { Cumulative }\end{array}$} & 7.36E-09 & $6.03 \mathrm{E}-09$ & $2.28 \mathrm{E}-09$ & $3.58 \mathrm{E}-09$ & $2.49 \mathrm{E}-09$ & $2.32 \mathrm{E}-09$ & & 3.09E-09 & \\
\hline & $7.36 \mathrm{E}-09$ & $1.34 \mathrm{E}-08$ & $1.57 \mathrm{E}-08$ & $1.92 \mathrm{E}-08$ & $2.17 \mathrm{E}-08$ & $2.41 \mathrm{E}-08$ & & $2.71 \mathrm{E}-08$ & \\
\hline \multirow{2}{*}{$\begin{array}{l}{ }^{86} \mathrm{Kr} \\
\text { Cumulative }\end{array}$} & $1.84 \mathrm{E}-07$ & $1.45 \mathrm{E}-07$ & 7.29E-08 & $1.37 \mathrm{E}-07$ & $1.43 \mathrm{E}-07$ & 8.82E-08 & & $1.18 \mathrm{E}-07$ & \\
\hline & $1.84 \mathrm{E}-07$ & $3.29 \mathrm{E}-07$ & 4.02E-07 & 5.39E-07 & $6.82 \mathrm{E}-07$ & $7.70 \mathrm{E}-07$ & & $8.89 \mathrm{E}-07$ & \\
\hline \multirow{2}{*}{\begin{tabular}{|l}
$\mathrm{Kr}$ \\
Cumulative
\end{tabular}} & $3.38 \mathrm{E}-07$ & $2.77 \mathrm{E}-07$ & $1.34 \mathrm{E}-07$ & $2.48 \mathrm{E}-07$ & $2.58 \mathrm{E}-07$ & $1.60 \mathrm{E}-07$ & & $2.19 \mathrm{E}-07$ & \\
\hline & $3.38 \mathrm{E}-07$ & $6.16 \mathrm{E}-07$ & $7.50 \mathrm{E}-07$ & $9.98 \mathrm{E}-07$ & $1.26 \mathrm{E}-06$ & $1.42 \mathrm{E}-06$ & & $1.64 \mathrm{E}-06$ & \\
\hline \multirow{2}{*}{ 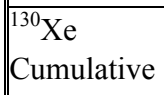 } & $1.47 \mathrm{E}-09$ & $1.21 \mathrm{E}-09$ & $4.55 \mathrm{E}-10$ & $1.19 \mathrm{E}-09$ & $6.23 \mathrm{E}-10$ & $4.64 \mathrm{E}-10$ & & $5.15 \mathrm{E}-10$ & \\
\hline & $1.47 \mathrm{E}-09$ & $2.68 \mathrm{E}-09$ & $3.13 \mathrm{E}-09$ & 4.33E-09 & $4.95 \mathrm{E}-09$ & 5.41E-09 & & 5.93E-09 & \\
\hline \multirow{2}{*}{$\begin{array}{l}{ }^{131} \mathrm{Xe} \\
\text { Cumulative }\end{array}$} & $3.53 \mathrm{E}-07$ & $2.77 \mathrm{E}-07$ & $1.55 \mathrm{E}-07$ & $2.45 \mathrm{E}-07$ & 2.62E-07 & $1.62 \mathrm{E}-07$ & & $2.01 \mathrm{E}-07$ & \\
\hline & $3.53 \mathrm{E}-07$ & $6.31 \mathrm{E}-07$ & $7.85 \mathrm{E}-07$ & $1.03 \mathrm{E}-06$ & $1.29 \mathrm{E}-06$ & $1.45 \mathrm{E}-06$ & & $1.65 \mathrm{E}-06$ & \\
\hline \multirow{2}{*}{$\begin{array}{l}132 \mathrm{Xe} \\
\text { Cumulative }\end{array}$} & $6.03 \mathrm{E}-07$ & $4.58 \mathrm{E}-07$ & $2.73 \mathrm{E}-07$ & $4.18 \mathrm{E}-07$ & $4.49 \mathrm{E}-07$ & $2.88 \mathrm{E}-07$ & & $3.24 \mathrm{E}-07$ & \\
\hline & $6.03 \mathrm{E}-07$ & $1.06 \mathrm{E}-06$ & $1.33 \mathrm{E}-06$ & $1.75 \mathrm{E}-06$ & $2.20 \mathrm{E}-06$ & $2.49 \mathrm{E}-06$ & & $2.81 \mathrm{E}-06$ & \\
\hline \multirow{2}{*}{$\begin{array}{l}{ }^{134} \mathrm{Xe} \\
\text { Cumulative }\end{array}$} & $9.57 \mathrm{E}-07$ & $7.23 \mathrm{E}-07$ & 4.37E-07 & $6.56 \mathrm{E}-07$ & $7.48 \mathrm{E}-07$ & 4.64E-07 & & $5.15 \mathrm{E}-07$ & \\
\hline & $9.57 \mathrm{E}-07$ & $1.68 \mathrm{E}-06$ & $2.12 \mathrm{E}-06$ & $2.77 \mathrm{E}-06$ & $3.52 \mathrm{E}-06$ & 3.99E-06 & & $4.50 \mathrm{E}-06$ & \\
\hline \multirow{2}{*}{$\stackrel{1136}{X e}_{\text {Cumulative }}$} & $1.40 \mathrm{E}-06$ & $1.09 \mathrm{E}-06$ & $6.38 \mathrm{E}-07$ & $9.55 \mathrm{E}-07$ & $1.06 \mathrm{E}-06$ & $6.50 \mathrm{E}-07$ & & 7.72E-07 & \\
\hline & $1.40 \mathrm{E}-06$ & $2.48 \mathrm{E}-06$ & 3.12E-06 & $4.08 \mathrm{E}-06$ & $5.14 \mathrm{E}-06$ & $5.78 \mathrm{E}-06$ & & $6.56 \mathrm{E}-06$ & \\
\hline \multirow{2}{*}{$\begin{array}{l}\Sigma \mathrm{Xe} \\
\text { Cumulative }\end{array}$} & $3.31 \mathrm{E}-06$ & $2.55 \mathrm{E}-06$ & $1.50 \mathrm{E}-06$ & $2.27 \mathrm{E}-06$ & $2.52 \mathrm{E}-06$ & $1.56 \mathrm{E}-06$ & & $1.81 \mathrm{E}-06$ & \\
\hline & $3.31 \mathrm{E}-06$ & $5.86 \mathrm{E}-06$ & $7.36 \mathrm{E}-06$ & 9.64E-06 & $1.22 \mathrm{E}-05$ & $1.37 \mathrm{E}-05$ & & $1.55 \mathrm{E}-05$ & \\
\hline \multirow{2}{*}{$\begin{array}{l}\text { Total Gas } \\
\text { Cumulative }\end{array}$} & $5.41 \mathrm{E}-03$ & $4.14 \mathrm{E}-03$ & 2.62E-03 & $4.15 \mathrm{E}-03$ & $4.39 \mathrm{E}-03$ & $2.78 \mathrm{E}-03$ & $1.35 \mathrm{E}-02$ & $3.25 \mathrm{E}-03$ & $3.11 \mathrm{E}-05$ \\
\hline & $5.41 \mathrm{E}-03$ & $9.55 \mathrm{E}-03$ & $1.22 \mathrm{E}-02$ & $1.63 \mathrm{E}-02$ & $2.07 \mathrm{E}-02$ & $2.35 \mathrm{E}-02$ & $3.70 \mathrm{E}-02$ & $4.03 \mathrm{E}-02$ & 4.03E-02 \\
\hline
\end{tabular}


Table 5.10. Net and Cumulative Quantities of Gas Evolved for SNF M500 80L (Test 6)

\begin{tabular}{|c|c|c|c|c|}
\hline \multirow[b]{2}{*}{ Gas } & \multicolumn{4}{|c|}{ Gas Quantities, Moles, at Sampling Times, hr } \\
\hline & $\begin{array}{c}136.3 \text { at } \\
\text { Ambient; } \\
251.7 \text { at } 80^{\circ} \mathrm{C}\end{array}$ & $\begin{array}{c}1253.3 \text { at } \\
80^{\circ} \mathrm{C}\end{array}$ & $\begin{array}{c}1754.3 \text { at } \\
80^{\circ} \mathrm{C}\end{array}$ & $\begin{array}{c}3124.0 \text { at } \\
\text { Ambient } \\
\text { (vent) }\end{array}$ \\
\hline \multirow{2}{*}{$\begin{array}{l}\mathrm{CO}_{2} \\
\text { Cumulative }\end{array}$} & $8.21 \mathrm{E}-06$ & $2.66 \mathrm{E}-05$ & $3.35 \mathrm{E}-06$ & \\
\hline & $8.21 \mathrm{E}-06$ & $3.48 \mathrm{E}-05$ & $3.82 \mathrm{E}-05$ & \\
\hline \multirow{2}{*}{$\begin{array}{l}\mathrm{H}_{2} \\
\text { Cumulative }\end{array}$} & $2.54 \mathrm{E}-02$ & $2.25 \mathrm{E}-02$ & $1.56 \mathrm{E}-03$ & \\
\hline & $2.54 \mathrm{E}-02$ & $4.80 \mathrm{E}-02$ & $4.95 \mathrm{E}-02$ & \\
\hline \multirow{2}{*}{$\begin{array}{l}\mathrm{N}_{2} \\
\text { Cumulative }\end{array}$} & $-1.53 \mathrm{E}-05$ & 4.64E-05 & $1.25 \mathrm{E}-05$ & \\
\hline & $-1.53 \mathrm{E}-05$ & $3.11 \mathrm{E}-05$ & $4.36 \mathrm{E}-05$ & \\
\hline \multirow{2}{*}{$\begin{array}{l}\mathrm{O}_{2} \\
\text { Cumulative }\end{array}$} & $-2.69 \mathrm{E}-05$ & $-3.48 \mathrm{E}-05$ & $-3.12 \mathrm{E}-05$ & \\
\hline & $-2.69 \mathrm{E}-05$ & $-6.16 \mathrm{E}-05$ & $-9.28 \mathrm{E}-05$ & \\
\hline \multirow{2}{*}{$\begin{array}{l}\mathrm{CH}_{4} \\
\text { Cumulative }\end{array}$} & $3.94 \mathrm{E}-05$ & $1.54 \mathrm{E}-05$ & $3.05 \mathrm{E}-06$ & \\
\hline & $3.94 \mathrm{E}-05$ & $5.48 \mathrm{E}-05$ & 5.79E-05 & \\
\hline \multirow{2}{*}{\begin{tabular}{|l}
$\mathrm{C}_{2} \mathrm{H}_{\mathrm{x}}$ \\
Cumulative
\end{tabular}} & 4.92E-06 & $6.39 \mathrm{E}-06$ & $2.74 \mathrm{E}-06$ & \\
\hline & $4.92 \mathrm{E}-06$ & $1.13 \mathrm{E}-05$ & $1.41 \mathrm{E}-05$ & \\
\hline \multirow{2}{*}{$\begin{array}{l}\geq \mathrm{C}_{3} \mathrm{H}_{\mathrm{x}} \\
\text { Cumulative }\end{array}$} & 2.19E-06 & $4.26 \mathrm{E}-06$ & $2.13 \mathrm{E}-06$ & \\
\hline & $2.19 \mathrm{E}-06$ & $6.45 \mathrm{E}-06$ & $8.58 \mathrm{E}-06$ & \\
\hline \multirow{2}{*}{\begin{tabular}{|l}
$\sum \mathrm{C}_{\mathrm{y}} \mathrm{H}_{\mathrm{x}} \mathrm{C}$ \\
Cumulative
\end{tabular}} & $5.62 \mathrm{E}-05$ & $4.17 \mathrm{E}-05$ & $1.53 \mathrm{E}-05$ & \\
\hline & $5.62 \mathrm{E}-05$ & $9.79 \mathrm{E}-05$ & $1.13 \mathrm{E}-04$ & \\
\hline \multirow{2}{*}{$\begin{array}{l}83 \mathrm{Kr} \\
\text { Cumulative }\end{array}$} & $1.64 \mathrm{E}-07$ & $2.13 \mathrm{E}-07$ & $9.15 \mathrm{E}-09$ & \\
\hline & $1.64 \mathrm{E}-07$ & $3.77 \mathrm{E}-07$ & $3.86 \mathrm{E}-07$ & \\
\hline \multirow{2}{*}{$\begin{array}{l}{ }^{84} \mathrm{Kr} \\
\text { Cumulative }\end{array}$} & $3.28 \mathrm{E}-07$ & $4.79 \mathrm{E}-07$ & $2.13 \mathrm{E}-08$ & \\
\hline & $3.28 \mathrm{E}-07$ & $8.07 \mathrm{E}-07$ & $8.29 \mathrm{E}-07$ & \\
\hline \multirow{2}{*}{$\begin{array}{l}85 \mathrm{Kr} \\
\text { Cumulative }\end{array}$} & $3.83 \mathrm{E}-08$ & $2.13 \mathrm{E}-08$ & & \\
\hline & $3.83 \mathrm{E}-08$ & $5.96 \mathrm{E}-08$ & $5.96 \mathrm{E}-08$ & \\
\hline \multirow{2}{*}{ 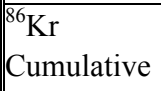 } & $8.21 \mathrm{E}-07$ & $8.52 \mathrm{E}-07$ & $3.05 \mathrm{E}-08$ & \\
\hline & $8.21 \mathrm{E}-07$ & $1.67 \mathrm{E}-06$ & $1.70 \mathrm{E}-06$ & \\
\hline \multirow{2}{*}{\begin{tabular}{|l|}
$\sum \mathrm{Kr}$ \\
Cumulative
\end{tabular}} & $1.35 \mathrm{E}-06$ & $1.56 \mathrm{E}-06$ & $6.10 \mathrm{E}-08$ & \\
\hline & $1.35 \mathrm{E}-06$ & $2.92 \mathrm{E}-06$ & $2.98 \mathrm{E}-06$ & \\
\hline \multirow{2}{*}{$\begin{array}{l}{ }^{130} \mathrm{Xe} \\
\text { Cumulative }\end{array}$} & $5.47 \mathrm{E}-09$ & $5.32 \mathrm{E}-09$ & & \\
\hline & $5.47 \mathrm{E}-09$ & $1.08 \mathrm{E}-08$ & $1.08 \mathrm{E}-08$ & \\
\hline \multirow{2}{*}{$\begin{array}{l}{ }^{131} \mathrm{Xe} \\
\text { Cumulative }\end{array}$} & $1.53 \mathrm{E}-06$ & $1.49 \mathrm{E}-06$ & $9.15 \mathrm{E}-08$ & \\
\hline & $1.53 \mathrm{E}-06$ & $3.02 \mathrm{E}-06$ & $3.11 \mathrm{E}-06$ & \\
\hline \multirow{2}{*}{$\begin{array}{l}{ }^{132} \mathrm{Xe} \\
\text { Cumulative }\end{array}$} & $2.68 \mathrm{E}-06$ & $2.56 \mathrm{E}-06$ & $1.52 \mathrm{E}-07$ & \\
\hline & $2.68 \mathrm{E}-06$ & $5.24 \mathrm{E}-06$ & 5.39E-06 & \\
\hline \multirow{2}{*}{$\begin{array}{l}{ }^{134} \mathrm{Xe} \\
\text { Cumulative }\end{array}$} & $4.43 \mathrm{E}-06$ & $3.99 \mathrm{E}-06$ & $2.13 \mathrm{E}-07$ & \\
\hline & $4.43 \mathrm{E}-06$ & $8.42 \mathrm{E}-06$ & $8.64 \mathrm{E}-06$ & \\
\hline \multirow{2}{*}{$\begin{array}{l}{ }^{136} \mathrm{Xe} \\
\text { Cumulative }\end{array}$} & $6.56 \mathrm{E}-06$ & $5.86 \mathrm{E}-06$ & $3.05 \mathrm{E}-07$ & \\
\hline & $6.56 \mathrm{E}-06$ & $1.24 \mathrm{E}-05$ & $1.27 \mathrm{E}-05$ & \\
\hline \multirow{2}{*}{\begin{tabular}{|l}
$\sum \mathrm{Xe}$ \\
Cumulative
\end{tabular}} & $1.52 \mathrm{E}-05$ & $1.39 \mathrm{E}-05$ & $7.62 \mathrm{E}-07$ & \\
\hline & $1.52 \mathrm{E}-05$ & $2.91 \mathrm{E}-05$ & 2.99E-05 & \\
\hline \multirow{2}{*}{\begin{tabular}{|l} 
Total Gas \\
Cumulative
\end{tabular}} & $2.80 \mathrm{E}-02$ & $2.42 \mathrm{E}-02$ & $1.16 \mathrm{E}-03$ & $-2.27 \mathrm{E}-04$ \\
\hline & $2.80 \mathrm{E}-02$ & $5.22 \mathrm{E}-02$ & $5.34 \mathrm{E}-02$ & $5.32 \mathrm{E}-02$ \\
\hline
\end{tabular}


Table 5.11. Net and Cumulative Quantities of Gas Evolved for SNF Mid 80L (Test 7)

\begin{tabular}{|c|c|c|c|c|c|}
\hline \multirow[b]{2}{*}{ Gas } & \multicolumn{5}{|c|}{ "Gas Quantities, Moles, at Sampling Times, hr } \\
\hline & $\begin{array}{c}136.3 \text { at } \\
\text { Ambient; } \\
641.3 \text { at } 80^{\circ} \mathrm{C}\end{array}$ & $\begin{array}{c}1235.3 \text { at } \\
80^{\circ} \mathrm{C}\end{array}$ & $\begin{array}{c}1736.3 \text { at } \\
95^{\circ} \mathrm{C}\end{array}$ & $\begin{array}{c}2653.7 \text { at } \\
95^{\circ} \mathrm{C}\end{array}$ & $\begin{array}{c}2987.7 \text { at } \\
\text { Ambient } \\
\text { (vent) }\end{array}$ \\
\hline \multirow{2}{*}{$\begin{array}{l}\mathrm{CO}_{2} \\
\text { Cumulative }\end{array}$} & $3.58 \mathrm{E}-06$ & $1.34 \mathrm{E}-06$ & $3.14 \mathrm{E}-05$ & $1.11 \mathrm{E}-05$ & \\
\hline & $3.58 \mathrm{E}-06$ & $4.93 \mathrm{E}-06$ & $3.64 \mathrm{E}-05$ & 4.74E-05 & \\
\hline \multirow{2}{*}{$\begin{array}{l}\mathrm{H}_{2} \\
\text { Cumulative }\end{array}$} & 4.03E-02 & $1.45 \mathrm{E}-02$ & $9.80 \mathrm{E}-03$ & $3.01 \mathrm{E}-03$ & \\
\hline & $4.03 \mathrm{E}-02$ & $5.48 \mathrm{E}-02$ & $6.46 \mathrm{E}-02$ & $6.76 \mathrm{E}-02$ & \\
\hline \multirow{2}{*}{$\begin{array}{l}\mathrm{N}_{2} \\
\text { Cumulative }\end{array}$} & $-3.16 \mathrm{E}-06$ & $1.72 \mathrm{E}-05$ & $1.20 \mathrm{E}-05$ & $2.93 \mathrm{E}-05$ & \\
\hline & $-3.16 \mathrm{E}-06$ & $1.40 \mathrm{E}-05$ & $2.60 \mathrm{E}-05$ & $5.53 \mathrm{E}-05$ & \\
\hline \multirow{2}{*}{$\begin{array}{l}\mathrm{O}_{2} \\
\text { Cumulative }\end{array}$} & $-2.13 \mathrm{E}-05$ & $-2.35 \mathrm{E}-05$ & $-3.23 \mathrm{E}-05$ & $1.73 \mathrm{E}-06$ & \\
\hline & $-2.13 \mathrm{E}-05$ & $-4.48 \mathrm{E}-05$ & $-7.72 \mathrm{E}-05$ & $-7.54 \mathrm{E}-05$ & \\
\hline \multirow{2}{*}{$\begin{array}{l}\mathrm{CH}_{4} \\
\text { Cumulative }\end{array}$} & 7.89E-06 & $1.79 \mathrm{E}-06$ & $2.48 \mathrm{E}-06$ & $2.42 \mathrm{E}-06$ & \\
\hline & 7.89E-06 & $9.68 \mathrm{E}-06$ & $1.22 \mathrm{E}-05$ & $1.46 \mathrm{E}-05$ & \\
\hline \multirow{2}{*}{\begin{tabular}{|l|}
$\mathrm{C}_{2} \mathrm{H}_{\mathrm{x}}$ \\
Cumulative
\end{tabular}} & & $8.95 \mathrm{E}-07$ & $1.65 \mathrm{E}-06$ & $1.04 \mathrm{E}-06$ & \\
\hline & $0.00 \mathrm{E}+00$ & $8.95 \mathrm{E}-07$ & $2.55 \mathrm{E}-06$ & $3.59 \mathrm{E}-06$ & \\
\hline \multirow{2}{*}{$\begin{array}{l}\geq \mathrm{C}_{3} \mathrm{H}_{\mathrm{x}} \\
\text { Cumulative }\end{array}$} & 7.17E-07 & & $8.27 \mathrm{E}-07$ & 6.91E-07 & \\
\hline & $7.17 \mathrm{E}-07$ & $7.17 \mathrm{E}-07$ & $1.54 \mathrm{E}-06$ & $2.24 \mathrm{E}-06$ & \\
\hline \multirow{2}{*}{$\begin{array}{l}\sum \mathrm{C}_{\mathrm{y}} \mathrm{H}_{\mathrm{x}} \mathrm{C} \\
\text { Cumulative }\end{array}$} & $1.02 \mathrm{E}-05$ & $3.58 \mathrm{E}-06$ & $8.41 \mathrm{E}-06$ & 6.69E-06 & \\
\hline & $1.02 \mathrm{E}-05$ & $1.37 \mathrm{E}-05$ & $2.22 \mathrm{E}-05$ & $2.88 \mathrm{E}-05$ & \\
\hline \multirow{2}{*}{$\begin{array}{l}{ }^{83} \mathrm{Kr} \\
\text { Cumulative }\end{array}$} & $3.58 \mathrm{E}-07$ & $1.34 \mathrm{E}-07$ & $8.27 \mathrm{E}-08$ & $3.46 \mathrm{E}-08$ & \\
\hline & $3.58 \mathrm{E}-07$ & $4.93 \mathrm{E}-07$ & 5.75E-07 & $6.10 \mathrm{E}-07$ & \\
\hline \multirow{2}{*}{$\begin{array}{l}{ }^{84} \mathrm{Kr} \\
\text { Cumulative }\end{array}$} & $7.17 \mathrm{E}-07$ & $2.69 \mathrm{E}-07$ & $2.07 \mathrm{E}-07$ & $3.46 \mathrm{E}-08$ & \\
\hline & $7.17 \mathrm{E}-07$ & $9.85 \mathrm{E}-07$ & $1.19 \mathrm{E}-06$ & $1.23 \mathrm{E}-06$ & \\
\hline \multirow{2}{*}{$\begin{array}{l}{ }^{85} \mathrm{Kr} \\
\text { Cumulative }\end{array}$} & $3.58 \mathrm{E}-08$ & $1.34 \mathrm{E}-08$ & $8.27 \mathrm{E}-09$ & $1.73 \mathrm{E}-09$ & \\
\hline & $3.58 \mathrm{E}-08$ & $4.93 \mathrm{E}-08$ & $5.75 \mathrm{E}-08$ & 5.93E-08 & \\
\hline \multirow{2}{*}{$\begin{array}{l}{ }^{86} \mathrm{Kr} \\
\text { Cumulative }\end{array}$} & $1.36 \mathrm{E}-06$ & $4.92 \mathrm{E}-07$ & $3.31 \mathrm{E}-07$ & 6.91E-08 & \\
\hline & $1.36 \mathrm{E}-06$ & $1.85 \mathrm{E}-06$ & $2.19 \mathrm{E}-06$ & $2.25 \mathrm{E}-06$ & \\
\hline \multirow{2}{*}{\begin{tabular}{|l}
$\mathrm{Kr}$ \\
Cumulative
\end{tabular}} & $2.47 \mathrm{E}-06$ & $9.09 \mathrm{E}-07$ & $6.29 \mathrm{E}-07$ & $1.40 \mathrm{E}-07$ & \\
\hline & $2.47 \mathrm{E}-06$ & $3.38 \mathrm{E}-06$ & $4.01 \mathrm{E}-06$ & $4.15 \mathrm{E}-06$ & \\
\hline \multirow{2}{*}{$\begin{array}{l}{ }^{130} \mathrm{Xe} \\
\text { Cumulative }\end{array}$} & 7.17E-09 & $3.13 \mathrm{E}-09$ & & $6.91 \mathrm{E}-10$ & \\
\hline & 7.17E-09 & $1.03 \mathrm{E}-08$ & $1.03 \mathrm{E}-08$ & $1.10 \mathrm{E}-08$ & \\
\hline \multirow{2}{*}{$\begin{array}{l}{ }^{131} \mathrm{Xe} \\
\text { Cumulative }\end{array}$} & $2.37 \mathrm{E}-06$ & $8.06 \mathrm{E}-07$ & 5.79E-07 & $2.07 \mathrm{E}-07$ & \\
\hline & $2.37 \mathrm{E}-06$ & $3.17 \mathrm{E}-06$ & $3.75 \mathrm{E}-06$ & $3.96 \mathrm{E}-06$ & \\
\hline \multirow{2}{*}{$\begin{array}{l}{ }^{132} \mathrm{Xe} \\
\text { Cumulative }\end{array}$} & 4.09E-06 & $1.48 \mathrm{E}-06$ & $1.03 \mathrm{E}-06$ & $3.46 \mathrm{E}-07$ & \\
\hline & $4.09 \mathrm{E}-06$ & $5.56 \mathrm{E}-06$ & $6.60 \mathrm{E}-06$ & $6.94 \mathrm{E}-06$ & \\
\hline \multirow{2}{*}{$\begin{array}{l}{ }^{134} \mathrm{Xe} \\
\text { Cumulative }\end{array}$} & $6.38 \mathrm{E}-06$ & $2.28 \mathrm{E}-06$ & $1.65 \mathrm{E}-06$ & $5.19 \mathrm{E}-07$ & \\
\hline & $6.38 \mathrm{E}-06$ & $8.66 \mathrm{E}-06$ & $1.03 \mathrm{E}-05$ & $1.08 \mathrm{E}-05$ & \\
\hline \multirow{2}{*}{$\begin{array}{l}{ }^{136} \mathrm{Xe} \\
\text { Cumulative }\end{array}$} & 9.32E-06 & $3.49 \mathrm{E}-06$ & $2.44 \mathrm{E}-06$ & $7.61 \mathrm{E}-07$ & \\
\hline & 9.32E-06 & $1.28 \mathrm{E}-05$ & $1.53 \mathrm{E}-05$ & $1.60 \mathrm{E}-05$ & \\
\hline \multirow{2}{*}{\begin{tabular}{|l}
$\sum \mathrm{Xe}$ \\
Cumulative
\end{tabular}} & $2.22 \mathrm{E}-05$ & $8.06 \mathrm{E}-06$ & $5.71 \mathrm{E}-06$ & $1.83 \mathrm{E}-06$ & \\
\hline & $2.22 \mathrm{E}-05$ & $3.02 \mathrm{E}-05$ & $3.59 \mathrm{E}-05$ & $3.78 \mathrm{E}-05$ & \\
\hline \multirow{2}{*}{$\begin{array}{l}\text { Total Gas } \\
\text { Cumulative }\end{array}$} & 4.01E-02 & $1.45 \mathrm{E}-02$ & 9.82E-03 & $2.46 \mathrm{E}-03$ & $1.44 \mathrm{E}-05$ \\
\hline & $4.01 \mathrm{E}-02$ & $5.47 \mathrm{E}-02$ & $6.45 \mathrm{E}-02$ & $6.69 \mathrm{E}-02$ & $6.70 \mathrm{E}-02$ \\
\hline
\end{tabular}


Table 5.12. Net and Cumulative Quantities of Gas Evolved for SNF Mid 80L Dup (Test 8)

\begin{tabular}{|c|c|c|c|c|c|}
\hline \multirow[b]{2}{*}{ Gas } & \multicolumn{5}{|c|}{ Gas Quantities, Moles, at Sampling Times, hr } \\
\hline & $\begin{array}{c}136.3 \text { at } \\
\text { Ambient; } \\
641.3 \text { at } 80^{\circ} \mathrm{C}\end{array}$ & $\begin{array}{c}1235.7 \text { at } \\
80^{\circ} \mathrm{C}\end{array}$ & $\begin{array}{c}1736.7 \text { at } \\
95^{\circ} \mathrm{C}\end{array}$ & $\begin{array}{c}2654.0 \text { at } \\
95^{\circ} \mathrm{C}\end{array}$ & $\begin{array}{c}2988.0 \text { at } \\
\text { Ambient } \\
\text { (vent) }\end{array}$ \\
\hline \multirow{2}{*}{$\begin{array}{l}\mathrm{CO}_{2} \\
\text { Cumulative }\end{array}$} & $8.47 \mathrm{E}-06$ & $1.05 \mathrm{E}-05$ & $3.40 \mathrm{E}-06$ & $3.22 \mathrm{E}-05$ & \\
\hline & $8.47 \mathrm{E}-06$ & $1.90 \mathrm{E}-05$ & $2.24 \mathrm{E}-05$ & $5.46 \mathrm{E}-05$ & \\
\hline \multirow{2}{*}{\begin{tabular}{|l}
$\mathrm{H}_{2}$ \\
Cumulative
\end{tabular}} & $4.46 \mathrm{E}-02$ & $1.34 \mathrm{E}-02$ & $6.08 \mathrm{E}-03$ & $1.34 \mathrm{E}-03$ & \\
\hline & $4.46 \mathrm{E}-02$ & $5.80 \mathrm{E}-02$ & $6.41 \mathrm{E}-02$ & $6.54 \mathrm{E}-02$ & \\
\hline \multirow{2}{*}{$\begin{array}{l}\mathrm{N}_{2} \\
\text { Cumulative }\end{array}$} & $-4.19 \mathrm{E}-05$ & $3.55 \mathrm{E}-05$ & $1.31 \mathrm{E}-05$ & $1.52 \mathrm{E}-05$ & \\
\hline & $-4.19 \mathrm{E}-05$ & $-6.43 \mathrm{E}-06$ & $6.71 \mathrm{E}-06$ & $2.19 \mathrm{E}-05$ & \\
\hline \multirow{2}{*}{\begin{tabular}{|l}
$\mathrm{O}_{2}$ \\
Cumulative
\end{tabular}} & $-3.44 \mathrm{E}-05$ & $-4.90 \mathrm{E}-06$ & $1.75 \mathrm{E}-04$ & $-2.17 \mathrm{E}-05$ & \\
\hline & $-3.44 \mathrm{E}-05$ & $-3.93 \mathrm{E}-05$ & $1.36 \mathrm{E}-04$ & $1.14 \mathrm{E}-04$ & \\
\hline \multirow{2}{*}{$\begin{array}{l}\mathrm{CH}_{4} \\
\text { Cumulative }\end{array}$} & $8.47 \mathrm{E}-06$ & $1.83 \mathrm{E}-06$ & $2.64 \mathrm{E}-06$ & $2.03 \mathrm{E}-06$ & \\
\hline & $8.47 \mathrm{E}-06$ & $1.03 \mathrm{E}-05$ & $1.29 \mathrm{E}-05$ & $1.50 \mathrm{E}-05$ & \\
\hline \multirow{2}{*}{$\begin{array}{l}\mathrm{C}_{2} \mathrm{H}_{\mathrm{x}} \\
\text { Cumulative }\end{array}$} & & $9.14 \mathrm{E}-07$ & $1.51 \mathrm{E}-06$ & $1.02 \mathrm{E}-06$ & \\
\hline & $0.00 \mathrm{E}+00$ & $9.14 \mathrm{E}-07$ & $2.43 \mathrm{E}-06$ & $3.44 \mathrm{E}-06$ & \\
\hline \multirow{2}{*}{$\begin{array}{l}\geq \mathrm{C}_{3} \mathrm{H}_{\mathrm{x}} \\
\text { Cumulative }\end{array}$} & $1.54 \mathrm{E}-06$ & & $7.56 \mathrm{E}-07$ & 3.39E-07 & \\
\hline & $1.54 \mathrm{E}-06$ & $1.54 \mathrm{E}-06$ & $2.30 \mathrm{E}-06$ & $2.63 \mathrm{E}-06$ & \\
\hline \multirow{2}{*}{$\begin{array}{l}\sum \mathrm{C}_{\mathrm{y}} \mathrm{H}_{\mathrm{x}} \mathrm{C} \\
\text { Cumulative }\end{array}$} & $1.34 \mathrm{E}-05$ & $3.66 \mathrm{E}-06$ & $8.06 \mathrm{E}-06$ & $5.14 \mathrm{E}-06$ & \\
\hline & $1.34 \mathrm{E}-05$ & $1.70 \mathrm{E}-05$ & $2.51 \mathrm{E}-05$ & $3.02 \mathrm{E}-05$ & \\
\hline \multirow{2}{*}{$\begin{array}{l}{ }^{83} \mathrm{Kr} \\
\text { Cumulative }\end{array}$} & $3.85 \mathrm{E}-07$ & $9.14 \mathrm{E}-08$ & $3.78 \mathrm{E}-08$ & $1.02 \mathrm{E}-08$ & \\
\hline & $3.85 \mathrm{E}-07$ & $4.76 \mathrm{E}-07$ & $5.14 \mathrm{E}-07$ & $5.24 \mathrm{E}-07$ & \\
\hline \multirow{2}{*}{\begin{tabular}{|l}
${ }^{84} \mathrm{Kr}$ \\
Cumulative
\end{tabular}} & $8.47 \mathrm{E}-07$ & $1.83 \mathrm{E}-07$ & $7.56 \mathrm{E}-08$ & $2.03 \mathrm{E}-08$ & \\
\hline & $8.47 \mathrm{E}-07$ & $1.03 \mathrm{E}-06$ & $1.11 \mathrm{E}-06$ & $1.13 \mathrm{E}-06$ & \\
\hline \multirow{2}{*}{$\begin{array}{l}{ }^{85} \mathrm{Kr} \\
\text { Cumulative }\end{array}$} & $3.85 \mathrm{E}-08$ & $9.14 \mathrm{E}-09$ & $3.78 \mathrm{E}-09$ & $1.36 \mathrm{E}-09$ & \\
\hline & $3.85 \mathrm{E}-08$ & 4.76E-08 & 5.14E-08 & $5.28 \mathrm{E}-08$ & \\
\hline \multirow{2}{*}{$\begin{array}{l}{ }^{86} \mathrm{Kr} \\
\text { Cumulative }\end{array}$} & $1.46 \mathrm{E}-06$ & $3.20 \mathrm{E}-07$ & $1.51 \mathrm{E}-07$ & $3.05 \mathrm{E}-08$ & \\
\hline & $1.46 \mathrm{E}-06$ & $1.78 \mathrm{E}-06$ & $1.93 \mathrm{E}-06$ & $1.96 \mathrm{E}-06$ & \\
\hline \multirow{2}{*}{\begin{tabular}{|l}
$\sum \mathrm{Kr}$ \\
Cumulative
\end{tabular}} & $2.73 \mathrm{E}-06$ & $6.03 \mathrm{E}-07$ & $2.68 \mathrm{E}-07$ & $6.24 \mathrm{E}-08$ & \\
\hline & $2.73 \mathrm{E}-06$ & $3.34 \mathrm{E}-06$ & $3.61 \mathrm{E}-06$ & $3.67 \mathrm{E}-06$ & \\
\hline \multirow{2}{*}{$\begin{array}{l}{ }^{130} \mathrm{Xe} \\
\text { Cumulative }\end{array}$} & $7.70 \mathrm{E}-09$ & $2.74 \mathrm{E}-09$ & & & \\
\hline & 7.70E-09 & 1.04E-08 & $1.04 \mathrm{E}-08$ & $1.04 \mathrm{E}-08$ & \\
\hline \multirow{2}{*}{$\begin{array}{l}{ }^{131} \mathrm{Xe} \\
\text { Cumulative }\end{array}$} & $2.62 \mathrm{E}-06$ & $7.31 \mathrm{E}-07$ & $4.16 \mathrm{E}-07$ & $1.02 \mathrm{E}-07$ & \\
\hline & $2.62 \mathrm{E}-06$ & $3.35 \mathrm{E}-06$ & $3.77 \mathrm{E}-06$ & $3.87 \mathrm{E}-06$ & \\
\hline \multirow{2}{*}{$\begin{array}{l}{ }^{132} \mathrm{Xe} \\
\text { Cumulative }\end{array}$} & 4.62E-06 & $1.33 \mathrm{E}-06$ & $6.80 \mathrm{E}-07$ & $1.36 \mathrm{E}-07$ & \\
\hline & $4.62 \mathrm{E}-06$ & $5.95 \mathrm{E}-06$ & $6.63 \mathrm{E}-06$ & $6.76 \mathrm{E}-06$ & \\
\hline \multirow{2}{*}{$\begin{array}{l}{ }^{134} \mathrm{Xe} \\
\text { Cumulative }\end{array}$} & $7.16 \mathrm{E}-06$ & $2.19 \mathrm{E}-06$ & $1.10 \mathrm{E}-06$ & 2.03E-07 & \\
\hline & $7.16 \mathrm{E}-06$ & $9.36 \mathrm{E}-06$ & $1.05 \mathrm{E}-05$ & $1.07 \mathrm{E}-05$ & \\
\hline \multirow{2}{*}{$\begin{array}{l}{ }^{136} \mathrm{Xe} \\
\text { Cumulative }\end{array}$} & $1.08 \mathrm{E}-05$ & $3.20 \mathrm{E}-06$ & $1.59 \mathrm{E}-06$ & 3.39E-07 & \\
\hline & $1.08 \mathrm{E}-05$ & $1.40 \mathrm{E}-05$ & $1.56 \mathrm{E}-05$ & $1.59 \mathrm{E}-05$ & \\
\hline \multirow{2}{*}{\begin{tabular}{|l}
$\mathrm{Xe}$ \\
Cumulative
\end{tabular}} & $2.52 \mathrm{E}-05$ & $7.45 \mathrm{E}-06$ & $3.78 \mathrm{E}-06$ & $7.80 \mathrm{E}-07$ & \\
\hline & $2.52 \mathrm{E}-05$ & $3.26 \mathrm{E}-05$ & $3.64 \mathrm{E}-05$ & $3.72 \mathrm{E}-05$ & \\
\hline \multirow{2}{*}{$\begin{array}{l}\text { Total Gas } \\
\text { Cumulative }\end{array}$} & $4.20 \mathrm{E}-02$ & $1.03 \mathrm{E}-02$ & $5.37 \mathrm{E}-03$ & $3.63 \mathrm{E}-03$ & $-6.46 \mathrm{E}-05$ \\
\hline & $4.20 \mathrm{E}-02$ & $5.23 \mathrm{E}-02$ & $5.76 \mathrm{E}-02$ & $6.13 \mathrm{E}-02$ & $6.12 \mathrm{E}-02$ \\
\hline
\end{tabular}


Table 5.13. Net and Cumulative Quantities of Gas Evolved for Fuel Fragment (Test 9)

\begin{tabular}{|c|c|c|c|c|c|c|}
\hline \multirow[b]{2}{*}{ Gas } & \multicolumn{6}{|c|}{ "Gas Quantities, Moles, at Sampling Times, hr } \\
\hline & $\begin{array}{c}307.3 \text { at } \\
80^{\circ} \mathrm{C}\end{array}$ & $\begin{array}{c}970.7 \text { at } \\
80^{\circ} \mathrm{C}\end{array}$ & $\begin{array}{c}1854.7 \text { at } \\
80^{\circ} \mathrm{C}\end{array}$ & $\begin{array}{c}3359.7 \text { at } \\
80^{\circ} \mathrm{C} \\
\text { (vent) }\end{array}$ & $\begin{array}{c}3912.7 \text { at } \\
80^{\circ} \mathrm{C}\end{array}$ & $\begin{array}{c}4250.0 \text { at } \\
\text { Ambient } \\
\text { (vent) }\end{array}$ \\
\hline \multirow{2}{*}{$\begin{array}{l}\mathrm{CO}_{2} \\
\text { Cumulative }\end{array}$} & $8.35 \mathrm{E}-07$ & $3.51 \mathrm{E}-06$ & $7.46 \mathrm{E}-07$ & & $4.33 \mathrm{E}-07$ & \\
\hline & $8.35 \mathrm{E}-07$ & $4.34 \mathrm{E}-06$ & 5.09E-06 & & $5.52 \mathrm{E}-06$ & \\
\hline \multirow{2}{*}{$\mid \begin{array}{l}\mathrm{H}_{2} \\
\text { Cumulative }\end{array}$} & $3.32 \mathrm{E}-04$ & $1.01 \mathrm{E}-03$ & $2.93 \mathrm{E}-03$ & & $1.35 \mathrm{E}-03$ & \\
\hline & $3.32 \mathrm{E}-04$ & $1.35 \mathrm{E}-03$ & $4.28 \mathrm{E}-03$ & & $5.62 \mathrm{E}-03$ & \\
\hline \multirow{2}{*}{$\mid \begin{array}{l}\mathrm{N}_{2} \\
\text { Cumulative }\end{array}$} & $-4.88 \mathrm{E}-07$ & $5.45 \mathrm{E}-07$ & $7.35 \mathrm{E}-07$ & & $-1.07 \mathrm{E}-07$ & \\
\hline & $-4.88 \mathrm{E}-07$ & 5.69E-08 & 7.92E-07 & & $6.85 \mathrm{E}-07$ & \\
\hline \multirow{2}{*}{$\begin{array}{l}\mathrm{O}_{2} \\
\text { Cumulative }\end{array}$} & $-1.01 \mathrm{E}-06$ & $-4.04 \mathrm{E}-06$ & $-9.94 \mathrm{E}-07$ & & $-8.04 \mathrm{E}-07$ & \\
\hline & $-1.01 \mathrm{E}-06$ & $-5.05 \mathrm{E}-06$ & $-6.04 \mathrm{E}-06$ & & $-6.85 \mathrm{E}-06$ & \\
\hline \multirow{2}{*}{$\begin{array}{l}\mathrm{CH}_{4} \\
\text { Cumulative }\end{array}$} & $7.49 \mathrm{E}-07$ & $1.48 \mathrm{E}-06$ & $2.63 \mathrm{E}-06$ & & 8.99E-07 & \\
\hline & 7.49E-07 & $2.22 \mathrm{E}-06$ & $4.86 \mathrm{E}-06$ & & $5.76 \mathrm{E}-06$ & \\
\hline \multirow{2}{*}{$\begin{array}{l}\mathrm{C}_{2} \mathrm{H}_{\mathrm{x}} \\
\text { Cumulative }\end{array}$} & $1.50 \mathrm{E}-07$ & $2.78 \mathrm{E}-07$ & $4.97 \mathrm{E}-07$ & & $2.00 \mathrm{E}-07$ & \\
\hline & $1.50 \mathrm{E}-07$ & $4.28 \mathrm{E}-07$ & $9.25 \mathrm{E}-07$ & & $1.13 \mathrm{E}-06$ & \\
\hline \multirow{2}{*}{$\begin{array}{l}\geq \mathrm{C}_{3} \mathrm{H}_{\mathrm{x}} \\
\text { Cumulative }\end{array}$} & $6.42 \mathrm{E}-08$ & $1.67 \mathrm{E}-07$ & $3.48 \mathrm{E}-07$ & & $1.33 \mathrm{E}-07$ & \\
\hline & $6.42 \mathrm{E}-08$ & $2.31 \mathrm{E}-07$ & $5.79 \mathrm{E}-07$ & & $7.12 \mathrm{E}-07$ & \\
\hline \multirow{2}{*}{\begin{tabular}{||l}
$\mathrm{C}_{\mathrm{y}} \mathrm{H}_{\mathrm{x}} \mathrm{C}$ \\
Cumulative
\end{tabular}} & $1.25 \mathrm{E}-06$ & $2.56 \mathrm{E}-06$ & $4.73 \mathrm{E}-06$ & & $1.72 \mathrm{E}-06$ & \\
\hline & $1.25 \mathrm{E}-06$ & $3.81 \mathrm{E}-06$ & $8.55 \mathrm{E}-06$ & & $1.03 \mathrm{E}-05$ & \\
\hline \multirow{2}{*}{$\begin{array}{l}{ }^{83} \mathrm{Kr} \\
\text { Cumulative }\end{array}$} & $2.14 \mathrm{E}-09$ & $8.35 \mathrm{E}-09$ & $3.48 \mathrm{E}-08$ & & $1.33 \mathrm{E}-08$ & \\
\hline & 2.14E-09 & $1.05 \mathrm{E}-08$ & $4.53 \mathrm{E}-08$ & & 5.86E-08 & \\
\hline \multirow{2}{*}{$\begin{array}{l}{ }^{84} \mathrm{Kr} \\
\text { Cumulative }\end{array}$} & $4.28 \mathrm{E}-09$ & $1.67 \mathrm{E}-08$ & $6.96 \mathrm{E}-08$ & & $2.33 \mathrm{E}-08$ & \\
\hline & $4.28 \mathrm{E}-09$ & $2.10 \mathrm{E}-08$ & $9.06 \mathrm{E}-08$ & & $1.14 \mathrm{E}-07$ & \\
\hline \multirow{2}{*}{ 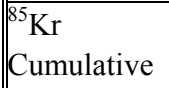 } & $8.56 \mathrm{E}-10$ & & $3.48 \mathrm{E}-09$ & & $1.33 \mathrm{E}-09$ & \\
\hline & $8.56 \mathrm{E}-10$ & $8.56 \mathrm{E}-10$ & 4.34E-09 & & $5.67 \mathrm{E}-09$ & \\
\hline \multirow{2}{*}{ 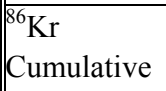 } & 8.56E-09 & $3.06 \mathrm{E}-08$ & $1.09 \mathrm{E}-07$ & & 4.33E-08 & \\
\hline & $8.56 \mathrm{E}-09$ & $3.92 \mathrm{E}-08$ & $1.49 \mathrm{E}-07$ & & $1.92 \mathrm{E}-07$ & \\
\hline \multirow{2}{*}{\begin{tabular}{|l}
$\mathrm{Kr}$ \\
Cumulative
\end{tabular}} & $1.58 \mathrm{E}-08$ & $5.57 \mathrm{E}-08$ & $2.17 \mathrm{E}-07$ & & $8.13 \mathrm{E}-08$ & \\
\hline & $1.58 \mathrm{E}-08$ & $7.15 \mathrm{E}-08$ & $2.89 \mathrm{E}-07$ & & $3.70 \mathrm{E}-07$ & \\
\hline \multirow{2}{*}{$\begin{array}{l}{ }^{130} \mathrm{Xe} \\
\text { Cumulative }\end{array}$} & & $2.78 \mathrm{E}-10$ & $4.97 \mathrm{E}-10$ & & $3.33 \mathrm{E}-10$ & \\
\hline & $0.00 \mathrm{E}+00$ & $2.78 \mathrm{E}-10$ & $7.75 \mathrm{E}-10$ & & $1.11 \mathrm{E}-09$ & \\
\hline \multirow{2}{*}{$\begin{array}{l}{ }^{131} \mathrm{Xe} \\
\text { Cumulative }\end{array}$} & $2.14 \mathrm{E}-08$ & $6.12 \mathrm{E}-08$ & $1.99 \mathrm{E}-07$ & & $8.33 \mathrm{E}-08$ & \\
\hline & $2.14 \mathrm{E}-08$ & $8.27 \mathrm{E}-08$ & $2.81 \mathrm{E}-07$ & & $3.65 \mathrm{E}-07$ & \\
\hline \multirow{2}{*}{$\begin{array}{l}{ }^{132} \mathrm{Xe} \\
\text { Cumulative }\end{array}$} & 3.64E-08 & $1.03 \mathrm{E}-07$ & $3.48 \mathrm{E}-07$ & & $1.47 \mathrm{E}-07$ & \\
\hline & $3.64 \mathrm{E}-08$ & $1.39 \mathrm{E}-07$ & $4.87 \mathrm{E}-07$ & & $6.34 \mathrm{E}-07$ & \\
\hline \multirow{2}{*}{$\begin{array}{l}{ }^{134} \mathrm{Xe} \\
\text { Cumulative }\end{array}$} & $5.78 \mathrm{E}-08$ & $1.67 \mathrm{E}-07$ & $5.47 \mathrm{E}-07$ & & $2.36 \mathrm{E}-07$ & \\
\hline & $5.78 \mathrm{E}-08$ & $2.25 \mathrm{E}-07$ & $7.72 \mathrm{E}-07$ & & $1.01 \mathrm{E}-06$ & \\
\hline \multirow{2}{*}{$\begin{array}{l}{ }^{136} \mathrm{Xe} \\
\text { Cumulative }\end{array}$} & $8.56 \mathrm{E}-08$ & $2.51 \mathrm{E}-07$ & $7.95 \mathrm{E}-07$ & & $3.33 \mathrm{E}-07$ & \\
\hline & $8.56 \mathrm{E}-08$ & $3.36 \mathrm{E}-07$ & $1.13 \mathrm{E}-06$ & & $1.46 \mathrm{E}-06$ & \\
\hline \multirow{2}{*}{$\mid \begin{array}{l}\sum \mathrm{Xe} \\
\text { Cumulative }\end{array}$} & $2.01 \mathrm{E}-07$ & $5.82 \mathrm{E}-07$ & $1.89 \mathrm{E}-06$ & & $8.00 \mathrm{E}-07$ & \\
\hline & $2.01 \mathrm{E}-07$ & $7.83 \mathrm{E}-07$ & $2.67 \mathrm{E}-06$ & & $3.47 \mathrm{E}-06$ & \\
\hline \multirow{2}{*}{$\begin{array}{l}\text { Total Gas } \\
\text { Cumulative }\end{array}$} & $3.51 \mathrm{E}-04$ & $1.05 \mathrm{E}-03$ & $3.14 \mathrm{E}-03$ & $4.59 \mathrm{E}-03$ & $1.40 \mathrm{E}-03$ & $1.75 \mathrm{E}-05$ \\
\hline & $3.51 \mathrm{E}-04$ & $1.40 \mathrm{E}-03$ & $4.54 \mathrm{E}-03$ & $9.14 \mathrm{E}-03$ & $1.05 \mathrm{E}-02$ & $1.06 \mathrm{E}-02$ \\
\hline
\end{tabular}


Estimates of uranium metal that reacted are shown in Table 5.14. These estimates are compared with the total amounts of uranium metal initially present in each test based on the weights of fuel particles added and the uranium concentrations in the particle populations. The uranium concentrations in the $<500-\mu \mathrm{m}$ population may be determined from the "Total Moles U" results of SNF M500 80L $\left(2.48 \times 10^{-2}\right.$; Table 5.14 divided by the number of moles $\mathrm{U}\left(3.34 \times 10^{-2}\right)$, assuming all $7.95 \mathrm{~g}$ of the SNF M500 80L were uranium metal. It is seen that SNF M500 80L is $74.2 \mathrm{wt} \%$ U metal. Similarly, the SNF Mid 80L and SNF mid 80L Dup are 90.8 and $95.2 \mathrm{wt} \% \mathrm{U}$ metal, respectively, or $93.0 \mathrm{wt} \% \mathrm{U}$ on average. The uranium concentration in the SNF P2000 80S test material ( $>2000-\mu \mathrm{m}$ particles) was assumed to be the same as that in the $500-2000-\mu \mathrm{m}$ population (i.e., $93.0 \mathrm{wt} \%$ uranium), and was used to estimate the initial uranium present in that test. The uranium metal concentration in the Fuel Fragment test (96.5 wt\%) was estimated from the initial fragment mass minus the mass of cladding shard $(0.13 \mathrm{~g})$ found in post-test examination.

All five tests occurred under anoxic conditions such that Reaction 1, to form $\mathrm{H}_{2}$, dominated the corrosion of uranium metal with only a minor $(<0.5 \%)$ contribution by Reaction 2 . The apparent amounts of uranium reacted, as determined by $\mathrm{Kr}$ and $\mathrm{Xe}$ fission gas release, agree to $10 \%$ or less for each test. This agreement is within the variability of the fission gas release rates found in the tests run to completion. The total moles of uranium reacted as determined by Reactions 1, 2, and 3 lags the total moles as determined by $\mathrm{Kr}$ and Xe gas release for the two tests (SNF P2000 80S and Fuel Fragment) not run to completion. The lags, however, are small $(\sim 6 \%)$ and within the variability of the gas-derived measurements. The agreement in total uranium reacted as determined by the combined Reactions 1, 2, and 3 and the $\mathrm{Kr}$ and $\mathrm{Xe}$ fission gas release for the Fuel Fragment test shows that the fission product gas concentrations held in the fragment were approximately the same as those present in the crushed fuel particles, and thus indicates similar burnup for the two populations.

Table 5.15 compares the observed $\mathrm{Kr}$ and $\mathrm{Xe}$ isotope ratios with the ratios expected based on burnup calculations predicted by the ORIGEN code. The Xe isotope mass distributions (except that of the scarce ${ }^{130} \mathrm{Xe}$ ) for the tests are similar and near those predicted by ORIGEN. The $\mathrm{Kr}$ mass distributions vary more widely but, if adjusted for ${ }^{85} \mathrm{Kr}$ decay, are consistent with the ORIGEN values (see Section 5.1).

Table 5.14. Reacted Metallic Uranium Calculated from Gas Generation and Consumption Reactions in Tests 5 Through 9

\begin{tabular}{|c|c|c|c|c|c|}
\hline \multirow[b]{2}{*}{ Reaction } & \multicolumn{5}{|c|}{ Moles U Reacted Based on Various Reactions } \\
\hline & $\begin{array}{l}\text { SNF P2000 80S } \\
\quad \text { (Test 5) }^{(\text {a) }}\end{array}$ & $\begin{array}{l}\text { SNF M500 80L } \\
\text { (Test 6) }\end{array}$ & $\begin{array}{l}\text { SNF Mid 80L } \\
\text { (Test 7) }\end{array}$ & $\begin{array}{l}\text { SNF Mid 80L } \\
\text { Dup (Test 8) }\end{array}$ & $\begin{array}{c}\text { Fuel Fragment } \\
(\text { Test 9) }\end{array}$ \\
\hline $\begin{array}{c}\text { Reaction } 1 \\
\mathrm{U}+2 \mathrm{H}_{2} \mathrm{O} \rightarrow \mathrm{UO}_{2}+2 \mathrm{H}_{2}\end{array}$ & $1.27 \mathrm{E}-2$ & $2.48 \mathrm{E}-2$ & $3.38 \mathrm{E}-2$ & $3.27 \mathrm{E}-2$ & $2.81 \mathrm{E}-3$ \\
\hline $\begin{array}{c}\text { Reaction } 2 \\
\mathrm{U}+\mathrm{O}_{2} \rightarrow \mathrm{UO}_{2}\end{array}$ & $5.63 \mathrm{E}-6$ & $9.28 \mathrm{E}-5$ & $7.54 \mathrm{E}-5$ & $-1.14 \mathrm{E}-4$ & $6.85 \mathrm{E}-6$ \\
\hline $\begin{array}{c}\text { Reaction } 3 \\
\mathrm{U}+0.875 \mathrm{~N}_{2} \rightarrow \mathrm{UN}_{1.75}\end{array}$ & $-2.85 \mathrm{E}-5$ & $-4.98 \mathrm{E}-5$ & $-6.32 \mathrm{E}-5$ & $-2.50 \mathrm{E}-5$ & $-7.83 \mathrm{E}-7$ \\
\hline $\begin{array}{c}\text { Total Moles U } \\
\text { (Sum of Reactions 1-3) }\end{array}$ & $1.27 \mathrm{E}-2$ & $2.48 \mathrm{E}-2$ & $3.38 \mathrm{E}-2$ & $3.26 \mathrm{E}-2$ & $2.82 \mathrm{E}-3$ \\
\hline Total Moles U by Kr Release & $1.38 \mathrm{E}-2$ & $2.51 \mathrm{E}-2$ & $3.49 \mathrm{E}-2$ & $3.09 \mathrm{E}-2$ & $3.12 \mathrm{E}-3$ \\
\hline Total Moles U by Xe Release & $1.30 \mathrm{E}-2$ & $2.49 \mathrm{E}-2$ & $3.15 \mathrm{E}-2$ & $3.11 \mathrm{E}-2$ & $2.90 \mathrm{E}-3$ \\
\hline Initial U Metal Present & $3.89 \mathrm{E}-2$ & $2.48 \mathrm{E}-2$ & $3.47 \mathrm{E}-2$ & $3.18 \mathrm{E}-2$ & $1.51 \mathrm{E}-2$ \\
\hline \multicolumn{6}{|c|}{$\begin{array}{l}\text { Results based on intervals for which gas sampled were analyzed. For Tests } 5 \text { and 9, gas was vented without analysis } \\
\text { for certain intervals. }\end{array}$} \\
\hline
\end{tabular}


Table 5.15. Fission Product Gas Isotope Data for Tests 5 Through 9 Compared with ORIGEN Predictions

\begin{tabular}{|c|c|c|c|c|c|c|}
\hline \multirow[b]{2}{*}{ Gas } & \multicolumn{5}{|c|}{ Isotopic Composition, atom\% ${ }^{(\mathbf{a})}$} & \multirow[b]{2}{*}{ ORIGEN $^{(\mathbf{b})}$} \\
\hline & $\begin{array}{l}\text { SNF P2000 80S } \\
\text { (Test 5) }\end{array}$ & $\begin{array}{c}\text { SNF M500 80L } \\
\text { (Test 6) }\end{array}$ & $\begin{array}{l}\text { SNF Mid 80L } \\
\text { (Test 7) }\end{array}$ & $\begin{array}{l}\text { SNF Mid 80L } \\
\text { Dup (Test 8) }\end{array}$ & $\begin{array}{c}\text { Fuel Fragment } \\
\text { (Test 9) }\end{array}$ & \\
\hline${ }^{83} \mathrm{Kr}$ & 14.5 & 13.0 & 14.7 & 14.3 & \begin{tabular}{|l|l|}
15.8 \\
\end{tabular} & 13.3 \\
\hline${ }^{84} \mathrm{Kr}$ & 29.5 & 27.8 & 29.6 & 30.7 & 30.8 & 28.3 \\
\hline${ }^{85} \mathrm{Kr}$ & 1.7 & 2.0 & 1.4 & 1.4 & 1.5 & 6.8 \\
\hline${ }^{86} \mathrm{Kr}$ & 54.3 & 57.2 & 54.3 & 53.6 & 51.8 & 51.5 \\
\hline${ }^{130} \mathrm{Xe}$ & 0.038 & 0.036 & 0.029 & 0.028 & 0.032 & 0.05 \\
\hline${ }^{131} \mathrm{Xe}$ & 10.7 & 10.4 & 10.5 & 10.4 & 10.5 & 10.7 \\
\hline${ }^{132} \mathrm{Xe}$ & 18.1 & 18.0 & 18.4 & 18.2 & 18.3 & 18.0 \\
\hline${ }^{134} \mathrm{Xe}$ & 29.0 & 28.9 & 28.7 & 28.6 & 29.0 & 28.0 \\
\hline${ }^{136} \mathrm{Xe}$ & 42.2 & 42.6 & 42.4 & 42.8 & 42.2 & 43.2 \\
\hline $\begin{array}{c}\mathrm{Xe}: \mathrm{Kr} \\
\text { mole ratio }\end{array}$ & 9.5 & 10.0 & 9.1 & 10.1 & 9.4 & 8.2 \\
\hline \multirow[b]{2}{*}{\begin{tabular}{|c|c|c|c|c|} 
Based on \\
${ }^{85} \mathrm{Kr}$ Decay
\end{tabular}} & \multicolumn{6}{|c|}{ Calculated Cooling Time, years ${ }^{(\mathrm{c})}$} \\
\hline & 21.5 & 20.0 & 24.5 & 24.5 & 23.5 & -- \\
\hline Based on & \multicolumn{6}{|c|}{ Burnup, MWD/TeU, from ORIGEN Fit } \\
\hline $\mathrm{Xe}$ & 3300 & 3270 & 3030 & 3080 & 3340 & -- \\
\hline $\mathrm{Kr}$ & 2800 & 2600 & 2660 & 2410 & 2880 & -- \\
\hline \multicolumn{7}{|c|}{$\begin{array}{l}\text { (a) Correcting the } \mathrm{Kr} \text { isotopic compositions for }{ }^{85} \mathrm{Kr} \text { decay would decrease the stated }{ }^{83} \mathrm{Kr} \text { values by } \sim 0.75 \% \text {, } \\
\text { decrease }{ }^{84} \mathrm{Kr} \text { values by } \sim 1.6 \% \text {, increase the }{ }^{85} \mathrm{Kr} \text { values by } \sim 5.25 \% \text {, and decrease the }{ }^{86} \mathrm{Kr} \text { values by } \sim 2.9 \% \text {. } \\
\text { (b) ORIGEN2 calculation for N Reactor MkIV fuel at } 2921 \mathrm{MWD} / \mathrm{TeU} \text {; ratios change }<3 \% \text { relative at lower } \\
\text { burnups; }{ }^{85} \mathrm{Kr} \text { has a } 10.76 \text {-year half-life. }\end{array}$} \\
\hline \multicolumn{7}{|c|}{$\begin{array}{l}\text { Cooling time estimates based on dates of mass spectrometric analysis of product gases - September } 2000 \\
\text { through January } 2001 .\end{array}$} \\
\hline
\end{tabular}

These trends also are true for the Fuel Fragment, which was taken from another portion of the same fuel element. The lower ${ }^{85} \mathrm{Kr}$ concentrations indicate cooling times since discharge of $22 \pm 2.8$ years for the four fuel particle tests and 23 years for the Fuel Fragment test. These cooling times are again in line with the fuel element discharge from $\mathrm{N}$ Reactor, 25 years prior to testing.

Methane and higher hydrocarbons were present in gas samples from these five tests with various particle size populations. Carbide carbon concentrations in the source uranium metal fuel were determined by comparing the hydrocarbon gas product carbon amounts with the hydrogen (which was generated almost solely by the reaction of water with uranium) or, more accurately, with the $\mathrm{Kr}$ and Xe fission product gas release. Carbon concentrations in the uranium metal are shown in Table 5.16 based on the cumulative $\mathrm{Kr} / \mathrm{Xe}$ and hydrocarbon gases released for the five tests.

The carbon quantities found as hydrocarbon gas released during uranium metal fuel corrosion agree well within each test based on $\mathrm{Kr}$ and $\mathrm{Xe}$, but are markedly lower than the 365 to 735 parts of carbon per million parts uranium expected in metal fuel (Weakley 1979). There is no trend of carbon concentration increasing or decreasing with particle size, with fuel piece population (Fuel Fragment versus the other 
tests derived from the same starting pieces shown in Table 5.16), or extent of reaction. Again, the reason for the shortfall in carbon is not known, but, as noted earlier, the fuel particles used in the present tests may have been anomalously low in carbon impurity or, less probably, the hydrocarbons were somehow retained in the solid corrosion products or solution without entering the gas phase.

The methane fraction of the total hydrocarbon carbon is about 51 and 58 atom\% for Tests 5 through 9 , similar to that observed in the two tests without added sludge (Tests 3 and 4). This is less than the 71\% to $74 \%$ for the tests with added sludge (Tests 1 and 2), about 92 atom $\%$ at $~ 40,000$ to 50,000 ppmp (up to pure UC), and about 71 atom $\%$ at $~ 20,000$ ppmp carbon in U/UC mixtures observed in $80^{\circ} \mathrm{C}$ water (Bradley and Ferris 1962, 1964).

Carbon dioxide production is very low (Table 5.17), ranging from $0.0082 \%$ to $0.098 \%$ in these five tests and is comparable to that observed in the two fuel particles-only tests (Test 3, SNF Mid 60S, 0.0039\%, and Test 4, SNF Mid 40S, 0.015\%) reported in Table 5.7. The $\mathrm{CO}_{2}$ likely comes from displacement of dissolved $\mathrm{CO}_{2}$ from the overlying $\mathrm{K}$ Basin supernatant water.

Table 5.16. Carbon Concentration Based on Hydrocarbon, Kr, and Xe Gas Release for Tests 5 Through 9

\begin{tabular}{||c|c|c|c|c|c||}
\hline & \multicolumn{5}{|c|}{ Carbon Concentration, ppmp U } \\
\cline { 2 - 6 } Based on & $\begin{array}{c}\text { SNF P2000 80S } \\
\text { (Test 5) }\end{array}$ & $\begin{array}{c}\text { SNF M500 80L } \\
\text { (Test 6) }\end{array}$ & $\begin{array}{c}\text { SNF Mid 80L } \\
\text { (Test 7) }\end{array}$ & $\begin{array}{c}\text { SNF Mid 80L } \\
\text { Dup (Test 8) }\end{array}$ & $\begin{array}{c}\text { Fuel Fragment } \\
\text { (Test 9) }\end{array}$ \\
\hline Kr Release & 70 & 227 & 42 & 49 & 166 \\
\hline Xe Release & 72 & 221 & 45 & 47 & 172 \\
\hline
\end{tabular}

Table 5.17. Carbon Dioxide Produced in Tests 5 Through 9

\begin{tabular}{|c|c|c|c|c|}
\hline \multicolumn{5}{|c|}{ Carbon Dioxide Concentration, \% of Total Gas } \\
\hline $\begin{array}{c}\text { SNF P2000 80S } \\
\text { (Test 5) }\end{array}$ & $\begin{array}{c}\text { SNF M500 80L } \\
\text { (Test 6) }\end{array}$ & $\begin{array}{c}\text { SNF Mid 80L } \\
\text { (Test 7) }\end{array}$ & $\begin{array}{c}\text { SNF Mid 80L } \\
\text { Dup (Test 8) }\end{array}$ & $\begin{array}{c}\text { Fuel Fragment } \\
\text { (Test 9) }\end{array}$ \\
\hline 0.0082 & 0.077 & 0.070 & 0.083 & 0.098 \\
\hline \hline
\end{tabular}

\subsection{Gas Analyses from Tests Run to Completion}

Tests 6 through 8 were conducted in $800-\mathrm{ml}$ vessels at $80^{\circ} \mathrm{C}$ and finished at $95^{\circ} \mathrm{C}$. The sludge-free fuel particles were run to depletion of the uranium metal. The maximum gas generation rates at $\sim 80^{\circ} \mathrm{C}$ were $19,8.2$, and 10.6 liters $/ \mathrm{kg}$ fuel particles-day (at standard temperature and pressure) for the SNF M500 80L, SNF Mid 80L, and SNF Mid 80L Dup tests, respectively. The rate with the fine $(<500-\mu \mathrm{m})$ particles was about twice as high as the rates observed in the duplicate tests of the mid-sized (500$2000-\mu \mathrm{m})$ particles

The quantities of gas produced and consumed in the SNF M500 80L, SNF Mid 80L, and SNF Mid 80L Dup tests are presented, respectively, in Tables 5.9 through 5.11 in Section 5.2. These data are based on measurements of total gas pressure, volume, and temperature, and gas composition by mass spectrometry. No gas products were vented without analysis. "Total Gas" values also are given in the last rows of Tables 5.9 through 5.11 to show trends in the total net gas evolved during each test. 
The gas products from the three tests have similar compositions and were $99.79 \%, 99.87 \%$, and $99.62 \%$ $\mathrm{H}_{2}$, respectively, whereas $\mathrm{CO}_{2}$ was present at $0.077 \%, 0.070 \%$, and $0.083 \%$. Hydrocarbon and fission product gases comprise the balance of the gas produced. Net $\mathrm{O}_{2}$ consumption occurred in the SNF M500 80L and SNF Mid 80L tests, but not in the SNF Mid 80L Dup test because of an anomalous $\mathrm{O}_{2}$ production in the third sample from that test (see Table 5.11). Nitrogen was consumed in the initial samples for all tests.

All three tests were taken to completion, and, as described in Section 4.3, the $\mathrm{Kr}$ and $\mathrm{Xe}$ fission product gas yields (per mass of uranium metal present) were derived from the observed $\mathrm{H}_{2}$ production and $\mathrm{O}_{2}$ and $\mathrm{N}_{2}$ consumption (corresponding to the respective uranium corrosion reactions 1, 2, and 3) (Table 5.18). The correlation of $\mathrm{Kr}$ and $\mathrm{Xe}$ fission product gas release with uranium metal corrosion calculated for these tests (results shown in Table 4.2) gives the average values for these tests of $42.2 \pm 1.9 \mu \mathrm{g} \mathrm{Kr} / \mathrm{g} \mathrm{U}$ and $651 \pm 26 \mu \mathrm{g} \mathrm{Xe/g} \mathrm{U.} \mathrm{Table} 5.18$ also gives estimates of uranium metal reacted, which agree by calculation with the total amounts of uranium metal initially present in each test based on the weights of fuel particles added and the uranium concentrations available in the particle populations.

Anoxic conditions prevailed in all three tests such that Reaction 1, to form $\mathrm{H}_{2}$, dominated uranium metal corrosion with a minor $(<0.4 \%)$ contribution by Reaction 2 . The apparent amounts of uranium reacted as determined by $\mathrm{Kr}$ and $\mathrm{Xe}$ fission gas release agree to $\pm 10 \%$ or less for each test. Because these tests were taken to completion and formed the basis for calculations of reaction for the other tests, the amounts of uranium reacted as determined by Reactions 1, 2, and 3 and by $\mathrm{Kr} / \mathrm{Xe}$ release, on average, agree by calculation (i.e., calculations were normalized to data from these tests run to completion).

The $\mathrm{Kr}$ and $\mathrm{Xe}$ isotope ratios observed in the product gases for the three tests and those expected based on burnup calculations predicted by the ORIGEN code were presented in Table 4.3. The Xe isotope mass distributions (except for the trace ${ }^{130} \mathrm{Xe}$ ) for the tests are similar and near those predicted by ORIGEN. The $\mathrm{Kr}$ mass distributions, if adjusted for ${ }^{85} \mathrm{Kr}$ decay, also are in line with the ORIGEN values. Again,

Table 5.18. Reacted Metallic Uranium Calculated from Gas Generation and Consumption Reactions in Tests 6 Through 8

\begin{tabular}{|c|c|c|c||}
\hline & \multicolumn{3}{|c|}{ Moles U Reacted Based on Various Reactions } \\
\cline { 2 - 4 } Reaction & $\begin{array}{c}\text { SNF M500 80L } \\
\text { (Test 6) }\end{array}$ & $\begin{array}{c}\text { SNF Mid 80L } \\
\text { (Test 7) }\end{array}$ & $\begin{array}{c}\text { SNF Mid 80L } \\
\text { Dup (Test 8) }\end{array}$ \\
\hline $\begin{array}{c}\text { Reaction 1 } \\
\mathrm{U}+2 \mathrm{H}_{2} \mathrm{O} \rightarrow \mathrm{UO}_{2}+2 \mathrm{H}_{2}\end{array}$ & $2.48 \mathrm{E}-2$ & $3.38 \mathrm{E}-2$ & $3.27 \mathrm{E}-2$ \\
\hline $\begin{array}{c}\text { Reaction } 2 \\
\mathrm{U}+\mathrm{O}_{2} \rightarrow \mathrm{UO}_{2}\end{array}$ & $9.28 \mathrm{E}-5$ & $7.54 \mathrm{E}-5$ & $-1.14 \mathrm{E}-4$ \\
\hline $\begin{array}{c}\text { Reaction } 3 \\
\mathrm{U}+0.875 \mathrm{~N}_{2} \rightarrow \mathrm{UN}_{1.75}\end{array}$ & $-4.98 \mathrm{E}-5$ & $-6.32 \mathrm{E}-5$ & $-2.50 \mathrm{E}-5$ \\
\hline $\begin{array}{c}\text { Total Moles U } \\
(\text { Sum of Reactions 1-3) }\end{array}$ & $2.48 \mathrm{E}-2$ & $3.38 \mathrm{E}-2$ & $3.26 \mathrm{E}-2$ \\
\hline Total Moles U by Kr Release & $2.51 \mathrm{E}-2$ & $3.49 \mathrm{E}-2$ & $3.09 \mathrm{E}-2$ \\
\hline Total Moles U by Xe Release & $2.49 \mathrm{E}-2$ & $3.15 \mathrm{E}-2$ & $3.11 \mathrm{E}-2$ \\
\hline Initial U Metal Present & $2.48 \mathrm{E}-2$ & $3.47 \mathrm{E}-2$ & $3.18 \mathrm{E}-2$ \\
\hline \hline
\end{tabular}


the ${ }^{85} \mathrm{Kr}$ concentrations indicate cooling times since discharge of $23.0 \pm 2.6$ years, consistent with fuel discharge in 1975 ( 25 years cooling). The $\mathrm{Xe}: \mathrm{Kr}$ mole ratios average $9.7 \pm 0.6$, at variance with the 8.2 ratio predicted by ORIGEN but again very likely reflecting the specific composition and local irradiation conditions of the selected crushed fuel particles.

The calculated fuel burnups based on the $\mathrm{Kr}$ and $\mathrm{Xe}$ results for the three 800-ml tests taken to completion (see Table 4.2) differ by about 20\% (i.e., $2560 \pm 120$ and $3120 \pm 120 \mathrm{MWD} / \mathrm{TeU}$, respectively). These burnup values, based on $\mathrm{Kr}$ and $\mathrm{Xe}$ released, total amount of uranium reacted (as found primarily in $\mathrm{H}_{2}$ released), and Equations $\mathrm{C}$ and $\mathrm{D}$ from the ORIGEN code, differ because the fuel particles (from a small area of one fuel element) are not representative of the entire fuel distribution in the reactor (i.e., average) as considered by ORIGEN.

Table 5.19 shows the carbon concentrations in the uranium metal based on the cumulative $\mathrm{Kr} / \mathrm{Xe}$ and hydrocarbon gases released. Again, carbon concentrations in the source uranium metal fuel were determined by comparing the hydrocarbon gas product carbon amounts with the $\mathrm{Kr}$ and $\mathrm{Xe}$ fission product gas release (which, in turn, can be correlated to total uranium metal corroded).

The carbon concentrations based on $\mathrm{Kr}$ and $\mathrm{Xe}$ agree within each test. Results from the SNF Mid 80L test and its duplicate also agree well, but are about 5-fold lower than found for the SNF M500 80L test, even though the fuel particles arose from the same source fuel fragments. The concentrations are lower than the 365 to 735 parts of carbon per million parts uranium expected in metal fuel (Weakley 1979) in both particle size populations. The reasons for the divergence and low carbon concentrations are not apparent, but again, the fuel fragments used in the present tests may have been anomalously low in carbon or the hydrocarbons retained in the corrosion products. The methane fraction of the total hydrocarbon carbon is about 50 atom\% in each test, lower than that observed in more carbon-rich materials (Bradley and Ferris 1962, 1964) but consistent with the fractions observed in these and the Series I tests.

Carbon dioxide production is low (Table 5.20) and consistent for these tests $(0.077 \%$ to $0.083 \%)$ but comparable to the other tests in Series III conducted with fuel particles only. The $\mathrm{CO}_{2}$ likely comes from the supernatant water.

Table 5.19. Carbon Concentration Based on Hydrocarbon, Kr, and Xe Gas Release for Tests 6 Through 8

\begin{tabular}{||c|c|c|c||}
\hline \multirow{2}{*}{ Based on } & \multicolumn{3}{|c|}{ Carbon Concentration, ppmp U } \\
\cline { 2 - 4 } & $\begin{array}{c}\text { SNF M500 80L } \\
\text { (Test 6) }\end{array}$ & $\begin{array}{c}\text { SNF Mid 80L } \\
\text { (Test 7) }\end{array}$ & $\begin{array}{c}\text { SNF Mid 80L } \\
\text { Dup (Test 8) }\end{array}$ \\
\hline Kr Release & 227 & 42 & 49 \\
\hline Xe Release & 221 & 45 & 47 \\
\hline
\end{tabular}


Table 5.20. Carbon Dioxide Produced in Tests 6 Through 8

\begin{tabular}{||c|c|c||}
\hline \multicolumn{3}{|c|}{ Carbon Dioxide Concentration, \% of Total Gas } \\
\hline $\begin{array}{c}\text { SNF M500 80L } \\
\text { (Test 6) }\end{array}$ & $\begin{array}{c}\text { SNF Mid 80L } \\
\text { (Test 7) }\end{array}$ & $\begin{array}{c}\text { SNF Mid 80L } \\
\text { Dup (Test 8) }\end{array}$ \\
\hline 0.077 & 0.070 & 0.083 \\
\hline
\end{tabular}

\subsection{Gas Analyses from Tests with Sludge Blanketing}

The sludge blanketing tests (Tests 10 and 11) conducted in 800-ml reaction vessels were primarily run at $60^{\circ} \mathrm{C}$, but were ramped to $80^{\circ} \mathrm{C}$ and then to $95^{\circ} \mathrm{C}$ for brief intervals. Neither of these tests was run to completion of the reaction of all uranium metal present. Based on fuel particle loadings and the observed gas production at the completion of testing ( 2.72 and 2.58 moles of gas per $\mathrm{kg}$ of uranium particles, SNF + Can $60 \mathrm{~L}$ and SNF + Floor 60L, respectively, versus an estimated 8.4 moles $/ \mathrm{kg}$ at full reaction), about $30 \%$ of the uranium corroded over the testing period (Figure 3.6).

The maximum gas generation rates, respectively, for the SNF + Can 60L and SNF + Floor 60L tests at $\sim 60^{\circ} \mathrm{C}$ were 0.80 and 0.72 liters $/ \mathrm{kg}$ fuel particles-day, 2.75 and 2.93 liters $/ \mathrm{kg}$ fuel particles-day at $\sim 80^{\circ} \mathrm{C}$, and 7.0 and 8.5 liters $/ \mathrm{kg}$ fuel particles-day at $\sim 95^{\circ} \mathrm{C}$, all at standard temperature and pressure. The rates were similar despite the differences in overlying sludge.

Quantities of gas produced and consumed in the SNF + Can 60L and SNF + Floor 60L tests, presented in Tables 5.21 and 5.22, respectively, are based on measurements of total gas pressure, volume, and temperature, and gas composition by mass spectrometry. No gas products were vented without analysis in the SNF + Floor 60L test and one venting without analysis occurred for the SNF + Can 60L test.

"Total Gas" values given in the last rows of each table estimate the total gas evolved over the durations of each test.

The combined sampled and analyzed gas products were $98.84 \%$ and $94.53 \% \mathrm{H}_{2}$ for the tests with canister and floor sludge, respectively. The single gas venting in the canister sludge test likely was $\sim 99 \% \mathrm{H}_{2}$ as well. Carbon dioxide was the next most prevalent gas at $0.51 \%$ and $5.12 \%$, respectively. $\mathrm{The}^{\mathrm{CO}_{2} \text { was }}$ substantially higher in the test with the floor sludge and was generated at increasing amounts and fractions with increasing temperature. Hydrocarbon and fission product gases provided the rest of the gas produced. Oxygen was consumed in all samples, and $\mathrm{N}_{2}$ was consumed in the initial samples for the test with the canister sludge over-burden.

The uranium fuel particles used in these two tests ranged from $0-6350 \mu \mathrm{m}$, completely encompassing the size definition for sludge. The particles arose from the same population of fuel fragments as used in the $800-\mathrm{ml}$ tests taken to completion. Therefore, if reactions of uranium metal contained in the overlying sludge are ignored, the amounts of uranium reacted during the intervals with gas sampling can be estimated based on $\mathrm{Kr}$ and $\mathrm{Xe}$ release and correlated to the specific fission product gas release derived in the tests taken to completion (i.e., $42.2 \pm 1.9 \mu \mathrm{g} \mathrm{Kr} / \mathrm{g} \mathrm{U}$ and $651 \pm 26 \mu \mathrm{g} \mathrm{Xe} / \mathrm{g} \mathrm{U}$ ).

Estimates of uranium metal that reacted during the gas sampling and analysis are shown in Table 5.23.

These estimates are compared with the total amounts of uranium metal initially present in each test based on the weights of fuel particles added and the estimated uranium metal concentrations in the particles. 
Table 5.21. Net and Cumulative Quantities of Gas Evolved for SNF + Can 60L (Test 10)

\begin{tabular}{|c|c|c|c|c|c|}
\hline \multirow[b]{2}{*}{ Gas } & \multicolumn{5}{|c|}{ Gas Quantities, Moles, at Sampling Times, hr } \\
\hline & $\begin{array}{c}136.3 \text { at } \\
\text { Ambient; } \\
639.3 \text { at } 60^{\circ} \mathrm{C}\end{array}$ & $\begin{array}{c}1234.0 \text { at } \\
60^{\circ} \mathrm{C} \\
\text { (vent) }\end{array}$ & $\begin{array}{c}1305.0 \text { at } \\
80^{\circ} \mathrm{C}\end{array}$ & $\begin{array}{c}1352.7 \text { at } \\
95^{\circ} \mathrm{C}\end{array}$ & $\begin{array}{c}3011.0 \text { at } \\
\text { Ambient } \\
\text { (vent) }\end{array}$ \\
\hline \multirow{2}{*}{$\begin{array}{l}\mathrm{CO}_{2} \\
\text { Cumulative }\end{array}$} & $1.15 \mathrm{E}-04$ & & $3.19 \mathrm{E}-05$ & $9.22 \mathrm{E}-05$ & \\
\hline & $1.15 \mathrm{E}-04$ & & $1.47 \mathrm{E}-04$ & 2.39E-04 & \\
\hline \multirow{2}{*}{$\begin{array}{l}\mathrm{H}_{2} \\
\text { Cumulative }\end{array}$} & $1.51 \mathrm{E}-02$ & & $1.28 \mathrm{E}-02$ & $1.81 \mathrm{E}-02$ & \\
\hline & $1.51 \mathrm{E}-02$ & & 2.79E-02 & 4.60E-02 & \\
\hline \multirow{2}{*}{$\begin{array}{l}\mathrm{N}_{2} \\
\text { Cumulative }\end{array}$} & $-4.94 \mathrm{E}-06$ & & $3.21 \mathrm{E}-05$ & $3.80 \mathrm{E}-05$ & \\
\hline & $-4.94 \mathrm{E}-06$ & & $2.72 \mathrm{E}-05$ & $6.51 \mathrm{E}-05$ & \\
\hline \multirow{2}{*}{$\begin{array}{l}\mathrm{O}_{2} \\
\text { Cumulative }\end{array}$} & $-2.49 \mathrm{E}-05$ & & $-5.60 \mathrm{E}-06$ & $-1.30 \mathrm{E}-07$ & \\
\hline & $-2.49 \mathrm{E}-05$ & & $-3.05 \mathrm{E}-05$ & $-3.06 \mathrm{E}-05$ & \\
\hline \multirow{2}{*}{$\begin{array}{l}\mathrm{CH}_{4} \\
\text { Cumulative }\end{array}$} & 4.34E-05 & & $7.43 \mathrm{E}-05$ & $1.09 \mathrm{E}-04$ & \\
\hline & 4.34E-05 & & $1.18 \mathrm{E}-04$ & $2.26 \mathrm{E}-04$ & \\
\hline \multirow{2}{*}{$\begin{array}{l}\mathrm{C}_{2} \mathrm{H}_{\mathrm{x}} \\
\text { Cumulative }\end{array}$} & $5.53 \mathrm{E}-06$ & & $8.58 \mathrm{E}-06$ & $1.37 \mathrm{E}-05$ & \\
\hline & $5.53 \mathrm{E}-06$ & & $1.41 \mathrm{E}-05$ & $2.78 \mathrm{E}-05$ & \\
\hline \multirow{2}{*}{$\begin{array}{l}\geq \mathrm{C}_{3} \mathrm{H}_{\mathrm{x}} \\
\text { Cumulative }\end{array}$} & $2.13 \mathrm{E}-06$ & & $3.27 \mathrm{E}-06$ & $4.56 \mathrm{E}-06$ & \\
\hline & $2.13 \mathrm{E}-06$ & & $5.39 \mathrm{E}-06$ & $9.96 \mathrm{E}-06$ & \\
\hline \multirow{2}{*}{\begin{tabular}{|l}
$\sum \mathrm{C}_{\mathrm{y}} \mathrm{H}_{\mathrm{x}} \mathrm{C}$ \\
Cumulative
\end{tabular}} & $6.12 \mathrm{E}-05$ & & $1.02 \mathrm{E}-04$ & $1.50 \mathrm{E}-04$ & \\
\hline & $6.12 \mathrm{E}-05$ & & $1.63 \mathrm{E}-04$ & $3.13 \mathrm{E}-04$ & \\
\hline \multirow{2}{*}{$\begin{array}{l}{ }^{83} \mathrm{Kr} \\
\text { Cumulative }\end{array}$} & $2.55 \mathrm{E}-07$ & & $1.63 \mathrm{E}-07$ & $1.83 \mathrm{E}-07$ & \\
\hline & $2.55 \mathrm{E}-07$ & & 4.19E-07 & $6.01 \mathrm{E}-07$ & \\
\hline \multirow{2}{*}{$\mid \begin{array}{l}{ }^{84} \mathrm{Kr} \\
\text { Cumulative }\end{array}$} & $4.68 \mathrm{E}-07$ & & $3.27 \mathrm{E}-07$ & $4.11 \mathrm{E}-07$ & \\
\hline & $4.68 \mathrm{E}-07$ & & $7.95 \mathrm{E}-07$ & $1.21 \mathrm{E}-06$ & \\
\hline \multirow{2}{*}{$\begin{array}{l}{ }^{85} \mathrm{Kr} \\
\text { Cumulative }\end{array}$} & $2.55 \mathrm{E}-08$ & & $1.63 \mathrm{E}-08$ & $2.28 \mathrm{E}-08$ & \\
\hline & $2.55 \mathrm{E}-08$ & & 4.19E-08 & $6.47 \mathrm{E}-08$ & \\
\hline \multirow{2}{*}{ 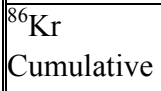 } & $8.08 \mathrm{E}-07$ & & 4.90E-07 & $6.39 \mathrm{E}-07$ & \\
\hline & $8.08 \mathrm{E}-07$ & & $1.30 \mathrm{E}-06$ & $1.94 \mathrm{E}-06$ & \\
\hline \multirow{2}{*}{\begin{tabular}{|l}
$\sum \mathrm{Kr}$ \\
Cumulative
\end{tabular}} & $1.56 \mathrm{E}-06$ & & $9.97 \mathrm{E}-07$ & $1.25 \mathrm{E}-06$ & \\
\hline & $1.56 \mathrm{E}-06$ & & $2.55 \mathrm{E}-06$ & $3.81 \mathrm{E}-06$ & \\
\hline \multirow{2}{*}{$\begin{array}{l}{ }^{130} \mathrm{Xe} \\
\text { Cumulative }\end{array}$} & $4.25 \mathrm{E}-09$ & & & $4.56 \mathrm{E}-09$ & \\
\hline & $4.25 \mathrm{E}-09$ & & $4.25 \mathrm{E}-09$ & $8.82 \mathrm{E}-09$ & \\
\hline \multirow{2}{*}{$\begin{array}{l}{ }^{131} \mathrm{Xe} \\
\text { Cumulative }\end{array}$} & $1.45 \mathrm{E}-06$ & & $8.58 \mathrm{E}-07$ & $1.14 \mathrm{E}-06$ & \\
\hline & $1.45 \mathrm{E}-06$ & & $2.30 \mathrm{E}-06$ & $3.44 \mathrm{E}-06$ & \\
\hline \multirow{2}{*}{$\begin{array}{l}{ }^{132} \mathrm{Xe} \\
\text { Cumulative }\end{array}$} & $2.51 \mathrm{E}-06$ & & $1.39 \mathrm{E}-06$ & $2.01 \mathrm{E}-06$ & \\
\hline & $2.51 \mathrm{E}-06$ & & $3.90 \mathrm{E}-06$ & $5.91 \mathrm{E}-06$ & \\
\hline \multirow{2}{*}{$\begin{array}{l}{ }^{134} \mathrm{Xe} \\
\text { Cumulative }\end{array}$} & $4.00 \mathrm{E}-06$ & & $2.29 \mathrm{E}-06$ & $3.10 \mathrm{E}-06$ & \\
\hline & $4.00 \mathrm{E}-06$ & & $6.29 \mathrm{E}-06$ & $9.39 \mathrm{E}-06$ & \\
\hline \multirow{2}{*}{$\begin{array}{l}{ }^{136} \mathrm{Xe} \\
\text { Cumulative }\end{array}$} & $5.96 \mathrm{E}-06$ & & $3.39 \mathrm{E}-06$ & $4.56 \mathrm{E}-06$ & \\
\hline & $5.96 \mathrm{E}-06$ & & $9.35 \mathrm{E}-06$ & $1.39 \mathrm{E}-05$ & \\
\hline \multirow{2}{*}{\begin{tabular}{|l}
$\mathrm{Xe}$ \\
Cumulative
\end{tabular}} & $1.39 \mathrm{E}-05$ & & $7.92 \mathrm{E}-06$ & $1.08 \mathrm{E}-05$ & \\
\hline & $1.39 \mathrm{E}-05$ & & $2.18 \mathrm{E}-05$ & $3.27 \mathrm{E}-05$ & \\
\hline \multirow{2}{*}{\begin{tabular}{|l} 
Total Gas \\
Cumulative
\end{tabular}} & $1.54 \mathrm{E}-02$ & $2.48 \mathrm{E}-02$ & $1.08 \mathrm{E}-02$ & $1.82 \mathrm{E}-02$ & $2.34 \mathrm{E}-03$ \\
\hline & $1.54 \mathrm{E}-02$ & $4.02 \mathrm{E}-02$ & $5.10 \mathrm{E}-02$ & $6.92 \mathrm{E}-02$ & $7.16 \mathrm{E}-02$ \\
\hline
\end{tabular}


Table 5.22. Net and Cumulative Quantities of Gas Evolved for SNF + Floor 60L (Test 11)

\begin{tabular}{|c|c|c|c|c|}
\hline \multirow[b]{2}{*}{ Gas } & \multicolumn{4}{|c|}{ Gas Quantities, Moles, at Sampling Times, hr } \\
\hline & \begin{tabular}{|c|}
136.3 at \\
Ambient; \\
1241.0 at $60^{\circ} \mathrm{C}$ \\
\end{tabular} & $\begin{array}{c}1312.0 \text { at } \\
80^{\circ} \mathrm{C}\end{array}$ & $\begin{array}{c}1359.7 \text { at } \\
95^{\circ} \mathrm{C}\end{array}$ & $\begin{array}{c}3018.0 \text { at } \\
\text { Ambient } \\
\text { (vent) }\end{array}$ \\
\hline \multirow{2}{*}{$\begin{array}{l}\mathrm{CO}_{2} \\
\text { Cumulative }\end{array}$} & 7.29E-04 & 8.37E-04 & $1.37 \mathrm{E}-03$ & \\
\hline & 7.29E-04 & $1.57 \mathrm{E}-03$ & $2.94 \mathrm{E}-03$ & \\
\hline \multirow{2}{*}{$\begin{array}{l}\mathrm{H}_{2} \\
\text { Cumulative }\end{array}$} & $2.96 \mathrm{E}-02$ & $9.53 \mathrm{E}-03$ & $1.51 \mathrm{E}-02$ & \\
\hline & $2.96 \mathrm{E}-02$ & $3.91 \mathrm{E}-02$ & $5.42 \mathrm{E}-02$ & \\
\hline \multirow{2}{*}{$\begin{array}{l}\mathrm{N}_{2} \\
\text { Cumulative }\end{array}$} & $5.78 \mathrm{E}-07$ & $1.79 \mathrm{E}-05$ & $2.74 \mathrm{E}-05$ & \\
\hline & $5.78 \mathrm{E}-07$ & $1.85 \mathrm{E}-05$ & $4.58 \mathrm{E}-05$ & \\
\hline \multirow{2}{*}{$\begin{array}{l}\mathrm{O}_{2} \\
\text { Cumulative }\end{array}$} & $-6.30 \mathrm{E}-05$ & $-2.00 \mathrm{E}-06$ & $-5.76 \mathrm{E}-06$ & \\
\hline & $-6.30 \mathrm{E}-05$ & $-6.50 \mathrm{E}-05$ & $-7.08 \mathrm{E}-05$ & \\
\hline \multirow{2}{*}{$\begin{array}{l}\mathrm{CH}_{4} \\
\text { Cumulative }\end{array}$} & 7.35E-05 & $2.72 \mathrm{E}-05$ & 4.17E-05 & \\
\hline & $7.35 \mathrm{E}-05$ & $1.01 \mathrm{E}-04$ & $1.42 \mathrm{E}-04$ & \\
\hline \multirow{2}{*}{$\begin{array}{l}\mathrm{C}_{2} \mathrm{H}_{\mathrm{x}} \\
\text { Cumulative }\end{array}$} & $7.00 \mathrm{E}-06$ & $3.50 \mathrm{E}-06$ & 5.89E-06 & \\
\hline & $7.00 \mathrm{E}-06$ & $1.05 \mathrm{E}-05$ & $1.64 \mathrm{E}-05$ & \\
\hline \multirow{2}{*}{$\begin{array}{l}\geq \mathrm{C}_{3} \mathrm{H}_{\mathrm{x}} \\
\text { Cumulative }\end{array}$} & $1.75 \mathrm{E}-06$ & $7.78 \mathrm{E}-07$ & $1.81 \mathrm{E}-06$ & \\
\hline & $1.75 \mathrm{E}-06$ & $2.53 \mathrm{E}-06$ & $4.34 \mathrm{E}-06$ & \\
\hline \multirow{2}{*}{$\begin{array}{l}\sum \mathrm{C}_{\mathrm{y}} \mathrm{H}_{\mathrm{x}} \mathrm{C} \\
\text { Cumulative }\end{array}$} & $9.30 \mathrm{E}-05$ & $3.67 \mathrm{E}-05$ & $5.92 \mathrm{E}-05$ & \\
\hline & $9.30 \mathrm{E}-05$ & $1.30 \mathrm{E}-04$ & $1.89 \mathrm{E}-04$ & \\
\hline \multirow{2}{*}{$\begin{array}{l}{ }^{83} \mathrm{Kr} \\
\text { Cumulative }\end{array}$} & $3.50 \mathrm{E}-07$ & $7.78 \mathrm{E}-08$ & $1.36 \mathrm{E}-07$ & \\
\hline & $3.50 \mathrm{E}-07$ & $4.28 \mathrm{E}-07$ & $5.64 \mathrm{E}-07$ & \\
\hline \multirow{2}{*}{$\begin{array}{l}{ }_{84}^{84} \mathrm{Kr} \\
\text { Cumulative }\end{array}$} & $6.41 \mathrm{E}-07$ & $1.56 \mathrm{E}-07$ & $2.72 \mathrm{E}-07$ & \\
\hline & $6.41 \mathrm{E}-07$ & $7.97 \mathrm{E}-07$ & $1.07 \mathrm{E}-06$ & \\
\hline \multirow{2}{*}{$\begin{array}{l}{ }^{85} \mathrm{Kr} \\
\text { Cumulative }\end{array}$} & $3.50 \mathrm{E}-08$ & & $1.36 \mathrm{E}-08$ & \\
\hline & $3.50 \mathrm{E}-08$ & $3.50 \mathrm{E}-08$ & 4.86E-08 & \\
\hline \multirow{2}{*}{$\begin{array}{l}{ }^{86} \mathrm{Kr} \\
\text { Cumulative }\end{array}$} & $1.17 \mathrm{E}-06$ & $3.11 \mathrm{E}-07$ & 4.98E-07 & \\
\hline & $1.17 \mathrm{E}-06$ & $1.48 \mathrm{E}-06$ & $1.98 \mathrm{E}-06$ & \\
\hline \multirow{2}{*}{\begin{tabular}{|l}
$\sum \mathrm{Kr}$ \\
Cumulative
\end{tabular}} & $2.19 \mathrm{E}-06$ & $5.45 \mathrm{E}-07$ & $9.20 \mathrm{E}-07$ & \\
\hline & 2.19E-06 & $2.74 \mathrm{E}-06$ & $3.66 \mathrm{E}-06$ & \\
\hline \multirow{2}{*}{$\begin{array}{l}{ }^{130} \mathrm{Xe} \\
\text { Cumulative }\end{array}$} & $1.17 \mathrm{E}-08$ & & & \\
\hline & $1.17 \mathrm{E}-08$ & $1.17 \mathrm{E}-08$ & $1.17 \mathrm{E}-08$ & \\
\hline \multirow{2}{*}{$\begin{array}{l}{ }^{131} \mathrm{Xe} \\
\text { Cumulative }\end{array}$} & $2.22 \mathrm{E}-06$ & $6.23 \mathrm{E}-07$ & $9.97 \mathrm{E}-07$ & \\
\hline & $2.22 \mathrm{E}-06$ & $2.84 \mathrm{E}-06$ & $3.83 \mathrm{E}-06$ & \\
\hline \multirow{2}{*}{$\begin{array}{l}{ }^{132} \mathrm{Xe} \\
\text { Cumulative }\end{array}$} & $3.73 \mathrm{E}-06$ & $1.09 \mathrm{E}-06$ & $1.63 \mathrm{E}-06$ & \\
\hline & $3.73 \mathrm{E}-06$ & $4.82 \mathrm{E}-06$ & $6.45 \mathrm{E}-06$ & \\
\hline \multirow{2}{*}{$\begin{array}{l}{ }^{134} \mathrm{Xe} \\
\text { Cumulative }\end{array}$} & 5.83E-06 & $1.75 \mathrm{E}-06$ & $2.63 \mathrm{E}-06$ & \\
\hline & 5.83E-06 & $7.58 \mathrm{E}-06$ & $1.02 \mathrm{E}-05$ & \\
\hline \multirow{2}{*}{$\begin{array}{l}{ }^{136} \mathrm{Xe} \\
\text { Cumulative }\end{array}$} & $8.74 \mathrm{E}-06$ & $2.53 \mathrm{E}-06$ & $3.90 \mathrm{E}-06$ & \\
\hline & $8.74 \mathrm{E}-06$ & $1.13 \mathrm{E}-05$ & $1.52 \mathrm{E}-05$ & \\
\hline \multirow{2}{*}{$\begin{array}{l}\mathrm{Xe} \\
\text { Cumulative }\end{array}$} & $2.05 \mathrm{E}-05$ & 5.99E-06 & $9.15 \mathrm{E}-06$ & \\
\hline & $2.05 \mathrm{E}-05$ & $2.65 \mathrm{E}-05$ & $3.57 \mathrm{E}-05$ & \\
\hline \multirow{2}{*}{\begin{tabular}{|l} 
Total Gas \\
Cumulative
\end{tabular}} & $3.46 \mathrm{E}-02$ & $1.05 \mathrm{E}-02$ & $1.84 \mathrm{E}-02$ & $2.24 \mathrm{E}-03$ \\
\hline & $3.46 \mathrm{E}-02$ & $4.51 \mathrm{E}-02$ & $6.35 \mathrm{E}-02$ & $6.57 \mathrm{E}-02$ \\
\hline
\end{tabular}


Table 5.23. Reacted Metallic Uranium Calculated from Gas Generation and Consumption Reactions in Tests 10 and 11

\begin{tabular}{|c|c|c|}
\hline \multirow[b]{2}{*}{ Reaction } & \multicolumn{2}{|c|}{$\begin{array}{l}\text { Moles U Reacted Based on } \\
\text { Various Reactions }\end{array}$} \\
\hline & \begin{tabular}{|c|} 
SNF + Can 60L \\
(Test 10) $^{(\mathbf{a})}$
\end{tabular} & $\begin{array}{l}\text { SNF + Floor 60L } \\
\quad \text { (Test 11) }\end{array}$ \\
\hline Reaction 1 & & \\
\hline $\mathrm{U}+2 \mathrm{H}_{2} \mathrm{O} \rightarrow \mathrm{UO}_{2}+2 \mathrm{H}_{2}$ & $2.30 \mathrm{E}-2$ & $2.71 \mathrm{E}-2$ \\
\hline Reaction 2 & & \\
\hline $\mathrm{U}+\mathrm{O}_{2} \rightarrow \mathrm{UO}_{2}$ & $3.06 \mathrm{E}-5$ & $7.08 \mathrm{E}-5$ \\
\hline Reaction 3 & & \\
\hline $\mathrm{U}+0.875 \mathrm{~N}_{2} \rightarrow \mathrm{UN}_{1.75}$ & $-7.44 \mathrm{E}-5$ & $-5.24 \mathrm{E}-5$ \\
\hline Total Moles U & & \\
\hline (Sum of Reactions 1-3) & $2.30 \mathrm{E}-2$ & $2.71 \mathrm{E}-2$ \\
\hline Total Moles U by Kr Release & $3.22 \mathrm{E}-2$ & $3.09 \mathrm{E}-2$ \\
\hline Total Moles U by Xe Release & $2.82 \mathrm{E}-2$ & $3.08 \mathrm{E}-2$ \\
\hline Initial U Metal Present & $10.30 \mathrm{E}-2$ & $9.97 \mathrm{E}-2$ \\
\hline \multicolumn{3}{|c|}{$\begin{array}{l}\text { Results based on intervals for which gas samples were analyzed } \\
\text { For Test } 10 \text {, gas was vented without analysis for one interval. }\end{array}$} \\
\hline
\end{tabular}

The $0-6350-\mu \mathrm{m}$ particles used in the SNF + Can 60L and SNF + Floor 60L tests were assumed to be $93.0 \mathrm{wt} \%$ uranium metal, the same as in the $500-2000-\mu \mathrm{m}$ population determined by the SNF Mid $80 \mathrm{~L}$ and SNF Mid 80L Dup tests.

Reaction 1 , to form $\mathrm{H}_{2}$, dominated uranium metal corrosion with $<0.3 \%$ contributed by Reaction 2 . The uranium metal amounts reacted as shown by the total of Reactions 1, 2, and 3 lag the amounts indicated by $\mathrm{Kr}$ and $\mathrm{Xe}$ release. The lag is again likely due to hydrogen uptake in the uranium metal to form the $\mathrm{UH}_{3}$ corrosion intermediate. The lag is greater for the test with added canister sludge. Thus, some hydrogen uptake also may be occurring by chemically reducing $\mathrm{U}(\mathrm{VI})$ minerals present in the sludge [e.g., by converting schoepite, $\left(\mathrm{UO}_{2}\right)_{8} \mathrm{O}_{2}(\mathrm{OH})_{12}\left(\mathrm{H}_{2} \mathrm{O}\right)_{12}$, to uranium octaoxide, $\mathrm{U}_{3} \mathrm{O}_{8}$, or uraninite, $\mathrm{UO}_{2}$ (Gillies 1958; Rovira et al. 2003)]. The amounts of uranium reacted as determined by $\mathrm{Kr}$ and $\mathrm{Xe}$ release agree to $13 \%$ for the test with the canister sludge and to $0.3 \%$ for the test with floor sludge. The relatively larger divergence in the canister sludge test results suggests that uranium metal fuel particles present in the sludge itself contributed to the fission product gas output.

Canister sludge sample, $\mathrm{KC}-2 / 3$ (whole), was used to make up the $\mathrm{KC}$ Can Comp. Based on the results of the Series I testing (Delegard et al. 2000), KC-2/3 (whole) contained $1.9 \mathrm{wt} \%$ uranium metal (settled sludge basis) in October 1999. If it is assumed no uranium oxidation occurred during hot cell storage of the sludge from October 1999 to September 2000 (i.e., start of Series I testing) and that the uranium metal content of KC Can Comp was the same as $\mathrm{KC}-2 / 3$, then the sludge in Test 10 would have contained about $1.3 \mathrm{~g}$ of uranium metal particles.

The $\mathrm{Kr}$ and $\mathrm{Xe}$ isotope ratios observed in the product gases for the 800 -ml sludge blanketing tests (Tests 10 and 11) are compared with those expected based on burnup calculations by ORIGEN (Table 5.24). The Xe isotope mass distributions (except for trace ${ }^{130} \mathrm{Xe}$ ) for the tests are similar for the two tests and near those predicted by ORIGEN. The Kr mass distributions for the SNF + Floor 60L test, if adjusted for ${ }^{85} \mathrm{Kr}$ decay, is consistent with the ORIGEN values, but the SNF + Can 60L test has relatively more ${ }^{84} \mathrm{Kr}$ and less ${ }^{86} \mathrm{Kr}$ than the $\mathrm{SNF}+$ Floor $60 \mathrm{~L}$ test and, thus, may indicate fission gas 
Table 5.24. Fission Product Gas Isotope Data for Tests 10 and 11

\begin{tabular}{|c|c|c|c|}
\hline \multirow[b]{2}{*}{ Gas } & \multicolumn{2}{|c|}{ "Isotopic Composition, atom\% $^{(\mathrm{a})}$} & \multirow[b]{2}{*}{ ORIGEN $^{(\mathbf{b})}$} \\
\hline & $\begin{array}{l}\text { SNF + Can 60L } \\
\text { (Test 10) }\end{array}$ & $\begin{array}{l}\text { SNF + Floor 60L } \\
\text { (Test 11) }\end{array}$ & \\
\hline${ }^{83} \mathrm{Kr}$ & 15.8 & 15.4 & 13.3 \\
\hline${ }^{84} \mathrm{Kr}$ & 31.7 & 29.2 & 28.3 \\
\hline${ }^{85} \mathrm{Kr}$ & 1.7 & 1.3 & 6.8 \\
\hline${ }^{86} \mathrm{Kr}$ & 50.9 & 54.0 & 51.5 \\
\hline${ }^{130} \mathrm{Xe}$ & 0.027 & 0.033 & 0.05 \\
\hline${ }^{131} \mathrm{Xe}$ & 10.6 & 10.7 & 10.7 \\
\hline${ }^{132} \mathrm{Xe}$ & 18.1 & 18.1 & 18.0 \\
\hline${ }^{134} \mathrm{Xe}$ & 28.7 & 28.6 & 28.0 \\
\hline${ }^{136} \mathrm{Xe}$ & 42.6 & 42.5 & 43.2 \\
\hline $\begin{array}{c}\mathrm{Xe}: \mathrm{Kr} \\
\text { mole ratio }\end{array}$ & 8.6 & 9.8 & 8.2 \\
\hline \multirow{2}{*}{$\begin{array}{l}\text { Based on } \\
{ }^{85} \text { Kr Decay }\end{array}$} & \multicolumn{3}{|c|}{ Calculated Cooling Time, $\mathrm{yr}^{(\mathrm{c})}$} \\
\hline & 21.5 & 25.7 & -- \\
\hline Based on & \multicolumn{3}{|c|}{ Burnup, MWD/TeU, from ORIGEN Fit } \\
\hline $\mathrm{Xe}$ & 3810 & 3560 & -- \\
\hline $\mathrm{Kr}$ & 3700 & 2960 & -- \\
\hline \multicolumn{4}{|c|}{$\begin{array}{l}\text { Correcting the } \mathrm{Kr} \text { isotopic compositions for }{ }^{85} \mathrm{Kr} \text { decay would } \\
\text { decrease the stated }{ }^{83} \mathrm{Kr} \text { values by } \sim 0.75 \% \text {, decrease }{ }^{84} \mathrm{Kr} \text { values } \\
\text { by } \sim 1.6 \% \text {, increase the }{ }^{85} \mathrm{Kr} \text { values by } \sim 5.25 \% \text {, and decrease the } \\
{ }^{86} \mathrm{Kr} \text { values by } \sim 2.9 \% \text {. }\end{array}$} \\
\hline \multicolumn{4}{|c|}{$\begin{array}{l}\text { b) ORIGEN2 calculation for } \mathrm{N} \text { Reactor MkIV fuel at } \\
2921 \mathrm{MWD} / \mathrm{TeU} \text {; ratios change }<3 \% \text { relative at lower } \\
\text { burnups; }{ }^{85} \mathrm{Kr} \text { has a } 10.76 \text {-year half-life. }\end{array}$} \\
\hline \multicolumn{4}{|c|}{$\begin{array}{l}\text { Cooling time estimates based on dates of mass spectrometric } \\
\text { analysis of product gases - September through November } 2000 \text {. }\end{array}$} \\
\hline
\end{tabular}

contribution from the canister sludge. The ${ }^{85} \mathrm{Kr}$ concentrations indicate cooling times since discharge of 21.5 and 25.7 years for SNF + Can 60L and SNF + Floor 60L, respectively. Both are in line with the 25 -year cooling time since fuel element discharge and the $23 \pm 2.6$-year cooling time found for the tests run to uranium metal extinction (Tests 6 through 8). The Xe:Kr mole ratios are 8.6 and 9.8, respectively, for Tests 10 and 11. The 9.8 value is higher than predicted by ORIGEN but compatible with the $9.7 \pm 0.6 \mathrm{Xe}: \mathrm{Kr}$ ratio average found for Tests 6 through 8 . The $\mathrm{Xe}: \mathrm{Kr}$ ratio of 8.6 found for the $\mathrm{SNF}+\mathrm{Can} 60 \mathrm{~L}$ test is low compared with the $9.7 \pm 0.6 \mathrm{Xe}: \mathrm{Kr}$ ratio average observed for the crushed fuel particles, and again may suggest some contribution from uranium metal particles in the canister sludge.

The calculated fuel burnups for Tests 10 and 11 are not meaningful, especially for the test with canister sludge (which showed evidence of uranium corrosion from the sludge component). In addition, the selected fuel particles do not represent the reactor-wide distribution considered in ORIGEN; the uranium metal reactions were not run to completion; one gas sample was vented without analysis; and some hydrogen likely was retained as uranium hydride, thus biasing the calculation.

Methane, ethane, and higher hydrocarbons again were found in gas samples from these tests. Based on the released hydrocarbon gas product, carbon concentrations in the corroded source uranium metal fuel (assayed by $\mathrm{Kr}$ and $\mathrm{Xe}$ release) were determined. The carbon concentrations in the uranium metal determined in this manner are shown in Table 5.25. 
Table 5.25. Carbon Concentration Based on Hydrocarbon, Kr, and Xe Gas Release for Tests 10 and 11

\begin{tabular}{|c|c|c||}
\hline \multirow{2}{*}{ Based on } & \multicolumn{2}{|c|}{ Carbon Concentration, ppmp U } \\
\cline { 2 - 3 } & $\begin{array}{c}\text { SNF + Can } \\
\text { 60L (Test 10) }\end{array}$ & $\begin{array}{c}\text { SNF + Floor } \\
\text { 60L (Test 11) }\end{array}$ \\
\hline Kr Release & 492 & 309 \\
\hline Xe Release & 559 & 309 \\
\hline
\end{tabular}

The carbon concentrations agree well with the 365 to 735 parts of carbon per million parts uranium expected in metal fuel (Weakley 1979). The results, however, do not agree with fuel particles-only tests performed in the present test series, which ranged from $42 \mathrm{ppmp}$ (for SNF Mid 80L, Test 7) to $227 \mathrm{ppmp}$ (for SNF M500 80L, Test 6). The contribution of the sludge blanketing evidently boosted the amounts of released hydrocarbon in Tests 10 and 11, as it did for the sludge-blanketed 60-ml tests SNF + Can Fines 60S ( 400 ppmp) and SNF + Can 60S ( 600 ppmp) (Tests 1 and 2).

The methane fraction of the total hydrocarbon carbon is about 72 to 75 atom $\%$ for the two tests, similar to the $71 \%$ to $74 \%$ observed for the two tests with added sludge (Tests 1 and 2 ), but lower than the $\sim 50 \%$ to $55 \%$ found in the fuel particles-only tests. About 92 atom $\%$ methane is found at 40,000 to 50,000 ppmp carbon (up to pure UC), and about 71 atom $\%$ at $~ 20,000$ ppmp carbon in U/UC mixtures corroded in $80^{\circ} \mathrm{C}$ water (Bradley and Ferris 1962, 1964).

Carbon dioxide constitutes about $0.51 \%$ of the product gas in the SNF + Can $60 \mathrm{~L}$ test and $5.11 \%$ of the gas in the SNF + Floor 60L test (Table 5.26). The fraction of $\mathrm{CO}_{2}$ produced increased with temperature for the test with the floor sludge, but was not clearly affected by temperature for the canister sludge test. The larger amounts of $\mathrm{CO}_{2}$ from the tests with sludge are likely derived from the reaction of solid phase calcite and schoepite (Reaction 8). The solution $\mathrm{pH}$, measured after testing, was 4.9 for the $\mathrm{SNF}+\mathrm{Can}$ $60 \mathrm{~L}$ test and 7.0 for the SNF + Floor $60 \mathrm{~L}$ test. The lower $\mathrm{pH}$ values are consistent with Reaction 8 and its accompanying carbonic acid production with $\mathrm{CO}_{2}$ release.

Table 5.26. Carbon Dioxide Produced in Tests 10 and 11

\begin{tabular}{|c||c|}
\hline \multicolumn{2}{|c|}{ Carbon Dioxide Concentration, \% of Total Gas } \\
\hline SNF + Can 60L (Test 10) & SNF + Floor 60L (Test 11) \\
\hline 0.51 & 5.12 \\
\hline
\end{tabular}

\subsection{Gas Analyses from Long-Term Test with Canister Sludge}

A 14-month (10,140-hr) test of gas generation from KC-2/3 P250L sludge was conducted in an 800-ml vessel held at ambient hot cell temperature (Test 12). Aside from an 888-hr (37 days) period when the apparatus was disconnected from the gas measurement system just after the initial $6120-\mathrm{hr}(\sim 81 / 2$ months $)$ period, gas evolution versus reaction time was measured continuously, and seven gas samples were taken for mass spectrometric analysis. No gases were vented without analysis. The initial test results for the first four samples showed that little gas generation occurred. Results for the remaining 4000-hr (5 $1 / 2$ month) period indicate that meager gas production amounts and rates continued over the lifetime of this test (Figure 3.7). Most significantly, this test apparently failed to achieve the rapid, $\mathrm{UH}_{3}$-mediated, uranium corrosion that had been observed for the same material in three prior 30-ml vessel tests 
(Delegard et al. 2000) run at $40^{\circ} \mathrm{C}, 60^{\circ} \mathrm{C}$, and $80^{\circ} \mathrm{C}$ with each test run to completion at $95^{\circ} \mathrm{C}$. These tests showed that the $\mathrm{KC}-2 / 3 \mathrm{P} 250$ sludge contained, on average, $\sim 7.4 \mathrm{wt} \%$ uranium metal.

As shown in Figure 3.7, gas production from the Series III KC-2/3 P250L test was erratic over the entire test period. Based on gas sampling and analysis, the amount of gas produced up to the time of the last gas sample collection, was 0.00146 moles, equivalent to about $32 \mathrm{ml}$ of gas at standard temperature and pressure, or 0.0219 moles ( 0.49 liters of gas at standard temperature and pressure) per kg sludge. Based on the sludge containing $7.4 \mathrm{wt} \%$ of metallic uranium, the amount of $\mathrm{H}_{2}$ gas produced by complete uranium corrosion should have been $\sim 30$ times higher (i.e., 0.041 moles total or 0.62 moles $/ \mathrm{kg}$ sludge).

Determining the gas generation rates for this test is difficult using only the erratic Figure 3.7 data. The plot is made irregular in appearance by the small amounts of gas generated relative to the $\sim 800$-ml vessel volume and fluctuations in the ambient hot cell temperature. More precise gas generation results based on mass spectrometric analyses of gas samples (Table B.24, Appendix B) show $\mathrm{H}_{2}$ rates ranging from $\sim 0.00003$ liters $/ \mathrm{kg}$ sludge-day to $\sim 0.00007$ liters $/ \mathrm{kg}$ sludge-day and $\mathrm{CO}_{2}$ rates of $\sim 0.0005$ to $\sim 0.004$ liters $/ \mathrm{kg}$ sludge-day. Based on Arrhenius equation extrapolation of the $30-\mathrm{ml}$ test rates obtained in Series I at $40^{\circ} \mathrm{C}, 60^{\circ} \mathrm{C}, 80^{\circ} \mathrm{C}$, and $95^{\circ} \mathrm{C}$, maximum gas generation rates in the $800-\mathrm{ml}$ vessel test at the $\sim 33^{\circ} \mathrm{C}$ hot cell temperature should have been $\sim 0.041$ liters $\mathrm{H}_{2} / \mathrm{kg}$ sludge-day and 0.00040 liters $\mathrm{CO}_{2} / \mathrm{kg}$ sludge-day (see Figure 4.2 of the Series I report, Delegard et al. 2000). The $\mathrm{CO}_{2}$ generation rate in the $800-\mathrm{ml}$ vessel test is thus consistent with that expected based on $30-\mathrm{ml}$ vessel test results, but the $\mathrm{H}_{2}$ rate is $\sim 1000$-fold lower.

Gas quantities produced and consumed in the KC-2/3 P250L test are shown in Table 5.27 for the entire test period. The individual gas quantities are based on pressure-volume-temperature measurements and gas composition by mass spectrometry. Many gas samples had Kr, Xe, and hydrocarbon gas concentrations below the analytical detection limit. The combined sampled and analyzed gas products were $3.06 \% \mathrm{H}_{2}$ and $96.90 \% \mathrm{CO}_{2}$. The remaining generated gases were isotopes of $\mathrm{Xe}$ and methane (only found in three and two of the seven samples, respectively). No $\mathrm{Kr}$ or higher hydrocarbons were detected in any sample. Oxygen was consumed in all samples, and $\mathrm{N}_{2}$ was consumed in most samples. Significant air contamination was present in the fifth sample taken after the 888-hr period the apparatus was open to the atmosphere (see Table B.23).

Estimates of uranium metal reacted based on Reactions 1, 2, and 3 and the corresponding gas analyses are shown in Table 5.28 for the three tests from Series I and for the Series III test. Analyses of the Kr and Xe gas generated in the Series I tests (all run to completion in the contained uranium metal) were compared with the amounts of uranium corroded for these tests to derive the $\mathrm{Kr}$ and Xe concentrations in the uranium metal. For these Series I tests, mass-averaged fission product gas concentrations are $43.8 \pm 7.5 \mu \mathrm{g} \mathrm{Kr} / \mathrm{g} \mathrm{U}$ and $561 \pm 67 \mu \mathrm{g} \mathrm{Xe/g} \mathrm{U,} \mathrm{comparable} \mathrm{with} \mathrm{the} 42.2 \pm 1.9 \mu \mathrm{g} \mathrm{Kr} / \mathrm{g} \mathrm{U}$ and $651 \pm 26 \mu \mathrm{g} \mathrm{Xe} / \mathrm{g} \mathrm{U}$ found in the fuel particle tests (SNF M500 80L, SNF Mid 80L, and SNF Mid 80L Dup). The $561 \mu \mathrm{g} \mathrm{Xe/g} \mathrm{U} \mathrm{concentration} \mathrm{was} \mathrm{used} \mathrm{to} \mathrm{derive} \mathrm{the} \mathrm{amount} \mathrm{of} \mathrm{uranium} \mathrm{reacted} \mathrm{during} \mathrm{the}$ three samplings when measurable Xe was found in the gas products of the $800-\mathrm{ml}$ vessel test. The amounts of uranium corroded by Reactions 1, 2, and 3 are listed in Table 5.28 with the estimates based on Xe release.

As can be derived from Table 5.28, about $99 \%$ of the overall uranium corrosion in the three Series I tests occurred by Reaction 1 to form $\mathrm{H}_{2}$. However, in the Series III test, only about $7 \%$ of the corrosion occurred by Reaction 1, with $\sim 70 \%$ by Reaction 2 with $\mathrm{O}_{2}$. Monitoring of uranium corrosion in the Series III test by fission product gas release was inconclusive, because the fission product gas concentrations were too low to measure for most test samples. Based on the gas production $\left(\mathrm{H}_{2}\right)$ and 
Table 5.27. Net and Cumulative Quantities of Gas Evolved for KC-2/3 P250L (Test 12)

\begin{tabular}{|c|c|c|c|c|c|c|c|}
\hline \multirow[b]{2}{*}{ Gas } & \multicolumn{7}{|c|}{ Gas Quantities, Moles, at Sampling Times, hr } \\
\hline & 453.7 & 3786.0 & 4666.0 & 6145.7 & 6600.7 & 8591.0 & 10143.0 \\
\hline \multirow{2}{*}{$\begin{array}{l}\mathrm{CO}_{2} \\
\text { Cumulative }\end{array}$} & $1.21 \mathrm{E}-04$ & $1.82 \mathrm{E}-04$ & $1.78 \mathrm{E}-04$ & $1.93 \mathrm{E}-04$ & $2.31 \mathrm{E}-04$ & 2.91E-04 & $2.19 \mathrm{E}-04$ \\
\hline & $1.21 \mathrm{E}-04$ & $3.03 \mathrm{E}-04$ & $4.81 \mathrm{E}-04$ & $6.74 \mathrm{E}-04$ & 9.05E-04 & $1.20 \mathrm{E}-03$ & $1.41 \mathrm{E}-03$ \\
\hline \multirow{2}{*}{$\begin{array}{l}\mathrm{H}_{2} \\
\text { Cumulative }\end{array}$} & $4.13 \mathrm{E}-06$ & $1.11 \mathrm{E}-05$ & $6.72 \mathrm{E}-06$ & $9.00 \mathrm{E}-06$ & $3.44 \mathrm{E}-06$ & & $1.02 \mathrm{E}-05$ \\
\hline & $4.13 \mathrm{E}-06$ & $1.52 \mathrm{E}-05$ & $2.19 \mathrm{E}-05$ & $3.09 \mathrm{E}-05$ & $3.44 \mathrm{E}-05$ & $3.44 \mathrm{E}-05$ & $4.46 \mathrm{E}-05$ \\
\hline \multirow{2}{*}{\begin{tabular}{||l}
$\mathrm{N}_{2}$ \\
Cumulative
\end{tabular}} & $-5.19 \mathrm{E}-05$ & $-1.56 \mathrm{E}-05$ & $-1.64 \mathrm{E}-06$ & $-5.98 \mathrm{E}-06$ & $1.58 \mathrm{E}-05$ & 5.91E-06 & $-7.54 \mathrm{E}-06$ \\
\hline & $-5.19 \mathrm{E}-05$ & $-6.75 \mathrm{E}-05$ & $-6.92 \mathrm{E}-05$ & $-7.52 \mathrm{E}-05$ & $-5.94 \mathrm{E}-05$ & $-5.35 \mathrm{E}-05$ & $-6.10 \mathrm{E}-05$ \\
\hline \multirow{2}{*}{$\begin{array}{l}\mathrm{O}_{2} \\
\text { Cumulative }\end{array}$} & $-4.64 \mathrm{E}-05$ & $-4.36 \mathrm{E}-06$ & $-1.88 \mathrm{E}-06$ & $-2.23 \mathrm{E}-06$ & $-1.42 \mathrm{E}-04$ & $-7.46 \mathrm{E}-06$ & $-7.06 \mathrm{E}-06$ \\
\hline & $-4.64 \mathrm{E}-05$ & $-5.08 \mathrm{E}-05$ & $-5.27 \mathrm{E}-05$ & $-5.49 \mathrm{E}-05$ & $-1.97 \mathrm{E}-04$ & $-2.04 \mathrm{E}-04$ & $-2.11 \mathrm{E}-04$ \\
\hline \multirow{2}{*}{\begin{tabular}{|l}
$\mathrm{CH}_{4}$ \\
Cumulative
\end{tabular}} & & 2.52E-07 & & & 2.65E-07 & & \\
\hline & $0.00 \mathrm{E}+00$ & $2.52 \mathrm{E}-07$ & $2.52 \mathrm{E}-07$ & $2.52 \mathrm{E}-07$ & 5.17E-07 & $5.17 \mathrm{E}-07$ & 5.17E-07 \\
\hline \multirow{2}{*}{\begin{tabular}{|l}
$\mathrm{C}_{2} \mathrm{H}_{\mathrm{x}}$ \\
Cumulative
\end{tabular}} & & & & & & & \\
\hline & $0.00 \mathrm{E}+00$ & $0.00 \mathrm{E}+00$ & $0.00 \mathrm{E}+00$ & $0.00 \mathrm{E}+00$ & $0.00 \mathrm{E}+00$ & $0.00 \mathrm{E}+00$ & $0.00 \mathrm{E}+00$ \\
\hline \multirow{2}{*}{\begin{tabular}{|l}
$\geq \mathrm{C}_{3} \mathrm{H}_{\mathrm{x}}$ \\
Cumulative
\end{tabular}} & & & & & & & \\
\hline & $0.00 \mathrm{E}+00$ & $0.00 \mathrm{E}+00$ & $0.00 \mathrm{E}+00$ & $0.00 \mathrm{E}+00$ & $0.00 \mathrm{E}+00$ & $0.00 \mathrm{E}+00$ & $0.00 \mathrm{E}+00$ \\
\hline \multirow{2}{*}{\begin{tabular}{||l}
$\sum \mathrm{C}_{\mathrm{y}} \mathrm{H}_{\mathrm{x}} \mathrm{C}$ \\
Cumulative
\end{tabular}} & & 2.52E-07 & & & 2.65E-07 & & \\
\hline & $0.00 \mathrm{E}+00$ & 2.52E-07 & 2.52E-07 & 2.52E-07 & 5.17E-07 & 5.17E-07 & 5.17E-07 \\
\hline \multirow{2}{*}{$\begin{array}{l}{ }^{83} \mathrm{Kr} \\
\text { Cumulative }\end{array}$} & & & & & & & \\
\hline & $0.00 \mathrm{E}+00$ & $0.00 \mathrm{E}+00$ & $0.00 \mathrm{E}+00$ & $0.00 \mathrm{E}+00$ & $0.00 \mathrm{E}+00$ & $0.00 \mathrm{E}+00$ & $0.00 \mathrm{E}+00$ \\
\hline \multirow{2}{*}{$\begin{array}{l}{ }^{84} \mathrm{Kr} \\
\text { Cumulative }\end{array}$} & & & & & & & \\
\hline & $0.00 \mathrm{E}+00$ & $0.00 \mathrm{E}+00$ & $0.00 \mathrm{E}+00$ & $0.00 \mathrm{E}+00$ & $0.00 \mathrm{E}+00$ & $0.00 \mathrm{E}+00$ & $0.00 \mathrm{E}+00$ \\
\hline \multirow{2}{*}{\begin{tabular}{l|l}
${ }^{85} \mathrm{Kr}$ \\
Cumulative
\end{tabular}} & & & & & & & \\
\hline & $0.00 \mathrm{E}+00$ & $0.00 \mathrm{E}+00$ & $0.00 \mathrm{E}+00$ & $0.00 \mathrm{E}+00$ & $0.00 \mathrm{E}+00$ & $0.00 \mathrm{E}+00$ & $0.00 \mathrm{E}+00$ \\
\hline \multirow{2}{*}{$\begin{array}{l}{ }^{86} \mathrm{Kr} \\
\text { Cumulative }\end{array}$} & & & & & & & \\
\hline & $0.00 \mathrm{E}+00$ & $0.00 \mathrm{E}+00$ & $0.00 \mathrm{E}+00$ & $0.00 \mathrm{E}+00$ & $0.00 \mathrm{E}+00$ & $0.00 \mathrm{E}+00$ & $0.00 \mathrm{E}+00$ \\
\hline \multirow{2}{*}{\begin{tabular}{|l}
$\sum \mathrm{Kr}$ \\
Cumulative
\end{tabular}} & $0.00 \mathrm{E}+00$ & $0.00 \mathrm{E}+00$ & $0.00 \mathrm{E}+00$ & $0.00 \mathrm{E}+00$ & $0.00 \mathrm{E}+00$ & $0.00 \mathrm{E}+00$ & $0.00 \mathrm{E}+00$ \\
\hline & $0.00 \mathrm{E}+00$ & $0.00 \mathrm{E}+00$ & $0.00 \mathrm{E}+00$ & $0.00 \mathrm{E}+00$ & $0.00 \mathrm{E}+00$ & $0.00 \mathrm{E}+00$ & $0.00 \mathrm{E}+00$ \\
\hline \multirow{2}{*}{$\begin{array}{l}{ }^{130} \mathrm{Xe} \\
\text { Cumulative }\end{array}$} & & & & \begin{tabular}{|l|}
$2.65 \mathrm{E}-09$ \\
\end{tabular} & & & \\
\hline & $0.00 \mathrm{E}+00$ & $0.00 \mathrm{E}+00$ & $0.00 \mathrm{E}+00$ & \begin{tabular}{|l|}
$2.65 \mathrm{E}-09$ \\
\end{tabular} & $2.65 \mathrm{E}-09$ & $2.65 \mathrm{E}-09$ & $2.65 \mathrm{E}-09$ \\
\hline \multirow{2}{*}{$\begin{array}{l}{ }^{131} \mathrm{Xe} \\
\text { Cumulative }\end{array}$} & & & & $2.65 \mathrm{E}-09$ & $2.65 \mathrm{E}-09$ & $2.46 \mathrm{E}-09$ & \\
\hline & $0.00 \mathrm{E}+00$ & $0.00 \mathrm{E}+00$ & $0.00 \mathrm{E}+00$ & \begin{tabular}{|l|}
$2.65 \mathrm{E}-09$ \\
\end{tabular} & \begin{tabular}{|l|}
$5.30 \mathrm{E}-09$ \\
\end{tabular} & 7.76E-09 & 7.76E-09 \\
\hline \multirow{2}{*}{$\begin{array}{l}132 \mathrm{Xe} \\
\text { Cumulative }\end{array}$} & & & & 5.29E-09 & $2.65 \mathrm{E}-09$ & 4.93E-09 & \\
\hline & $0.00 \mathrm{E}+00$ & $0.00 \mathrm{E}+00$ & $0.00 \mathrm{E}+00$ & 5.29E-09 & 7.94E-09 & $1.29 \mathrm{E}-08$ & $1.29 \mathrm{E}-08$ \\
\hline \multirow{2}{*}{$\begin{array}{l}{ }^{134} \mathrm{Xe} \\
\text { Cumulative }\end{array}$} & & & & 7.94E-09 & 5.30E-09 & \begin{tabular}{|l|}
$4.93 \mathrm{E}-09$ \\
\end{tabular} & \\
\hline & $0.00 \mathrm{E}+00$ & $0.00 \mathrm{E}+00$ & $0.00 \mathrm{E}+00$ & 7.94E-09 & $1.32 \mathrm{E}-08$ & $1.82 \mathrm{E}-08$ & $1.82 \mathrm{E}-08$ \\
\hline \multirow{2}{*}{$\begin{array}{l}{ }^{136} \mathrm{Xe} \\
\text { Cumulative }\end{array}$} & & & & & 5.30E-09 & \begin{tabular}{|l}
$7.39 \mathrm{E}-09$ \\
\end{tabular} & \\
\hline & $0.00 \mathrm{E}+00$ & $0.00 \mathrm{E}+00$ & $0.00 \mathrm{E}+00$ & $0.00 \mathrm{E}+00$ & 5.30E-09 & $1.27 \mathrm{E}-08$ & $1.27 \mathrm{E}-08$ \\
\hline \multirow{2}{*}{\begin{tabular}{|l}
$\sum \mathrm{Xe}$ \\
Cumulative
\end{tabular}} & $0.00 \mathrm{E}+00$ & $0.00 \mathrm{E}+00$ & $0.00 \mathrm{E}+00$ & $1.85 \mathrm{E}-08$ & $1.59 \mathrm{E}-08$ & $1.97 \mathrm{E}-08$ & $0.00 \mathrm{E}+00$ \\
\hline & $0.00 \mathrm{E}+00$ & $0.00 \mathrm{E}+00$ & $0.00 \mathrm{E}+00$ & $1.85 \mathrm{E}-08$ & 3.44E-08 & 5.41E-08 & $5.41 \mathrm{E}-08$ \\
\hline \multirow{2}{*}{$\begin{array}{l}\text { Total Gas } \\
\text { Cumulative }\end{array}$} & $-2.42 \mathrm{E}-04$ & $-2.02 \mathrm{E}-04$ & $6.80 \mathrm{E}-05$ & 4.14E-04 & $-1.00 \mathrm{E}-05$ & $1.18 \mathrm{E}-04$ & $-3.93 \mathrm{E}-05$ \\
\hline & $-2.42 \mathrm{E}-04$ & $-4.44 \mathrm{E}-04$ & $-3.76 \mathrm{E}-04$ & $3.80 \mathrm{E}-05$ & $2.80 \mathrm{E}-05$ & $1.46 \mathrm{E}-04$ & $1.07 \mathrm{E}-04$ \\
\hline
\end{tabular}


Table 5.28. Reacted Metallic Uranium Calculated from Gas Generation and Consumption Reactions in Series I and Series III Tests with KC-2/3 P250

\begin{tabular}{|c|c|c|c|c||}
\hline \multirow{2}{*}{ Reaction } & \multicolumn{4}{|c|}{ Moles U Reacted Based on Various Reactions } \\
\cline { 2 - 4 } & \multicolumn{3}{|c|}{ Series I (Delegard et al. 2000) } & Series III \\
\cline { 2 - 4 } & $\mathbf{4 0}^{\circ} \mathbf{C}$ & $\mathbf{6 0}^{\circ} \mathbf{C}$ & $\mathbf{8 0}{ }^{\circ} \mathbf{C}$ & Test 12 \\
\hline $\begin{array}{c}\text { Reaction } 1 \\
\mathrm{U}+2 \mathrm{H}_{2} \mathrm{O} \rightarrow \mathrm{UO}_{2}+2 \mathrm{H}_{2}\end{array}$ & $7.61 \mathrm{E}-3$ & $6.14 \mathrm{E}-3$ & $3.65 \mathrm{E}-3$ & $2.21 \mathrm{E}-5$ \\
\hline $\begin{array}{c}\text { Reaction } 2 \\
\mathrm{U}+\mathrm{O}_{2} \rightarrow \mathrm{UO}_{2}\end{array}$ & $1.02 \mathrm{E}-5$ & $3.58 \mathrm{E}-5$ & $8.40 \mathrm{E}-6$ & $2.11 \mathrm{E}-4$ \\
\hline $\begin{array}{c}\text { Reaction } 3 \\
\mathrm{U}+0.875 \mathrm{~N}_{2} \rightarrow \mathrm{UN}_{1.75}\end{array}$ & $4.00 \mathrm{E}-6$ & $1.26 \mathrm{E}-4$ & $1.05 \mathrm{E}-5$ & $7.03 \mathrm{E}-5$ \\
\hline $\begin{array}{c}\text { Total Moles U } \\
\text { Sum of Reactions 1-3) }\end{array}$ & $7.63 \mathrm{E}-3$ & $6.30 \mathrm{E}-3$ & $3.66 \mathrm{E}-3$ & $3.04 \mathrm{E}-4$ \\
\hline Total Moles U by Kr Release & $7.66 \mathrm{E}-3$ & $5.49 \mathrm{E}-3$ & $4.44 \mathrm{E}-3$ & -- \\
\hline Total Moles U by Xe Release & $7.91 \mathrm{E}-3$ & $5.57 \mathrm{E}-3$ & $4.10 \mathrm{E}-3$ & $5.44 \mathrm{E}-5$ \\
\hline Initial U Metal Present & $7.36 \mathrm{E}-3$ & $5.80 \mathrm{E}-3$ & $4.26 \mathrm{E}-3$ & $2.05 \mathrm{E}-2$ \\
\hline Amount of Uranium Reacted & All & All & All & $1.5 \%$ \\
\hline
\end{tabular}

consumption $\left(\mathrm{O}_{2}, \mathrm{~N}_{2}\right)$ data, only about $1.5 \%$ of the uranium metal in the Series III test corroded at ambient hot cell temperature during the time $(10,140 \mathrm{hr})$ the gas samples were collected. The behavior of the Series III test at $\sim 33^{\circ} \mathrm{C}$ may be compared with the behavior of the Series I test that began at $40^{\circ} \mathrm{C}$. Although the $40^{\circ} \mathrm{C}$ Series I test required a $\sim 335-\mathrm{hr}$ induction time before significant corrosion occurred, the reaction then accelerated to proceed at a smooth rate and achieve $\sim 50 \%$ uranium corrosion after another $\sim 3220 \mathrm{hr}$ (134 days) (see Figure 4.1 in Bryan et al. 2001). It is recognized that some hydrogen may have been retained as $\mathrm{UH}_{3}$ in the Series III test. However, Xe and $\mathrm{Kr}$ gas releases were insufficient, either by reaching detectable limits or, even when detectable, by quantity, to confirm that significant corrosion to the hydride intermediate had transpired. Based on the combined gas analytical findings, the Series III test clearly did not overcome the induction time to achieve the rapid hydride-mediated corrosion by the mechanisms afforded by Reactions 4 and 5 .

No Kr gas isotopes were detected by mass spectrometry in the seven Series III gas samples, and Xe gas isotopes were only found in three of the seven samples. Therefore, the $\mathrm{Xe}: \mathrm{Kr}$ ratios could not be determined. The overall Xe isotope mass distributions for the three samples are compared (Table 5.29) with the fission product gas distributions found in the Series I tests. The Xe isotopic composition in the Series III test differs from that found in the combined Series I tests and from those predicted by ORIGEN. The discrepancies likely are due to uncertainties in mass spectrometric analyses for concentrations near the detection limit.

Methane was the only hydrocarbon found in gas samples from the Series III test and was detected in only two of the seven samples. No meaningful inferences on carbide carbon concentration can be made from these limited data.

Carbon dioxide provided $96.90 \%$ of the total product gas generated by the Series III test. The $\mathrm{CO}_{2}$ gas generation rate did not markedly decrease over the 10,140 hr of testing (Table B.24), thus indicating that the $\mathrm{CO}_{2}$-producing reactions (such as Reaction 8 to produce becquerelite) had not gone to completion. The amount of $\mathrm{CO}_{2}$ released is consistent with a TIC concentration in the sludge of $256 \mathrm{ppm}$ (dry sludge basis). In contrast, the Series I tests, run to apparent completion in gas generation at $40^{\circ} \mathrm{C}, 60^{\circ} \mathrm{C}$, and 
Table 5.29. Fission Product Gas Isotope Data for Tests with KC-2/3 P 250

\begin{tabular}{|c|c|c|c||}
\hline \multirow{2}{*}{ Gas } & \multicolumn{2}{|c||}{ Isotopic Composition, atom\% } & \multirow{2}{*}{ ORIGEN $^{(a)}$} \\
\cline { 2 - 4 } & Series I & Series III & 13.3 \\
\hline${ }^{83} \mathrm{Kr}$ & 16.0 & -- & 28.3 \\
\hline${ }^{84} \mathrm{Kr}$ & 29.9 & -- & 6.8 \\
\hline${ }^{85} \mathrm{Kr}$ & 2.3 & -- & 51.5 \\
\hline${ }^{86} \mathrm{Kr}$ & 51.9 & -- & 0.05 \\
\hline${ }^{130} \mathrm{Xe}$ & 0.046 & -- & 10.7 \\
\hline${ }^{131} \mathrm{Xe}$ & 11.0 & 25.0 & 28.0 \\
\hline${ }^{132} \mathrm{Xe}$ & 18.0 & 35.2 & 43.2 \\
\hline${ }^{134} \mathrm{Xe}$ & 29.6 & 24.8 & 8.2 \\
\hline${ }^{136} \mathrm{Xe}$ & 41.4 & \multicolumn{3}{|c||}{ Calculated Cooling Time, yr } \\
\hline $\begin{array}{c}\text { Xe:Kr } \\
\text { mole ratio }\end{array}$ & 8.0 & -- & - \\
\hline $\begin{array}{c}\text { Based on } \\
85\end{array}$ & \multicolumn{3}{|c||}{ Kr Decay }
\end{tabular}

$80^{\circ} \mathrm{C}$ (and finished at $95^{\circ} \mathrm{C}$ ), had TIC concentrations of 1460,840 , and $1880 \mathrm{ppm}$, respectively. The final $\mathrm{pH}$ of the Series III test, 5.9, is consistent with Reaction 8 and its release of $\mathrm{CO}_{2}$, and compares with $\mathrm{pH}$ values of 6.4, 5.4, and 5.1 for the respective Series I tests.

The gas generation behavior of the KC-2/3 P250L test suggests that if certain conditions occur, uranium metal particles in $\mathrm{K}$ Basin sludge may undergo very little oxidation during storage. In contrast, the gas generation behaviors exhibited by other KE sludge samples show that it is also possible for uranium metal particles in sludge to rapidly transition through an induction period and undergo rapid oxidation, even in open vessels at ambient hot cell temperature as discussed in the following paragraphs.

In June 1996, KE canister sludge samples 96-05 and 96-06 were transferred from sealed shipping containers to open-top 2-liter graduated cylinders (Appendix B of Makenas et al. 1997 and Delegard et al. 2000). These samples were collected from the KE Basin in April 1996. When the ball valves on the shipping containers were opened, supernatant was ejected, indicating that the samples were reacting and generating gas during transportation. Within a few days of transfer to the graduated cylinders, gas bubbles were observed being released from the settled sludge. In late July 1996, the sludge in the graduated cylinders was sparged with air for about $5 \mathrm{~min}$ to obtain homogeneous slurry for settling rate studies. After air sparging, significant gas generation was observed in samples 96-05 and 96-06, with gas retention observed in Sample 96-05. Subsequent analyses confirmed that the gas was primarily hydrogen and included traces of fission product gas (isotopes of $\mathrm{Kr}$ and $\mathrm{Xe}$ ). These observations suggest that the uranium metal particles in the two canister sludge samples were reacting while in the shipping container, and that neither the exposure of the slurry to air during the transfer to the graduated cylinders nor subsequent air sparging disrupted or poisoned the rapid $\mathrm{UH}_{3}$-mediated corrosion. 
The differences in gas generation behavior between KC-2/3 P250L and the $1996 \mathrm{KE}$ canister sludge samples are not readily explained. The time between collecting the samples from the KE Basin and starting the gas generation testing/observations for the KC-2/3 P250L test ( $\sim 4$ months) was similar to that of 96-05 and 96-06 ( $\sim 3$ months). It is possible that handling during sample collection and shipment of samples 96-05 and 96-06 may have increased the reactivity of the uranium metal particle surfaces by removing the oxide coating. In the Series II gas generation testing (Bryan et al. 2001), a canister sludge subsample that had been aggressively agitated and sieved reacted nine times as much uranium as a similar, but gently handled, subsample under parallel conditions. However, with the exception that samples 96-05 and 96-06 were subjected to more gas sparging during settling tests, the extent of sample handling for samples 96-05 and 96-06 was similar to that of the $\mathrm{KC}-2 / 3 \mathrm{P} 250$ sample.

Several contributing factors for the differences in observed offgas generation behavior can be postulated. Samples 96-05 and 96-06 may have contained a finer distribution of uranium metal than KC-2/3 P250L (which only contained particles larger than $250 \mu \mathrm{m}$ ). As shown in Test 1 (SNF + Can Fines 60S), uranium metal fines blanketed with sludge can quickly progress to the $\mathrm{UH}_{3}$-mediated corrosion. Bed depth and its effect on limiting hydrogen diffusion outward and on oxygen diffusion inward may have been a factor. The bed depth in the KC-2/3 P250L test was about $1 \mathrm{~cm}$ compared to about $7 \mathrm{~cm}$ in the 965 and 96-06 tests in the 2-liter graduated cylinders, about $5 \mathrm{~cm}$ in the $\mathrm{KC}-2 / 3 \mathrm{P} 250$ Series I test run at $40^{\circ} \mathrm{C}$ (Delegard et al. 2000), and about $4.6 \mathrm{~cm}$ in Test 1 (SNF + Can Fines 60S). For KC-2/3 P250L, bulk water circulation may have occurred within the 1-cm layer of sludge that contained particles between 250 and $6350 \mu \mathrm{m}$ (i.e., no fine particulate). The sludge layer was likely too permeable to promote a buildup of sufficient hydrogen partial pressure and provided little resistance to oxygen convection and diffusion, preventing the uranium metal from undergoing $\mathrm{UH}_{3}$-mediated corrosion.

During containerization and storage of $\mathrm{K}$ Basin sludge, it is expected that most of the uranium metal particles will be blanketed by more than $5 \mathrm{~cm}$ of sludge and a significant fraction of the sludge will be made up of particles less than $250 \mu \mathrm{m}$. Consequently, the gas generation behavior of KC-2/3 P250L should not be assumed to be representative of the behavior of K Basin sludge during retrieval, containerization, or storage.

\subsection{Assessment of Uranium Metal Reacted During Testing}

This section provides an assessment of the amount uranium metal that reacted in each test system during the course of the Series III testing. The assessment is based on all test intervals, including the intervals in which gas samples were not analyzed. The final test interval, in which all test vessels were held at ambient hot cell temperature, has also been included in this analysis.

The results of the assessment are summarized in Table 5.30, which includes data on initial uranium metal content, test duration, total gas evolved, and average hydrogen concentration in the analyzed gas. Percent uranium reacted was calculated on two bases: 1) mass of fuel fragments and 2) mass of uranium metal initially present. The "mass of uranium metal initially present" basis takes into account the fact that the initial fuel fragments were not $100 \%$ uranium metal.

Three techniques were used to estimate the fraction of uranium reacted. In the first technique, designated " $\mathrm{H}_{2}$, PVT" in Table 5.30, the percent of uranium reacted was determined based on Reaction 1 (Section 4.0 ) and using the total moles of gas generated during the testing and the average $\mathrm{H}_{2}$ concentration (as determined by mass spectrometry). The total moles of gas generated was determined from the continuous pressure measurements, most of which were made at elevated temperatures. While the contribution of the 
vapor pressure of water was deducted (based on the temperature of the gas phase in the reaction vessels), minor temperature gradients across the vessels existed, which in turn created some inaccuracies in the total gas calculation. Also, in the 800-ml reaction vessels, intermittent offgas line blockage occurred, resulting in noise in the pressure measurements. This noise also contributed to some minor errors to the total offgas measurements. The first technique is illustrated by the total gas generation figures (Figures 3.2, 3.4, 3.5, and 3.6) and can be used to approximate the percent uranium metal reacted.

In the second technique, designated " $\mathrm{H}_{2}$, MS," the percent uranium reacted was determined (from Reaction 1) by summing the $\mathrm{H}_{2}$ generated (as determined by mass spectrometry) during each individual test interval. The volume of gas generated during each interval was measured after cooling the reaction vessel to ambient hot cell temperature (minimizing temperature gradients across the test system). For the test intervals in which gas samples were not analyzed, the average $\mathrm{H}_{2}$ concentration for the test was used. The values for percent uranium reacted based on the " $\mathrm{H}_{2}$, MS" are believed to be more accurate than those based on the " $\mathrm{H}_{2}$, PVT" technique; therefore, the " $\mathrm{H}_{2}$, MS" values are used in this report. In general, the values from the first and second techniques are in good agreement.

For the third technique, "Xe, MS," the percent uranium reacted is based on fission product Xe released (as measured by mass spectrometry), using the correlation developed in Section 4.3 that relates Xe mass directly to metallic fuel particle mass. While there are some assumptions and uncertainties associated with the correlation (discussed in Section 4.3), the "Xe, MS" technique is probably the most accurate of the three techniques. The "Xe, MS" percent uranium reacted values can be compared directly with the " $\mathrm{H}_{2}$, MS" values, since both are based on the measurements and samplings conducted at ambient cell temperature. For the tests with fuel particles only, the relative percent differences between the percent reacted values using the "Xe, MS" and the " $\mathrm{H}_{2}$, MS" techniques are less than $10 \%$. ${ }^{\text {(a) }}$ However, a much greater difference exists between these two techniques for the tests in which sludge, especially canister sludge, has been added (relative percent differences range from $13 \%$ to $45 \%$ ). In the tests with sludge, the overlying sludge burden may have held the product $\mathrm{H}_{2}$ closer to the unreacted uranium metal, increasing the possibility that the $\mathrm{H}_{2}$ would react with the metal to form $\mathrm{UH}_{3}$ rather than bubble away from the condensed phases. Therefore, when significant quantities of sludge are present, the first and second techniques, based on $\mathrm{H}_{2}$ measurements in the offgas, likely underestimate the quantity of uranium metal reacted when the uranium metal is not reacted to completion. As shown in the Series I tests, when the uranium metal in samples of $\mathrm{KC}-2 / 3 \mathrm{P} 250$ canister sludge was completely reacted, the percent uranium reacted based on the $\mathrm{H}_{2}$ measurements agreed well with the values calculated based on the "Xe, MS" technique.

The percent reacted values, on a uranium metal basis, for samples SNF M500 80L, SNF Mid 80L, and SNF Mid 80L Dup (Test 6 through 8), theoretically should be 100\%. The differences between these values in Table 5.30 and $100 \%$ provide an indication of their accuracy (i.e., $\sim \pm 7 \%$ ).

(a) Example relative percent difference (RPD) calculation: Sample SNF Mid 60S; \% Uranium Reacted $=26.3 \%$ and $27.4 \%$, " $\mathrm{H}_{2}, \mathrm{MS}$ " and "Xe, MS", respectively:

$$
\mathrm{RPD}=100 \% \times \frac{(27.4-26.3)}{[0.5 \times(27.4+26.3)]}=4.1 \%
$$


Table 5.30. Uranium Metal Reacted During Series III Testing

\begin{tabular}{|c|c|c|c|c|c|c|c|c|c|c|c|c|}
\hline \multirow{3}{*}{$\begin{array}{l}\text { Test } \\
\text { No. }\end{array}$} & \multirow{3}{*}{ Test ID } & \multirow{2}{*}{\multicolumn{2}{|c|}{ Initial Fuel Mass, $\mathbf{g}$}} & \multirow{2}{*}{\multicolumn{3}{|c|}{ Conditions at Termination of Testing }} & \multicolumn{6}{|c|}{ "Uranium Metal Reacted, \%, based on } \\
\hline & & & & & & & \multicolumn{3}{|c|}{ Fuel Particle Mass } & \multicolumn{3}{|c|}{ Uranium Metal Mass } \\
\hline & & Total & $\mathbf{U}^{(\mathbf{a})}$ & $\begin{array}{c}\text { Duration, } \\
\mathrm{hr}\end{array}$ & $\begin{array}{c}\text { Moles Gas/kg } \\
\text { Fuel Particles }^{(\mathbf{b})}\end{array}$ & $\begin{array}{c}{\left[\mathrm{H}_{2}\right] \text { in Gas, }} \\
\%^{(\mathrm{c})}\end{array}$ & \begin{tabular}{c|}
$\mathbf{H}_{2}$ \\
$\mathbf{P V T}^{(\mathbf{d})}$
\end{tabular} & $\begin{array}{c}\mathbf{H}_{2}, \\
\mathbf{M S}^{(\mathbf{e})}\end{array}$ & $\begin{array}{c}\mathbf{X e}, \\
\mathbf{M S}^{(f)}\end{array}$ & \begin{tabular}{|c|}
$\mathbf{H}_{2}$, \\
PVT $^{(\mathbf{d})}$
\end{tabular} & $\begin{array}{c}\mathbf{H}_{2}, \\
\mathbf{M S}^{(\mathbf{e})}\end{array}$ & $\begin{array}{c}\text { Xe, } \\
\text { MS }^{(\mathbf{f})}\end{array}$ \\
\hline 1 & SNF + Can Fines 60S & 4.27 & 3.17 & 2966 & 3.30 & 98.88 & 38.9 & 37.2 & 58.5 & 52.4 & 50.1 & 78.8 \\
\hline 2 & SNF + Can 60S & 8.39 & 7.80 & 2999 & 1.64 & 98.22 & 19.2 & 17.6 & 22.7 & 20.6 & 19.0 & 24.4 \\
\hline 3 & SNF Mid 60S & 8.24 & 7.66 & 2981 & 2.35 & 99.88 & 27.9 & 26.3 & 27.4 & 30.0 & 28.3 & 29.4 \\
\hline 4 & SNF Mid 40S & 8.61 & 8.01 & 3133 & 1.10 & 99.86 & 13.1 & 12.4 & 13.7 & 14.0 & 13.3 & 14.7 \\
\hline 5 & SNF P2000 80S & 9.95 & 9.25 & 2908 & 4.05 & 99.87 & 48.2 & 46.5 & 49.2 & 51.8 & 50.1 & 52.9 \\
\hline 6 & SNF M500 80L & 7.95 & 5.90 & 3124 & 69 & 99.79 & 79.5 & 74.2 & 77.3 & 107.0 & 100.0 & 104.2 \\
\hline 7 & SNF Mid 80L & 8.87 & 8.25 & 2988 & 7.55 & 99.87 & 89.8 & 90.8 & 87.6 & 96.5 & 97.6 & 94.2 \\
\hline 8 & SNF Mid 80L Dup & 8.15 & 7.57 & 2988 & 7.51 & 99.62 & 89.3 & 95.2 & 93.9 & 95.9 & 102.5 & 101.1 \\
\hline 9 & Fuel Fragment & 3.72 & 3.59 & 4250 & 2.84 & 99.70 & 33.7 & 32.7 & 34.8 & 34.9 & 33.9 & 36.1 \\
\hline 10 & SNF + Can 60L & 26.36 & 24.51 & 3011 & 2.72 & 98.84 & 31.6 & 31.8 & 39.1 & 34.4 & 34.2 & 42.0 \\
\hline 11 & SNF + Floor 60L & 25.52 & 23.73 & 3018 & 2.58 & 94.53 & 29.8 & 25.3 & 28.8 & 31.2 & 27.2 & 30.9 \\
\hline 12 & KC-2/3 P250L & $65.98^{(\mathrm{g})}$ & $4.88^{(\mathrm{g})}$ & 10,143 & $0.0219^{(\mathrm{h})}$ & 3.06 & -- & -- & -- & 0.00798 & 1.5 & -- \\
\hline \multicolumn{13}{|c|}{$\begin{array}{l}\text { (a) Fuel consists of uranium metal, oxidized uranium, and associated cladding particles. Uranium metal amounts determined based on analyses of gas from } \\
\text { reactions, to completion, of Tests } 6 \text { through } 8 \text { to form } \mathrm{H}_{2} \text { and } \mathrm{UO}_{2} \text { (Section 4.3) and post-test analysis of Test } 9 \text { to determine cladding mass. } \\
\text { (b) From pressure/volume/temperature (PVT) evolved gas measurements for tests at reaction temperatures (Section 3.0). } \\
\text { (c) Average } \mathrm{H}_{2} \text { concentrations observed in combined gas samples for each experiment (note, not all product gas was analyzed). } \\
\text { (d) Amounts of fuel particle or uranium metal reacted, respectively, based on the total moles of product gas at the termination of testing (by PVT } \\
\text { measurements of the system at the reaction temperature) and the average } \mathrm{H}_{2} \text { concentration. } \\
\text { (e) Amount of fuel particle or uranium metal reacted, respectively, during sampling events, based on the moles of product gas (by PVT measurements of } \\
\text { the system at ambient hot cell temperature during sampling) and the individual } \mathrm{H}_{2} \text { concentrations, plus the amounts reacted during the vented intervals, } \\
\text { based on PVT measurements and the overall average } \mathrm{H}_{2} \text { concentrations. }\end{array}$} \\
\hline \multicolumn{13}{|c|}{$\begin{array}{l}\text { f) Amount of fuel particle or uranium metal reacted, respectively, during sampling events, based on the amounts of fission product Xe gas released and the } \\
\text { factor } 651 \pm 26 \mu \mathrm{g} \mathrm{Xe} / \mathrm{g} \text { U (derived based on Tests } 6 \text { through } 8 \text { taken to complete reaction of the contained U metal; Section } 4.3 \text { ), plus the amounts } \\
\text { reacted during the vented intervals, based on PVT measurements and the overall average Xe concentrations. } \\
\text { g) The } 65.98 \mathrm{~g} \text { of initial KC-2/3 P } 250 \text { sludge contains an estimated } 4.88 \mathrm{~g} \text { U metal based on reacting smaller aliquots of KC-2/3 P250 sludge to completion } \\
\text { at elevated temperatures (Delegard et al. 2000). } \\
\text { h) Moles gas/kg-sludge. }\end{array}$} \\
\hline
\end{tabular}




\subsection{Reaction Rate Data Analysis and Comparisons to Related Spent Nuclear Fuel and Literature Equation Rates}

In this section, the gas generation rates observed in Series III testing are compared with rates found in the literature. In the analysis of the gas generation data from tests with fuel particles plus sludge, the gas quantities generated from the sludge composites (KC-2/3 M250, KC Can Comp, and KC Floor) were assumed to be negligible relative to the hydrogen gas produced by the corroding uranium metal particles. Therefore, all those data were normalized to a basis of gas generated per unit mass of fuel particles (i.e., the masses of the KE Basin sludge samples, added in some tests, were not considered). The assumption of gas generation being dominated by uranium metal corrosion (which largely occurred in these anoxic test conditions to produce $\mathrm{H}_{2}$ gas) is supported by the fact that the product gas compositions were $94.5 \%$ to $98.9 \% \mathrm{H}_{2}$ in the tests with both fuel particles and sludge, and were $99.62 \%$ to $99.87 \% \mathrm{H}_{2}$ in the tests with fuel particles only. However, one of the tests with both fuel particles and sludge (SNF + Can 60L) had slightly different fission product gas compositions, suggesting that the sludge component contained some uranium metal as well (see Section 5.4). In addition to $\mathrm{H}_{2}$ gas generation rates, the rates of metal fuel matrix-trapped $\mathrm{Kr}$ and $\mathrm{Xe}$ fission gas release were used to monitor fuel corrosion rates.

Appendix $\mathrm{C}$ describes the step-by-step analysis of the gas generation rate data based on $\mathrm{H}_{2}$ evolution and the release of fission product gases ( $\mathrm{Kr}$ and $\mathrm{Xe}$ ). In this analysis, actual fuel particle sizes (i.e., nominal diameters determined from sieving, corrected by the amount of uranium lost to corrosion as determined by the total gas as $\mathrm{H}_{2}, \mathrm{Kr}$, or Xe evolution) were compared to calculated theoretical particle sizes. The theoretical particle sizes were calculated by determining the "effective particle diameters" required to generate the measured Series III gas rate if the uranium metal, as spheres, reacted in accordance with the rate laws published in the technical literature. Two rate laws were considered and used to calculate the theoretical particle diameters: the rate equation provided in the SNF Databook, Vol. 1 (Reilly 1998) and a rate correlation provided in Hilton (2000) for uranium metal in oxygen-free (anoxic) water. The potential impacts of the generation of oxidizing species from radiolysis on the assumption of "oxygenfree" (anoxic) water were evaluated (Appendix D). Based on this evaluation, it was judged that the potential quantity of oxygen generated by radiolysis was sufficiently low to have no significant impact on the validity of the comparison of the Series III test results with the SNF and literature oxygen-free rate equations.

\subsection{Reaction Rate Comparison Factors}

The reaction rate enhancement factor (or comparison factor) can be determined as the ratio of the theoretical reaction surface area (on uranium metal particles) to the known (or actual) reaction surface area. The reaction rate enhancement factor is also shown to be the ratio of the actual to theoretical particle radii (see Appendix C, Section C.1). The rate enhancement factors or ratios of the reactions thus can be used to adjust the literature rate law to reflect the actual uranium metal reaction rates observed in the Series III testing. The results from actual and theoretical particle size analysis were used to derive rate comparison factors. In the SNF Project, the reaction rate law multiplier (enhancement factor) is applied to the expected rate as derived by critical analyses of the published uranium corrosion studies (i.e., Reilly 1998) for design calculations and safety basis analyses. The SNF Project's rate enhancement factor has two components: an experimental component based on comparing observed reaction rates with the predicted rates and a conservatism component based on engineering judgment. The analysis provided here and more explicitly in Appendix $\mathrm{C}$ focuses only on the experimentally based component of the enhancement factor. 
Table 6.1 summarizes the rate comparison factors developed from each gas generation data set $(\mathrm{Kr}, \mathrm{Xe}$, and $\mathrm{H}_{2}$ ) with the SNF baseline rate equation (Reilly 1998) and the Hilton (2000) rate equation that are given in detail in Tables C.1 and C. 2 of Appendix C. The comparison factors generated from the tests conducted with fuel particles (no added sludge) are listed separately from those generated from tests that included both fuel particles and added sludge. The factors for $\mathrm{Kr}$ and $\mathrm{Xe}$ were developed from the test intervals for which gas samples were collected and analyzed. The factors for $\mathrm{H}_{2}$ were developed from total gas generation data, and taking into account that $>94 \%$ of the gas was $\mathrm{H}_{2}$.

The rate enhancement factor for the fuel particles is about $0.33 \pm 0.16$, based on the SNF rate equation (Reilly 1998) and fission product gas data; that is, the fuel particles in Series III reacted at about one-third of the rate predicted by the SNF rate equation. The rate enhancement factor for fuel particles is about $0.41 \pm 0.18$, based on the Hilton (2000) rate equation and fission product gas data. The Hilton correlation thus provides a slightly better fit with the Series III data than the Reilly (1998) correlation, as the rate enhancement factor is closer to unity.

As shown in Table 6.1, the rate enhancement factors are remarkably consistent within the data sets for each rate law. The fission product $(\mathrm{Kr}$ and $\mathrm{Xe})$ gas data, both with and without sludge addition, give the same values for the enhancement factors. Overall, the $\mathrm{H}_{2}$ data set, without sludge addition, exhibits greater scatter, but agrees with the fission product data sets.

Table 6.1. Rate Comparison/Enhancement Factors

\begin{tabular}{|c|c|c|c|c|}
\hline Reilly (1998) & $\begin{array}{c}\log k^{\prime}(\mu \mathrm{m} / \mathrm{hr})= \\
8.226-3016 / T\end{array}$ & $\begin{array}{l}\text { No. of Data } \\
\text { Points }\end{array}$ & Average & $\begin{array}{l}\text { Standard } \\
\text { Deviation }\end{array}$ \\
\hline \multirow{2}{*}{ Kr Release } & Fuel Particles Only & 10 & 0.33 & 0.16 \\
\hline & Fuel Particles+Sludge & 12 & 0.34 & 0.19 \\
\hline \multirow{2}{*}{ Xe Release } & Fuel Particles Only & 10 & 0.33 & 0.15 \\
\hline & Fuel Particles+Sludge & 12 & 0.32 & 0.15 \\
\hline \multirow{2}{*}{$\mathrm{H}_{2}$ Generation } & Fuel Particles Only & 29 & 0.28 & 0.22 \\
\hline & Fuel Particles+Sludge & 23 & 0.18 & 0.17 \\
\hline \multicolumn{2}{|c|}{ All Data (Reilly 1998) } & 96 & 0.28 & 0.25 \\
\hline Hilton (2000) & $\begin{array}{c}\log k^{\prime}(\mu \mathrm{m} / \mathrm{hr})= \\
9.422-3470 / T\end{array}$ & $\begin{array}{l}\text { No. of Data } \\
\text { Points }\end{array}$ & Average & $\begin{array}{l}\text { Standard } \\
\text { Deviation }\end{array}$ \\
\hline \multirow{2}{*}{ Kr Release } & Fuel Particles Only & 10 & 0.41 & 0.18 \\
\hline & Fuel Particles+Sludge & 12 & 0.42 & 0.25 \\
\hline \multirow{2}{*}{ Xe Release } & Fuel Particles Only & 10 & 0.41 & 0.17 \\
\hline & Fuel Particles+Sludge & 12 & 0.40 & 0.22 \\
\hline \multirow{2}{*}{$\mathrm{H}_{2}$ Generation } & Fuel Particles Only & 29 & 0.40 & 0.32 \\
\hline & Fuel Particles+Sludge & 23 & 0.25 & 0.20 \\
\hline \multicolumn{2}{|c|}{ All Data (Hilton 2000) } & 96 & 0.37 & 0.25 \\
\hline
\end{tabular}


However, enhancement factors from the $\mathrm{H}_{2}$ data for tests containing both fuel particles and sludge are $35 \%$ to $40 \%$ lower than those derived from the other data sets. This finding strongly suggests that the sludge blanket consumes or entraps a significant fraction of the $\mathrm{H}_{2}$ that is released during uranium metal corrosion. This observation also indicates that the enhancement factors developed for the $\mathrm{H}_{2}$ data sets with both fuel particles and sludge are biased low.

The enhancement factors based on the $\mathrm{H}_{2}$ data for the individual tests containing fuel particles but no added sludge (Tables C.1 and C.2) generally decrease as metal continues to corrode. This observation would support the hypothesis that the reaction rate decreases as the uranium metal surface becomes buried in a sludge corrosion product layer.

The rate decrease caused by sludge blanketing becomes more pronounced as the depth of the overlying sludge increases. This is shown in Figures 6.1 and 6.2, for SNF Databook (Reilly 1998) and Hilton (2000) rates, respectively, based on Xe generation rate data (the most reliable measurements) for the $80^{\circ} \mathrm{C}$ tests (which are the most extensive in the Series III testing). The sludge depth was determined from posttest examination and measurements of sludge density. In general, these figures show that, as the sludge depth increases, observed reaction rates decrease and deviate away from those predicted by the literature rate laws.

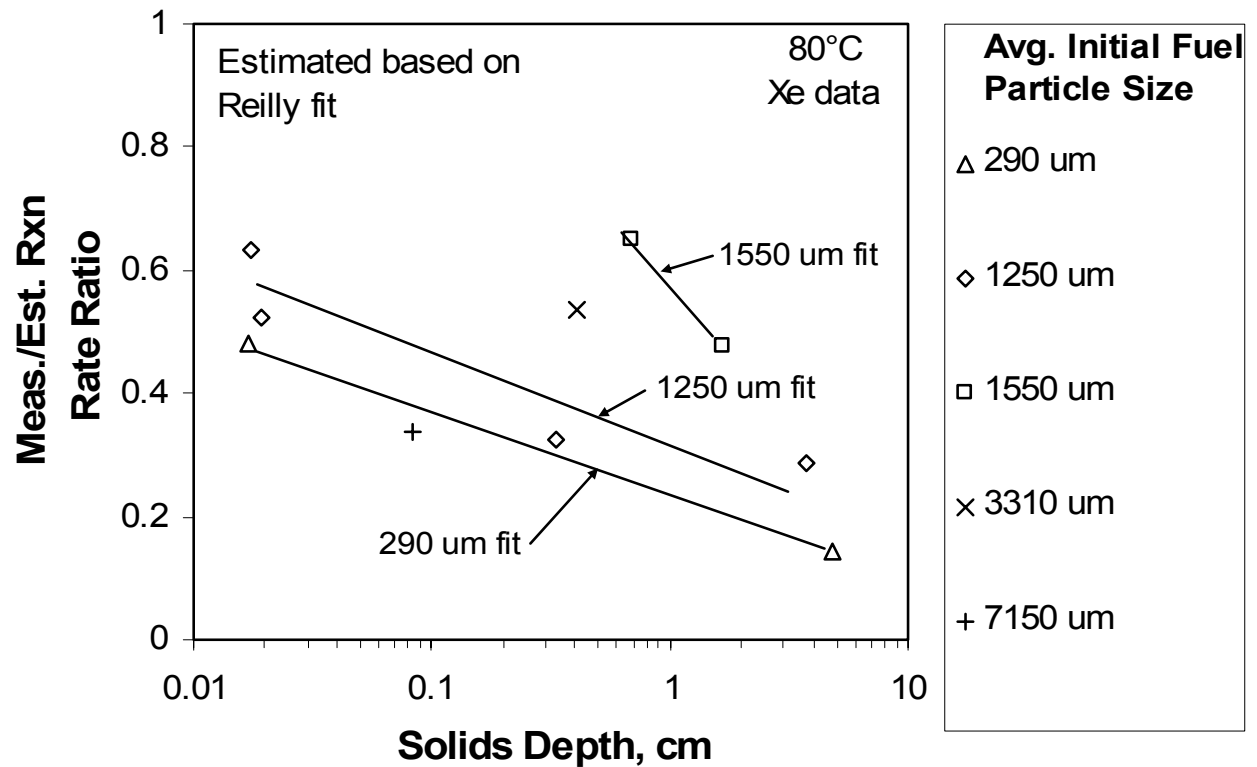

Figure 6.1. Ratio of Actual to Theoretical Fuel Particle Diameters (Enhancement Factor) as a Function of Solids Depth (Sludge Blanket) in the Gas Generation Reaction Vessels (Reilly Fit). The theoretical particle diameters were determined from the measured Xe gas release and the SNF Databook (Vol. 1) reaction rate equation for uranium metal in oxygen-free water provided in Reilly (1998). Solids depth was determined by dividing the known solids volume by the vessel cross-sectional area. 


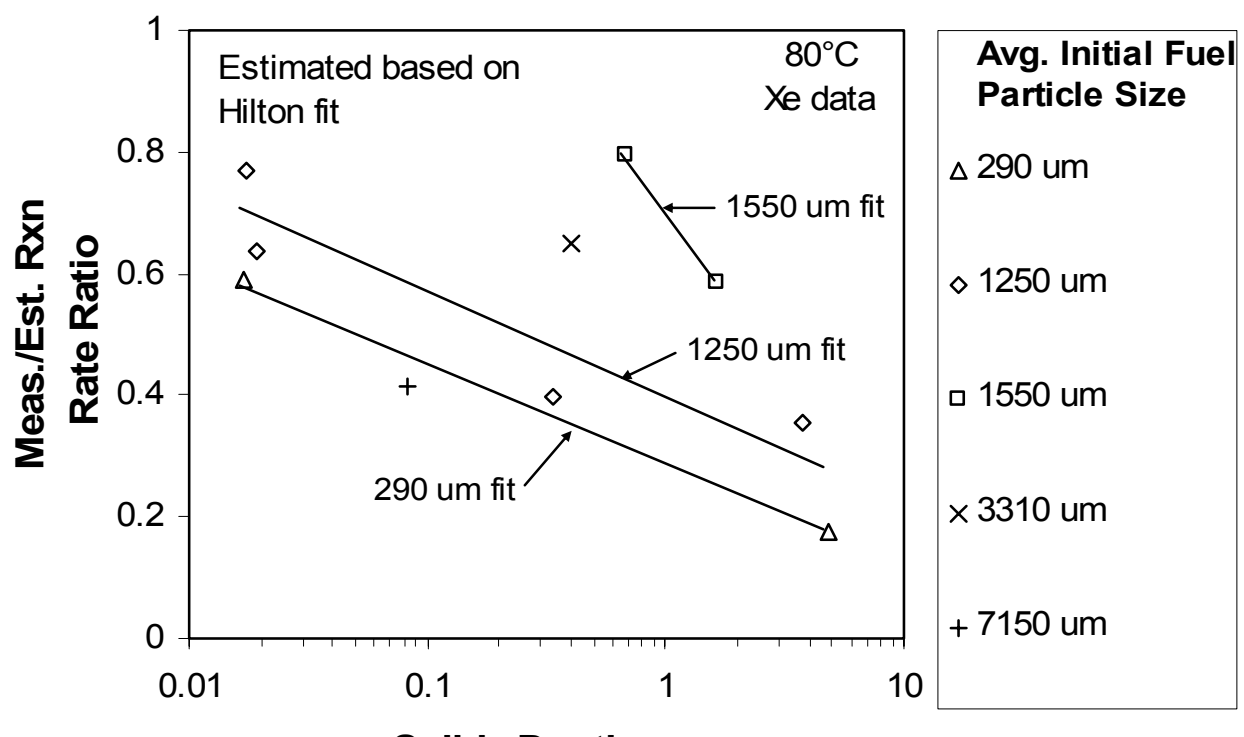

Solids Depth, cm

Figure 6.2. Ratio of Actual to Theoretical Fuel Particle Diameters (Enhancement Factor) as a Function of Solids Depth (Sludge Blanket) in the Gas Generation Reaction Vessels (Hilton Fit). The theoretical particle diameters were determined from the measured Xe gas release and the reaction rate equation for uranium metal in oxygen-free water provided in Hilton (2000). Solids depth was determined by dividing the known solids volume by the vessel crosssectional area.

The rates of total gas generated at $80^{\circ} \mathrm{C}$ for tests run to completion (Tests 6 through 8 ) are compared with the hydrogen generation rates predicted based on the Reilly (1998) and Hilton (2000) fits of published reaction kinetics (Figures 6.3 and 6.4, respectively). The time-scales for the test data were re-indexed to start from the onset of vessel heating to $80^{\circ} \mathrm{C}$ (i.e., the initial test intervals at hot cell temperatures shown in Figure 3.5 are not included in Figures 6.3 and 6.4).

The total gas generation rate (at $80^{\circ} \mathrm{C}$ ) from SNF M500 80L (Test 6) is compared in Figure 6.3 with the $\mathrm{H}_{2}$ generation profile predicted by the Reilly (1998) and Hilton (2000) kinetics for monodisperse 290- $\mu \mathrm{m}$ fuel particles containing $74.2 \mathrm{wt} \%$ uranium metal. Consistent with the analysis in Appendix C (Tables C.1 and C.2), Figure 6.3 shows that the predicted $\mathrm{H}_{2}$ gas generation rates based on Reilly (1998) and Hilton (2000) are significantly greater than the rates measured during all test intervals for Test 6.

The total gas generation profiles (at $80^{\circ} \mathrm{C}$ ) from SNF Mid 80L and SNF Mid 80L Dup (Tests 7 and 8 ) are compared in Figure 6.4 with the $\mathrm{H}_{2}$ generation predicted by Reilly (1998) and Hilton (2000) for monodisperse $1250-\mu \mathrm{m}$ fuel particles containing $93 \mathrm{wt} \%$ uranium metal. Consistent with the rate analysis in Appendix C, the reaction rates for SNF Mid 80 Dup (Test 8) exceeded the literature rates during the initial $\sim 250 \mathrm{hr}$ at $80^{\circ} \mathrm{C}$. Also, in the initial test interval analyzed (Appendix C), the rate predicted by Hilton (2000) slightly exceeded the rate measured for SNF Mid 80L (Test 7). Tests 7 and 8 are the only tests in Series III in which the predicted literature rates exceeded the actual measured rates for some test intervals. Part of the reason for the minor discrepancies between the predicted and actual data is that the predictions assumed a single nominal particle size $(1250 \mu \mathrm{m})$, while the actual fuel fragments included a distribution of particle sizes. Smaller particles, with greater surface area per unit mass, dominate the initial gas production and thus would proceed faster than what would be predicted for the larger nominal 


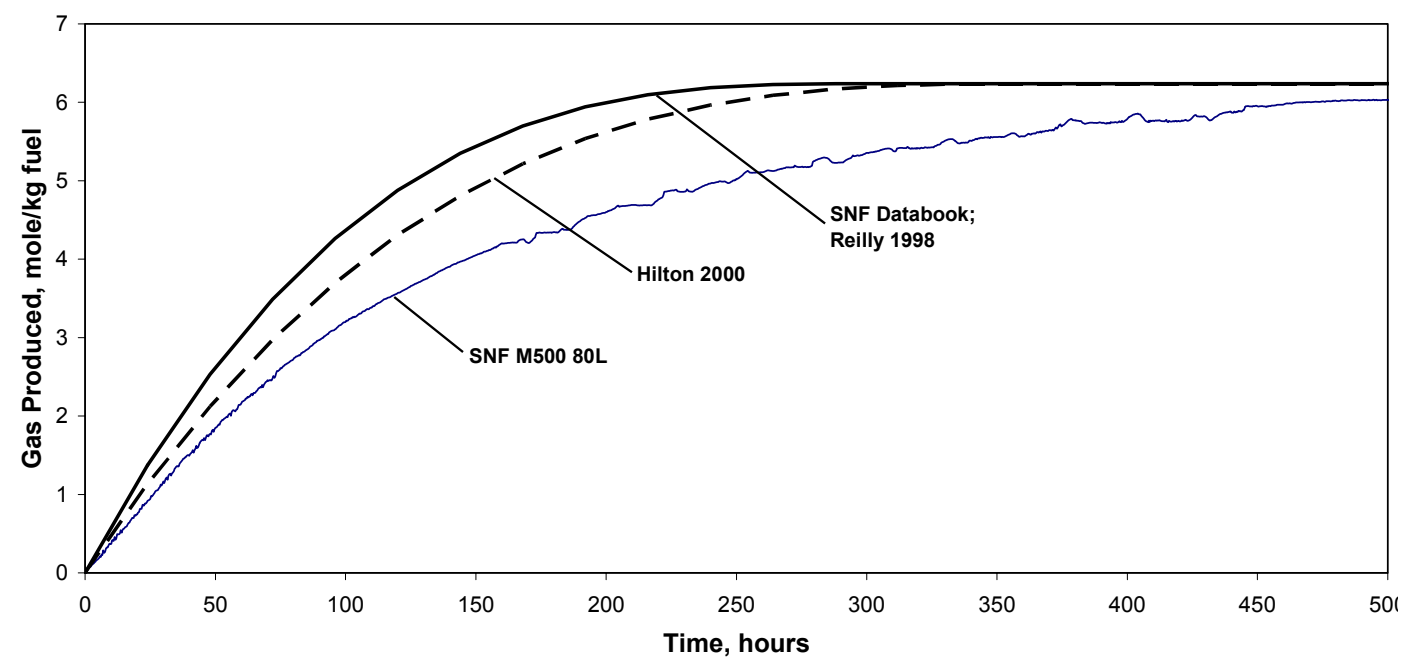

Figure 6.3. Comparison of Total Gas Generation at $80^{\circ} \mathrm{C}$ from SNF M500 80L $(<500 \mu \mathrm{m})$ (Test 6) with Gas Generation Profiles Predicted by the SNF Databook Equation and Hilton Equation for Monodisperse 290- $\mu \mathrm{m}$ Fuel Particles Containing 74.2 wt\% Uranium Metal

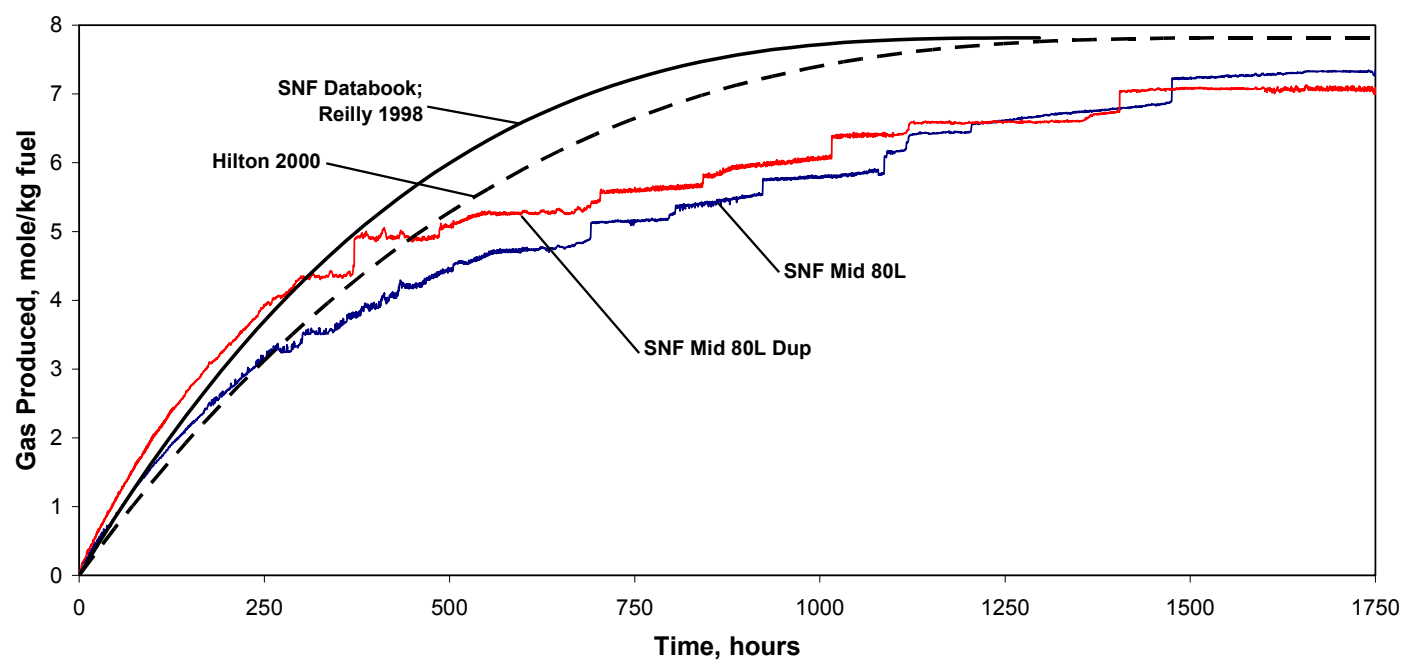

Figure 6.4. Comparison of Total Gas Generation at $80^{\circ} \mathrm{C}$ from SNF Mid 80L and SNF Mid 80L Dup $(500-2000 \mu \mathrm{m})($ Tests 7 and 8$)$ with Gas Generation Profiles Predicted by the SNF Databook Equation and Hilton Equation for Monodisperse 1250- $\mu \mathrm{m}$ Fuel Particles Containing $93 \mathrm{wt} \%$ Uranium Metal

particle size. Conversely, larger particles, with lower surface area per unit mass, dominate the later part of the gas production (Figure 6.4) and would react at lower rates than would be predicted at advanced reaction times. The single representative particle size, $1250 \mu \mathrm{m}$, was based on a mass average of the particle size distribution (Section 2.2.1). If a surface area weighted average particle size had been used $(1120 \mu \mathrm{m})$, both (Reilly 1998) and Hilton (2000) reaction equations would have predicted higher initial gas generation rates. However, use of a surface area weighted average particle size provides less conservative rate comparisons. 


\subsection{Activation Energy Evaluation}

Activation energies for uranium metal corrosion in the Series III tests were also evaluated for comparison with the published values and the values found in the Series I testing. The steps to derive the activation energy parameters by the Arrhenius equation are:

1. Calculate inverse absolute temperatures $(1 / T)$ and the natural logarithms $(\ln )$ of the inverse cubic rates (ICR; see Appendix C, Section C.1, for a discussion of rate parameters).

2. Plot $\ln (\mathrm{ICR})$ versus $1 / \mathrm{T}$ and determine the slopes of the plots for the $\mathrm{Kr}, \mathrm{Xe}$, and $\mathrm{H}_{2}$ gas generation rate data.

3. Calculate the activation energies $\left(\mathrm{E}_{\mathrm{a}}\right)$ by multiplying the slopes by the gas constant, $1.987 \mathrm{cal} / \mathrm{mole}-\mathrm{K}$.

Fission product gas and $\mathrm{H}_{2}$ gas generation rate data were analyzed to determine the activation energies of uranium metal corrosion reactions in the Series III testing. The gas generation rate data include not only the results from tests at elevated temperatures (at about $40^{\circ} \mathrm{C}, 60^{\circ} \mathrm{C}, 80^{\circ} \mathrm{C}$, and $95^{\circ} \mathrm{C}$ ) but also the data from the initial periods from 70 to $130 \mathrm{hr}$ of reaction time when the materials were at ambient hot cell temperature $\left(\sim 33^{\circ} \mathrm{C}\right)$ and had overcome their induction periods. Table 6.2 presents the ICRs from specified time intervals during the gas generation tests. The ICRs were determined as described in Steps 4 and 5 in Section C.1 of Appendix C.

Independent data sets were developed from the $\mathrm{Kr}, \mathrm{Xe}$, and $\mathrm{H}_{2}$ inverse cubic gas generation rates. The rate data, and the corresponding inverse absolute temperature data, then were used to prepare Arrhenius plots (Figures 6.5 through 6.10). Linear regressions of the plots were used to obtain the Arrhenius equation parameters and to calculate the activation energies from the slopes. Table 6.3 summarizes the Arrhenius parameters and activation energies developed from the kinetic rate analysis. Values for the goodness of fit $\left(\mathrm{R}^{2}\right.$; correlation coefficients) are 0.95 or higher in all cases with most above 0.99 (Table 6.3).

The activation energies are consistently higher for the $\mathrm{H}_{2}$-based plots than for the $\mathrm{Kr}$ - or Xe-based plots. The divergence between the $\mathrm{H}_{2}$ and fission product gas data is greater for the fuel particles-plus-sludge tests than for the fuel particles-only tests. The higher activation energy for $\mathrm{H}_{2}$ measurements may reflect the effect of higher temperature in driving $\mathrm{H}_{2}$ from the fuel particles to prevent its retention in metal hydrides (Reaction 4; Section 4.1).

The activation energies for the fuel particles-only tests for all gases are closely grouped, lying between 16.4 and $17.1 \mathrm{kcal} / \mathrm{mole}$. This range of activation energies is closer to the Hilton (2000) activation energy $(15.9 \mathrm{kcal} / \mathrm{mole})$ than to the Reilly (1998) value $(13.8 \mathrm{kcal} / \mathrm{mole})$ and near the KC-2/3 P250 Series I test value of $15.8 \mathrm{kcal} / \mathrm{mole}$ as found based on Xe release rate data (Section 4.1.1 of Bryan et al. 2001). The range of activation energies $(15.5$ to $17.1 \mathrm{kcal} / \mathrm{mole})$ observed from fission product gas data in the fuel particles-plus-sludge tests (Tests 2 and 10) with KE canister sludge also are nearer the Hilton (2000) activation energy and Series I results than to the SNF Databook, Vol. 1 (Reilly 1998) value.

In contrast, the fuel particles-plus-sludge tests with canister fines (SNF + Can Fines 60S, Test 1) or floor sludge (SNF + Floor 60L, Test 11) have fission product gas activation energies (10.7 to $12.8 \mathrm{kcal} / \mathrm{mole}$ ) significantly lower than either the Hilton (2000) or Reilly (1998) values. It is suspected that the canister fines sludge (the M250 fraction of $\mathrm{KC}-2 / 3$ ) had suffered some air oxidation such that both the floor sludge and canister fines sludge contained hexavalent uranium (for example, in the form of schoepite). 
The hexavalent uranium present in the sludge could have acted as a sink for evolved $\mathrm{H}_{2}$ to react and form phases such as $\mathrm{U}_{3} \mathrm{O}_{8}$ (Gillies 1958; Rovira et al. 2003). By consuming $\mathrm{H}_{2}$, the $\mathrm{UH}_{3}$-mediated corrosion of the uranium metal would be inhibited; however, this explanation remains speculative.

Table 6.2. Inverse Cubic Rates $\left[(1-\mathrm{f})^{1 / 3} / \mathrm{hr}\right]$ and Fractional Rates $[\mathrm{f} / \mathrm{hr}]$ for Series III Tests

\begin{tabular}{|c|c|c|c|c|c|c|c|c|}
\hline \multirow[b]{2}{*}{ Fuel Particles Only } & \multirow[b]{2}{*}{ Time, hr } & \multirow[b]{2}{*}{ Temp., ${ }^{\circ} \mathrm{C}$} & \multicolumn{3}{|c|}{ Rate, $(1-f)^{1 / 3} / \mathrm{hr}$} & \multicolumn{3}{|c|}{ Rate, $\mathbf{f} / \mathbf{h r}$} \\
\hline & & & $\mathbf{K r}$ & $\mathbf{X e}$ & $\mathbf{H}_{2}$ & $\mathbf{K r}$ & $\mathbf{X e}$ & $\mathbf{H}_{2}$ \\
\hline \multirow{4}{*}{$\begin{array}{c}\text { SNF Mid 60S } \\
\text { Test } 3\end{array}$} & $70-130$ & 33.33 & -- & -- & $7.22 \mathrm{E}-06$ & -- & -- & $2.16 \mathrm{E}-05$ \\
\hline & $300-964.6$ & 60.80 & $6.05 \mathrm{E}-05$ & $5.70 \mathrm{E}-05$ & $6.60 \mathrm{E}-05$ & $1.82 \mathrm{E}-04$ & $1.71 \mathrm{E}-04$ & $1.98 \mathrm{E}-04$ \\
\hline & $1223-1294$ & 80.54 & $2.16 \mathrm{E}-04$ & $2.22 \mathrm{E}-04$ & $2.62 \mathrm{E}-04$ & $6.46 \mathrm{E}-04$ & $6.67 \mathrm{E}-04$ & 7.87E-04 \\
\hline & $1294-1323.3$ & 95.47 & $6.36 \mathrm{E}-04$ & $5.93 \mathrm{E}-04$ & 7.89E-04 & $1.91 \mathrm{E}-03$ & $1.78 \mathrm{E}-03$ & $2.37 \mathrm{E}-03$ \\
\hline \multirow{4}{*}{$\begin{array}{l}\text { SNF Mid } 40 \mathrm{~S} \\
\text { Test } 4\end{array}$} & $70-130$ & 33.03 & -- & -- & $6.85 \mathrm{E}-06$ & -- & -- & $2.06 \mathrm{E}-05$ \\
\hline & $140-1266$ & 42.49 & $1.30 \mathrm{E}-05$ & $1.37 \mathrm{E}-05$ & $1.21 \mathrm{E}-05$ & $3.91 \mathrm{E}-05$ & $4.12 \mathrm{E}-05$ & $3.64 \mathrm{E}-05$ \\
\hline & $1266-1577$ & 61.28 & -- & -- & $6.33 \mathrm{E}-05$ & -- & -- & 1.90E-04 \\
\hline & $1577-1624.3$ & 80.10 & -- & -- & $2.87 \mathrm{E}-04$ & -- & -- & $8.61 \mathrm{E}-04$ \\
\hline \multirow{2}{*}{$\begin{array}{l}\text { SNF P2000 80S } \\
\text { Test } 5\end{array}$} & $70-130$ & 33.04 & -- & -- & $2.85 \mathrm{E}-06$ & -- & -- & $8.54 \mathrm{E}-06$ \\
\hline & 145 & 80.86 & $1.78 \mathrm{E}-04$ & $1.77 \mathrm{E}-04$ & $1.91 \mathrm{E}-04$ & $5.33 \mathrm{E}-04$ & $5.32 \mathrm{E}-04$ & 5.73E-04 \\
\hline \multirow{2}{*}{$\begin{array}{l}\text { SNF M500 80L } \\
\text { Test } 6\end{array}$} & $70-130$ & 34.28 & -- & -- & $1.84 \mathrm{E}-05$ & -- & -- & $5.53 \mathrm{E}-05$ \\
\hline & 150 & 80.26 & $1.34 \mathrm{E}-03$ & $1.54 \mathrm{E}-03$ & $1.98 \mathrm{E}-03$ & $4.00 \mathrm{E}-03$ & $4.62 \mathrm{E}-03$ & $5.94 \mathrm{E}-03$ \\
\hline \multirow{2}{*}{$\begin{array}{l}\text { SNF Mid 80L } \\
\text { Test } 7\end{array}$} & & & -- & -- & & -- & -- & \\
\hline & & & $3.98 \mathrm{E}-04$ & $3.66 \mathrm{E}-04$ & $2.96 \mathrm{E}-04$ & $1.19 \mathrm{E}-03$ & $1.10 \mathrm{E}-03$ & \\
\hline \multirow{2}{*}{$\begin{array}{l}\text { SNF Mid 80L Dup } \\
\text { Test } 8\end{array}$} & & & -- & -- & $2.83 \mathrm{E}-05$ & -- & -- & $8.4 \mathrm{C}$ \\
\hline & 150 & & 79E-04 & $4.53 \mathrm{E}-04$ & $8-04$ & \begin{tabular}{|l}
$1.44 \mathrm{E}-03$ \\
\end{tabular} & $1.36 \mathrm{E}-03$ & 2.4 \\
\hline \multirow{3}{*}{$\begin{array}{c}\text { SNF Fragment } \\
\text { (Fuel Fragment) } \\
\text { Test } 9\end{array}$} & & & -- & -- & -05 & -- & -- & $3.58 \mathrm{E}-05$ \\
\hline & 15 & 80.00 & $9.62 \mathrm{E}-06$ & $1.25 \mathrm{E}-05$ & 1.2 & $2.88 \mathrm{E}-05$ & $3.76 \mathrm{E}-05$ & 3.6 \\
\hline & 1600 & 80.00 & $4.59 \mathrm{E}-05$ & $4.09 \mathrm{E}-05$ & 5.5 & $1.38 \mathrm{E}-04$ & $1.23 \mathrm{E}-04$ & $1.67 \mathrm{E}-04$ \\
\hline \multicolumn{9}{|l|}{$\begin{array}{c}\text { Fuel Particles } \\
\text { Plus Sludge }\end{array}$} \\
\hline \multirow{4}{*}{$\begin{array}{c}\text { SNF }+ \text { Can Fines } 60 \mathrm{~S} \\
\text { Test } 1\end{array}$} & $70-$ & 38.17 & -- & -- & $2.29 \mathrm{E}-05$ & -- & -- & $6.87 \mathrm{E}-05$ \\
\hline & $650-900$ & 63.67 & $1.68 \mathrm{E}-04$ & $1.63 \mathrm{E}-04$ & $1.18 \mathrm{E}-04$ & $5.05 \mathrm{E}-04$ & $4.89 \mathrm{E}-04$ & $3.55 \mathrm{E}-04$ \\
\hline & $1206-1278$ & 81.16 & $3.68 \mathrm{E}-04$ & $3.81 \mathrm{E}-04$ & $3.44 \mathrm{E}-04$ & $1.10 \mathrm{E}-03$ & $1.14 \mathrm{E}-03$ & $1.03 \mathrm{E}-03$ \\
\hline & $1278-1$ & 94.62 & $6.51 \mathrm{E}-04$ & $6.57 \mathrm{E}-04$ & 7.12E-04 & $1.95 \mathrm{E}-03$ & $1.97 \mathrm{E}-03$ & $2.14 \mathrm{E}-03$ \\
\hline \multirow{4}{*}{$\begin{array}{c}\text { SNF }+ \text { Can } 60 \mathrm{~S} \\
\text { Test } 2\end{array}$} & $70-130$ & 33.94 & -- & -- & $4.64 \mathrm{E}-07$ & -- & -- & $1.39 \mathrm{E}-06$ \\
\hline & $660-1239.6$ & 60.06 & $5.14 \mathrm{E}-05$ & $5.11 \mathrm{E}-05$ & $3.30 \mathrm{E}-05$ & $1.54 \mathrm{E}-04$ & $1.53 \mathrm{E}-04$ & 9.90E-05 \\
\hline & $1239.6-1312.3$ & 80.24 & $2.26 \mathrm{E}-04$ & $2.06 \mathrm{E}-04$ & $2.14 \mathrm{E}-04$ & $6.78 \mathrm{E}-04$ & $6.19 \mathrm{E}-04$ & $6.44 \mathrm{E}-04$ \\
\hline & $1312.3-1341.6$ & 94.74 & $5.88 \mathrm{E}-04$ & $5.87 \mathrm{E}-04$ & 7.09E-04 & $1.76 \mathrm{E}-03$ & $1.76 \mathrm{E}-03$ & $2.13 \mathrm{E}-03$ \\
\hline \multirow{4}{*}{$\begin{array}{c}\mathrm{SNF}+\mathrm{Can} 60 \mathrm{~L} \\
\text { Test } 10\end{array}$} & $70-130$ & 32.26 & -- & -- & $1.95 \mathrm{E}-06$ & -- & -- & 5.84E-06 \\
\hline & $150-1234$ & 60.26 & $9.18 \mathrm{E}-05$ & $8.41 \mathrm{E}-05$ & $6.59 \mathrm{E}-05$ & $2.75 \mathrm{E}-04$ & $2.52 \mathrm{E}-04$ & $1.98 \mathrm{E}-04$ \\
\hline & $1234-1305$ & 80.21 & $4.33 \mathrm{E}-04$ & $3.53 \mathrm{E}-04$ & $2.62 \mathrm{E}-04$ & $1.30 \mathrm{E}-03$ & $1.06 \mathrm{E}-03$ & $7.87 \mathrm{E}-04$ \\
\hline & $1305-1352.6$ & 94.64 & $8.34 \mathrm{E}-04$ & \begin{tabular}{|l|}
$7.37 \mathrm{E}-04$ \\
\end{tabular} & 7.05E-04 & $2.50 \mathrm{E}-03$ & $2.21 \mathrm{E}-03$ & $2.12 \mathrm{E}-03$ \\
\hline \multirow{4}{*}{$\begin{array}{c}\text { SNF + Floor } 60 \mathrm{~L} \\
\text { Test } 11\end{array}$} & & 30.87 & -- & -- & $4.41 \mathrm{E}-06$ & -- & -- & $1.32 \mathrm{E}-05$ \\
\hline & $150-1241$ & 60.29 & $1.08 \mathrm{E}-04$ & $1.04 \mathrm{E}-04$ & $6.15 \mathrm{E}-05$ & $3.25 \mathrm{E}-04$ & $3.12 \mathrm{E}-04$ & $1.84 \mathrm{E}-04$ \\
\hline & 1241-1312 & 79.59 & $2.22 \mathrm{E}-04$ & $2.51 \mathrm{E}-04$ & $2.78 \mathrm{E}-04$ & $6.66 \mathrm{E}-04$ & $7.52 \mathrm{E}-04$ & $8.33 \mathrm{E}-04$ \\
\hline & $1312-1359.6$ & 92.78 & 5.85E-04 & 5.97E-04 & $8.58 \mathrm{E}-04$ & $1.75 \mathrm{E}-03$ & $1.79 \mathrm{E}-03$ & $2.58 \mathrm{E}-03$ \\
\hline
\end{tabular}




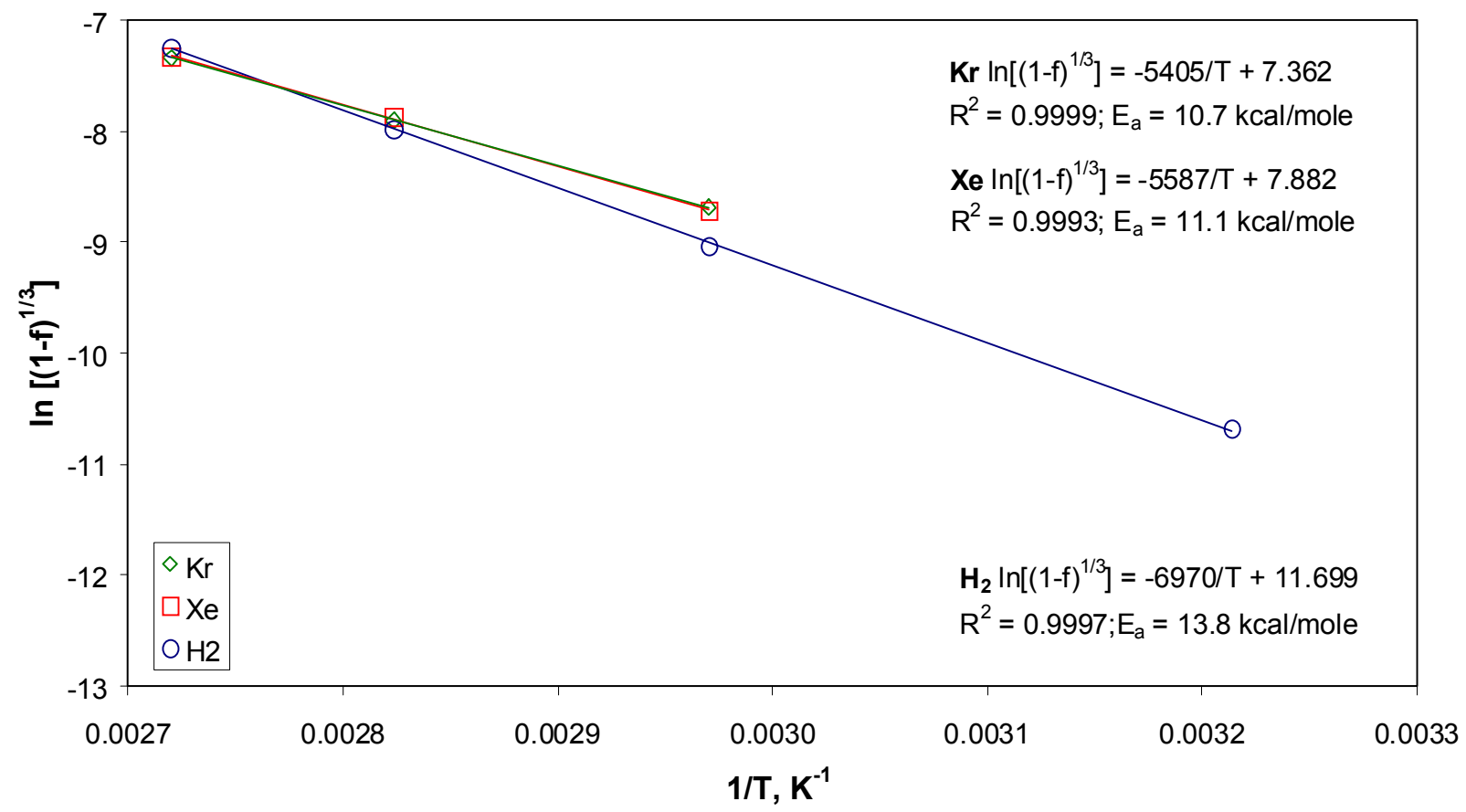

Figure 6.5. Arrhenius Plot (Kr, Xe, and $\mathrm{H}_{2}$ Determined Inverse Cubic Rates) for $\mathrm{SNF}+\mathrm{Can}$ Fines, Test 1 (i.e., KC-2/3 M250 canister sludge with $0-500-\mu \mathrm{m}$ fuel particles)

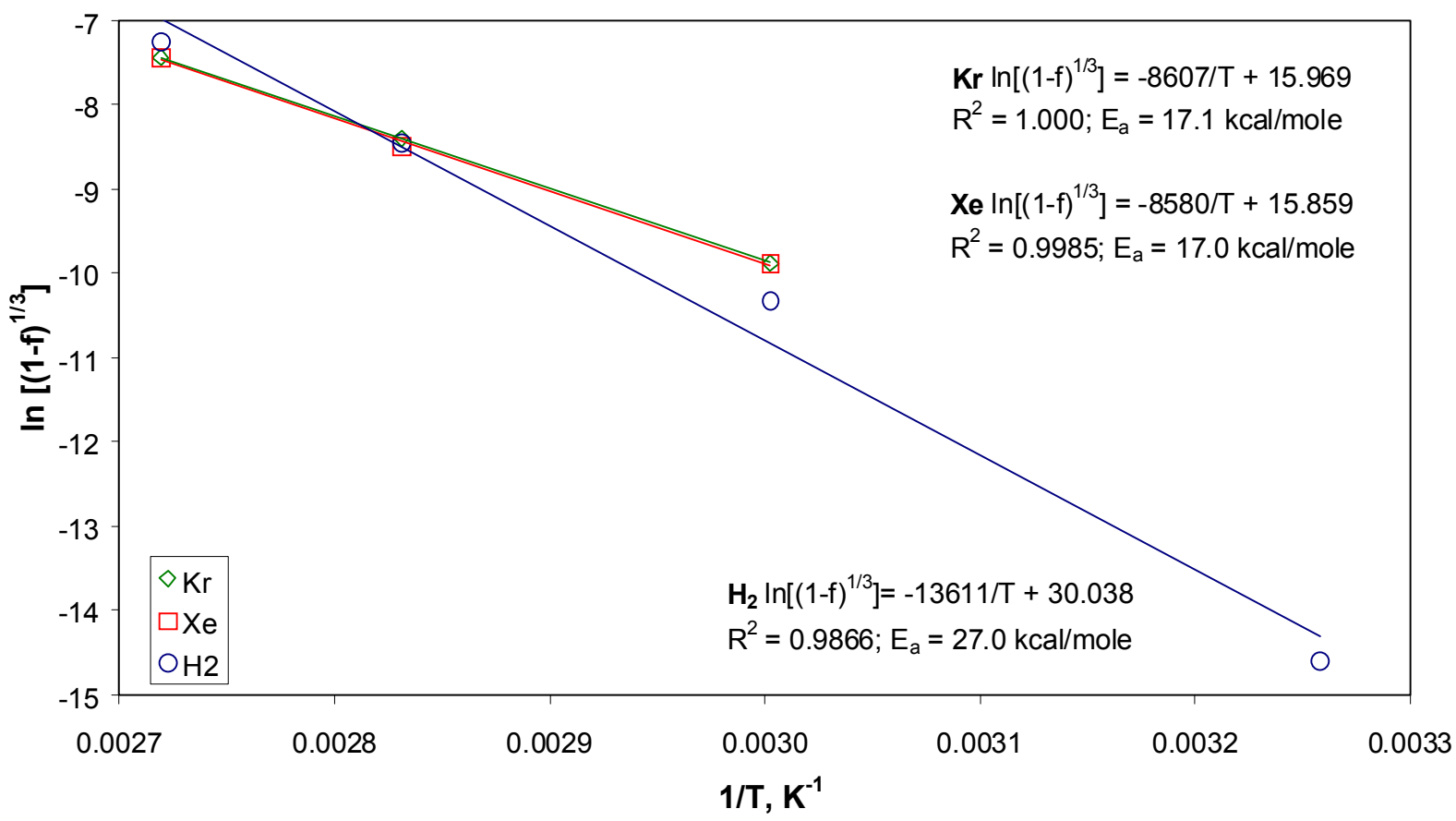

Figure 6.6. Arrhenius Plot (Kr, Xe, and $\mathrm{H}_{2}$ Determined Inverse Cubic Rates) for SNF + Can $60 \mathrm{~S}$, Test 2 (i.e., KC Can Comp sludge with $500-2000-\mu \mathrm{m}$ fuel particles) 


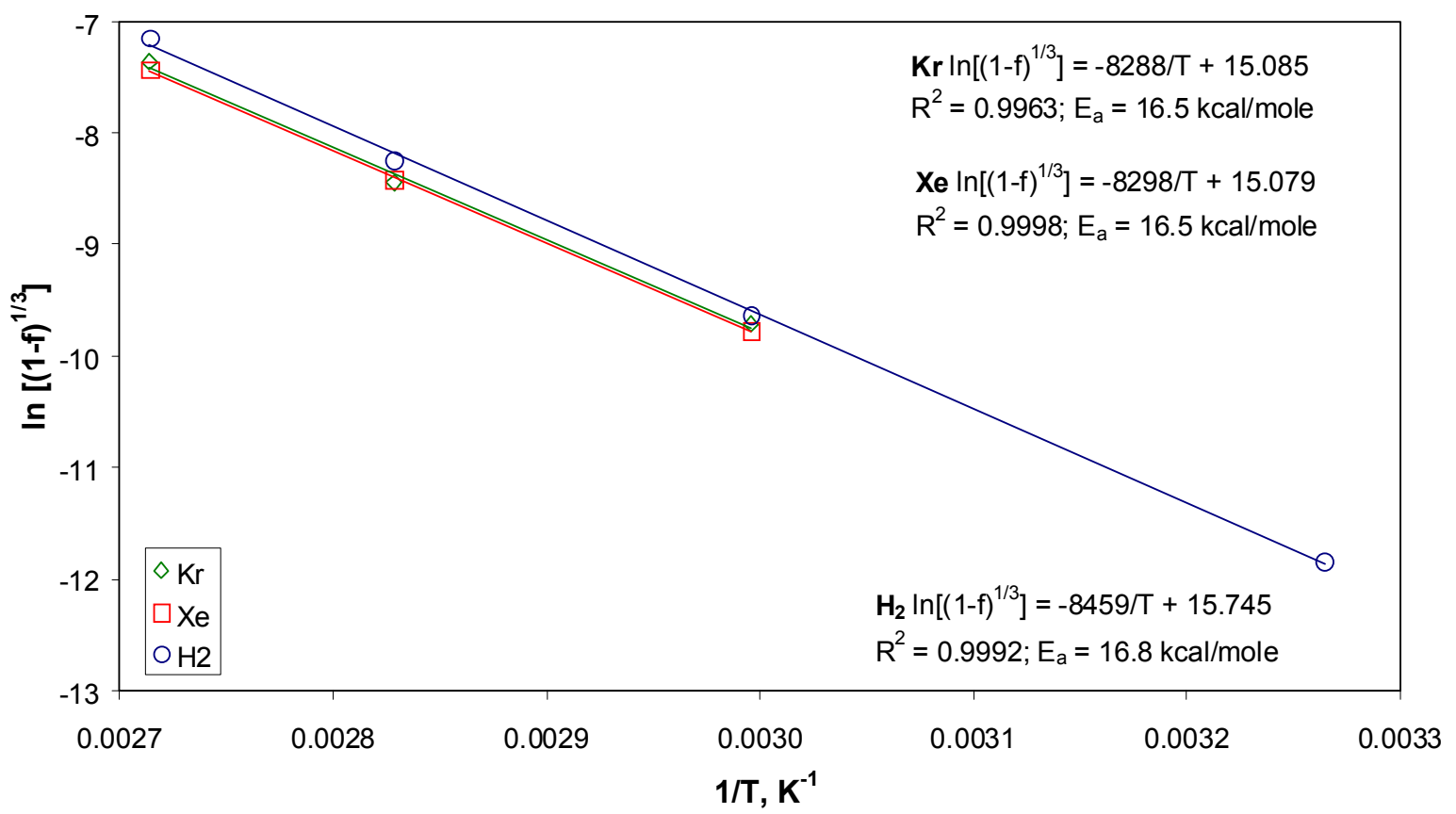

Figure 6.7. Arrhenius Plot (Kr, Xe, and $\mathrm{H}_{2}$ Determined Inverse Cubic Rates) for SNF Mid 60S, Test 3 (i.e., $500-2000-\mu \mathrm{m}$ fuel particles, no added sludge)

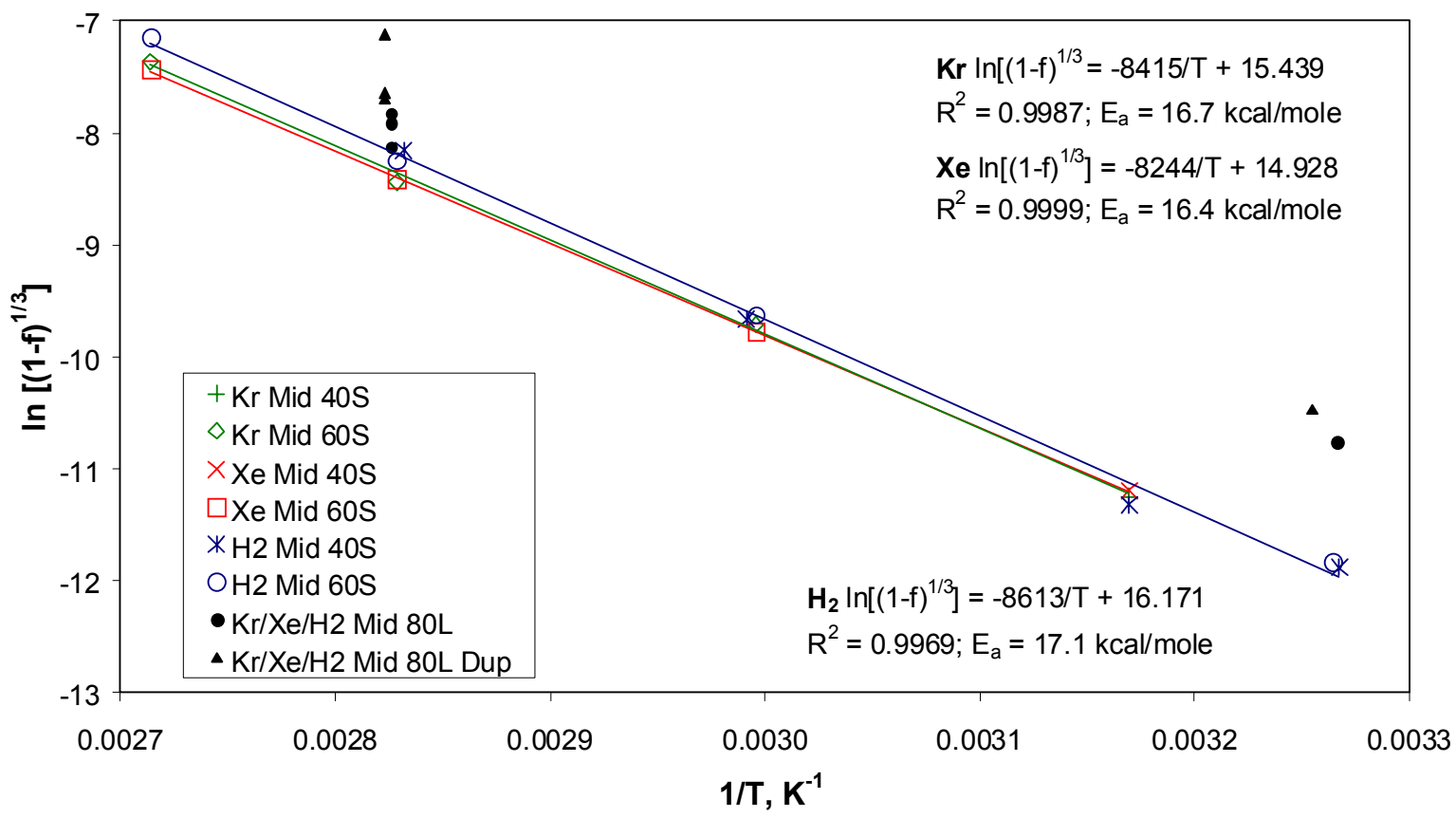

Figure 6.8. Arrhenius Plot (Kr, Xe, and $\mathrm{H}_{2}$ Determined Inverse Cubic Rates) for SNF Mid 60S, SNF Mid 40S, SNF Mid 80L, and SNF Mid 80L Dup, Tests 3, 4, 7, and 8 (i.e., all contained $500-2000-\mu \mathrm{m}$ fuel particles, with no added sludge) 


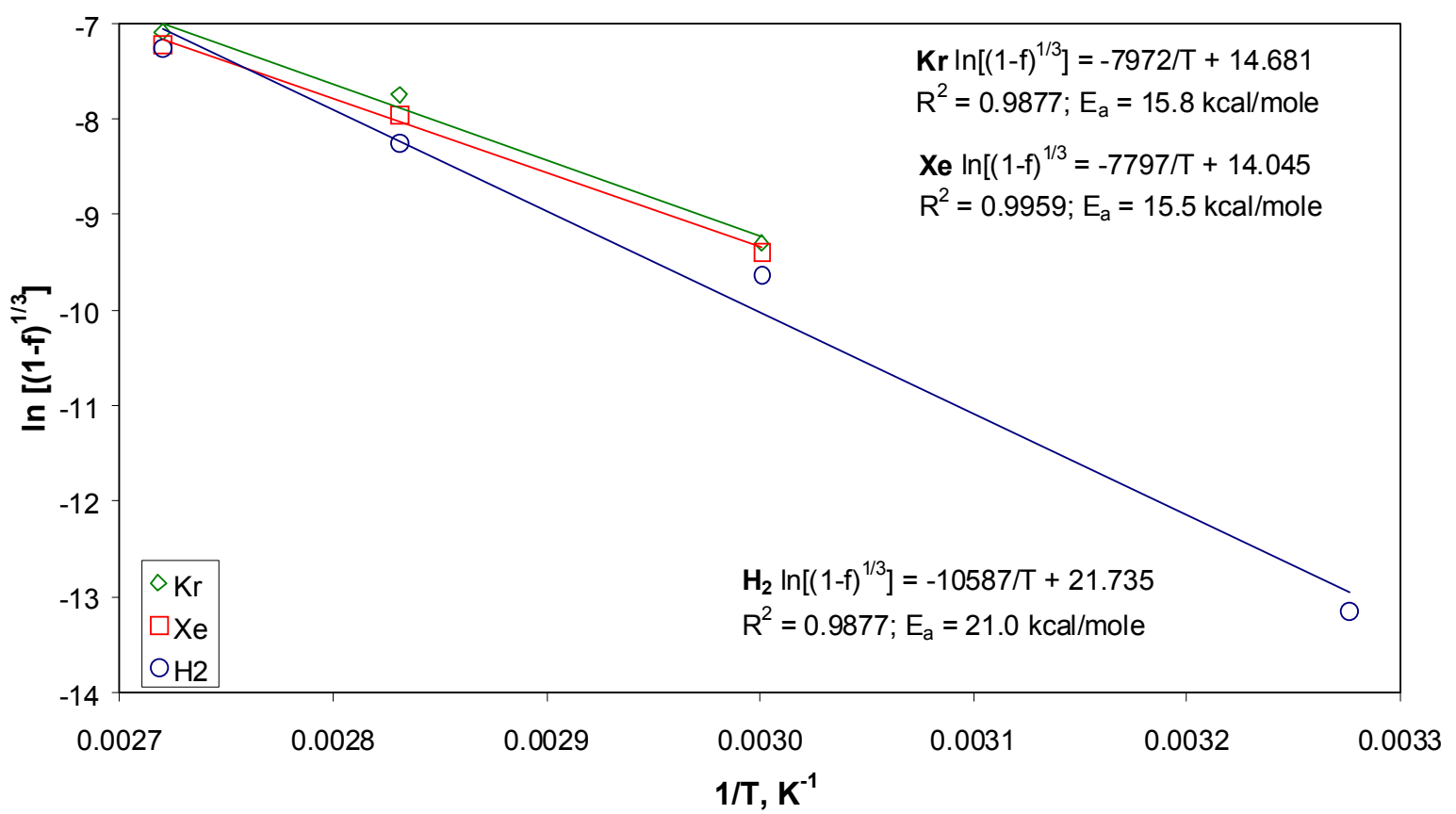

Figure 6.9. Arrhenius Plot (Kr, $\mathrm{Xe}$, and $\mathrm{H}_{2}$ Determined Inverse Cubic Rates) for $\mathrm{SNF}+\mathrm{Can} 60 \mathrm{~L}$, Test 10 (i.e., KC Can Comp sludge with $0-6350-\mu \mathrm{m}$ fuel fragments)

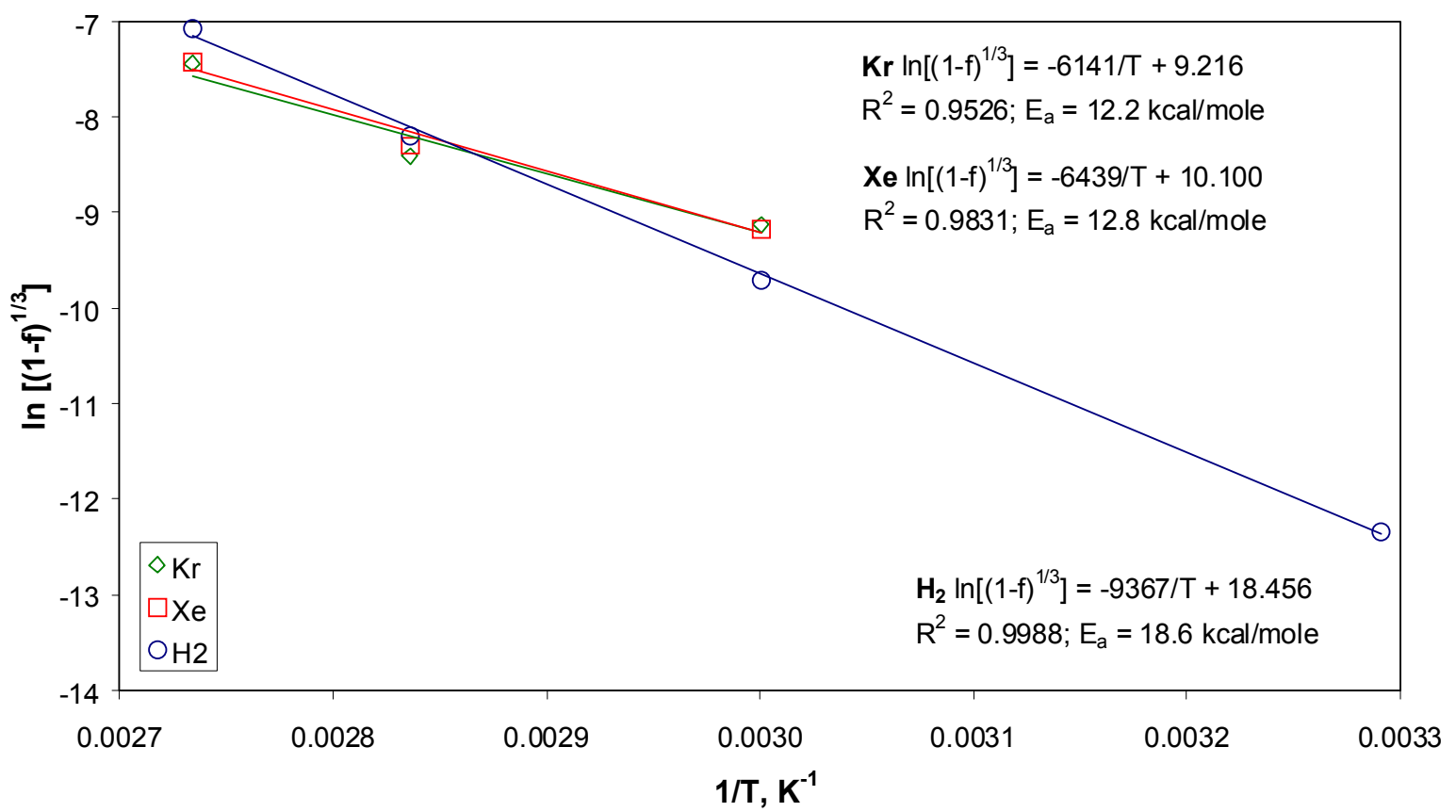

Figure 6.10. Arrhenius Plot (Kr, $\mathrm{Xe}$, and $\mathrm{H}_{2}$ Determined Inverse Cubic Rates) for $\mathrm{SNF}+$ Floor 60L, Test 11 (i.e., KC Floor Comp sludge with $0-6350-\mu \mathrm{m}$ fuel particles) 
Table 6.3. Arrhenius Parameters and Activation Energies from Inverse Cubic Rates $\left[(1-\mathrm{f})^{1 / 3} / \mathrm{hr}\right]$

\begin{tabular}{|c|c|c|c|c|c|c|}
\hline \multirow[b]{2}{*}{ Fuel Particles Only } & \multirow[b]{2}{*}{ Plot } & \multirow{2}{*}{$\begin{array}{l}\text { No. } \\
\text { Points }\end{array}$} & \multicolumn{3}{|c|}{$\ln \left[(1-f)^{1 / 3}\right]=A / T+B$} & \multirow[b]{2}{*}{$\mathbf{E}_{\mathrm{a}}, \mathrm{kcal} / \mathrm{mole}$} \\
\hline & & & $\mathbf{A}$ & B & $\mathbf{R}^{2}$ & \\
\hline \multirow{3}{*}{$\begin{array}{l}\text { SNF Mid 60S } \\
\text { Test } 3\end{array}$} & $\mathrm{Kr}$ & 3 & -8288 & 15.085 & 0.9963 & 16.5 \\
\hline & $\mathrm{Xe}$ & 3 & -8298 & 15.079 & 0.9998 & 16.5 \\
\hline & $\mathrm{H}_{2}$ & 4 & -8459 & 15.745 & 0.9992 & 16.8 \\
\hline \multirow{3}{*}{$\begin{array}{c}\text { SNF Mid } 40 \mathrm{~S} \& 60 \mathrm{~S} \\
\text { Tests } 4 \& 3\end{array}$} & $\mathrm{Kr}$ & 4 & -8415 & 15.439 & 0.9987 & 16.7 \\
\hline & $\mathrm{Xe}$ & 4 & -8244 & 14.928 & 0.9999 & 16.4 \\
\hline & $\mathrm{H}_{2}$ & 8 & -8613 & 16.171 & 0.9969 & 17.1 \\
\hline \multicolumn{7}{|l|}{$\begin{array}{l}\text { Fuel Particles } \\
\text { Plus Sludge } \\
\end{array}$} \\
\hline \multirow{3}{*}{$\begin{array}{c}\text { SNF }+ \text { Can Fines } 60 \mathrm{~S} \\
\text { Test } 1\end{array}$} & $\mathrm{Kr}$ & 3 & -5405 & 7.362 & 0.9999 & 10.7 \\
\hline & $\mathrm{Xe}$ & 3 & -5587 & 7.882 & 0.9993 & 11.1 \\
\hline & $\mathrm{H}_{2}$ & 4 & -6970 & 11.699 & 0.9997 & 13.8 \\
\hline \multirow{3}{*}{$\begin{array}{c}\text { SNF }+ \text { Can } 60 \mathrm{~S} \\
\text { Test } 2\end{array}$} & $\mathrm{Kr}$ & 3 & -8607 & 15.969 & 1.0000 & 17.1 \\
\hline & $\mathrm{Xe}$ & 3 & -8580 & 15.859 & 0.9985 & 17.0 \\
\hline & $\mathrm{H}_{2}$ & 4 & -13611 & 30.038 & 0.9866 & 27.0 \\
\hline \multirow{3}{*}{$\begin{array}{c}\mathrm{SNF}+\text { Can } 60 \mathrm{~L} \\
\text { Test } 10\end{array}$} & $\mathrm{Kr}$ & 3 & -7972 & 14.681 & 0.9877 & 15.8 \\
\hline & $\mathrm{Xe}$ & 3 & -7797 & 14.045 & 0.9959 & 15.5 \\
\hline & $\mathrm{H}_{2}$ & 4 & -10587 & 21.735 & 0.9877 & 21.0 \\
\hline \multirow{3}{*}{$\begin{array}{c}\text { SNF }+ \text { Floor } 60 \mathrm{~L} \\
\text { Test } 11\end{array}$} & $\mathrm{Kr}$ & 3 & -6141 & 9.216 & 0.9526 & 12.2 \\
\hline & $\mathrm{Xe}$ & 3 & -6439 & 10.100 & 0.9831 & 12.8 \\
\hline & $\mathrm{H}_{2}$ & 4 & -9367 & 18.456 & 0.9988 & 18.6 \\
\hline \multirow{3}{*}{ Literature Values } & \multicolumn{5}{|c|}{$\begin{array}{r}\mathrm{KC}-2 / 3 \mathrm{P} 250, \mathrm{ICR}, \mathrm{H}_{2} \\
\text { Delegard et al. (2000) }\end{array}$} & 15.8 \\
\hline & \multicolumn{5}{|c|}{ Reilly (1998) } & 13.8 \\
\hline & \multicolumn{5}{|c|}{ Hilton (2000) } & 15.9 \\
\hline
\end{tabular}

\subsection{Conclusions from Reaction Rate Analysis}

The data and analyses of the Series III kinetic studies results compare with the Series III objectives as follows:

- Reaction rate data, obtained as a function of temperature and fuel particle size, may be used to calibrate and validate the thermal stability and gas generation models. The data show that uranium metal particle corrosion occurs at rates that are about one-third to one-half of those predicted in the technical literature. The differences may lie in the fact that most prior studies were over short experimental times with massive uranium pieces and, therefore, had little overlying corrosion product to inhibit reaction. The reaction rate activation energies are near those obtained by the Hilton (2000) Arrhenius model and Series I studies, but are higher than those obtained by the SNF Databook, Vol. 1 (Reilly 1998) fit of published uranium corrosion rate data.

- Corrosion of the smaller particles follows kinetics consistent with an isotropic "shrinking core" model. A larger particle (Fuel Fragment test) initially showed increased corrosion rate with increasing reaction time, seemingly consistent with fragmentation. However, post-test examination showed that the acceleration likely was due to the increased surface area afforded by loss of an initially adhering piece of cladding. The remaining large piece of fuel maintained its sharp-edged appearance, as did smaller residual fuel particles observed in other experiments. No fragmentation was observed in this or other testing. 
- Sludge layers intentionally added to cover (or blanket) the underlying uranium metal fuel particles were observed to decrease the uranium metal corrosion rate. Lower observed rates also seemed to occur with self-blanketing by the metal corrosion product. The decrease in rate became more pronounced as the blanketing depth increased. In some cases, the overlying sludge layer source (e.g., floor versus canister sludge) and the size of the fuel particles had little effect on the uranium metal reaction rate. However, hydrogen consumption seems to have occurred for some sludge, inhibiting the reaction rates as observed by $\mathrm{H}_{2}$ gas generation and fission product gas release. The effect of blanketing diminished as temperature increased.

- The observed uranium metal fuel corrosion rates were lower than those reported in the technical literature by a factor of 2 to 3 . Any reaction rate safety factors for the sludge should consider the finding here, along with the associated system design requirements (i.e., safety factors derived from the literature rate laws may be more conservative than needed for the sludge). 


\subsection{Post-Test Observations and Analyses}

The results of post-test analyses performed on sludge and on completely reacted and partially reacted fuel particles are discussed here, along with material recovery observations. The post-test analyses conducted on the materials from each of the tests are shown in the matrix in Table 7.1. The test materials from SNF Mid 80L and SNF Mid 80L Dup were combined during recovery to provide a larger volume of material, designated as SNF Mid 80L Comp.

Once the gas generation testing was completed, the reaction vessels were opened, and the supernatant liquid, sludge, and fuel particles were recovered as described and documented in PNNL Test Instruction 40143-T11, Addendum 1 "System Shut-down and Vessel Opening." Following sample recovery, the material from a select number of gas generation tests was sieved using wire mesh screens in accordance with PNNL Test Instruction TI-41591-T01, "Post Gas Generation Series III Sieving and Subsampling." Also, a number of subsamples from the sieving operation were analyzed to determine the dry particle density. This analysis was performed in accordance with PNNL Test Instruction TI41591-T09, "Dry Particle Density Measurement of Material Remaining after K Basin Fuel Fragment Gas Generation Tests - Series III Testing." Other subsamples from the sieving operation were analyzed via XRD, in accordance with procedure PNNL-RPG-268, Rev. 1 (Solids Analysis, X-Ray Diffraction), to identify crystalline mineral compounds still present or formed from the corrosion of fuel particles.

Appendix E contains flowcharts that illustrate the operations performed on the recovered samples and the data (e.g., mass, density, $\mathrm{pH}$ ) collected from the fractionated subsamples generated from the post-test sieving operations. A series of photos captured from videotape of the test material before and after gas generation testing are also included.

The fuel particles-only tests were subjected to more extensive post-test analyses than tests with both sludge and fuel particles. For the tests with sludge initially added, it would have been very difficult to determine which post-test characteristics could be attributed to the initial sludge and which could be attributed to the reacted and remaining fuel particles. From the results of the post-test characterization data, estimates were made of the volumetric expansion of the completely reacted fuel particles.

\subsection{Recovery of Sludge/Fuel Particles from Reaction Vessels}

When testing was completed, each reaction vessel was opened; 10 to $20 \mathrm{ml}$ of supernatant solution were carefully decanted; and the $\mathrm{pH}$ was measured. Next, the material was recovered from the vessel as a wet slurry by agitating the vessel contents with a stainless steel spatula, and pouring and sluicing the material into sample jars and centrifuge tubes.

After the initial recovery, it was evident that a portion of the test material was left in the vessels. The residual materials (sludge and fuel particles) were allowed to dry, and the dried material was recovered and weighed, but was kept separate from the material recovered as a wet slurry. Observations made from the initial sludge recovery are summarized below: 
Table 7.1. Matrix of Post-Testing Analyses

\begin{tabular}{|c|c|c|c|c|c|c|c|c|c|c|c|}
\hline \multirow[b]{2}{*}{$\begin{array}{l}\text { Test } \\
\text { No. }\end{array}$} & \multirow[b]{2}{*}{ Sample ID } & \multicolumn{2}{|c|}{ Fuel Particles } & \multirow[b]{2}{*}{$\begin{array}{l}\text { Sludge } \\
\text { Added }\end{array}$} & \multirow[b]{2}{*}{$\begin{array}{c}\%^{(\mathrm{a})} \\
\text { Reacted }\end{array}$} & \multicolumn{6}{|c|}{ Post-Test Analyses Performed } \\
\hline & & $\begin{array}{c}\text { Size Range, } \\
\mu \mathrm{m}\end{array}$ & Mass, $\mathbf{g}$ & & & $\mathbf{p H}^{(\mathbf{b})}$ & $\begin{array}{l}\text { Settled } \\
\text { Density }\end{array}$ & Sieve $^{(\mathrm{c})}$ & \% Solids & $\begin{array}{l}\text { Particle } \\
\text { Density }\end{array}$ & XRD \\
\hline 1 & $\begin{array}{l}\text { SNF + Can } \\
\text { Fines } 60 \mathrm{~S} \\
\end{array}$ & $0-500$ & 4.27 & Yes & 37 & Yes & No & No & No & No & No \\
\hline 2 & $\begin{array}{l}\text { SNF + Can } \\
60 S\end{array}$ & $500-2000$ & 8.39 & Yes & 18 & Yes & No & No & No & No & No \\
\hline 3 & SNF Mid 60S & $500-2000$ & 8.24 & No & 26 & Yes & Yes & Yes & No & Yes & Yes \\
\hline 4 & SNF Mid 40S & $500-2000$ & 8.61 & No & 12 & Yes & Yes & Yes & No & Yes & No \\
\hline 5 & $\begin{array}{l}\text { SNF P2000 } \\
80 \mathrm{~S}\end{array}$ & $2000-6350$ & 9.95 & No & 47 & Yes & Yes & Yes & No & No & No \\
\hline 6 & $\begin{array}{l}\text { SNF M500 } \\
80 \mathrm{~L}\end{array}$ & $0-500$ & 7.95 & No & 74 & Yes & Yes & Yes & Yes & Yes & Yes \\
\hline 7 & SNF Mid 80L & $500-2000$ & 8.87 & No & 91 & Yes & & & & & \\
\hline 8 & $\begin{array}{l}\text { SNF Mid 80L } \\
\text { Dup }\end{array}$ & $500-2000$ & 8.15 & No & 95 & Yes & $\mathrm{Yes}^{(\mathrm{d})}$ & $\mathrm{Yes}^{(\mathrm{d})}$ & Yes $^{(\mathrm{d})}$ & $\mathrm{Yes}^{(\mathrm{d})}$ & $\mathrm{Yes}^{(\mathrm{d})}$ \\
\hline 9 & $\begin{array}{l}\text { Fuel } \\
\text { Fragment } \\
\end{array}$ & $\sim 7150$ & 3.72 & No & 33 & Yes & Yes & Yes & No & No & No \\
\hline 10 & $\begin{array}{l}\text { SNF + Can } \\
60 \mathrm{~L}\end{array}$ & $0-6350$ & 26.36 & Yes & 32 & Yes & No & No & No & No & No \\
\hline 11 & $\begin{array}{l}\text { SNF Floor } \\
60 \mathrm{~L}\end{array}$ & $0-6350$ & 25.52 & Yes & 25 & Yes & No & No & No & No & No \\
\hline 12 & $\begin{array}{l}\mathrm{KC}-2 / 3 \\
\mathrm{P} 250 \mathrm{~L} \\
\end{array}$ & None & 0 & Yes & 1.5 & Yes & No & No & No & No & No \\
\hline $\begin{array}{l}\text { (a) } \\
\text { (b) } \\
\text { (c) } \\
\text { (d) }\end{array}$ & $\begin{array}{l}\text { Percent of the ori } \\
\text { initial crushed fue } \\
\mathrm{pH} \text { of decanted su } \\
\text { Appropriate sized } \\
\text { Analyses perform } \\
\text { 80L Dup. }\end{array}$ & $\begin{array}{l}\text { nal sample ma } \\
\text { was not } 100 \% \\
\text { ernatant from t } \\
\text { creens were se } \\
\text { d on SNF Mid } \\
\end{array}$ & $\begin{array}{l}\text {, as uraniu } \\
\text { ranium me } \\
\text { e reaction } \\
\text { cted, and } t \\
\text { L Comp, }\end{array}$ & $\begin{array}{l}\text { metal, c } \\
1, \text { but ev } \\
\text { essels wa } \\
\text { e wet ma } \\
\text { hich was }\end{array}$ & $\begin{array}{l}\text { oded. As s } \\
\text { ntly contair } \\
\text { neasured. } \\
\text { ial was scre } \\
\text { rmed by co }\end{array}$ & $\begin{array}{l}\text { en for T } \\
\text { d some } \\
\text { ned. } \\
\text { bining }\end{array}$ & $\begin{array}{l}\text { s } 6 \text { throu } \\
\text { adding an } \\
\text { material }\end{array}$ & $\begin{array}{l}\text { which } \\
\text { nium }\end{array}$ & m SNF M & $80 \mathrm{~L}$ and $\mathrm{S}$ & F Mid \\
\hline
\end{tabular}

- Masses of the reaction vessels and contents were obtained during initial loading and after completion of the testing, but before material recovery. During the course of the testing, mass losses ranging from $1.7 \%$ to $3.1 \%$ of the initial free water were measured for nine of the 12 vessels. [Initial freewater is defined as the water above the settled sludge/fuel pieces at the time of vessel loading.] Losses (\% of initial free water) for SNF + Can 60L, SNF + Floor 60L, and KC-2/3 P250L were $5.5 \%, 9.4 \%$, and $4.7 \%$, respectively. Water losses likely resulted during gas purging, gas sampling, and venting operations.

- Recovery of uranium metal particles from the vessels was difficult. The high-density material settled very rapidly and was difficult to mobilize. Consequently, it is expected that in the $\mathrm{K}$ Basins, metallic uranium particles in the sludge will not disperse much beyond their original location without strong hydraulic motivation.

- The corrosion products from the fuel particles formed a hard cake. The vessels could be tipped at a steep angle to remove supernatant that contained very little particulate. However, the hard cake layer could be broken up with moderate ease using a stainless steel spatula.

- After the sludge and fuel materials were removed, the inside of the vessels appeared very clean. Sludge material on the walls was readily removed by rinsing with water. Thermocouples that had been submerged in the water/sludge were fairly clean when removed from the vessels. 
- After mixing and recovery of the SNF Mid 80L and 80L Dup reactor contents (fuel particles ranging from 500 to $2000 \mu \mathrm{m}$ and reacted to completion), the supernatant remained cloudy even after 1 week of settling.

- After the initial removal of wet sludge and fuel particles, the remaining residual materials in the 800-ml vessels were allowed to dry. After drying, the dried sludge and fuel particles were readily removed by scraping with a spatula, with the exception of SNF + Floor 60L. The dried material in $\mathrm{SNF}+$ Floor 60L tenaciously adhered to the vessel bottom.

\subsection{Supernatant pH}

The $\mathrm{pH}$ of the water (K Basin water) in the vessels was measured with a wand-type $\mathrm{pH}$ meter (Piccolo H198113) both before and after gas generation testing. For each set of measurements, the meter accuracy was verified and the $\mathrm{pH}$ values corrected based on measurements of standard solutions. The measurement accuracy was estimated to be $\pm 0.2 \mathrm{pH}$ units.

When the vessels were initially loaded with fuel particles and sludge, K Basin decant water (water that had been in contact with sludge) was added. Generally, the water from the K Basins is maintained at a near-neutral $\mathrm{pH}$ value, since it is continually passed through a mixed-bed anion and cation exchange system. However, after samples are collected for testing, the $\mathrm{pH}$ in the water associated with the samples changes, as corrosion continues and $\mathrm{CO}_{2}$ is absorbed. For this reason, the $\mathrm{pH}$ of the water initially added to the vessels ranged from 4.9 to about 10 . The terminal $\mathrm{pH}$ of the supernatants from the vessels containing only fuel particles ranged from about 7.9 to 10.9 (Table 7.2). In comparison, for the tests in

Table 7.2. $\mathrm{pH}$ of Supernatant Before and After Series III Tests

\begin{tabular}{|c|l|c|c||}
\hline $\begin{array}{c}\text { Test } \\
\text { No. }\end{array}$ & \multicolumn{1}{|c|}{ Sample ID } & $\begin{array}{c}\text { Basin Water } \\
\text { Added at Start of } \\
\text { Test, pH }\end{array}$ & Post-Test pH \\
\hline 1 & SNF + Can Fines 60S & 4.9 & 8.6 \\
\hline 2 & SNF + Can 60S & 5.3 & 8.6 \\
\hline 3 & SNF Mid 60S & 7.1 & 8.7 \\
\hline 4 & SNF Mid 40S & 7.1 & 7.9 \\
\hline 5 & SNF P2000-80S & 10 & 10.0 \\
\hline 6 & SNF M500-80L & 10 & 8.7 \\
\hline 7 & SNF Mid-80L & 10 & 10.9 \\
\hline 8 & SNF Mid 80L Dup & 10 & 8.4 \\
\hline 9 & Fuel Fragment & 5.0 & 8.8 \\
\hline 10 & SNF + Can 60L & 5.3 & 4.9 \\
\hline 11 & SNF + Floor 60L & 7.1 & 7.0 \\
\hline 12 & KC-2/3 P250L & Not measured & 5.9 \\
\hline \hline
\end{tabular}


which sludge was added, the terminal $\mathrm{pH}$ ranged from 4.9 to 8.6 . The terminal $\mathrm{pH}$ values in the tests with sludge addition were similar to the terminal values measured in the Series II testing (i.e., floor, pit, and canister sludge; Bryan et al. 2001).

\subsection{Settled Sludge Density Measurements and Void Fraction Estimates}

Settled density measurements were performed by placing recovered sample material into 40-ml graduated centrifuge tubes (Kimbal Glass Inc., Item 45200-40), allowing it to settle, and then measuring volumes (settled sludge and water) and weight. The vendor information for the graduated centrifuge tubes stated that the graduations were calibrated "to contain," with the following accuracies: $0.5 \mathrm{ml}$, from 0 to $10 \mathrm{ml}$; and $1 \mathrm{ml}$, from 10 to $40 \mathrm{ml}$. However, when the accuracies of the graduations were checked using deionized water, the graduations were found to be much more accurate than the ranges provided by the vendor.

The settled sludge density measurements, along with information on the percent of the initial fuel particles reacted (from metal to oxides), are provided in Table 7.3 and plotted in Figure 7.1. As expected, because uranium metal has a higher density than its product oxide, the data show that the settled density decreases as the fraction of the uranium metal reacted increases (Figure 7.1). The settled densities of the material in which $100 \%$ of the gas-generating reactions were completed $\left(2.5\right.$ and $2.8 \mathrm{~g} / \mathrm{cm}^{3}$ for SNF M500 80L and SNF Mid 80L Comp, respectively) are similar to those measured for high-uranium-content KE canister sludge (Makenas et al. 1997). Extrapolating the data points for the incompletely reacted SNF Mid 40S, SNF Mid 60S, and SNF P2000 80S tests back to 0\% reaction (Figure 7.1) suggests a starting density of about $6.4 \mathrm{~g} / \mathrm{ml}$. This starting density is consistent with a mixture of $34 \mathrm{vol} \%$ uranium metal fuel particles (containing $6.9 \mathrm{wt} \%$ Zircaloy-2 cladding) and $66 \mathrm{vol} \%$ water (void fraction $\sim 0.66$ ). In comparison, the nominal and safety basis volume fraction water (void fraction) for fuel piece sludge is given as 0.40 (Plys and Pearce 2002). Table 7.3 provides data on the sludge volumes measured for the settled density determinations. Those volumes are small $\left(0.95\right.$ to $\left.7.5 \mathrm{~cm}^{3}\right)$, and it is possible that the settled sludge would have compacted further (increasing the settled density) if larger sample volumes had been available.

Table 7.3. Post-Test Settled Density Measurements

\begin{tabular}{||l|c|c|c||}
\hline \multicolumn{1}{|c|}{ Sample ID } & $\begin{array}{c}\text { \% of Initial } \\
\text { Material } \\
\text { Reacted }\end{array}$ & $\begin{array}{c}\text { Volume of } \\
\text { Settled } \\
\text { Sludge, } \mathbf{c m}^{\mathbf{3}}\end{array}$ & $\begin{array}{c}\text { Density, } \\
\mathbf{g} / \mathbf{c m}^{\mathbf{3}}\end{array}$ \\
\hline SNF Mid 60S & 26 & 1.55 & 4.7 \\
\hline SNF Mid 40S & 12 & 1.45 & 5.6 \\
\hline SNF P2000 80S & 47 & 2.6 & 3.5 \\
\hline SNF M500 80L & 74 & 3.0 & 2.5 \\
\hline SNF Mid 80L Comp & 93 & 7.5 & 2.8 \\
\hline Fuel Fragment & 33 & 0.95 & 3.6 \\
\hline
\end{tabular}




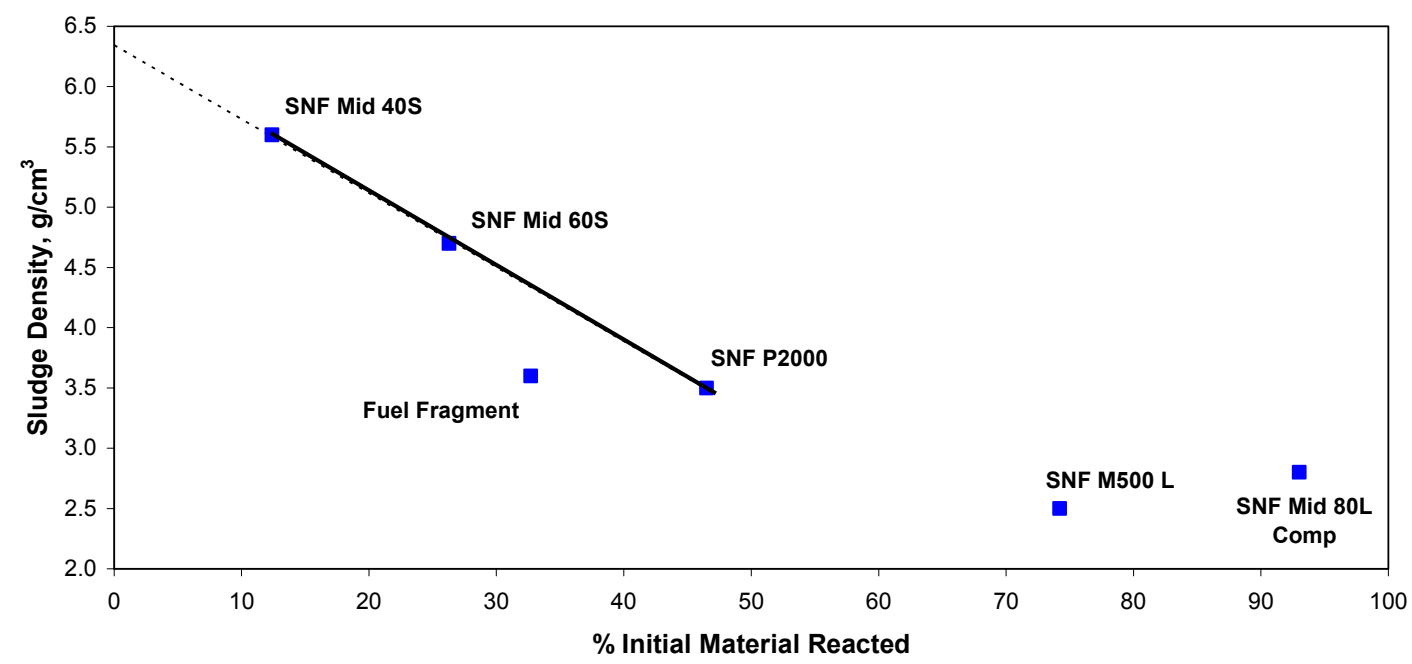

Figure 7.1. Density of Post-Test Sludge as a Function of Percent Fuel Particles (Uranium Metal) Reacted

The void fractions for the various sludges at the end of testing were estimated from measured settled densities and calculated post-test compound distributions based on gas generation values (Table 7.4). It was also assumed that the starting fuel particles contained $7 \mathrm{wt} \%$ cladding in the SNF Mid 60S, SNF Mid 40S, and SNF P2000 80S tests and $3.5 \mathrm{wt} \%$ cladding in the Fuel Fragment test. The SNF M500 80L and SNF Mid 80L Comp tests were run to completion and thus contained no residual uranium metal. The void fraction estimates for the tests not run to complete reaction of the uranium metal range from 0.68 to 0.81 and average $0.75 \pm 0.07$, consistent with the 0.75 void fraction design and safety basis value for KE canister sludge (Plys and Pearce 2002).

Figure 7.2 shows the relationship of calculated sludge void fraction (vol\% water) with percent uranium reacted. As expected, void fraction generally increases as the fraction of the uranium metal reacted increases. Extrapolating the data points for the incompletely reacted SNF Mid 40S, SNF Mid 60S, and SNF P2000 80S tests back to $0 \%$ reacted suggests an initial volume fraction water of 0.64 . Again, this value is considerably higher than the nominal and safety basis void fraction for fuel piece sludge of 0.40 (Plys and Pearce 2002).

Table 7.4. Void Fraction Estimates Based on Measured Settled Densities and Assumed Post-Test Compound Distribution

\begin{tabular}{|c|c|c|c|c|c|c|c|c|c|c|}
\hline \multirow{3}{*}{ Sample ID } & \multirow{3}{*}{$\begin{array}{c}\% \text { U } \\
\text { Metal } \\
\text { Reacted }\end{array}$} & \multirow{3}{*}{$\begin{array}{c}\text { Measured } \\
\text { Settled } \\
\text { Density, g/cm }\end{array}$} & \multicolumn{7}{|c|}{ Initial 100 g Crushed Fuel Particle Basis } & \multirow{3}{*}{$\begin{array}{c}\text { Calculated } \\
\text { Sludge Void } \\
\text { Fraction }\end{array}$} \\
\hline & & & \multicolumn{3}{|c|}{ Mass, $\mathrm{g}$} & \multicolumn{4}{|c|}{ Volume, ml } & \\
\hline & & & $\mathbf{U O}_{2}$ & $\mathbf{U}$ & $\mathbf{Z r}$ & $\mathbf{U O}_{2}$ & $\mathbf{U}$ & $\mathbf{Z r}$ & $\mathrm{H}_{2} \mathrm{O}$ & \\
\hline SNF Mid 60S & 26.3 & 4.7 & 29.9 & 73.7 & 7.0 & 2.72 & 3.88 & 1.08 & 20.1 & 0.72 \\
\hline SNF Mid 40S & 12.4 & 5.6 & 14.1 & 87.6 & 7.0 & 1.28 & 4.61 & 1.08 & 15.1 & 0.68 \\
\hline SNF P2000 80S & 46.5 & 3.5 & 52.8 & 53.5 & 7.0 & 4.80 & 2.82 & 1.08 & 33.2 & 0.79 \\
\hline SNF M500 80L & 74.2 & 2.5 & 110.1 & 0.0 & 7.0 & 10.01 & 0.00 & 1.08 & 59.6 & 0.84 \\
\hline $\begin{array}{l}\text { SNF Mid 80L } \\
\text { Comp }\end{array}$ & 93.0 & 2.8 & 105.7 & 0.0 & 7.0 & 9.61 & 0.00 & 1.08 & 46.0 & 0.81 \\
\hline Fuel Fragment & 32.7 & 3.6 & 37.2 & 67.3 & 3.5 & 3.38 & 3.54 & 0.54 & 31.2 & 0.81 \\
\hline
\end{tabular}




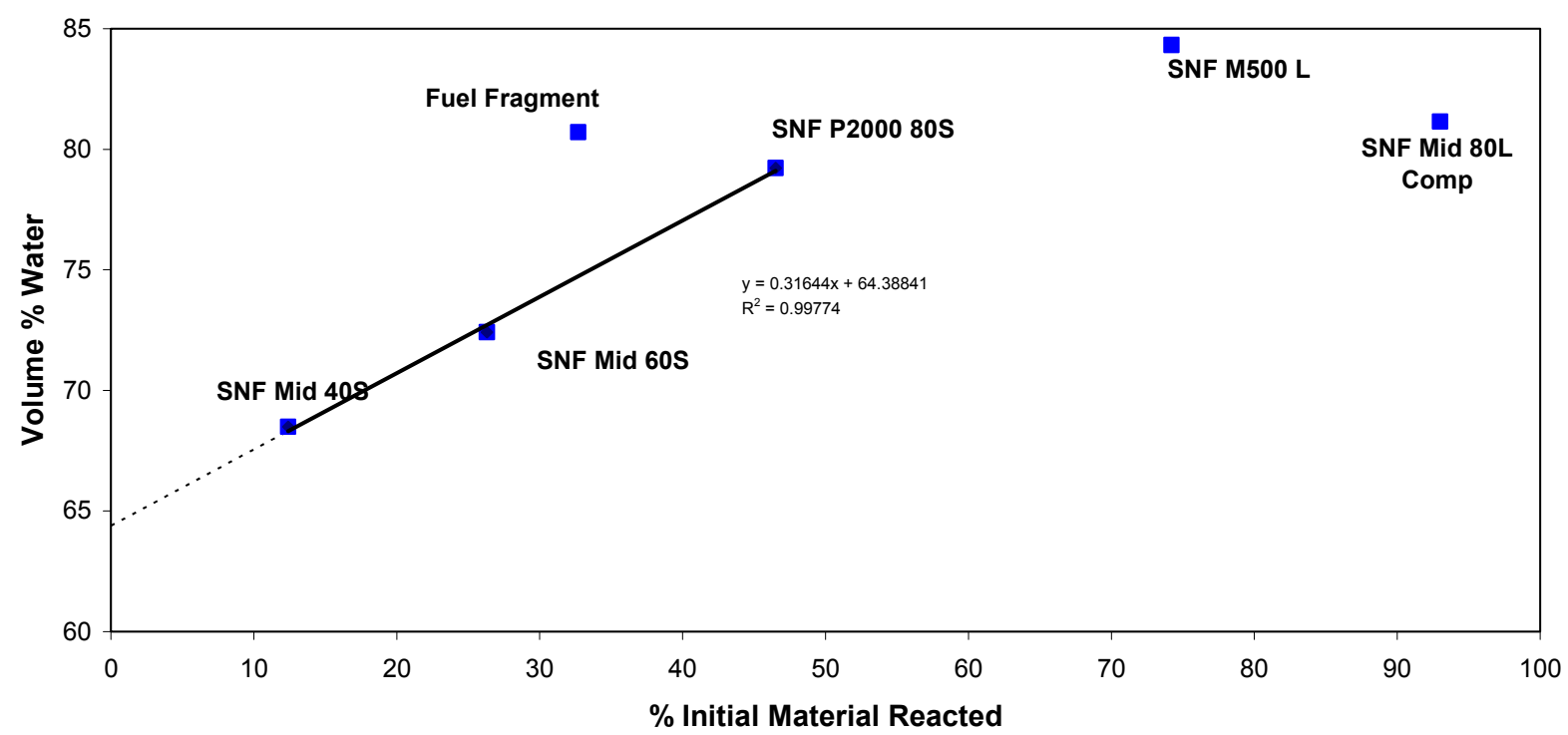

Figure 7.2. Calculated Volume Percent Water in Post-Test Sludge as a Function of Percent Fuel Particles (Uranium Metal) Reacted

\subsection{Results from Post-Test Sieving}

The particle size distributions of the fuel particles were quantified by sieving before the gas generation testing (Section 2.2). After testing, particle size distributions were again quantified by sieving to evaluate how the fuel particles corroded. Sieving also provided an opportunity to closely examine the partially corroded fuel particles, providing insight on whether fuel pieces undergo fragmentation during corrosion, or whether they corrode in accordance with a shrinking core model (see photos in Appendix E.) Sieving was also used to fractionate material for particle density measurements and XRD analysis.

Sieving was only performed on material originating from tests containing fuel particles only. The selection of sieve sizes used for each sample varied and was based on post-test objectives. For example, for SNF M500 80L and SNF Mid 80L Comp, which were reacted to completion, a single sieve was used to search the material for cladding.

For the sieving operations, 3-in.-diameter wire mesh sieves were stacked sequentially, with largest mesh sieve on top, and a receiver pan on the bottom. Next, the wet material was poured on the top sieve, and additional K Basin supernatant was used as needed to wash finer particles through each sieve. After sieving, the materials on each sieve and the receiver pan were dried and weighed. However, the materials in the receiver pan from SNF M500 80L and SNF Mid 80L Comp were maintained in a wet state.

Tables 7.5 and 7.6 present the results of the post-test sieving.

After the sieving was completed, the mass of recovered material was found to be less than expected. Consequently, additional material was recovered from the reactor vessels. The quantities of material collected during the second recovery effort are shown in Table 7.5, see Additional Material Recovered.

In the tests in which the fuel particles were only partially reacted, the residual particles displayed sharp edges, and did not look rounded or weathered (see photographs in Appendix E). The visual 
Table 7.5. Sieving Results from Tests with Partially Reacted Fuel Particles

\begin{tabular}{|c|c|c|c|c|c|c|c|c|}
\hline \multirow{3}{*}{$\begin{array}{c}\begin{array}{c}\text { Initial Fuel } \\
\text { Particles }^{(a)} \mathrm{g}\end{array} \\
\text { US Mesh No. }(\mu \mathrm{m})\end{array}$} & \multirow{2}{*}{\multicolumn{2}{|c|}{$\begin{array}{c}\text { SNF Mid 40S } \\
8.61 \\
\end{array}$}} & \multirow{2}{*}{\multicolumn{2}{|c|}{$\begin{array}{c}\text { SNF Mid 60S } \\
8.24 \\
\end{array}$}} & \multirow{2}{*}{\multicolumn{2}{|c|}{$\begin{array}{c}\mathrm{P2000} 80 \mathrm{~S} \\
9.95\end{array}$}} & \multirow{2}{*}{\multicolumn{2}{|c|}{$\begin{array}{c}\text { Fuel Fragment } \\
3.72 \\
\end{array}$}} \\
\hline & & & & & & & & \\
\hline & $\begin{array}{c}\text { Mass } \\
\text { retained, } \mathrm{g}\end{array}$ & $\begin{array}{c}\text { Wt\% of } \\
\text { Total }\end{array}$ & $\begin{array}{c}\text { Mass } \\
\text { retained, } \mathrm{g}\end{array}$ & $\begin{array}{c}\text { Wt\% of } \\
\text { Total }\end{array}$ & $\begin{array}{c}\text { Mass } \\
\text { retained, } \mathrm{g}\end{array}$ & $\begin{array}{c}\text { Wt\% of } \\
\text { Total }\end{array}$ & $\begin{array}{c}\text { Mass } \\
\text { retained, } \mathrm{g}\end{array}$ & $\begin{array}{c}\text { Wt \% of } \\
\text { Total }\end{array}$ \\
\hline $6 \quad(3350)$ & \multicolumn{2}{|c|}{--} & \multicolumn{2}{|c|}{--} & 0.32 & 3.4 & 2.01 & 53 \\
\hline $10(2000)$ & \multicolumn{2}{|c|}{--} & \multicolumn{2}{|c|}{--} & 0.84 & 8.9 & $\overline{0}$ & $\overline{0}$ \\
\hline $18(1000)$ & 2.72 & 32 & 1.44 & 18 & 0.61 & 6.5 & 0.01 & 0.26 \\
\hline $25(710)$ & 1.07 & 13 & 0.80 & 10 & 0.09 & 0.95 & 0.004 & 0.11 \\
\hline $35(500)$ & 1.08 & 13 & 0.74 & 9.2 & 0.06 & 0.64 & 0.01 & 0.26 \\
\hline $45(355)$ & 0.55 & 6.5 & \multicolumn{2}{|c|}{--} & \multicolumn{2}{|c|}{--} & \multicolumn{2}{|c|}{--} \\
\hline $60(250)$ & 0.38 & 4.5 & \multicolumn{2}{|c|}{--} & \multicolumn{2}{|c|}{--} & \multicolumn{2}{|c|}{--} \\
\hline $\operatorname{Pan}^{(\mathrm{b})}$ & 2.10 & 25 & 3.89 & 49 & 5.08 & 54 & 1.43 & 38 \\
\hline Total Sieved & 7.90 & 94 & 6.87 & 86 & 7.00 & 74 & 3.46 & 92 \\
\hline $\begin{array}{l}\text { Additional Material } \\
\text { Recovered }^{(\mathrm{c})}\end{array}$ & $0.53^{(\mathrm{d})}$ & 6.3 & $1.15^{(\mathrm{d})}$ & 14 & $2.43^{(\mathrm{e})}$ & 26 & $0.32^{(\mathrm{f})}$ & 8.5 \\
\hline Total Recovered & 8.43 & 100 & 8.02 & 100 & 9.43 & 100 & 3.78 & 100 \\
\hline$\%$ Recovery $^{(\mathrm{g})}$ & \multicolumn{2}{|l|}{$98 \%$} & \multicolumn{2}{|l|}{$97 \%$} & \multicolumn{2}{|l|}{$95 \%$} & \multicolumn{2}{|l|}{$102 \%$} \\
\hline $\begin{array}{ll}\text { (a) } & \text { Initial Fuel Parti } \\
\text { (b) } & \text { Pan = material th } \\
\text { (c) } & \text { Additional dried } \\
\text { (d) } & \text { The additional r } \\
& \text { would have beer } \\
\text { (e) } & \text { This material co } \\
\text { (f) } & \text { A fragment of cl } \\
\text { (g) } & \% \text { Recovery }=\mathrm{T} \\
& \text { uranium metal c }\end{array}$ & $\begin{array}{l}\mathrm{s}=\text { mass of } \mathrm{c} \\
\text { passed throu, } \\
\text { aterial was re } \\
\text { vered dried } \mathrm{n} \\
\text { ecovered in th } \\
\text { sted primarily } \\
\text { ding }(0.13 \mathrm{~g}) \\
\text { l Recovered/ } \\
\text { odes to urani }\end{array}$ & $\begin{array}{l}\text { shed fuel } \mathrm{p} \\
\text { smallest si } \\
\text { vered from } \\
\text { terial from } \\
\text { Pan. } \\
\text { f larger fue } \\
\text { as found du } \\
\text { itial Fuel Pa } \\
\text { n oxides. }\end{array}$ & $\begin{array}{l}\text { ticles added t } \\
\text { ye used. } \\
\text { he reaction ve } \\
\text { NF Mid } 40 \mathrm{~S} \\
\text { fragment piec } \\
\text { ng the additio } \\
\text { ticles. This re }\end{array}$ & $\begin{array}{l}\text { reactor ves } \\
\text { sels after s } \\
\text { d Mid } 60 \mathrm{~S} \\
\text { s. } \\
\text { al recovery } \\
\text { overy valu }\end{array}$ & $\begin{array}{l}\text { el at start of } t \\
\text { ving. This } m \\
\text { was very fine } \\
\text { from the reac } \\
\text { neglects the }\end{array}$ & $\begin{array}{l}\text { st. } \\
\text { terial was n } \\
\text { articulate, } \\
\text { on vessel. } \\
\text { eight gain }\end{array}$ & $\begin{array}{l}\text { t sieved. } \\
\text { hich if sieve }\end{array}$ & $\begin{array}{l}\text { probably } \\
\text { xygen as }\end{array}$ \\
\hline
\end{tabular}

appearance of the partially reacted fuel particles indicates that they corroded uniformly, and confirms the applicability of the use of a "shrinking core model" to predict corrosion reaction rates.

After the SNF Mid 60S material was sieved (26\% reacted), the material that passed through the finest sieve $(<500-\mu \mathrm{m}$ screen) was air-dried overnight (after first decanting excess supernatant) and then placed in an oven at $103^{\circ} \mathrm{C}$ for $4 \mathrm{hr}$. While a stainless steel spatula was being used to recover this material, a spark was observed; however, efforts to repeat the sparking (more aggressive scraping) were uneventful. It is speculated that the sparking was caused by disturbing uranium hydride.

Gas generation data indicate that $33 \%(\sim 35 \%$, based on Xe release $)$ of the original single fuel fragment sample (Test 9) reacted (total sample basis). Sample recovery data indicate that about $53 \%$ of the residual fuel fragment sample mass was greater than $500 \mu \mathrm{m}$ (not including cladding), implying that $47 \%$ of the fragment corroded. If it is assumed that $6.5 \mathrm{wt} \%$ of the initial fuel fragment was cladding (Plys and Pearce 2002), the gas generation data would predict $36 \%$ of the metal in the sample reacted, and the posttest sample recovery data would predict that $44 \%$ of the sample reacted. Therefore, some fraction of the $<500-\mu \mathrm{m}$ material likely contained metallic particles. This finding suggests that metallic particle attrition (spalling) occurred. However, the subsequent enhanced gas generation rates that should have followed such spalling were not observed (suggesting perhaps an oxide layer, or a layer of oxide corrosion products, partially protected the metal particles). 
After wet sieving SNF M500 80L and SNF Mid 80L Comp, the materials collected in the receiver pans were allowed to settle; excess supernatant was decanted; and subsamples of the settled sludge ( $\sim \mathrm{g})$ were collected in duplicate for percent solids determination. The aliquots of settled sludge were dried overnight at approximately $102^{\circ} \mathrm{C}$ and reweighed to determine the solids content in the settled sludge (Table 7.7). The percent solids values in Table 7.7 are very similar to the values measured for KE canister sludge (Makenas et al. 1997), with a total uranium concentration in the range of 82 to $88 \mathrm{wt} \%$ (dry basis).

The SNF Mid 80L Comp material was sieved using only a 500- $\mu$ m screen. It was anticipated that significant Zircaloy cladding particles would be captured (5\% to $15 \%$ of the initial sample mass).

However, from approximately $20 \mathrm{~g}$ of settled sludge, only $0.032 \mathrm{~g}$ of material was captured on the sieve (Table 7.6). A 250- $\mu \mathrm{m}$ sieve was used for the SNF M500 80L material. From about $8 \mathrm{~g}$ of settled sludge, only $0.015 \mathrm{~g}$ of material was collected (Table 7.6).

Table 7.6. Sieving Results from Tests with Completely Reacted Fuel Particles

\begin{tabular}{|c|c|c|c|c|}
\hline \multirow{3}{*}{$\begin{array}{c}\text { Initial Fuel } \\
\text { Particles, }^{(a)} \mathbf{g} \\
\text { US Mesh No. }(\mu \mathrm{m})\end{array}$} & \multirow{2}{*}{\multicolumn{2}{|c|}{$\begin{array}{c}\text { SNF M500 80L } \\
7.95\end{array}$}} & \multirow{2}{*}{\multicolumn{2}{|c|}{$\begin{array}{c}\text { SNF Mid 80L Comp } \\
17.02\end{array}$}} \\
\hline & & & & \\
\hline & $\begin{array}{c}\text { Mass } \\
\text { retained, g }\end{array}$ & $\begin{array}{c}\mathrm{Wt} \% \text { of } \\
\text { Total }\end{array}$ & $\begin{array}{c}\text { Mass } \\
\text { retained, } g\end{array}$ & $\begin{array}{c}\mathrm{Wt} \% \text { of } \\
\text { Total }\end{array}$ \\
\hline $35(500)$ & \multicolumn{2}{|c|}{--} & 0.032 & 0.21 \\
\hline $60(250)$ & 0.015 & 0.27 & \multicolumn{2}{|c|}{--} \\
\hline $\operatorname{Pan}^{(b)}$ & $5.6^{(\mathrm{c})}$ & 100 & $15.2^{(\mathrm{c})}$ & 100 \\
\hline Total Sieved & 5.61 & 100 & 15.23 & 100 \\
\hline$\%$ Recovery & \multicolumn{2}{|c|}{$71 \%$} & \multicolumn{2}{|c|}{$89 \%$} \\
\hline \multicolumn{5}{|c|}{$\begin{array}{l}\text { Mass of crushed fuel particles added to reaction vessel at start of } \\
\text { test. } \\
\text { Pan = material that passed through smallest sieve used. } \\
\text { Dry mass estimated from sample volume and percent solids } \\
\text { determination on subsamples. }\end{array}$} \\
\hline
\end{tabular}

Table 7.7. Percent Solids Results, SNF M500 80L and SNF Mid 80L Comp

\begin{tabular}{||c|c|c|c|c||}
\hline \multirow{2}{*}{$\begin{array}{c}\text { Material } \\
\text { Measured }\end{array}$} & \multicolumn{2}{|c|}{$\begin{array}{c}\text { SNF M500 80L } \\
\text { Passed Through } \\
\text { 250- } \mu \text { Sieve }\end{array}$} & \multicolumn{2}{c||}{$\begin{array}{c}\text { SNF Mid 80L Comp } \\
\text { Passed Through } \\
\text { 500- } \mu \text { Sieve }\end{array}$} \\
\hline Subsample & 1 & 2 & 1 & 2 \\
\hline \% Solids & 72.5 & 72.2 & 76.6 & 75.8 \\
\hline Avg. \% Solids & \multicolumn{2}{|c|}{72.4} & \multicolumn{2}{c||}{76.2} \\
\hline
\end{tabular}




\subsection{Dry Particle Density Measurements}

Dry particle density measurements were performed on some of the size-fractionated material generated from the sieving (Section 7.4). This measurement quantifies the particle density of the material in an aliquot of the dry sludge. The measurements were made using a Micromeritics AccuPyc 1330 pyncometer, modified for glovebox operation. The calibration of the AccuPyc 1330 was confirmed by checking the system with a tungsten standard (error $<0.2 \%$ ). The results from the dry particle density measurements are provided in Table 7.8. The particles retained on the various sieves for SNF Mid 40S and SNF Mid 60S exhibited particle densities similar to that of uranium metal $\left(19 \mathrm{~g} / \mathrm{cm}^{3}\right)$. The $<250-\mu \mathrm{m}$ and $<500-\mu \mathrm{m}$ particles exhibited particle densities consistent with that of uraninite $\left(\mathrm{UO}_{2}=10.95 \mathrm{~g} / \mathrm{cm}^{3}\right.$; $\mathrm{U}_{4} \mathrm{O}_{9}=11.3 \mathrm{~g} / \mathrm{cm}^{3}$; and $\left.\mathrm{U}_{3} \mathrm{O}_{7}=11.32 \mathrm{~g} / \mathrm{cm}^{3}\right)$.

Table 7.8. Results from Dry Particle Density Measurements

\begin{tabular}{|c|c|c|c|c|}
\hline \multirow[b]{2}{*}{ Sieve Size, $\mu \mathrm{m}$} & \multicolumn{4}{|c|}{ Measured Particle Density, $\mathrm{g} / \mathrm{cm}^{3}$} \\
\hline & SNF Mid 60S & SNF Mid 40S & SNF Mid 80L Comp & SNF M500 80L \\
\hline 1000 & 18.1 & -- & \multirow{5}{*}{--} & \multirow{6}{*}{--} \\
\hline 710 & 18.2 & -- & & \\
\hline 500 & 18.1 & -- & & \\
\hline 355 & \multirow{2}{*}{--} & 17.6 & & \\
\hline 250 & & 17.2 & & \\
\hline $\mathrm{M}^{2} 00^{(\mathrm{a})}$ & 10.9 & -- & 9.4 & \\
\hline $\mathrm{M} 250^{(\mathrm{b})}$ & -- & -- & -- & 8.9 \\
\hline \multicolumn{5}{|c|}{$\begin{array}{l}\text { (a) M500 - particles that passed through a } 500-\mu \mathrm{m} \text { sieve and captured in the receiver pan. } \\
\text { (b) M250 - particles that passed through a } 250 \text { - } \mathrm{m} \text { sieve and captured in the receiver pan. }\end{array}$} \\
\hline
\end{tabular}

\subsection{X-Ray Diffraction Analysis}

X-ray diffraction analyses were performed on four post-test subsamples to identify crystalline mineral compounds formed from the corrosion of uranium metal fuel particles. Subsample descriptions and results of the XRD analyses are given in Table 7.9. All subsamples had peak patterns and positions characteristic of $\mathrm{UO}_{3}, \mathrm{U}_{4} \mathrm{O}_{9}$, and $\mathrm{U}_{3} \mathrm{O}_{7}$, or a combination of these phases. To distinguish between the three phases, profiles were fitted to the 47 - and the 56- to 59-degree peaks, and relative errors were examined for the uranium phases. The $\mathrm{U}_{4} \mathrm{O}_{9}$ gave the best match for the data, although a mixture of $\mathrm{U}_{4} \mathrm{O}_{9}$ and $\mathrm{UO}_{2}$ also provided a reasonable match, which suggests the oxygen-to-uranium ratios may be slightly less than 2.25 (i.e., $\mathrm{U}_{4} \mathrm{O}_{9}=\mathrm{UO}_{2.25}$ ). Subsample SNF M500 M60 also contained a small quantity of metaschoepite $\left(\mathrm{UO}_{3} \cdot 2 \mathrm{H}_{2} \mathrm{O}\right)$. Prior to the analyses, the post-test sludge was handled in air (e.g., sieving), and the XRD sample aliquots were dried in air. Consequently, some uranium oxidation likely occurred between the time the gas generation tests ended and when the subsamples were analyzed. Therefore, the $\mathrm{XRD}$ results are not inconsistent with the assumption in Section 4.0 that uranium metal was oxidized to $\mathrm{UO}_{2}$ during the gas generation tests.

Searches for elemental uranium, uranium hydride, elemental zirconium, zirconium hydride, and zirconium oxide were performed by direct comparison to International Centre for Diffraction Data 
Table 7.9. Crystalline Phases Identified by X-Ray Diffraction in Recovered Post-Test Material

\begin{tabular}{||l|l|l||}
\hline \hline Subsample ID & \multicolumn{1}{|c||}{ Subsample Description } & \multicolumn{1}{|c||}{ Phases Identified } \\
\hline SNF M500 M60 & $\begin{array}{l}\text { Fine black particulate that passed through a } \\
250-\mu \mathrm{m} \text { (US mesh 60) sieve }\end{array}$ & $\begin{array}{l}\text { Uraninite, } \mathrm{U}_{4} \mathrm{O}_{9} \\
\text { Metaschoepite, } \mathrm{UO}_{3} \cdot 2 \mathrm{H}_{2} \mathrm{O}, \text { small amount } \\
\text { Unknown, very small amount }\end{array}$ \\
\hline SNF Mid $60 \mathrm{M} 32$ & $\begin{array}{l}\text { Fine black particulate that passed through a } \\
500-\mu \mathrm{m} \text { (US mesh 60) sieve. This material } \\
\text { sparked when being scraped from a drying pan }\end{array}$ & $\begin{array}{l}\text { Uraninite, } \mathrm{U}_{4} \mathrm{O}_{9} \\
\text { Unknown, very small amount }\end{array}$ \\
\hline SNF Mid $80 \mathrm{P} 32$ & $\begin{array}{l}\text { Gray particles collected on a 500- } \mu \mathrm{m} \\
\text { (US mesh 60) sieve. Particles appeared to be } \\
\text { cladding }\end{array}$ & Uraninite, $\mathrm{U}_{4} \mathrm{O}_{9}$ \\
\hline SNF Mid $80 \mathrm{M} 32$ & $\begin{array}{l}\text { Fine black particulate that passed through a } \\
500-\mu \mathrm{m} \text { sieve }\end{array}$ & Uraninite, $\mathrm{U}_{4} \mathrm{O}_{9}$ \\
\hline
\end{tabular}

(ICDD) cards. The search/match routines did not suggest any of these phases. The failure to identify a zirconium phase in subsample SNF Mid 80 P32 cannot be readily explained, as, visually, the sample material appeared to be made up of gray Zircaloy cladding fragments (Section 7.4).

\subsection{Volume Expansion Due to Corrosion}

During storage, metallic uranium and uranium oxides in the $\mathrm{K}$ Basin sludge will corrode and hydrate. The end-state (state of sludge after estimated 30 years of storage at T Plant) corrosion products will have a lower particle density and a higher void fraction (or volume fraction of sludge occupied by water) than the sludge at the beginning of storage (starting-state). As the particle density and void fraction change, the volume occupied by a given mass of sludge will also change. Estimates are given here of the volumetric expansion of the completely reacted fuel particles from the post-test data collected from SNF M500 80L and SNF Mid 80L Comp. The approaches used for estimating the sludge expansion were: 1) direct observations/measurements, and 2) calculation of expansion using void fraction, settled density, and particle density measurements. The results from these analyses can be used to predict how much space should be provided in sludge storage containers to accommodate expansion from corrosion. A more detailed analysis of the volumetric expansion of various types of sludge from corrosion is provided separately (Schmidt and Delegard 2003).

\subsubsection{Initial Void Fraction, Settled Densities, and Uranium Content of Fuel Particles}

Because the settled volume of the fuel fragment initially added to the reaction vessels was not measured, the volume of the fuel particles at the beginning of the tests had to be estimated. From Plys and Pearce (2002), the initial void fraction of fuel particles is expected to be 0.40 . From Series III measurements, SNF Mid 80L Comp was determined to be $93 \%$ U metal. Post-test examinations showed that this material contained essentially no zirconium. Assuming an initial 93:7 weight mix of $\mathrm{U}_{\text {(met) }}$ and $\mathrm{UO}_{2}$, an 
initial particle density of $18.1 \mathrm{~g} / \mathrm{cm}^{3}$ can be calculated. (a) Assuming an initial 0.60 solids volume fraction, the dry bulk density of the fuel particles at the start of the test is estimated to be:

$$
=0.6\left(\mathrm{~cm}^{3} \text { solids } / \mathrm{cm}^{3} \text { sludge }\right) \times 18.1\left(\text { g solids } / \mathrm{cm}^{3} \text { solids }\right)=10.9 \mathrm{~g} \text { dry solids } / \mathrm{cm}^{3} \text { sludge } .
$$

In addition to solids, the settled sludge also contains water. Therefore, the initial wet settled density of the fuel particles is [assuming $40 \%$ void (water) volume]:

$$
\begin{aligned}
& =10.9 \mathrm{~g} \text { dry solids } / \mathrm{cm}^{3} \text { sludge }+0.4\left(\mathrm{~cm}^{3} \text { water } / \mathrm{cm}^{3} \text { sludge }\right) \times 1\left(\mathrm{~g} \text { water } / \mathrm{cm}^{3} \text { water }\right) \\
& =11.3 \mathrm{~g} / \mathrm{cm}^{3} \text { settled fuel particles for SNF Mid } 80 \mathrm{~L} \text { Comp }
\end{aligned}
$$

The initial uranium concentration for SNF Mid 80L Comp is:

$$
\begin{aligned}
& =0.6\left(\mathrm{~cm}^{3} \text { solids } / \mathrm{cm}^{3} \text { sludge }\right) \times 18.1\left(\text { g solids } / \mathrm{cm}^{3} \text { solids }\right) \times[(0.93 \times 1 \mathrm{~g} \mathrm{U} / \mathrm{g} \text { solids }) \\
& \left.+0.07 \mathrm{~g} \mathrm{UO}_{2} \times\left(238 \mathrm{~g} \mathrm{U} / 270 \mathrm{~g} \mathrm{UO}_{2}\right)\right]=10.8 \mathrm{~g} \mathrm{U} / \mathrm{cm}^{3} .
\end{aligned}
$$

Also from gas generation measurements, SNF M500 80L is $74.2 \% \mathrm{U}_{(\text {met })}$ (mixture particle density of $16.0 \mathrm{~g} / \mathrm{cm}^{3}$ ). The dry bulk density of the fuel particles at the start of the test is estimated to be:

$$
=0.6\left(\mathrm{~cm}^{3} \text { solids } / \mathrm{cm}^{3} \text { sludge }\right) \times 16.0\left(\text { g solids } / \mathrm{cm}^{3} \text { solids }\right)=9.6 \mathrm{~g} \text { dry solids } / \mathrm{cm}^{3} \text { sludge } .
$$

The initial wet settled density of the fuel particles is:

$=9.6 \mathrm{~g}$ dry solids $/ \mathrm{cm}^{3}$ sludge $+0.4\left(\mathrm{~cm}^{3}\right.$ water $/ \mathrm{cm}^{3}$ sludge $) \times 1\left(\mathrm{~g}\right.$ water $/ \mathrm{cm}^{3}$ water $)$

$=10.1 \mathrm{~g} / \mathrm{cm}^{3}$ for settled fuel particles for SNF M500 80L.

The initial uranium concentration for SNF M500 80L is:

$=0.6\left(\mathrm{~cm}^{3}\right.$ solids $/ \mathrm{cm}^{3}$ sludge $) \times 16.0\left(\mathrm{~g}\right.$ solids $/ \mathrm{cm}^{3}$ solids $) \times[(0.742 \times 1 \mathrm{~g} \mathrm{U} / \mathrm{g}$ solids $)$

$\left.+0.258 \mathrm{~g} \mathrm{UO}_{2} \times\left(238 \mathrm{~g} \mathrm{U} / 270 \mathrm{~g} \mathrm{UO}_{2}\right)\right]=9.3 \mathrm{~g} \mathrm{U} / \mathrm{cm}^{3}$.

\subsubsection{Volumetric Expansion Based on Observations/Measurements}

The volumetric expansion of the fuel particles in SNF Mid 80L Comp and SNF M500 80L can be expressed as the ratio of the volume of the recovered reactor contents (settled) to the volume of the initial fuel particles. In Section 7.7.1, the bulk density of the initial fuel particles was estimated. By dividing mass of the initial fuel particles by the bulk density of the fuel particles, the settled volume of particles can be estimated (Table 7.10).

As a part of the post-test analyses, the contents from each reaction vessel were recovered, and settled volume and density measured (Section 7.3). The recovered materials (or subsamples of the recovered

(a) Assuming $0.93 \mathrm{~g} \mathrm{U}_{(\text {met })}$ and $0.07 \mathrm{~g} \mathrm{UO}_{2.25}$

$$
\text { density }=\frac{\text { Mass }\left[\mathrm{Umetal}_{\mathrm{H}}+\mathrm{UO}_{2}\right]}{\text { Volume }\left[\mathrm{Umetal}_{\mathrm{m}}+\mathrm{UO}_{2}\right]}=\frac{[0.93+0.07] \mathrm{g}}{[0.0489+0.00639] \mathrm{cm}^{3}}=18.1 \mathrm{~g} / \mathrm{cm}^{3}
$$


Table 7.10. Volumetric Expansion Based on Direct Observation/Measurements

\begin{tabular}{|c|c|c|}
\hline Parameter & SNF Mid 80L Comp & SNF M500 80L \\
\hline \multicolumn{3}{|c|}{ Initial Conditions (Starting-State Fuel Particles) } \\
\hline Mass of particles initially added, $g$ & 17.02 & 7.95 \\
\hline Settled density of particles, $\mathrm{g} / \mathrm{cm}^{3}$ (Section 7.7.1) & 10.9 & 9.6 \\
\hline Initial settled volume of particles, $\mathrm{cm}^{3}$ & 1.56 & 0.82 \\
\hline \multicolumn{3}{|c|}{ Post-Test Measurements/Observations } \\
\hline Volume of settled sludge, $\mathrm{cm}^{3}$ (Table 7.3) & 7.5 & 3.0 \\
\hline$\%$ of initial mass recovered (Table 7.6 ) & 89 & 71 \\
\hline Adjusted $^{(\mathrm{a})}$ volume of sludge recovered, $\mathrm{cm}^{3}$ & 8.4 & 4.2 \\
\hline $\begin{array}{l}\text { Expansion factor [(adjusted volume sludge } \\
\text { recovered)/(volume initial particles)] }\end{array}$ & 5.4 & 5.1 \\
\hline
\end{tabular}

material) were dried, and estimates were made to determine the overall mass recovery. ${ }^{(a)}$ Using the mass recoveries, the volume of settled sludge was adjusted to account for material that may have been left in the vessels. In Table 7.10, the adjusted volume of settled sludge is divided by the initial volume of particles to give the volumetric expansion. As shown in Table 7.10, the volume of the initial fuel particles for both SNF Mid 80L Comp and SNF M500 80L increased by a factor of 5 to 6 .

\subsubsection{Volumetric Expansion Based on Measured Properties}

The sludge expansion factor is the ratio of the end-state sludge volume to the starting-state settled sludge volume. Therefore the expansion factor can be determined by calculating the volume and uranium concentration of the end-state sludge that will be generated from a unit volume of starting-state sludge. In this section, the end-state volume and uranium concentration are calculated from the measured void fraction, settled density, and particle density measurements. The starting-state volume was estimated in Section 7.7.1.

\subsubsection{Post-Test Conditions of Reacted Fuel (Sludge) Recovered from Series III Tests}

Given a final settled density of $2.75 \mathrm{~g} / \mathrm{cm}^{3}$ (Table 7.3) for the SNF Mid 80L Comp, and a dry particle density of $9.4 \mathrm{~g} / \mathrm{cm}^{3}$ (Table 7.8) for the uranium corrosion products, the void fraction $(\phi)$ of the recovered sludge may be calculated:

$$
\begin{aligned}
& \text { SNF Mid 80L Comp: }\left[(1-\phi) \times 9.4 \mathrm{~g} / \mathrm{cm}^{3}\right]+\left(\phi \times 1 \mathrm{~g} / \mathrm{cm}^{3}\right)=2.75 \mathrm{~g} / \mathrm{cm}^{3} \\
& \phi=0.79,
\end{aligned}
$$

(a) Note: In determining the mass recovery, the weight gain associated with the oxygen as $\mathrm{U}_{(\text {met })}+1.125 \cdot \mathrm{O}_{2} \rightarrow$ $\mathrm{UO}_{2.25}$ was not accounted for. Assuming $100 \%$ of the initial fuel particles were $\mathrm{U}_{(\mathrm{met})}$, by not accounting for the $\mathrm{O}_{2}$, the stated recoveries could be low by about $15 \%$ (i.e., $100 \times 274 / 238$ ). 
which indicates a solids mass fraction of 0.71 [(2.75 - 0.79)/2.75], close to the measured value of 0.76 in Table 7.6.

The void fraction can also be calculated from the settled density, the weight fraction water, and $1 \mathrm{~g}_{2} \mathrm{O}=$ $1 \mathrm{~cm}^{3} \mathrm{H}_{2} \mathrm{O}$ :

$$
\begin{aligned}
\phi= & {\left[(\text { weight fraction water }) \times\left(\text { sludge settled density, } \mathrm{g} / \mathrm{cm}^{3}\right) \times\left(1 \mathrm{~cm}^{3} \mathrm{H}_{2} \mathrm{O} / \mathrm{g} \mathrm{H}_{2} \mathrm{O}\right)\right] / } \\
& \left(1 \mathrm{~cm}^{3} \text { sludge }\right) \\
\phi= & {\left[(1-0.76) \times\left(2.75 \mathrm{~g} / \mathrm{cm}^{3}\right) \times\left(1 \mathrm{~cm}^{3} / \mathrm{g}\right)\right] /\left(1 \mathrm{~cm}^{3}\right)=0.66 }
\end{aligned}
$$

If it is assumed that the best value for the void fraction is an average of the two values, then:

$$
\phi_{\text {avg }}=(0.79+0.66) / 2=0.73 \text {. }
$$

A void fraction of 0.73 is very close to the nominal and safety basis void fraction value of 0.75 for KE canister and floor sludge provided in Plys and Pearce (2002).

Based on a final settled density of $2.35 \mathrm{~g} / \mathrm{cm}^{3}$ (Table 7.3 ) and a dry particle density of $8.9 \mathrm{~g} / \mathrm{cm}^{3}$ (Table 7.8) for the sludge generated from SNF M500 80L tests, the void fraction $(\phi)$ can be calculated as:

$$
\begin{aligned}
& \text { SNF M500 80L: } \quad\left[(1-\phi) \times 8.9 \mathrm{~g} / \mathrm{cm}^{3}\right]+\left(\phi \times 1 \mathrm{~g} / \mathrm{cm}^{3}\right)=2.35 \mathrm{~g} / \mathrm{cm}^{3} \\
& \phi=0.83,
\end{aligned}
$$

which indicates a solids mass fraction of 0.65 [(2.35 - 0.83)/2.35], reasonably close to the measured value of 0.72 (Table 7.6).

The post-test void fraction for the material from SNF M500 80L can also be calculated as:

$$
\begin{aligned}
& \phi=\left[(\text { weight fraction water }) \times\left(\text { sludge settled density, } \mathrm{g} / \mathrm{cm}^{3}\right) \times\left(1 \mathrm{~cm}^{3} \mathrm{H}_{2} \mathrm{O} / \mathrm{g} \mathrm{H}_{2} \mathrm{O}\right)\right] / \\
& \quad\left(1 \mathrm{~cm}^{3} \text { sludge }\right) \\
& \phi=\left[(1-0.72) \times\left(2.35 \mathrm{~g} / \mathrm{cm}^{3}\right) \times\left(1 \mathrm{~cm}^{3} / \mathrm{g}\right)\right] /\left(1 \mathrm{~cm}^{3}\right)=0.66
\end{aligned}
$$

If it is assumed that the best value for the void fraction for SNF M500 80L is the average of the two values:

$$
\phi_{\text {avg }}=(0.83+0.66) / 2=0.75 .
$$

\subsubsection{Uranium Concentration in Reacted Sludge}

From XRD analyses, the predominant phase in the reacted sludge from SNF Mid 80L Comp and SNF M500 80L is $\mathrm{U}_{4} \mathrm{O}_{9}$ (molecular weight $\left.=274 \mathrm{~g} / \mathrm{mol}\right) . \mathrm{U}_{4} \mathrm{O}_{9}$ has a particle density $\left(11.30 \mathrm{~g} / \mathrm{cm}^{3}\right)$ consistent with that determined from the actual measurements $\left(9.4\right.$ and $8.9 \mathrm{~g} / \mathrm{cm}^{3}$, respectively, for the Mid 80L Comp and M500 80L tests). With the assumption that $\mathrm{U}_{4} \mathrm{O}_{9}$ is the representative phase for the corrosion products, the end-state uranium concentration in the settled sludge can be determined:

SNF Mid 80L Comp Post-test $[\mathrm{U}]=(1-0.73)\left(\mathrm{cm}^{3}\right.$ solids $/ \mathrm{cm}^{3}$ sludge $) \times 9.4\left(\mathrm{~g}\right.$ solids $/ \mathrm{cm}^{3}$ solid $)$ $\times(238 / 274)(\mathrm{g} \mathrm{U} / \mathrm{g}$ solids $)=2.20 \mathrm{~g} \mathrm{U} / \mathrm{cm}^{3}$ sludge . 
Therefore, for the SNF Mid 80L tests, the test material expanded by a factor of $4.3\left[10.8\left(\mathrm{~g} \mathrm{U} / \mathrm{cm}^{3}\right.\right.$ sludge, starting state $) / 2.20\left(\mathrm{~g} \mathrm{U} / \mathrm{cm}^{3}\right.$ sludge, end state $\left.)\right]$.

Similarly, the end-state uranium concentration for the SNF M500 80L material is:

SNF M500 80L Post-test $[\mathrm{U}]=(1-0.75)\left(\mathrm{cm}^{3}\right.$ solids $/ \mathrm{cm}^{3}$ sludge $) \times 8.9\left(\mathrm{~g}\right.$ solids $/ \mathrm{cm}^{3}$ solids $)$ $\times(238 / 274)(\mathrm{g} \mathrm{U} / \mathrm{g}$ solids $)=1.93 \mathrm{~g} \mathrm{U} / \mathrm{cm}^{3}$ sludge .

Therefore, for SNF M500 80L, the test material expanded by a factor of $4.8\left[9.3\left(\mathrm{~g} \mathrm{U} / \mathrm{cm}^{3}\right.\right.$ sludge, starting state $) / 1.93\left(\mathrm{~g} \mathrm{U} / \mathrm{cm}^{3}\right.$ sludge, end state) $]$.

\subsubsection{Comparison of Expansion Factor Results}

For the two sample materials evaluated, the two approaches gave similar expansion factors that ranged from 4.3 to 5.4. These values would apply to fuel particles that react in an anoxic (oxygen free) environment to form $\mathrm{UO}_{2.25}$ over a relatively short period of time $(\sim 3000 \mathrm{hr})$. At longer storage times (e.g., 30 years), oxygen generated from radiolysis and from diffusion could result in the conversion of $\mathrm{UO}_{2.25}$ to species that are more oxidized and hydrated, resulting in further volumetric expansion of the sludge. 


\subsection{References}

Baker, R. B., T. L. Welsh, and B. J. Makenas. 2000. Sampling and Analysis Plan for Sludge from the 105-K Basins to Support Transport to and Storage in T Plant. HNF-6479, Rev. 0, Fluor Hanford, Richland, WA.

Bradley, M. J., and L. M. Ferris. 1962. "Hydrolysis of Uranium Carbides between 25 and $100^{\circ}$. I. Uranium Monocarbide." Inorganic Chemistry 1(3):683-687.

Bradley, M. J., and L. M. Ferris. 1964. "Hydrolysis of Uranium Carbides between 25 and 100". II. Uranium Dicarbide, Uranium Metal-Monocarbide Mixtures, and Uranium Monocarbide-Dicarbide Mixtures." Inorganic Chemistry 3(2):189-195.

Bredt, P. R., C. H. Delegard, A. J. Schmidt, and K. L. Silvers. 1999. Testing and Analysis of Consolidated Sludge Sample from 105K East Basin Floor and Canisters. PNNL-13341, Pacific Northwest National Laboratory, Richland, WA.

Bryan, S. A., C. H. Delegard, A. J. Schmidt, R. L. Sell, K. L. Silvers, S. R. Gano, and B. M. Thornton. 2001. Gas Generation from K East Basin Sludges - Series II Testing. PNNL-13446, Pacific Northwest National Laboratory, Richland, WA.

Cordfunke, E.H.P. 1969. The Chemistry of Uranium, p. 188. Elsevier Publishing Company, Amsterdam, Netherlands.

Delegard, C. H., S. A. Bryan, A. J. Schmidt, P. R. Bredt, C. M. King, R. L. Sell, L. L. Burger, and K. L. Silvers. 2000. Gas Generation from K East Basin Sludges - Series I Testing. PNNL-13320, Pacific Northwest National Laboratory, Richland, WA.

Duncan, D. R. 2001. Spent Nuclear Fuel Project Technical Datebook, Vol. 1. HNF-SD-SNF-TI-015, Rev. 7, Fluor Hanford, Richland, WA.

Fonnesbeck, J. E. 2000. Quantitative Analysis of Hydrogen Gas Formed by Aqueous Corrosion of Metallic Uranium. ANL-00/19, Argonne National Laboratory, Idaho Falls, ID.

Gillies, D. M. 1958. "Some Studies of the Reactions of Uranium Oxides with Hydrogen, Oxygen, and Water." In Chemistry of Uranium Collected Papers, pp. 746-747, Paper 76, J. J. Katz and E. Rabinowitch, editors. TID-5290, U.S. Atomic Energy Commission, Oak Ridge, TN.

Haber, F., and R. le Rossignol. 1913. "Über die technische Darstellung von Ammoniak aus Elementen" ("On the Technical Production of Ammonia from the Elements"). Zeitschrift für Elektrochemie 19:53-108 (in German).

Hilton, B. A. 2000. Review of Oxidation Rates of DOE Spent Nuclear Fuel Part 1: Metallic Fuel. ANL-00/24, Argonne National Laboratory, Idaho Falls, Idaho. 
Johnson, A. B., R. G. Ballinger, and K. A. Simpson. 1994. "Kinetic and Thermodynamic Bases to Resolve Issues Regarding Conditioning of Uranium Metal Fuels.” PNL-SA-24458, Pacific Northwest Laboratory, Richland, WA.

Katsura, M., K. Nishimaki, T. Nakagawa, and K. Takahashi. 1998. "The Formation of Uranium Sesquinitride by Reactions of $\mathrm{U}$ or $\mathrm{UH}_{3}$ with a $\mathrm{N}_{2}-\mathrm{H}_{2}$ Mixture." Journal of Alloys and Compounds 271-273:662-665.

Makenas, B. J., T. L. Welsh, R. B. Baker, D. R. Hansen, and G. R. Golcar. 1996. Analysis of Sludge from Hanford K East Basin Floor and Weasel Pit. WHC-SP-1182, Westinghouse Hanford Company, Richland, WA.

Makenas, B. J., T. L. Welsh, R. B. Baker, E. W. Hoppe, A. J. Schmidt, J. Abrefah, J. M. Tingey, P. R. Bredt, and G. R. Golcar. 1997. Analysis of Sludge from Hanford K East Basin Canisters. HNF-SP-1201, Duke Engineering and Services Hanford, Inc., Richland, WA.

Makenas, B. J., T. L. Welsh, R. B. Baker, G. R. Golcar, P. R. Bredt, A. J. Schmidt, and J. M. Tingey. 1998. Analysis of Sludge from Hanford K West Basin Canisters. HNF-1728, Rev. 0, Fluor Daniel Hanford, Richland, WA.

Makenas, B. J., A. J. Schmidt, K. L. Silvers, P. R. Bredt, C. H. Delegard, E. W. Hoppe, J. M. Tingey, A. H. Zacher, T. L. Welsh, and R. B. Baker. 1999. Supplementary Information on K-Basin Sludges. HNF-2367, Rev. 0, Fluor Daniel Hanford, Richland, WA.

Makenas, B. J. 2000. Data Quality Objectives for Analysis of Hanford K Basin Sludge to Support Transport to and Storage in T Plant. HNF-5345, Rev. 0, Fluor Hanford, Inc., Richland, WA.

Marschman, S. C., T. D. Pyecha, and J. Abrefah. 1997. Metallographic Examination of Damaged N Reactor Spent Nuclear Fuel Element SFEC5,4378. PNNL-11438, Pacific Northwest National Laboratory, Richland, WA.

Montenyohl, V. I. 1960. "Corrosion of Uranium." Chapter 7, Reactor Handbook, $2^{\text {nd }}$ edition, Vol. I, Materials, C. R. Tipton, Jr., editor. Interscience Publishers, Inc., New York.

Pearce, K. L. 2001. 105-K Basin Material Design Basis Feed Description for Spent Nuclear Fuel Project Facilities, Volume 2, Sludge. HNF-SD-SNF-TI-009, Rev. 4, Fluor Hanford, Richland, WA.

Pitner, A. L. 1997. K Basin Fuel Subsurface Examination and Surface Coating Sampling. HNF-SDSNF-TI-060, Rev. 0. Duke Engineering and Services Hanford, Inc., Richland, WA.

Pitner, A. L. 1999. K East Basin Sludge/Sampling 1999 Campaigns. HNF-4746, Rev. 0, Numatec Hanford Corporation, Richland, WA.

Plys, M. G., and K. L. Pearce. 2002. Supporting Basis for Spent Nuclear Fuel Project Sludge Technical Databook. SNF-7765, Rev. 1, Fluor Hanford, Richland, WA. 
Reilly, M. A. 1998. Spent Nuclear Fuel Project Technical Databook, Volume 1. HNF-SD-SNF-TI-015, Rev. 6, DE\&S Hanford, Inc., Richland, WA.

Rovira, M., J. de Pablo, S. El Aamrani, L. Duro, M. Grive, and J. Bruno. 2003. Study of the Role of Magnetite in the Immobilisation of U(VI) by Reduction to U(IV) Under the Presence of $\mathrm{H}_{2}(\mathrm{~g})$ in Hydrogen Carbonate Medium. SKB TR-03-04, Svensk Karnbranslehantering AB, Stockholm, Sweden.

Sandino, M., C. Amaia, and B. Grambow. 1994. "Solubility Equilibria in the U(VI)-Ca-K-Cl- $\mathrm{H}_{2} \mathrm{O}$ System: Transformation of Schoepite into Becquerelite and Compreignacite." Radiochimica Acta 66/67:37-43.

Schmidt, A. J., C. H. Delegard, K. L. Silvers, P. R. Bredt, C. D. Carlson, E. W. Hoppe, J. C. Hayes, D. E. Rinehart, S. R. Gano, and B. M. Thornton. 1999. Validation Testing of the Nitric Acid Dissolution Step Within the K Basin Sludge Pretreatment Process. PNNL-12120, Pacific Northwest National Laboratory, Richland, WA.

Schmidt A. J., and C. H. Delegard. 2003. Updated Volumetric Expansion Factors for K Basin Sludge During Storage. PNNL-14228, Pacific Northwest National Laboratory, Richland, WA.

Silvers, K. L., J. J. Wagner, and R. T. Steele. 2000. TCLP Preparation and Analysis of K East Basin Composite Sludge Samples. PNNL-13280, Pacific Northwest National Laboratory, Richland, WA.

Sowder, A. G., S. B. Clark, and R. A. Fjeld. 1996. "The Effect of Silica and Phosphate on the Transformation of Schoepite to Becquerelite and Other Uranyl Phases." Radiochimica Acta 74:45-49.

Sowder, A. G., S. B. Clark, and R. A. Fjeld. 1999. "The Transformation of Uranyl Oxide Hydrates: The Effect of Dehydration on Synthetic Metaschoepite and Its Alteration to Becquerelite." Environmental Science and Technology 33:3552-3557.

Sunder, S., and N. H. Miller. 1998. "XPS and XRD Studies of Corrosion of Uranium Nitride by Water," Journal of Alloys and Compounds 271-273:568-572.

Tagawa, H. 1973. "Formation of Uranium Nitride by the Reaction of Uranium Hydride with Nitrogen and Ammonia." Bulletin of the Chemical Society of Japan 46:1158-1161.

Troutner, V. H. 1960. Mechanisms and Kinetics of Uranium Corrosion and Uranium Core Fuel Element Ruptures in Water and Steam. HW-67370, Hanford Atomic Products Operation, Richland, WA.

Tyfield, S. P. 1988. "Corrosion of Reactor Grade Uranium in Aqueous Solutions Relevant to Storage and Transport." Nuclear Engineering 27(2):91-98.

Vochten, R., and L. Van Haverbeke. 1990. "Transformation of Schoepite into the Uranyl Oxide Hydrates: Becquerelite, Billietite and Wölsendorfite.” Mineralogy and Petrology 43:65-72.

Waber, J. T. 1956. A Review of the Corrosion Behavior of Uranium. LA-2035, Los Alamos Scientific Laboratory, Los Alamos, NM. 
Weakley, E. A. 1979. Fuels Engineering Technical Handbook. UNI-M-61, UNC Nuclear Industries, Richland, WA.

Weber, L. A. 1999. "Estimating the Virial Coefficients of the Ammonia + Water Mixture." Fluid Phase Equilibria 162:31-49.

Wilkinson, W. D. 1962. Uranium Metallurgy. Interscience Publishers, New York.

Wronkiewicz, D. J., J. K. Bates, S. F. Wolf, and E. C. Buck. 1996. “Ten-Year Results from Unsaturated Drip Tests with $\mathrm{UO}_{2}$ at $90^{\circ} \mathrm{C}$ : Implications for the Corrosion of Spent Nuclear Fuel." Journal of Nuclear Materials 238:78-95. 


\section{Appendix A}

\section{Preparation of Fuel Particles for Series III}


40143-RPT04

Rev. 0

\section{Preparation of K Basin Spent Nuclear Fuel Fragments for Gas Generation Testing}

M. R. Elmore

A. J. Schmidt

August 2000

Prepared for

Fluor Hanford, Inc.

Work supported by

the U.S. Department of Energy

under Contract DE-AC06-76RLO 1830

Pacific Northwest National Laboratory

Richland, Washington 99352 


\section{Contents}

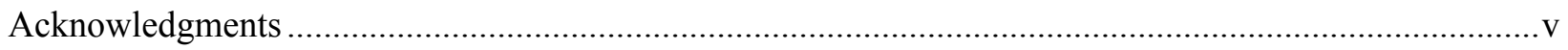

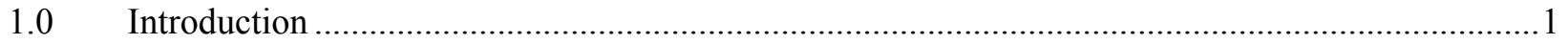

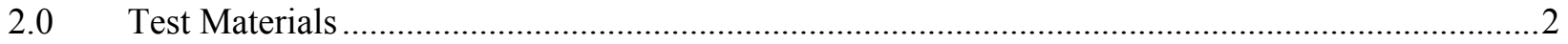

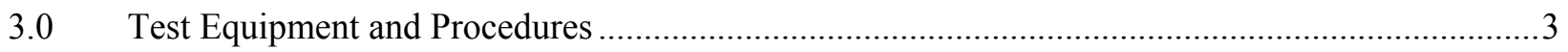

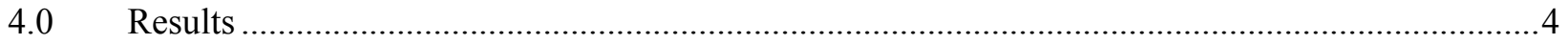

\section{Tables}

$1 \quad$ Test Matrix for Gas Generation Testing with Crushed SNF Fuel Fragments and K Basin Sludge

2 Required Quantities of Crushed and Screened Spent Fuel Particles ...........................................2

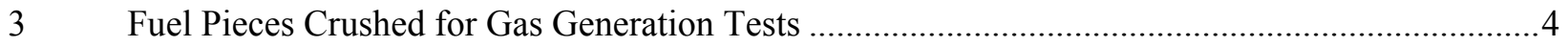

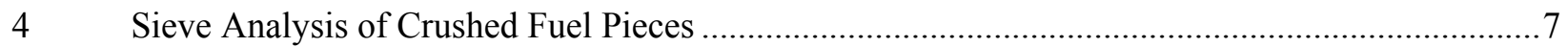

\section{Figures}

$1 \quad$ Sketch of Broken SNF Element (SFEC04, 2540E) Showing Locations of Sectioned SNF Archived Samples Used as Feed for the Crushing Operation ..............................................2

$2 \quad$ Hardened Steel Mortar and Pestle Used for Crushing Fuel Pieces .............................................

$3 \quad$ Fuel Piece 04-S1 (End Piece) Showing Broken Edges …............................................................5

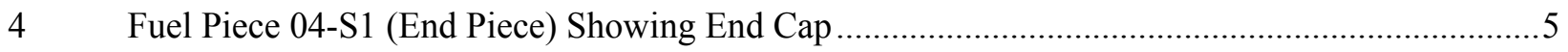

$5 \quad$ Fuel Piece 04-S2 C on Mortar Base Before Crushing ...............................................................

$6 \quad$ Hammer Used to Crush Fuel in Mortar and Pestle..................................................................6

$7 \quad$ Particle Size Distribution of the Crushed Fuel Prepared for Gas Generation Testing ....................7

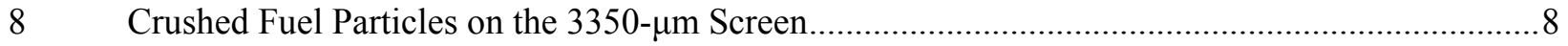

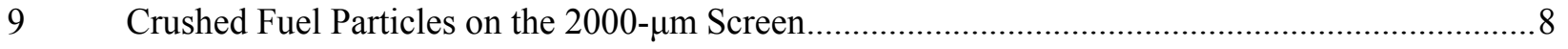

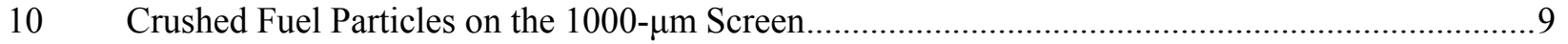




\section{Figures (continued)}

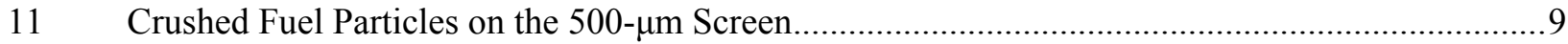

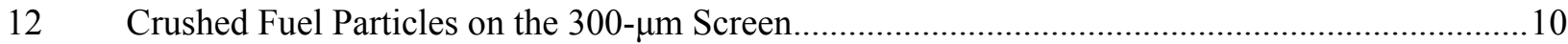

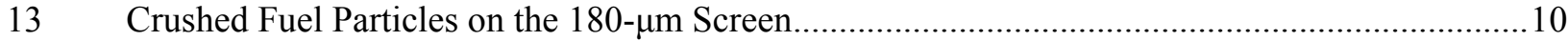

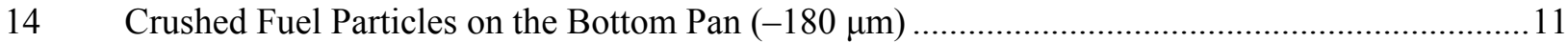




\section{Acknowledgments}

The authors would like to thank R. C. Lettau of Pacific Northwest National Laboratory for his technical support in performing the crushing operations. 


\subsection{Introduction}

This report discusses a size reduction method that was selected to produce crushed $\mathrm{K}$ Basin spent fuel samples needed for subsequent gas generation testing. During the study reported here, archived samples of an irradiated metallic uranium fuel element were crushed to resemble the crumbled fuel pieces expected in the retrieved K Basin sludge. A "Plattner's" mortar and pestle, made from a hardened alloy tool steel, and a manipulator-held hammer were used. A similar mortar and pestle was recently used in another evaluation of crushing techniques. ${ }^{(a)}$ In the earlier work it was noted that the uranium near a fractured surface tends to be more brittle and friable than uranium even a short distance from the fracture. Consequently, fuel pieces with at least one broken face were selected for crushing, and hammering was found to be a suitable size reduction technique.

The gas generation tests will be performed with crushed spent nuclear fuel (SNF) to determine how gas generation rates in $\mathrm{K}$ Basin sludge may vary as a function of uranium particle size and test temperature. Fuel fragments are expected to be part of the sludge waste stream generated during the proposed fuel element washing process, most likely uranium particulates from previously fractured surfaces. Table 1 shows the initial temperatures and fuel fragment and sludge subsamples that will be used. The data from these tests will be used to calibrate and validate thermal stability and gas generation models, which provide safety-basis input for the design of sludge storage and shipping systems.

Table 1. Test Matrix for Gas Generation Testing with Crushed SNF Fuel Fragments and K Basin Sludge

\begin{tabular}{|c|c|c|c|c|c|c|c|c|c|}
\hline \multirow[b]{2}{*}{$\#$} & \multirow{2}{*}{ Test ID } & \multicolumn{2}{|c|}{ Fuel Fragments } & \multicolumn{2}{|c|}{$\begin{array}{c}\begin{array}{c}\text { Sludge Sample } \\
\text { Fraction }\end{array} \\
\end{array}$} & \multirow{2}{*}{$\begin{array}{c}\text { Test } \\
\text { Temp, } \\
{ }^{\circ} \mathrm{C}\end{array}$} & \multirow{2}{*}{$\begin{array}{c}\text { Reactor } \\
\text { Volume, } \\
\text { ml }\end{array}$} & \multirow{2}{*}{$\begin{array}{c}\text { Sample } \\
\text { Volume, } \\
\text { ml }\end{array}$} & \multirow{2}{*}{$\begin{array}{c}\text { Max } \\
\text { Gas Gen } \\
\text { Rate, } \\
\text { ml/day }\end{array}$} \\
\hline & & Fraction & $\begin{array}{c}\text { Mass, } \\
\text { g }\end{array}$ & $\begin{array}{l}\text { Sample } \\
\text { ID }\end{array}$ & $\begin{array}{l}\text { Mass, } \\
\text { g }\end{array}$ & & & & \\
\hline 1 & SNF M500-80L & M500 $^{(1)}$ & 8 & None & & 80 & 800 & 2 & 312 \\
\hline 2 & SNF Mid-80L & $500-2000$ & 8 & None & & 80 & 800 & 2 & 77 \\
\hline 3 & SNF P2000-80S & 2000-6250 & 10 & None & & 80 & 60 & 2 & 31 \\
\hline 4 & SNF Mid 40S & $500-2000$ & 8 & None & & 40 & 60 & 2 & 6.4 \\
\hline 5 & SNF Mid 60S & $500-2000$ & 8 & None & & 60 & 60 & 2 & 24 \\
\hline 6 & SNF Mid 80L Dup & $500-2000$ & 8 & None & & 80 & 800 & 2 & 77 \\
\hline 7 & $\mathrm{SNF}+\mathrm{Can} 60 \mathrm{~S}$ & $500-2000$ & 8 & $\begin{array}{c}\text { KC-Can } \\
\text { Comp }\end{array}$ & 20 & 60 & 60 & 15 & 27 \\
\hline 8 & $\begin{array}{c}\text { SNF+Can Fines } \\
60 \mathrm{~S}\end{array}$ & M500 $^{(1)}$ & 4 & $\begin{array}{c}\mathrm{KC}-2 / 3 \\
\mathrm{M} 250\end{array}$ & 20 & 60 & 60 & 14 & 50 \\
\hline 9 & $\mathrm{SNF}+\mathrm{Can} 60 \mathrm{~L}$ & All $^{(2)}$ & 25 & $\begin{array}{c}\text { KC-Can } \\
\text { Comp }\end{array}$ & 60 & 60 & 800 & 30 & 82 \\
\hline 10 & SNF+Floor 60L & All $^{(2)}$ & 25 & KC Floor & 100 & 60 & 800 & 88 & 87 \\
\hline 11 & $\begin{array}{c}\text { Fuel Fragment } \\
\text { Ongoing }\end{array}$ & Whole & 3.72 & none & 0 & 80 & 60 & 0.2 & 15 \\
\hline 12 & $\begin{array}{c}\text { KC-2/3 P250 } \\
\text { Ongoing }\end{array}$ & None & 0 & $\begin{array}{c}\mathrm{KC}-2 / 3 \\
\mathrm{P} 250\end{array}$ & 65 & $\sim 32$ & 800 & 30 & $\sim 2$ \\
\hline
\end{tabular}

(1) $\mathrm{M} 500=$ fragments that are less than $500 \mu \mathrm{m}$

(2) All $=$ fragments made up of entire particle size distribution under $6350 \mu \mathrm{m}$.

(a) M. R. Elmore and A. J. Schmidt. 2000. "Initial K Basin Fuel Crushing Demonstration for Gas Generation Testing." Letter report 40143-RPT03 to W. W. Rutherford, Fluor Hanford, Inc. 
Target amounts for crushed fuel of the various size fractions needed are shown in Table 2. The minus $6350-\mu \mathrm{m}(-1 / 4-$ in.) amount was revised (as indicated in Table 2) when one of the planned tests was eliminated. Instead, the duration of a similar test already in progress in PNNL's Radiochemical Processing Laboratory (RPL, 325 Building) was extended. The results of the crushing tests are given here, including photographs of the crushed fuel particles.

Table 2. Required Quantities of Crushed and Screened Spent Fuel Particles

\begin{tabular}{|c|c|}
\hline Screen Fraction, $\boldsymbol{\mu m}$ & Mass, $\mathbf{g}$ \\
\hline-500 & 12 \\
\hline$+500-2000$ & 40 \\
\hline$+2000-6350$ & 10 \\
\hline-6350 & 75 (later revised to 52) \\
\hline
\end{tabular}

\subsection{Test Materials}

The spent fuel starting materials to be used for crushing and the subsequent gas generation testing were selected from archived samples of K Basin SNF element [SFEC04, 2540E] that were stored in an argoninerted storage can in the A-Cell of the High Level Radiochemistry Facility (HLRF) in the RPL. Figure 1 is a sketch of the archived samples that were produced by sectioning the damaged top end of the fuel element into smaller pieces $04-\mathrm{S} 2 \mathrm{~A}$ through $\mathrm{K}$. Of the samples available in the storage can, samples 04-S2 C, D, E2, F, and G were selected for crushing. The conical-shaped end piece (04-S1) was stored in the same sample can, and was also used as a feed source for the size reduction operation.

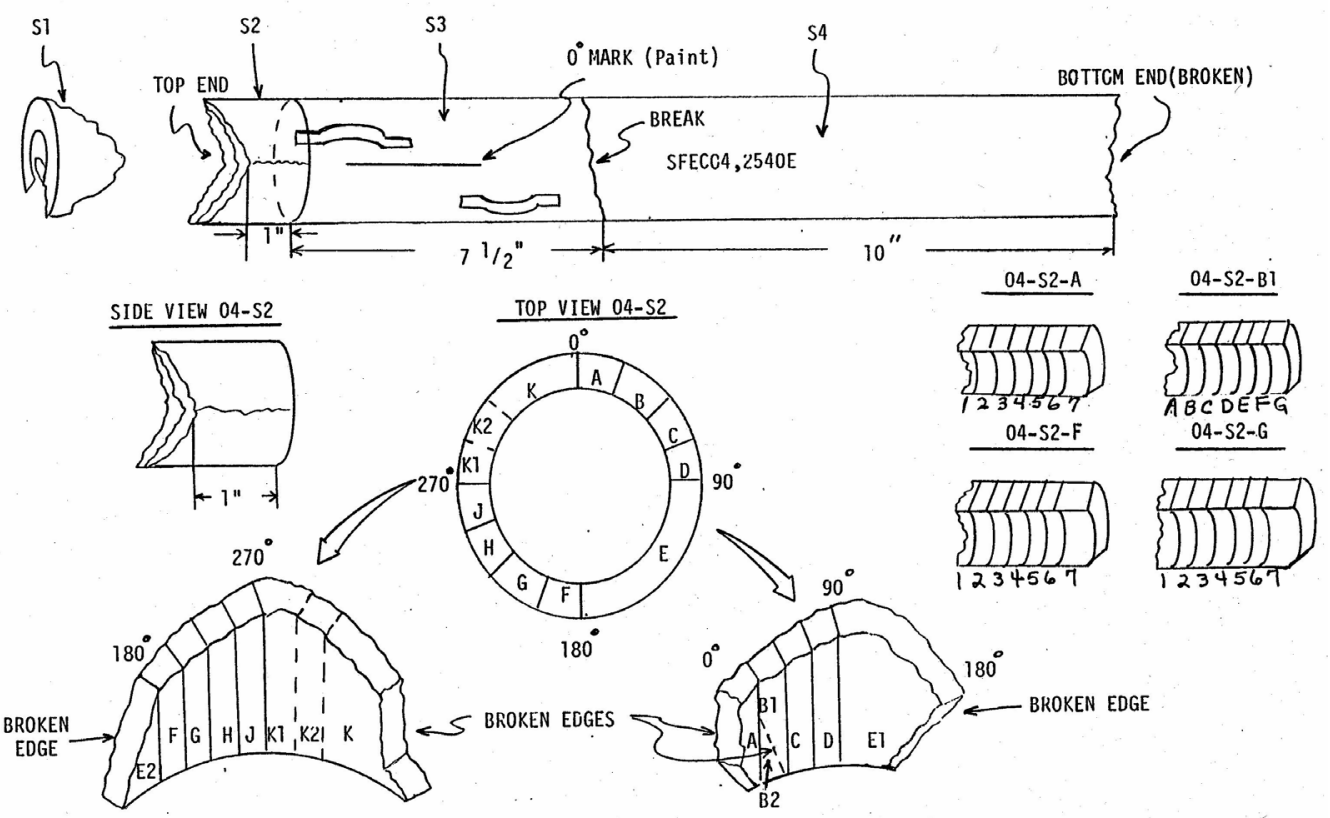

Figure 1. Sketch of Broken SNF Element (SFEC04, 2540E) Showing Locations of Sectioned SNF Archived Samples Used as Feed for the Crushing Operation 


\subsection{Test Equipment and Procedures}

The mortar and pestle used to perform the crushing operation are shown in Figure 2. The 1-in.-diameter pestle fits inside a 1-in.-ID sleeve. The sleeve fits into a $\sim 1 \frac{1}{4}-$-in.-diameter $\mathrm{X} 1 / 4$-in.-deep well in the mortar base. The piece of fuel to be crushed was placed onto the base inside the sleeve. The pestle was inserted into the sleeve and was struck repeatedly with a manipulator-held hammer until the fuel piece was crushed. The crushed fuel was subsequently screened through a series of 3-in.-diameter US Standard Testing Sieves to produce the desired quantities of specified size fractions for the gas generation tests, and to characterize the size distribution of the fuel particles. During the size reduction operation, the crushed material was periodically poured from the mortar through the screens. Clean cladding pieces on the $6350-\mu \mathrm{m}$ screen were removed from the crushed fuel and set aside. Any remaining oversized fuel material was returned to the mortar for further crushing, or returned to storage if too difficult to fracture. All the fuel pieces were size-reduced in this manner. Even though the uranium that was eventually crushed was fairly brittle (did not behave as a malleable metal), all the crushing required significant physical effort.

Because the crushed fuel was screened frequently, with oversized pieces recrushed as necessary, the crushing was closely monitored and did not generate an excess of fines. As a result, as the fuel was first crushed to $-6350 \mu \mathrm{m}$, the coarse size fraction $(-6350+2000 \mu \mathrm{m})$ had an excess of material. Material on the 2000- $\mu \mathrm{m}$ screen was further crushed until the required amount (with a small excess) remained. The $-2000-\mu \mathrm{m}$ fraction held an excess of $-2000+500-\mu \mathrm{m}$ material. The $+500-\mu \mathrm{m}$ material was likewise crushed until the necessary amount plus a small excess remained on the $500-\mu \mathrm{m}$ screen. The remaining $-500-\mu \mathrm{m}$ material that was required for subsequent testing plus a minimal amount of extra fines.

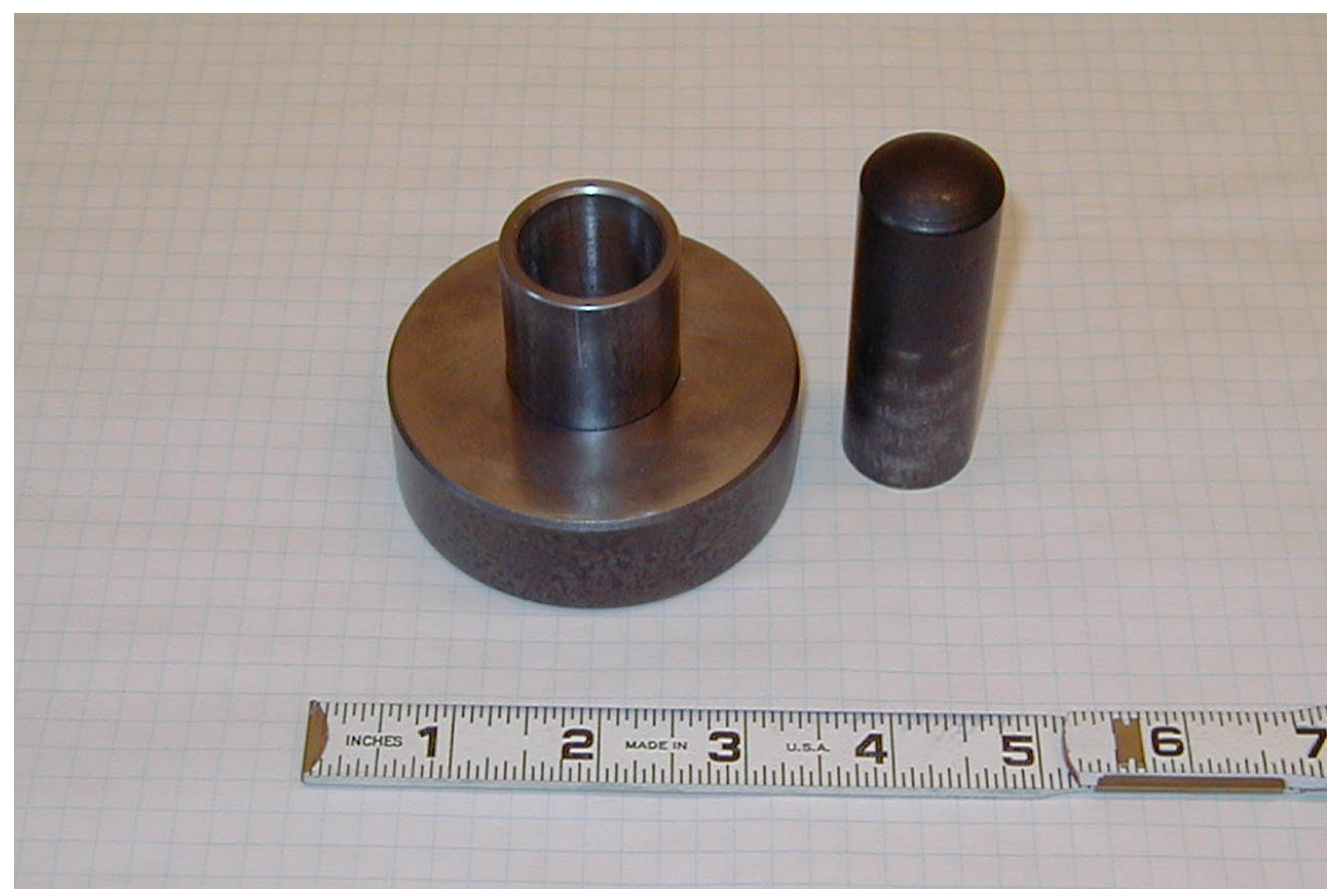

Figure 2. Hardened Steel Mortar and Pestle Used for Crushing Fuel Pieces 
Table 3 describes each fuel piece subjected to crushing, including the original sample weights (recorded and measured), the quantity of sample crushed, and the weight of samples returned to storage (some returned sample vials contained only cladding). Residual uncrushed fuel and associated Zircaloy cladding was returned to the original vials, placed into SNF Sample \#1 (1-gal paint can), inerted with argon, and returned to A-Cell.

At this point, with the necessary masses of appropriate size distributions prepared, all the crushed material was placed into a jar and well mixed by tumbling the jar. The material was then poured out of the jar into a pile. This pile was divided into subfractions by "cone and quartering" the larger amount into two batches (one containing $\sim 52 \mathrm{~g}$ for the $-6350-\mu \mathrm{m}$ batch, the other $\sim 100 \mathrm{~g}$ for additional screening). The $52-\mathrm{g}$ sample of $-6350-\mu \mathrm{m}$ material was placed into a labeled vial and held for the gas generation testing. The remaining $\sim 100 \mathrm{~g}$ was screened through a stack of sieves containing additional screens to provide more detail on the actual size distribution of the crushed fuel.

Table 3. Fuel Pieces Crushed for Gas Generation Tests

\begin{tabular}{|c|l|c|c|c|}
\hline Sample ID & \multicolumn{1}{|c|}{ Description } & $\begin{array}{c}\text { Recorded } \\
\text { Starting Wt, g }\end{array}$ & $\begin{array}{c}\text { Measured } \\
\text { Starting Wt, g }\end{array}$ & $\begin{array}{c}\text { Returned to } \\
\text { Storage, }\end{array}$ \\
\hline 04-S1 & $\begin{array}{l}\text { Broken end piece of fuel element } \\
\text { (See Figures 3 and 4) }\end{array}$ & 436.0 & 457.47 & 436.49 \\
\hline 04-S2 C & $\begin{array}{l}\text { Rectangular, one face broken, two } \\
\text { clad faces, and three sawn faces. }\end{array}$ & 33.0 & 34.75 & 27.13 \\
\hline 04-S2 D & $\begin{array}{l}\text { Rectangular, one face at break, } \\
\text { two clad faces, and three sawn } \\
\text { faces. }\end{array}$ & 46.0 & 49.28 & 3.02 \\
\hline 04-S2 E2 & $\begin{array}{l}\text { Wedge-shaped, longest face at } \\
\text { break, two clad faces, and three } \\
\text { sawn faces) }\end{array}$ & 23.0 & 24.61 & 1.12 \\
\hline 04-S2 F & $\begin{array}{l}\text { Rectangular, one face at break, } \\
\text { two clad faces, and three sawn } \\
\text { faces }\end{array}$ & 31.0 & 32.63 & 1.65 \\
\hline 04-S2 G & $\begin{array}{l}\text { Rectangular, similar to 04-S2 F, } \\
\text { that broke into two pieces }\end{array}$ & 46.0 & 49.52 & 2.09 \\
\hline
\end{tabular}

\subsection{Results}

Fuel piece 04-S1was a large fractured end piece from the fuel element (SFEC04, 2540E), somewhat conical in shape. It was originally thought that all the crushed fuel required for gas generation testing could be recovered from $04-\mathrm{S} 1$. The end piece was highly fractured but tightly bonded to the cladding and a metallic endcap. Figures 3 and 4 show the end piece 04-S1. Some of the material was removed from 04-S1 with a sharp pick-like instrument and a hammer. After much time and effort to separate some of the fractured pieces and remove most of the cladding from them, only about $20 \mathrm{~g}$ of uranium fuel pieces were recovered that could then be further crushed. Consequently, the large end piece (now in three separate pieces) was returned to storage. 


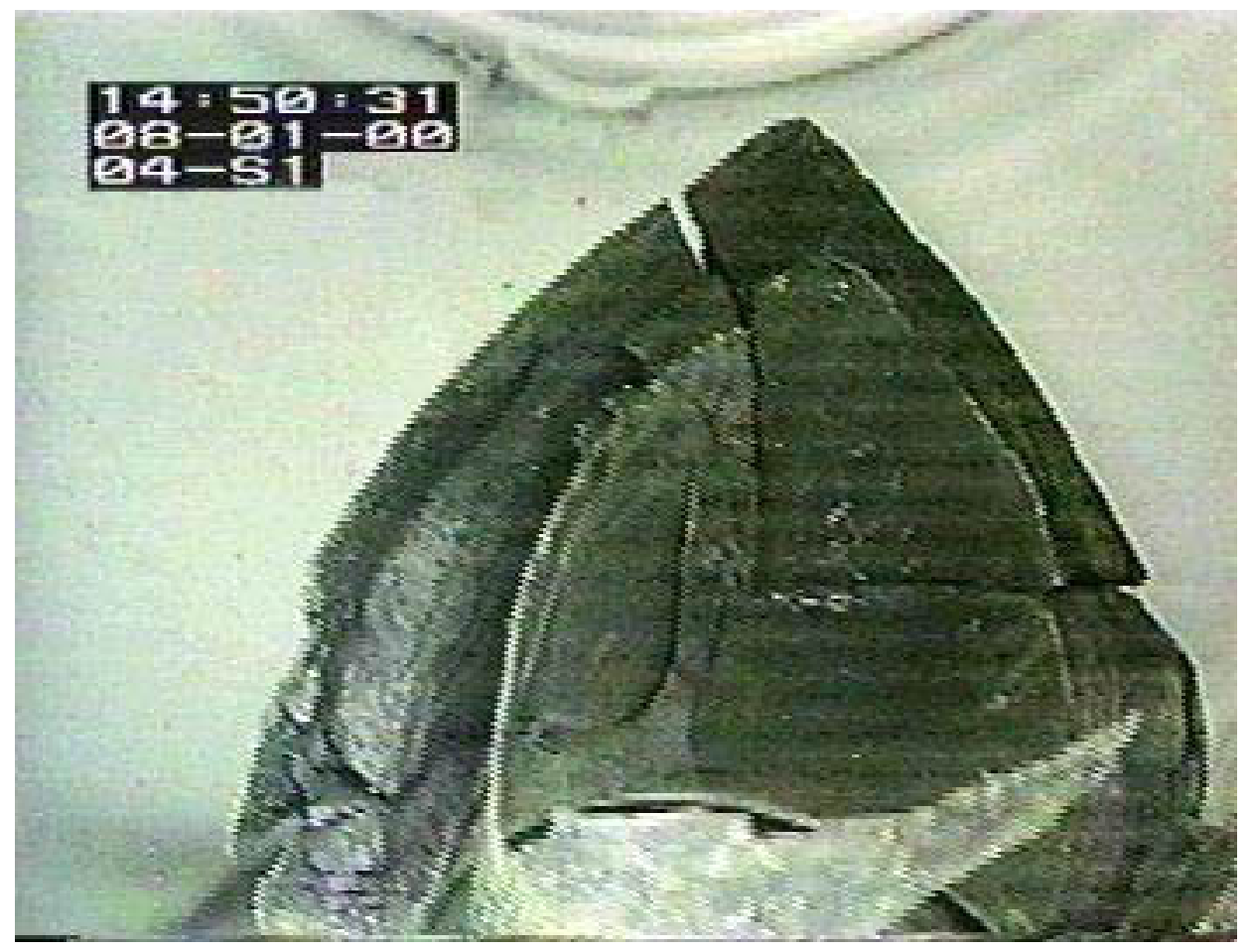

Figure 3. Fuel Piece 04-S1 (End Piece) Showing Broken Edges

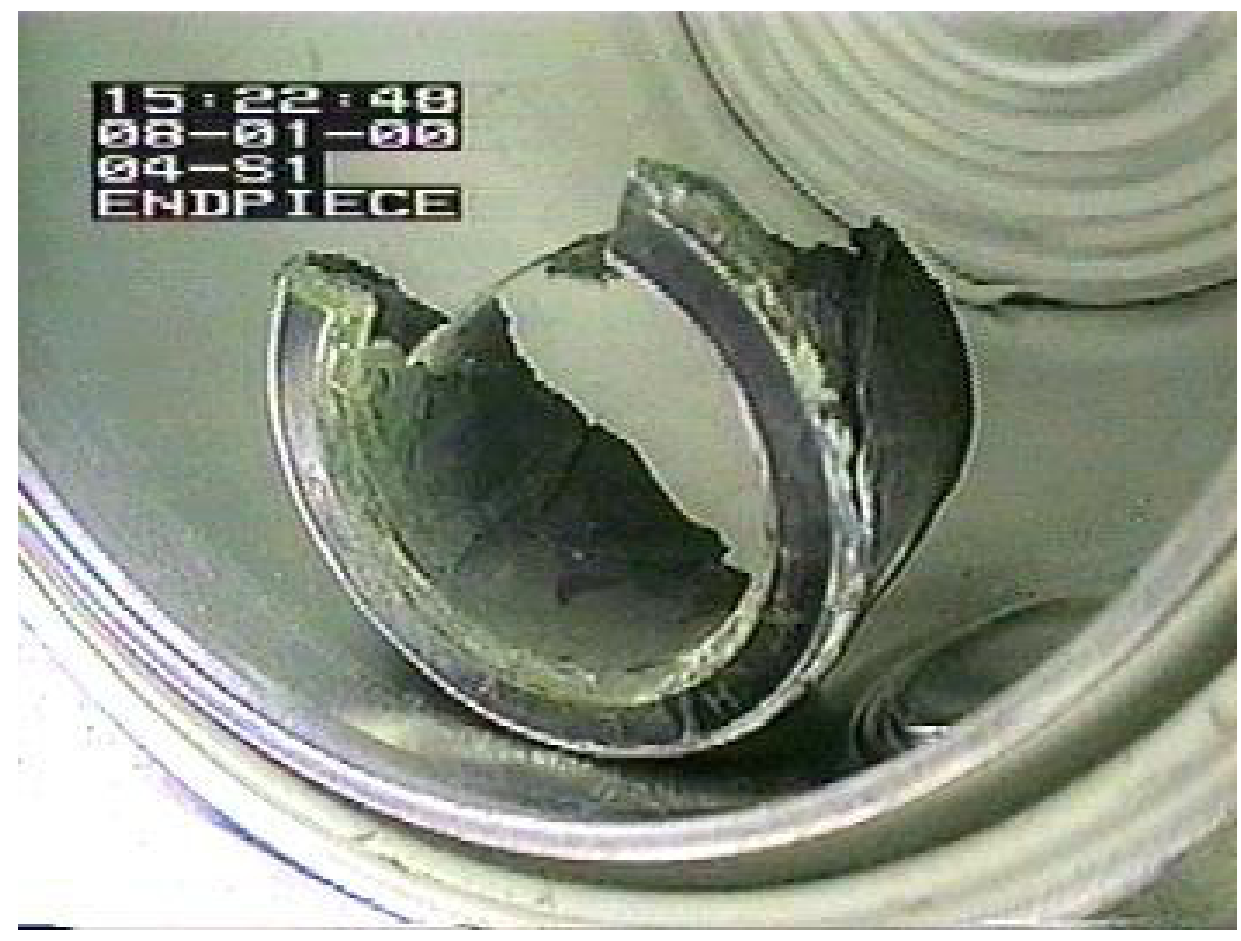

Figure 4. Fuel Piece 04-S1 (End Piece) Showing End Cap 
Most of the other pieces were crushed completely with the mortar and pestle, also after significant time and effort. One piece, however, 04-S2 C, was much more difficult to crush than the other pieces.

Figure 5 shows fuel piece 04-S2 C lying on the mortar base before crushing. The cavity in the mortar base is $\sim 1 \frac{1}{4}$ in. diameter. After much hammering and damage to the mortar sleeve, most of the sample was unbroken and consequently was returned to storage (Table 3 ). Figure 6 shows the unused and the damaged faces of the hammer as an indication of the effort required to break up the fuel pieces.

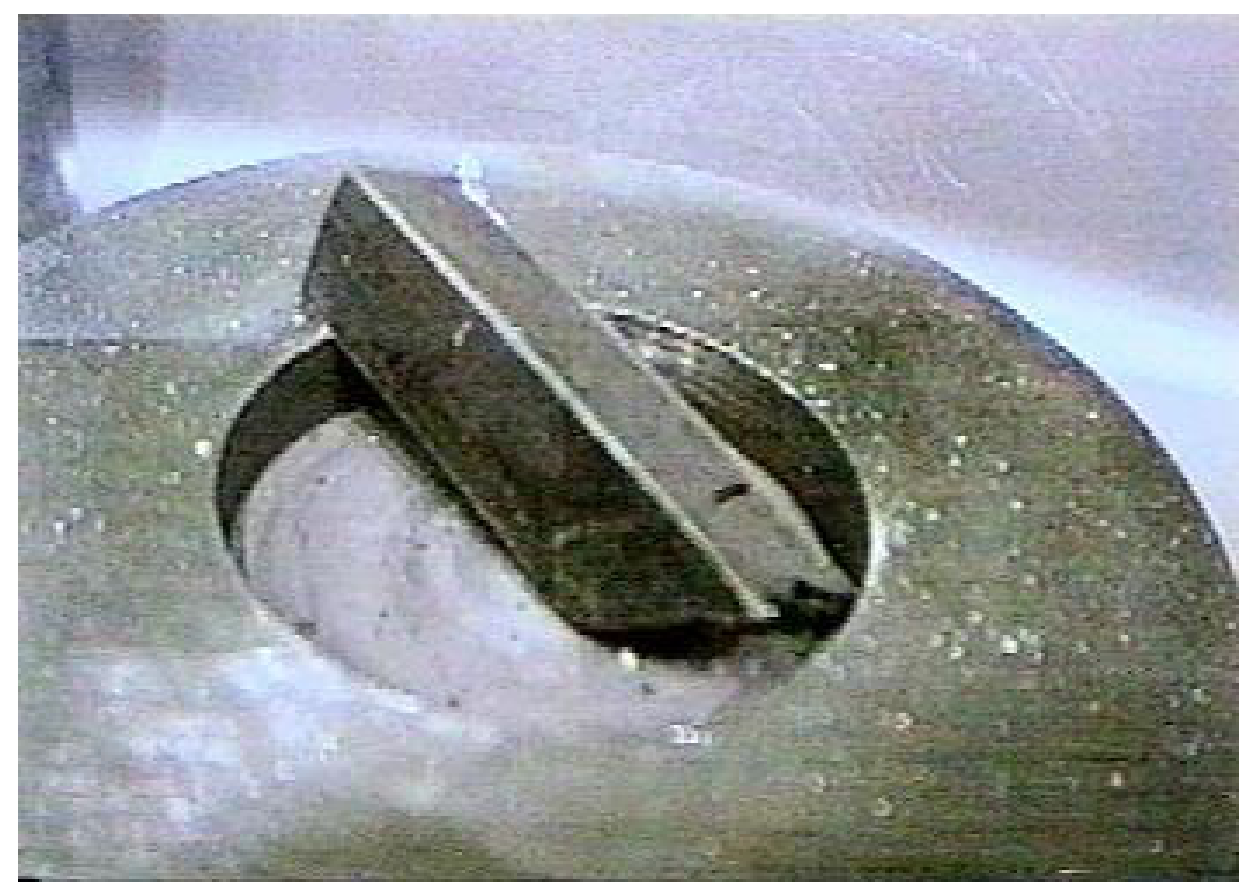

Figure 5. Fuel Piece 04-S2 C on Mortar Base Before Crushing

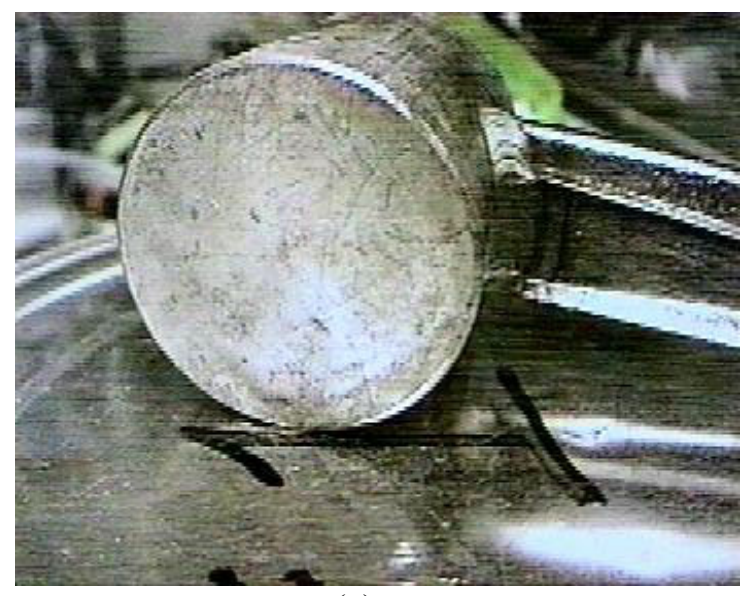

(a)

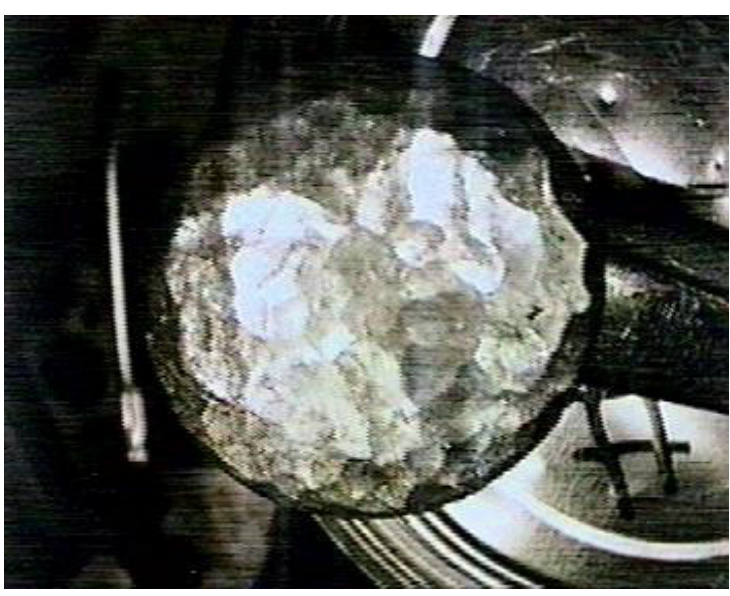

(b)

Figure 6. Hammer Used to Crush Fuel in Mortar and Pestle; (a) Unused Face, (b) Damaged Face from Repeated Hard Hammer Blows 
Table 4 shows the results of the final screening. Once the remaining crushed fuel was screened, the required size fractions were composited from the appropriate screens, and labeled vials with the crushed fuel samples were set aside for subsequent testing. Table 4 also shows the size fractions and weights for samples produced from the crushing and screening. Figure 7 illustrates the size distribution of crushed fuel pieces shown in Table 4. Figures 8 through 14 show the crushed fuel particles retained on each of the various screens listed in Table 4, including the fines (less than $180 \mu \mathrm{m}$ ) in the bottom pan.

Table 4. Sieve Analysis of Crushed Fuel Pieces

\begin{tabular}{|c|c|c|c|c|}
\hline Screen Size, $\mu \mathrm{m}$ & $\begin{array}{l}\text { Mass on } \\
\text { Screen, } g\end{array}$ & $\begin{array}{c}\text { Cumulative \% } \\
\text { Finer }\end{array}$ & $\begin{array}{l}\text { Composited Size Fraction for } \\
\text { Gas Generation Tests, } \mu \mathrm{m}\end{array}$ & Mass, $\mathrm{g}$ \\
\hline 6350 (1/4-in.) & 0.00 & 100.0 & \multirow{3}{*}{$-6350+2000$} & \multirow{3}{*}{20.70} \\
\hline 3350 & 5.93 & 93.7 & & \\
\hline 2000 & 14.86 & 77.8 & & \\
\hline 1000 & 37.94 & 37.4 & \multirow{2}{*}{$-2000+500$} & \multirow{2}{*}{57.58} \\
\hline 500 & 19.79 & 16.3 & & \\
\hline 300 & 7.97 & 7.8 & \multirow{3}{*}{-500} & \multirow{3}{*}{15.23} \\
\hline 180 & 3.51 & 4.1 & & \\
\hline-180 (bottom pan) & 3.85 & $\mathrm{~N} / \mathrm{A}$ & & \\
\hline \multicolumn{3}{|c|}{ Separated prior to screening $\rightarrow$} & -6350 (full distribution) & 51.92 \\
\hline
\end{tabular}

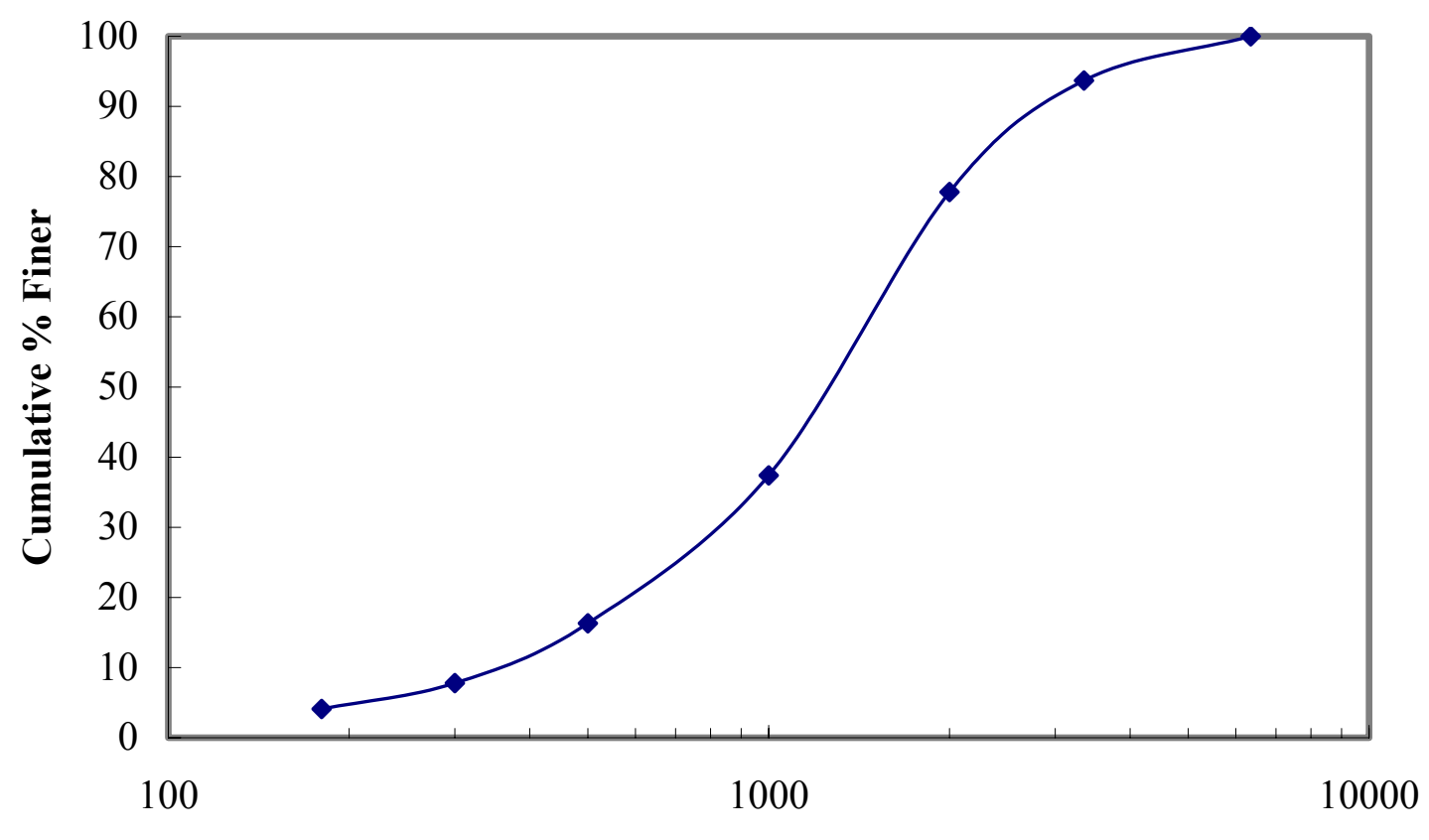

Particle Size, $\mu \mathrm{m}$

Figure 7. Particle Size Distribution of the Crushed Fuel Prepared for Gas Generation Testing 


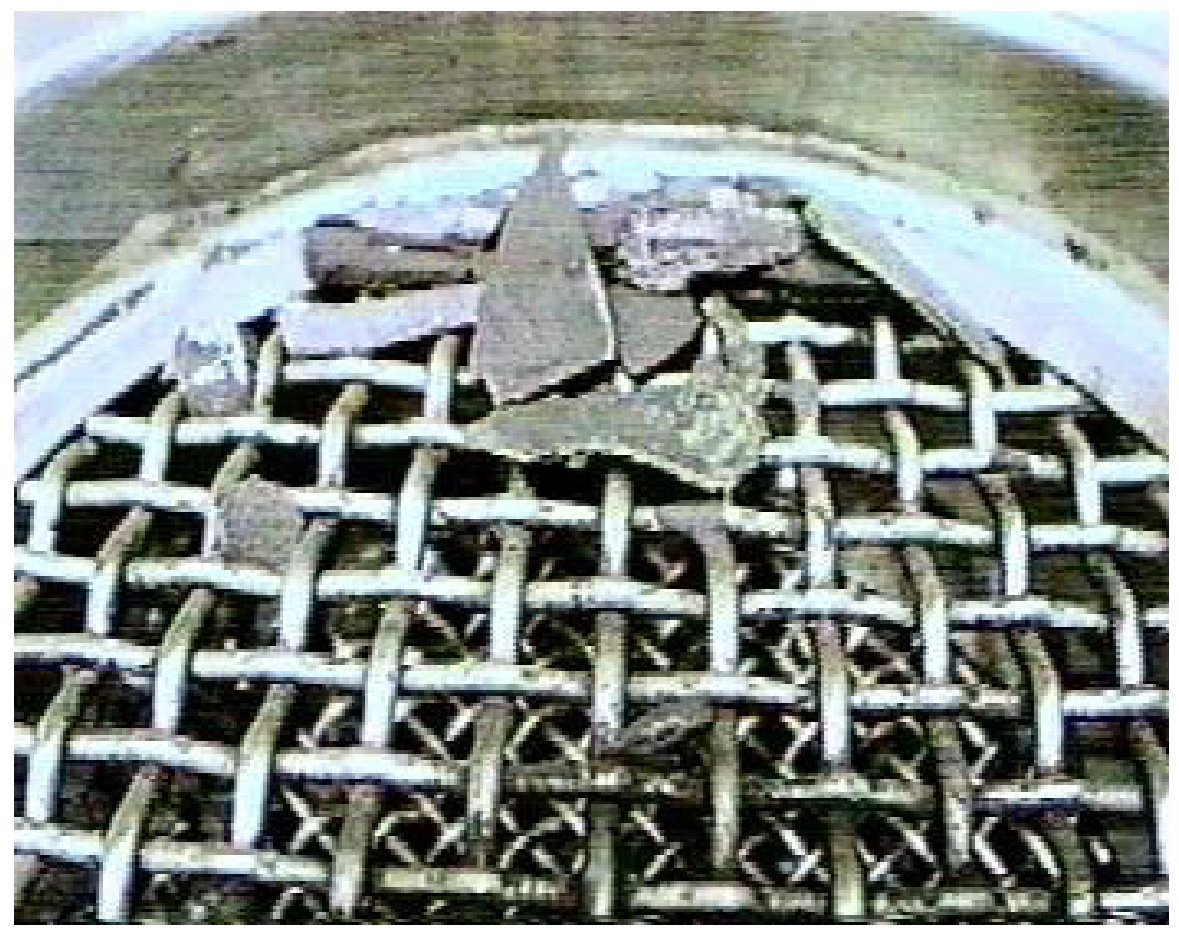

Figure 8. Crushed Fuel Particles on the $3350-\mu \mathrm{m}$ Screen

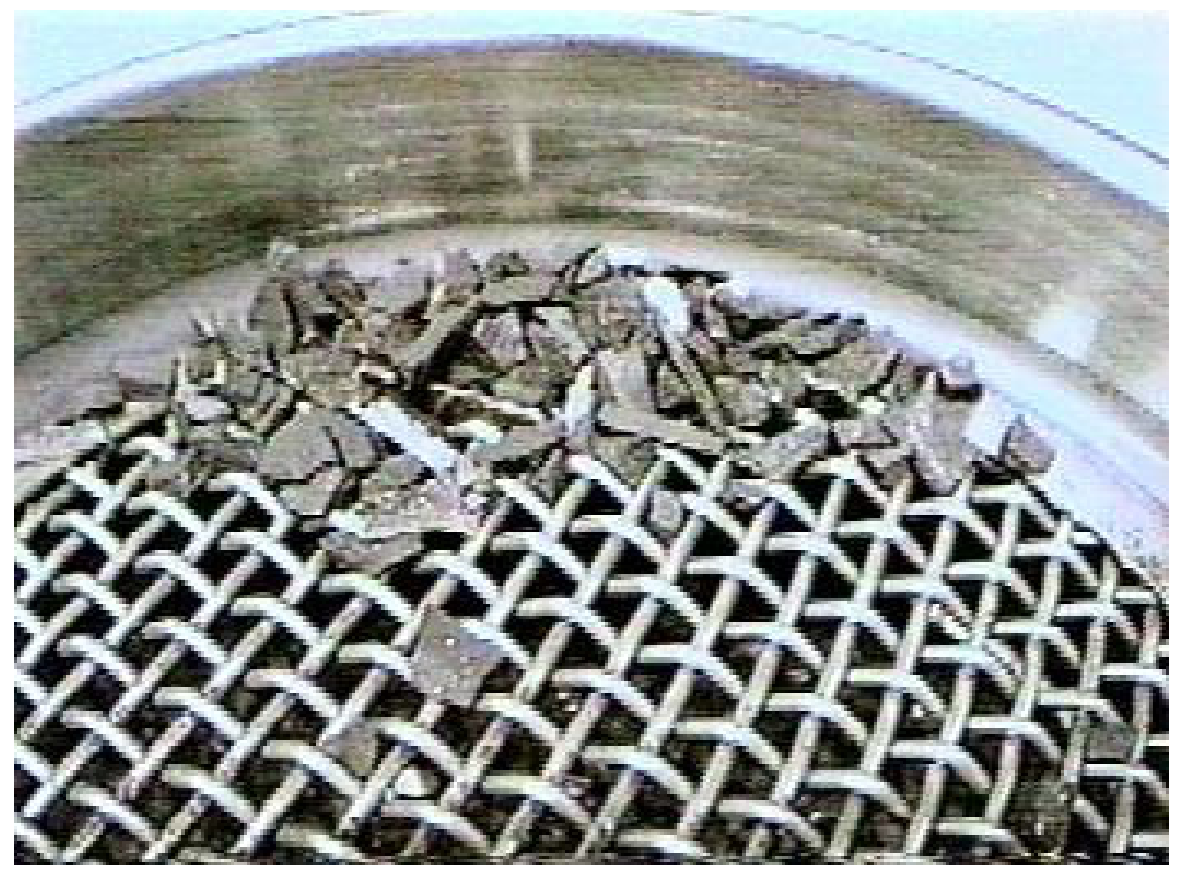

Figure 9. Crushed Fuel Particles on the 2000- $\mu \mathrm{m}$ Screen 


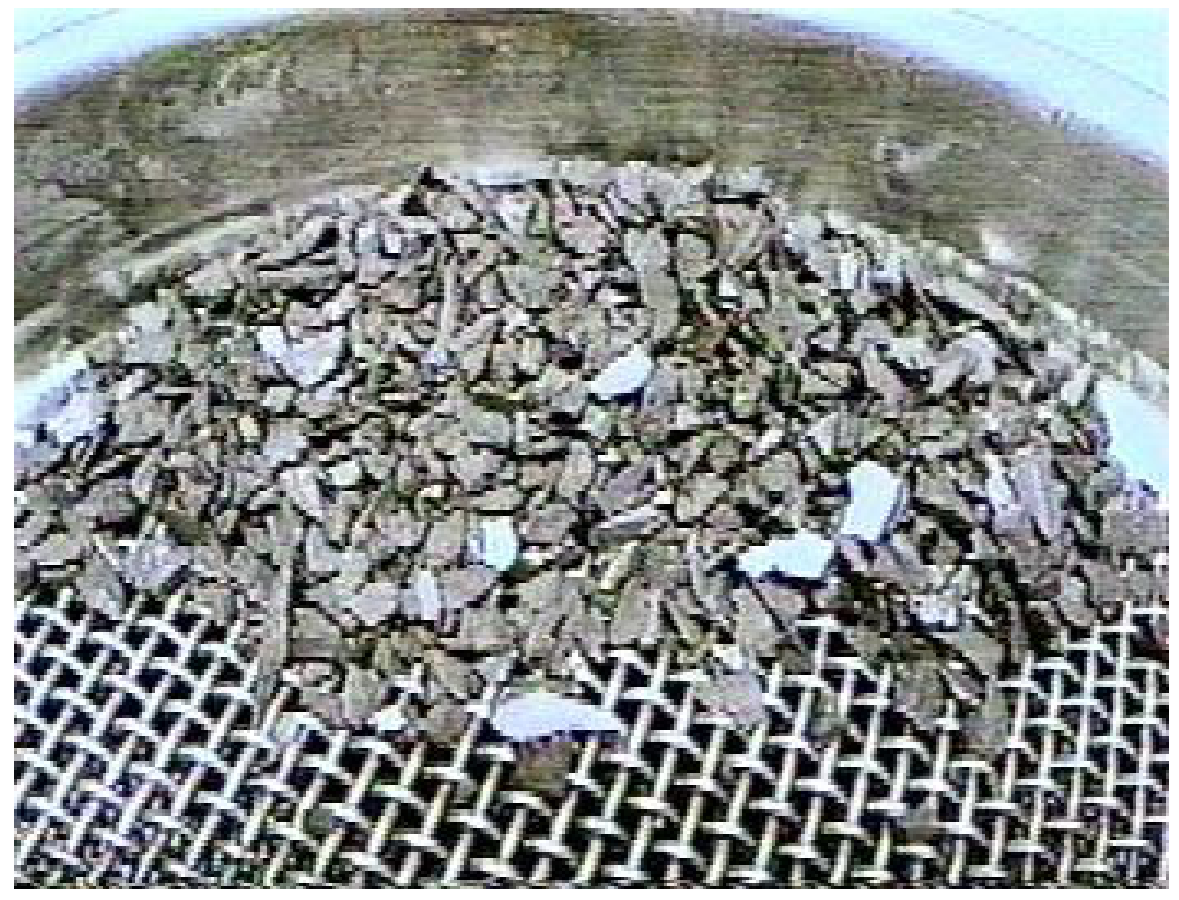

Figure 10. Crushed Fuel Particles on the $1000-\mu \mathrm{m}$ Screen

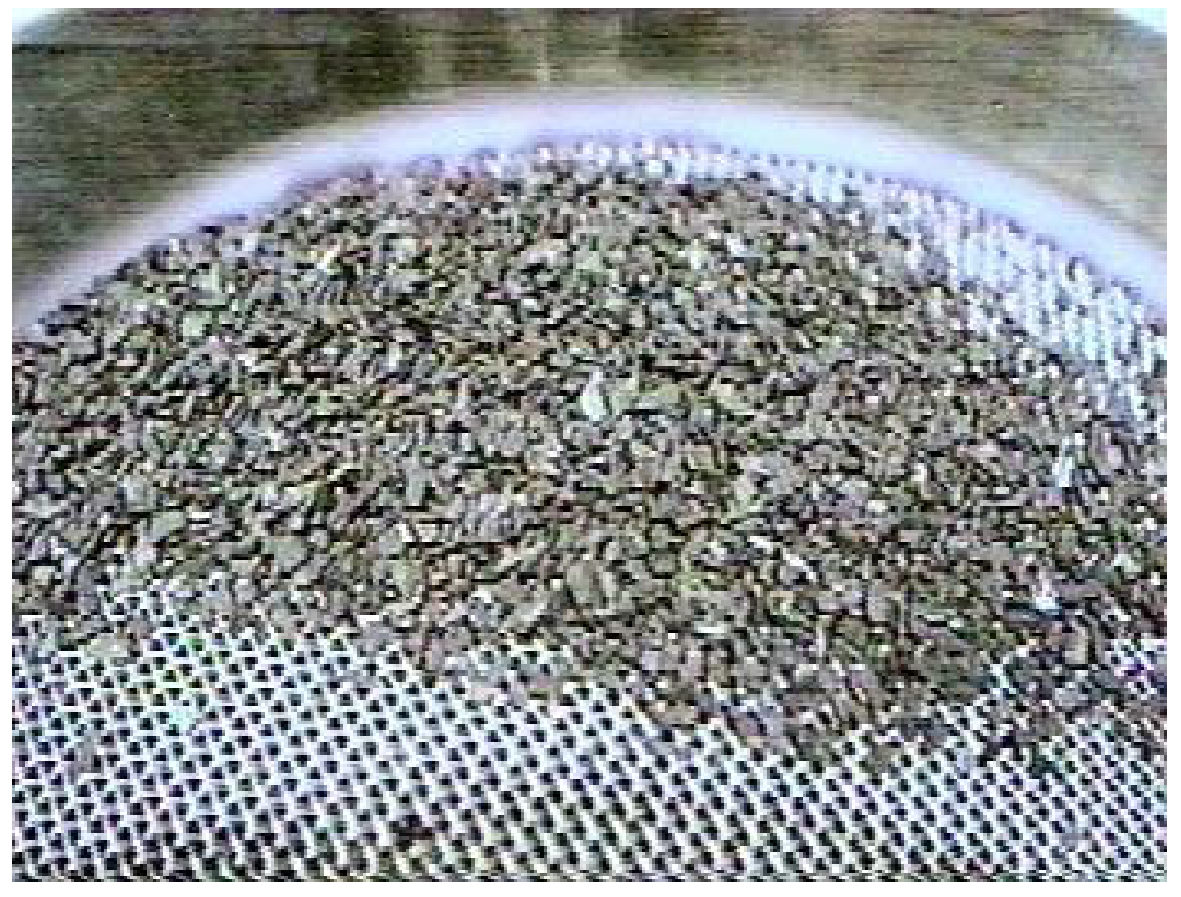

Figure 11. Crushed Fuel Particles on the $500-\mu \mathrm{m}$ Screen 


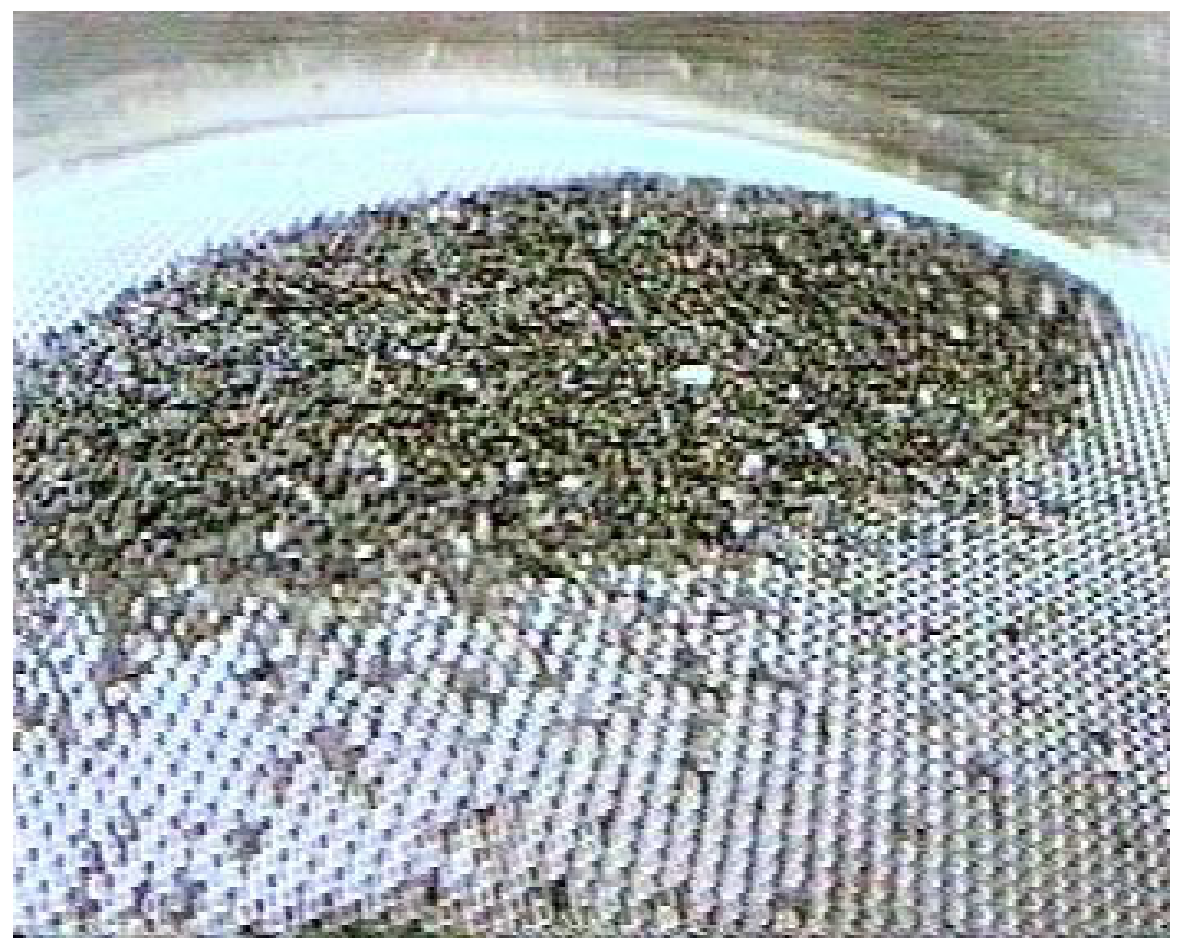

Figure 12. Crushed Fuel Particles on the $300-\mu \mathrm{m}$ Screen

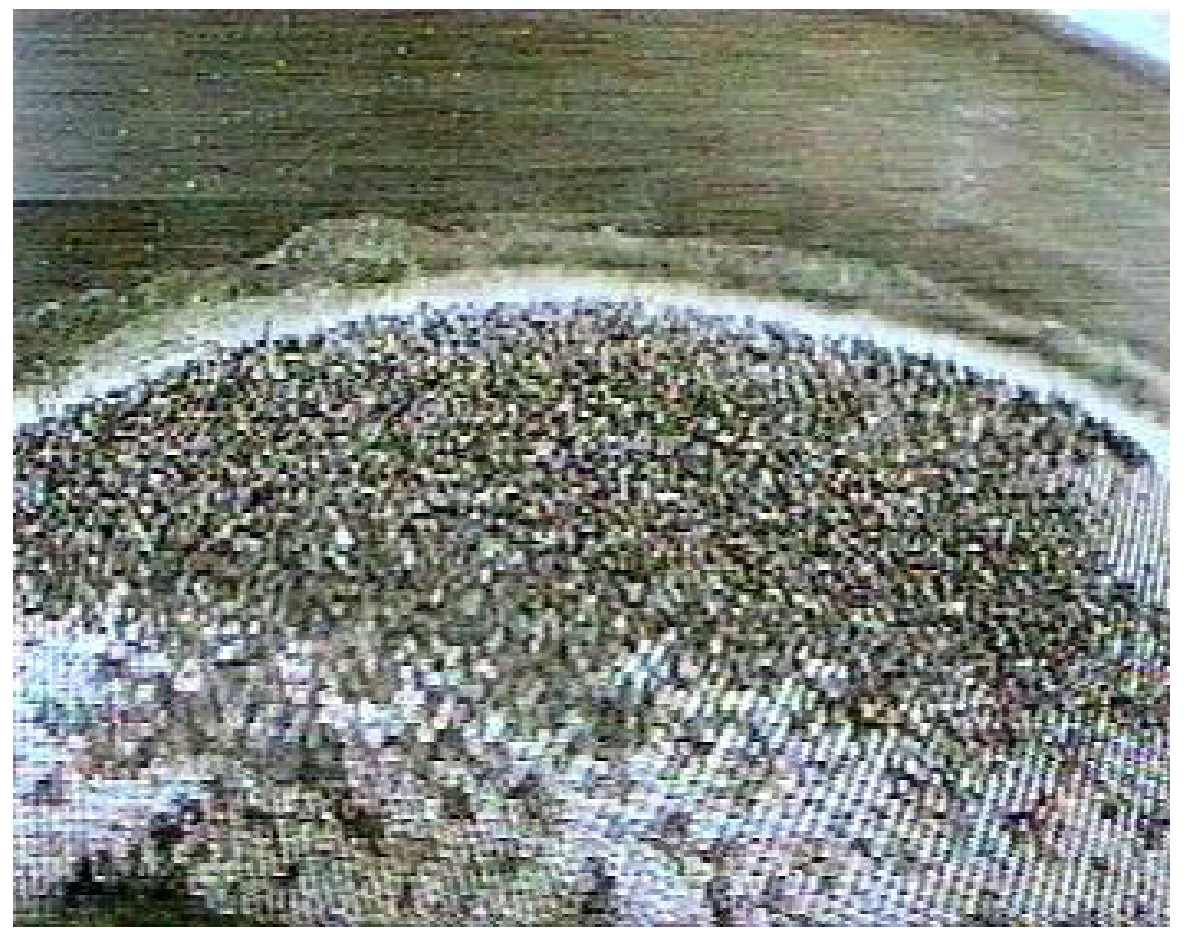

Figure 13. Crushed Fuel Particles on the $180-\mu \mathrm{m}$ Screen 


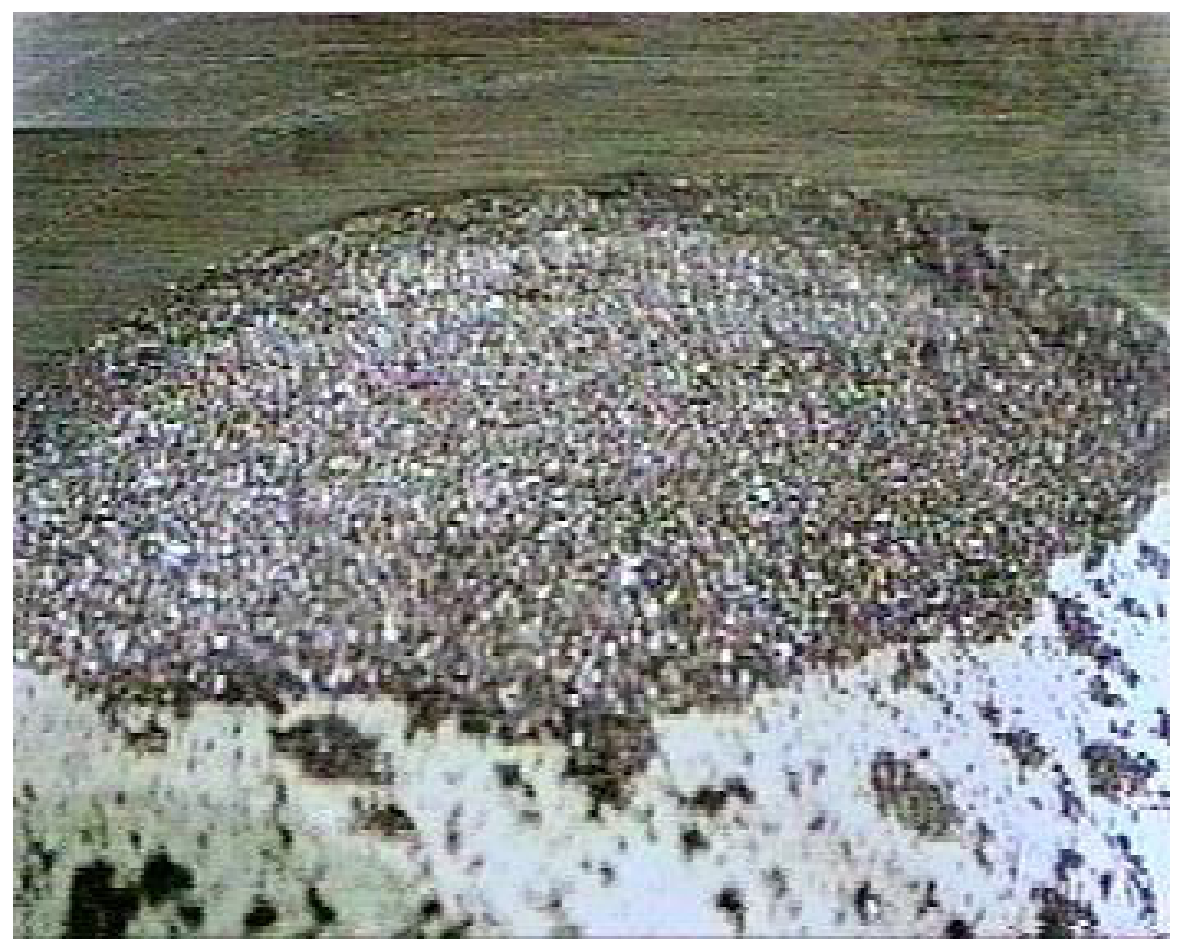

Figure 14. Crushed Fuel Particles on the Bottom Pan $(-180 \mu \mathrm{m})$ 


\section{Appendix B}

Gas Analysis and Gas Generation Rate Data 
Table B.1. Gas Analyses for Test SNF + Can Fines $60 \mathrm{~S}$ at $60^{\circ} \mathrm{C}, 80^{\circ} \mathrm{C}$, and $95^{\circ} \mathrm{C}$ (Test 1 )

\begin{tabular}{|c|c|c|c|c|c|c|c|c|c|c|c|c|c|c|c|c|c|c|c|c|}
\hline $\begin{array}{c}\text { Run } \\
\text { Sys -1 } \\
\end{array}$ & \begin{tabular}{|c|} 
Temp. \\
${ }^{\circ} \mathrm{C}$
\end{tabular} & $\overline{\mathrm{NNe}}$ & $\overline{\mathrm{Ar}}$ & $\overline{\mathrm{H}}$ & 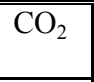 & $\overline{\mathrm{C} \mathrm{CH}_{4}}$ & $\mid \mathrm{C}_{2} \mathrm{HC}$ & $\mathrm{C}_{>2} \mathrm{HC}$ & $\mathrm{N}_{2}$ & $\overline{\mathrm{O}_{2}}$ & Kr 83 & Kr 84 & Kr 85 & Kr 86 & Xe 130 & \begin{tabular}{|l|} 
Xe 131 \\
\end{tabular} & $\overline{\mid X e} 132$ & Xe 134 & \begin{tabular}{|l|} 
Xe 136 \\
\end{tabular} & Time, $\mathrm{h}$ \\
\hline \multirow{2}{*}{$\begin{array}{c}1 \\
22 \mathrm{~K} 68\end{array}$} & \multirow{2}{*}{$\begin{array}{c}\text { Amb., } \\
60\end{array}$} & 43 & 0.029 & 53.4 & 0.55 & 0.154 & 0.019 & 0.007 & 2.31 & 0.48 & $7.0 \mathrm{E}-04$ & \begin{tabular}{|l|}
$1.4 \mathrm{E}-03$ \\
\end{tabular} & \begin{tabular}{|l|}
$1.0 \mathrm{E}-04$ \\
\end{tabular} & $2.9 \mathrm{E}-03$ & $2.0 \mathrm{E}-05$ & \begin{tabular}{|l|}
$5.5 \mathrm{E}-03$ \\
\end{tabular} & \begin{tabular}{|c|}
$9.4 \mathrm{E}-03$ \\
\end{tabular} & $1.5 \mathrm{E}-02$ & \begin{tabular}{|l|}
$2.2 \mathrm{E}-02$ \\
\end{tabular} & \multirow{2}{*}{$\begin{array}{l}138.7 \\
113.3\end{array}$} \\
\hline & & & & 98.55 & 1.015 & 0.284 & 0.035 & 0.013 & -0.0569 & -0.273 & $1.3 \mathrm{E}-03$ & $2.6 \mathrm{E}-03$ & $1.8 \mathrm{E}-04$ & \begin{tabular}{|l|}
$5.4 \mathrm{E}-03$ \\
\end{tabular} & $3.7 \mathrm{E}-05$ & \begin{tabular}{|l|}
$1.0 \mathrm{E}-02$ \\
\end{tabular} & \begin{tabular}{|l|}
$1.7 \mathrm{E}-02$ \\
\end{tabular} & $2.8 \mathrm{E}-02$ & \begin{tabular}{|l|}
$4.1 \mathrm{E}-02$ \\
\end{tabular} & \\
\hline \multirow{2}{*}{$\begin{array}{c}2 \\
22 \mathrm{~K} 73\end{array}$} & \multirow{2}{*}{60} & 37.9 & 0.007 & 61 & 0.164 & 0.12 & 0.022 & 0.009 & 0.59 & 0.118 & $1.2 \mathrm{E}-03$ & \begin{tabular}{|l|}
$2.7 \mathrm{E}-03$ \\
\end{tabular} & \begin{tabular}{|l|}
$1.0 \mathrm{E}-04$ \\
\end{tabular} & $4.1 \mathrm{E}-03$ & $3.0 \mathrm{E}-05$ & \begin{tabular}{|l|}
$7.9 \mathrm{E}-03$ \\
\end{tabular} & \begin{tabular}{|l|}
$1.3 \mathrm{E}-02$ \\
\end{tabular} & $2.1 \mathrm{E}-02$ & \begin{tabular}{|l|}
$3.1 \mathrm{E}-02$ \\
\end{tabular} & \multirow{2}{*}{381.7} \\
\hline & & & & 99.36 & 0.267 & 0.191 & 0.036 & 0.015 & 0.144 & -0.0270 & $2.0 \mathrm{E}-03$ & \begin{tabular}{|l|}
$4.4 \mathrm{E}-03$ \\
\end{tabular} & \begin{tabular}{|l|}
$1.6 \mathrm{E}-04$ \\
\end{tabular} & $6.7 \mathrm{E}-03$ & $4.9 \mathrm{E}-05$ & \begin{tabular}{|l|}
$1.3 \mathrm{E}-02$ \\
\end{tabular} & $2.1 \mathrm{E}-02$ & $3.4 \mathrm{E}-02$ & \begin{tabular}{|l|}
$5.0 \mathrm{E}-02$ \\
\end{tabular} & \\
\hline \multirow{2}{*}{$\begin{array}{c}3 \\
22 \mathrm{~K} 76\end{array}$} & \multirow{2}{*}{60} & 38 & 0.016 & 59.9 & 0.114 & 0.23 & 0.033 & 0.012 & 1.36 & 0.318 & $9.0 \mathrm{E}-04$ & \begin{tabular}{|l|}
$1.6 \mathrm{E}-03$ \\
\end{tabular} & \begin{tabular}{|l|}
$7.0 \mathrm{E}-05$ \\
\end{tabular} & $2.9 \mathrm{E}-03$ & $2.0 \mathrm{E}-05$ & \begin{tabular}{|l|}
$5.3 \mathrm{E}-03$ \\
\end{tabular} & \begin{tabular}{|l|}
$9.3 \mathrm{E}-03$ \\
\end{tabular} & $1.5 \mathrm{E}-02$ & $2.2 \mathrm{E}-02$ & \multirow{2}{*}{309.7} \\
\hline & & & & 99.3 & 0.19 & 0.39 & 0.055 & 0.020 & 0.176 & -0.0305 & $1.5 \mathrm{E}-03$ & $2.7 \mathrm{E}-03$ & \begin{tabular}{|l|}
$1.2 \mathrm{E}-04$ \\
\end{tabular} & \begin{tabular}{|l|}
$4.8 \mathrm{E}-03$ \\
\end{tabular} & $3.3 \mathrm{E}-05$ & \begin{tabular}{|l|}
$8.8 \mathrm{E}-03$ \\
\end{tabular} & \begin{tabular}{|l|}
$1.5 \mathrm{E}-02$ \\
\end{tabular} & $2.5 \mathrm{E}-02$ & $3.6 \mathrm{E}-02$ & \\
\hline 4 & \multirow{2}{*}{60} & & & & & & & & & & & & & & & & & & & \multirow{2}{*}{263.3} \\
\hline Vent & & & & & & & & & & & & & & & & & & & & \\
\hline \multirow{2}{*}{$\begin{array}{c}5 \\
22 \mathrm{~K} 83\end{array}$} & \multirow{2}{*}{80} & 47.4 & 0.011 & 50.9 & 0.15 & 0.39 & 0.046 & 0.014 & 0.89 & 0.203 & $5.0 \mathrm{E}-04$ & $1.0 \mathrm{E}-03$ & $5.0 \mathrm{E}-05$ & $1.9 \mathrm{E}-03$ & $1.0 \mathrm{E}-05$ & $3.7 \mathrm{E}-03$ & $6.2 \mathrm{E}-03$ & $9.9 \mathrm{E}-03$ & $1.5 \mathrm{E}-02$ & \multirow{2}{*}{71.3} \\
\hline & & & & 98.8 & 0.29 & 0.75 & 0.09 & 0.027 & 0.105 & -0.0413 & $9.7 \mathrm{E}-04$ & $1.9 \mathrm{E}-03$ & $9.7 \mathrm{E}-05$ & $3.7 \mathrm{E}-03$ & $1.9 \mathrm{E}-05$ & $7.2 \mathrm{E}-03$ & $1.2 \mathrm{E}-02$ & $1.9 \mathrm{E}-02$ & $2.9 \mathrm{E}-02$ & \\
\hline \multirow{2}{*}{$\begin{array}{c}6 \\
22 \mathrm{~K} 86\end{array}$} & \multirow{2}{*}{95} & 54.5 & 0.012 & 43.6 & 0.345 & 0.41 & 0.046 & 0.014 & 0.96 & \begin{tabular}{|l|}
0.107 \\
\end{tabular} & $4.0 \mathrm{E}-04$ & \begin{tabular}{|c|}
$9.0 \mathrm{E}-04$ \\
\end{tabular} & \begin{tabular}{|l|}
$4.0 \mathrm{E}-05$ \\
\end{tabular} & \begin{tabular}{|l|}
$1.5 \mathrm{E}-03$ \\
\end{tabular} & $1.0 \mathrm{E}-05$ & \begin{tabular}{|l|}
$3.0 \mathrm{E}-03$ \\
\end{tabular} & \begin{tabular}{|l|}
$5.0 \mathrm{E}-03$ \\
\end{tabular} & 7.9E-03 & \begin{tabular}{|l|}
$1.2 \mathrm{E}-02$ \\
\end{tabular} & \multirow{2}{*}{29.3} \\
\hline & & & & 98.1 & 0.78 & 0.92 & 0.10 & 0.031 & 0.091 & \begin{tabular}{|l|}
-0.314 \\
\end{tabular} & $9.0 \mathrm{E}-04$ & $2.0 \mathrm{E}-03$ & $9.0 \mathrm{E}-05$ & $3.4 \mathrm{E}-03$ & $2.2 \mathrm{E}-05$ & \begin{tabular}{|l|}
$6.7 \mathrm{E}-03$ \\
\end{tabular} & $1.1 \mathrm{E}-02$ & $1.8 \mathrm{E}-02$ & $2.7 \mathrm{E}-02$ & \\
\hline
\end{tabular}

Table B.2. Gas Analyses for Test SNF + Can $60 \mathrm{~S}$ at $60^{\circ} \mathrm{C}, 80^{\circ} \mathrm{C}$, and $95^{\circ} \mathrm{C}$ (Test 2)

\begin{tabular}{|c|c|c|c|c|c|c|c|c|c|c|c|c|c|c|c|c|c|c|c|c|}
\hline $\begin{array}{c}\text { Run } \\
\text { Sys }-2 \\
\end{array}$ & $\begin{array}{c}\text { Temp. } \\
{ }^{\circ} \mathrm{C}\end{array}$ & $\overline{\mathrm{Ne}}$ & $\overline{\mathrm{Ar}}$ & 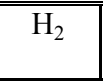 & $\mathrm{CO}_{2}$ & 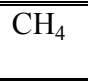 & 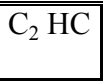 & $\mathrm{C}_{>_{2}} \mathrm{HC}$ & $\overline{\mathrm{N}_{2}}$ & $\overline{\overline{\mathrm{O}_{2}}}$ & \begin{tabular}{|l|}
$\mathrm{Kr} 83$ \\
\end{tabular} & Kr 84 & Kr 85 & Kr 86 & Xe 130 & Xe 131 & Xe 132 & Xe 134 & Xe 136 & Time, $\mathrm{h}$ \\
\hline 1 & \multirow{2}{*}{$\begin{array}{c}\text { Amb., } \\
60\end{array}$} & 38.2 & 0.007 & 60.3 & 0.55 & 0.19 & 0.022 & \begin{tabular}{|l|}
0.008 \\
\end{tabular} & 0.56 & 0.116 & $8.0 \mathrm{E}-04$ & $1.8 \mathrm{E}-03$ & $9.0 \mathrm{E}-05$ & $3.1 \mathrm{E}-03$ & $2.0 \mathrm{E}-05$ & $6.1 \mathrm{E}-03$ & $1.0 \mathrm{E}-02$ & $1.6 \mathrm{E}-02$ & $2.4 \mathrm{E}-02$ & \multirow{2}{*}{\begin{tabular}{|c|}
138.3 \\
507.3 \\
\end{tabular}} \\
\hline $22 \mathrm{~K} 73$ & & & & 98.64 & 0.900 & 0.314 & 0.036 & \begin{tabular}{|l|}
0.013 \\
\end{tabular} & 0.096 & \begin{tabular}{|c|}
-0.0304 \\
\end{tabular} & \begin{tabular}{|l}
$1.3 \mathrm{E}-03$ \\
\end{tabular} & $2.9 \mathrm{E}-03$ & $1.5 \mathrm{E}-04$ & $5.1 \mathrm{E}-03$ & $3.3 \mathrm{E}-05$ & $1.0 \mathrm{E}-02$ & $1.6 \mathrm{E}-02$ & $2.6 \mathrm{E}-02$ & $3.9 \mathrm{E}-02$ & \\
\hline 2 & \multirow{2}{*}{60} & & & & & & & & & & & & & & & & & & & \multirow{2}{*}{594.0} \\
\hline Vent & & & & & & & & & & & & & & & & & & & & \\
\hline 3 & \multirow{2}{*}{80} & 41.4 & 0.009 & 56.8 & 0.385 & 0.38 & 0.044 & \begin{tabular}{|l|}
0.013 \\
\end{tabular} & 0.79 & \begin{tabular}{|l|l}
0.183 \\
\end{tabular} & $7.0 \mathrm{E}-04$ & $1.3 \mathrm{E}-03$ & $7.0 \mathrm{E}-05$ & $2.2 \mathrm{E}-03$ & $1.0 \mathrm{E}-05$ & $4.1 \mathrm{E}-03$ & $6.9 \mathrm{E}-03$ & $1.1 \mathrm{E}-02$ & $1.6 \mathrm{E}-02$ & \multirow{2}{*}{72.7} \\
\hline $22 \mathrm{~K} 83$ & & & & 98.5 & 0.67 & 0.66 & 0.076 & \begin{tabular}{|l|}
0.023 \\
\end{tabular} & 0.21 & \begin{tabular}{|l|}
0.0062 \\
\end{tabular} & \begin{tabular}{|l|}
$1.2 \mathrm{E}-03$ \\
\end{tabular} & $2.3 \mathrm{E}-03$ & $1.2 \mathrm{E}-04$ & $3.8 \mathrm{E}-03$ & $1.7 \mathrm{E}-05$ & $7.1 \mathrm{E}-03$ & $1.2 \mathrm{E}-02$ & $1.9 \mathrm{E}-02$ & $2.8 \mathrm{E}-02$ & \\
\hline 4 & \multirow{2}{*}{95} & 38.1 & 0.008 & 59.7 & 0.89 & 0.48 & 0.057 & \begin{tabular}{|l|}
0.017 \\
\end{tabular} & 0.64 & \begin{tabular}{|l|}
0.133 \\
\end{tabular} & \begin{tabular}{|c|}
$5.0 \mathrm{E}-04$ \\
\end{tabular} & $1.2 \mathrm{E}-03$ & $6.0 \mathrm{E}-05$ & $2.0 \mathrm{E}-03$ & $1.0 \mathrm{E}-05$ & $4.0 \mathrm{E}-03$ & $6.6 \mathrm{E}-03$ & $1.1 \mathrm{E}-02$ & \begin{tabular}{|l}
$1.5 \mathrm{E}-02$ \\
\end{tabular} & \multirow{2}{*}{29.3} \\
\hline $22 \mathrm{~K} 86$ & & & & \begin{tabular}{|l|}
97.57 \\
\end{tabular} & 1.45 & 0.78 & 0.093 & \begin{tabular}{|l|}
0.028 \\
\end{tabular} & 0.090 & $\mid-0.0392$ & $8.2 \mathrm{E}-04$ & $2.0 \mathrm{E}-03$ & $9.8 \mathrm{E}-05$ & $3.3 \mathrm{E}-03$ & $1.6 \mathrm{E}-05$ & $6.5 \mathrm{E}-03$ & $1.1 \mathrm{E}-02$ & $1.8 \mathrm{E}-02$ & $2.5 \mathrm{E}-02$ & \\
\hline
\end{tabular}


Table B.3. Gas Analyses for Test SNF Mid $60 \mathrm{~S}$ at $60^{\circ} \mathrm{C}, 80^{\circ} \mathrm{C}$, and $95^{\circ} \mathrm{C}$ (Test 3)

\begin{tabular}{|c|c|c|c|c|c|c|c|c|c|c|c|c|c|c|c|c|c|c|c|c|}
\hline $\begin{array}{c}\text { Run } \\
\text { Sys }-3 \\
\end{array}$ & \begin{tabular}{|c|} 
Temp. \\
${ }^{\circ} \mathrm{C}$ \\
\end{tabular} & $\mathrm{Ne}$ & $\mathrm{Ar}$ & $\mathrm{H}_{2}$ & $\mathrm{CO}_{2}$ & $\mathrm{CH}_{4}$ & $\mathrm{C}_{2} \mathrm{HC}$ & $\mathrm{C}_{>2} \mathrm{HC}$ & $\mathrm{N}_{2}$ & $\mathrm{O}_{2}$ & $\mathrm{Kr} 83$ & $\mathrm{Kr} 84$ & $\mathrm{Kr} 85$ & $\mathrm{Kr} 86$ & Xe 130 & $\mathrm{Xe} 131$ & Xe 132 & Xe 134 & $\mathrm{Xe} 136$ & Time, $\mathrm{h}$ \\
\hline \multirow{2}{*}{$\begin{array}{c}1 \\
22 \mathrm{~K} 71\end{array}$} & \multirow{2}{*}{$\begin{array}{c}\text { Amb., } \\
60\end{array}$} & 27.8 & 0.007 & 71.5 & 0.004 & 0.039 & 0.006 & 0.003 & 0.53 & 0.06 & $6.0 \mathrm{E}-04$ & $1.1 \mathrm{E}-03$ & $9.0 \mathrm{E}-05$ & $2.4 \mathrm{E}-03$ & $2.0 \mathrm{E}-05$ & $4.3 \mathrm{E}-03$ & $7.6 \mathrm{E}-03$ & $1.2 \mathrm{E}-02$ & $1.8 \mathrm{E}-02$ & \multirow{2}{*}{\begin{tabular}{|l}
138.3 \\
362.7
\end{tabular}} \\
\hline & & & & 99.86 & 0.006 & 0.054 & 0.008 & 0.004 & 0.0397 & \begin{tabular}{|l|}
-0.104 \\
\end{tabular} & $8.4 \mathrm{E}-04$ & \begin{tabular}{|l|}
$1.5 \mathrm{E}-03$ \\
\end{tabular} & $1.3 \mathrm{E}-04$ & \begin{tabular}{|l|}
$3.4 \mathrm{E}-03$ \\
\end{tabular} & $2.8 \mathrm{E}-05$ & \begin{tabular}{|l|}
$6.0 \mathrm{E}-03$ \\
\end{tabular} & $1.1 \mathrm{E}-02$ & $1.7 \mathrm{E}-02$ & $2.5 \mathrm{E}-02$ & \\
\hline \multirow{2}{*}{\begin{tabular}{c|c|}
2 \\
$22 \mathrm{~K} 76$ \\
\end{tabular}} & \multirow{2}{*}{60} & 30.4 & 0.006 & 68.9 & 0.002 & 0.01 & 0.005 & 0.003 & 0.51 & 0.124 & $8.0 \mathrm{E}-04$ & $1.5 \mathrm{E}-03$ & $7.0 \mathrm{E}-05$ & $2.5 \mathrm{E}-03$ & $2.0 \mathrm{E}-05$ & $4.8 \mathrm{E}-03$ & $7.9 \mathrm{E}-03$ & $1.3 \mathrm{E}-02$ & $1.9 \mathrm{E}-02$ & \multirow{2}{*}{458.7} \\
\hline & & & & 99.89 & 0.003 & 0.019 & 0.007 & 0.004 & 0.133 & 0.0172 & $1.2 \mathrm{E}-03$ & $2.2 \mathrm{E}-03$ & $1.0 \mathrm{E}-04$ & $3.6 \mathrm{E}-03$ & $2.9 \mathrm{E}-05$ & $7.0 \mathrm{E}-03$ & $1.1 \mathrm{E}-02$ & $1.9 \mathrm{E}-02$ & $2.8 \mathrm{E}-02$ & \\
\hline 3 & \multirow{2}{*}{60} & & & & & & & & & & & & & & & & & & & \multirow{2}{*}{263.3} \\
\hline Vent & & & & & & & & & & & & & & & & & & & & \\
\hline \multirow{2}{*}{$\begin{array}{c}4 \\
22 \mathrm{~K} 83\end{array}$} & \multirow{2}{*}{80} & 39.7 & 0.008 & 59.4 & 0.002 & 0.02 & 0.003 & 0.002 & 0.69 & 0.165 & $4.0 \mathrm{E}-04$ & $1.0 \mathrm{E}-03$ & $5.0 \mathrm{E}-05$ & $2.0 \mathrm{E}-03$ & $1.0 \mathrm{E}-05$ & $3.6 \mathrm{E}-03$ & $6.2 \mathrm{E}-03$ & $9.9 \mathrm{E}-03$ & $1.5 \mathrm{E}-02$ & \multirow{2}{*}{71.0} \\
\hline & & & & 99.90 & 0.00 & 0.03 & 0.005 & 0.003 & 0.18 & 0.0135 & $6.7 \mathrm{E}-04$ & $1.7 \mathrm{E}-03$ & $8.4 \mathrm{E}-05$ & $3.4 \mathrm{E}-03$ & $1.7 \mathrm{E}-05$ & $6.1 \mathrm{E}-03$ & $1.0 \mathrm{E}-02$ & $1.7 \mathrm{E}-02$ & $2.5 \mathrm{E}-02$ & \\
\hline \multirow{2}{*}{$\begin{array}{c}5 \\
22 \mathrm{~K} 86 \\
\end{array}$} & \multirow{2}{*}{95} & 38.2 & 0.006 & 61.1 & 0.002 & 0.02 & 0.004 & 0.002 & 0.53 & 0.123 & $6.0 \mathrm{E}-04$ & $1.2 \mathrm{E}-03$ & $6.0 \mathrm{E}-05$ & $2.0 \mathrm{E}-03$ & $2.0 \mathrm{E}-05$ & $3.7 \mathrm{E}-03$ & $6.4 \mathrm{E}-03$ & $1.0 \mathrm{E}-02$ & $1.5 \mathrm{E}-02$ & \multirow{2}{*}{29.3} \\
\hline & & & & 99.9 & 0.00 & 0.03 & 0.01 & 0.003 & 0.18 & 0.0178 & $9.8 \mathrm{E}-04$ & $2.0 \mathrm{E}-03$ & $9.8 \mathrm{E}-05$ & $3.3 \mathrm{E}-03$ & $3.3 \mathrm{E}-05$ & $6.0 \mathrm{E}-03$ & $1.0 \mathrm{E}-02$ & $1.6 \mathrm{E}-02$ & $2.5 \mathrm{E}-02$ & \\
\hline
\end{tabular}

Table B.4. Gas Analyses for Test SNF Mid $40 \mathrm{~S}$ at $40^{\circ} \mathrm{C}, 60^{\circ} \mathrm{C}$, and $80^{\circ} \mathrm{C}$ (Test 4)

\begin{tabular}{|c|c|c|c|c|c|c|c|c|c|c|c|c|c|c|c|c|c|c|c|c|}
\hline \begin{tabular}{|c|} 
Run \\
Sys -4 \\
\end{tabular} & $\begin{array}{c}\text { Temp. } \\
{ }^{\circ} \mathrm{C}\end{array}$ & $\mathrm{Ne}$ & $\mathrm{Ar}$ & $\mathrm{H}_{2}$ & $\mathrm{CO}_{2}$ & $\mathrm{CH}_{4}$ & $\mathrm{C}_{2} \mathrm{HC}$ & $\mathrm{C}_{>2} \mathrm{HC}$ & $\mathrm{N}_{2}$ & $\mathrm{O}_{2}$ & $\mathrm{Kr} 83$ & $\mathrm{Kr} 84$ & $\mathrm{Kr} 85$ & $\mathrm{Kr} 86$ & Xe 130 & Xe 131 & Xe 132 & Xe 134 & Xe 136 & Time, $\mathrm{h}$ \\
\hline 1 & \multirow{2}{*}{$\begin{array}{c}\text { Amb., } \\
40\end{array}$} & 40.5 & 0.012 & 58.4 & 0.009 & 0.025 & 0.005 & 0.003 & 0.84 & 0.157 & $5.0 \mathrm{E}-04$ & $1.0 \mathrm{E}-03$ & $5.0 \mathrm{E}-05$ & $2.1 \mathrm{E}-03$ & $1.0 \mathrm{E}-05$ & $3.8 \mathrm{E}-03$ & $6.7 \mathrm{E}-03$ & $1.1 \mathrm{E}-02$ & $1.6 \mathrm{E}-02$ & \multirow{2}{*}{\begin{tabular}{|c|}
138.3 \\
1127.7 \\
\end{tabular}} \\
\hline $22 \mathrm{~K} 78$ & & & & 99.86 & 0.02 & 0.043 & 0.009 & 0.005 & -0.136 & -0.153 & $8.5 \mathrm{E}-04$ & $1.7 \mathrm{E}-03$ & $8.5 \mathrm{E}-05$ & $3.6 \mathrm{E}-03$ & $1.7 \mathrm{E}-05$ & $6.5 \mathrm{E}-03$ & $1.1 \mathrm{E}-02$ & 1.9E-02 & $2.7 \mathrm{E}-02$ & \\
\hline 2 & \multirow{2}{*}{60} & & & & & & & & & & & & & & & & & & & \multirow{2}{*}{311.0} \\
\hline Vent & & & & & & & & & & & & & & & & & & & & \\
\hline 3 & \multirow{2}{*}{80} & & & & & & & & & & & & & & & & & & & \multirow{2}{*}{47.3} \\
\hline Vent & & & & & & & & & & & & & & & & & & & & \\
\hline
\end{tabular}

Table B.5. Gas Generation Rates from SNF + Can Fines $60 \mathrm{~S}$ at $60^{\circ} \mathrm{C}, 80^{\circ} \mathrm{C}$, and $95^{\circ} \mathrm{C}$ (Test 1 )

\begin{tabular}{|c|c|c|c|c|c|c|c|c|c|c|c|c|c|c|c|c|c|c|}
\hline \multirow[b]{2}{*}{ Run } & \multirow{2}{*}{$\begin{array}{c}\text { Temp. } \\
{ }^{\circ} \mathrm{C}\end{array}$} & \multicolumn{17}{|c|}{ Gas Generation Rate, moles/kg fuel particles-day } \\
\hline & & $\mathrm{H}_{2}$ & $\mathrm{CO}_{2}$ & $\mathrm{CH}_{4}$ & $\mathrm{C}_{2} \mathrm{HC}$ & $\mathrm{C}_{>2} \mathrm{HC}$ & $\mathrm{N}_{2}$ & $\mathrm{O}_{2}$ & $\mathrm{Kr} 83$ & $\mathrm{Kr} 84$ & $\mathrm{Kr} 85$ & $\mathrm{Kr} 86$ & $\mathrm{Xe} 130$ & $\mathrm{Xe} 131$ & $\mathrm{Xe} 132$ & Xe 134 & $\mathrm{Xe} 136$ & Time, $\mathrm{h}$ \\
\hline 1 & 60 & $1.3 \mathrm{E}-1$ & $1.4 \mathrm{E}-3$ & $3.9 \mathrm{E}-4$ & $4.8 \mathrm{E}-5$ & $1.8 \mathrm{E}-5$ & $-7.8 \mathrm{E}-5$ & $-3.7 \mathrm{E}-4$ & $1.8 \mathrm{E}-6$ & $3.5 \mathrm{E}-6$ & $2.5 \mathrm{E}-7$ & $7.3 \mathrm{E}-6$ & $5.0 \mathrm{E}-8$ & $1.4 \mathrm{E}-5$ & $2.4 \mathrm{E}-5$ & $3.8 \mathrm{E}-5$ & $5.5 \mathrm{E}-5$ & 113.3 \\
\hline 2 & 60 & $3.8 \mathrm{E}-2$ & $1.0 \mathrm{E}-4$ & $7.4 \mathrm{E}-5$ & $1.4 \mathrm{E}-5$ & $5.7 \mathrm{E}-6$ & $5.6 \mathrm{E}-5$ & $-1.0 \mathrm{E}-5$ & $7.5 \mathrm{E}-7$ & $1.7 \mathrm{E}-6$ & $6.3 \mathrm{E}-8$ & $2.6 \mathrm{E}-6$ & $1.9 \mathrm{E}-8$ & $5.0 \mathrm{E}-6$ & $8.2 \mathrm{E}-6$ & $1.3 \mathrm{E}-5$ & $1.9 \mathrm{E}-5$ & 381.7 \\
\hline 3 & 60 & $4.9 \mathrm{E}-2$ & $9.3 \mathrm{E}-5$ & $1.9 \mathrm{E}-4$ & $2.7 \mathrm{E}-5$ & $9.8 \mathrm{E}-6$ & $8.7 \mathrm{E}-5$ & $-1.5 \mathrm{E}-5$ & $7.4 \mathrm{E}-7$ & $1.3 \mathrm{E}-6$ & $5.7 \mathrm{E}-8$ & $2.4 \mathrm{E}-6$ & $1.6 \mathrm{E}-8$ & $4.3 \mathrm{E}-6$ & $7.6 \mathrm{E}-6$ & $1.2 \mathrm{E}-5$ & $1.8 \mathrm{E}-5$ & 309.7 \\
\hline 4 & 60 & Vent & Vent & Vent & Vent & Vent & Vent & Vent & Vent & Vent & Vent & Vent & Vent & Vent & Vent & Vent & Vent & 263.3 \\
\hline 5 & 80 & $1.4 \mathrm{E}-1$ & $4.3 \mathrm{E}-4$ & $1.1 \mathrm{E}-3$ & $1.3 \mathrm{E}-4$ & $4.0 \mathrm{E}-5$ & $1.5 \mathrm{E}-4$ & $-6.0 \mathrm{E}-5$ & $1.4 \mathrm{E}-6$ & $2.8 \mathrm{E}-6$ & $1.4 \mathrm{E}-7$ & 5.4E-6 & $2.8 \mathrm{E}-8$ & $1.0 \mathrm{E}-5$ & $1.8 \mathrm{E}-5$ & $2.8 \mathrm{E}-5$ & $4.3 \mathrm{E}-5$ & 71.3 \\
\hline 6 & 95 & 2.7E-1 & $2.1 \mathrm{E}-3$ & $2.5 \mathrm{E}-3$ & $2.8 \mathrm{E}-4$ & $8.5 \mathrm{E}-5$ & $2.5 \mathrm{E}-4$ & $-8.5 \mathrm{E}-4$ & $2.4 \mathrm{E}-6$ & $5.5 \mathrm{E}-6$ & $2.4 \mathrm{E}-7$ & $9.1 \mathrm{E}-6$ & $6.1 \mathrm{E}-8$ & $1.8 \mathrm{E}-5$ & $3.0 \mathrm{E}-5$ & $4.8 \mathrm{E}-5$ & $7.3 \mathrm{E}-5$ & 29.3 \\
\hline
\end{tabular}


Table B.6. Gas Generation Rates from SNF + Can $60 \mathrm{~S}$ at $60^{\circ} \mathrm{C}, 80^{\circ} \mathrm{C}$, and $95^{\circ} \mathrm{C}$ (Test 2)

\begin{tabular}{|c|c|c|c|c|c|c|c|c|c|c|c|c|c|c|c|c|c|c|}
\hline \multirow[t]{2}{*}{ Run } & \multirow{2}{*}{$\begin{array}{c}\text { Temp. } \\
{ }^{\circ} \mathrm{C}\end{array}$} & \multicolumn{17}{|c|}{ "Gas Generation Rate, moles/kg fuel particles-day } \\
\hline & & $\mathrm{H}_{2}$ & $\mathrm{CO}_{2}$ & $\mathrm{CH}_{4}$ & $\mathrm{C}_{2} \mathrm{HC}$ & $\mathrm{C}_{>2} \mathrm{HC}$ & $\mathrm{N}_{2}$ & $\mathrm{O}_{2}$ & Kr 83 & $\mathrm{Kr} 84$ & $\mathrm{Kr} 85$ & $\mathrm{Kr} 86$ & $\mathrm{Xe} 130$ & Xe 131 & Xe 132 & $\mathrm{Xe} 134$ & $\mathrm{Xe} 136$ & Time, $\mathrm{h}$ \\
\hline 1 & 60 & $1.8 \mathrm{E}-2$ & $1.6 \mathrm{E}-4$ & $5.7 \mathrm{E}-5$ & $6.5 \mathrm{E}-6$ & $2.4 \mathrm{E}-6$ & $1.7 \mathrm{E}-5$ & $-5.5 \mathrm{E}-6$ & $2.4 \mathrm{E}-7$ & $5.3 \mathrm{E}-7$ & $2.7 \mathrm{E}-8$ & $9.2 \mathrm{E}-7$ & 5.9E-9 & $1.8 \mathrm{E}-6$ & $3.0 \mathrm{E}-6$ & $4.7 \mathrm{E}-6$ & $7.1 \mathrm{E}-6$ & 507.3 \\
\hline 2 & 60 & Vent & Vent & Vent & Vent & Vent & Vent & Vent & Vent & Vent & Vent & Vent & Vent & Vent & Vent & Vent & Vent & 594.0 \\
\hline 3 & 80 & $1.0 \mathrm{E}-1$ & $6.8 \mathrm{E}-4$ & $6.7 \mathrm{E}-4$ & $7.8 \mathrm{E}-5$ & $2.3 \mathrm{E}-5$ & $2.1 \mathrm{E}-4$ & $6.3 \mathrm{E}-6$ & $1.2 \mathrm{E}-6$ & $2.3 \mathrm{E}-6$ & $1.2 \mathrm{E}-7$ & $3.9 \mathrm{E}-6$ & $1.8 \mathrm{E}-8$ & $7.2 \mathrm{E}-6$ & $1.2 \mathrm{E}-5$ & $1.9 \mathrm{E}-5$ & $2.8 \mathrm{E}-5$ & 72.7 \\
\hline 4 & 95 & $3.1 \mathrm{E}-1$ & $4.6 \mathrm{E}-3$ & $2.5 \mathrm{E}-3$ & $3.0 \mathrm{E}-4$ & $8.9 \mathrm{E}-5$ & $2.9 \mathrm{E}-4$ & $-1.2 \mathrm{E}-4$ & $2.6 \mathrm{E}-6$ & $6.2 \mathrm{E}-6$ & $3.1 \mathrm{E}-7$ & $1.0 \mathrm{E}-5$ & $5.2 \mathrm{E}-8$ & $2.1 \mathrm{E}-5$ & $3.4 \mathrm{E}-5$ & $5.7 \mathrm{E}-5$ & $7.8 \mathrm{E}-5$ & 29.3 \\
\hline
\end{tabular}

Table B.7. Gas Generation Rates from SNF Mid $60 \mathrm{~S}$ at $60^{\circ} \mathrm{C}, 80^{\circ} \mathrm{C}$, and $95^{\circ} \mathrm{C}$ (Test 3)

\begin{tabular}{|c|c|c|c|c|c|c|c|c|c|c|c|c|c|c|c|c|c|c|}
\hline \multirow[t]{2}{*}{ Run } & \multirow{2}{*}{$\begin{array}{c}\text { Temp. } \\
{ }^{\circ} \mathrm{C}\end{array}$} & \multicolumn{17}{|c|}{ Gas Generation Rate, moles/kg fuel particles-day } \\
\hline & & $\mathrm{H}_{2}$ & $\mathrm{CO}_{2}$ & $\mathrm{CH}_{4}$ & $\mathrm{C}_{2} \mathrm{HC}$ & $\mathrm{C}_{>2} \mathrm{HC}$ & $\mathrm{N}_{2}$ & $\mathrm{O}_{2}$ & $\mathrm{Kr} 83$ & $\mathrm{Kr} 84$ & $\mathrm{Kr} 85$ & $\mathrm{Kr} 86$ & Xe 130 & Xe 131 & Xe 132 & Xe 134 & Xe 136 & Time, $\mathrm{h}$ \\
\hline 1 & 60 & $4.1 \mathrm{E}-2$ & $2.3 \mathrm{E}-6$ & $2.2 \mathrm{E}-5$ & $3.4 \mathrm{E}-6$ & $1.7 \mathrm{E}-6$ & $1.6 \mathrm{E}-5$ & $-4.3 \mathrm{E}-5$ & $3.4 \mathrm{E}-7$ & $6.3 \mathrm{E}-7$ & $5.2 \mathrm{E}-8$ & $1.4 \mathrm{E}-6$ & $1.1 \mathrm{E}-8$ & $2.5 \mathrm{E}-6$ & $4.4 \mathrm{E}-6$ & $6.9 \mathrm{E}-6$ & $1.0 \mathrm{E}-5$ & 362.7 \\
\hline 2 & 60 & $2.9 \mathrm{E}-2$ & $8.3 \mathrm{E}-7$ & $5.4 \mathrm{E}-6$ & $2.1 \mathrm{E}-6$ & $1.2 \mathrm{E}-6$ & $3.8 \mathrm{E}-5$ & 4.9E-6 & $3.3 \mathrm{E}-7$ & $6.2 \mathrm{E}-7$ & $2.9 \mathrm{E}-8$ & $1.0 \mathrm{E}-6$ & $8.3 \mathrm{E}-9$ & $2.0 \mathrm{E}-6$ & $3.3 \mathrm{E}-6$ & 5.4E-6 & 7.9E-6 & 458.7 \\
\hline 3 & 60 & Vent & Vent & Vent & Vent & Vent & Vent & Vent & Vent & Vent & Vent & Vent & Vent & Vent & Vent & Vent & Vent & 263.3 \\
\hline 4 & 80 & $1.2 \mathrm{E}-1$ & $4.2 \mathrm{E}-6$ & $3.1 \mathrm{E}-5$ & $6.2 \mathrm{E}-6$ & $4.2 \mathrm{E}-6$ & $2.2 \mathrm{E}-4$ & $1.7 \mathrm{E}-5$ & $8.3 \mathrm{E}-7$ & $2.1 \mathrm{E}-6$ & $1.0 \mathrm{E}-7$ & $4.2 \mathrm{E}-6$ & $2.1 \mathrm{E}-8$ & $7.5 \mathrm{E}-6$ & $1.3 \mathrm{E}-5$ & $2.1 \mathrm{E}-5$ & $3.1 \mathrm{E}-5$ & 71.0 \\
\hline 5 & 95 & $3.4 \mathrm{E}-1$ & $1.1 \mathrm{E}-5$ & $1.2 \mathrm{E}-4$ & $2.2 \mathrm{E}-5$ & $1.1 \mathrm{E}-5$ & $6.1 \mathrm{E}-4$ & $6.0 \mathrm{E}-5$ & $3.3 \mathrm{E}-6$ & $6.6 \mathrm{E}-6$ & $3.3 \mathrm{E}-7$ & $1.1 \mathrm{E}-5$ & $1.1 \mathrm{E}-7$ & $2.0 \mathrm{E}-5$ & $3.5 \mathrm{E}-5$ & $5.5 \mathrm{E}-5$ & $8.2 \mathrm{E}-5$ & 29.3 \\
\hline
\end{tabular}

Table B.8. Gas Generation Rates from SNF Mid $40 \mathrm{~S}$ at $40^{\circ} \mathrm{C}, 60^{\circ} \mathrm{C}$, and $80^{\circ} \mathrm{C}$ (Test 4)

\begin{tabular}{|c|c|c|c|c|c|c|c|c|c|c|c|c|c|c|c|c|c|c|}
\hline \multirow[t]{2}{*}{ Run } & \multirow{2}{*}{$\begin{array}{c}\text { Temp. } \\
{ }^{\circ} \mathrm{C}\end{array}$} & \multicolumn{17}{|c|}{ Gas Generation Rate, moles/kg fuel particles-day } \\
\hline & & $\mathrm{H}_{2}$ & $\mathrm{CO}_{2}$ & $\mathrm{CH}_{4}$ & $\mathrm{C}_{2} \mathrm{HC}$ & $\mathrm{C}_{>2} \mathrm{HC}$ & $\mathrm{N}_{2}$ & $\mathrm{O}_{2}$ & $\mathrm{Kr} 83$ & $\mathrm{Kr} 84$ & $\mathrm{Kr} 85$ & $\mathrm{Kr} 86$ & $\mathrm{Xe} 130$ & Xe 131 & $\mathrm{Xe} 132$ & $\mathrm{Xe} 134$ & Xe 136 & Time, $\mathrm{h}$ \\
\hline 1 & 40 & $6.9 \mathrm{E}-3$ & $1.1 \mathrm{E}-6$ & $3.0 \mathrm{E}-6$ & $5.9 \mathrm{E}-7$ & $3.6 \mathrm{E}-7$ & $-9.5 \mathrm{E}-6$ & $-1.1 \mathrm{E}-5$ & 5.9E-8 & $1.2 \mathrm{E}-7$ & 5.9E-9 & $2.5 \mathrm{E}-7$ & $1.2 \mathrm{E}-9$ & $4.5 \mathrm{E}-7$ & $8.0 \mathrm{E}-7$ & $1.3 \mathrm{E}-6$ & $1.9 \mathrm{E}-6$ & 1127.7 \\
\hline 2 & 60 & Vent & Vent & Vent & Vent & Vent & Vent & Vent & Vent & Vent & Vent & Vent & Vent & Vent & Vent & Vent & Vent & 311.0 \\
\hline 3 & 80 & Vent & Vent & Vent & Vent & Vent & Vent & Vent & Vent & Vent & Vent & Vent & Vent & Vent & Vent & Vent & Vent & 47.3 \\
\hline
\end{tabular}


Table B.9. Gas Analyses for Test SNF P2000 80 S at $80^{\circ} \mathrm{C}$ (Test 5)

\begin{tabular}{|c|c|c|c|c|c|c|c|c|c|c|c|c|c|c|c|c|c|c|c|c|}
\hline $\begin{array}{c}\text { Run } \\
\text { Sys }-5\end{array}$ & $\begin{array}{c}\text { Temp. } \\
{ }^{\circ} \mathrm{C}\end{array}$ & $\mathrm{Ne}$ & $\overline{\mathrm{Ar}}$ & $\overline{\mathrm{H}_{2}}$ & $\mathrm{CO}_{2}$ & $\overline{\mathrm{CH}_{4}}$ & $\mathrm{C}_{2} \mathrm{HC}$ & $\mathrm{C}_{>2} \mathrm{HC}$ & $\mathrm{N}_{2}$ & $\overline{\mathrm{O}_{2}}$ & Kr 83 & Kr 84 & Kr 85 & Kr 86 & \begin{tabular}{|l|} 
Xe 130 \\
\end{tabular} & $\mid \overline{\mid X e} 131$ & \begin{tabular}{|l|l|} 
Xe 132 \\
\end{tabular} & Xe 134 & Xe 136 & Time, $\mathrm{h}$ \\
\hline \multirow{2}{*}{$\begin{array}{c}1 \\
22 \mathrm{~K} 68\end{array}$} & \multirow{2}{*}{$\begin{array}{c}\text { Amb., } \\
80\end{array}$} & 9.2 & 9 & 69.90 & 0.00 & 067 & 0.01 & 0.005 & 0.61 & 0.095 & $0 \mathrm{E}-04$ & \begin{tabular}{|l|}
$1.4 \mathrm{E}-03$ \\
\end{tabular} & $1.0 \mathrm{E}-04$ & $2.5 \mathrm{E}-03$ & $2.0 \mathrm{E}-05$ & \begin{tabular}{|l|}
$4.8 \mathrm{E}-03$ \\
\end{tabular} & \begin{tabular}{|l|}
$8.2 \mathrm{E}-03$ \\
\end{tabular} & $1.3 \mathrm{E}-02$ & \begin{tabular}{|l|}
$1.9 \mathrm{E}-02$ \\
\end{tabular} & \multirow{2}{*}{\begin{tabular}{|l|}
138.3 \\
114.7 \\
\end{tabular}} \\
\hline & & & & 99.810 & 0.00 & .096 & 0.014 & 0.007 & -0.0840 & -0.121 & $8.6 \mathrm{E}-04$ & $2.0 \mathrm{E}-03$ & $1.4 \mathrm{E}-04$ & $3.6 \mathrm{E}-03$ & $2.9 \mathrm{E}-05$ & $6.9 \mathrm{E}-03$ & $1.2 \mathrm{E}-02$ & $1.9 \mathrm{E}-02$ & $2.7 \mathrm{E}-02$ & \\
\hline \multirow{2}{*}{\begin{tabular}{c|}
2 \\
$22 \mathrm{~K} 70$
\end{tabular}} & \multirow{2}{*}{80} & 4.0 & 06 & 65.3 & 0.009 & 0.02 & 0.005 & 0.003 & 0.48 & 0.113 & $8.0 \mathrm{E}-04$ & \begin{tabular}{|l|}
$1.3 \mathrm{E}-03$ \\
\end{tabular} & $1.0 \mathrm{E}-04$ & $2.4 \mathrm{E}-03$ & $2.0 \mathrm{E}-05$ & $4.6 \mathrm{E}-03$ & \begin{tabular}{|l|}
$7.6 \mathrm{E}-03$ \\
\end{tabular} & $1.2 \mathrm{E}-02$ & \begin{tabular}{|l|}
$1.8 \mathrm{E}-02$ \\
\end{tabular} & \multirow{2}{*}{92.7} \\
\hline & & & & 99.87 & 0.01 & 0.03 & 0.008 & 0.005 & 0.0948 & 0.0013 & $1.2 \mathrm{E}-03$ & $2.0 \mathrm{E}-03$ & $1.5 \mathrm{E}-04$ & $3.7 \mathrm{E}-03$ & $3.1 \mathrm{E}-05$ & $7.0 \mathrm{E}-03$ & $1.2 \mathrm{E}-02$ & $1.8 \mathrm{E}-02$ & $2.8 \mathrm{E}-02$ & \\
\hline \multirow{2}{*}{$\begin{array}{c}3 \\
22 \mathrm{~K} 71\end{array}$} & \multirow[b]{2}{*}{0} & 3.3 & 007 & 55.8 & 0.011 & 0.02 & & 0.002 & 0.65 & 0.143 & $4.0 \mathrm{E}-04$ & $9.0 \mathrm{E}-04$ & $5.0 \mathrm{E}-05$ & $1.6 \mathrm{E}-03$ & $1.0 \mathrm{E}-05$ & $3.4 \mathrm{E}-03$ & $6.0 \mathrm{E}-03$ & $9.6 \mathrm{E}-03$ & $1.4 \mathrm{E}-02$ & \multirow{2}{*}{73.7} \\
\hline & & & & 99.88 & 0.02 & 0.03 & & 0.004 & 0.266 & 0.0151 & $7.2 \mathrm{E}-04$ & $1.6 \mathrm{E}-03$ & $9.0 \mathrm{E}-05$ & $2.9 \mathrm{E}-03$ & 1.8 & -03 & $1.1 \mathrm{E}-02$ & $1.7 \mathrm{E}-02$ & $2.5 \mathrm{E}-02$ & \\
\hline \multirow{2}{*}{\begin{tabular}{c|}
4 \\
$22 \mathrm{~K} 73$ \\
\end{tabular}} & \multirow{2}{*}{80} & 35.0 & 006 & 64.3 & 0.004 & 0.02 & $\overline{004}$ & 0.002 & 0.50 & 0.119 & $6.0 \mathrm{E}-04$ & $1.2 \mathrm{E}-03$ & $6.0 \mathrm{E}-05$ & $2.3 \mathrm{E}-03$ & 05 & -03 & $7.0 \mathrm{E}-03$ & $1.1 \mathrm{E}-02$ & $1.6 \mathrm{E}-02$ & \multirow{2}{*}{123.0} \\
\hline & & & & 100 & 0.01 & 0.028 & 0.006 & 0.003 & 0.127 & 0.0107 & $9.3 \mathrm{E}-04$ & \begin{tabular}{|l|}
$1.9 \mathrm{E}-03$ \\
\end{tabular} & $9.3 \mathrm{E}-05$ & $3.6 \mathrm{E}-03$ & $3.1 \mathrm{E}-05$ & $6.4 \mathrm{E}-03$ & \begin{tabular}{|l|}
$1.1 \mathrm{E}-02$ \\
\end{tabular} & $1.7 \mathrm{E}-02$ & $2.5 \mathrm{E}-02$ & \\
\hline \multirow{2}{*}{$\begin{array}{c}5 \\
22 \mathrm{~K} 75\end{array}$} & & 2.4 & 00 & 66.8 & 0.004 & 0.02 & 0.005 & 0.003 & 0.53 & \begin{tabular}{|l|}
0.124 \\
\end{tabular} & $6.0 \mathrm{E}-04$ & \begin{tabular}{|l|}
$1.2 \mathrm{E}-03$ \\
\end{tabular} & $4.0 \mathrm{E}-05$ & $2.3 \mathrm{E}-03$ & $1.0 \mathrm{E}-05$ & \begin{tabular}{|l|}
$4.2 \mathrm{E}-03$ \\
\end{tabular} & \begin{tabular}{|l|}
$7.2 \mathrm{E}-03$ \\
\end{tabular} & $1.2 \mathrm{E}-02$ & \begin{tabular}{|l|}
$1.7 \mathrm{E}-02$ \\
\end{tabular} & \multirow{2}{*}{165.7} \\
\hline & & & & 100 & 0.01 & 0.030 & 0.007 & 0.004 & 0.168 & 0.0177 & $9.0 \mathrm{E}-04$ & \begin{tabular}{|l|}
$1.8 \mathrm{E}-03$ \\
\end{tabular} & $6.0 \mathrm{E}-05$ & $3.4 \mathrm{E}-03$ & $1.5 \mathrm{E}-05$ & 03 & \begin{tabular}{|l|}
$1.1 \mathrm{E}-02$ \\
\end{tabular} & $1.8 \mathrm{E}-02$ & $2.5 \mathrm{E}-02$ & \\
\hline \multirow{2}{*}{$\begin{array}{c}6 \\
22 \mathrm{~K} 76\end{array}$} & \multirow{2}{*}{80} & 41.8 & 009 & 57.2 & 0.005 & 0.02 & 0.005 & 0.002 & 0.76 & \begin{tabular}{|l|}
0.186 \\
\end{tabular} & $5.0 \mathrm{E}-04$ & \begin{tabular}{|l|}
$1.0 \mathrm{E}-03$ \\
\end{tabular} & $5.0 \mathrm{E}-05$ & $1.9 \mathrm{E}-03$ & $1.0 \mathrm{E}-05$ & $3.5 \mathrm{E}-03$ & \begin{tabular}{|l|}
$6.2 \mathrm{E}-03$ \\
\end{tabular} & $1.0 \mathrm{E}-02$ & \begin{tabular}{|l|}
$1.4 \mathrm{E}-02$ \\
\end{tabular} & \multirow{2}{*}{124.0} \\
\hline & & & & 100 & 0.01 & 0.030 & 0.009 & 0.003 & 0.159 & 0.0115 & $8.7 \mathrm{E}-04$ & $1.7 \mathrm{E}-03$ & $8.7 \mathrm{E}-05$ & $3.3 \mathrm{E}-03$ & $1.7 \mathrm{E}-05$ & $6.1 \mathrm{E}-03$ & $1.1 \mathrm{E}-02$ & $1.7 \mathrm{E}-02$ & $2.4 \mathrm{E}-02$ & \\
\hline 7 & \multirow{2}{*}{80} & & & & & & & & & & & & & & & & & & & \multirow{2}{*}{1186.0} \\
\hline 3 Vents & & & & & & & & & & & & & & & & & & & & \\
\hline \multirow{2}{*}{\begin{tabular}{c|}
8 \\
$22 \mathrm{~K} 93$
\end{tabular}} & \multirow{2}{*}{80} & 37.6 & 0.009 & 61.5 & 0.004 & 0.02 & 0.006 & 0.003 & 0.72 & 0.154 & $6.0 \mathrm{E}-04$ & $1.3 \mathrm{E}-03$ & $6.0 \mathrm{E}-05$ & $2.3 \mathrm{E}-03$ & $1.0 \mathrm{E}-05$ & $3.9 \mathrm{E}-03$ & $6.3 \mathrm{E}-03$ & $1.0 \mathrm{E}-02$ & $1.5 \mathrm{E}-02$ & \multirow{2}{*}{552.3} \\
\hline & & & & 100 & & 0.034 & 0.010 & 0.005 & 0.0831 & \begin{tabular}{|c|}
-0.0413 \\
\end{tabular} & $9.7 \mathrm{E}-04$ & \begin{tabular}{|l|}
$2.1 \mathrm{E}-03$ \\
\end{tabular} & $9.7 \mathrm{E}-05$ & $3.7 \mathrm{E}-03$ & \begin{tabular}{|c|}
$1.6 \mathrm{E}-05$ \\
\end{tabular} & \begin{tabular}{|c|}
$6.3 \mathrm{E}-03$ \\
\end{tabular} & \begin{tabular}{|l|}
$1.0 \mathrm{E}-02$ \\
\end{tabular} & \begin{tabular}{l|l}
$1.6 \mathrm{E}-02$ \\
\end{tabular} & $2.4 \mathrm{E}-02$ & \\
\hline
\end{tabular}

Blank entries are below detection limits. Shaded values denote the generated gas composition (i.e., neon cover gas contribution deducted).

Table B.10. Gas Analyses for Test SNF M500 $80 \mathrm{~L}$ at $90^{\circ} \mathrm{C}$ and $95^{\circ} \mathrm{C}$ (Test 6)

\begin{tabular}{|c|c|c|c|c|c|c|c|c|c|c|c|c|c|c|c|c|c|c|c|c|}
\hline $\begin{array}{c}\text { Run } \\
\text { Sys }-6\end{array}$ & $\begin{array}{c}\text { Temp. } \\
{ }^{\circ} \mathrm{C}\end{array}$ & $\mathrm{Ne}$ & $\overline{\mathrm{Ar}}$ & $\overline{\mathrm{H}_{2}}$ & $\overline{\mathrm{CO}_{2}}$ & $\overline{\mathrm{CH}_{4}}$ & $\mathrm{C}_{2} \mathrm{HC}$ & $\bar{~} \mathrm{C}_{>2} \mathrm{HC}$ & $\overline{\mathrm{N}_{2}}$ & $\overline{\mathrm{O}} \mathrm{O}_{2}$ & Kr 83 & $\mathrm{Kr} 84$ & Kr 85 & $\mathrm{Kr} 86$ & Xe 130 & "Xe 131 & "Xe 132 & "Xe 134 & "Xe 136 & Time, $\mathrm{h}$ \\
\hline \multirow{2}{*}{$\begin{array}{c}1 \\
22 \mathrm{~K} 68\end{array}$} & \multirow{2}{*}{$\begin{array}{c}\text { Amb., } \\
80\end{array}$} & 52.9 & 0.006 & 46.50 & 0.0 & 0.072 & 0.009 & 0.004 & 0.39 & 0.063 & $3.0 \mathrm{E}-04$ & $6.0 \mathrm{E}-04$ & $7.0 \mathrm{E}-05$ & \begin{tabular}{|l|}
$1.5 \mathrm{E}-03$ \\
\end{tabular} & $1.0 \mathrm{E}-05$ & $2.8 \mathrm{E}-03$ & $4.9 \mathrm{E}-03$ & $8.1 \mathrm{E}-03$ & $1.2 \mathrm{E}-02$ & \multirow{2}{*}{\begin{tabular}{|c}
136.3 \\
115.3
\end{tabular}} \\
\hline & & & & 99.7 & & 0.154 & 0.019 & 0.009 & -0.0601 & \begin{tabular}{|l|}
-0.105 \\
\end{tabular} & \begin{tabular}{|l|}
$6.4 \mathrm{E}-04$ \\
\end{tabular} & \begin{tabular}{|l|}
$1.3 \mathrm{E}-03$ \\
\end{tabular} & \begin{tabular}{|l|}
$1.5 \mathrm{E}-04$ \\
\end{tabular} & \begin{tabular}{|l|}
$3.2 \mathrm{E}-03$ \\
\end{tabular} & $2.1 \mathrm{E}-05$ & $6.0 \mathrm{E}-03$ & $1.1 \mathrm{E}-02$ & \begin{tabular}{|l|}
$1.7 \mathrm{E}-02$ \\
\end{tabular} & $2.6 \mathrm{E}-02$ & \\
\hline \multirow{2}{*}{$\begin{array}{c}2 \\
22 \mathrm{~K} 78\end{array}$} & \multirow{2}{*}{80} & 57.2 & 0.004 & 42.30 & 0.1 & 0.029 & 0.012 & 0.008 & 0.338 & 0.002 & $4.0 \mathrm{E}-04$ & $9.0 \mathrm{E}-04$ & $4.0 \mathrm{E}-05$ & \begin{tabular}{|l|}
$1.6 \mathrm{E}-03$ \\
\end{tabular} & $1.0 \mathrm{E}-05$ & $2.8 \mathrm{E}-03$ & $4.8 \mathrm{E}-03$ & $7.5 \mathrm{E}-03$ & $1.1 \mathrm{E}-02$ & \multirow{2}{*}{1001.7} \\
\hline & & & & 99.7 & & 0.068 & 0.028 & 0.019 & 0.206 & -0.154 & 9.4E-04 & $2.1 \mathrm{E}-03$ & 9.4E-05 & $3.8 \mathrm{E}-03$ & $2.4 \mathrm{E}-05$ & $6.6 \mathrm{E}-03$ & $1.1 \mathrm{E}-02$ & $1.8 \mathrm{E}-02$ & $2.6 \mathrm{E}-02$ & \\
\hline 3 & \multirow{2}{*}{95} & 94.3 & 0.006 & 5.10 & 0.0 & 0.01 & 0.009 & 0.007 & 0.459 & 0.01 & $3.0 \mathrm{E}-05$ & $7.0 \mathrm{E}-05$ & & $1.0 \mathrm{E}-04$ & & $3.0 \mathrm{E}-04$ & $5.0 \mathrm{E}-04$ & 7.0E-04 & $1.0 \mathrm{E}-03$ & \multirow{2}{*}{501.0} \\
\hline $22 \mathrm{~K} 89$ & & & & 99.2 & & 0.19 & 0.18 & 0.14 & 0.798 & -1.99 & $5.8 \mathrm{E}-04$ & $1.4 \mathrm{E}-03$ & & $1.9 \mathrm{E}-03$ & & $5.8 \mathrm{E}-03$ & $9.7 \mathrm{E}-03$ & $1.4 \mathrm{E}-02$ & $1.9 \mathrm{E}-02$ & \\
\hline
\end{tabular}


Table B.11. Gas Analyses for Test SNF Mid $80 \mathrm{~L}$ at $80^{\circ} \mathrm{C}$ and $95^{\circ} \mathrm{C}$ (Test 7)

\begin{tabular}{|c|c|c|c|c|c|c|c|c|c|c|c|c|c|c|c|c|c|c|c|c|}
\hline $\begin{array}{c}\text { Run } \\
\text { Sys }-7\end{array}$ & $\begin{array}{c}\text { Temp. } \\
{ }^{\circ} \mathrm{C}\end{array}$ & $\mathrm{Ne}$ & $\mathrm{Ar}$ & $\overline{\mathrm{H}_{2}}$ & $\mathrm{CO}_{2}$ & $\overline{\mathrm{C} \mathrm{CH}_{4}}$ & $\mathrm{C}_{2} \mathrm{HC}$ & $\mathrm{C}_{>2} \mathrm{HC}$ & $\mathrm{N}_{2}$ & 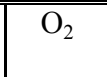 & $\mathrm{Kr} 83$ & Kr 84 & $\mathrm{Kr} 85$ & Kr 86 & Xe 130 & $\overline{\mid X e} 131$ & Xe 132 & Xe 134 & Xe 136 & Time, $\mathrm{h}$ \\
\hline \multirow{2}{*}{$\begin{array}{c}1 \\
22 \mathrm{~K} 73\end{array}$} & \multirow{2}{*}{$\begin{array}{c}\text { Amb., } \\
80\end{array}$} & 3.3 & 005 & 56.20 & 0.0 & 0.011 & & 0.001 & 0.33 & 0.06 & $5.0 \mathrm{E}-04$ & $1.0 \mathrm{E}-03$ & $5.0 \mathrm{E}-05$ & \begin{tabular}{|l|}
$1.9 \mathrm{E}-03$ \\
\end{tabular} & $1.0 \mathrm{E}-05$ & $3.3 \mathrm{E}-03$ & $5.7 \mathrm{E}-03$ & \begin{tabular}{|l|}
$8.9 \mathrm{E}-03$ \\
\end{tabular} & $1.3 \mathrm{E}-02$ & \multirow{2}{*}{\begin{tabular}{|c}
136.3 \\
505.0
\end{tabular}} \\
\hline & & & & 99.909 & & 0.0196 & & 0.002 & -0.0078 & -0.0528 & $8.9 \mathrm{E}-04$ & $1.8 \mathrm{E}-03$ & $8.9 \mathrm{E}-05$ & \begin{tabular}{|l|}
$3.4 \mathrm{E}-03$ \\
\end{tabular} & $1.8 \mathrm{E}-05$ & $5.9 \mathrm{E}-03$ & $1.0 \mathrm{E}-02$ & $1.6 \mathrm{E}-02$ & $2.3 \mathrm{E}-02$ & \\
\hline \multirow{2}{*}{$\begin{array}{c}2 \\
22 \mathrm{~K} 78\end{array}$} & \multirow{2}{*}{80} & 66.8 & 0.007 & 32.50 & 0.0 & 0.004 & 0.002 & & 0.54 & 0.082 & $3.0 \mathrm{E}-04$ & $6.0 \mathrm{E}-04$ & $3.0 \mathrm{E}-05$ & $1.1 \mathrm{E}-03$ & $7.0 \mathrm{E}-06$ & $1.8 \mathrm{E}-03$ & 3.3E-03 & $5.1 \mathrm{E}-03$ & $7.8 \mathrm{E}-03$ & \multirow{2}{*}{594.0} \\
\hline & & & & 99.911 & & 0.0123 & 0.006 & & 0.118 & -0.162 & $9.2 \mathrm{E}-04$ & $1.8 \mathrm{E}-03$ & $9.2 \mathrm{E}-05$ & $3.4 \mathrm{E}-03$ & $2.2 \mathrm{E}-05$ & $5.5 \mathrm{E}-03$ & $1.0 \mathrm{E}-02$ & $1.6 \mathrm{E}-02$ & 2.4E-02 & \\
\hline \multirow{2}{*}{$\begin{array}{c}3 \\
22 \mathrm{~K} 89\end{array}$} & \multirow{2}{*}{95} & 75.8 & 0.006 & 23.70 & 0.1 & 0.006 & 0.004 & 0.002 & 0.447 & 0.034 & $2.0 \mathrm{E}-04$ & $5.0 \mathrm{E}-04$ & $2.0 \mathrm{E}-05$ & $8.0 \mathrm{E}-04$ & & $1.4 \mathrm{E}-03$ & $2.5 \mathrm{E}-03$ & $4.0 \mathrm{E}-03$ & $5.9 \mathrm{E}-03$ & \multirow{2}{*}{501.0} \\
\hline & & & & 99.566 & & 0.0252 & 0.017 & 0.008 & 0.122 & -0.328 & $8.4 \mathrm{E}-04$ & $2.1 \mathrm{E}-03$ & $8.4 \mathrm{E}-05$ & $3.4 \mathrm{E}-03$ & & $5.9 \mathrm{E}-03$ & $1.1 \mathrm{E}-02$ & $1.7 \mathrm{E}-02$ & $2.5 \mathrm{E}-02$ & \\
\hline \multirow{2}{*}{$\begin{array}{c}4 \\
22 \mathrm{~K} 93\end{array}$} & \multirow{2}{*}{95} & 90.4 & 0.008 & 8.70 & 0.0 & 0.007 & 0.003 & 0.002 & 0.67 & 0.162 & $1.0 \mathrm{E}-04$ & $1.0 \mathrm{E}-04$ & $5.0 \mathrm{E}-06$ & $2.0 \mathrm{E}-04$ & $2.0 \mathrm{E}-06$ & $6.0 \mathrm{E}-04$ & $1.0 \mathrm{E}-03$ & $1.5 \mathrm{E}-03$ & $2.2 \mathrm{E}-03$ & \multirow{2}{*}{917.3} \\
\hline & & & & 99.43 & & 0.0800 & 0.034 & 0.023 & 0.97 & 0.057 & $1.1 \mathrm{E}-03$ & $1.1 \mathrm{E}-03$ & 5.7E-05 & $2.3 \mathrm{E}-03$ & $2.3 \mathrm{E}-05$ & $6.9 \mathrm{E}-03$ & $1.1 \mathrm{E}-02$ & $1.7 \mathrm{E}-02$ & $2.5 \mathrm{E}-02$ & \\
\hline
\end{tabular}

Table B.12. Gas Analyses for Test Mid $80 \mathrm{~L}$ Dup at $80^{\circ} \mathrm{C}$ and $95^{\circ} \mathrm{C}$ (Test 8)

\begin{tabular}{|c|c|c|c|c|c|c|c|c|c|c|c|c|c|c|c|c|c|c|c|c|}
\hline $\begin{array}{c}\text { Run } \\
\text { Sys }-8\end{array}$ & $\begin{array}{c}\text { Temp. } \\
{ }^{\circ} \mathrm{C}\end{array}$ & $\mathrm{Ne}$ & $\overline{\mathrm{Ar}}$ & $\overline{\mathrm{H}_{2}}$ & $\overline{\mathrm{C} \mathrm{CO}_{2}}$ & $\overline{\mathrm{C} \mathrm{CH}_{4}}$ & $\mathrm{C}_{2} \mathrm{HC}$ & $\mathrm{C}_{>2} \mathrm{HC}$ & $\mathrm{N}_{2}$ & 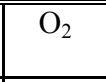 & $\mathrm{Kr} 83$ & $\mathrm{Kr} 84$ & $\mathrm{Kr} 85$ & $\mathrm{Kr} 86$ & Xe 130 & Xe 131 & Xe 132 & Xe 134 & Xe 136 & Time, $\mathrm{h}$ \\
\hline \multirow{2}{*}{$\begin{array}{c}1 \\
22 \mathrm{~K} 73\end{array}$} & \multirow{2}{*}{$\begin{array}{c}\text { Amb., } \\
80\end{array}$} & 41.7 & 0.005 & 57.9 & 0.011 & 0.01 & & 0.002 & 0.28 & 0.045 & $5.0 \mathrm{E}-04$ & $1.1 \mathrm{E}-03$ & $5.0 \mathrm{E}-05$ & $1.9 \mathrm{E}-03$ & $1.0 \mathrm{E}-05$ & $3.4 \mathrm{E}-03$ & $6.0 \mathrm{E}-03$ & 9.3E-03 & 1.4E-02 & \multirow{2}{*}{$\begin{array}{c}136.3, \\
505.0 \\
\end{array}$} \\
\hline & & & & 100 & 0.02 & 0.02 & & 0.003 & -0.0939 & \begin{tabular}{|l|}
-0.0771 \\
\end{tabular} & $8.6 \mathrm{E}-04$ & $1.9 \mathrm{E}-03$ & $8.6 \mathrm{E}-05$ & 3.3E-03 & $1.7 \mathrm{E}-05$ & $5.9 \mathrm{E}-03$ & $1.0 \mathrm{E}-02$ & $1.6 \mathrm{E}-02$ & 2.4E-02 & \\
\hline \multirow{2}{*}{$\begin{array}{c}2 \\
22 \mathrm{~K} 78\end{array}$} & \multirow{2}{*}{80} & 70.1 & 0.005 & 29.4 & 0.023 & 0.00 & \begin{tabular}{|l|}
0.002 \\
\end{tabular} & & 0.41 & \begin{tabular}{|l|}
0.079 \\
\end{tabular} & $2.0 \mathrm{E}-04$ & $4.0 \mathrm{E}-04$ & $2.0 \mathrm{E}-05$ & $7.0 \mathrm{E}-04$ & $6.0 \mathrm{E}-06$ & $1.6 \mathrm{E}-03$ & $2.9 \mathrm{E}-03$ & $4.8 \mathrm{E}-03$ & 7.0E-03 & \multirow{2}{*}{594.3} \\
\hline & & & & 100 & 0.1 & 0.01 & \begin{tabular}{|l|}
0.007 \\
\end{tabular} & & 0.264 & -0.0364 & $6.8 \mathrm{E}-04$ & $1.4 \mathrm{E}-03$ & $6.8 \mathrm{E}-05$ & $2.4 \mathrm{E}-03$ & $2.0 \mathrm{E}-05$ & $5.4 \mathrm{E}-03$ & $9.8 \mathrm{E}-03$ & \begin{tabular}{|l|}
$1.6 \mathrm{E}-02$ \\
\end{tabular} & 2.4E-02 & \\
\hline \multirow{2}{*}{$\begin{array}{c}3 \\
22 \mathrm{~K} 89 \\
\end{array}$} & \multirow{2}{*}{95} & 83.2 & 0.008 & 16.1 & 0.009 & 0.01 & 0.004 & 0.002 & 0.62 & \begin{tabular}{|l|}
0.119 \\
\end{tabular} & $1.0 \mathrm{E}-04$ & $2.0 \mathrm{E}-04$ & $1.0 \mathrm{E}-05$ & $4.0 \mathrm{E}-04$ & & $1.1 \mathrm{E}-03$ & $1.8 \mathrm{E}-03$ & $2.9 \mathrm{E}-03$ & 4.2E-03 & \multirow{2}{*}{501.0} \\
\hline & & & & 99 & 0.1 & 0.04 & 0.02 & 0.01 & 0.214 & 2.85 & $6.2 \mathrm{E}-04$ & $1.2 \mathrm{E}-03$ & $6.2 \mathrm{E}-05$ & $2.5 \mathrm{E}-03$ & & $6.8 \mathrm{E}-03$ & $1.1 \mathrm{E}-02$ & $1.8 \mathrm{E}-02$ & $2.6 \mathrm{E}-02$ & \\
\hline 4 & \multirow{2}{*}{95} & 95.2 & 0.008 & 3.94 & 0.095 & 0.01 & 0.003 & 0.001 & 0.63 & 0.093 & $3.0 \mathrm{E}-05$ & $6.0 \mathrm{E}-05$ & $4.0 \mathrm{E}-06$ & $9.0 \mathrm{E}-05$ & & $3.0 \mathrm{E}-04$ & $4.0 \mathrm{E}-04$ & $6.0 \mathrm{E}-04$ & $1.0 \mathrm{E}-03$ & \multirow{2}{*}{917.3} \\
\hline $22 \mathrm{~K} 93$ & & & & 97 & 2 & 0.1 & 0.07 & 0.02 & 1.11 & -1.58 & $7.4 \mathrm{E}-04$ & $1.5 \mathrm{E}-03$ & 9.9E-05 & $2.2 \mathrm{E}-03$ & & 7.4E-03 & 9.9E-03 & $1.5 \mathrm{E}-02$ & $2.5 \mathrm{E}-02$ & \\
\hline
\end{tabular}


Table B.13. Gas Analyses for Test Fuel Fragment at $80^{\circ} \mathrm{C}$ (Test 9)

\begin{tabular}{|c|c|c|c|c|c|c|c|c|c|c|c|c|c|c|c|c|c|c|c|c|}
\hline \begin{tabular}{|c|} 
Run \\
Sys -11 \\
\end{tabular} & \begin{tabular}{|c|} 
Temp. \\
${ }^{\circ} \mathrm{C}$
\end{tabular} & $\mathrm{Ne}$ & $\mathrm{Ar}$ & $\mathrm{H}_{2}$ & $\mathrm{CO}_{2}$ & $\mathrm{CH}_{4}$ & $\mathrm{C}_{2} \mathrm{HC}$ & $\mathrm{C}_{>2} \mathrm{HC}$ & $\mathrm{N}_{2}$ & $\mathrm{O}_{2}$ & $\mathrm{Kr} 83$ & $\mathrm{Kr} 84$ & $\mathrm{Kr} 85$ & $\mathrm{Kr} 86$ & Xe 130 & $\mathrm{Xe} 131$ & Xe 132 & Xe 134 & Xe 136 & Time, $\mathrm{h}$ \\
\hline \multirow{2}{*}{$\begin{array}{c}1 \\
22 \mathrm{~K} 49\end{array}$} & \multirow{2}{*}{$\begin{array}{c}\text { Amb., } \\
80\end{array}$} & 84.2 & 0.004 & 15.50 & 0.039 & 0.035 & \begin{tabular}{|l|}
0.007 \\
\end{tabular} & \begin{tabular}{|l|}
0.003 \\
\end{tabular} & 0.228 & 0.02 & $1.0 \mathrm{E}-04$ & $2.0 \mathrm{E}-04$ & $4.0 \mathrm{E}-05$ & $4.0 \mathrm{E}-04$ & & $1.0 \mathrm{E}-03$ & $1.7 \mathrm{E}-03$ & $2.7 \mathrm{E}-03$ & $4.0 \mathrm{E}-03$ & \multirow{2}{*}{307.3} \\
\hline & & & & 99.40 & & 0.224 & 0.045 & 0.019 & \begin{tabular}{|c|}
-0.146 \\
\end{tabular} & -0.303 & $6.4 \mathrm{E}-04$ & \begin{tabular}{|l|}
$1.3 \mathrm{E}-03$ \\
\end{tabular} & $2.6 \mathrm{E}-04$ & \begin{tabular}{|l|}
$2.6 \mathrm{E}-03$ \\
\end{tabular} & & \begin{tabular}{|l|}
$6.4 \mathrm{E}-03$ \\
\end{tabular} & $1.1 \mathrm{E}-02$ & \begin{tabular}{|l|}
$1.7 \mathrm{E}-02$ \\
\end{tabular} & \begin{tabular}{|l|}
$2.6 \mathrm{E}-02$ \\
\end{tabular} & \\
\hline \multirow{2}{*}{$\begin{array}{c}2 \\
22 \mathrm{~K} 61\end{array}$} & \multirow{2}{*}{80} & 62 & 0.015 & 36.40 & 0.126 & 0.053 & 0.01 & 0.006 & 1.19 & 0.169 & $3.0 \mathrm{E}-04$ & $6.0 \mathrm{E}-04$ & & $1.1 \mathrm{E}-03$ & $1.0 \mathrm{E}-05$ & $2.2 \mathrm{E}-03$ & $3.7 \mathrm{E}-03$ & $6.0 \mathrm{E}-03$ & $9.0 \mathrm{E}-03$ & \multirow{2}{*}{663.3} \\
\hline & & & & 99.40 & 0.3 & 0.145 & 0.027 & 0.016 & 0.0535 & -0.396 & $8.2 \mathrm{E}-04$ & $1.6 \mathrm{E}-03$ & & \begin{tabular}{|l|}
$3.0 \mathrm{E}-03$ \\
\end{tabular} & \begin{tabular}{|l|}
$2.7 \mathrm{E}-05$ \\
\end{tabular} & \begin{tabular}{|l|}
$6.0 \mathrm{E}-03$ \\
\end{tabular} & $1.0 \mathrm{E}-02$ & \begin{tabular}{|l|}
$1.6 \mathrm{E}-02$ \\
\end{tabular} & & \\
\hline \multirow{2}{*}{$\begin{array}{c}3 \\
22 \mathrm{~K} 73 \\
\end{array}$} & \multirow{2}{*}{80} & 40.1 & 0.008 & 59.00 & 0.015 & 0.053 & 0.01 & 0.007 & 0.6 & 0.137 & $7.0 \mathrm{E}-04$ & $1.4 \mathrm{E}-03$ & $7.0 \mathrm{E}-05$ & $2.2 \mathrm{E}-03$ & \begin{tabular}{|l|}
$1.0 \mathrm{E}-05$ \\
\end{tabular} & \begin{tabular}{|l|}
$4.0 \mathrm{E}-03$ \\
\end{tabular} & 7.0E-03 & $1.1 \mathrm{E}-02$ & $1.6 \mathrm{E}-02$ & \multirow{2}{*}{884.0} \\
\hline & & & & 99.79 & 0.03 & 0.090 & 0.017 & 0.012 & \begin{tabular}{|l|}
0.0250 \\
\end{tabular} & -0.0338 & $1.2 \mathrm{E}-03$ & $2.4 \mathrm{E}-03$ & \begin{tabular}{|l|}
$1.2 \mathrm{E}-04$ \\
\end{tabular} & \begin{tabular}{|l|}
$3.7 \mathrm{E}-03$ \\
\end{tabular} & \begin{tabular}{|l|}
$1.7 \mathrm{E}-05$ \\
\end{tabular} & \begin{tabular}{|c|}
$6.8 \mathrm{E}-03$ \\
\end{tabular} & \begin{tabular}{|l|}
$1.2 \mathrm{E}-02$ \\
\end{tabular} & \begin{tabular}{|l|}
$1.9 \mathrm{E}-02$ \\
\end{tabular} & \begin{tabular}{|l|}
$2.7 \mathrm{E}-02$ \\
\end{tabular} & \\
\hline 4 & \multirow{2}{*}{80} & & & & & & & & & & & & & & & & & & & \multirow{2}{*}{1505.0} \\
\hline Vent & & & & & & & & & & & & & & & & & & & & \\
\hline \multirow{2}{*}{$\begin{array}{c}5 \\
22 \mathrm{~K} 93\end{array}$} & \multirow{2}{*}{80} & 58.2 & 0.013 & 40.40 & 0.013 & 0.027 & \begin{tabular}{|l|}
0.006 \\
\end{tabular} & 0.004 & 1 & 0.245 & $4.0 \mathrm{E}-04$ & $7.0 \mathrm{E}-04$ & $4.0 \mathrm{E}-05$ & \begin{tabular}{|l|}
$1.3 \mathrm{E}-03$ \\
\end{tabular} & \begin{tabular}{|l|}
$1.0 \mathrm{E}-05$ \\
\end{tabular} & \begin{tabular}{|l|}
$2.5 \mathrm{E}-03$ \\
\end{tabular} & $4.4 \mathrm{E}-03$ & 7.1E-03 & $1.0 \mathrm{E}-02$ & \multirow{2}{*}{553.0} \\
\hline & & & & 99.81 & 0.0321 & 0.0667 & \begin{tabular}{|l|}
0.0148 \\
\end{tabular} & 0.0099 & -0.0080 & -0.0596 & $9.9 \mathrm{E}-04$ & $1.7 \mathrm{E}-03$ & $9.9 \mathrm{E}-05$ & $3.2 \mathrm{E}-03$ & \begin{tabular}{|l|}
$2.5 \mathrm{E}-05$ \\
\end{tabular} & \begin{tabular}{|l|}
$6.2 \mathrm{E}-03$ \\
\end{tabular} & $1.1 \mathrm{E}-02$ & $1.8 \mathrm{E}-02$ & \begin{tabular}{|l|}
$2.5 \mathrm{E}-02$ \\
\end{tabular} & \\
\hline
\end{tabular}

Table B.14. Gas Generation Rates from SNF P2000 80S at $80^{\circ} \mathrm{C}$ (Test 5)

\begin{tabular}{|c|c|c|c|c|c|c|c|c|c|c|c|c|c|c|c|c|c|c|}
\hline \multirow[t]{2}{*}{ Run } & \multirow{2}{*}{$\begin{array}{c}\text { Temp. } \\
{ }^{\circ} \mathrm{C}\end{array}$} & \multicolumn{17}{|c|}{ "Gas Generation Rate, moles/kg fuel particles-day } \\
\hline & & $\mathrm{H}_{2}$ & $\mathrm{CO}_{2}$ & $\mathrm{CH}_{4}$ & $\mathrm{C}_{2} \mathrm{HC}$ & $\mathrm{C}_{>2} \mathrm{HC}$ & $\mathrm{N}_{2}$ & $\mathrm{O}_{2}$ & $\mathrm{Kr} 83$ & $\mathrm{Kr} 84$ & $\mathrm{Kr} 85$ & $\mathrm{Kr} 86$ & Xe 130 & Xe 131 & Xe 132 & Xe 134 & Xe 136 & Time, $\mathrm{h}$ \\
\hline 1 & 80 & $1.1 \mathrm{E}-1$ & $2.6 \mathrm{E}-6$ & $1.0 \mathrm{E}-4$ & $1.6 \mathrm{E}-5$ & $7.8 \mathrm{E}-6$ & $-9.1 \mathrm{E}-5$ & $-1.3 \mathrm{E}-4$ & $9.3 \mathrm{E}-7$ & $2.2 \mathrm{E}-6$ & $1.6 \mathrm{E}-7$ & $3.9 \mathrm{E}-6$ & $3.1 \mathrm{E}-8$ & $7.5 \mathrm{E}-6$ & $1.3 \mathrm{E}-5$ & $2.0 \mathrm{E}-5$ & $2.9 \mathrm{E}-5$ & 114.7 \\
\hline 2 & 80 & $1.0 \mathrm{E}-1$ & $1.4 \mathrm{E}-5$ & $3.5 \mathrm{E}-5$ & $7.9 \mathrm{E}-6$ & $4.7 \mathrm{E}-6$ & $9.8 \mathrm{E}-5$ & $1.4 \mathrm{E}-6$ & $1.3 \mathrm{E}-6$ & $2.0 \mathrm{E}-6$ & $1.6 \mathrm{E}-7$ & $3.8 \mathrm{E}-6$ & $3.2 \mathrm{E}-8$ & $7.2 \mathrm{E}-6$ & $1.2 \mathrm{E}-5$ & $1.9 \mathrm{E}-5$ & $2.8 \mathrm{E}-5$ & 92.7 \\
\hline 3 & 80 & $8.4 \mathrm{E}-2$ & $1.6 \mathrm{E}-5$ & $2.4 \mathrm{E}-5$ & & $3.0 \mathrm{E}-6$ & $2.2 \mathrm{E}-4$ & $1.3 \mathrm{E}-5$ & $6.0 \mathrm{E}-7$ & $1.3 \mathrm{E}-6$ & $7.5 \mathrm{E}-8$ & $2.4 \mathrm{E}-6$ & $1.5 \mathrm{E}-8$ & $5.1 \mathrm{E}-6$ & $9.0 \mathrm{E}-6$ & $1.4 \mathrm{E}-5$ & $2.1 \mathrm{E}-5$ & 73.7 \\
\hline 4 & 80 & $7.5 \mathrm{E}-2$ & $4.7 \mathrm{E}-6$ & $2.1 \mathrm{E}-5$ & $4.7 \mathrm{E}-6$ & $2.3 \mathrm{E}-6$ & $9.6 \mathrm{E}-5$ & $8.0 \mathrm{E}-6$ & 7.0E-7 & $1.4 \mathrm{E}-6$ & $7.0 \mathrm{E}-8$ & $2.7 \mathrm{E}-6$ & $2.3 \mathrm{E}-8$ & $4.8 \mathrm{E}-6$ & $8.2 \mathrm{E}-6$ & $1.3 \mathrm{E}-5$ & $1.9 \mathrm{E}-5$ & 123.0 \\
\hline 5 & 80 & $6.1 \mathrm{E}-2$ & $3.6 \mathrm{E}-6$ & $1.8 \mathrm{E}-5$ & $4.5 \mathrm{E}-6$ & $2.7 \mathrm{E}-6$ & $1.0 \mathrm{E}-4$ & $1.1 \mathrm{E}-5$ & $5.5 \mathrm{E}-7$ & $1.1 \mathrm{E}-6$ & $3.6 \mathrm{E}-8$ & $2.1 \mathrm{E}-6$ & $9.1 \mathrm{E}-9$ & $3.8 \mathrm{E}-6$ & $6.5 \mathrm{E}-6$ & $1.1 \mathrm{E}-5$ & $1.5 \mathrm{E}-5$ & 165.7 \\
\hline 6 & 80 & $5.2 \mathrm{E}-2$ & $4.5 \mathrm{E}-6$ & $1.5 \mathrm{E}-5$ & $4.5 \mathrm{E}-6$ & $1.8 \mathrm{E}-6$ & $8.3 \mathrm{E}-5$ & $6.0 \mathrm{E}-6$ & $4.5 \mathrm{E}-7$ & $9.1 \mathrm{E}-7$ & $4.5 \mathrm{E}-8$ & $1.7 \mathrm{E}-6$ & $9.1 \mathrm{E}-9$ & $3.2 \mathrm{E}-6$ & $5.6 \mathrm{E}-6$ & $9.1 \mathrm{E}-6$ & $1.3 \mathrm{E}-5$ & 124.0 \\
\hline 7 & 80 & 3 Vents & 3 Vents & 3 Vents & 3 Vents & 3 Vents & 3 Vents & 3 Vents & 3 Vents & 3 Vents & 3 Vents & 3 Vents & 3 Vents & 3 Vents & 3 Vents & 3 Vents & 3 Vents & 1196 \\
\hline 8 & 80 & $1.4 \mathrm{E}-2$ & $9.0 \mathrm{E}-7$ & $4.7 \mathrm{E}-6$ & $1.3 \mathrm{E}-6$ & $6.7 \mathrm{E}-7$ & $1.2 \mathrm{E}-5$ & $-5.7 \mathrm{E}-6$ & $1.3 \mathrm{E}-7$ & $2.9 \mathrm{E}-7$ & $1.3 \mathrm{E}-8$ & $5.2 \mathrm{E}-7$ & $2.2 \mathrm{E}-9$ & $8.8 \mathrm{E}-7$ & $1.4 \mathrm{E}-6$ & $2.2 \mathrm{E}-6$ & $3.4 \mathrm{E}-6$ & 552.3 \\
\hline
\end{tabular}

Table B.15. Gas Generation Rates from SNF M500 80L at $90^{\circ} \mathrm{C}$ and $95^{\circ} \mathrm{C}$ (Test 6)

\begin{tabular}{|c|c|c|c|c|c|c|c|c|c|c|c|c|c|c|c|c|c|c|}
\hline \multirow[t]{2}{*}{ Run } & \multirow{2}{*}{$\begin{array}{c}\text { Temp. } \\
{ }^{\circ} \mathrm{C}\end{array}$} & \multicolumn{17}{|c|}{ Gas Generation Rate, moles/kg fuel particles-day } \\
\hline & & $\mathrm{H}_{2}$ & $\mathrm{CO}_{2}$ & $\mathrm{CH}_{4}$ & $\mathrm{C}_{2} \mathrm{HC}$ & $\mathrm{C}_{>2} \mathrm{HC}$ & $\mathrm{N}_{2}$ & $\mathrm{O}_{2}$ & $\mathrm{Kr} 83$ & $\mathrm{Kr} 84$ & $\mathrm{Kr} 85$ & $\mathrm{Kr} 86$ & Xe 130 & Xe 131 & Xe 132 & $\mathrm{Xe} 134$ & Xe 136 & Time, $\mathrm{h}$ \\
\hline 1 & 80 & $6.7 \mathrm{E}-1$ & $2.2 \mathrm{E}-4$ & $1.0 \mathrm{E}-3$ & $1.3 \mathrm{E}-4$ & $5.7 \mathrm{E}-5$ & $-4.0 \mathrm{E}-4$ & $-7.1 \mathrm{E}-4$ & $4.3 \mathrm{E}-6$ & $8.6 \mathrm{E}-6$ & $1.0 \mathrm{E}-6$ & $2.2 \mathrm{E}-5$ & $1.4 \mathrm{E}-7$ & $4.0 \mathrm{E}-5$ & $7.0 \mathrm{E}-5$ & $1.2 \mathrm{E}-4$ & $1.7 \mathrm{E}-4$ & 115.3 \\
\hline 2 & 80 & $6.8 \mathrm{E}-2$ & $8.0 \mathrm{E}-5$ & $4.7 \mathrm{E}-5$ & $1.9 \mathrm{E}-5$ & $1.3 \mathrm{E}-5$ & \begin{tabular}{|l|}
$1.4 \mathrm{E}-4$ \\
\end{tabular} & $-1.0 \mathrm{E}-4$ & $6.4 \mathrm{E}-7$ & $1.4 \mathrm{E}-6$ & $6.4 \mathrm{E}-8$ & $2.6 \mathrm{E}-6$ & $1.6 \mathrm{E}-8$ & $4.5 \mathrm{E}-6$ & \begin{tabular}{|l|}
$7.7 \mathrm{E}-6$ \\
\end{tabular} & $1.2 \mathrm{E}-5$ & $1.8 \mathrm{E}-5$ & 1001.7 \\
\hline 3 & 95 & $9.4 \mathrm{E}-3$ & $2.0 \mathrm{E}-5$ & $1.8 \mathrm{E}-5$ & $1.7 \mathrm{E}-5$ & $1.3 \mathrm{E}-5$ & $7.5 \mathrm{E}-5$ & $-1.9 \mathrm{E}-4$ & $5.5 \mathrm{E}-8$ & $1.3 \mathrm{E}-7$ & & $1.8 \mathrm{E}-7$ & & $5.5 \mathrm{E}-7$ & $9.2 \mathrm{E}-7$ & $1.3 \mathrm{E}-6$ & $1.8 \mathrm{E}-6$ & 501.0 \\
\hline
\end{tabular}


Table B.16. Gas Generation Rates from SNF Mid $80 \mathrm{~L}$ at $80^{\circ} \mathrm{C}$ and $95^{\circ} \mathrm{C}$ (Test 7)

\begin{tabular}{|c|c|c|c|c|c|c|c|c|c|c|c|c|c|c|c|c|c|c|}
\hline \multirow[b]{2}{*}{ Run } & \multirow{2}{*}{$\begin{array}{c}\text { Temp. } \\
{ }^{\circ} \mathrm{C}\end{array}$} & \multicolumn{17}{|c|}{ Gas Generation Rate, moles $/ \mathrm{kg}$ fuel particles-day } \\
\hline & & $\mathrm{H}_{2}$ & $\mathrm{CO}_{2}$ & $\mathrm{CH}_{4}$ & $\mathrm{C}_{2} \mathrm{HC}$ & $\mathrm{C}_{>2} \mathrm{HC}$ & $\mathrm{N}_{2}$ & $\mathrm{O}_{2}$ & $\mathrm{Kr} 83$ & $\mathrm{Kr} 84$ & Kr 85 & Kr 86 & Xe 130 & Xe 131 & $\mathrm{Xe} 132$ & Xe 134 & Xe 136 & Time, $\mathrm{h}$ \\
\hline 1 & 80 & \begin{tabular}{|l|}
$2.2 \mathrm{E}-1$ \\
\end{tabular} & $1.9 \mathrm{E}-5$ & $4.2 \mathrm{E}-5$ & & $3.8 \mathrm{E}-6$ & $-1.7 \mathrm{E}-5$ & \begin{tabular}{|l|l|}
$-1.1 \mathrm{E}-4$ \\
\end{tabular} & $1.9 \mathrm{E}-6$ & $3.8 \mathrm{E}-6$ & $1.9 \mathrm{E}-7$ & $7.3 \mathrm{E}-6$ & $3.8 \mathrm{E}-8$ & $1.3 \mathrm{E}-5$ & $2.2 \mathrm{E}-5$ & $3.4 \mathrm{E}-5$ & $5.0 \mathrm{E}-5$ & 505.0 \\
\hline 2 & 80 & \begin{tabular}{|c|}
$6.6 \mathrm{E}-2$ \\
\end{tabular} & $6.1 \mathrm{E}-6$ & $8.2 \mathrm{E}-6$ & $4.1 \mathrm{E}-6$ & & $7.8 \mathrm{E}-5$ & \begin{tabular}{|l|l|}
$-1.1 \mathrm{E}-4$ \\
\end{tabular} & $6.1 \mathrm{E}-7$ & $1.2 \mathrm{E}-6$ & $6.1 \mathrm{E}-8$ & $2.2 \mathrm{E}-6$ & $1.4 \mathrm{E}-8$ & $3.7 \mathrm{E}-6$ & $6.7 \mathrm{E}-6$ & $\begin{array}{ll}1.0 \mathrm{E}-5 \\
\end{array}$ & $1.6 \mathrm{E}-5$ & 594.0 \\
\hline 3 & 95 & $5.3 \mathrm{E}-2$ & $1.7 \mathrm{E}-4$ & $1.3 \mathrm{E}-5$ & $8.9 \mathrm{E}-6$ & $4.5 \mathrm{E}-6$ & $6.5 \mathrm{E}-5$ & \begin{tabular}{|l}
$-1.7 \mathrm{E}-4$ \\
\end{tabular} & $4.5 \mathrm{E}-7$ & $1.1 \mathrm{E}-6$ & $4.5 \mathrm{E}-8$ & $1.8 \mathrm{E}-6$ & & $3.1 \mathrm{E}-6$ & $5.6 \mathrm{E}-6$ & $8.9 \mathrm{E}-6$ & $1.3 \mathrm{E}-5$ & 501.0 \\
\hline 4 & 95 & \begin{tabular}{|l|}
$8.9 \mathrm{E}-3$ \\
\end{tabular} & $3.3 \mathrm{E}-5$ & $7.1 \mathrm{E}-6$ & $3.1 \mathrm{E}-6$ & $2.0 \mathrm{E}-6$ & $8.7 \mathrm{E}-5$ & $5.1 \mathrm{E}-6$ & $1.0 \mathrm{E}-7$ & $1.0 \mathrm{E}-7$ & $5.1 \mathrm{E}-9$ & $2.0 \mathrm{E}-7$ & $2.0 \mathrm{E}-9$ & $6.1 \mathrm{E}-7$ & $1.0 \mathrm{E}-6$ & \begin{tabular}{l|}
$1.5 \mathrm{E}-6$ \\
\end{tabular} & $2.2 \mathrm{E}-6$ & 917.3 \\
\hline
\end{tabular}

Table B.17. Gas Generation Rates from Mid $80 \mathrm{~L}$ Dup at $80^{\circ} \mathrm{C}$ and $95^{\circ} \mathrm{C}$ (Test 8)

\begin{tabular}{|c|c|c|c|c|c|c|c|c|c|c|c|c|c|c|c|c|c|c|}
\hline \multirow[b]{2}{*}{ Run } & \multirow{2}{*}{$\begin{array}{c}\text { Temp. } \\
{ }^{\circ} \mathrm{C}\end{array}$} & \multicolumn{17}{|c|}{ Gas Generation Rate, moles $/ \mathrm{kg}$ fuel particles-day } \\
\hline & & $\mathrm{H}_{2}$ & $\mathrm{CO}_{2}$ & $\mathrm{CH}_{4}$ & $\mathrm{C}_{2} \mathrm{HC}$ & $\mathrm{C}_{>2} \mathrm{HC}$ & $\mathrm{N}_{2}$ & $\mathrm{O}_{2}$ & $\mathrm{Kr} 83$ & $\mathrm{Kr} 84$ & $\mathrm{Kr} 85$ & $\mathrm{Kr} 86$ & Xe 130 & Xe 131 & $\mathrm{Xe} 132$ & Xe 134 & Xe 136 & Time, $\mathrm{h}$ \\
\hline 1 & 80 & $2.6 \mathrm{E}-1$ & $4.9 \mathrm{E}-5$ & $4.9 \mathrm{E}-5$ & & $9.0 \mathrm{E}-6$ & $-2.4 \mathrm{E}-4$ & $-2.0 \mathrm{E}-4$ & $2.2 \mathrm{E}-6$ & $4.9 \mathrm{E}-6$ & $2.2 \mathrm{E}-7$ & $8.5 \mathrm{E}-6$ & $4.5 \mathrm{E}-8$ & $1.5 \mathrm{E}-5$ & $2.7 \mathrm{E}-5$ & $4.2 \mathrm{E}-5$ & $6.3 \mathrm{E}-5$ & 505.0 \\
\hline 2 & 80 & $6.7 \mathrm{E}-2$ & $5.2 \mathrm{E}-5$ & $9.1 \mathrm{E}-6$ & $4.5 \mathrm{E}-6$ & & $1.8 \mathrm{E}-4$ & $-2.4 \mathrm{E}-5$ & $4.5 \mathrm{E}-7$ & $9.1 \mathrm{E}-7$ & $4.5 \mathrm{E}-8$ & $1.6 \mathrm{E}-6$ & $1.4 \mathrm{E}-8$ & $3.6 \mathrm{E}-6$ & $6.6 \mathrm{E}-6$ & $1.1 \mathrm{E}-5$ & $1.6 \mathrm{E}-5$ & 594.3 \\
\hline 3 & 95 & $3.6 \mathrm{E}-2$ & $2.0 \mathrm{E}-5$ & $1.6 \mathrm{E}-5$ & $8.9 \mathrm{E}-6$ & $4.4 \mathrm{E}-6$ & $7.7 \mathrm{E}-5$ & $1.0 \mathrm{E}-3$ & $2.2 \mathrm{E}-7$ & $4.4 \mathrm{E}-7$ & $2.2 \mathrm{E}-8$ & $8.9 \mathrm{E}-7$ & & $2.4 \mathrm{E}-6$ & $4.0 \mathrm{E}-6$ & $6.4 \mathrm{E}-6$ & $9.3 \mathrm{E}-6$ & 501.0 \\
\hline 4 & 95 & $4.3 \mathrm{E}-3$ & $1.0 \mathrm{E}-4$ & $6.5 \mathrm{E}-6$ & $3.3 \mathrm{E}-6$ & $1.1 \mathrm{E}-6$ & $4.9 \mathrm{E}-5$ & \begin{tabular}{|l}
$-7.0 \mathrm{E}-5$ \\
\end{tabular} & $3.3 \mathrm{E}-8$ & $6.5 \mathrm{E}-8$ & $4.4 \mathrm{E}-9$ & $9.8 \mathrm{E}-8$ & & $3.3 \mathrm{E}-7$ & $4.4 \mathrm{E}-7$ & $6.5 \mathrm{E}-7$ & $1.1 \mathrm{E}-6$ & 917.3 \\
\hline
\end{tabular}

Table B.18. Gas Generation Rates from Fuel Fragment at $80^{\circ} \mathrm{C}$ (Test 9)

\begin{tabular}{|c|c|c|c|c|c|c|c|c|c|c|c|c|c|c|c|c|c|c|}
\hline \multirow[b]{2}{*}{ Run } & \multirow{2}{*}{$\begin{array}{c}\text { Temp. } \\
{ }^{\circ} \mathrm{C}\end{array}$} & \multicolumn{17}{|c|}{ Gas Generation Rate, moles/kg fuel particles-day } \\
\hline & & $\mathrm{H}_{2}$ & $\mathrm{CO}_{2}$ & $\mathrm{CH}_{4}$ & $\mathrm{C}_{2} \mathrm{HC}$ & $\mathrm{C}_{>2} \mathrm{HC}$ & $\mathrm{N}_{2}$ & $\mathrm{O}_{2}$ & $\mathrm{Kr} 83$ & $\mathrm{Kr} 84$ & $\mathrm{Kr} 85$ & $\mathrm{Kr} 86$ & $\mathrm{Xe} 130$ & Xe 131 & $\mathrm{Xe} 132$ & $\mathrm{Xe} 134$ & Xe 136 & Time, $\mathrm{h}$ \\
\hline 1 & 80 & $7.0 \mathrm{E}-3$ & $1.8 \mathrm{E}-5$ & $1.6 \mathrm{E}-5$ & $3.1 \mathrm{E}-6$ & $1.3 \mathrm{E}-6$ & $-1.0 \mathrm{E}-5$ & $-2.1 \mathrm{E}-5$ & $4.5 \mathrm{E}-8$ & $9.0 \mathrm{E}-8$ & $1.8 \mathrm{E}-8$ & $1.8 \mathrm{E}-7$ & & $4.5 \mathrm{E}-7$ & $7.6 \mathrm{E}-7$ & $1.2 \mathrm{E}-6$ & $1.8 \mathrm{E}-6$ & 307.3 \\
\hline 2 & 80 & $9.9 \mathrm{E}-3$ & $3.4 \mathrm{E}-5$ & $1.4 \mathrm{E}-5$ & $2.7 \mathrm{E}-6$ & $1.6 \mathrm{E}-6$ & $5.3 \mathrm{E}-6$ & $-3.9 \mathrm{E}-5$ & $8.1 \mathrm{E}-8$ & $1.6 \mathrm{E}-7$ & & $3.0 \mathrm{E}-7$ & $2.7 \mathrm{E}-9$ & $6.0 \mathrm{E}-7$ & $1.0 \mathrm{E}-6$ & $1.6 \mathrm{E}-6$ & $2.4 \mathrm{E}-6$ & 663.3 \\
\hline 3 & 80 & $2.1 \mathrm{E}-2$ & $5.4 \mathrm{E}-6$ & $1.9 \mathrm{E}-5$ & $3.6 \mathrm{E}-6$ & $2.5 \mathrm{E}-6$ & $5.4 \mathrm{E}-6$ & $-7.3 \mathrm{E}-6$ & $2.5 \mathrm{E}-7$ & $5.1 \mathrm{E}-7$ & $2.5 \mathrm{E}-8$ & $8.0 \mathrm{E}-7$ & $3.6 \mathrm{E}-9$ & $1.5 \mathrm{E}-6$ & $2.5 \mathrm{E}-6$ & $4.0 \mathrm{E}-6$ & $5.8 \mathrm{E}-6$ & 884.0 \\
\hline 4 & 80 & Vent & Vent & Vent & Vent & Vent & Vent & Vent & Vent & Vent & Vent & Vent & Vent & Vent & Vent & Vent & Vent & 1505.0 \\
\hline 5 & 80 & $1.6 \mathrm{E}-2$ & $5.1 \mathrm{E}-6$ & $1.1 \mathrm{E}-5$ & $2.3 \mathrm{E}-6$ & $1.6 \mathrm{E}-6$ & $-1.3 \mathrm{E}-6$ & $-9.4 \mathrm{E}-6$ & $1.6 \mathrm{E}-7$ & $2.7 \mathrm{E}-7$ & $1.6 \mathrm{E}-8$ & $5.1 \mathrm{E}-7$ & $3.9 \mathrm{E}-9$ & $9.7 \mathrm{E}-7$ & $1.7 \mathrm{E}-6$ & $2.8 \mathrm{E}-6$ & $3.9 \mathrm{E}-6$ & 553.0 \\
\hline
\end{tabular}


Table B.19. Gas Analyses for Test SNF + Can $60 \mathrm{~L}$ at $60^{\circ} \mathrm{C}, 80^{\circ} \mathrm{C}$, and $95^{\circ} \mathrm{C}$ (Test 10)

\begin{tabular}{|c|c|c|c|c|c|c|c|c|c|c|c|c|c|c|c|c|c|c|c|c|}
\hline $\begin{array}{c}\text { Run } \\
\text { Sys }-9\end{array}$ & \begin{tabular}{|c|} 
Temp. \\
${ }^{\circ} \mathrm{C}$
\end{tabular} & $\mathrm{Ne}$ & $\mathrm{Ar}$ & $\mathrm{H}_{2}$ & $\mathrm{CO}_{2}$ & $\mathrm{CH}_{4}$ & $\mathrm{C}_{2} \mathrm{HC}$ & $\mathrm{C}_{>2} \mathrm{HC}$ & $\mathrm{N}_{2}$ & $\mathrm{O}_{2}$ & $\mathrm{Kr} 83$ & $\mathrm{Kr} 84$ & $\mathrm{Kr} 85$ & $\mathrm{Kr} 86$ & Xe 130 & $\mathrm{Xe} 131$ & Xe 132 & Xe 134 & Xe 136 & Time, $\mathrm{h}$ \\
\hline \multirow{2}{*}{$\begin{array}{c}1 \\
22 \mathrm{~K} 73\end{array}$} & \multirow{2}{*}{$\begin{array}{c}\text { Amb., } \\
60\end{array}$} & 63.4 & 0.007 & 35.60 & 0.270 & 0.102 & 0.013 & \begin{tabular}{|l|}
0.005 \\
\end{tabular} & 0.490 & 0.076 & $6.0 \mathrm{E}-04$ & $1.1 \mathrm{E}-03$ & $6.0 \mathrm{E}-05$ & $1.9 \mathrm{E}-03$ & \begin{tabular}{|l|}
$1.0 \mathrm{E}-05$ \\
\end{tabular} & $3.4 \mathrm{E}-03$ & $5.9 \mathrm{E}-03$ & $9.4 \mathrm{E}-03$ & $1.4 \mathrm{E}-02$ & \multirow{2}{*}{\begin{tabular}{|c}
136.3 \\
503.0
\end{tabular}} \\
\hline & & & & 98.817 & 0.749 & 0.283 & 0.036 & 0.014 & -0.032 & -0.163 & \begin{tabular}{|l|}
$1.7 \mathrm{E}-03$ \\
\end{tabular} & $3.1 \mathrm{E}-03$ & 1.7E-04 & \begin{tabular}{|l|}
$5.3 \mathrm{E}-03$ \\
\end{tabular} & $2.8 \mathrm{E}-05$ & 9.4E-03 & $1.6 \mathrm{E}-02$ & 2.6E-02 & 3.9E-02 & \\
\hline 2 & \multirow{2}{*}{60} & & & & & & & & & & & & & & & & & & & \multirow{2}{*}{594.7} \\
\hline Vent & & & & & & & & & & & & & & & & & & & & \\
\hline \multirow{2}{*}{$\begin{array}{c}3 \\
22 \mathrm{~K} 83\end{array}$} & \multirow{2}{*}{80} & 67.9 & 0.005 & 31.30 & 0.078 & 0.18 & 0.021 & 0.008 & 0.413 & 0.076 & \begin{tabular}{|l|}
$4.0 \mathrm{E}-04$ \\
\end{tabular} & $8.0 \mathrm{E}-04$ & $4.0 \mathrm{E}-05$ & $1.2 \mathrm{E}-03$ & & $2.1 \mathrm{E}-03$ & $3.4 \mathrm{E}-03$ & $5.6 \mathrm{E}-03$ & $8.3 \mathrm{E}-03$ & \multirow{2}{*}{71.0} \\
\hline & & & & 99.017 & 0.247 & 0.576 & 0.066 & 0.025 & 0.249 & \begin{tabular}{|l|}
-0.043 \\
\end{tabular} & \begin{tabular}{|l|}
$1.3 \mathrm{E}-03$ \\
\end{tabular} & $2.5 \mathrm{E}-03$ & $1.3 \mathrm{E}-04$ & $3.8 \mathrm{E}-03$ & & $6.6 \mathrm{E}-03$ & $1.1 \mathrm{E}-02$ & $1.8 \mathrm{E}-02$ & $2.6 \mathrm{E}-02$ & \\
\hline \multirow{2}{*}{$\begin{array}{c}4 \\
22 \mathrm{~K} 86\end{array}$} & \multirow{2}{*}{95} & 59.4 & 0.004 & 39.70 & 0.202 & 0.24 & 0.03 & 0.01 & 0.334 & \begin{tabular}{|l|}
0.067 \\
\end{tabular} & \begin{tabular}{|l|}
$4.0 \mathrm{E}-04$ \\
\end{tabular} & $9.0 \mathrm{E}-04$ & $5.0 \mathrm{E}-05$ & \begin{tabular}{|l|}
$1.4 \mathrm{E}-03$ \\
\end{tabular} & $1.0 \mathrm{E}-05$ & $2.5 \mathrm{E}-03$ & 4.4E-03 & $6.8 \mathrm{E}-03$ & $1.0 \mathrm{E}-02$ & \multirow{2}{*}{47.7} \\
\hline & & & & \begin{tabular}{|l|}
98.740 \\
\end{tabular} & 0.502 & 0.592 & 0.075 & 0.025 & 0.207 & -0.0007 & $9.9 \mathrm{E}-04$ & $2.2 \mathrm{E}-03$ & $1.2 \mathrm{E}-04$ & $3.5 \mathrm{E}-03$ & $2.5 \mathrm{E}-05$ & $6.2 \mathrm{E}-03$ & $1.1 \mathrm{E}-02$ & $1.7 \mathrm{E}-02$ & $2.5 \mathrm{E}-02$ & \\
\hline
\end{tabular}

Table B.20. Gas Analyses for Test SNF + Floor $60 \mathrm{~L}$ at $60^{\circ} \mathrm{C}, 80^{\circ} \mathrm{C}$, and $95^{\circ} \mathrm{C}$ (Test 11)

\begin{tabular}{|c|c|c|c|c|c|c|c|c|c|c|c|c|c|c|c|c|c|c|c|c|}
\hline \begin{tabular}{|c|} 
Run \\
Sys -10 \\
\end{tabular} & $\begin{array}{c}\text { Temp. } \\
{ }^{\circ} \mathrm{C}\end{array}$ & $\mathrm{Ne}$ & $\mathrm{Ar}$ & $\mathrm{H}_{2}$ & $\mathrm{CO}_{2}$ & $\mathrm{CH}_{4}$ & $\mathrm{C}_{2} \mathrm{HC}$ & $\mathrm{C}_{>2} \mathrm{HC}$ & $\mathrm{N}_{2}$ & $\mathrm{O}_{2}$ & $\mathrm{Kr} 83$ & $\mathrm{Kr} 84$ & $\mathrm{Kr} 85$ & $\mathrm{Kr} 86$ & Xe 130 & Xe 131 & Xe 132 & Xe 134 & Xe 136 & Time, $\mathrm{h}$ \\
\hline \multirow{2}{*}{$\begin{array}{c}1 \\
22 \mathrm{~K} 78\end{array}$} & \multirow{2}{*}{$\begin{array}{c}\text { Amb., } \\
60\end{array}$} & 47.5 & 0.006 & 50.70 & 1.250 & 0.126 & 0.012 & 0.003 & 0.419 & 0.004 & $6.0 \mathrm{E}-04$ & $1.1 \mathrm{E}-03$ & $6.0 \mathrm{E}-05$ & $2.0 \mathrm{E}-03$ & $2.0 \mathrm{E}-05$ & $3.8 \mathrm{E}-03$ & $6.4 \mathrm{E}-03$ & $1.0 \mathrm{E}-02$ & $1.5 \mathrm{E}-02$ & \multirow{2}{*}{\begin{tabular}{|c}
136.3, \\
1104.7
\end{tabular}} \\
\hline & & & & 97.257 & 2.398 & 0.242 & 0.023 & 0.006 & 0.002 & -0.207 & $1.2 \mathrm{E}-03$ & $2.1 \mathrm{E}-03$ & $1.2 \mathrm{E}-04$ & $3.8 \mathrm{E}-03$ & $3.8 \mathrm{E}-05$ & $7.3 \mathrm{E}-03$ & $1.2 \mathrm{E}-02$ & $1.9 \mathrm{E}-02$ & $2.9 \mathrm{E}-02$ & \\
\hline \multirow{2}{*}{$\begin{array}{c}2 \\
22 \mathrm{~K} 83\end{array}$} & \multirow{2}{*}{80} & 72.7 & 0.006 & 24.50 & 2.150 & 0.070 & \begin{tabular}{|l|}
0.009 \\
\end{tabular} & 0.002 & 0.464 & 0.107 & $2.0 \mathrm{E}-04$ & $4.0 \mathrm{E}-04$ & & 8.0E-04 & & $1.6 \mathrm{E}-03$ & $2.8 \mathrm{E}-03$ & $4.5 \mathrm{E}-03$ & $6.5 \mathrm{E}-03$ & \multirow{2}{*}{71.0} \\
\hline & & & & 91.60 & 8.038 & 0.262 & \begin{tabular}{|l|}
0.034 \\
\end{tabular} & 0.007 & 0.172 & -0.019 & $7.5 \mathrm{E}-04$ & $1.5 \mathrm{E}-03$ & & $3.0 \mathrm{E}-03$ & & $6.0 \mathrm{E}-03$ & $1.0 \mathrm{E}-02$ & $1.7 \mathrm{E}-02$ & $2.4 \mathrm{E}-02$ & \\
\hline \multirow{2}{*}{$\begin{array}{c}3 \\
22 \mathrm{~K} 86\end{array}$} & \multirow{2}{*}{95} & 62.3 & 0.012 & 33.40 & 3.030 & 0.092 & \begin{tabular}{|l|}
0.013 \\
\end{tabular} & 0.004 & 0.980 & 0.234 & $3.0 \mathrm{E}-04$ & $6.0 \mathrm{E}-04$ & $3.0 \mathrm{E}-05$ & $1.1 \mathrm{E}-03$ & & $2.2 \mathrm{E}-03$ & $3.6 \mathrm{E}-03$ & $5.8 \mathrm{E}-03$ & $8.6 \mathrm{E}-03$ & \multirow{2}{*}{47.7} \\
\hline & & & & 91.354 & 8.287 & 0.252 & 0.036 & 0.011 & 0.165 & -0.035 & $8.2 \mathrm{E}-04$ & $1.6 \mathrm{E}-03$ & $8.2 \mathrm{E}-05$ & $3.0 \mathrm{E}-03$ & & 6.0E-03 & $9.8 \mathrm{E}-03$ & $1.6 \mathrm{E}-02$ & 2.4E-02 & \\
\hline
\end{tabular}

Table B.21. Gas Generation Rates from SNF + Can $60 \mathrm{~L}$ at $60^{\circ} \mathrm{C}, 80^{\circ} \mathrm{C}$, and $95^{\circ} \mathrm{C}$ (Test 10 )

\begin{tabular}{|c|c|c|c|c|c|c|c|c|c|c|c|c|c|c|c|c|c|c|}
\hline \multirow[b]{2}{*}{ Run } & \multirow{2}{*}{$\begin{array}{c}\text { Temp. } \\
{ }^{\circ} \mathrm{C}\end{array}$} & \multicolumn{17}{|c|}{ Gas Generation Rate, moles/kg fuel particles-day } \\
\hline & & $\mathrm{H}_{2}$ & $\mathrm{CO}_{2}$ & $\mathrm{CH}_{4}$ & $\mathrm{C}_{2} \mathrm{HC}$ & $\mathrm{C}_{>2} \mathrm{HC}$ & $\mathrm{N}_{2}$ & $\mathrm{O}_{2}$ & $\mathrm{Kr} 83$ & $\mathrm{Kr} 84$ & $\mathrm{Kr} 85$ & $\mathrm{Kr} 86$ & $\mathrm{Xe} 130$ & Xe 131 & $\mathrm{Xe} 132$ & Xe 134 & $\mathrm{Xe} 136$ & Time, $\mathrm{h}$ \\
\hline 1 & 60 & $2.7 \mathrm{E}-2$ & $2.1 \mathrm{E}-4$ & $7.8 \mathrm{E}-5$ & $9.9 \mathrm{E}-6$ & $3.8 \mathrm{E}-6$ & $-8.9 \mathrm{E}-6$ & $-4.5 \mathrm{E}-5$ & $4.6 \mathrm{E}-7$ & $8.4 \mathrm{E}-7$ & $4.6 \mathrm{E}-8$ & $1.5 \mathrm{E}-6$ & $7.6 \mathrm{E}-9$ & $2.6 \mathrm{E}-6$ & $4.5 \mathrm{E}-6$ & $7.2 \mathrm{E}-6$ & $1.1 \mathrm{E}-5$ & 503.0 \\
\hline 2 & 60 & Vent & Vent & Vent & Vent & Vent & Vent & Vent & Vent & Vent & Vent & Vent & Vent & Vent & Vent & Vent & Vent & 594.7 \\
\hline 3 & 80 & $1.6 \mathrm{E}-1$ & $4.1 \mathrm{E}-4$ & $9.5 \mathrm{E}-4$ & $1.1 \mathrm{E}-4$ & $4.2 \mathrm{E}-5$ & $4.1 \mathrm{E}-4$ & $-7.1 \mathrm{E}-5$ & $2.1 \mathrm{E}-6$ & $4.2 \mathrm{E}-6$ & $2.1 \mathrm{E}-7$ & $6.3 \mathrm{E}-6$ & & $1.1 \mathrm{E}-5$ & $1.8 \mathrm{E}-5$ & $2.9 \mathrm{E}-5$ & $4.3 \mathrm{E}-5$ & 71.0 \\
\hline 4 & 95 & $3.4 \mathrm{E}-1$ & $1.7 \mathrm{E}-3$ & $2.1 \mathrm{E}-3$ & $2.6 \mathrm{E}-4$ & $8.7 \mathrm{E}-5$ & $7.2 \mathrm{E}-4$ & $-2.5 \mathrm{E}-6$ & $3.5 \mathrm{E}-6$ & $7.8 \mathrm{E}-6$ & $4.3 \mathrm{E}-7$ & $1.2 \mathrm{E}-5$ & $8.7 \mathrm{E}-8$ & $2.2 \mathrm{E}-5$ & $3.8 \mathrm{E}-5$ & $5.9 \mathrm{E}-5$ & $8.7 \mathrm{E}-5$ & 47.7 \\
\hline
\end{tabular}


Table B.22. Gas Generation Rates from SNF + Floor $60 \mathrm{~L}$ at $60^{\circ} \mathrm{C}, 80^{\circ} \mathrm{C}$, and $95^{\circ} \mathrm{C}$ (Test 11)

\begin{tabular}{|c|c|c|c|c|c|c|c|c|c|c|c|c|c|c|c|c|c|c|}
\hline \multirow[b]{2}{*}{ Run } & \multirow{2}{*}{$\begin{array}{c}\text { Temp. } \\
{ }^{\circ} \mathrm{C}\end{array}$} & \multicolumn{17}{|c|}{ Gas Generation Rate, moles/kg fuel particles-day } \\
\hline & & $\mathrm{H}_{2}$ & $\mathrm{CO}_{2}$ & $\mathrm{CH}_{4}$ & $\mathrm{C}_{2} \mathrm{HC}$ & $\mathrm{C}_{>2} \mathrm{HC}$ & $\mathrm{N}_{2}$ & $\mathrm{O}_{2}$ & Kr 83 & Kr 84 & $\mathrm{Kr} 85$ & Kr 86 & \begin{tabular}{|l|}
$\mathrm{Xe} 130$ \\
\end{tabular} & Xe 131 & \begin{tabular}{|l|}
$\mathrm{Xe} 132$ \\
\end{tabular} & Xe 134 & \begin{tabular}{|l|}
$\mathrm{Xe} 136$ \\
\end{tabular} & Time, $\mathrm{h}$ \\
\hline 1 & 60 & $2.5 \mathrm{E}-2$ & $6.2 \mathrm{E}-4$ & $6.2 \mathrm{E}-5$ & $5.9 \mathrm{E}-6$ & $1.5 \mathrm{E}-6$ & $4.9 \mathrm{E}-7$ & \begin{tabular}{|l|}
$-5.3 \mathrm{E}-5$ \\
\end{tabular} & $3.0 \mathrm{E}-7$ & $5.4 \mathrm{E}-7$ & $3.0 \mathrm{E}-8$ & $9.9 \mathrm{E}-7$ & 9.9E-9 & $1.9 \mathrm{E}-6$ & $3.2 \mathrm{E}-6$ & $4.9 \mathrm{E}-6$ & $\begin{array}{l}7.4 \mathrm{E}-6 \\
\end{array}$ & 1104.7 \\
\hline 2 & 80 & $1.3 \mathrm{E}-1$ & $1.1 \mathrm{E}-2$ & $3.6 \mathrm{E}-4$ & $4.6 \mathrm{E}-5$ & $1.0 \mathrm{E}-5$ & $2.4 \mathrm{E}-4$ & $-2.7 \mathrm{E}-5$ & $1.0 \mathrm{E}-6$ & $2.1 \mathrm{E}-6$ & & $4.1 \mathrm{E}-6$ & & $8.2 \mathrm{E}-6$ & $1.4 \mathrm{E}-5$ & $2.3 \mathrm{E}-5$ & $3.4 \mathrm{E}-5$ & 71.0 \\
\hline 3 & 95 & $3.0 \mathrm{E}-1$ & $2.7 \mathrm{E}-2$ & $8.3 \mathrm{E}-4$ & $1.2 \mathrm{E}-4$ & $3.6 \mathrm{E}-5$ & $5.4 \mathrm{E}-4$ & $-1.1 \mathrm{E}-4$ & $2.7 \mathrm{E}-6$ & $5.4 \mathrm{E}-6$ & $2.7 \mathrm{E}-7$ & $9.9 \mathrm{E}-6$ & & $2.0 \mathrm{E}-5$ & $3.2 \mathrm{E}-5$ & $5.2 \mathrm{E}-5$ & $7.7 \mathrm{E}-5$ & $\overline{47.7}$ \\
\hline
\end{tabular}

Table B.23. Gas Analyses for Test KC-2/3 at Ambient Hot Cell Temperature $\left(\sim 32^{\circ} \mathrm{C}\right)$ (Test 12$)$

\begin{tabular}{|c|c|c|c|c|c|c|c|c|c|c|c|c|c|c|c|c|c|c|c|c|}
\hline \begin{tabular}{|c|} 
Run \\
Sys $-{ }^{\mathrm{a}}$ \\
\end{tabular} & \begin{tabular}{|c|} 
Temp. \\
${ }^{\circ} \mathrm{C}$
\end{tabular} & $\mathrm{Ne}$ & $\mathrm{Ar}$ & $\mathrm{H}_{2}$ & $\mathrm{CO}_{2}$ & $\mathrm{CH}_{4}$ & $\mathrm{C}_{2} \mathrm{HC}$ & $\mathrm{C}_{>2} \mathrm{HC}$ & $\mathrm{N}_{2}$ & $\mathrm{O}_{2}$ & $\mathrm{Kr} 83$ & $\mathrm{Kr} 84$ & $\mathrm{Kr} 85$ & $\mathrm{Kr} 86$ & Xe 130 & Xe 131 & Xe 132 & Xe 134 & Xe 136 & Time, $\mathrm{h}$ \\
\hline \multirow{2}{*}{$\begin{array}{c}1 \\
21 \mathrm{H} 133 \\
\end{array}$} & \multirow{2}{*}{$\sim 32$} & 98.8 & 0.011 & 0.014 & 0.41 & & & & 0.66 & 0.07 & & & & & & & & & & \multirow{2}{*}{453.7} \\
\hline & & & & 3.2 & 92 & & & & -39.64 & -35.42 & & & & & & & & & & \\
\hline \multirow{2}{*}{$\begin{array}{c}2 \\
21 \mathrm{H} 149 \\
\end{array}$} & \multirow{2}{*}{$\sim 32$} & 99 & 0.004 & 0.044 & 0.72 & 0.001 & & & 0.19 & 0.05 & & & & & & & & & & \multirow{2}{*}{3332.3} \\
\hline & & & & 5.3 & 87 & 0.121 & & & -7.49 & -2.10 & & & & & & & & & & \\
\hline \multirow{2}{*}{$\begin{array}{c}3 \\
22 \mathrm{~K} 7 \\
\end{array}$} & \multirow{2}{*}{$\sim 32$} & 99.3 & 0.001 & 0.023 & 0.61 & & & & 0.08 & 0.02 & & & & & & & & & & \multirow{2}{*}{880.0} \\
\hline & & & & 3.3 & 88 & & & & -0.81 & -0.93 & & & & & & & & & & \\
\hline \multirow{2}{*}{$\begin{array}{c}4 \\
22 \mathrm{~K} 11 \\
\end{array}$} & \multirow{2}{*}{$\sim 32$} & 99.2 & 0.001 & 0.034 & 0.73 & & & & 0.061 & 0.014 & & & & & $1.0 \mathrm{E}-05$ & $1.0 \mathrm{E}-05$ & $2.0 \mathrm{E}-05$ & $3.0 \mathrm{E}-05$ & & \multirow{2}{*}{1479.7} \\
\hline & & & & 5 & 100 & & & & -3.08 & -1.15 & & & & & \begin{tabular}{|l|}
$1.4 \mathrm{E}-03$ \\
\end{tabular} & \begin{tabular}{|l|}
$1.4 \mathrm{E}-03$ \\
\end{tabular} & $2.7 \mathrm{E}-03$ & $4.1 \mathrm{E}-03$ & & \\
\hline \multicolumn{20}{|c|}{ Gas sampling line disconnected. } & 888.0 \\
\hline \multirow{2}{*}{\begin{tabular}{|c|}
5 \\
$22 \mathrm{~K} 52$ \\
\end{tabular}} & \multirow{2}{*}{$\sim 32$} & 90.1 & 0.09 & 0.01 & 0.87 & 0.001 & & & 7.5 & 1.46 & & & & & & \begin{tabular}{|l|}
$1.0 \mathrm{E}-05$ \\
\end{tabular} & $1.0 \mathrm{E}-05$ & $2.0 \mathrm{E}-05$ & $2.0 \mathrm{E}-05$ & \multirow{2}{*}{455.0} \\
\hline & & & & 3 & 214 & & & & 14.6 & -132 & & & & & & $2.5 \mathrm{E}-03$ & $2.5 \mathrm{E}-03$ & $4.9 \mathrm{E}-03$ & $4.9 \mathrm{E}-03$ & \\
\hline \multirow{2}{*}{\begin{tabular}{|c|}
6 \\
$22 \mathrm{~K} 78$ \\
\end{tabular}} & \multirow{2}{*}{$\sim 32$} & 97.8 & 0.011 & & 1.18 & & & & 0.86 & 0.194 & & & & & & \begin{tabular}{|l|}
$1.0 \mathrm{E}-05$ \\
\end{tabular} & $2.0 \mathrm{E}-05$ & $2.0 \mathrm{E}-05$ & $3.0 \mathrm{E}-05$ & \multirow{2}{*}{1990.3} \\
\hline & & & & & 101 & & & & 2.04 & -2.58 & & & & & & $8.5 \mathrm{E}-04$ & $1.7 \mathrm{E}-03$ & $1.7 \mathrm{E}-03$ & $2.6 \mathrm{E}-03$ & \\
\hline \multirow{2}{*}{\begin{tabular}{|c|}
7 \\
$22 \mathrm{~K} 93$ \\
\end{tabular}} & \multirow{2}{*}{$\sim 32$} & 98.0 & 0.012 & 0.04 & 0.86 & & & & 0.89 & 0.219 & & & & & & & & & & \multirow{2}{*}{1552.0} \\
\hline & & & & 5 & 102 & & & & -3.51 & -3.29 & & & & & & & & & & \\
\hline
\end{tabular}

Blank entries are below detection limits. Shaded values denote the generated gas composition (i.e., neon cover gas contribution deducted).

a System 4 used for the first four samples; system 12 used for the final three samples. 
Table B.24. Gas Generation Rates from KC-2/3 at Ambient Hot Cell Temperature $\left(\sim 32^{\circ} \mathrm{C}\right)$ (Test 12$)$

\begin{tabular}{|c|c|c|c|c|c|c|c|c|c|c|c|c|c|c|c|c|c|c|}
\hline \multirow[b]{2}{*}{ Run } & \multirow{2}{*}{$\begin{array}{c}\text { Temp. } \\
{ }^{\circ} \mathrm{C}\end{array}$} & \multicolumn{17}{|c|}{ Gas Generation Rate, moles/kg sludge-day } \\
\hline & & $\mathrm{H}_{2}$ & $\mathrm{CO}_{2}$ & $\mathrm{CH}_{4}$ & $\mathrm{C}_{2} \mathrm{HC}$ & $\mathrm{C}_{>2} \mathrm{HC}$ & $\mathrm{N}_{2}$ & $\mathrm{O}_{2}$ & Kr 83 & $\mathrm{Kr} 84$ & $\mathrm{Kr} 85$ & $\mathrm{Kr} 86$ & $\mathrm{Xe} 130$ & Xe 131 & Xe 132 & Xe 134 & Xe 136 & Time, $\mathrm{h}$ \\
\hline 1 & $\sim 32$ & $3.3 \mathrm{E}-6$ & $9.7 \mathrm{E}-5$ & & & & $-4.2 \mathrm{E}-5$ & $-3.7 \mathrm{E}-5$ & & & & & & & & & & 453.7 \\
\hline 2 & $\sim 32$ & $1.3 \mathrm{E}-6$ & $2.1 \mathrm{E}-5$ & $2.9 \mathrm{E}-8$ & & & $-1.8 \mathrm{E}-6$ & $-5.0 \mathrm{E}-7$ & & & & & & & & & & 3332.3 \\
\hline 3 & -32 & $2.4 \mathrm{E}-6$ & $6.5 \mathrm{E}-5$ & & & & $-5.9 \mathrm{E}-7$ & $-6.8 \mathrm{E}-7$ & & & & & & & & & & 880.0 \\
\hline 4 & $\sim 32$ & $2.2 \mathrm{E}-6$ & $4.7 \mathrm{E}-5$ & & & & $-1.4 \mathrm{E}-6$ & $-5.4 \mathrm{E}-7$ & & & & & $6.4 \mathrm{E}-10$ & $6.4 \mathrm{E}-10$ & $1.3 \mathrm{E}-9$ & $1.9 \mathrm{E}-9$ & & 1479.7 \\
\hline \multicolumn{18}{|c|}{ Gas sampling line disconnected. } & 888.0 \\
\hline 5 & $\sim 32$ & $2.8 \mathrm{E}-6$ & $1.8 \mathrm{E}-4$ & $2.1 \mathrm{E}-7$ & & & $1.3 \mathrm{E}-5$ & $-1.1 \mathrm{E}-4$ & & & & & & $2.1 \mathrm{E}-9$ & $2.1 \mathrm{E}-9$ & $4.2 \mathrm{E}-9$ & $4.2 \mathrm{E}-9$ & 455.0 \\
\hline 6 & \begin{tabular}{c|c|}
2 \\
\end{tabular} & & $5.3 \mathrm{E}-5$ & & & & $1.1 \mathrm{E}-6$ & $-1.4 \mathrm{E}-6$ & & & & & & $4.5 \mathrm{E}-10$ & $9.0 \mathrm{E}-10$ & $9.0 \mathrm{E}-10$ & $1.4 \mathrm{E}-9$ & 1990.3 \\
\hline 7 & $\sim 32$ & $2.4 \mathrm{E}-6$ & $5.1 \mathrm{E}-5$ & & & & $-1.8 \mathrm{E}-6$ & $-1.6 \mathrm{E}-6$ & & & & & & & & & & 1552.0 \\
\hline
\end{tabular}




\section{Appendix C}

Analysis of Reaction Rate Data from Series III and Comparison to Related Spent Nuclear Fuel and Literature Equation Rates 


\section{Appendix C}

\section{Analysis of Reaction Rate Data from Series III and Comparison to Related Spent Nuclear Fuel and Literature Equation Rates}

The following text provides a step-by-step description of the gas generation data analysis to determine uranium metal fuel corrosion rates based on hydrogen evolution and the release of fission product gases ( $\mathrm{Kr}$ and $\mathrm{Xe}$ ). In this analysis, actual fuel fragment particle sizes [i.e., nominal diameters determined from sieving, corrected by the amount of uranium lost to corrosion as determined by the total gas $\left(>94 \% \mathrm{H}_{2}\right)$ evolution] were compared to calculated theoretical particle sizes. The theoretical particle sizes were calculated by determining the "effective particle diameters" required to produce the measured gas rate for the eleven Series III tests having added uranium metal fuel if the metal reacted in accordance with published rate laws. The SNF Databook, Vol 1. (Reilly 1998) rate equation and a rate correlation provided in Hilton (2000) for uranium metal in oxygen-free water were the rate laws used in the calculation of the theoretical particle diameters.

Series III gas generation data used for these calculations included $\mathrm{Kr}$ and $\mathrm{Xe}$ release rates and the $\mathrm{H}_{2}$ gas generation rates. The results from actual and theoretical particle size analysis were used to derive rate comparison factors (i.e., rate enhancement factors, or ratios that can be used to adjust the literature rate law to reflect the actual uranium metal reaction rate observed in the Series III testing). In the SNF Project, the reaction rate law multiplier (enhancement factor) is applied to laboratory-derived rate data (i.e., Reilly 1998) for design calculations and safety basis analyses. The SNF enhancement factor has two components: an experimentally based component (observed reaction rates vs. predicted rates), and an engineering-judgment conservatism component. The analysis provided here focuses only on the experimentally based component of the enhancement factor.

\section{C.1 Steps to Calculate Particle Diameters and Rate Enhancement Factors}

The steps used to derive the apparent particle diameters and to compare the expected and observed corrosion rates are described in this section.

1. Determine the ratios between the $\mathrm{Kr}$ and $\mathrm{Xe}$ released and the uranium metal reacted.

The observed averaged $\mathrm{Kr} / \mathrm{H}_{2}$ and $\mathrm{Xe} / \mathrm{H}_{2}$ ratios for the SNF M500 80L, SNF Mid 80L, and SNF Mid 80L Dup tests were used instead of the ORIGEN values. Based on the gas analyses and the reaction stoichiometry:

$$
\mathrm{U}+2 \mathrm{H}_{2} \mathrm{O} \rightarrow \mathrm{UO}_{2}+2 \mathrm{H}_{2}
$$

the derived $\mathrm{Kr} / \mathrm{U}$ mass ratio is $42.2 \pm 1.9 \mu \mathrm{g} \mathrm{Kr} / \mathrm{g} \mathrm{U}$ (instead of 47.2 based on $2900 \mathrm{MWd} / \mathrm{TeU}$ from ORIGEN) and Xe/U is $651 \pm 26 \mu \mathrm{g} \mathrm{Xe/g} \mathrm{U} \mathrm{(instead} \mathrm{of} \mathrm{602)} \mathrm{as} \mathrm{described} \mathrm{in} \mathrm{Section} \mathrm{4.3.}$ These ratios were used throughout the data interpretation because all the particles tested were derived from the same parent spent fuel element. The ratios differed from the ORIGEN ratios because the actual burnup experienced by the fuel is spatially dependent (i.e., can be different across the length and diameter of the fuel assembly). 
2. Determine the uranium metal concentrations in the crushed fuel.

The uranium metal fraction in the fuel pieces can be estimated to be 0.93 , based on historical fuel element composition data (the balance being $\mathrm{Zr}$ cladding). However, because Mid (500 $2000-\mu \mathrm{m})$ and M500 $(<500 \mu \mathrm{m})$ particles were reacted to completion in the SNF Mid 80L, SNF Mid 80L Dup, and SNF M500 80L tests, the fractions of uranium metal in the Mid and M500 materials could be measured by $\mathrm{H}_{2}$ gas generation (see Section 4.3). The uranium metal fractions thus determined are 0.930 for the Mid particle fraction and 0.742 for the M500 fraction. The Mid materials were used in the SNF + Can 60S, the SNF Mid 40S, and the SNF Mid $60 \mathrm{~S}$ tests, as well as the SNF Mid 80L and SNF Mid 80L Dup tests. The M500 materials, used in the SNF M500 80L and SNF + Can Fines 60S tests, have lower U metal fractions than the Mid materials. Evidently the Mid and M500 materials were partially oxidized by the crushing necessary to reduce the particle sizes; sparking was noted in the preparation of the M500 materials. It was assumed that the $\mathrm{U}$ metal fractions were 0.93 for the larger particle size materials used in the SNF P2000 80S, SNF + Floor 60L, and SNF + Can 60L tests. The U metal fraction in the Fuel Fragment test was 0.965 , based on the mass of the original fragment and the mass of the cladding shard found in post-test examination.

3. Convert the $\mathrm{Kr}$ and $\mathrm{Xe}$ gas generation rates to fractional uranium metal corrosion rates.

The $\mathrm{Kr}$ and $\mathrm{Xe}$ gas generation rates over given constant temperature intervals were calculated based on analyses of the gas samples taken for those intervals and the total gas generation rates found by the PVT (pressure-volume-temperature) measurements. The $\mathrm{Kr}$ and $\mathrm{Xe}$ gas generation rate data then were converted to fractional rates (defined as FR) of uranium oxidation by the following respective equations for the cases in which 0.93 of the fuel consisted of uranium metal (similar equations were used for other $\mathrm{U}$ metal fractions):

$$
\begin{aligned}
& \text { FR, fraction } \mathrm{U} / \mathrm{hr}(\mathrm{Kr})=\frac{(\text { Rate, } \mathrm{moles} \mathrm{Kr} / \mathrm{kg} \text { fuel } \cdot \mathrm{d}) \times(84.8 \mathrm{~g} \mathrm{Kr} / \mathrm{mole})}{(0.0422 \mathrm{~g} \mathrm{Kr} / \mathrm{kg} \mathrm{U}) \times(0.93 \mathrm{~kg} \mathrm{U} / \mathrm{kg} \text { fuel }) \times(24 \mathrm{hr} / \mathrm{d})} \\
& \text { FR, fraction } \mathrm{U} / \mathrm{hr}(\mathrm{Xe})=\frac{(\text { Rate, } \mathrm{moles} \mathrm{Xe} / \mathrm{kg} \text { fuel } \cdot \mathrm{d}) \times(134.2 \mathrm{~g} \mathrm{Xe} / \mathrm{mole})}{(0.651 \mathrm{~g} \mathrm{Xe} / \mathrm{kg} \mathrm{U}) \times(0.93 \mathrm{~kg} \mathrm{U} / \mathrm{kg} \text { fuel }) \times(24 \mathrm{hr} / \mathrm{d})}
\end{aligned}
$$

4. Convert fractional uranium metal corrosion rates based on $\mathrm{Kr}$ and $\mathrm{Xe}$ to inverse cubic rates needed for particle size analysis.

The rates of uranium corrosion based on $\mathrm{Kr}$ and Xe release may be converted from units of fraction (f) uranium reacted per hour (FR) to inverse cubic rates [ICR, i.e., $(1-\mathrm{f})^{1 / 3}$ per hour; see the footnote (a) to Step 7]. The ICR is the slope of the plot of $(1-\mathrm{f})^{1 / 3}$ vs. time and is determined by solving for $(1-\mathrm{f})^{1 / 3}$ at zero and 1-hour reaction times and dividing by the elapsed reaction time ( 1 hour). At zero hours, the fraction reacted, $f$, is $F R \times 0$ hour $=0$ and $(1-f)^{1 / 3}=1$. At 1 hour, the fraction reacted, $f$, is $F R \times 1$ hour and $(1-f)^{1 / 3}=(1-F R \times 1)^{1 / 3}$. Therefore, the ICR, in terms of $(1-f)^{1 / 3}$ per hour, is:

$$
\mathrm{ICR},(1-\mathrm{f})^{1 / 3} / \text { hour }=\frac{(1-\mathrm{FR} \times 1 \text { hour })^{1 / 3}-1}{1 \text { hour }}
$$


5. Derive inverse cubic rates of uranium metal oxidation based on $\mathrm{H}_{2}$ gas release rates.

ICRs of uranium oxidation are derived from least squares fits of slopes of the ICR $\left[(1-\mathrm{f})^{1 / 3}\right]$ versus time curves at the various test temperatures. Because the total gas generation was $>94 \% \mathrm{H}_{2}$, the rate of total gas production represents the rate of uranium metal corrosion. Note, however, that this assumption is compromised by any $\mathrm{H}_{2}$ uptake or release caused by the respective formation and decomposition of the $\mathrm{UH}_{3}$ intermediate and possible reduction by $\mathrm{H}_{2}$ of $\mathrm{U}(\mathrm{VI})$ compounds present in sludge to form reduced $\mathrm{U}$ phases such as $\mathrm{U}_{3} \mathrm{O}_{8}$.

6. Derive the linear penetration rates of uranium metal corrosion in water based on prior studies.

The Reilly (1998) and Hilton (2000) Arrhenius fits of uranium metal corrosion rates in water, in units of $\mathrm{g} / \mathrm{cm}^{2}-\mathrm{hr}$, can be restated to express rate in terms of linear penetration corrosion of uranium metal by dividing by uranium metal density $\left(19.1 \mathrm{~g} / \mathrm{cm}^{3}\right)$. Linear penetration rates $\left(\mathrm{k}^{\prime}\right)$ were calculated for the various test temperatures by the following two equations ( $\mathrm{T}$ is absolute temperature):

$\log$ rate $\mathrm{U}$ penetration, $\mu \mathrm{m} / \mathrm{hr}($ Reilly $)=\log \mathrm{k}^{\prime}=8.226-3016 / \mathrm{T}$

$\log$ rate $\mathrm{U}$ penetration, $\mu \mathrm{m} / \mathrm{hr}$ (Hilton) $=\log \mathrm{k}^{\prime}=9.422-3470 / \mathrm{T}$

7. $\quad$ Convert inverse cubic rates to theoretical particle radii and diameters.

The radii of the nominally monodisperse and spherical $U$ metal particles are calculated by dividing the linear penetration rate at the test temperature (based on either the Reilly or Hilton correlations) by the ICR observed based on the $\mathrm{Kr}, \mathrm{Xe}$, or $\mathrm{H}_{2}$ data. ${ }^{(\mathrm{a})}$ The particle diameter is two times the radius.

$$
(1-\mathrm{f})^{\frac{1}{3}}=1-\frac{\mathrm{k}^{\prime} \mathrm{t}}{\mathrm{r}}
$$

(a) The linear penetration rate of corrosion, $\mathrm{k}^{\prime}$, is expressed by the following differential equation:

$$
\frac{\mathrm{dy}}{\mathrm{dt}}=\mathrm{k}^{\prime}
$$

in which the rate of penetration in depth $y$ over time $t$ is constant at rate $\mathrm{k}^{\prime}$. Integrating, the depth penetrated at time $t$ is:

$$
\mathrm{y}_{\mathrm{t}}=\mathrm{k}^{\prime} \mathrm{t}
$$

The volume, $\mathrm{V}_{\mathrm{s}}$, of material remaining from a corroding sphere after a period of time t may be expressed by two alternative equations:

$$
\mathrm{V}_{\mathrm{s}}=\frac{4}{3} \pi\left(\mathrm{r}-\mathrm{y}_{\mathrm{t}}\right)^{3}=\frac{4}{3} \pi \mathrm{r}^{3}(1-\mathrm{f})
$$

in which $r$ is the sphere's original radius, $y_{t}$ is the depth removed by corrosion, and $f$ is the fraction of the original material which has been corroded. Dividing and taking cube roots yields, in order, the following two equations:

By substituting $\mathrm{k}^{\prime} \mathrm{t}$ for $\mathrm{y}_{\mathrm{t}}$ and rearranging:

$$
\begin{aligned}
& \left(r-y_{t}\right)^{3}=r^{3}(1-f) \\
& \left(r-y_{t}\right)=r(1-f)^{\frac{1}{3}}
\end{aligned}
$$

$$
(1-\mathrm{f}) \frac{1}{3}=1-\frac{\mathrm{k}^{\prime} \mathrm{t}}{\mathrm{r}}
$$


Note that the particle diameters derived based on the gas generation rates are theoretical metal particle sizes in that they follow from the $\mathrm{H}_{2}, \mathrm{Kr}$, and $\mathrm{Xe}$ gas release rates predicted based on the Reilly or Hilton correlations for reaction of monodisperse spherical uranium metal pieces.

8. Determine the actual particle size based on initial size and the amount of uranium corroded.

The actual particle diameters remaining at various stages in the testing were calculated based on the nominal initial particle diameters (M500 $=290 \mu \mathrm{m}, \mathrm{Mid}=1250 \mu \mathrm{m}, \mathrm{SNF}$ in Floor 60L and in Can $60 \mathrm{~L}=1550 \mu \mathrm{m}, \mathrm{P} 2000=3310 \mu \mathrm{m}$, and Fuel Fragment $=7150 \mu \mathrm{m})$ corrected by the amount of uranium lost to corrosion to that point as shown by total gas $\left(>94 \% \mathrm{H}_{2}\right)$ evolution. For example, if the initial particle diameter was $290 \mu \mathrm{m}$, and 30\% reaction had occurred based on total gas evolution (i.e., 0.7 of the initial uranium metal remains), the following equations apply:

$$
\begin{gathered}
\text { Initial uranium volume } \equiv \mathrm{V}_{\mathrm{i}}=\frac{4}{3} \pi \mathrm{r}_{\mathrm{i}}^{3} \\
\text { Final uranium volume } \equiv \mathrm{V}_{\mathrm{f}}=0.7 \mathrm{~V}_{\mathrm{i}}=\frac{4}{3} \pi \mathrm{r}_{\mathrm{f}}^{3} \\
\qquad \frac{\mathrm{r}_{\mathrm{f}}^{3}}{\mathrm{r}_{\mathrm{i}}^{3}}=0.7 ; \text { or } \mathrm{r}_{\mathrm{f}}=\sqrt[3]{0.7} \mathrm{r}_{\mathrm{i}}
\end{gathered}
$$

where $r_{i}$ is the initial radius $(290 / 2=145 \mu \mathrm{m})$ and, in this case, $r_{f}$ is the radius after $30 \%$ reaction. Solving, the particle radius after $30 \%$ reaction is $0.7^{1 / 3}$ of the initial particle radius or $\sim 128 \mu \mathrm{m}$.

The particle sizes derived for the crushed fuel therefore do not reflect surface roughness, departure from spherical geometry, or the thickness of overlying corrosion product layers, and thus may not perfectly reflect the sieve size of the material. ${ }^{(b)}$

9. Show that the ratio of actual to theoretical particle diameter size is equal to the reaction rate enhancement factor.

As noted under Step 6, the baseline SNF reaction equation (Reilly 1998) for uranium metal corrosion in oxygen-free water is conventionally stated in units of $\mathrm{g} / \mathrm{cm}^{2}$-hr (i.e., a surface area based rate). Therefore, the enhancement factor (or comparison factor) can be determined as the ratio of the theoretical reaction surface area (on uranium metal particles) to the known (or actual) reaction surface area. In Step 7, the theoretical radii of the nominally monodisperse and spherical uranium metal particles are calculated (based on either the Reilly or Hilton correlations) from the $\mathrm{ICR}$, based on the $\mathrm{Kr}, \mathrm{Xe}$, or $\mathrm{H}_{2}$ data. In Step 8, the actual radii of the nominally monodisperse particles remaining at various stages in the testing are calculated based on the nominal initial particle diameters. From the theoretical and actual radii, the reaction rate enhancement factor can be determined as follows: 


$$
\begin{aligned}
& \text { Enhancement factor }=\frac{\text { Surface area }(\text { theoretical }) / \text { Unit mass }}{\text { Surface area (actual) } / \text { Unit mass }} \\
& \text { Enhancement factor }=\frac{4 \pi r_{\text {theo. }}^{2} / \frac{4}{3} \pi r_{\text {theo. }}^{3} \rho}{4 \pi r_{\text {act. }}^{2} / \frac{4}{3} \pi r_{\text {act. }}^{3} \rho}=\frac{r_{\text {act. }}}{r_{\text {theo. }}}
\end{aligned}
$$

(b) The deviation between the surface areas estimated based on nominal sieve dimensions and the actual surface area can be illustrated for the Fuel Fragment in Test 9. The fragment shape can be described as a thick slice-of-pie or a five-faced wedge with a slight arch. Two faces were cut with a saw, and cladding (roughly right triangles) covered two other faces. The fifth face was a rectangular, broken rough surface, with a visually estimated area about $20 \%$ greater than the product of its width $\times$ length (i.e., a surface roughness factor for this face of 1.2). The fragment is depicted in Figures E.23 and E.24 (Appendix E).

The fragment dimensions were measured before testing with calipers and estimates based on videotape images of the fragment lying on a US \#4 screen (4.76- $\mathrm{mm}$ screen opening, 1.57- $\mathrm{mm}$ wire diameter). The following surface area estimates were obtained for the five faces:

- $\quad$ Smaller sawn surface $=47 \mathrm{~mm}^{2}$

- $\quad$ Larger sawn surface $=75 \mathrm{~mm}^{2}$

- $\quad$ Two cladding surfaces $=\sim 50 \mathrm{~mm}^{2}$

- $\quad$ Rough surface $=86 \mathrm{~mm}^{2}$, or $103 \mathrm{~mm}^{2}$ when multiplied by the 1.2 roughness factor

- Total effective surface area $=47+75+103=225 \pm \sim 25 \mathrm{~mm}^{2}$ without cladding, or

$$
275 \pm \sim 30 \mathrm{~mm}^{2} \text { after cladding removal. }
$$

In contrast, the surface area based on the Fuel Fragment as a sphere with nominal initial particle diameter of $7150 \mu \mathrm{m}(7.15 \mathrm{~mm})$ is $161 \mathrm{~mm}^{2}$. Thus, the fragment's effective geometric surface area of $275 \mathrm{~mm}^{2}$ is about 1.7 times that of its nominal spherical surface area. In comparison, the ratio of the surface areas of a cube and sphere of diameter identical to the cube edge dimension is 1.9 .

An element of conservatism, therefore, is added when comparing the observed gas generation rates with those predicted for spherical particles, based on the SNF Databook (Reilly 1998) and the Hilton (2000) rate equations. This is because the corrosion rates are directly proportional to the metal surface area, and the spherical geometry has the lowest weight-specific surface area of any geometric solid. 


\section{C.2 Results of Particle Diameter and Rate Enhancement Factor Calculations}

The results of the particle size and enhancement factor calculations (Steps 1 through 9 given in Section C.1) are summarized in Tables C.1 and C.2, and presented graphically in Figures C.1 through C.10. Table C.1 (a comparison with the results as based on Reilly 1998 kinetics) and Table C.2 (a comparison based on the Hilton 2000 compilation) compare the theoretical particle diameters (Step 7) with the actual (observed) diameters (Step 8) at various run time intervals.

For each complete data set (or row in Tables C.1 and C.2), three predicted (theoretical) particle diameters were calculated based on $\mathrm{Kr}$ release, $\mathrm{Xe}$ release, and $\mathrm{H}_{2}$ generation data, respectively. Because the gas production (predominantly $\mathrm{H}_{2}$ ) in the testing was monitored continuously, there are numerous data points on the particle diameters based on the $\mathrm{H}_{2}$ gas release. The number of data points for the particle diameters based on the $\mathrm{Kr}$ and $\mathrm{Xe}$ release are limited, since each of these data points required a discrete gas sampling event and were followed by mass spectrometric analysis.

As noted in Step 9, the ratios of actual to theoretical particle radii (or diameter) give the reaction rate enhancement or comparison factors. These are given for $\mathrm{Kr}, \mathrm{Xe}$, and $\mathrm{H}_{2}$, respectively, in the last three columns in Tables C.1 and C.2. The tables and figures show that for a fixed mass of uranium metal particles, the actual particle sizes are about 0.33 and 0.42 times the theoretical particle diameters from the SNF baseline rate in Reilly (1998) and Hilton (2000), respectively. That is, the uranium metal fragments reacted at a lower rate than that predicted by the literature rate laws. Furthermore, the data show, in general, that the enhancement factors are very similar for the fuel fragments with and without sludge.

The diameter ratios (enhancement factors) based on the $\mathrm{H}_{2}$ data for the tests containing fuel particles but no added sludge show that, in general, the enhancement factors for a given test tend to decrease as metal continues to corrode. This observation would support the hypothesis that the reaction rate decreases as the uranium metal fragments become buried in their self-generated corrosion sludge layer. Overall, the gas generation data agree somewhat better with the rate equation in Hilton (2000), since the average enhancement factor is closer to unity.

Figures C.1 through C.3 are plots of the theoretical particle diameters [based on Reilly (1998), as determined from the $\mathrm{Kr}, \mathrm{Xe}$, and $\mathrm{H}_{2}$ data] versus the actual diameters. The plots are similar. However, Figure C.3, based on the $\mathrm{H}_{2}$ data, contains more data points and exhibits greater data scatter. Figure C.4 shows how the enhancement factor $\left[\mathrm{H}_{2}\right.$ data (Reilly 1998)] varies with test temperature. Although Figure C.4 exhibits considerable scatter, on average, the enhancement factor trends higher, approaching unity, as temperature increases. Figures C.5 through C.8, based on the rate law provided in Hilton (2000), are analogous to Figures C.1 through C.4, including the data trending. 
Table C.1. Fit to Reilly (log rate, $\mu \mathrm{m} / \mathrm{hr}=8.226-3016 / \mathrm{T})$

\begin{tabular}{|c|c|c|c|c|c|c|c|c|c|c|}
\hline \multirow[b]{2}{*}{ Metal Alone } & \multirow[b]{2}{*}{ Time, hr } & \multirow{2}{*}{$\begin{array}{c}\text { Fraction U } \\
\text { Reacted }\end{array}$} & \multirow[b]{2}{*}{ Temp., ${ }^{\circ} \mathrm{C}$} & \multicolumn{3}{|c|}{ Theoretical Diameter, $\mu \mathrm{m}$} & \multirow{2}{*}{$\begin{array}{c}\text { Actual } \\
\text { Diameter, } \\
\mu \mathrm{m}\end{array}$} & \multicolumn{3}{|c|}{$\begin{array}{c}\text { Ratio, } \\
\text { Actual:Theoretical }^{(a)}\end{array}$} \\
\hline & & & & $\mathbf{K r}$ & $\mathrm{Xe}$ & $\mathrm{H}_{2}$ & & $\mathbf{K r}$ & $\mathrm{Xe}$ & $\mathrm{H}_{2}$ \\
\hline \multirow{8}{*}{ SNF Mid 60S } & $70-130$ & 0.99 & 33.33 & -- & -- & 6730 & 1246 & -- & -- & 0.19 \\
\hline & $300-964.6$ & 0.95 & 60.80 & 5173 & 5492 & 4743 & 1229 & 0.24 & 0.22 & 0.26 \\
\hline & $959.6-1223$ & 0.82 & 60.75 & -- & -- & 6008 & 1170 & -- & -- & 0.19 \\
\hline & $1223-1294$ & 0.79 & 80.54 & 4637 & 4493 & 3810 & 1156 & 0.25 & 0.26 & 0.30 \\
\hline & $1294-1323.3$ & 0.73 & 95.47 & 3482 & 3731 & 2807 & 1126 & 0.32 & 0.30 & 0.40 \\
\hline & $1323.3-1413.3$ & 0.70 & 39.42 & -- & -- & 14511 & 1110 & -- & -- & 0.08 \\
\hline & $1503.3-1583.3$ & 0.70 & 36.47 & -- & -- & 14400 & 1110 & -- & -- & 0.08 \\
\hline & $1643.3-2523.3$ & 0.70 & 31.22 & -- & -- & 22647 & 1110 & -- & -- & 0.05 \\
\hline \multirow{6}{*}{ SNF Mid 40S } & $70-130$ & 0.99 & 33.03 & -- & -- & 6928 & 1246 & -- & -- & 0.18 \\
\hline & $140-1266$ & 0.97 & 42.49 & 7198 & 6828 & 7728 & 1237 & 0.17 & 0.18 & 0.16 \\
\hline & $1266-1577$ & 0.93 & 61.28 & -- & -- & 5096 & 1220 & -- & -- & 0.24 \\
\hline & $1577-1624.3$ & 0.89 & 80.10 & -- & -- & 3398 & 1202 & -- & -- & 0.35 \\
\hline & $1629.3-1724.3$ & 0.86 & 39.37 & -- & -- & 13725 & 1189 & -- & -- & 0.09 \\
\hline & $1804.3-2724.3$ & 0.86 & 34.70 & -- & -- & 33935 & 1189 & -- & -- & 0.04 \\
\hline \multirow{4}{*}{ SNF P2000 80S } & $70-130$ & 0.99 & 33.04 & -- & -- & 16702 & 3299 & -- & -- & 0.20 \\
\hline & $145-500$ & 0.90 & 80.86 & 5724 & 5733 & 5325 & 3196 & 0.56 & 0.56 & 0.60 \\
\hline & $1900-2570.3$ & 0.45 & 80.00 & -- & -- & 23832 & 2536 & -- & -- & 0.11 \\
\hline & $2640.3-2870.3$ & 0.50 & 29.10 & -- & -- & 63380 & 2627 & -- & -- & 0.04 \\
\hline \multirow{2}{*}{ SNF M500 80L } & $70-130$ & 0.99 & 34.28 & -- & -- & 2827 & 289 & -- & -- & 0.10 \\
\hline & $150-220$ & 0.92 & 80.26 & 737 & 638 & 498 & 282 & 0.38 & 0.44 & 0.57 \\
\hline \multirow{3}{*}{ SNF Mid 80L } & $70-130$ & 0.99 & 33.14 & -- & -- & 2274 & 1246 & -- & -- & 0.55 \\
\hline & $150-400$ & 0.80 & 80.85 & 2554 & 2779 & 3433 & 1160 & 0.45 & 0.42 & 0.34 \\
\hline & $420-900$ & 0.40 & 81.10 & -- & -- & 1650 & 921 & -- & -- & 0.56 \\
\hline \multirow{3}{*}{ SNF Mid 80L Dup } & $70-130$ & 0.99 & 34.25 & -- & -- & 1837 & 1246 & -- & -- & 0.68 \\
\hline & $150-400$ & 0.80 & 81.20 & 2164 & 2290 & 1277 & 1160 & 0.54 & 0.51 & 0.91 \\
\hline & $420-900$ & 0.35 & 81.20 & -- & -- & 4315 & 881 & -- & -- & 0.20 \\
\hline & $70-130$ & 0.99 & 80.00 & -- & -- & 81208 & 7126 & -- & -- & 0.09 \\
\hline $\begin{array}{l}\text { Fuel Fragment } \\
\text { (SNF Fragment) }\end{array}$ & $150-220$ & 0.99 & 80.00 & 100874 & 77409 & 80668 & 7126 & 0.07 & 0.09 & 0.09 \\
\hline & $1600-2100$ & 0.85 & 80.00 & 21147 & 23700 & 17477 & 6773 & 0.32 & 0.29 & 0.39 \\
\hline & & & & & & Metal & one Average & 0.33 & 0.33 & 0.28 \\
\hline & & & & & Meta & one Stan & d Deviation & 0.16 & 0.15 & 0.22 \\
\hline Metal Plus Slud & & & & & & & & & & \\
\hline & $70-130$ & 0.98 & 38.17 & -- & -- & 3014 & 288 & -- & -- & 0.10 \\
\hline & $650-900$ & 0.80 & 63.67 & 2220 & 2294 & 3159 & 269 & 0.12 & 0.12 & 0.09 \\
\hline $\mathrm{SNF}+$ Can Fines $60 \mathrm{~S}$ & $1206-1278$ & 0.65 & 81.16 & 2812 & 2716 & 3011 & 251 & 0.09 & 0.09 & 0.08 \\
\hline SNF + Can Fines ous & $1278-1307.3$ & 0.60 & 94.62 & 3254 & 3227 & 2979 & 245 & 0.08 & 0.08 & 0.08 \\
\hline & $1307.3-1567.3$ & 0.58 & 40.69 & -- & -- & 29695 & 242 & -- & -- & 0.01 \\
\hline & $1607.3-2473.3$ & 0.58 & 35.14 & -- & -- & 85850 & 242 & -- & -- & 0.00 \\
\hline & $70-130$ & 0.99 & 33.94 & -- & -- & 109428 & 1246 & -- & -- & 0.01 \\
\hline & $660-1239.6$ & 0.90 & 60.06 & 5814 & 5848 & 9064 & 1207 & 0.21 & 0.21 & 0.13 \\
\hline $\mathrm{SNF}+\mathrm{Can} 60 \mathrm{~S}$ & $1239.6-1312.3$ & 0.87 & 80.24 & 4351 & 4765 & 4584 & 1193 & 0.27 & 0.25 & 0.26 \\
\hline pine t Can ous & $1312.3-1341.6$ & 0.82 & 94.74 & 3627 & 3631 & 3010 & 1170 & 0.32 & 0.32 & 0.39 \\
\hline & $1341.6-1591.6$ & 0.80 & 36.99 & -- & -- & 23615 & 1160 & -- & -- & 0.05 \\
\hline & $1661.6-2998.6$ & 0.80 & 30.82 & -- & -- & 39106 & 1160 & -- & -- & 0.03 \\
\hline & $70-130$ & 0.99 & 32.26 & -- & -- & 23057 & 1545 & -- & -- & 0.07 \\
\hline & $150-1234$ & 0.92 & 60.26 & 3300 & 3599 & 4591 & 1508 & 0.46 & 0.42 & 0.33 \\
\hline $\mathrm{SNF}+\mathrm{Can} 60 \mathrm{I}$ & $1234-1305$ & 0.80 & 80.21 & 2265 & 2777 & 3743 & 1439 & 0.64 & 0.52 & 0.38 \\
\hline PNF + Can oOL & $1305-1352.6$ & 0.72 & 94.64 & 2545 & 2877 & 3008 & 1389 & 0.55 & 0.48 & 0.46 \\
\hline & $1352.6-2452.6$ & 0.67 & 33.25 & -- & -- & 12766 & 1356 & -- & -- & 0.11 \\
\hline & $2752.6-3010.6$ & 0.67 & 28.68 & -- & -- & 70031 & 1356 & -- & -- & 0.02 \\
\hline & $70-130$ & 0.99 & 30.87 & -- & -- & 9161 & 1545 & -- & -- & 0.17 \\
\hline & $150-1241$ & 0.92 & 60.29 & 2798 & 2912 & 4934 & 1508 & 0.54 & 0.52 & 0.31 \\
\hline SNF + Floor 60L & $1241-1312$ & 0.80 & 79.59 & 4269 & 3783 & 3415 & 1439 & 0.34 & 0.38 & 0.42 \\
\hline & $1312-1359.6$ & 0.72 & 92.78 & 3295 & 3228 & 2248 & 1389 & 0.42 & 0.43 & 0.62 \\
\hline & $1359.6-3017.6$ & 0.67 & 28.09 & -- & -- & 10574 & 1356 & -- & -- & 0.13 \\
\hline & & & & & & al Plus S & ge Average & 0.34 & 0.32 & 0.18 \\
\hline & & & & & tal Plus & lge Stand & d Deviation & 0.19 & 0.16 & 0.17 \\
\hline & & & & & & & tal Average & 0.33 & 0.32 & 0.24 \\
\hline (a) Actual: theoretical 1 & neter $=$ rate enhal & ment factor. & & & & tal Stan & d Deviation & 0.17 & 0.15 & 0.21 \\
\hline
\end{tabular}




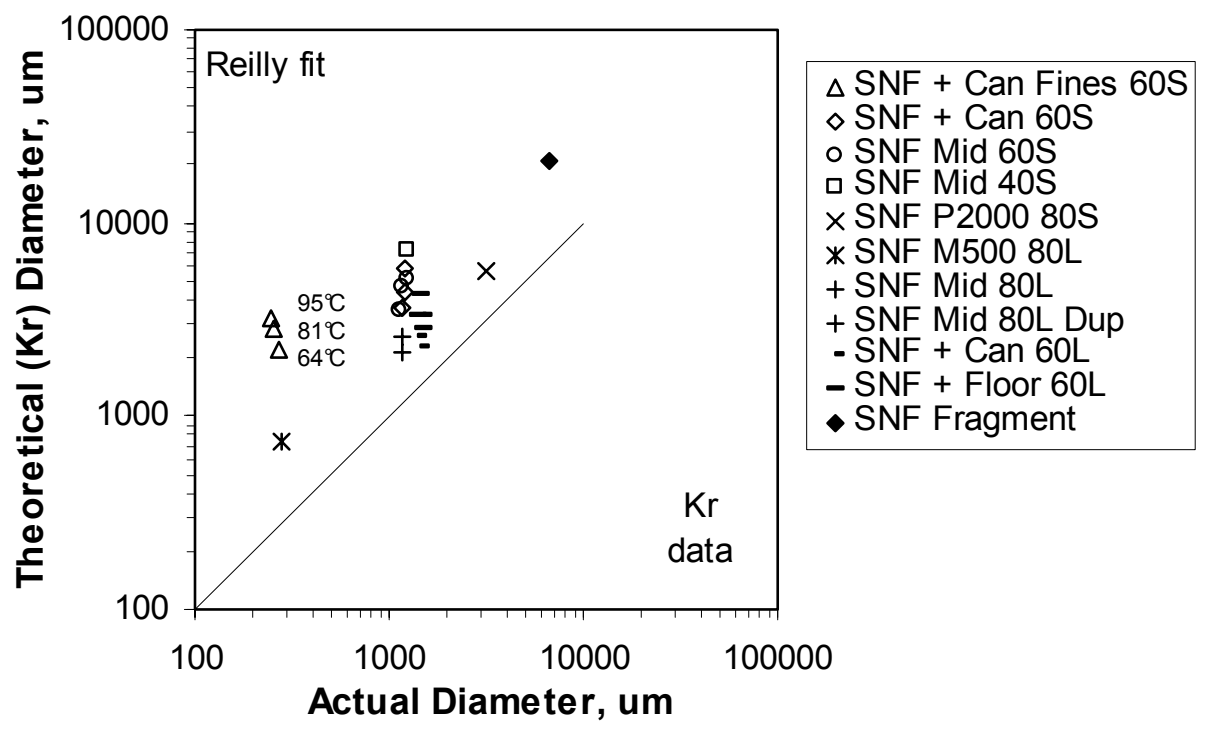

Figure C.1. Comparison of Theoretical with Actual Fuel Particle Diameters Based on Kr. Theoretical particle diameters were calculated from the measured $\mathrm{Kr}$ gas release and the SNF Databook (Vol. 1) reaction rate equation for uranium metal in oxygen-free water (Reilly 1998).

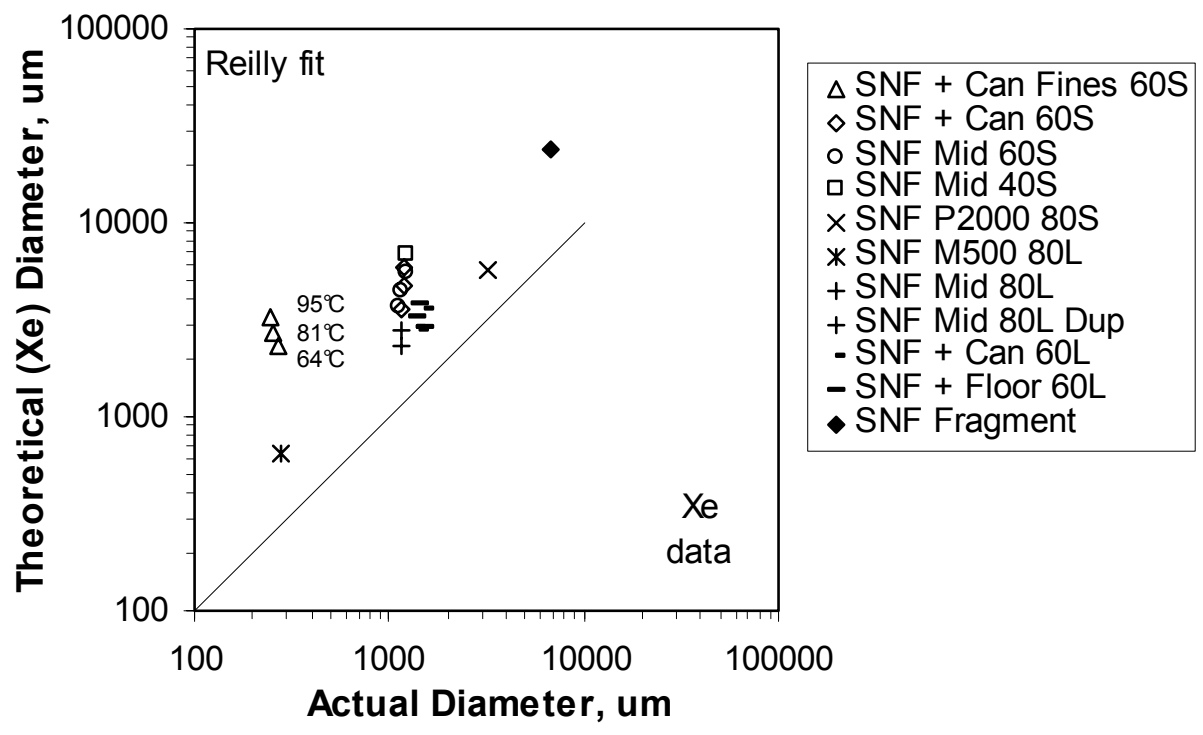

Figure C.2. Comparison of Theoretical with Actual Fuel Particle Diameters Based on Xe. Theoretical particle diameters were calculated from the measured $\mathrm{Xr}$ gas release and the SNF Databook (Vol. 1) reaction rate equation for uranium metal in oxygen-free water (Reilly 1998). 


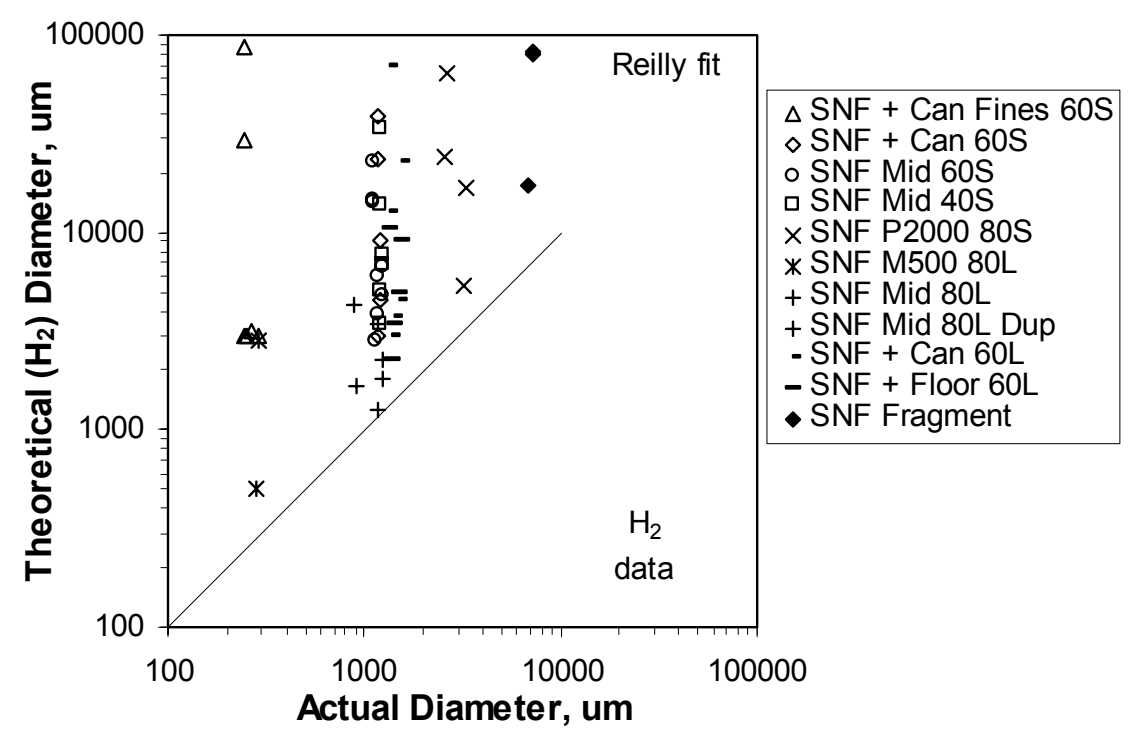

Figure C.3. Comparison of Theoretical with Actual Fuel Particle Diameters Based on $\mathrm{H}_{2}$. Theoretical particle diameters were calculated from the measured $\mathrm{H}_{2}$ gas generation and the SNF Databook (Vol. 1) reaction rate equation for uranium metal in oxygen-free water (Reilly 1998).

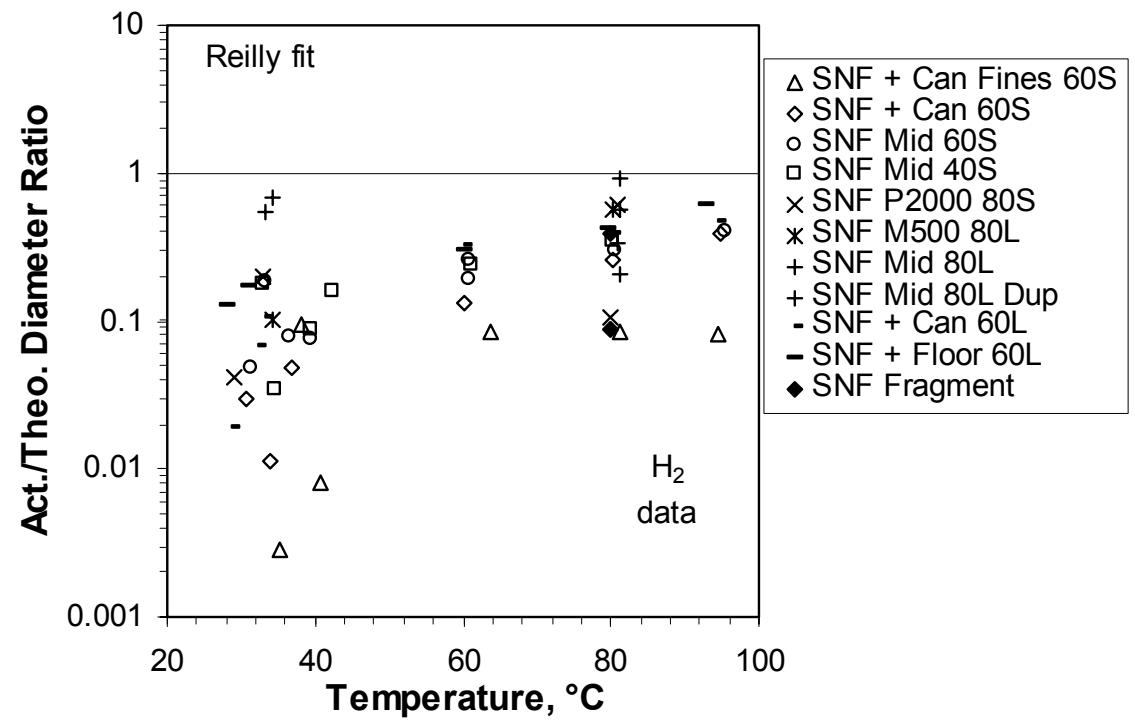

Figure C.4. Ratio of Actual to Theoretical Fuel Particle Diameters (i.e., Reaction Rate Enhancement Factor) as a Function of Test Temperature Based on $\mathrm{H}_{2}$. Theoretical particle diameters were calculated from the measured $\mathrm{H}_{2}$ gas generation and the SNF Databook (Vol. 1) reaction rate equation for uranium metal in oxygen-free water (Reilly 1998). 
Table C.2. Fit to Hilton (log rate, $\mu \mathrm{m} / \mathrm{hr}=9.422-3470 / \mathrm{T})$

\begin{tabular}{|c|c|c|c|c|c|c|c|c|c|c|}
\hline \multirow[b]{2}{*}{ Metal Alone } & \multirow[b]{2}{*}{ Time, hr } & \multirow{2}{*}{$\begin{array}{c}\text { Fraction U } \\
\text { Reacted }\end{array}$} & \multirow[b]{2}{*}{ Temp., ${ }^{\circ} \mathrm{C}$} & \multicolumn{3}{|c|}{ Theoretical Diameter, $\mu \mathrm{m}$} & \multirow{2}{*}{$\begin{array}{c}\text { Actual } \\
\text { Diameter, } \\
\mu \mathrm{m}\end{array}$} & \multicolumn{3}{|c|}{$\begin{array}{c}\text { Ratio, } \\
\text { Actual:Theoretical }^{(a)}\end{array}$} \\
\hline & & & & $\mathbf{K r}$ & $\mathbf{X e}$ & $\mathbf{H}_{2}$ & & $\mathbf{K r}$ & $\mathbf{X e}$ & $\mathrm{H}_{2}$ \\
\hline \multirow{8}{*}{ SNF Mid 60S } & $70-130$ & 0.99 & 33.33 & -- & -- & 3489 & 1246 & -- & -- & 0.36 \\
\hline & $300-964.6$ & 0.95 & 60.80 & 3551 & 3769 & 3255 & 1229 & 0.35 & 0.33 & 0.38 \\
\hline & $959.6-1223$ & 0.82 & 60.75 & -- & -- & 4122 & 1170 & -- & -- & 0.28 \\
\hline & $1223-1294$ & 0.79 & 80.54 & 3790 & 3672 & 3114 & 1156 & 0.30 & 0.31 & 0.37 \\
\hline & $1294-1323.3$ & 0.73 & 95.47 & 3208 & 3437 & 2586 & 1126 & 0.35 & 0.33 & 0.44 \\
\hline & $1323.3-1413.3$ & 0.70 & 39.42 & -- & -- & 8039 & 1110 & -- & -- & 0.14 \\
\hline & $1503.3-1583.3$ & 0.70 & 36.47 & -- & -- & 7728 & 1110 & -- & -- & 0.14 \\
\hline & $1643.3-2523.3$ & 0.70 & 31.22 & -- & -- & 11466 & 1110 & -- & -- & 0.10 \\
\hline \multirow{6}{*}{ SNF Mid 40S } & $70-130$ & 0.99 & 33.03 & -- & -- & 3580 & 1246 & -- & -- & 0.35 \\
\hline & $140-1266$ & 0.97 & 42.49 & 4120 & 3908 & 4423 & 1237 & 0.30 & 0.32 & 0.28 \\
\hline & $1266-1577$ & 0.93 & 61.28 & -- & -- & 3513 & 1220 & -- & -- & 0.35 \\
\hline & $1577-1624.3$ & 0.89 & 80.10 & -- & -- & 2767 & 1202 & -- & -- & 0.43 \\
\hline & $1629.3-1724.3$ & 0.86 & 39.37 & -- & -- & 7600 & 1189 & -- & -- & 0.16 \\
\hline & $1804.3-2724.3$ & 0.86 & 34.70 & -- & -- & 17861 & 1189 & -- & -- & 0.07 \\
\hline \multirow{4}{*}{ SNF P2000 80S } & $70-130$ & 0.99 & 33.04 & -- & -- & 8630 & 3299 & -- & -- & 0.38 \\
\hline & $145-500$ & 0.90 & 80.86 & 4691 & 4698 & 4364 & 3196 & 0.68 & 0.68 & 0.73 \\
\hline & $1900-2570.3$ & 0.45 & 80.00 & -- & -- & 19390 & 2536 & -- & -- & 0.13 \\
\hline & $2640.3-2870.3$ & 0.50 & 29.10 & -- & -- & 31325 & 2627 & -- & -- & 0.08 \\
\hline \multirow[b]{2}{*}{ SNF M500 80L } & $70-130$ & 0.99 & 34.28 & -- & -- & 1481 & 289 & -- & -- & 0.20 \\
\hline & $150-220$ & 0.92 & 80.26 & 601 & 520 & 406 & 282 & 0.47 & 0.54 & 0.69 \\
\hline \multirow{3}{*}{ SNF Mid 80L } & $70-130$ & 0.99 & 33.14 & -- & -- & 1176 & 1246 & -- & -- & 1.06 \\
\hline & $150-400$ & 0.80 & 80.85 & 2093 & 2277 & 2813 & 1160 & 0.55 & 0.51 & 0.41 \\
\hline & $420-900$ & 0.40 & 81.10 & -- & -- & 1355 & 921 & -- & -- & 0.68 \\
\hline \multirow{3}{*}{ SNF Mid 80L Dup } & $70-130$ & 0.99 & 34.25 & -- & -- & 962 & 1246 & -- & -- & 1.30 \\
\hline & $150-400$ & 0.80 & 81.20 & 1779 & 1882 & 1050 & 1160 & 0.65 & 0.62 & 1.11 \\
\hline & $420-900$ & 0.35 & 81.20 & -- & -- & 3546 & 881 & -- & -- & 0.25 \\
\hline & $70-130$ & 0.99 & 80.00 & -- & -- & 66073 & 7126 & -- & -- & 0.11 \\
\hline Fuet Fragment & $150-220$ & 0.99 & 80.00 & 82074 & 62982 & 65634 & 7126 & 0.09 & 0.11 & 0.11 \\
\hline & $1600-2100$ & 0.85 & 80.00 & 17206 & 19283 & 14219 & 6773 & 0.39 & 0.35 & 0.48 \\
\hline & & & & & & Metal A & ne Average & 0.41 & 0.41 & 0.40 \\
\hline & & & & & Metal & ne Stand & d Deviation & 0.18 & 0.17 & 0.32 \\
\hline Metal Plus Sludg & & & & & & & & & & \\
\hline & $70-130$ & 0.98 & 38.17 & -- & -- & 1647 & 288 & -- & -- & 0.17 \\
\hline & $650-900$ & 0.80 & 63.67 & 1565 & 1617 & 2227 & 269 & 0.17 & 0.17 & 0.12 \\
\hline & $1206-1278$ & 0.65 & 81.16 & 2310 & 2231 & 2474 & 251 & 0.11 & 0.11 & 0.10 \\
\hline SNF + Can Fines 60S & $1278-1307.3$ & 0.60 & 94.62 & 2978 & 2954 & 2726 & 245 & 0.08 & 0.08 & 0.09 \\
\hline & $1307.3-1567.3$ & 0.58 & 40.69 & -- & -- & 16676 & 242 & -- & -- & 0.01 \\
\hline & $1607.3-2473.3$ & 0.58 & 35.14 & -- & -- & 45405 & 242 & -- & -- & 0.01 \\
\hline & $70-130$ & 0.99 & 33.94 & -- & -- & 57113 & 1246 & -- & -- & 0.02 \\
\hline & $660-1239.6$ & 0.90 & 60.06 & 3963 & 3985 & 6178 & 1207 & 0.30 & 0.30 & 0.20 \\
\hline & $1239.6-1312.3$ & 0.87 & 80.24 & 3547 & 3885 & 3737 & 1193 & 0.34 & 0.31 & 0.32 \\
\hline $\mathrm{SNF}+\mathrm{Can} 60 \mathrm{~S}$ & $1312.3-1341.6$ & 0.82 & 94.74 & 3323 & 3326 & 2757 & 1170 & 0.35 & 0.35 & 0.42 \\
\hline & $1341.6-1591.6$ & 0.80 & 36.99 & -- & -- & 12745 & 1160 & -- & -- & 0.09 \\
\hline & $1661.6-2998.6$ & 0.80 & 30.82 & -- & -- & 19710 & 1160 & -- & -- & 0.06 \\
\hline & $70-130$ & 0.99 & 32.26 & -- & -- & 11810 & 1545 & -- & -- & 0.13 \\
\hline & $150-1234$ & 0.92 & 60.26 & 2253 & 2458 & 3135 & 1508 & 0.67 & 0.61 & 0.48 \\
\hline $\mathrm{SNF}+\operatorname{Can} 60 \mathrm{I}$ & $1234-1305$ & 0.80 & 80.21 & 1846 & 2264 & 3050 & 1439 & 0.78 & 0.64 & 0.47 \\
\hline SINF + Can oUL & $1305-1352.6$ & 0.72 & 94.64 & 2329 & 2634 & 2754 & 1389 & 0.60 & 0.53 & 0.50 \\
\hline & $1352.6-2452.6$ & 0.67 & 33.25 & -- & -- & 6612 & 1356 & -- & -- & 0.21 \\
\hline & $2752.6-3010.6$ & 0.67 & 28.68 & -- & -- & 34445 & 1356 & -- & -- & 0.04 \\
\hline & $70-130$ & 0.99 & 30.87 & -- & -- & 4620 & 1545 & -- & -- & 0.33 \\
\hline & $150-1241$ & 0.92 & 60.29 & 1911 & 1989 & 3370 & 1508 & 0.79 & 0.76 & 0.45 \\
\hline $\mathrm{SNF}+$ Floor $60 \mathrm{~L}$ & $1241-1312$ & 0.80 & 79.59 & 3462 & 3068 & 2769 & 1439 & 0.42 & 0.47 & 0.52 \\
\hline & $1312-1359.6$ & 0.72 & 92.78 & 2973 & 2912 & 2028 & 1389 & 0.47 & 0.48 & 0.69 \\
\hline & $1359.6-3017.6$ & 0.67 & 28.09 & -- & -- & 5166 & 1356 & -- & -- & 0.26 \\
\hline & & & & & & 1 Plus Sl & dge Average & 0.42 & 0.40 & 0.25 \\
\hline & & & & & al Plus S & ge Stand & d Deviation & 0.25 & 0.22 & 0.20 \\
\hline & & & & & & & tal Average & 0.42 & 0.40 & 0.33 \\
\hline (a) Actual: theoretical p & liameter $=$ rate enh & ient factor. & & & & tal Stand & d Deviation & 0.21 & 0.19 & 0.28 \\
\hline
\end{tabular}




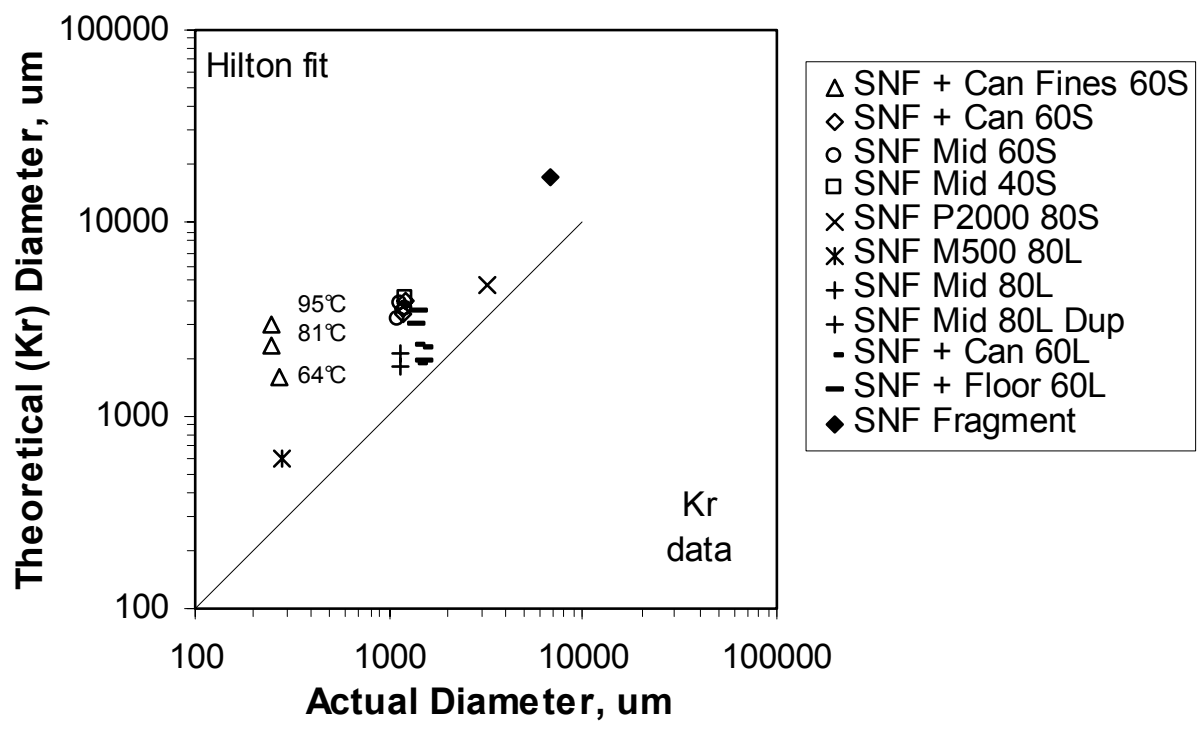

Figure C.5. Comparison of Theoretical with Actual Fuel Particle Diameters Based on Kr. Theoretical particle diameters were calculated from the measured $\mathrm{Kr}$ gas release and the reaction rate equation for uranium metal in oxygen-free water provided in Hilton (2000).

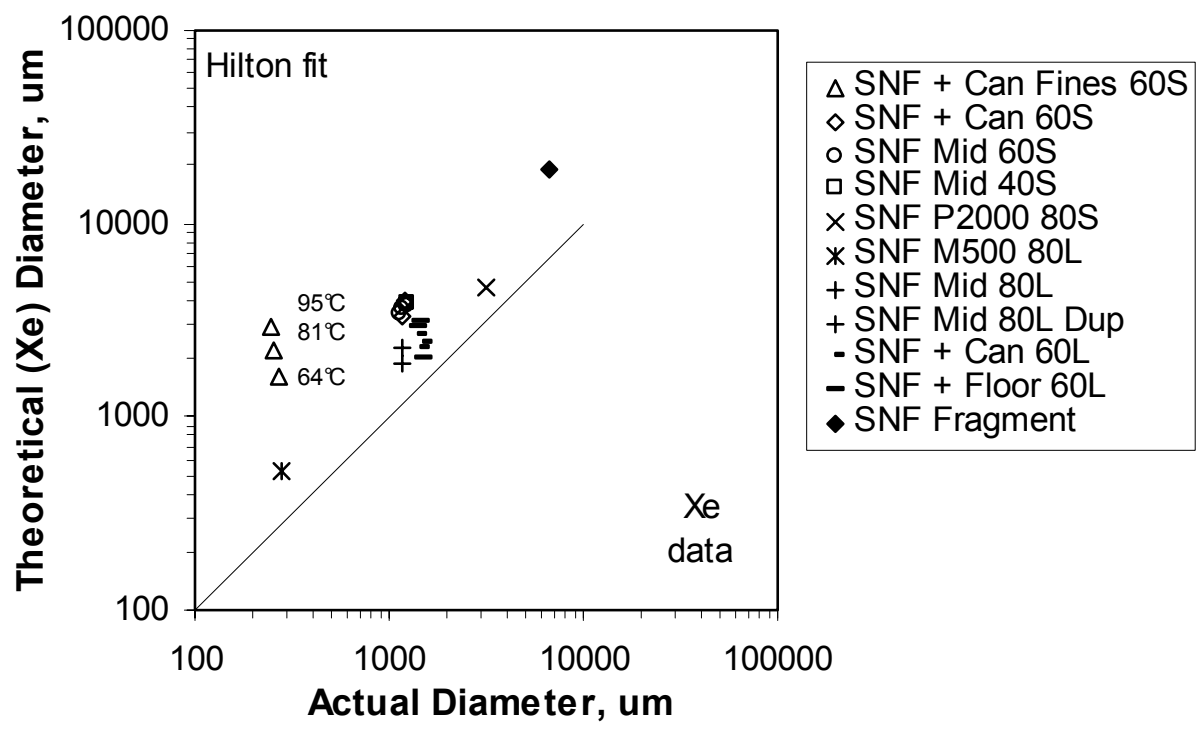

Figure C.6. Comparison of Theoretical with Actual Fuel Particle Diameters Based on Xe. Theoretical particle diameters were calculated from the measured $\mathrm{Xr}$ gas release and the reaction rate equation for uranium metal in oxygen-free water provided in Hilton (2000). 


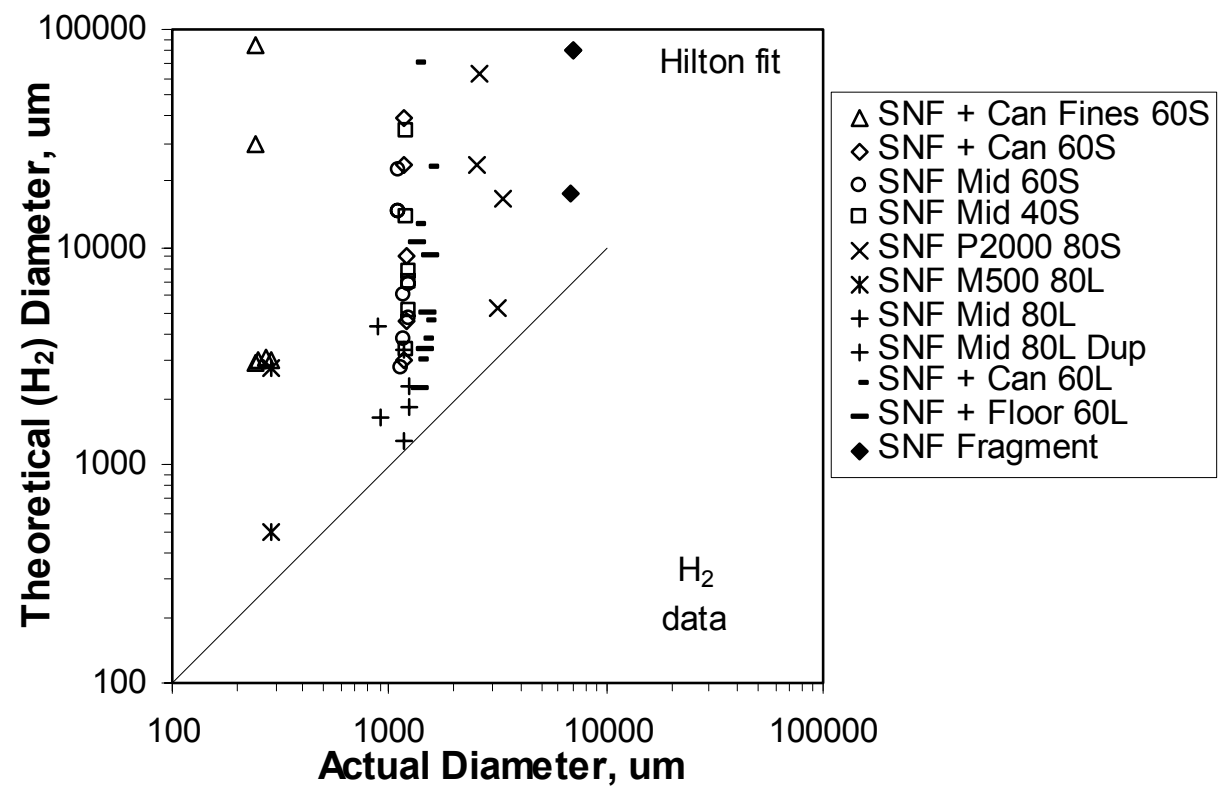

Figure C.7. Comparison of Theoretical with Actual Fuel Particle Diameters Based on $\mathrm{H}_{2}$. Theoretical particle diameters were calculated from the measured $\mathrm{H}_{2}$ gas generation and the reaction rate equation for uranium metal in oxygen-free water provided in Hilton (2000).

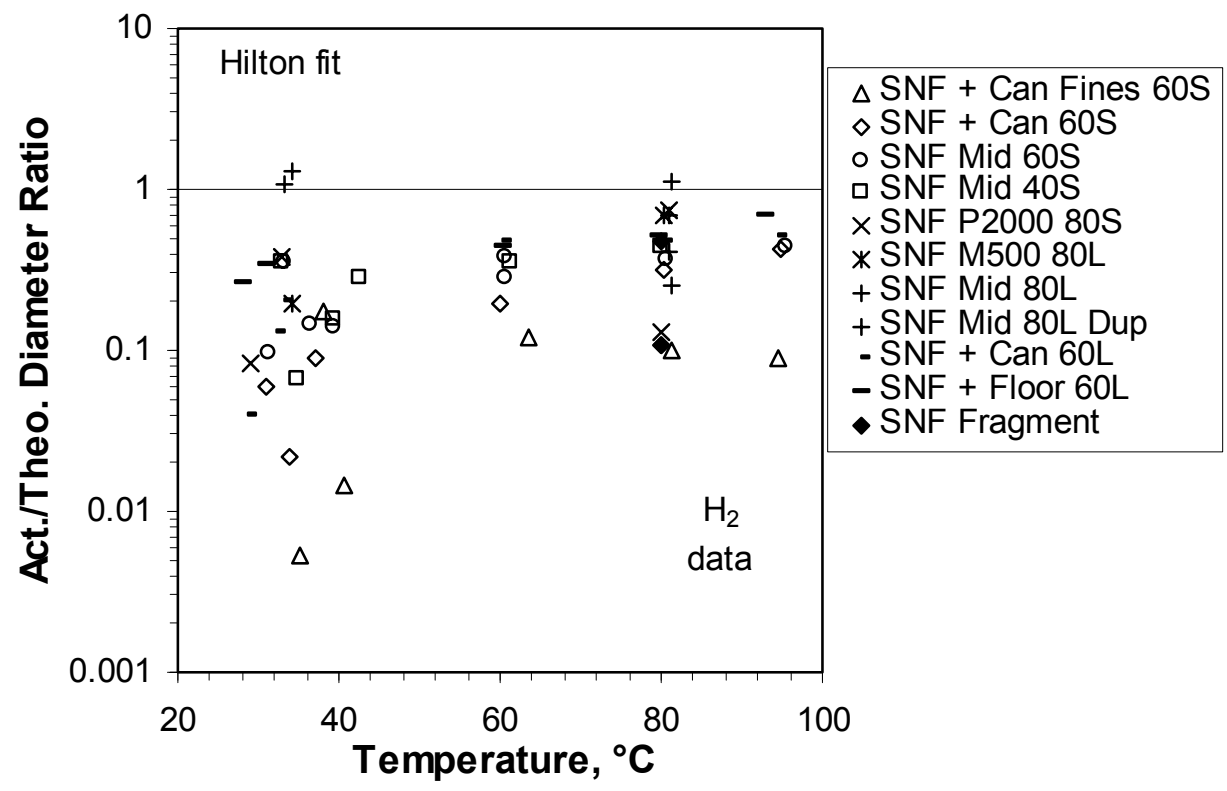

Figure C.8. Ratio of Actual to Theoretical Fuel Particle Diameters as a Function of Test Temperature Based on $\mathrm{H}_{2}$. Theoretical particle diameters were calculated from the measured $\mathrm{H}_{2}$ gas generation and the reaction rate equation for uranium metal in oxygen-free water provided in Hilton (2000). 


\section{C.3 References}

Hilton, B. A. 2000. Review of Oxidation Rates of DOE Spent Nuclear Fuel Part 1: Metallic Fuel. ANL-00/24, Argonne National Laboratory, Idaho Falls, Idaho.

Reilly, M. A. 1998. Spent Nuclear Fuel Project Technical Databook, Volume 1. HNF-SD-SNF-TI-015, Rev. 6, Duke Engineering and Services Hanford, Inc., Richland, WA. 


\section{Appendix D}

Impacts of Radiolysis on Assumption of Oxygen-Free Reaction Environment 


\section{Appendix D}

\section{Impacts of Radiolysis on Assumption of Oxygen-Free Reaction Environment}

Anoxic conditions were achieved in the Series III tests by alternately filling and evacuating the test vessels at least eight times with $99.999 \%$ neon. Besides the hydrogen radicals and hydrogen gas chemically produced by reaction of uranium metal with water, in-situ generation of chemically reduced and oxidized species can occur by water radiolysis. The stable reduced product of water radiolysis is hydrogen gas, $\mathrm{H}_{2}$.

Oxidized species arising from water radiolysis are the peroxide radical, $\mathrm{OH}$, and hydrogen peroxide, $\mathrm{H}_{2} \mathrm{O}_{2}$. Both $\mathrm{OH}$ and $\mathrm{H}_{2} \mathrm{O}_{2}$ are reactive, chemically unstable, and potentially can oxidize uranium compounds (e.g., convert $\mathrm{UO}_{2}$ ) in two steps through intermediate formation of the uranium(VI) oxide hydrate, schoepite $\left[\left(\mathrm{UO}_{2}\right)_{8} \mathrm{O}_{2}(\mathrm{OH})_{12}\left(\mathrm{H}_{2} \mathrm{O}\right)_{12}\right]$, which could then react with more $\mathrm{OH}$ or $\mathrm{H}_{2} \mathrm{O}_{2}$ to form studtite:

$$
\begin{gathered}
10 \mathrm{H}_{2} \mathrm{O}+8 \mathrm{H}_{2} \mathrm{O}_{2}+8 \mathrm{UO}_{2} \rightarrow\left(\mathrm{UO}_{2}\right)_{8} \mathrm{O}_{2}(\mathrm{OH})_{12}\left(\mathrm{H}_{2} \mathrm{O}\right)_{12} \\
6 \mathrm{H}_{2} \mathrm{O}+8 \mathrm{H}_{2} \mathrm{O}_{2}+\left(\mathrm{UO}_{2}\right)_{8} \mathrm{O}_{2}(\mathrm{OH})_{12}\left(\mathrm{H}_{2} \mathrm{O}\right)_{12} \rightarrow 8 \mathrm{UO}_{4} \cdot 4 \mathrm{H}_{2} \mathrm{O} \\
2 \mathrm{H}_{2} \mathrm{O}+2 \mathrm{H}_{2} \mathrm{O}_{2}+\mathrm{UO}_{2} \rightarrow \mathrm{UO}_{4} \cdot 4 \mathrm{H}_{2} \mathrm{O}
\end{gathered}
$$

or disproportionate to produce $\mathrm{H}_{2} \mathrm{O}$ and $\mathrm{O}_{2}$ gas:

$$
\begin{gathered}
4 \mathrm{OH} \rightarrow 2 \mathrm{H}_{2} \mathrm{O}+\mathrm{O}_{2} \\
2 \mathrm{H}_{2} \mathrm{O}_{2} \rightarrow 2 \mathrm{H}_{2} \mathrm{O}+\mathrm{O}_{2} .
\end{gathered}
$$

In the Series I report, $\mathrm{H}_{2}$ generation from $\beta-\gamma$ and $\alpha$ radiolysis was evaluated using respective $\mathrm{G}$ values of 0.45 and 1.5 molecules per $100 \mathrm{eV}$ absorbed dose. Thus, $0.058 \mathrm{~cm}^{3} \mathrm{H}_{2} /(\mathrm{hr}-\mathrm{kg}$ irradiated U metal) was estimated to be generated by $\beta-\gamma$ radiation and $0.072 \mathrm{~cm}^{3} \mathrm{H}_{2} /(\mathrm{hr}-\mathrm{kg}$ irradiated $\mathrm{U}$ metal) by $\alpha$ radiation to give about $0.13 \mathrm{~cm}^{3} \mathrm{H}_{2} /(\mathrm{hr}-\mathrm{kg}$ irradiated $\mathrm{U}$ metal) total (Delegard et al. 2000, Appendix C). Based on conservatively arbitrary $\mathrm{G}$ values of 10 for both the $\beta-\gamma$ and $\alpha$ radiations, a cumulative $\mathrm{H}_{2}$ generation rate of $2 \mathrm{~cm}^{3} /(\mathrm{hr}-\mathrm{kg}$ irradiated $\mathrm{U}$ metal) also was estimated.

At this rate, in $1000 \mathrm{hr}$ of gas generation testing, radiolysis of $1 \mathrm{~kg}$ of uranium fuel particles would generate approximately 0.0058 moles of $\mathrm{H}_{2}$ according to published $\mathrm{G}$ values or 0.089 moles of $\mathrm{H}_{2}$ using the conservative $\mathrm{G}$ value of 10 , compared with 8.4 moles of $\mathrm{H}_{2}$ if $100 \%$ of the uranium metal corroded to $\mathrm{UO}_{2}$.

The radiolytic yields of $\mathrm{OH}$ and $\mathrm{H}_{2} \mathrm{O}_{2}$ in water are 0.5 and 1.3 molecules/100 eV absorbed dose for $\alpha$ radiolysis and 2.86 and 0.61 molecules per $100 \mathrm{eV}$ for $\beta-\gamma$ radiolysis. Radiolytic formation of $\mathrm{O}_{2}$ through $\mathrm{OH}$ by $\alpha$ and $\beta-\gamma$ radiolysis based on $1 \mathrm{~kg}$ of $\mathrm{U}$ metal and sufficient water to absorb all the effective radiation gives, respectively: 


$$
\begin{gathered}
\left(2.6 \times 10^{16} \mathrm{eV} / \mathrm{kg}-\mathrm{s}\right)(0.5 \mathrm{OH} / 100 \mathrm{eV})\left(\mathrm{O}_{2} / 4 \mathrm{OH}\right)(25000 \mathrm{ml} / \mathrm{mole}) /\left(6.02 \times 10^{23} \text { molecules } / \mathrm{mole}\right) \\
=1.4 \times 10^{-6} \mathrm{ml} / \mathrm{s} \\
\left(1.1 \times 10^{17} \mathrm{eV} / \mathrm{kg}-\mathrm{s}\right)(2.86 \mathrm{OH} / 100 \mathrm{eV})\left(\mathrm{O}_{2} / 4 \mathrm{OH}\right)(25000 \mathrm{ml} / \mathrm{mole}) /\left(6.02 \times 10^{23} \text { molecules } / \mathrm{mole}\right) \\
=3.3 \times 10^{-5} \mathrm{ml} / \mathrm{s}
\end{gathered}
$$

or a total of about $0.12 \mathrm{ml} / \mathrm{hr}-\mathrm{kg}$ irradiated $\mathrm{U}$ metal. Using an arbitrary $\mathrm{G}$ value of 10 for all radiations gives an $\mathrm{O}_{2}$ yield from $\mathrm{OH}$ of about $0.5 \mathrm{ml} / \mathrm{hr}-\mathrm{kg}$ irradiated $\mathrm{U}$ metal. Similar calculations for radiolytic formation of $\mathrm{O}_{2}$ through $\mathrm{H}_{2} \mathrm{O}_{2}$ give $7.0 \times 10^{-6} \mathrm{ml} / \mathrm{s}$ and $1.4 \times 10^{-5} \mathrm{ml} / \mathrm{s}$, respectively, or $0.075 \mathrm{ml} / \mathrm{hr}-\mathrm{kg}$ irradiated $\mathrm{U}$ metal. These figures for $\mathrm{H}_{2} \mathrm{O}_{2}$ rise to $5.4 \times 10^{-5} \mathrm{ml} / \mathrm{s}, 2.3 \times 10^{-4} \mathrm{ml} / \mathrm{s}$, and $1.02 \mathrm{ml} / \mathrm{hr}-\mathrm{kg}$ irradiated $\mathrm{U}$ metal, respectively, at the arbitrary $\mathrm{G}$ value of 10 .

Over a 1000-hr test period, from 0.0048 to 0.04 moles of $\mathrm{O}_{2}$ (at an arbitrary $\mathrm{G}$ value of 10 ) would be generated per $\mathrm{kg}$ of uranium fuel. As each $\mathrm{kg}$ of fuel particles contains 4.20 moles of $\mathrm{U}$ metal, the mole ratio of uranium to $\mathrm{O}_{2}$ would be $\sim 875: 1$ (or 105:1 at the arbitrary $\mathrm{G}$ value of 10 ). Based on this conservative analysis, especially in light of the high quantities of chemically generated hydrogen, radiolytic oxygen generation is expected to have minimal impact on the assumption of anoxic conditions in the Series III tests.

The above hydrogen generation rates from radiolysis are probably unreasonably conservative. Close examination of the gas generation profiles for the tests run to completion shows no significant increase in total gas generated while the vessels were held at ambient hot cell temperature for prolonged periods. For example, Test 6 (SNF M500 80L) was held at ambient hot cell temperature for approximately $1370 \mathrm{hr}$ after all the uranium metal was reacted to uranium oxide (Table 2.4). During this period, combined $\mathrm{H}_{2}$ and $\mathrm{O}_{2}$ generation predicted from radiolysis would be 0.00011 moles, or $\sim 2.7 \mathrm{ml}$ of gas, at nominal $\mathrm{G}$ values or 0.0014 moles $(\sim 33 \mathrm{ml})$ at the arbitrary $\mathrm{G}$ value of 10 . Figure 3.4 shows that gas quantities actually decreased about 0.00024 moles $(\sim 5.7 \mathrm{ml})$ during this period, indicating the above $\mathrm{G}$ values are very conservative. Therefore, radiolytic oxygen generation is judged to have no significant impact on the validity of the comparison of the Series III test results with the SNF Databook, Vol. 1 (Reilly 1998) and literature oxygen-free rate equations (Hilton 2000).

\section{D.1 References}

Delegard, C. H., S. A. Bryan, A. J. Schmidt, P. R. Bredt, C. M. King, R. L. Sell, L. L. Burger, and K. L. Silvers. 2000. Gas Generation from K East Basin Sludges - Series I Testing. PNNL-13320, Pacific Northwest National Laboratory, Richland, WA.

Hilton, B. A. 2000. Review of Oxidation Rates of DOE Spent Nuclear Fuel Part 1: Metallic Fuel. ANL-00/24, Argonne National Laboratory, Idaho Falls, Idaho.

Reilly, M. A. 1998. Spent Nuclear Fuel Project Technical Databook, Volume 1. HNF-SD-SNF-TI-015, Rev. 6, Duke Engineering and Services Hanford, Inc., Richland, WA. 


\section{Appendix E}

\section{Post-Test Sample Flowcharts and Photographs}




\title{
Appendix E
}

\section{Post-Test Sample Flowcharts and Photographs}

SNF Mid 60S - (500 to 2000 micron fuel particles partially reacted)

\author{
Mass of fuel particles \\ added to reaction vessel, $\mathrm{g}$ :
}

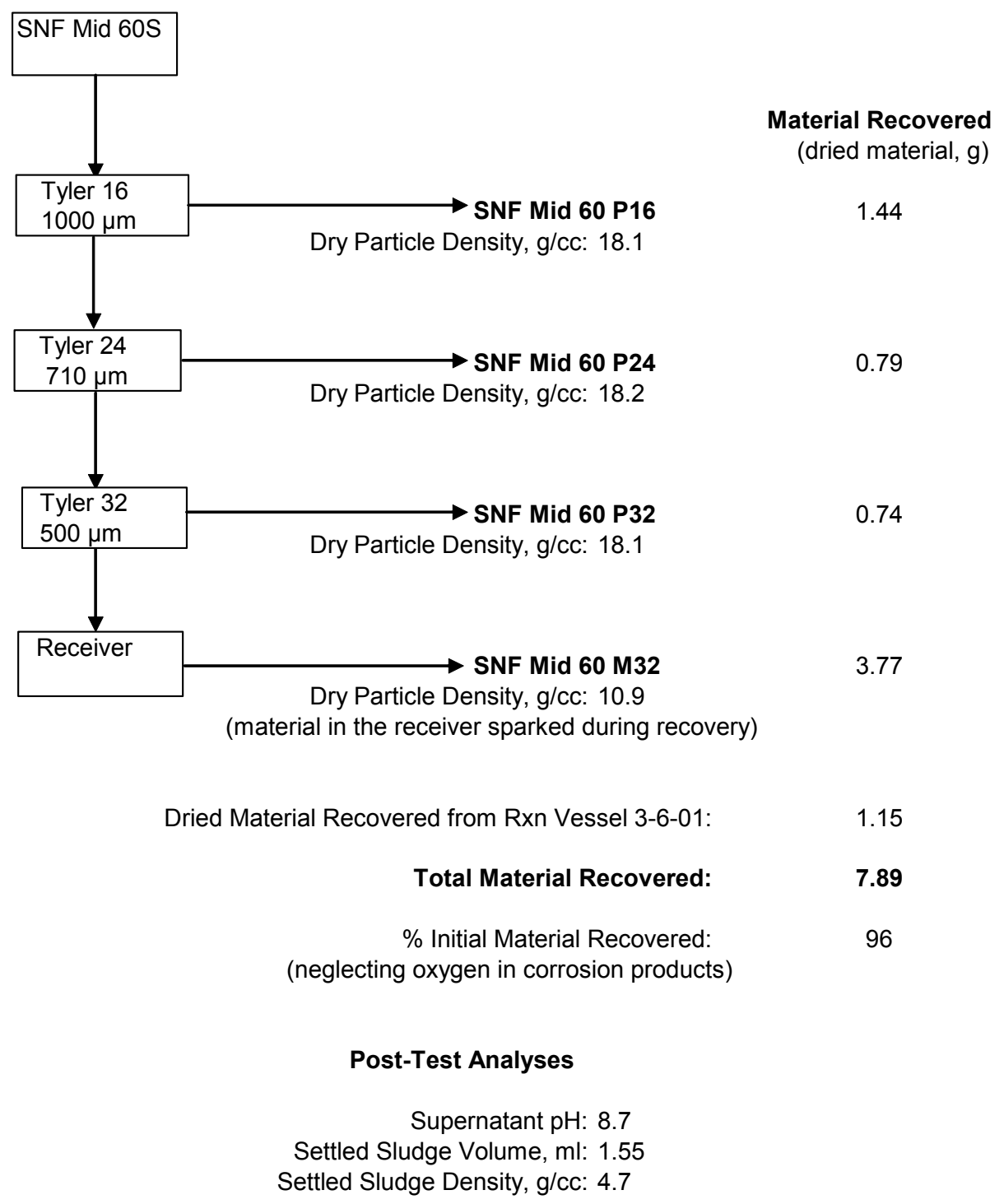

Figure E.1. Post-Test Flowchart for SNF Mid 60S (Test 3) 
SNF Mid 60S (Test 3), 500 to $2000 \mu \mathrm{m}$ fuel particles, reacted until $28 \%$ of the metallic uranium metal was corroded at $60^{\circ} \mathrm{C}, 80^{\circ} \mathrm{C}$, and $95^{\circ} \mathrm{C}$.

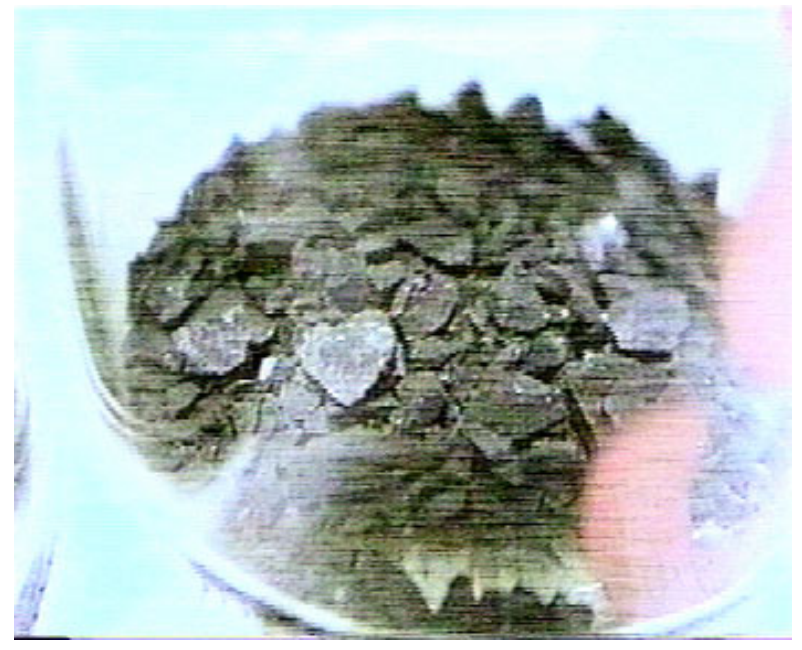

Figure E.2. SNF Mid 60S Fuel Particles (500 to $2000 \mu \mathrm{m}), 8.24 \mathrm{~g}$, Before Loading into Reaction Vessel

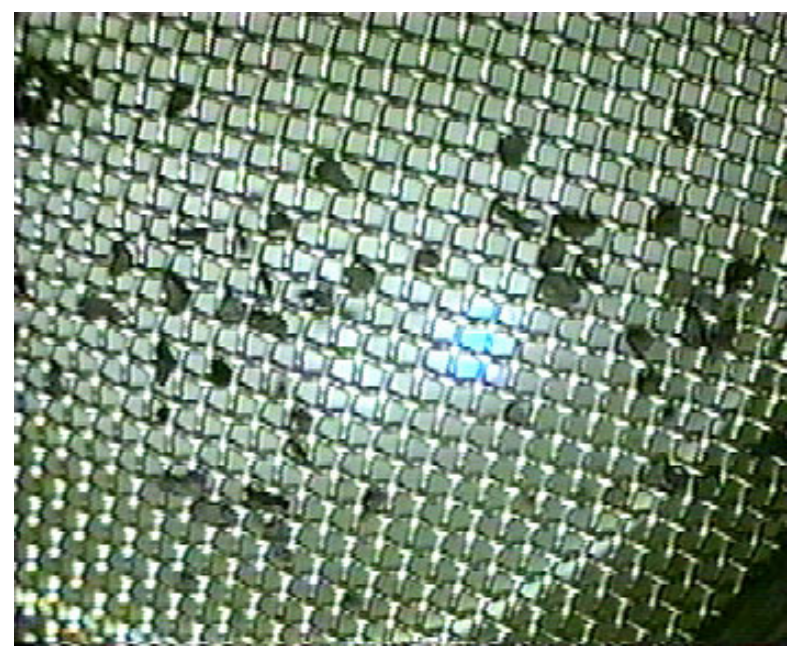

Figure E.4. Post-Test SNF Mid 60S Fuel Particles (dry), Collected on Tyler 24 Sieve $(710 \mu \mathrm{m})$

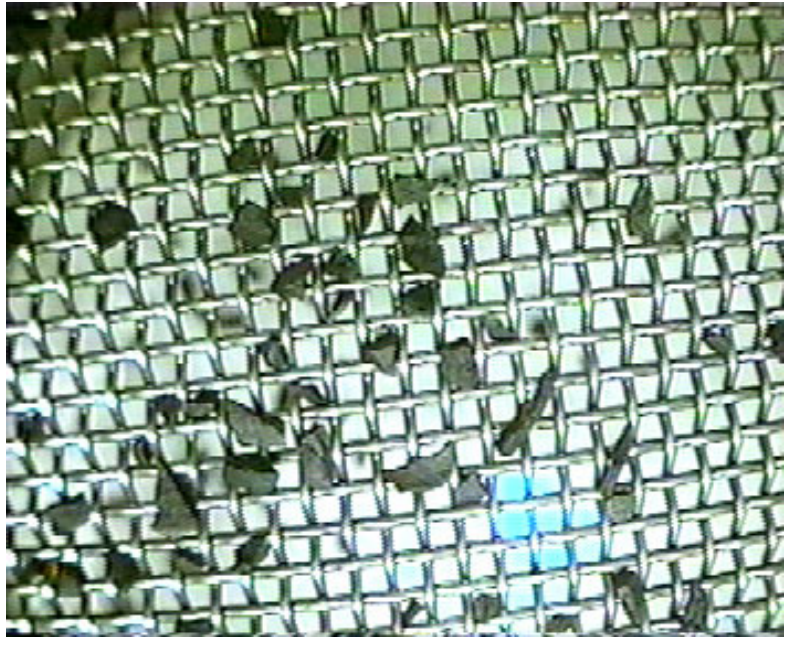

Figure E.3. Post-Test SNF Mid 60S Fuel Particles (dry), Collected on Tyler 16 Sieve $(1000 \mu \mathrm{m})$

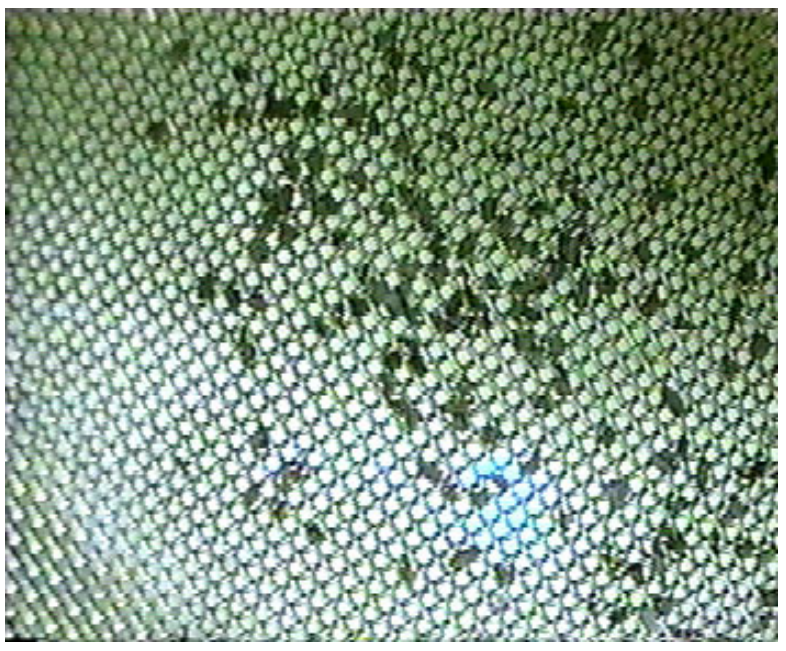

Figure E.5. Post-Test SNF Mid 60S Fuel Particles (dry), Collected on Tyler 32 Sieve $(500 \mu \mathrm{m})$ 
SNF Mid 40S - (500 to 2000 micron fuel particles partially reacted)

Mass of fuel particles

added to reaction vessel, g:

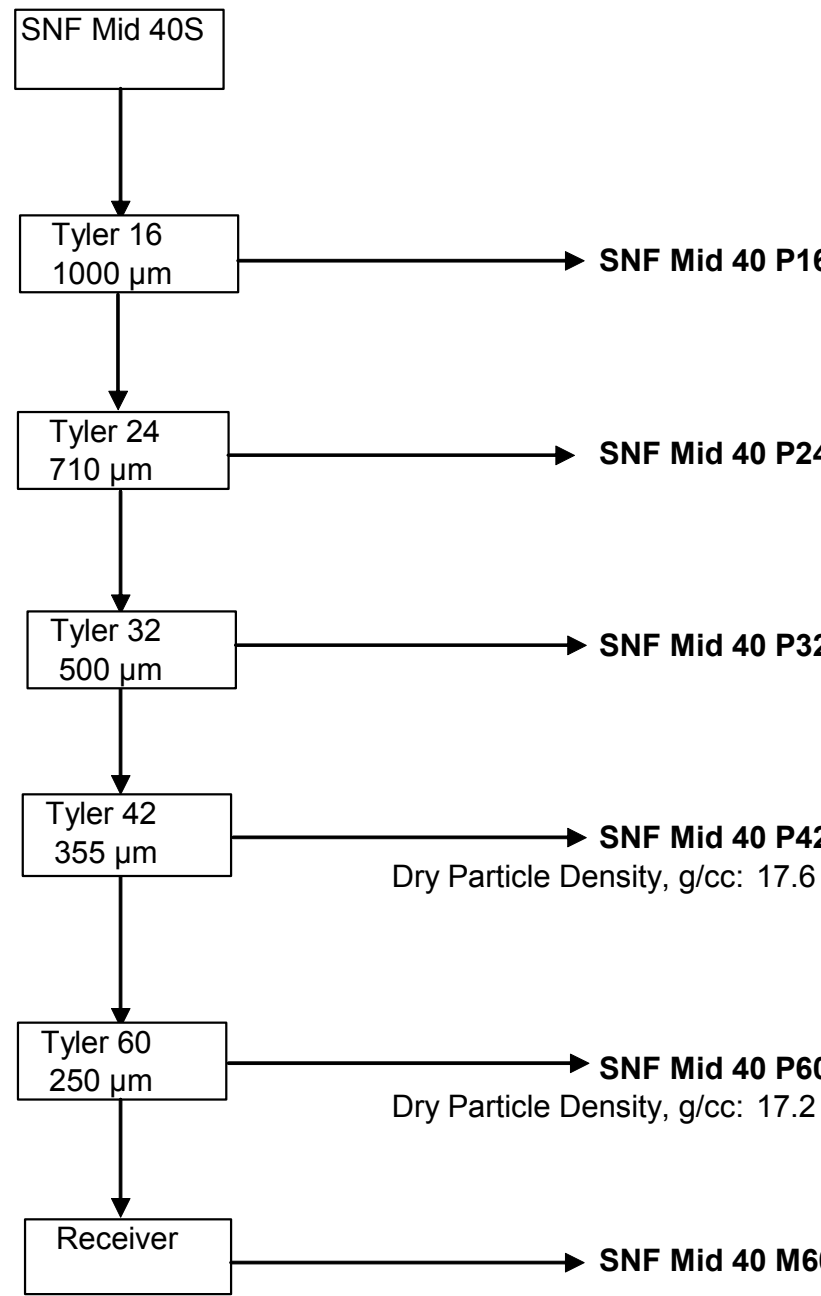

Material Recovered

(dried material, g)

2.72

1.07

1.08

0.55

0.38

Dried Material Recovered from Rxn Vessel 3-6-01:

2.1

0.53

Total Material Recovered:

8.43

$\%$ of Initial Material Recovered:

98 (neglecting oxygen in corrosion products)

\section{Post-Test Analyses}

Supernatant $\mathrm{pH}: 7.9$

Settled Sludge Volume, ml: 1.45

Settled Sludge Density, g/cc: 5.6

Figure E.6. Post-Test Flowchart for SNF Mid 40S (Test 4) 
SNF Mid 40S (Test 4), 500 to $2000 \mu \mathrm{m}$ fuel particles, reacted until $\sim 13 \%$ of the metallic uranium metal was corroded at $40^{\circ} \mathrm{C}, 60^{\circ} \mathrm{C}$, and $80^{\circ} \mathrm{C}$.

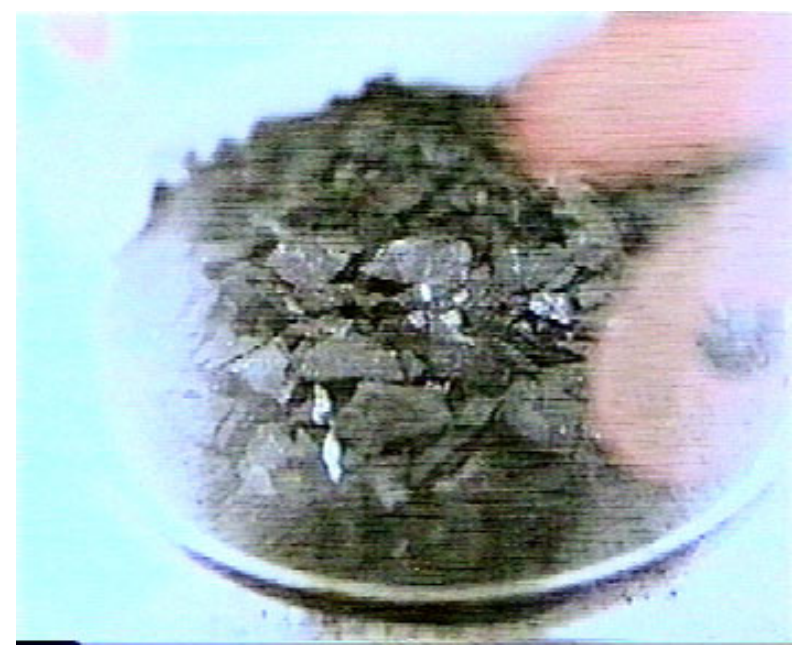

Figure E.7. SNF Mid 40S Fuel Particles (500 to $2000 \mu \mathrm{m}) 8.61 \mathrm{~g}$, Before Loading into Reaction Vessel

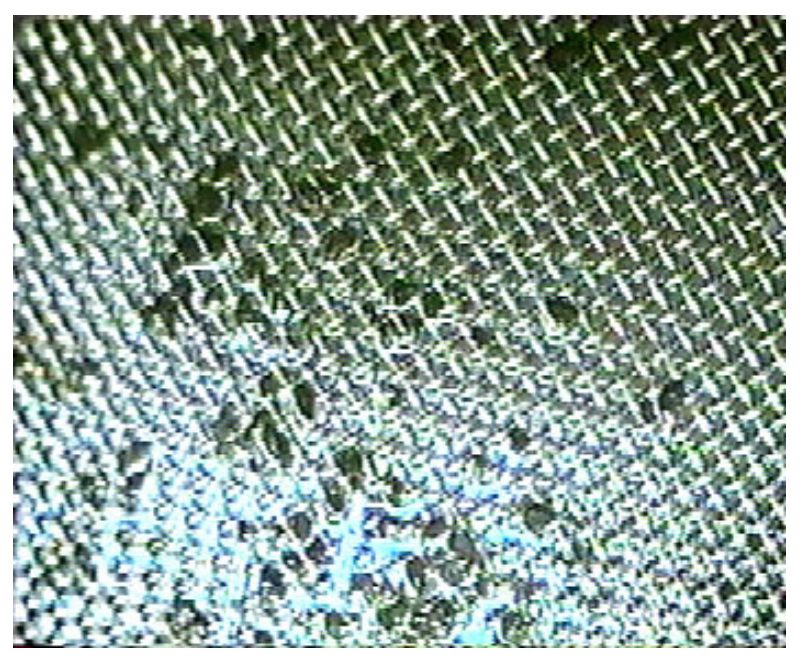

Figure E.9. Post-Test SNF Mid 40S Fuel Particles (wet), Collected on Tyler 24 Sieve $(710 \mu \mathrm{m})$

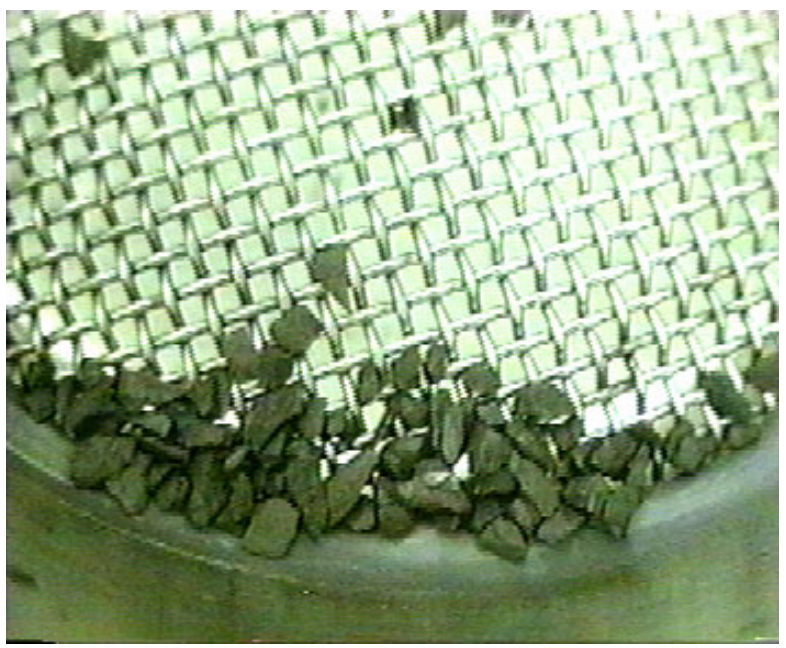

Figure E.8. Post-Test SNF Mid 40S Fuel Particles (dry), Collected on Tyler 16 Sieve $(1000 \mu \mathrm{m})$

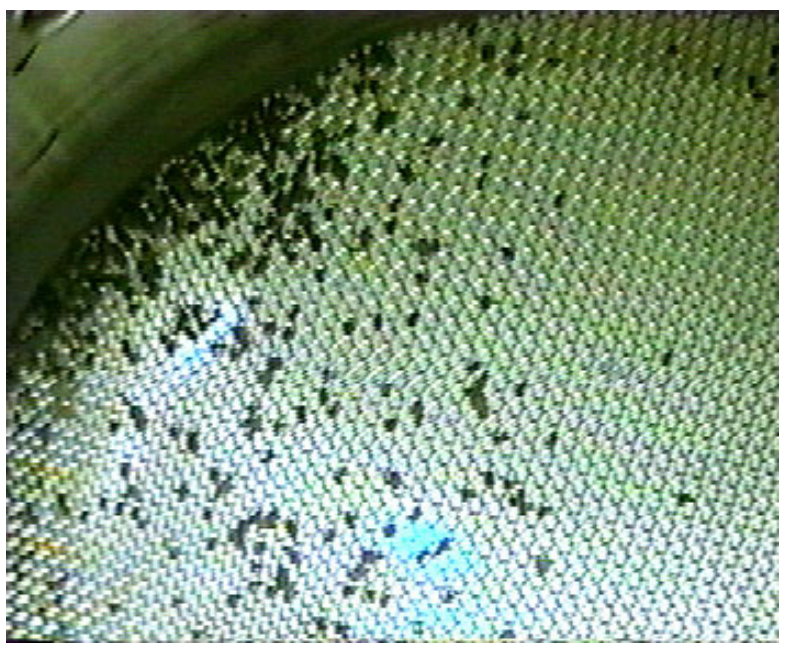

Figure E.10. Post-Test SNF Mid 40S Fuel Particles (dry), Collected on Tyler 42 Sieve (354 $\mu \mathrm{m})$ 
SNF P2000 80 S - (2000 to 6350 micron fuel particles partially reacted)

Mass of fuel particles

added to reaction vessel, g:

9.95

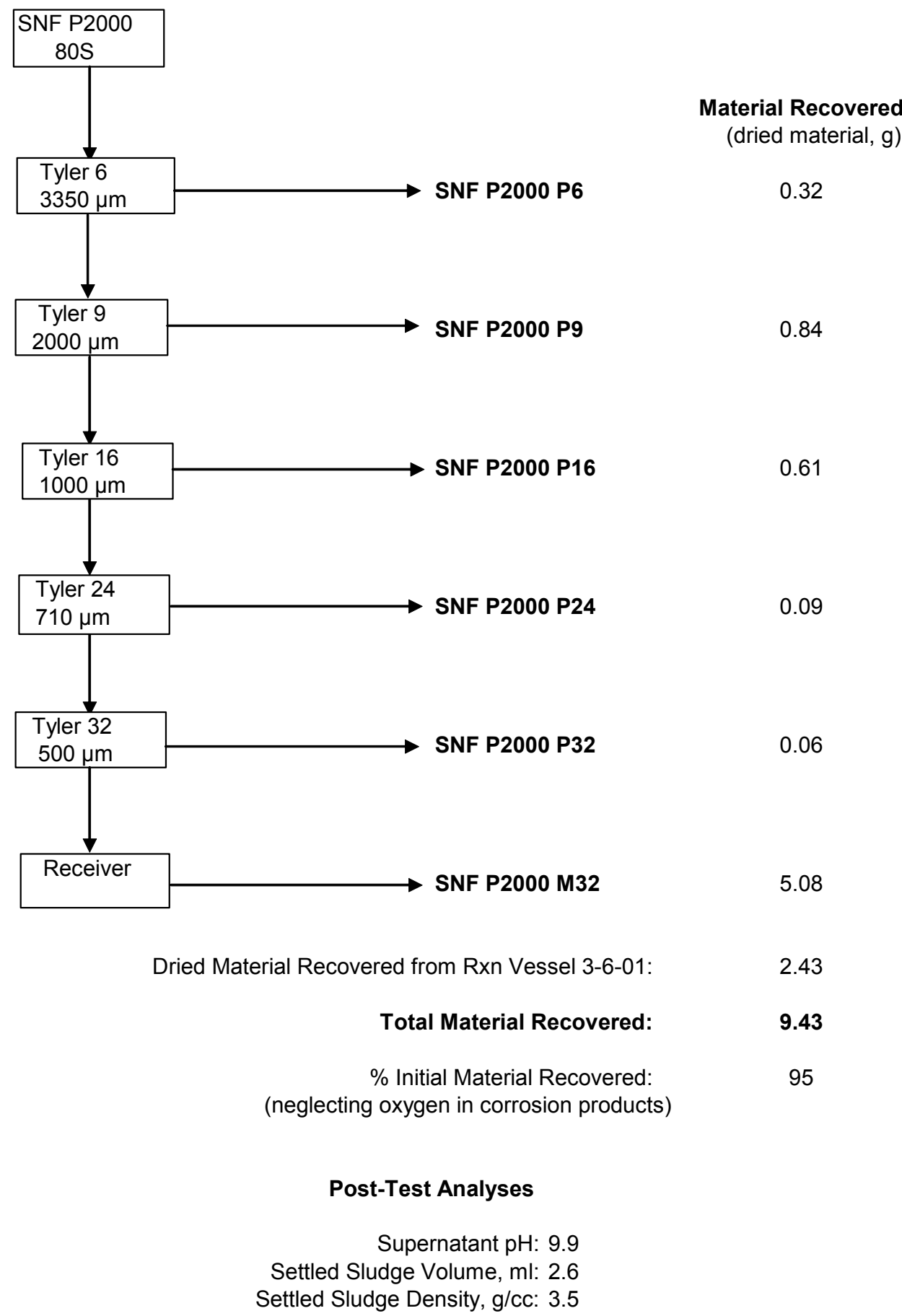

Figure E.11. Post-Test Flowchart for SNF P2000 80S (Test 5) 
SNF P2000 80S (Test 5), 2000 to $6350 \mu \mathrm{m}$ fuel particles reacted at $80^{\circ} \mathrm{C}$ for 2500 hours. Approximately $48 \%$ of the metallic uranium reacted during the test.

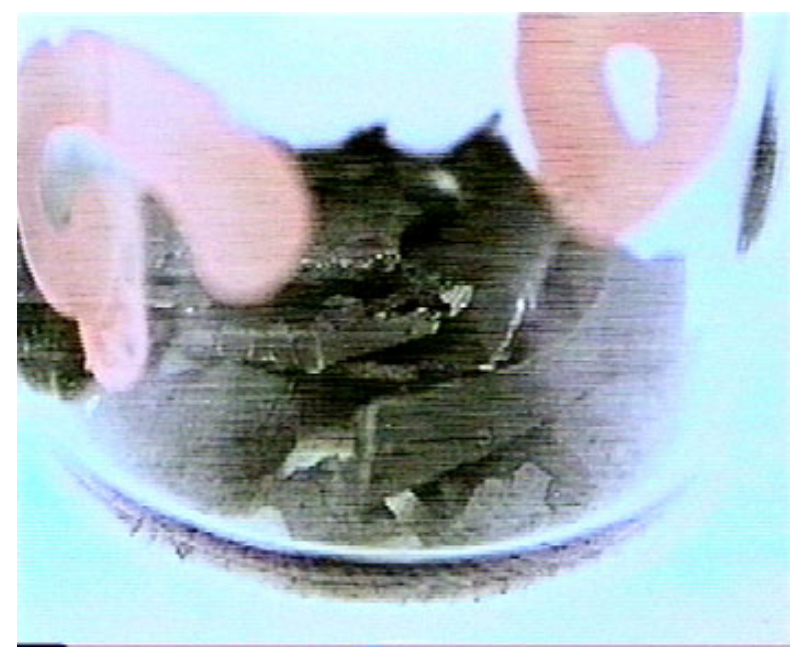

Figure E.12. SNF P2000 80S Fuel Particles (9.95 g), Before Loading into Reaction Vessel

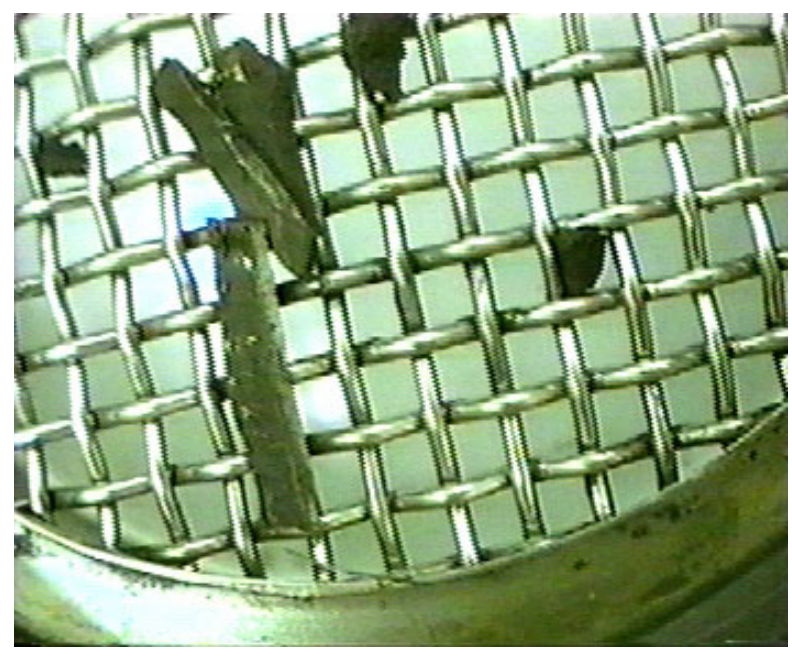

Figure E.14. Post-Test SNF P2000 80S Fuel Particles (dry) Captured on Tyler 9 Sieve $(2000 \mu \mathrm{m})$. Note, long pieces with cladding fell from Tyler 6 Sieve (Figure E.13).

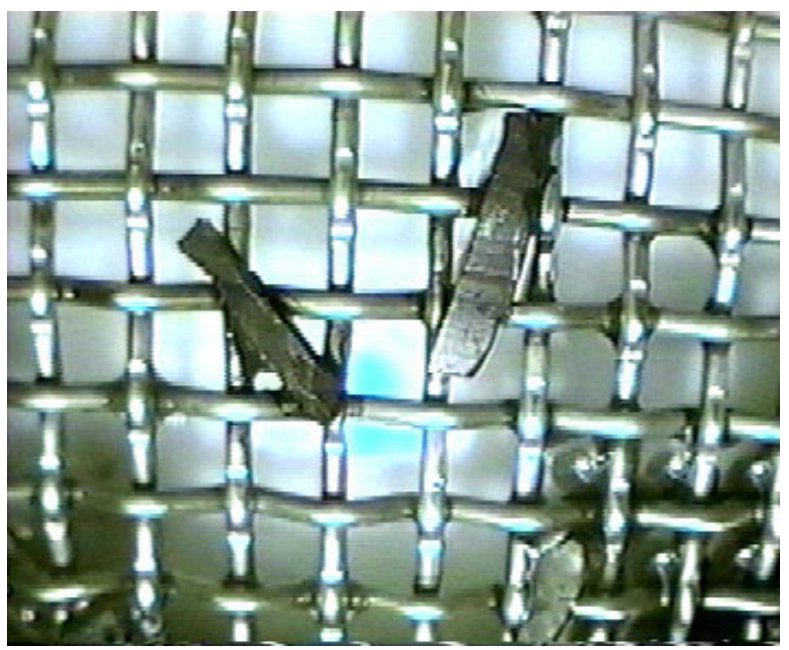

Figure E.13. Post-Test SNF P2000 80S (wet) Fuel Particles Captured on Tyler 6 Sieve $(3360 \mu \mathrm{m})$

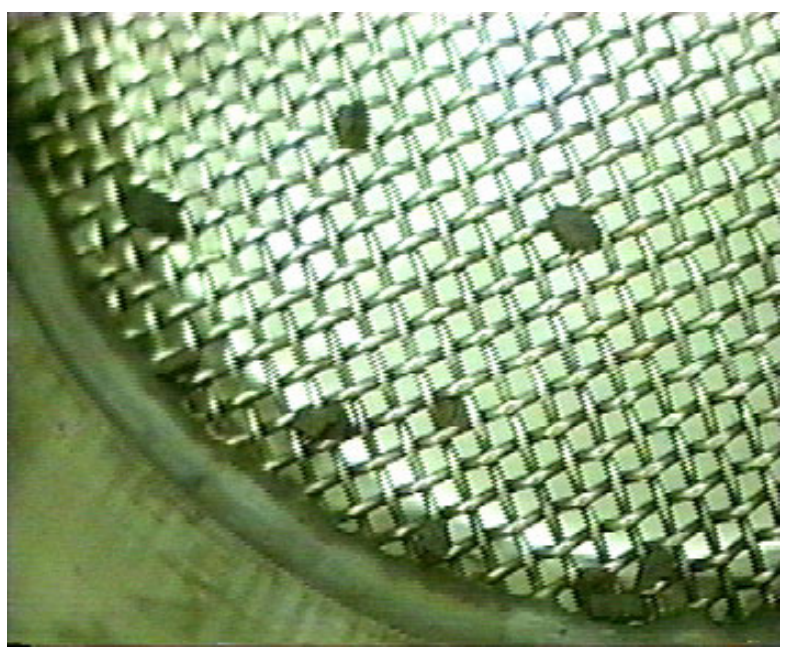

Figure E.15. Post-Test SNF P2000 80S Fuel Particles (after drying) Captured on Tyler 16 Sieve $(1000 \mu \mathrm{m})$ 
SNF M500 80L - (Minus 500 micron fuel particles reacted to extinction)

Mass of fuel particles

added to reaction vessel, g:

7.95

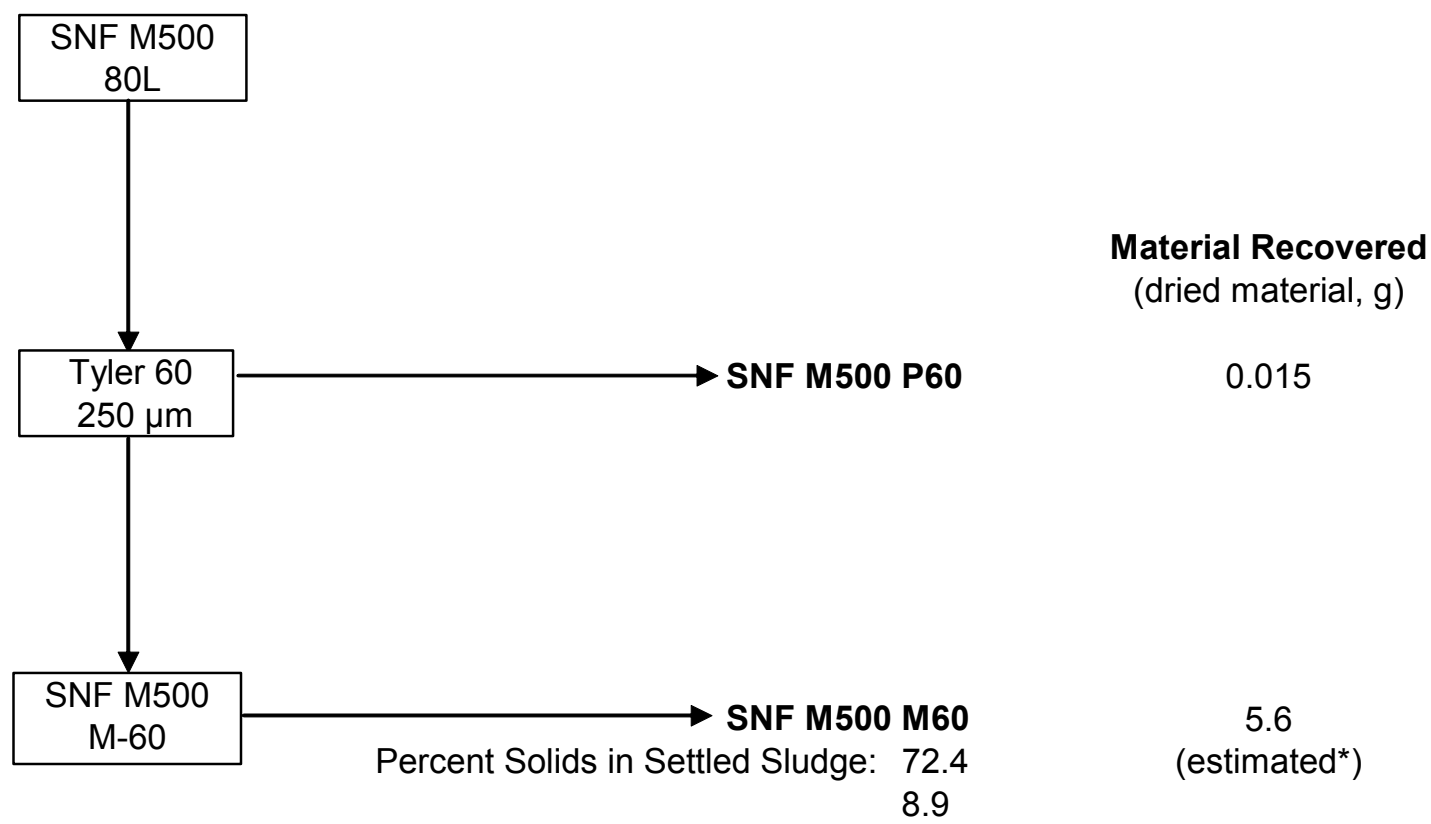

Dried Material Recovered from Rxn Vessel 3-6-01: No recovery attempted

Total Material Recovered:

5.61

$\%$ Initial Material Recovered:

71

(neglecting oxygen in corrosion products)

\section{Post-Test Analyses}

Supernatant $\mathrm{pH}: 8.7$

Settled Sludge Volume, $\mathrm{ml}: 3$

Settled Sludge Density, g/cc: 2.5

*SNF M500 M60 was not dried. Dry mass estimated by multiplying settled sludge mass by weight percent solids in settled sludge.

Figure E.16. Post-Test Flowchart for SNF M500 80L (Test 6) 
SNF Mid 80L Comp - (500 to 2000 micron fuel particles reacted to extinction)

Mass of fuel particles added to

SNF Mid 80L and Mid 80L Dup, g:

17.02

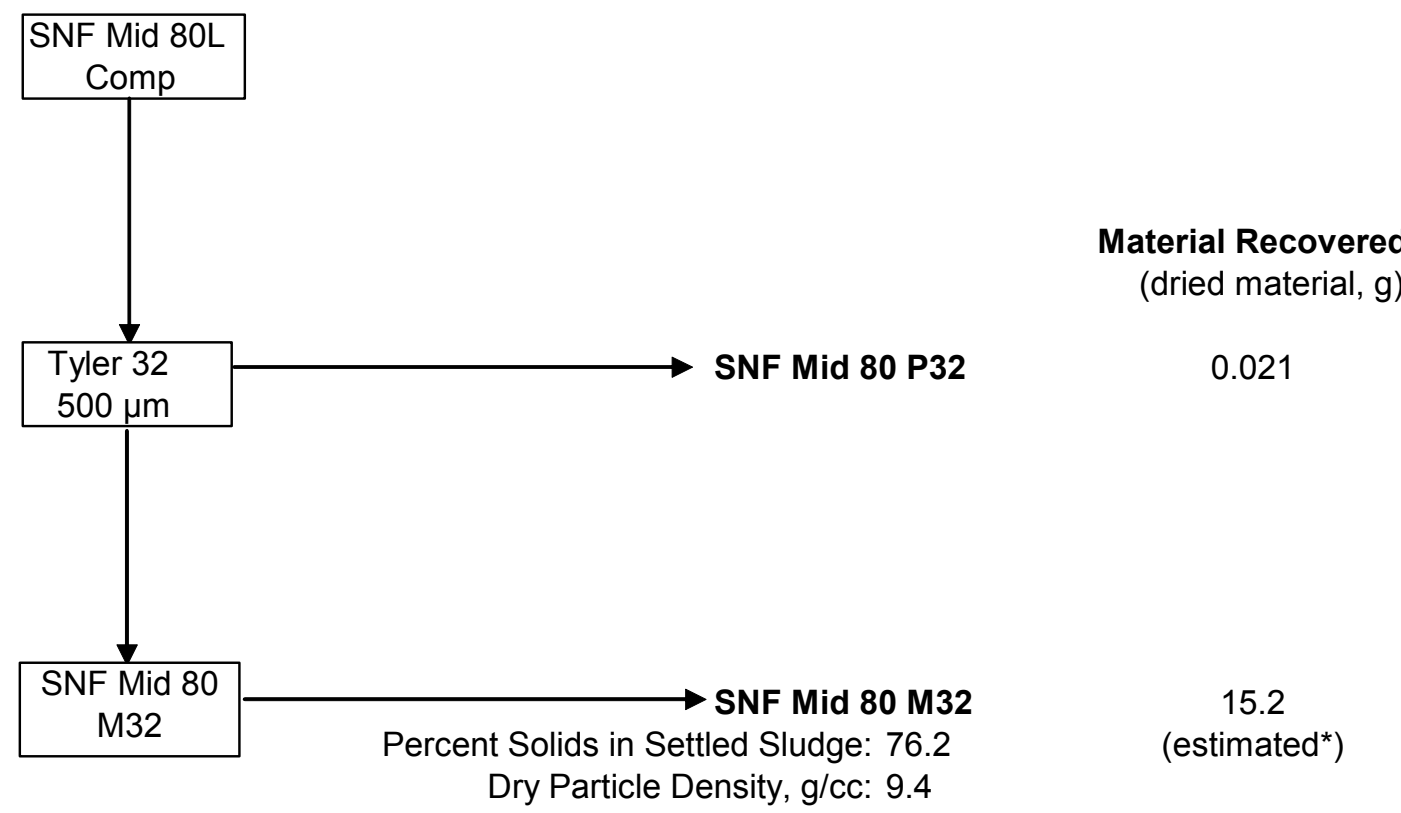

Dried Material Recovered from Rxn Vessel 3-6-01: No recovery attempted

Total Material Recovered: $\quad 15.22$

\% Initial Material Recovered: $\quad 89$

(neglecting oxygen in corrosion products)

\section{Post-Test Analyses}

Supernatant pH: 9.7 (avg)

Settled Sludge Volume, ml: 7.5

Settled Sludge Density, g/cc: 2.8

*SNF Mid 80 M32 was not dried. Dry mass estimated by multiplying settled sludge mass by weight percent solids in settled sludge.

Figure E.17. Post-Test Flowchart for SNF Mid 80L Comp (Tests 7 and 8) 
SNF M500 80L (Test 6, minus $500 \mu \mathrm{m}$ ) and Mid 80L (Tests 7 and 8, 500 to $2000 \mu \mathrm{m}$ ) reacted until all uranium metal was corroded at $80^{\circ} \mathrm{C}$ and $95^{\circ} \mathrm{C}$.

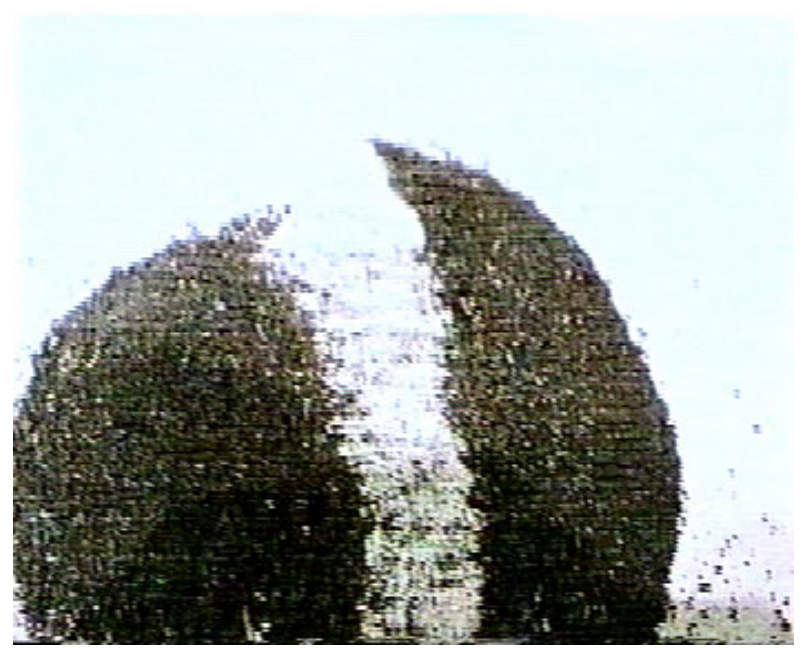

Figure E.18. Minus $500 \mu \mathrm{m}$ Fuel Particles (dry), Before Loading into Reaction Vessel

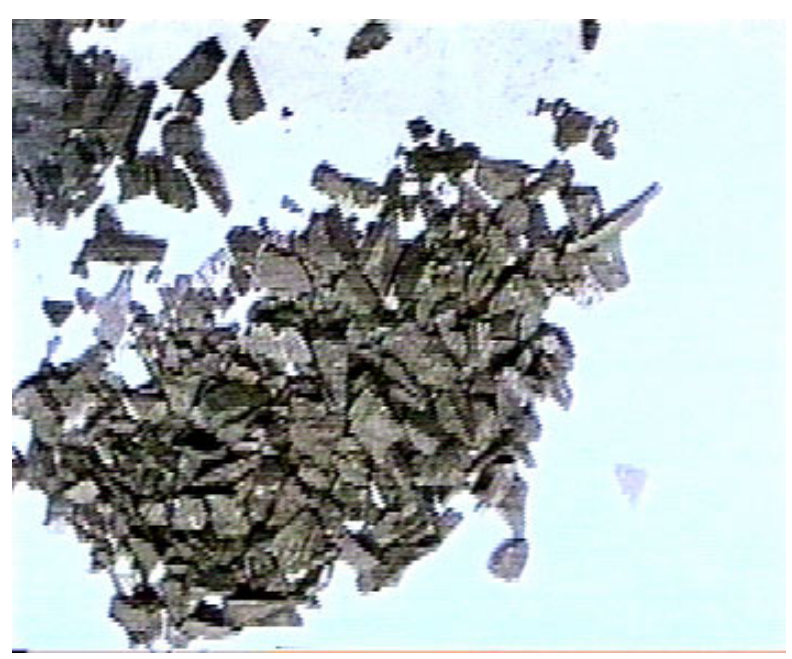

Figure E.20. 500 to $2000 \mu \mathrm{m}$ Fuel Particles (dry), Before Loading into Reaction Vessels

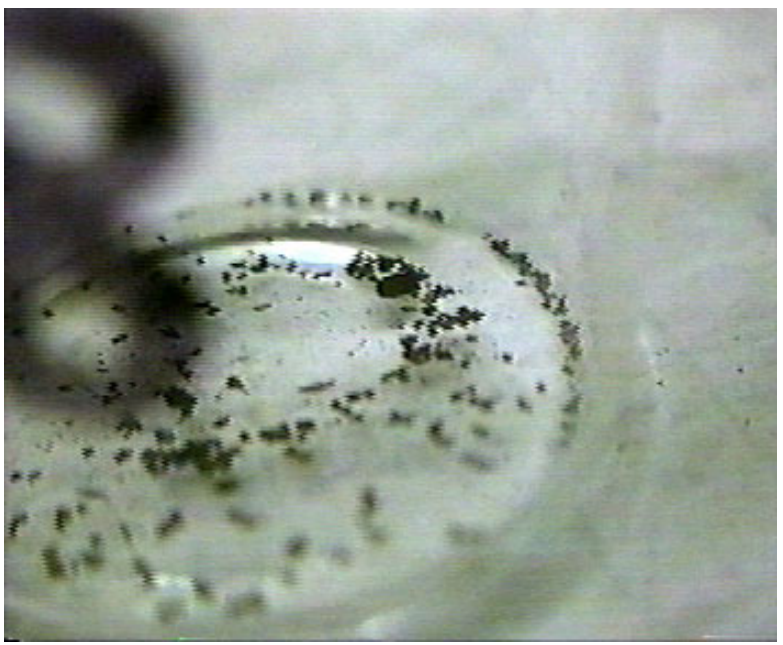

Figure E.19. Post-Test SNF M500 80L Residual Fuel Particles (dry) (mostly cladding) Captured on Tyler 60 Sieve $(250 \mu \mathrm{m})$. Residual fragments are inside a $20-\mathrm{ml}$ vial (vial inside diameter $\sim 2.2 \mathrm{~cm}$ ).

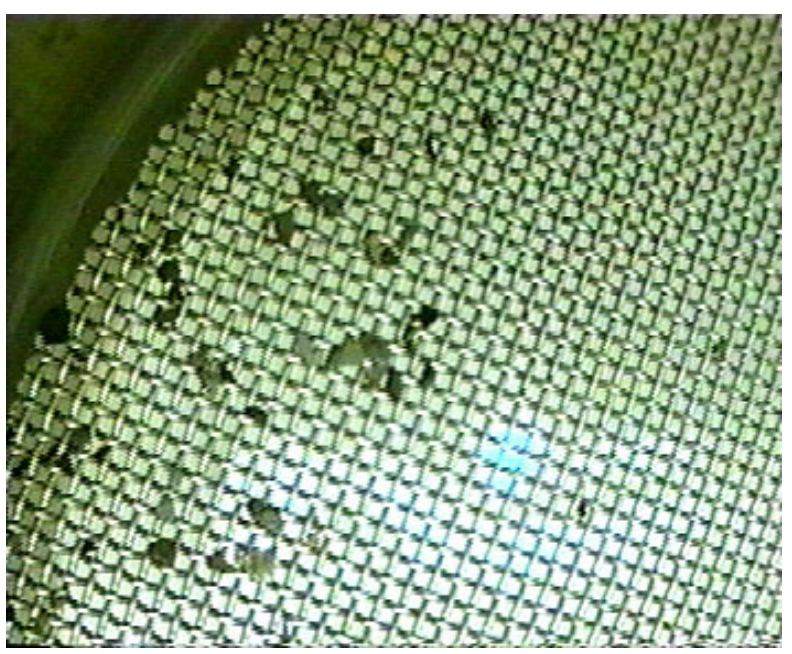

Figure E.21. Post-Test SNF Mid 80L Comp Residual Particles (mostly cladding), Collected on Tyler 32 Sieve $(500 \mu \mathrm{m})$ 
Fuel Frag (Partially reacted $3.72 \mathrm{~g}$ single fuel fragment)

Mass of fuel fragment

added to reaction vessel, g:

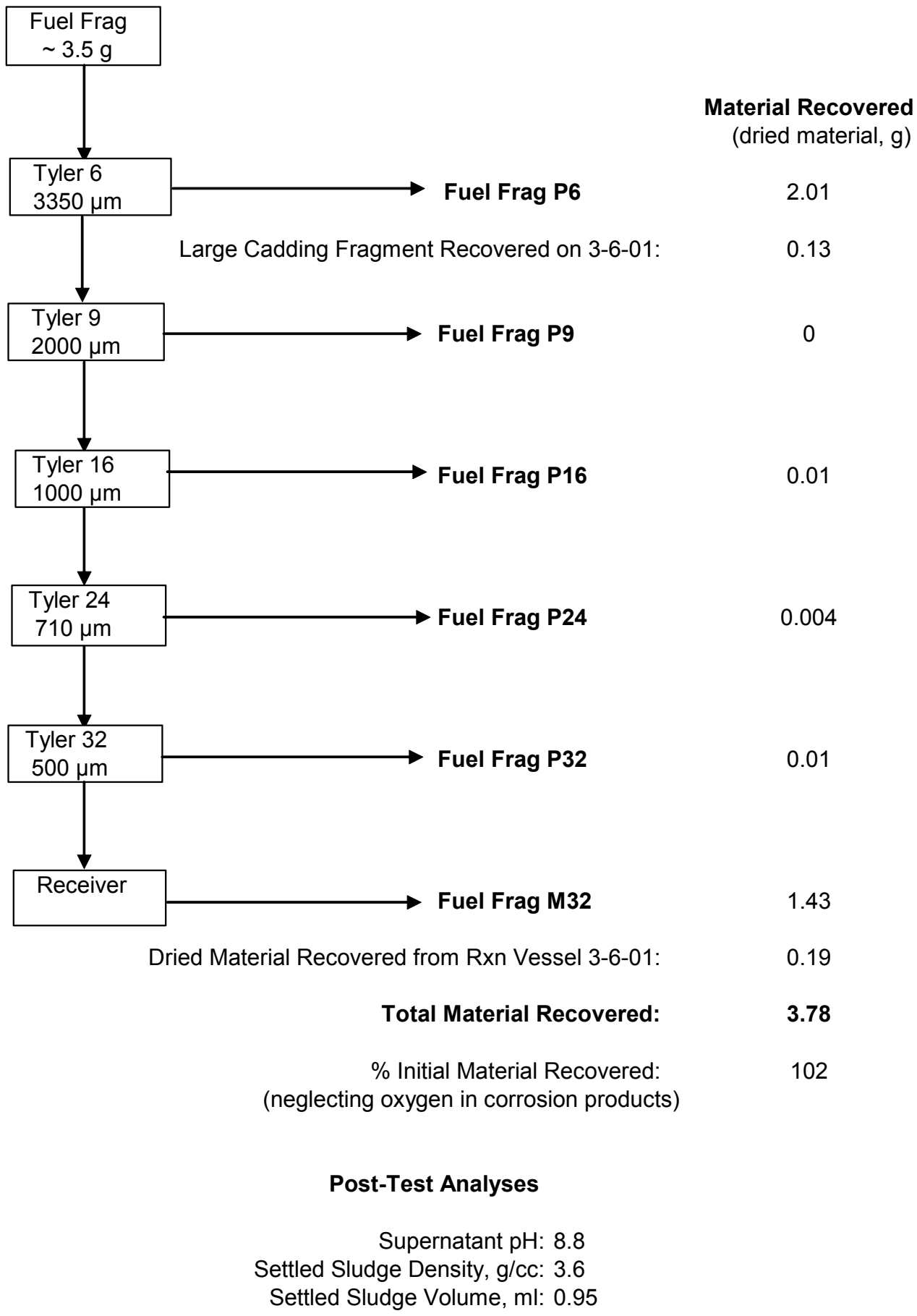

Figure E.22. Post-Test Flowchart for Fuel Fragment (Test 9) 
Fuel Fragment (Test 9), single 3.7-g SNF fragment, reacted at $80^{\circ} \mathrm{C}$, for about 4000 hours. Approximately $33 \%$ of the metallic uranium reacted during the test.

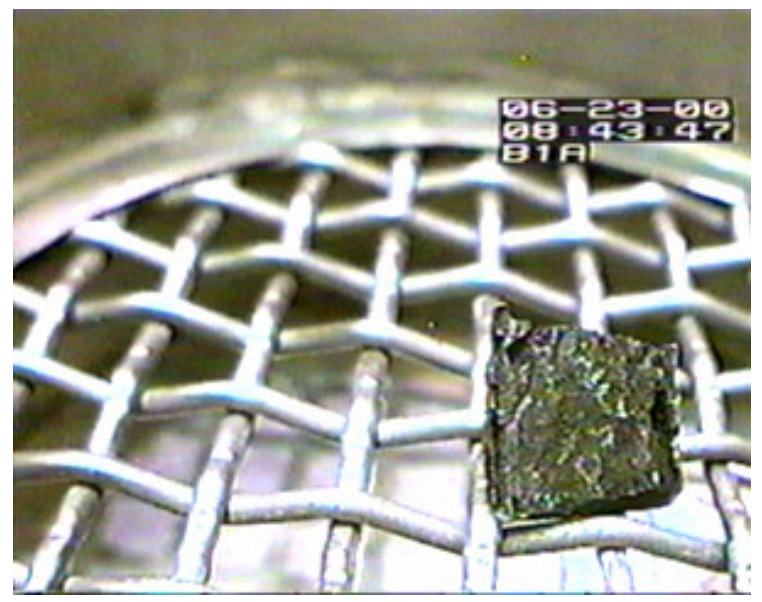

Figure E.23. SNF Fuel Fragment B1A (3.7-g fragment) on Tyler 6 Sieve $(3350 \mu \mathrm{m})$, Before Loading into Reaction Vessel

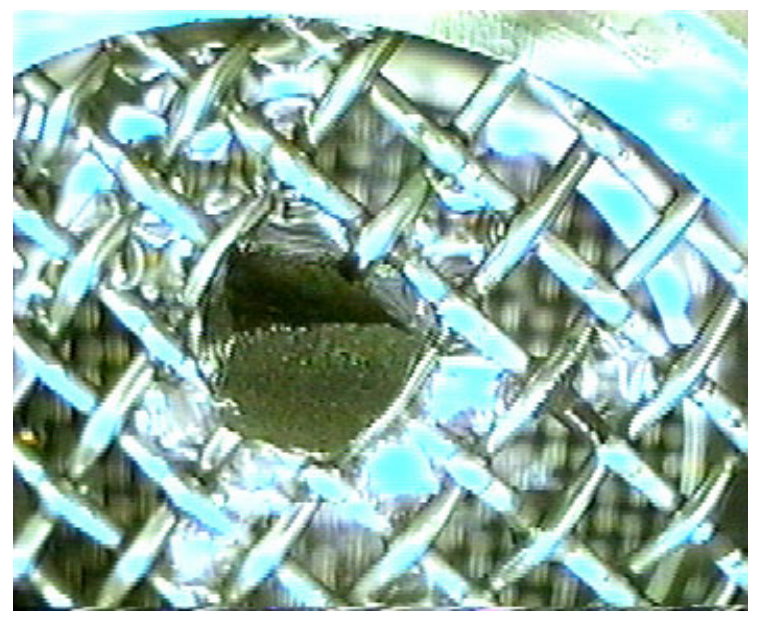

Figure E.25. Post-Test SNF Fuel Fragment (wet) Captured on Tyler 6 Sieve $(3350 \mu \mathrm{m})$. Fragment weighs $1.92 \mathrm{~g}$ (dry).

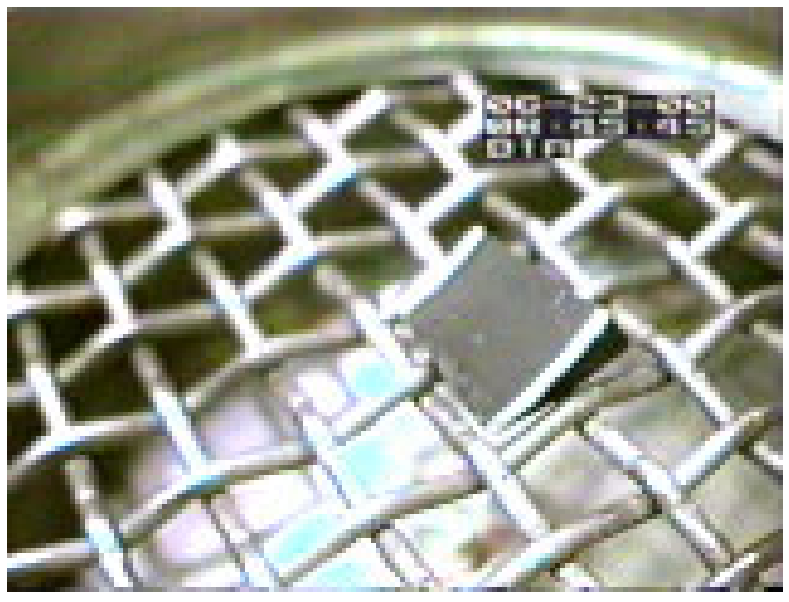

Figure E.24. SNF Fuel Fragment B1A (3.7-g fragment) on Tyler 6 Sieve $(3350 \mu \mathrm{m})$, Before Loading into Reaction Vessel

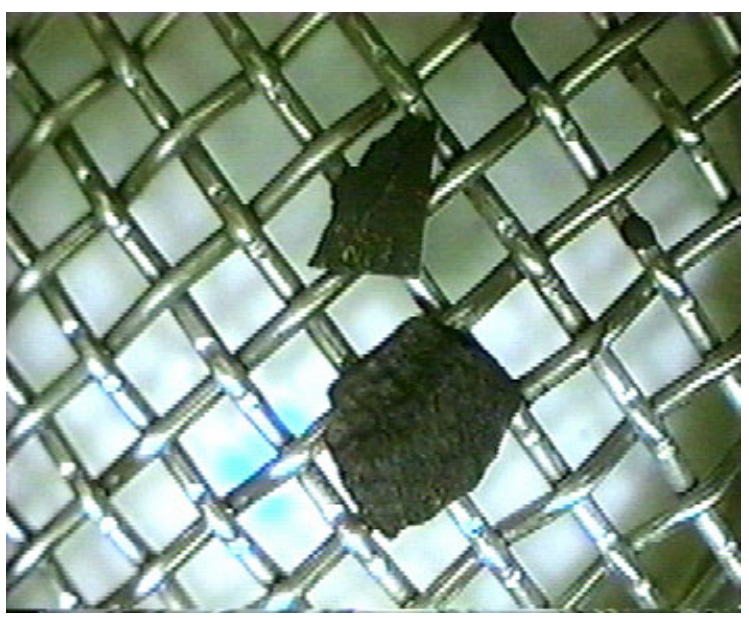

Figure E.26. Post-Test SNF Fuel Fragment (dry) Captured on Tyler 6 Sieve $(3350 \mu \mathrm{m})$. Large piece weighs $1.92 \mathrm{~g}$. Small piece (cladding) weighs $0.078 \mathrm{~g}$. 